Historic, Archive Document

Do not assume content reflects current scientific knowledge, policies, or practices. 



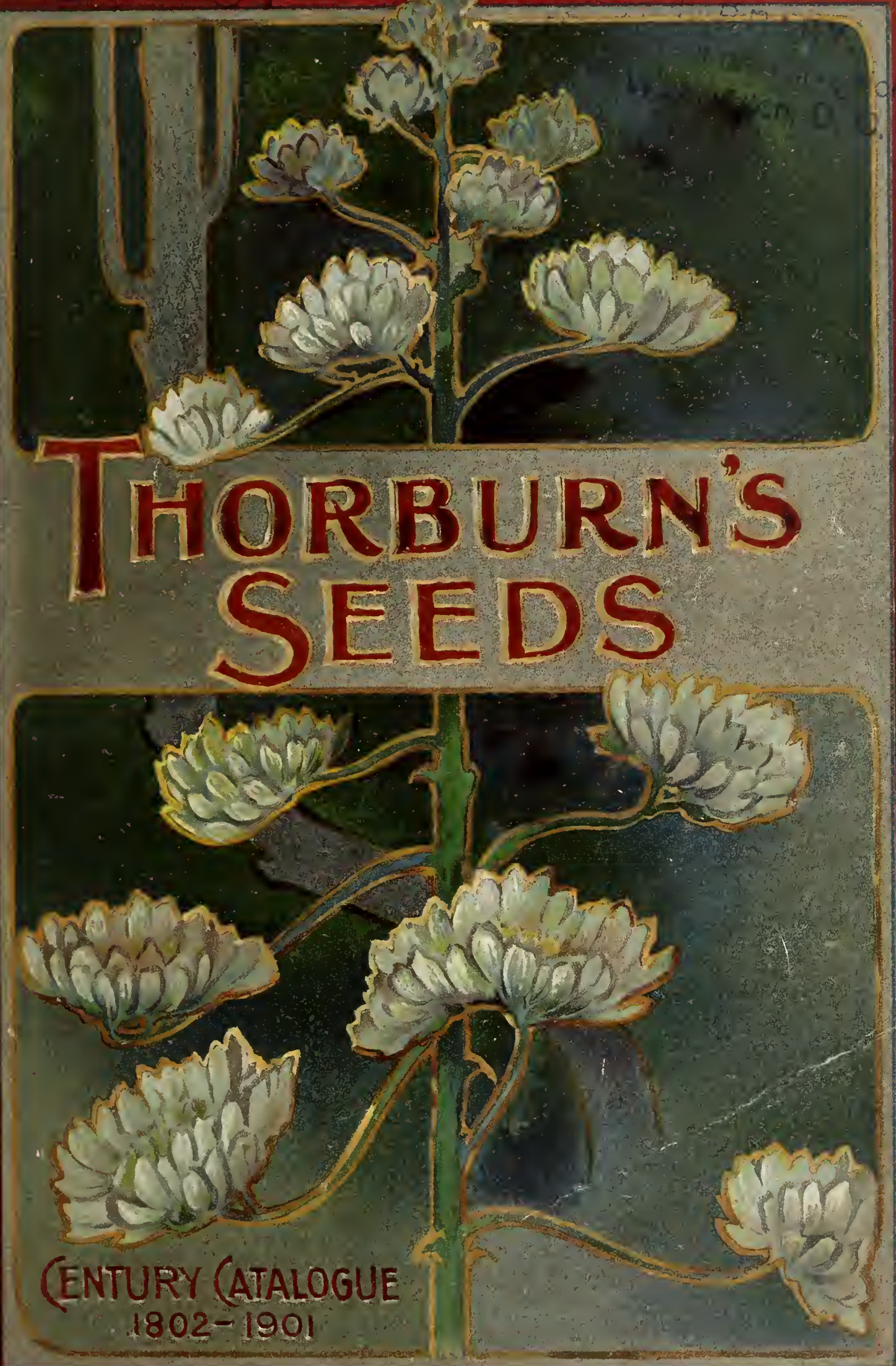


These assortments contain only the choicest sorts, and are sure to give satisfaction. The proportions are arranged to suit large and small gardens.

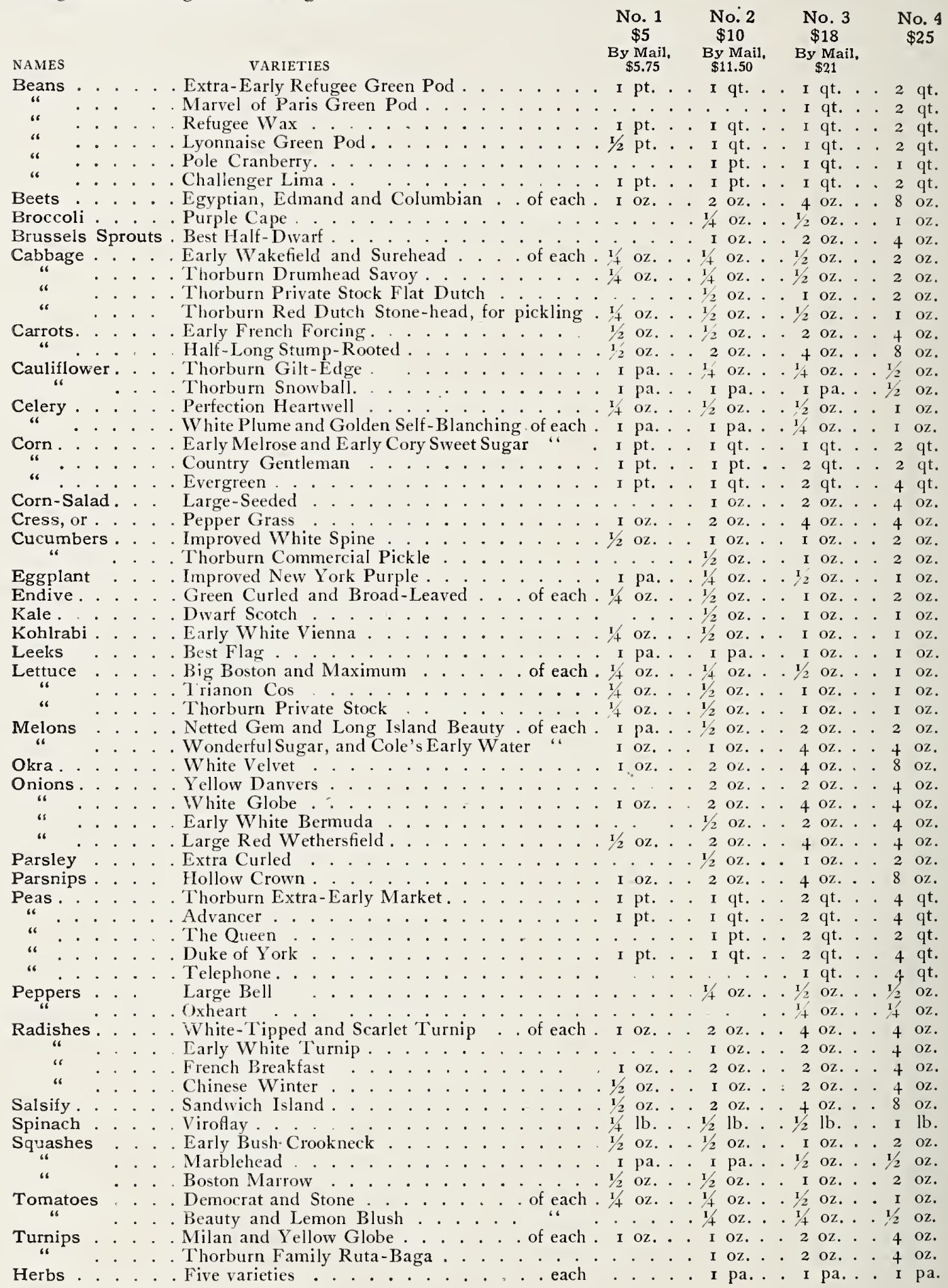




\title{
THORBURN'S CENTURY
}

\author{
I] (9) (1) I]
}

\section{J.M.THORBURN \& CO. ONE HUNDREDTH} ANNUAl Catalogue

F.W.Bruggerlhof President E. Li.Bruggerh of VPreskTreas. R.R.Mackenzie Secretary

36 CORTLANDT STREET NEW YORK 


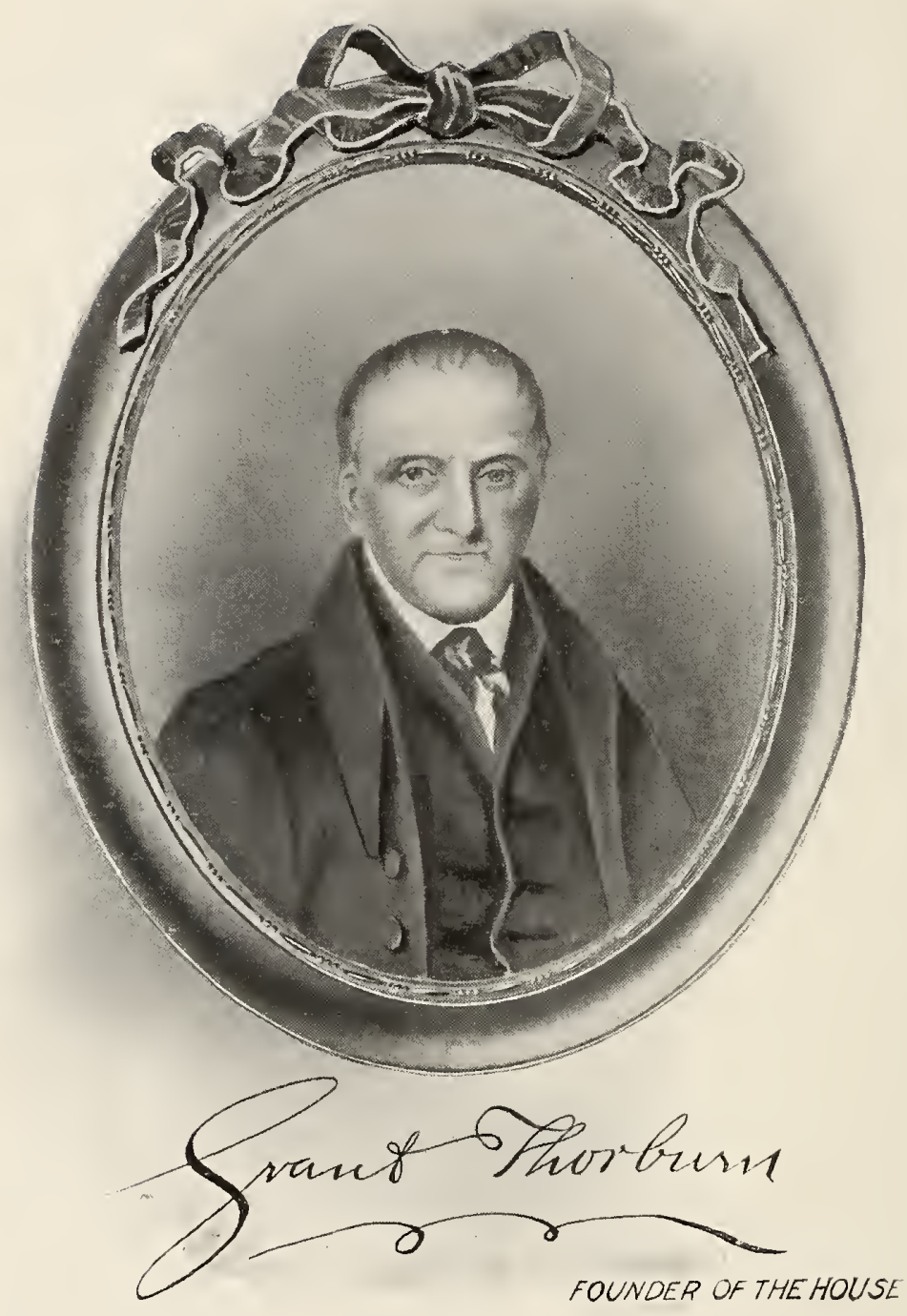




\section{Thorburn's Century}

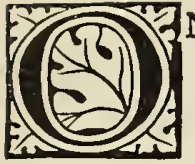

NCE in a century even the quiet worker may pause to review his work. The occasion seems to demand it. In issuing our Hundredth Annual Catalogue we are accordingly taking advantage of the opportunity to present to our friends and patrons a portrait of Mr. Grant Thorburn, and to say a few words about the business founded by him in 1802 .

New York was then a small town of about 60,000 inhabitants, but he quickly placed his business in the position of relative importance which it maintains in the great city of today. He was a man of probity and worth, who took a pride in his work, and the newspapers of that period afford a characteristic glimpse of him, disputing with William Cobbett as to which of them first introduced Rutabaga seed to America. That the solid principles upon which he founded were conserved by his successors may be readily accepted in view of their continued success in a business that implies to a peculiar degree the confidence of its clients.

Grant Thorburn retired in I835, and the subsequent firm names represent the interest of his son and grandson, George C. Thorburn and James M. Thorburn, respectively. It was in 1849 that F.W. Bruggerhof, president of the company since its incorporation, and for many years previously its active head, began his fifty years' connection with the house. He takes this opportunity of acknowledging the encouragement he has received in his work from the many friends whose familiar handwriting he sees with every returning spring.

It is only by a long retrospect that the result of the seedsman's labor can be appreciated. He works with Nature, who hurries never, and the improvements effected by him are so gradual that they pass unnoticed. But any one who can recall the vegetables, fruits and flowers of fifty years ago will admit the superiority of those of the present day in every point of merit. Every year brings some new strains, or some improvements upon old ones, until it seems as if perfection must soon be attained and that "the force of Nature can no further go." Even then the seedsman's constant care would be required to retain what has been gained; for the tendency to revert is so strong in highly cultivated plants that a few years of neglect would reduce them to the simple original types.

It may be safely said that science has done more for horticulture and agriculture in the century just closed than experience in all time previous; and it is equally safe, though perhaps less modest, to assert that J. M. Thorburn \& Co. have contributed more than any individual to that result. The shortness of life and the greatness of art have often been felt to place a discouraging limit upon human endeavor, but this is somewhat obviated in a business house, where the accumulated experience of several generations is preserved with the unity of an individual purpose. What we know about seed-growing could not have been learned in a shorter time, nor at all but by scientific methods. There are certain subtle conditions of soil and climate which affect the quality of the seed of plants. We have ascertained in what countries and localities these conditions are most favorable, and we grow our seeds there, without regard to the cost of production.

Of course we have done these things for money, and have had our reward. But there are some features of our work for which the commercial side of our business provides no pecuniary compensation, and on account of which we consider ourselves to 
have deserved well of the State. We refer to the hundreds of valuable and now standard vegetables and flowers originated or introduced by us, often after years of selection and breeding, and always at great expense. There are no patent rights in plants, and a new sort passes beyond our control in the first season. We may also allude to the hundreds of rare sorts carried at a loss, for the benefit of botanists and specialists.

The policy which we have pursued in the past will be continued. We hope that the encouragement we have received will be increased, and that the arrival of our next centennial may find a wider interest in agriculture, which is the basis of prosperity, and a deeper love of gardening, which is the measure of a nation's refinement.

It is very important that our customers send in their orders immediately on receipt of this Catalogue, instead of waiting till they wish to sow the seeds, as in the spring months we are so busy that there is sometimes unavoidable delay in filling them.

Cultural Directions.--These apply to the climate of New York and vicinity. For more northern or southern localities the necessary changes in time of sowing, etc., will readily suggest themselves to gardeners.

Whenever our customers desire it, we will select an assortment of seasonable seeds suited to their wants. The only information we require is the size of the garden and the sum proposed to be expended for seeds.

Orders should be written on our order sheet or on a blank sheet separate from letter, making sure that name and address are very legibly written. Orders from new customers should be accompanied by a remittance in the form of a Post Office or Express Money Order, or bank bills, if the amount enclosed is not large.

Prices.- The prices quoted are net, and do not include free transit, except for seeds in ounces and packets. All seeds can be had in 5-cent papers, except those otherwise quoted.

Seeds by Mail or Express.-8 cents per pound should be added for prepayment of postage, if wanted by mail or prepaid express. By special arrangement with the express companies we can ship seeds and bulbs at a reduction of 20 per cent from the regular rates. We do not guarantee the safe arrival of goods sent by mail ; it is rarely, however, that seeds fail to reach their destination safely in that way. Unless otherwise instructed, we shall send all express orders C. O. D. Orders from unknown customers not desiring this mode of carriage should be accompanied by the cash.

Name, Address etc.-We beg our correspondents to give us very exactly, on $\mathrm{EACH}$ order, the correct name and address; also, to indicate very precisely the means of carriage which they prefer, whether by EXPRESS, FREIGHT, or MAIL, and the office or railroad station which best serves their locality. In case these directions are not followed out, or if they are not sufficient, we shall choose ourselves the most advantageous and convenient means, but entirely at the risk of the customer, avoiding ourselves all responsibility.

Warranties. - Seeds of the best quality will often fail through improper treatment. Thus, a small seed may be sown so deeply that the young plant cannot reach the surface. More failures result from disregard of the conditions necessary to germination than from inferiority of the seeds used. These conditions are: a proper temperature, sufficient moisture, and free access of air. Besides these, the soil must be in proper condition, and present no physical obstacle to the growth of the young plant. If heavy rains have compacted the surface of the soil, and the sun has baked it to a hard crust, it will be impossible, even if all other conditions are favorable, for the seedling plants to force their way through it, and many perish from this cause alone. Seeds differ greatly as to the temperature required for germination. Beets, Cress, Peas, etc., germinate rapidly at a temperature of $45^{\circ}$; but if Melons and other seeds of that family, bush or pole Beans, and other plants of subtropical origin, are sown under the same conditions, they will be apt to decay, as for their prompt germination they require a heat of at least $60^{\circ}$. For this reason many seeds fail yearly from too early sowing. The second condition, proper moisture, is likely to be violated by an excess rather than by too small a proportion. The proper amount is that which a well-drained soil will naturally hold. Free access of air is all-important, and this is interfered with by an excess of water in the soil. In germination complex chemical changes take place in the seeds, in which the air performs an important part. A portion of the seed is consumed, carbonic acid gas being given off in changing the starch and other constituents of the seed into nutriment to forward the growth of the germ or embryo plant, which depends upon the contents of the seed until it has formed roots below ground and leaves above, and is able to sustain itself. Besides these conditions affecting the germination of the seed, the young plants, after they have made their way to the surface, are liable to various accidents; a sudden current of very cold air, or a continuous drying wind, may check their growth, or destroy them altogether. In addition, there are numerous insects, both below and above ground, that may attack the plants, some of them being so small that they often destroy a crop before they are discovered. We may also mention the well-known tendency of many vegetables to revert to their original types, notwithstanding the care of the seed-grower; the yellow-podded wax Beans becoming green, the yellow and white Celery becoming more or less green, dwarf Peas becoming running sorts, etc.

Messrs. J. M. Thorburn \& Co. give no warranty, express or implied, as to description, quality, productiveness, or any other matter of any seeds, bulbs or plants they send out, and they will not be in any way responsible for the crop. If the purchaser does not accept the goods on these terms, they are at once to be returned. 


\section{Directions for the Cultivation of Vegetables}

To secure a good crop of vegetables, three things at least are necessary; viz., a suitable soil, pure seed, and clean culture. The exposure for a vegetable garden should be perfectly south or southeast, or nearly so. The soil should be naturally rich and friable, a sandy loam being among the best. If the soil be stiff, it should be gradually mellowed by the free use of barnyard manure, or, if convenient, by the addition of sand. If wet, or inclined to hold an excess of moisture, it should be underdrained, preferably by tile; but if possible, a location should be selected naturally dry and free from surface water.

A dark colored soil, or one supplied with a goodly portion of decayed vegetable matter, will produce the earliest crops. If the soil be shallow, it should be deepened gradually by plowing or spading an inch or two deeper each year, and not all at once by trenching or subsoiling, unless manure and money both be abundant. A sandy soil may be greatly improved by adding more or less vegetable mould from the woods. To produce the best results, the vegetable garden should have at least one foot of good, rich soil. The roots of large trees should not be allowed to encroach on any part of the garden, though large trees, especially evergreens, sufficiently far off, afford a valuable protection on the north and west.

Mark the garden off into squares or beds of convenient size, to facilitate the practice of a rotation of crops, which is an important matter. As a rule, never let the same crop or kind of vegetable occupy the same bed or spot two years in succession. Potatoes, onions, and a few other things may form an exception to this rule, but it is nevertheless better to keep up rotation. Every year these beds must be warmed up by a liberal coat of manure, which should be thoroughly mixed with the soil. Grow everything in drills or straight lines. Larger crops from a given surface are grown in this way, and cultivation becomes simple and comparatively easy. The space between the drills, and other special information, is given in the body of the Catalogue; the least distance is named, in order to economize space; it might be increased in some cases with advantage. The ground should be frequently hoed, to kill the weeds and keep the soil mellow; and the proper time to hoe is just when the weeds appear above ground. Briefly, the proper way to kill weeds is never to let them grow; but whether weeds appear or not, the ground should be frequently stirred.

Much time may be gained by starting certain kinds of plants in a hotbed, or even in a coldframe, the latter heing a very convenient thing, even on a small place. The hotbed is chiefly intended for raising early Tomatoes, Eggplants, Peppers, Cabbage, Cauliflower, Lettuce, etc., but as all these plants can now be bought cheaply of the seedsmen at the proper time, the expense and labor of a hotbed may be dispensed with, especially on small places.

To Prepare a Coldframe.- The coldframe is simply a frame set on the ground, no bottom heat being applied. It is banked up on the outside during the winter with salt hay, straw or coarse litter. The soil is prepared by forking in and thoroughly mixing to the depth of 10 or 12 inches a liberal quantity of old, wellrotted manure. The manure of an old hotbed is good for the purpose. The frame is prepared in the fall, and young Cabbage, Cauliflower and Lettuce plants are set out in it in time to get well established before very cold weather. Cauliflower and Cabbage should be set down to the first leaf, and the soil made firm around the plants. The seed is usually sown, in the vicinity of New York, from the I 5 th to the 2oth of September, but the very early kinds some 8 or ro days later. The young plants will be ready to transplant in about 25 or 30 days. During cold nights and stormy days, the beds should be closely covered with the sashes, and these further protected by straw mats or shutters. Cauliflower needs more and closer protection than Cabbage, as it is rather more tender. During mild days admit air freely, the object being to keep the plants in a dormant state, without actual freezing, so that when spring comes the plants are in a forward state for setting out early crops. Seeds of Cabbage, Cauliflower, Lettuce and Radish may be sown in a coldframe in the spring from the last week in February to the first week in March. The frame should stand in a warm and sheltered spot, and be kept from freezing by mats or a thick covering of straw during cold nights.

\section{Directions for Making a Hotbed}

In the vicinity of New York, from the first to the middle of March is quite early enough to make a hotbed, and even a little later will do well enough. The time must vary according to the latitude. Provide a quan tity of fresh horse-manure from the stables, and add to this, if they can be had, one-third to one-half of its bulk of leaves. Mix them thoroughly, tramping down the mass in successive layers, and form into a large pile, so that fermentation will proceed, even in severely cold weather. In two or three days fermentation will be apparent by the escape of steam from the heap. Now turn again, and allow the heap to remain two or three days longer, or until the second fermentation commences. Make an excavation or pit $21 / 2$ feet deep, and of a size suited to the number of plants required. The pit will be better if built up of brick. It should be made in some dry, sheltered spot, facing the south or east, if possible. Hotbed sashes are usually $3 \times 6$ feet, and one or two sashes will give early plants enough for a small family. The frame for sashes should be 18 inches high at the back and 12 inches in front, which will give the proper slope to catch the sunlight. Cross-pieces should be placed for the sashes to slide on, to facilitate opening and shutting the frames. When everything is ready, the manure is placed in the pit and trodden down firmly in layers to the required depth, 2 to $21 / 2$ feet. Then put on the sashes, and keep the pit closed until the heat rises. At first it will probably be roo or more, which is too hot to sow the seed in; but in two or three days it will subside to $90^{\circ}$ or a little less, when the soil may be put on to the depth of 6 to 8 inches. The heat may be readily ascertained by plunging a thermometer in the manure. The soil should be of well-rotted sod (or common garden soil will do), mixed with about a third of fine, old manure, and in this the seeds may be sown thinly in drills 2 to 3 inches apart, and afterwards (as soon as out of the seed-leaf) either thinned out or else transplanted to another frame. Air must be given every mild day by raising the sashes at the back. Water with tepid water whenever necessary, and during cold nights and snow storms keep covered with mats or board shutters. Tomatoes, Peppers and Eggplants should be sown in a separate frame from Cabbage, Cauliflower and Lettuce, as they require more heat. The same directions may apply to hotbeds made on the surface of the ground, except that the manure should be at least a foot wider on all sides than the frame. 


\section{HORTICULTURAL BOOKS}

THE CYCLOPEDIA OF AMERICAN HORTICUL- PRICE TURE. By L. H. Bailey, of Cornell University, assisted by Wilhelm Miller, and many expert cultivators and botanists. 4 vols. Over 2,000 original engravings . price per volume, $\$ 500$

GARDEN-MAKING. All the information wanted by every one who buys a single packet of seed or grows one plant. Fully illustrated. 8vo, cloth ................. I 00

THE AMATEUR'S PRACTICAL GARDEN-BOOK. Directions for growing the commonest plants of house and garden. Illustrated. r2mo, flexible cloth .............. I o

NATURE'S GARDEN. By Neltje Blanchan, author of "Bird Neighbors." Wild flowers and their ins $a t$ friends and foes, with many superb colored plates and other illustrations. Made directly from the living wild-flowers. Cloth, 400 pages..........

The HoRTiculturist's Rule-Book. For the garden, fruit -farm and glasshouse. Cloth, 3 I2 pages . . . . . . . . . . .

THE NURSERY-BOOK. Complete details as to all forms of propagation, budding, grafting, seed-sowing, etc. Illustrated. Cloth, 365 pages...............

Forage Crops Other Than Grasses. How to cultivate, harvest and use them. By Thomas Shaw, Professor of Animal Husbandry at the University of Minnesota . . . . . .

SOILING CROPS AND THE Silo. By 'Thomas Shaw. How to cultivate and harvest crops. How to build and fill a silo. How to use ensilage. Cloth..........

HEDGES, WIND-BREAKS, SHELTERS AND LIVE FENCES. The planting, growth and management of hedge plants. By E. P. Powell. Illustrated . . . . . . . . . . .

PLANT-BREEDING. Treats of crossing, hybridizing, pollination, etc......... I 00

THE Forcing-Book. How to grow vegetables under glass. Cloth . . . . . . .

The PRuning-Book. A manual of pruning and training. Cloth, 540 pages .....

The Spraying of Plants. By E. C. Lodeman. A manual for the application of fungicides and insecticides. Cloth . . . . .

THE Soll. By Prof. Franklin H. King, of the Unversity of Wisconsin. Illustrated. 8vo, cloth, 303 pages ...........

IRRIGATION AND DRAINAGE. By F. H. King. Irrigation culture and farm drainage. 500 pages, 163 illustrations ........

THE FERTILITY OF THE LAND. The maintaining of the productiveness of the soil. By Prof. I. P. Roberts, Cornell University . . .

MILK AND ITS PRODUCTS. The nature and qualities of dairy milk, and the manufacture of butter and cheese. By Prof. Henry $\mathbf{H}$. Wing............

THE PRINCIPLES OF FrUit-GRowing. By L. H. Bailey. Necessary to every American fruit-grower. Illustrated. 8vo, cloth, 508 pages I 25

THE SuRvival OF THE UNLIKE. By L. H. Bailey. A collection of evolution essays. 8vo, cloth, 515 pages .......2 200
Evolution of OUR Native Fruits. By L. Price H. Bailey. Traces the origin and development of American fruits. Cloth, 485 pages . $\$ 2$ oo

Fertilizers. By Prof. E. B. Voorhees. Very practical, plain, clear, untechnical. 8vo, cloth, 335 pages ............ I co

Cabbage, Cauliflower and allied VEGETABLES. By C. L. Allen. Illustrated. Cloth . . . . . . . . . .

Asparagus Culture. Barnes \& Robinson .

Botany: THE STORY OF PLANT LifE. By Julia McNair Wright..........

BROOM CORN AND BROOMS ........

First Lessons in Agriculture. By Prof. F. A. Gulley, M.S. . . . . . . . . I oo

FLOWERS: HOW TO GROW THEM. By Eben E. Rexford . . . . . . . . . 50 Forest Planting. By H. N. Jarchow, LL.D. I 50 Fruit Garden. By P. Barty. New edition. 200 Grape Culturist. By. A. S. Fuller. New edition ............... I 50 How Crops Grow. By Prof. S. W. Johnson. 2 oo How to DESTROY INSECTS . . . . . . 20 How to Plan THE Home GaRden. By Samuel Parsons, Jr., late Superintendent of Parks, New York City . . . . . . . . I oo

Insects AND Insecticides. By Prof. C. M. Weed............... I 50

LANDSCAPE GARDEnING. By Samuel Parsons, Jr., late Superintendent of Parks, New York City. . . . . . . . . . . . .

LESSONS AND MANUAL IN BOTANY. By Prof. Asa Gray. 800 pages. Illustrated. . 2 50

MuSHROOMS: How TO GROW THEM. By William Falconer . . . . . . . . . . . . I oo

ORNAMENTAL GARDENING FOR AMERICANS. Long . . . . . . . . . . . . 200 PEACH Culture. By Hon. J. Alexander Fulton .. . . . . . . . . . . I 50

SMALl-Fruit Culturist. By And. S. Fuller I 50 SugAR. The sugar industry of America, cane sugar, beet sugar, culture of the sugar beet .

Practical Forestry. By A. S. Fuller .

THE GARDEN as considered in literature by certain polite writers. With a critical essay by Walter Howe. . . . . . . . . . . I 00

THE LEAF-COLLECTOR'S HANDBOOK AND Herbarium. By Charles S. Newhall. An aid in the classification of specimen leaves. Illustrated . . . . . . . . . . . . 200

THE NEW ONION CULTURE. A book that should be owned by every practical gardener. By $\mathbf{T}$. Greiner .........

THE PRINCIPLES OF PLANT CULTURE. A first-class all-round instruction book in horticulture. By Prof. E. S. Goff . . . . . . I 00

The Sugar Beet. By Lewis S. Ware . . 400 THE TREES OF NORTHEASTERN AMERICA. By Chas. S. Newhall. With illustrations . 2 50 TOBACCO LEAF. Its culture and cure, marketing and manufacture. By J. B. Killebrew, Ph.D., and Herbert Myrick, B.S. . . . 200 TOBACCo Culture. Full practical details . 25 TruCK-Farming at the South. By Dr. A. Oemler .......... I. 50 


\section{Specialties and Novelties in Flower Seeds}

\section{Midsummer Triumph Aster}

In growth and bloom this new sort is identical with the favorite Triumph Aster, the bushy little plants producing beautiful deep scarlet flowers of perfect incurved shape. But it differs from Triumph entirely by its extreme earliness, beginning to flower as early as the zoth of June and continuing in full bloom from the middle of July for a long period. It comes true from seed and makes a splendid early-blooming pot-plant. A very valuable new Aster. Per pkt., 30 cts.

\section{Triumph Aster, Carmine}

A valuable addition to the well-known Triumph class. It is of the same very dwarf compact habit and long duration and abundance of bloom. The large flowers open light carmine with a whitish center, and then change to carmine. A splendid sort for pot culture. Per pkt., 25 cts.

\section{Christmas-Tree Aster}

The name of this novelty alludes to the branching habit of the plant, resembling the regular horizontal arrangement of the branches on a fir tree. The plants grow about 20 inches high, and measure 24 to 28 inches across at the base. It is early and

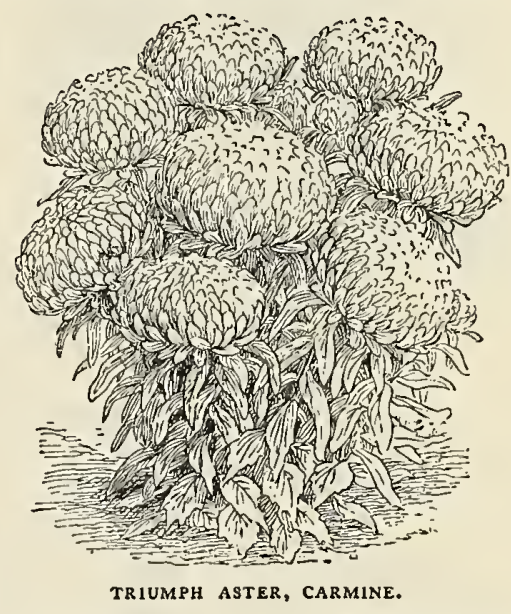

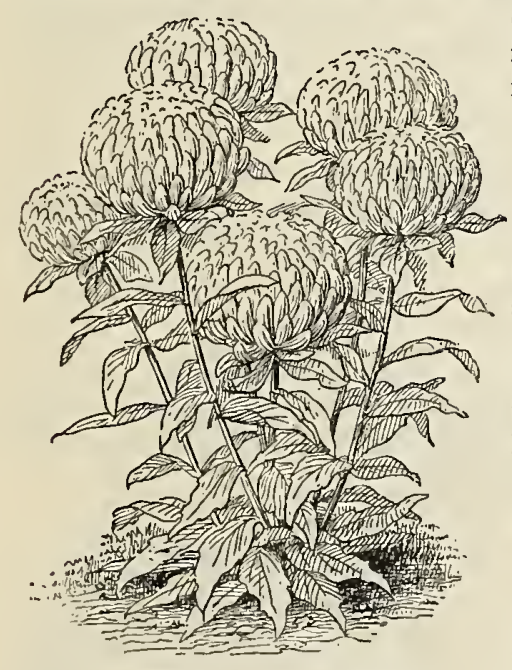

MIDSUMMER TRIUMPH ASTER.

exceedingly floriferous, many plants bearing 70 to 100 well-developed flowers, of which one always appears at the end of each stem. It is suitable for beds or for pot culture. Per pkt., to cts.

\section{Ageratum grandiflorum, Pure White}

This large-flowering pure white Ageratum will be welcomed as a valuable addition to this popular class. The flowers are perfect in shape, borne on strong stalks and have a delightful apple fragrance. They are thus first-class for cutting. The plants continue blooming for an exceptionally long period, from July till frost. They are also very suitable for pot culture in a cool house for winter cutting. Per pkt., 25 cts.

\section{Arctotis grandis}

The elegant habit of this new plant is shown by our illustration. It is an annual from South Africa, but grows perfectly in our climate. It forms neat, many-branched plants of about two feet in height and the same in breadth. The flowers are borne in great abundance from early summer to autumn. The stems are long and the flowers large and showy, from $2 \frac{1}{2}$ to 3 inches across. The ray florets are pure white on upper surface with a narrow yellow zone at their base; the under side of the petals is pale lilac. In the sunlight the flowers spread out almost flat, when the pure white of the ray florets contrasts beautifully with the light blue of the disk. A splendid novelty of easy culture which we recommend to all our customers. Per pkt., 25 cts.

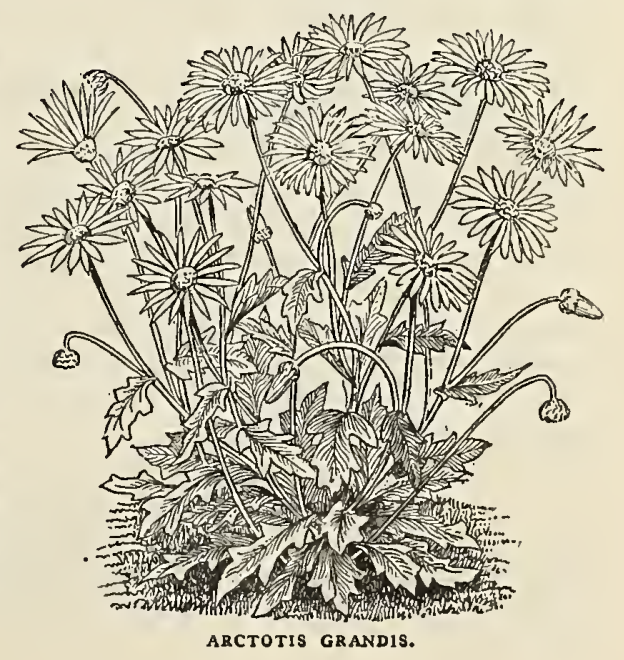




\section{Chrysanthemum Maximum, Princess Henry}

This hardy perennial Chrysanthemum lasts without any attention for many years and is one of the most useful of plants for cutting. "Princess Henry" is a new and highly improved strain, coming true from seed, and producing its handsome white flowers in great abundance. The flowers are often 4 inches and over in

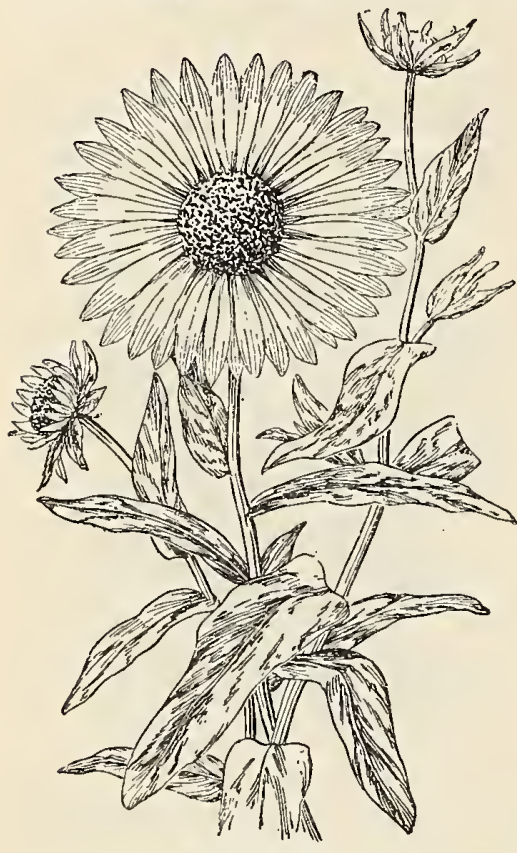

GAILLARDIA GRANDIFLORA FOLIIS AUREOVARIEGATIS. diameter. The plant grows very compactly, globular shaped, only 18 inches high and is very decorative. Per pkt., 2oc.

\section{Butterfly Cyclamen (Cyclamen persicum papilio)}

The new Butterfly Cyclamen may be justly called the most striking floral novelty of recent years. The flowers have finely curled or gracefully waved petals. In color they exhibit all the variety of shades of the old class; that is, from pure white to dark red, and also such tints as creamy white, light yellow and greenish yellow. These mostly appear as bordering to other colors, producing most charming effects. The flowers are borne on long slender stems, and are thus suitable for bouquets. The plant flowers profusely and for a long time, and makes a most desirable pot-plant for room decoration. Awarded first-class certificate at the Ghent, London, Paris and Antwerp exhibitions. Per pkt. of ro seeds, 50 cts.

\section{Erigeron aurantiacus hybridus}

While the ordinary "Orange Daisy" bears only one or two flowers on a stem, this new hybrid produces many branched flowerstems about a foot in height, with numerous large flowers $1 \frac{1}{2}$ to 2 inches in diameter, and in all shades of delicate coloring from white to rose and from yellow to deep orange. It is a valuable addition to the list of early-flowering perennials. Per pkt., $30 \mathrm{cts}$.

\section{Eschscholtzia Californica caniculata rosea}

A new and distinct form of $E$. Californica, or California Poppy. The form of the flowers is quite unlike that of any other Eschscholtzia, the petals being delicately channeled or fluted with tiny folds radiating from the center. The color is rosy white, exquisitely tinged with soft primrose yellow. Per pkt., 20 cts.

\section{Pillar-Shaped Forget-Me-Not, "Royal Blue"}

This new class is remarkable for its erect habit, the branches all growing perpendicularly, and very close together, so that each plant forms a regular pillar or column. The flowers are very large and of a splendid deep dark blue color, and produced so abundantly as to make a brilliant mass of rich color. It is most suitable for growing in pots and for edging and bedding. Per pkt., $20 \mathrm{cts}$.

\section{Gaillardia grandiflora foliis aureo-variegatis}

The Gailliardia grandiflora is one of the most popular hardy perennials, and is equally valuable as a cut flower or as a long and free-blooming border plant. The new variety, now first offered, has the foliage marbled and blotched in golden yellow, as shown in our illustration. This characteristic is displayed as soon as the leaves unfold, and extends almost to the buds, thus producing a charming contrast to the magnificent flowers. This novelty is a welcome addition to the small group of variegated-leaved perennials. Per pkt., 20 cts.

\section{Godetia, Rosamond}

An exquisitely beautiful new variety, with very large, glossy, light pink flowers-a rare shade among Godetias. It is of very neat dwarf compact habit, and very effective for bedding or for borders. Per pkt., 20 cts.

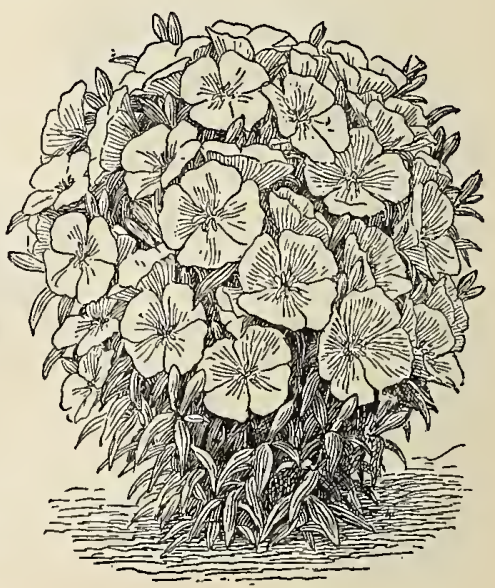

GODETIA, ROSAMOND. 


\section{Imperial Japanese Morning-Glory}

A new class of Morning-Glory from Japan. The flowers are of exquisite beauty in form and coloring, and of enormous size, often 5 to 6 inches in diameter. They are easily cultivated, and grow rapidly to a height of 30 or 40 feet. The colors vary from pure white to rose, crimson and carmine, through blues and purples to almost black, some being mottled, striped, penciled and bordered in infinite variety and diversity. The foliage also is often prettily variegated in coloring, and varies much in form. Per pkt., ro cts.

\section{Yellow Japanese Morning-Glory}

The flowers are light sulphur color, and produced in great profusion. The foliage is quite unique, being curiously crinkled and curled, giving a peculiarly sleepy and oriental effect. Per pkt., ro cts.

\section{Pansy, "Masterpiece"}

This superb new Pansy is distinct from all others in the form of flowers, the border of every petal being conspicuously undulated and curled. The flowers are extremely large and nearly all of them exhibit this peculiarity. The curled petals give the flowers a fuller and more globular appearance than those of other

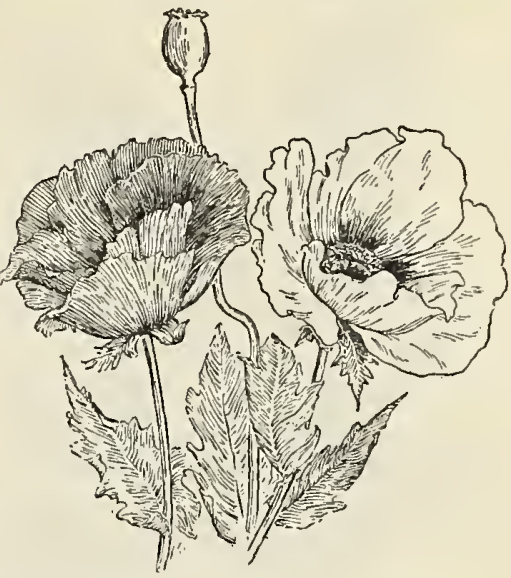

PAPAVER ORIENTALE HYBRIDUM. classes of Pansy. This new class is remarkable also for the wonderful combinations of color which it shows, including some tints hitherto unknown in Pansies. The plants are very vigorous and bloom profusely. Per pkt., 25 cts.

\section{Papaver orientale hybridum}

By artificial crossing three splendid new colors have been obtained in this popular class. The Oriental Poppy is perfectly hardy and perennial and succeeds anywhere. The new colors now offered are Rose, Lilac and Copper-Red, a mixture which in the open ground will produce a gorgeous effect. For large bouquets these giant brilliantly colored flowers will be found very valuable. Per pkt., $15 \mathrm{cts}$.

\section{Petunia hybrida, Thorburn's Century Prize}

This strain surpasses in size, perfection of form and coloring anything ever offered. It is saved only from flowers hand-fertilized or hybridized by crossing. The flowers are of gigantic size, and extremely deep-throated. The colors are infinitely varied, many of them intense and some of them in combinations hitherto unknown in

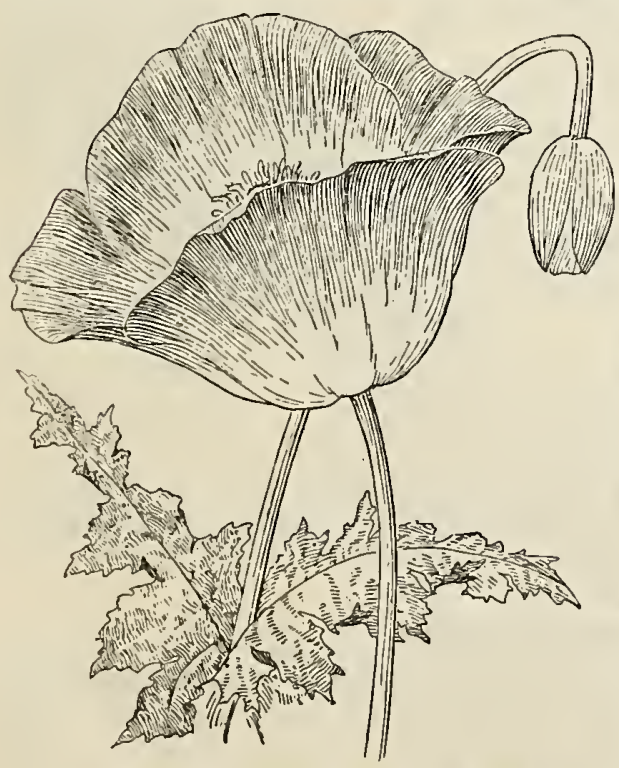

SINGLE PAEONY-FLOWERED POPPY, MISS SHERWOOD.

Petunias. Per pkt., 50 cts.

\section{Poppy, Single Pæony-Flowered, Miss Sherwood}

One of the most delicately beautiful flowers ever introduced. Its elegant form is shown by our cut, but the color is indescribable. It is a shining satiny white, with the upper half of the corolla silky chamois-rose-a combination quite virginal in its delicacy. The plants are very robust, growing about $2 \frac{1}{2}$ feet high, with noble foliage. It comes quite true from seed. The flowers are of great substance and fine for cutting. Per pkt., $20 \mathrm{cts}$.

\section{Pyrethrum roseum hybridum grandiflorum}

An extra large-flowering strain of the beautiful hybrids of Pyrethrum roseum. The flowers often measure as much as 4 inches in diameter, and present all the variations of color between light rose and deep carmine. Their vivid colors and duration of bloom make them most effective in the open border, either singly or in groups, while the large, long-stalked, ray-shaped flowers are unsurpassed for cutting. Few hardy perennials are so handsome. Pkt., 25 cts. 


\section{Thorburn's New Salvia splendens, "Silverspot"}

For many years we have grown Salvia splendens on a large scale, and have given much attention to its improvement. The well-known $S$. splendens nana compacta erecta (largely advertised as "Bonfire") was

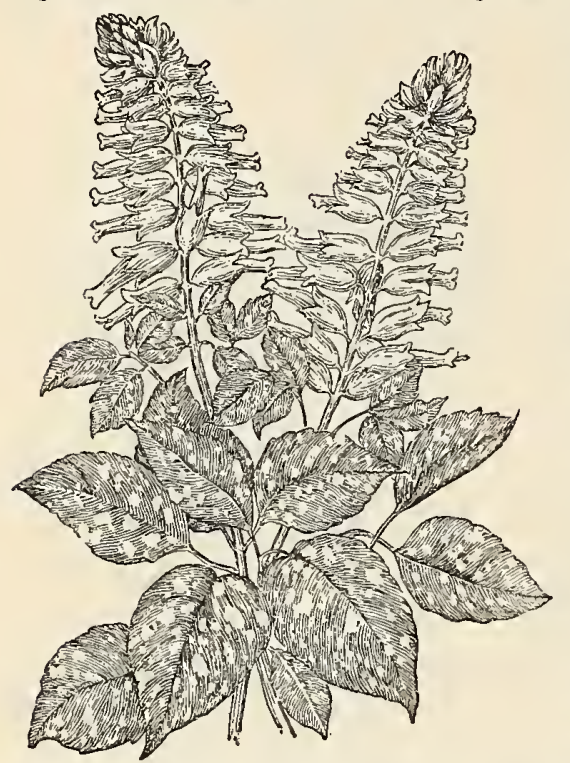
first introduced by us, and we are confident that the popularity which that variety has earned will be eclipsed by the popularity of the novelty we now offer. Its most distinctive feature is its strikingly handsome spotted foliage. The leaves are rich, soft dark green, with light sulphur or cream-colored spots of various sizes liberally sprinkled over them. It is impossible to describe in writing the charming effect produced by these spots. The unique and elegant foliage is very abundant, and has an extremely fresh and healthy appearance. The intense, bright scarlet flowers are very large, and the plants of neat, compact habit, and as floriferous as the ordinary sorts. In four years' trials we found that 85 per cent came true from seed. Per pkt., 25 cts.

\section{Winter Stock, "Empress Elizabeth"}

This splendid large-flowering Stock grows about 18 inches high, with a very strong main stem and many branches in candelabra form. Both main and side stems are covered with large, rose-shaped flowers of the brightest imaginable tints of carmine-rose. The whole plant forms a grand pyramidalshaped bouquet, the charming effect of which is enhanced by the bright green foliage. It blooms early, stands unfavorable THORBURN'S NEW SALVIA SPLENDENS, "sILvERSPot." weather well, and produces about 70 per cent of double flowers. It is not only an excellent plant for pots and groups, but also a cut-flower of the first rank. Per pkt., 25 cts.

\section{New Sweet Pea, Mont Blanc}

So much has been done in the past few years in improving Sweet Peas that it seems as if perfection has already been attained. The size and number of the flowers have been greatly increased and hundreds of new shades and combinations of colors obtained. Attention is now being directed to habit of growth and to earliness, and Mont Blanc, the new pure white now offered, marks a great advance in both these directions. The plant is neat and dwarfer than other sorts, but its peculiar merit is its extreme earliness, being at least a week earlier in flowering than the earliest sort hitherto grown. The flowers are of the purest white, very large and borne clear above the foliage.

Sown under glass on February 20, Mont Blanc produced its first flowers on May I, and was in full bloom on May ro. It may, therefore, be highly recommended for forcing, for which Sweet Peas are now being largely used with success. The elegant form of the flowers is shown by our illustration. Per pkt., 2oc.

\section{Aster Sinensis}

THE TRUE ORIGINAL SINGLE TYPE FROM CHINA

This plant was described in "The Garden," as being "far more elegant in habit and beautiful in flower than any of the

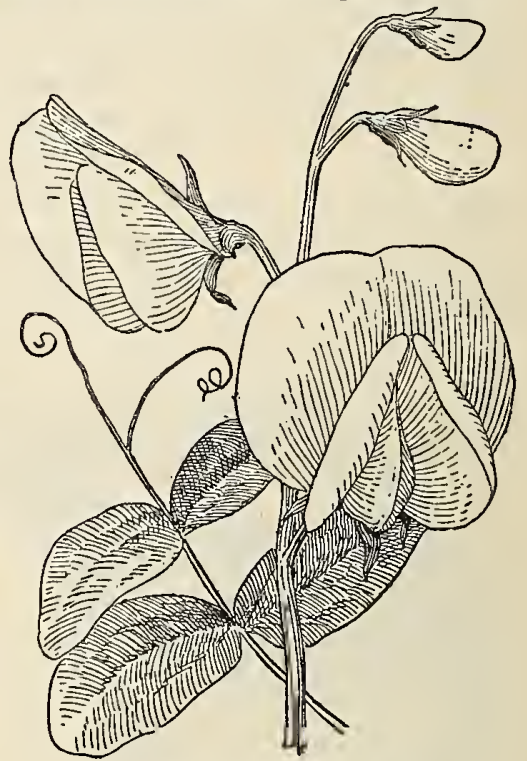

NEW SWEET PEA, MONT BLANC. garden forms of Asters now in cultivation." The plants are of branching habit, about ${ }_{5} 5$ inches high; the flowers are 3 to 4 inches across, and have a single row of delicate pale mauve ray florets, with a golden central disk. A first-class border and cutting plant that cannot be too highly recommended. Per pkt., r5c.

\section{FERN BALLS (Davallia bullata)}

We have imported some of these interesting Ferns from Japan. They are easily grown and occupy little space, being suspended in the room. In the fall the leaves die off, and the plants need a rest for two months, during which time it is recommended to keep them out of doors. The frost does not hurt them, but when taking them in, they should be gradually thawed out. We handle only the long-leaved variety. Price, 50 cts. each. 


\section{Specialties and Novelties in Vegetable Seeds}

\section{Marvel of Paris Bean}

We again invite special attention to this most excellent ${ }^{-}$Bean. It ought to be more widely known. For family use it is one of the very best, being extra-early, extremely productive, wit - long slender pods of a bright green color, very tender and of delicate flavor. Per qt., $30 \mathrm{cts} . ; 1 / 2 \mathrm{pk}$., $\$ 1 ; \mathrm{pk} \$ 1.75$.

\section{Golden Crown Stringless Wax Bean}

This new and distinct Bean is remarkable for handsome appearance, extreme productiveness, freedom from string and fine quality. It is a true bush in type, of vigorous growth, producing in addition to the mat of pods in the center, numerous spikelets, bearing pods well above the foliage, to which peculiarity its name refers. The plants are very healthy, free from rust and blight, and ripen their pods very early. Besides its great value as a string Bean, the beans are also excellent dried, being about the size of White Kidneys and of fine flavor. Per $1 / 2$ pt., 25 cts. ; pt., 40 cts. ; qt., 75 cts.

\section{Jones' Stringless White Wax Bean}

A splendid new Bean obtained by crossing the Yosemite Mammoth Wax with a white seed cross of the old Ivory Pod Wax. The pods are perfectly round, very solid, of a delicate light yellow color, and perfectly stringless and brittle. In habit it is dwarf and stocky, very vigorous in growth, absolutely rust-proof and extremely productive. Per $1 / 2 \mathrm{pt} ., 25 \mathrm{cts}$; $\mathrm{pt}$, $40 \mathrm{cts}$.; qt., $75 \mathrm{cts}$.

\section{Red Pickling Cabbage, "Niggerhead"}

The name refers to the very dark red-almost black-color. The head is solid, heary and stone hard, and is highly recommended for pickling. Per pkt., $20 \mathrm{cts}$.

\section{Celery, Thorburn Fin de Siècle}

A green winter Celery deserving special notice. After growing to a great size, it lends itself readily to the blanching process, assuming a rich yellow tinge in the heart, and presenting a very attractive appearance. As to its more important qualities, we may mention that a large Celery-grower, who has had it for trial several years, pronounced it the very best for market purposes of all the sorts he grows. With ourselves it proved to be the largest, hardiest, solidest, crispest, oest keeping and best shipping winter Celery we know of. Per pkt., 5 cts. ; oz., 30 cts. ; $1 / 4 \mathrm{lb} ., 85$ cts. ; lb., $\$ 3$.

\section{Giant Crystal Head Lettuce}

A new strain of Cabbage Lettuce remarkable for size, firmness, weight, productiveness and long-keeping qualities. The outcide leaves are bright green, slightly fringed and tipped red. The inside is crystal white with a yellowish heart, of fine flavor, and very crisp and tender. Per pkt., 25 cts.

\section{New Pea, "Athlete"}

This new Pea is quite distinct in several respects. It is of remarkably vigorous growth, the stems being often over three inches in circumference and so spreading that the seeds should be sown at a distance of 3 feet apart. Each plant requires a strong pole to be tied to as it develops. The yield of peas is enormous and the plants continue bearing for a long period. The quality is said to be very good. Should be planted in rich soil. Per pkt., 25 cts.

\section{Pepper, Chinese Giant}

An extra large new sort, very early and productive, thick-fleshed and very mild. The plant is of dwarf habit and vigorous growth, and the fruits of the brightest scarlet color. A decidedly valuable acquisition. Per pkt. of 30 seeds, 10 cts.

\section{Pepper, Giant of Valencia}

This new Pepper has enormously large, very fleshy fruits of a bright scarlet color and very mild flavor. Per pkt., I 5 cts.

\section{Radish, Sakurajima Mammoth}

A Japanese Radish growing about 3 feet in circumference and weighing from 20 to 30 lbs. It is by far the largest Radish in existence. Per pkt., $10 \mathrm{cts}$. ; oz., $30 \mathrm{cts}$.

\section{The Thorburn Century Tomato}

This fine new Tomato is entirely worthy of the occasion to which its name refers. An illustration of it, taken from a photograph, appears on Plate No. XIV. It is quite distinct, very large, extremely productive and as early as Atlantic Prize. The fruits are of a fine dark scarlet color, perfectly smooth, thick and always full and plump. Per pkt., 25 cts.

\section{Turnip, Tennoji}

A very large, flat, Japanese Turnip, growing about 8 inches in diameter. Per pkt., so cts. ; oz., 30 cts. 


\section{VEGETABLE SEEDS}

195ease notice that we pay postage or express charges on all seeds in packets or ounces.

See inside front cover of this Catalogue for Complete Assortments of Vegetable SEeds of approved and choice sorts for from $\$ 5$ to $\$ 25$.

\section{ARTICHOKE}

\section{ARtichaut Alcachofa ârtidjode}

Culture.-Deep, rich, sandy loam, with plenty of well-rotted manure. Sow seeds in April and May, and when large enough transplant into rows 3 to 4 feet apart and 2 feet in the rows. They reach maturity the second year. When cold weather sets in bank the earth to the top, first cutting off and tying up the leaves so that they will occupy less space, and in the spring fork in a dressing of manure. Artichoke may also be treated as an annual by sowing the seed in hotbed during February and transplanting in May. The heads should be cut off and used as they get ready. If left to ripen on the plant they will exhaust it, and no more will be produced that season. Heads are unfit for culinary purposes after the flowers expand.

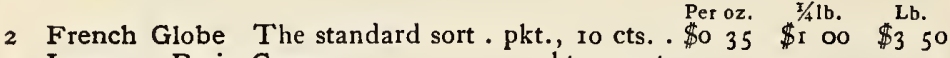

3 Laon, or Paris Green . . . . . pkt., Io cts. . 40 I oo 400

4 Early Purple, or Violet . . . . . . " Io cts. . 40 I oo 4 oo

5 Italian Purple ................ 35 I oo 350

6 Large Flat Brittany . . . . . . . . . . . . 40 I $00 \quad 400$

7 Jerusalem Artichoke... . qt., 20 cts.; bus., $\$ 4$.

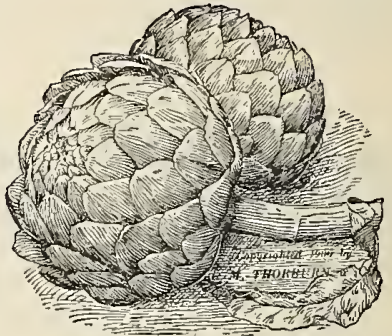

FRENCH GLOBE ARTICHOKE.

\section{ASPARAGUS}

\section{Asperge Esparrago Spargel}

Culture.-Sow the seed thinly in rows I foot apart in April or May ( 4 to 5 lbs. to the acre), and keep down all weeds. To secure strong, healthy plants, thin out the seedlings to 3 or 4 inches in the rows, saving only the strongest. The I-year-old plants should be set out in spring, in a rich, sandy loam, A. $\mathrm{ug}$ I8 inches deep, into which has been worked plenty of well-rotted manure. If a stiff clay soil is all that can be had, add plenty of sand and sifted coal ashes to loosen it up, and also see that it is well underdrained. In planting for private use, set out in beds 5 feet wide, three rows in a bed, the outer being each I foot from the edge, and allow 12 inches in the rows; set the plants at least 6 inches below the surface. If set out in autumn, top-dress with 6 inches of manure. For market on a large scale, set out

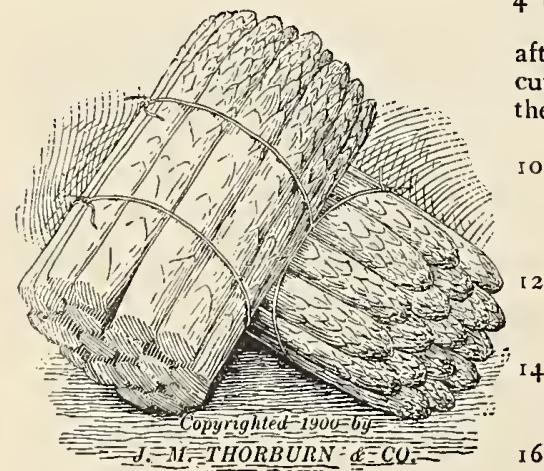

ASPARAGUS. 4 by $I \frac{1}{2}$ feet.

Every fall a good dressing of coarse manure should be applied after the tops have been cut, and in the spring forked in. Never cut too closely. The roots need the benefit of some foliage during the year, else they will weaken and die.

Io Colossal. The most approved and standard Per oz. $3 / 4 \mathrm{lb}$. Lb. sort. The famous Argenteuil of the French is identical with it.....\$o ro \$o 20 \$0 50

Two-year-old roots . 100, 75c.; $1,000, \$ 6$.

Palmetto. Of southern origin; a very desirable bright green Asparagus $\quad . .10 \quad 20 \quad 50$

Two-year-old roots . 10o, $75 \mathrm{c}$.; $1,000, \$ 6$.

Barr Mammoth. Has very large, tender stalks of a very light color......... Io $20 \quad 50$

Two-year-old roots . 100, $75 \mathrm{c}$; 1 , 000, $\$ 6$.

Columbian Mammoth White. A variety producing large white shoots . . . . 10 $20 \quad 50$

Two-year-old roots . . I00, \$1; 1,000, \$7.

\section{BORAGE}

The young leaves of this annual, which smell somewhat like a Cucumber, are used as a salad, or boiled like Spinach. Should be sown at intervals, as the leaves are palatable only when young. Sow in the spring, in light soil; transplant in shallow drills, a foót apart, when of six weeks' growth. 


\section{BEANS}

As a farinaceous food for man, the Bean is considered far superior to any other legume, and next in importance to wheat. The modern varieties leave little to be desired; the great care given to their improvement has resulted in superior sorts, greatly extending the season of use, as well as varying of flavor.

Culture.-About the first of May select a warm, dry, sheltered spot; dig and manure slightly; make drills 2 inches deep and 18 inches to 2 feet apart; drop the beans 3 inches apart in the drills, and cover not more than 2 inches deep. Hoe well in dry weather to keep down the weeds. Sow every two weeks for a succession.

\section{DWARF GREEN-PODDED SNAP BEANS}

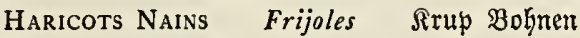

Thorburn Prolific Market Bean. Enormously productive, the light green pods being borne in thick clusters; pods long, round, solid. . . . \$o 30

Marvel of Paris. Long, slender, flat pods; early and productive . . . 30

New Everbearing, or Inexhaustible. A new and quite distinct variety, very prolific, and continuing to bear for a long time. It is the earliest of all the Dwarf Beans. The pods are green and flat, and the beans small, white, kidney-shaped ... . . . . . . . . . . . .

Triumph of the Frames. A dwarf green-seeded variety, which, by its extreme earliness and small size, is the best of all for growing in frames . .

Emperor of Russia. Extremely productive new French sort, of the finest quality; coffee-colored pods

Vienna Forcer. Extra-early, dwarf, very suitable for forcing; extra long, flat, slender green pods; stringless . - * - * * . . . . .

Ne Plus Ultra. An extra-early sort; green, full, flat pods; exceedingly productive; also suitable for forcing . . - . - . - . - . - . colored beans. An improvement on the old Dun-colored . . . . . 30

Best of All. Early and superior; round, green, fleshy pods . . . . . . 30

Extra-Early Valentine. Early strain of this popular round-pod Bean . . 25

Early Mohawk. Long, flat and straight pods; very hardy and productive . 30

Early Warwick. Extra-early green bush Bean; short flat pods; fine market sort. 30

Early China. White, pink eye; early and bears long; flat pods . . . . 25

Pride of Newtown. Light green flat pods; very early and productive . . . 30

Long Yellow Six Weeks. Early; leading market sort; full, flat, green pods . 30

Round Six Weeks. Full, green, roundish pods; very early and productive . 30

Dwarf Horticultural. Late and productive; flat pods ... . . . . . . . 30

Dwarf Chocolate. Very early ; long, slender, flat green pods ; small chocolate-colored beans; very productive ............. . 30

Longfellow. Long, straight, round, solid green pods; fine quality . . . . 35

Lightning. Extra-early, very productive and of fine quality. . . . . 35

Byer Dwarf. Round pod, very productive and of fine quality . . . . . . . 30

Stringless Green Pod. Extra-early; quite stringless; very prolific; fine quality. 30 Giant Green Pod Stringless. A new and improved extra large podded strain of the above fine sort . . . . . . . . . . . . . . . . . 35

Dwarf Lyonnaise. A fine sort, with very long, roundish, slender pods . . . 30

Victoria Dwarf Flageolet. Enormous leaves; very large, handsome beans, white, striped violet; extra long, flat, slender green pods . . . . . . 35 Refugee, Thorburn Extra-Early. Has all the superior qualities of the famous Refugee, and is fully two weeks earlier in podding. . . . . 30 Late, or 1,000-to-1. Medium to late; very productive and tender; largely grown for main crop; round pod . . . . . . . . 30 Golden. Pods of very light green color; of strong growth, and very productive. One of the best in every respect . . . . . . . . 30 “ Galega. An improved, large Late Refugee; very productive . . . 30

I 25

\section{DWARF WAX BEANS}

8o Thorburn Valentine Wax. First in earliness, first in productiveness, and first in quality. A perfect Valentine Bean, with wax pods. (See Plate I.) $\$ 0$ 30 $\quad \begin{array}{lllllll}\text { I } & \text { \$I } & 75 & \$ 6 & 50\end{array}$ Thorburn Refugee Wax, Stringless. A perfect Refugee, with long, round, yellow wax pods. Suitable for early or late sowing, and an immense

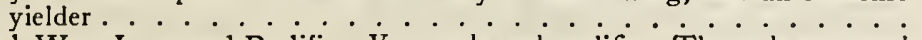

Black Wax, Improved Prolific. Very early and prolific. The pods are round,

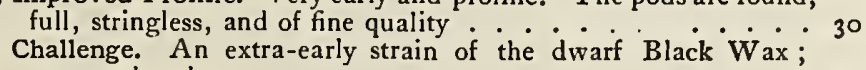

" Bound pods . Bismarck. Reser hling in growth Wardwell Kidney Wax * 30

" " Bismarck. Reserr hling in growth Wardwell Kidney Wax . . 30

" " Pencil-Pod. Very slender, long pods........... 35

92 Detroit Wax. Very much like Golden Wax; flat pods. . . . . . . 30
I 00

I 75

650

I 00

I 75

650

I 00

I 75

650

I 00

I 00

I 25

75

I 75

225

650

6
8

650 
DWARF WAX BEANS, continued

93

94

95

97

Flageolet Red Wax. Flat, yellow, stringless pods of great size .... . \$o qt. Improved Golden Wax. Very early; flat golden pods, long and stringless . 30 Golden-Eyed Wax. Very hardy and prolific, with flat yellow pods; very early and exceptionally free from rust; a very desirable and popular sort . . 30 Keeney Rustless Golden Wax. Golden yellow pods, thick and flat when young and semi-round later; stringless and of good quality . . . . 30 Wardwell Kidney Wax. Early; long, flat, purely wax pods; fine shipper . 30 Davis Kidney Wax. Long, handsome waxy white pods; beans white . . . 30 White Wax. Flat, yellow pods . . . . . . . . . . . . . . 30 Fillbasket Wax. Fine, round pod, stringless; thick-fleshed, tender, productive. 35 Yosemite Mammoth Wax. Very long, thick, solid pods, of finest quality - 40

1/2pk. Pk. "Bus. $\$ \mathrm{I}$ oO $\$ \mathrm{I} 75 \quad \$ 650$ I 00 I $75 \quad 650$ I $00 \quad$ I $75 \quad 650$ I $00 \quad$ I $75 \quad 650$ I 00 I $75 \quad 650$ I 00 I $75 \quad 650$ I OO I $75 \quad 650$

I $25 \quad 225 \quad 800$
I $50 \quad 250 \quad 850$

\section{WHITE BEANS}

I 10 Thorburn Dwarf Lima (Kumerle Strain). The dwarf form of our famous Challenger Lima - the finest of all Limas. It possesses the flavor of the genuine Challenger Lima, thus differing from all other Bush Limas. It is exceedingly productive, bearing from 50 to 60 pods on the bush. (See Plate II.). . . . . . . . . . . . . . \$o 40

I I Burpee Bush Lima. A bush form of the large flat Pole Lima, growing only 18 or 20 inches high; it is an immense yielder ....... 35

I12 Henderson Bush Lima, or Sieva. Productive ............ . . . 35

II3 New Everbearing. Extra early, very prolific; green, flat pods and small white, kidney-shaped beans . . . . . . . . . . . . . 30

I 4 Dwarf White Flageolet. Long white flageolet, with flat green pods; good as a shell bean .................. 30

I 5 White Kidney. Excellent, either green or ripe; for baking. . . . 20

I 6 White Marrow. Good either green or ripe; for baking. . . . . . . . . . 20

$\$ 1$ 50 $\$ 250 \quad \$ 900$

$\begin{array}{llllll}\text { I } 25 & 2 & 25 & 8 & 00\end{array}$

I $25 \quad 2$ O0 750

I $00 \quad$ I $75 \quad 550$

I $00 \quad 175 \quad 650$

$\begin{array}{lllll}75 & 1 & 25 & 4 & 00\end{array}$

$75 \quad$ I $25 \quad 400$

\section{ENGLISH DWARF BEANS}

\section{Feve de Marals Haba Grope Bohnen}

Culture.-Sow in drills 2 feet apart, as early in the spring as the ground can be worked (these are as hardy as Peas), in order to get them into pod before the heat of summer. When in pod break off the top of the plant to check the growth. Plant and hoe the same as for Dwarf Beans. A strong soil suits them best. These Beans are eaten shelled.

130 Early Mazagan. The earliest of this class ........... \$o qt. 25 132 Broad Windsor. The largest and best of the class of English Dwarf Beans . 30 133 Sword Long Pod. A size smaller than Windsor .......... 25

134 Green Windsor. A green "Long Pod"................... 30

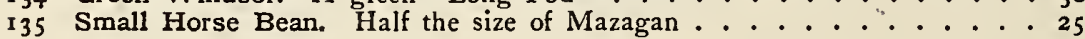

\begin{tabular}{|c|c|c|}
\hline $\begin{array}{l}1 / 2 \mathrm{pk} . \\
\$ 075\end{array}$ & $\stackrel{\text { Pk. }}{\$ 125}$ & $\begin{array}{l}\text { Bus. } \\
\$ 450\end{array}$ \\
\hline 90 & I 50 & \\
\hline 75 & 125 & \\
\hline 90 & I 50 & \\
\hline 75 & I 25 & \\
\hline
\end{tabular}

\section{POLE, or RUNNING BEANS}

\section{HaRicots a RAMES Frijole de Bejuco Stangen=\$ohnen}

Culture.-Sow as the soil becomes warm and dry, from the first part of May (for all except Limas) to the latter part of May, in hills 4 feet each way. Limas should not be planted until warm weather has fairly set in. One quart of Limas will plant about roo hills, allowing four or five beans to a hill, and of the smaller sorts about 200 hills. Poles 8 or ro feet long should be firmly set in the hills before planting seed.

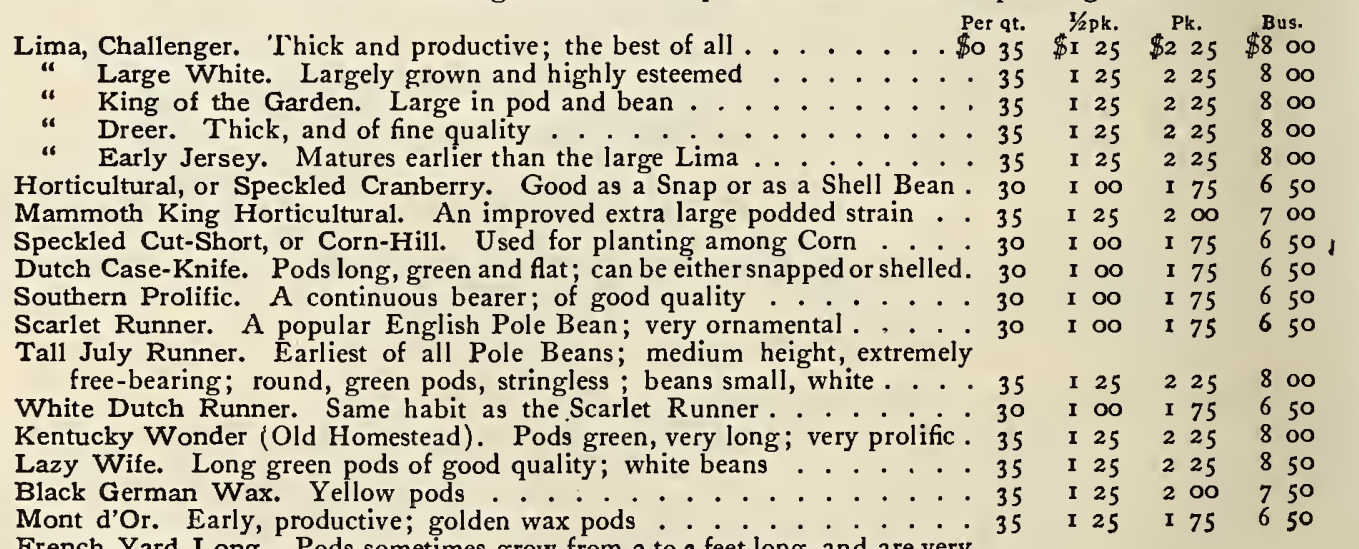

French Yard Long. Pods sometimes grow from 2 to 3 feet long, and are very slender, like a pipe-stem; very curious; should be grown on pea brush. 


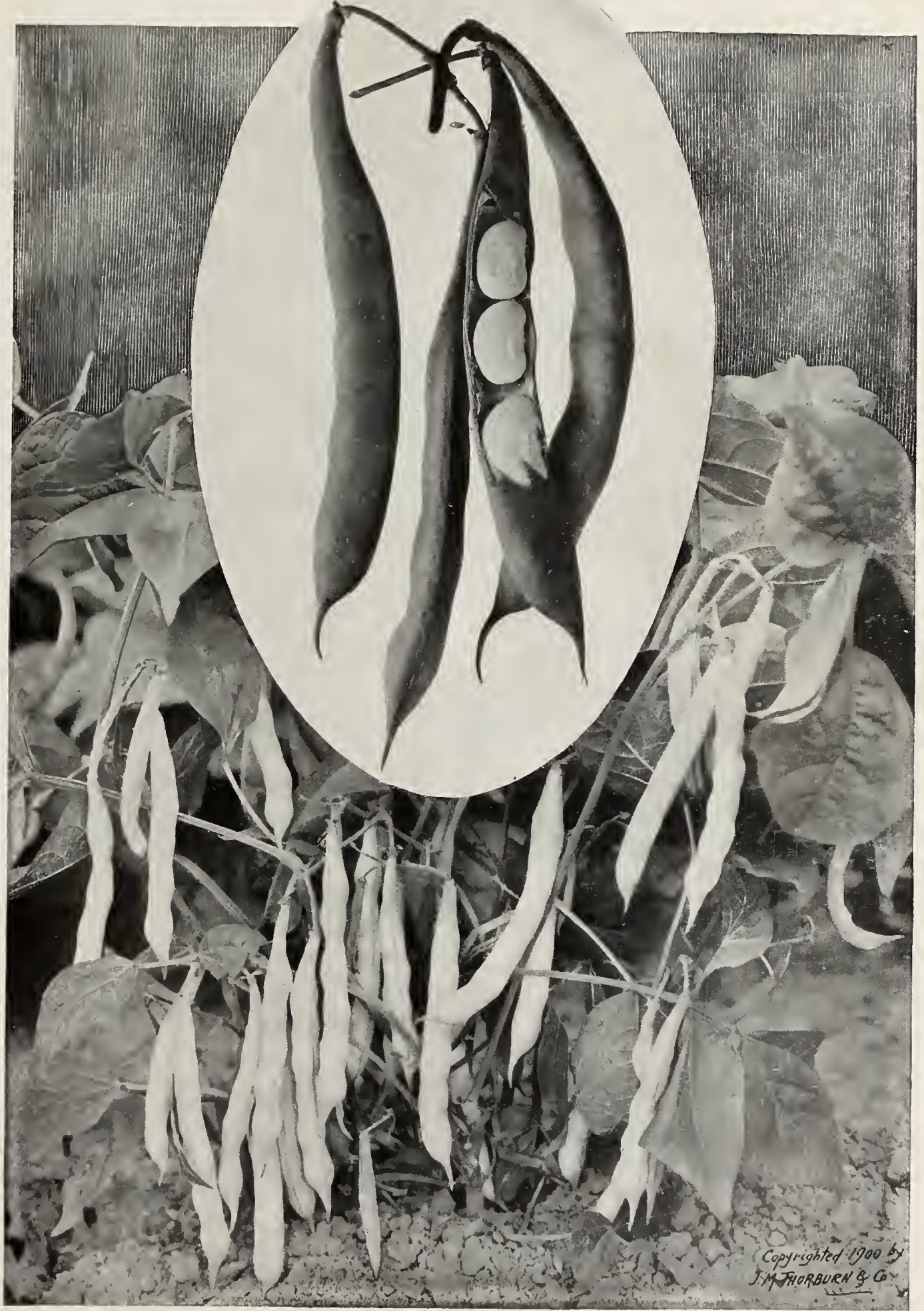

New Everbearing Bean

Thorburn's Valentine Wax Bean

Plate I 


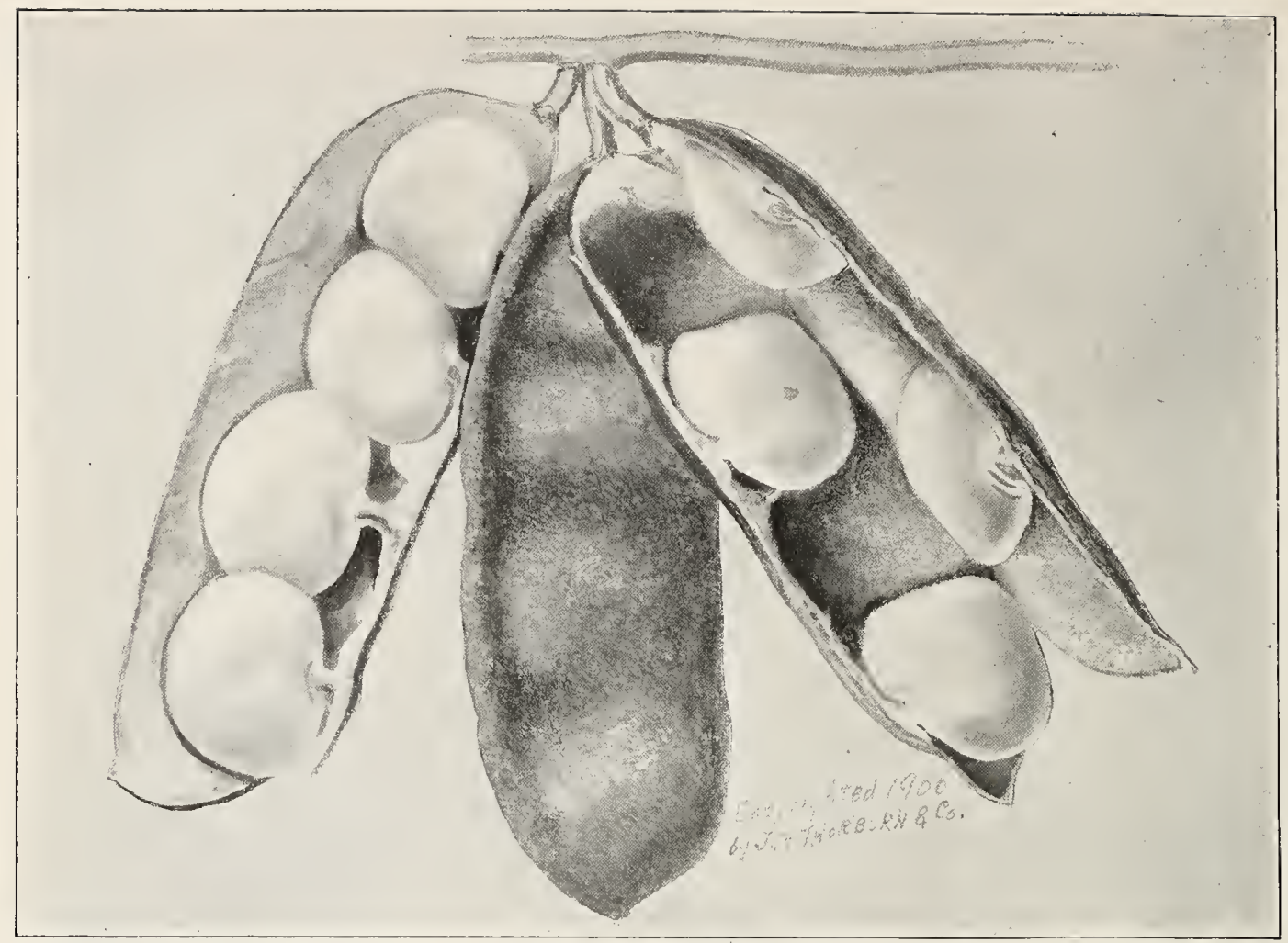

Thorburn Dwarf Lima Bean

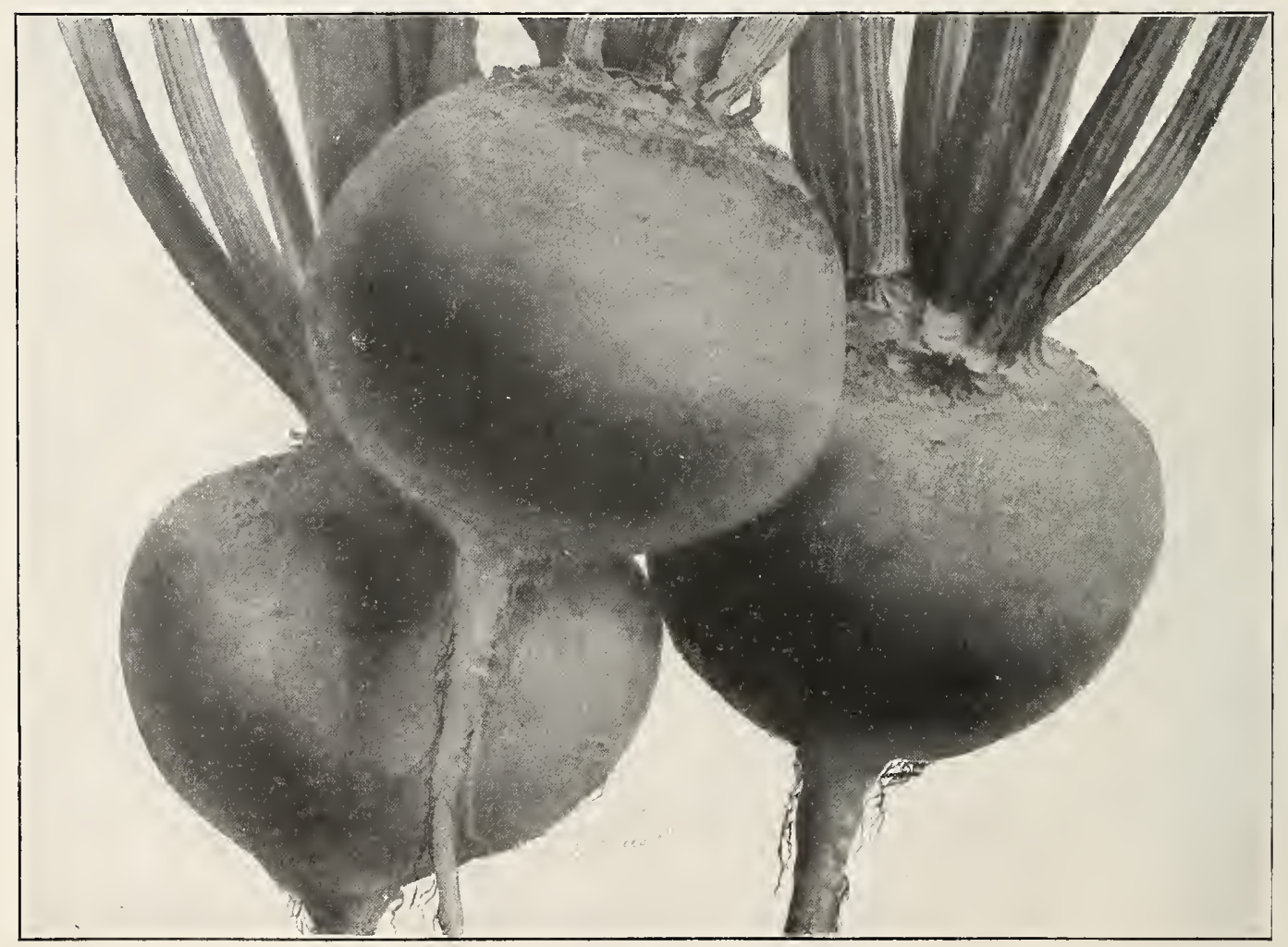

Columbia Beet

Plate II 


\section{BEETS}

\section{BetTerave Remolacha Salatrübe}

CULTURE. - Sow as early in the spring as the ground can be worked ( 5 to $6 \mathrm{lbs}$. to the acre), and every two weeks after for a succession, up to the first week of July. For general crop sow about the middle of May. The soil should be light, sandy loam, well enriched with stable manure, and plowed and harrowed until very fine. Sow in drills I foot to 15 inches apart, and when well up thin from 4 to 6 inches. The young Beets pulled out of the row are excellent used as Spinach.

180 Early Turin. Very early, round, deep blood color, tender ......... \$0 10 $\$ 020 \$ 060$

185 Detroit Dark Red Turnip. Fine round shape; skin dark blood-red; flesh bright red,

very tender and sweet......................... 2060

I86 New Crimson Globe. Fine globular shape; flesh rich deep purple, fine quality. . Io $25 \quad 75$

187 Egyptian. Very early, and of dark blood color; rather flat in shape ........ Io 20 I0

188 Crosby Egyptian. Extra-early, round, dark red . . . . . . . . . 10 2060

189 Eclipse. Very early; round-rooted and bright red ............... 10 2060

190 Electric. Extra-early, nearly round variety; bright red color and fine table quality . 10 $20 \quad 60$

192 Dewing Early. Of fine form and flavor, and good for market ......... 10 20 50

193 Bastian. An early, light-colored turnip Beet; good . . . . ...... 10 $20 \quad 50$

194 Columbia. A round, smooth-skinned variety, with deep blood-red flesh . . . . . ro 20 ro

209 Edmand Blood Turnip. A market-gardener's strain of great regularity in shape, and very dark flesh of best quality $\ldots \ldots \ldots$ ro 20 ................... 50

2 ro Early Blood Turnip. Dark red, and of fine flavor; good for winter . . . . . Io 20 10 45

2 I Bassano. Early; light color . . . . . . . . . . . . . . ro 20 ro 50

220 Half-Long Blood. Fine dark strain, for winter. . . . . . . . . . . . 10 2060

222 Black Queen. Very dark, half-long roots; leaves almost pure black . . . . . . 10 20 60

226 Victoria. Metallic red foliage ...................... 15 35 I 25

228 Dell. Black-leaved ............................... 35 I 25

230 Long Smooth Blood. A good late variety for winter . . . . . . . . . Io 20 . 50

\section{FOLIAGE BEETS}

These varieties are grown only for their handsome foliage, which is very ornamental and decorative.

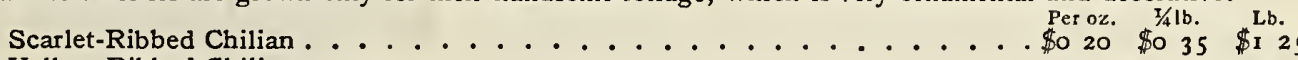

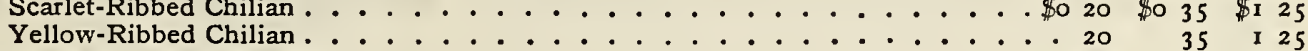

Crimson-Veined Brazilian ... . . . . . . . . . . . . . . . 20 35 1 25

Golden-Veined Brazilian. . . . . . . . . . . . . . . . . . . $20 \quad 35$ 125

Scarlet-Veined Brazilian. . . . . . . . . . . . . . . . . 20 35 I 25

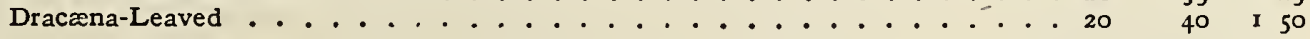

\section{MANGEL-WURZEL, SUGAR BEETS, ETC.}

Sunfelrüben

CULture.-As all Mangels require a deep soil in order to grow well, plow and subsoil at least a foot to 18 inches, and apply plenty of rich stable or Thorburn's Complete Manure. Sow in May or June ( 5 to 8

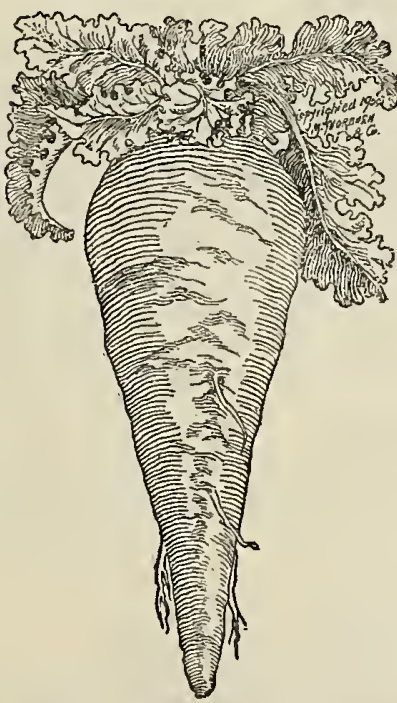

KLEIN WANZLEBEN IMPROVED OUGAR BEET. (See page 14.) pounds to the acre), in rows 18 inches to 2 feet apart, and thin to 8 inches in the rows. Young plants may be transplanted to fill up vacancies. Sow in addition, when the plants are 3 to 4 inches high, at the rate of $200 \mathrm{lbs}$. Complete Manure, 200 lbs. bone flour, and $400 \mathrm{lbs}$. salt per acre. As soon as frost occurs, dig the crop. But in order to be well preserved for gradual consumption during the winter, Mangel-Wurzels should be heaped to a height of perhaps 6 feet, on a dry, sloping situation; cover at first with a piece of canvas, and as the cold increases this should be replaced by about 6 inches of either salt-hay, straw, sea-weed, or corn-stalks. Lest this covering be displaced by the wind, a light layer of earth is necessary. As soon as this surface soil becomes frozen, about 6 or 8 inches more of earth should be placed over the entire heap. By following up this gradual process of covering, all danger of heating will be obviated, and the roots will keep in perfect order. Sow from 5 to 8 pounds to the acre.

\section{MANGEL-WURZEL}

260 Mammoth Long Red Mangel-Wurzel. Very Peroz. 1/4lb. Lb. large, selected strain ; enormously productive under careful culture. rolbs. and over, @ 25 cts. per lb. . . . . . \$0 10 \$0 15 \$0 30

26I Yellow Ovoid Mangel-Wurzel. Of distinct shape; one of the most productive sorts. ro lbs. and over@2 $25 \mathrm{cts}$. per lb. . . . Io 1530

263 Golden Tankard Mangel-Wurzel. Bright yellow; handsome and sweet, and very productive. ro lbs. and over @ 25 cts. per lb. Io 1530

We pay postage or express charges on all seeds bought by the ounce or packet. 
MANGEL-WURZEL, continued

267 Giant Yellow Intermediate. A very large yellow sort. Iolbs. and over@25c. per lb. \$o Io

268 Red Globe Mangel-Wurzel. Similar to the Yellow Globe; productive. Io Ibs, and

269 Yellow Globe Mangel-Wurzel. Large and productive; keeps well, and is relished by stock. Io lbs. and over @25 cts. per lb.

27I Orange Globe Mangel-Wurzel. Similar to the above, but of a deeper, richer color. ro lbs. and over @2 $25 \mathrm{cts}$. per lb............... ro $\$ 0$ I 15 \$o 30 $10 \quad 30$ I0 $15 \quad 30$ 10 Is 30

\section{SUGAR BEET}

In view of the increasing interest in the culture of the Sugar Beet, we have had grown for us, under the direction of men of long experience, a supply of the very choicest seeds of several highly improved varieties. On application we shall be pleased to mail circular giving directions for their culture. We recommend 20 to 25 lbs. of seed to the acre. We offer them, so long as unsold, at the following prices :

1 to 5 lbs. 5 to rolbs. 10 to 25 lbs. 25 lbs. and over per lb. per lb.

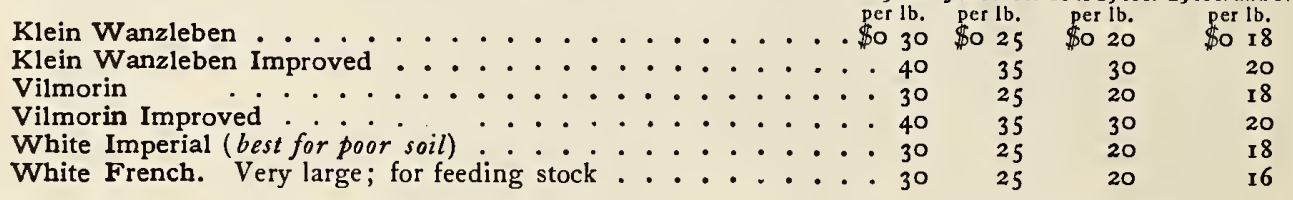

\section{BROCCOLI}

\section{Broccoll Broculi Spargelfogl}

Culture.-Sow early sorts as soon as the ground can be worked in the spring, in shallow drills, drawn 3 or 4 inches apart. Plant out 2 feet apart each way when the plants are about 4 inches high. Cultivate the same as Cabbage, in rich soil. Use the same remedies for insect attacks as are recommended for Cabbage.

The following are sorts best adapted to this climate, and the only ones which succeed generally; they are excellent, and deserve much wider culture than is usual in this country. We recommend No. 292 as the most certain to give satisfactory results.

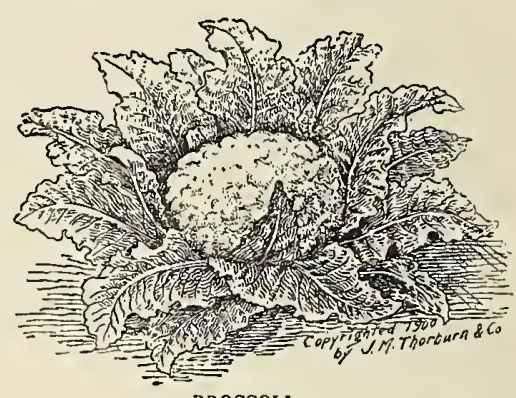

BROCCOLI.

$$
\text { Per oz. }
$$

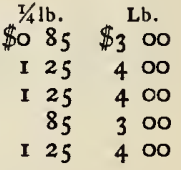

\section{BRUSSELS SPROUTS}

\section{Chou de Bruxelles Berza de Brusels Rojenfogl}

Culture.-Sow in May, in the same manner as Cauliflower, and transplant in July, I foot apart in the rows, which should be $I / 2$ feet apart. In gardens, both large and small, the Brussels Sprout is, without exception, the very best winter vegetable that can be grown. Not the least valuable point connected with the Brussels Sprout is that it is as hardy as the common Curled Greens. The common Cabbage is hardy enough in a young state, but when full grown and hearted, frost soon destroys the largest heads, which rot and fall to

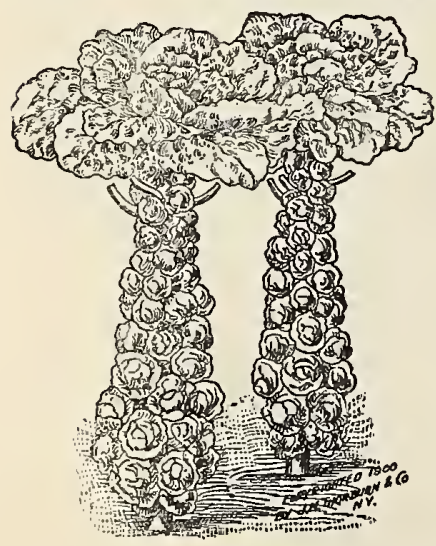

BRUSSELS SPROUTS. pieces. Not so the Brussels Sprout; being small and hard, it is not in the least affected by frost. The real Sprout is not much larger than a marble, and as firm and hard almost as the stalk itself. These are the sorts which cooks prefer. They strip off the outer covering, cook them whole, and serve them up artistically in that fashion. When cooked through and no more, such Sprouts melt in the mouth, like the tenderest Caulifiower, and are equally as good. If more widely known, the Brussels Sprout would be as popular as it is valuable; few people appreciate it at its full worth.

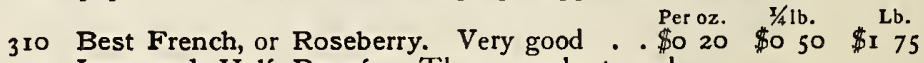
3 I2 Improved Half Dwarf. The very best and surest strain ........... 20 50 I 75

314 Improved Dwarf. Compact heads of fine quality. $\begin{array}{lll}25 & 25 & 25\end{array}$ 316 Improved Long Island Grown....... 40 I $25 \quad 400$

\section{BURNET}

\section{Pimpernelle Petite Pimpinela \$impernell}

The leaves have a warm, piquant taste, and are useful for salads and soups. Sow early in the spring, half an inch deep, thinly in rows. 320 Garden. Per oz., ro cts.; 1/4lb., 30 cts.; lb., \$1.

We pay postage or express charges on all seeds bought by the ounce or packet. 


\title{
CABBAGE
}

\author{
Chou Berza de repollo Rohl
}

CUlture.-Suil for Cabbage should be rich and heavy loam, with good drainage. On such a soil, with an abundance of stable or Thorburn's Complete Manure, excellent crops are sure to be grown. For early spring, sow in fall; not too early, or the plants are liable to bolt in the spring, instead of heading. In a month the plants will be fit to transplant to coldframes, where they are wintered, taking care, in planting, to set the young plants down to the first leaves. Transplant in spring as soon as the ground can be worked, setting the plants 2 feet apart one way and from 12 to 18 inches the other, according to the variety. If it is desirable to economize space, Lettuce or Radish may be sown between the rows, as they will be out of the way before the Cabbage needs the room. For late or winter crops the seed is sown in May, and the plants set out in July. In this case they are set in rows 2 by 3 feet, so as to work them with a horse and cultivator. To destroy the green worm that is so destructive to the leaves and heads of Cabbage and Cauliflower, an experienced grower says: "Take one ounce of saltpetre and dissolve it in 12 quarts of water; then take a shorthandled whisk broom, dip it in the solution, and sprinkle the plants well. One application is sufficient, unless the stuff is washed off by heavy rains. The liquid, being perfectly clear, never colors the Cauliflower or Cabbage heads." To prevent the turnip flea attacking the young plants, sift fine air-slaked lime or tobacco dust over them, as soon as they appear above the ground.

Early Spring. New, flat, extra-early Per oz. T/4Ib.

Early Sugar Loaf. Small, pointed; very early, fine quality . . . . . . . . I5

Early York. The standard English sort. . . . . . . . . . . . . I5

Large Early York. Larger than the above . . . . . . . . . . . . . I5

335 Express. Extra-early; small, solid heads of fine quality. . . . . . . . . . 25

336 Early Jersey Wakefield. Well known, and most valuable for early. (See Plate III.) 30

337 Charleston Wakefield. Very large strain of the above . . . . . . . 30

338 Early Winnigstadt. A standard second-early variety . . . . . . . . . . . . I5

340 Stein Early Flat Dutch. A remarkably fine strain; a sure header, the heads weighing from 10 to 12 pounds. Most valuable for forcing, or for general crop . . 25

Improved Early Summer. A superior second-early sort; produces large and solid heads of the finest quality .

Surehead Improved. Large, solid heads of fine quality . . . . . . . . 25

$3+3$ Selected All-Seasons. One of the finest for second-early or late, growing to a large size quickly and surely. The true sure-header $\quad . . *^{*}+. .25$

344 Succession Improved. An excellent second-early sort, on style of All-Seasons . . 30

$3+5$ Filder Kraut, or Pomeranian Pointed Head. . . . . . . . . . . . 20

346 Fottler Brunswick. Good solid heads, either for second-early or late . . . . . . 20

348 Large Late Drumhead. A standard winter Cabbage for main crop . . . . . . 20

350 Large Late Flat Dutch. Also a valuable main-crop sort for market . . . . . . . 20

352 Thorburn Market-Gardener's Private Stock Flat Dutch. Fine strain of the immense winter Cabbage grown on Long Island for market . . . . . . . . .

353 Thorburn Colossal. A new strain of the Private Stock, obtained by careful selection from immense heads only. It is an unfailing producer of heads of enormous size and of the finest quality. We recommend it as positively the finest winter Cabbage grown .................. . . . . 30

Autumn King. Extra-large solid winter Cabbage . . . . . . . . . . . . . 30

Danish Ball Head Winter, or Hollander. Very round, solid winter sort, largely grown in Denmark for the London market. A fine shipper. . . . . . . . 30

$35^{8}$ Green Glazed. Glossy green; suitable for hot climates . . . . . . . . . . . . . 20

359 Thorburn Improved Red Stone Head. Very large, solid red heads; the finest strain . 30

360 Savoy, Early Dwarf. The earliest Savoy variety; fine quality . . . . . . . 20

361 " Early Vienna. Very small; of delicate flavor . . . . . . . . . . 20

$362 "$ Early Ulm. Small, round, deep green head; very early . . . . . . . 20

364 "Thorburn Drumhead. Very fine, improved strain ...........25

367 Chinese Cabbage (Pe-Tsai). Grows like Cos Lettuce . $\ldots \ldots$

$\begin{array}{lll}\text { I/4Ib. } & \text { Lb. } \\ \text { I } 50 & \$ 5 & 00 \\ 40 & 1 & 25 \\ 50 & 1 & 50 \\ 50 & 1 & 50 \\ 75 & 2 & 50 \\ 85 & 3 & 00 \\ 85 & 3 & 00 \\ 50 & 1 & 50 \\ 75 & 2 & 50 \\ 75 & & \\ 75 & 2 & 50 \\ 75 & 2 & 50 \\ & & \\ 75 & 2 & 50 \\ 85 & 3 & 00 \\ 50 & 1 & 50 \\ 50 & 1 & 50 \\ 60 & 2 & 00 \\ 60 & 2 & 00 \\ & & \\ 85 & 3 & 00 \\ & & \\ & & \\ 85 & 3 & 00 \\ 85 & 3 & 00 \\ 85 & 3 & 00 \\ 60 & 2 & 00 \\ 85 & 3 & 00 \\ 50 & 1 & 75 \\ 50 & 1 & 75 \\ 50 & 1 & 75 \\ 75 & 2 & 50 \\ 75 & 2 & 50\end{array}$

\section{CARDOON}

\section{Cardoon Cardo carbon}

CULTURE. - Sow early in spring, in rows where they are to stand, and thin them to $\mathbf{I}$ foot apart. When full size, bind the plants together with bast or raffia, and earth up like Celery to blanch. The stems of the leaves are used for salads, soups and stews.

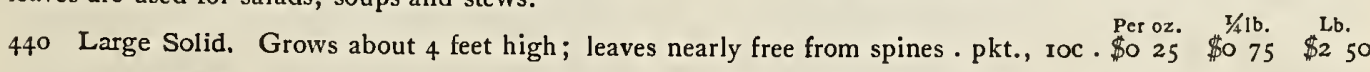
We pay postage or express charges on all seeds bought by the ounce or packet.

J. M. THORBURN \& CO.

Interlachen, Fla., July 21,1898

Gentlemen: In reply to your favor, we would state that, in our opinion, based on our sales of it for the past five years, your GiltEdge Cauliflower is by far the best variety for the lower South, and for the past 2 years we have sold more of it than of all other varieties combined.

We are so well satisfied with it that we have no desire to list other new introductions, for they have not proved to be its equal ln actual field tests. 


\section{CELERY \\ Celeri Apios Seflerie}

CULTURE.-Sow the seed in a light, rich, dry border, as early as the ground can be worked, in drills 8 or Io inches apart, and cover the seeds about a quarter of an inch deep, rolling or treading them in if the ground be dry. When fairly out of the seed-leaf, they may be transplanted to another bed, or they may be thinned out to 6 or 8 inches apart, and let grow until wanted to plant out in beds or trenches. The beds should be kept well weeded, and an occasional soaking with water in dry weather will do the plants good. Early in July at the north, a month or six weeks later in the southern states, is the proper time to set the plants out in beds or trenches. Press the soil firmly against the roots. In the garden the better way is to set the plants in shallow trenches. We say shallow, for it is obviously a bad plan to remove all the good soil (as must be done in a deep trench) and put the plants in that which is poor. The plants must be set in a single row in a narrow trench, or the trench may be made into a bed wide enough to hold two, three or four rows, and in this case the plants are in a compact form to be covered for the winter where they grow. This will save much labor where there is no root-cellar for storage, as often happens to be the case. When grown in beds in this way, the rows should be I foot apart, and the plants about 8 inches apart in the rows. A bed 4 feet wide will take 4 rows of plants, leaving 6 inches space on the outside of the first and last rows. The bed should be made very rich with thoroughly decomposed manure. The plants will need to be earthed up two or three times; and in doing this, care should be taken not to let the earth get into the heart of the plant. In field culture the plants are set on the surface in rows 4 feet apart when the Celery is to be earthed up in the field for early use, and 2 feet apart when the plants are to be taken and blanched in the cellar for winter use. The plants are set 6 inches apart in rows. If not grown in beds, the best way to store is to dig trenches in a welldrained spot in the open ground, I foot wide, and of a depth a few inches less than the height of the Celery. The plants are then lifted and set close together. The edges of the trench should be made sloping from the tops of the plants. When severe cold weather comes on, cover gradually with leaves, hay or straw, and place boards on top. In such a trench the stalks will blanch perfectly, and may be taken out any time during the winter for use or sale as required. The turnip-rooted or "Knob" Celery needs no earthing up, and may be planted in rows I foot apart.

$45^{\circ}$ Thorburn Fin de Siecle. We consider this the largest, hardiest, solidest, crispest, Per oz. 1/4lb. Lb. best keeping and best shipping winter Celery we know of . . . . . . . \$ \$ 30 \$0 $85 \$ 30$

456 Improved White Plume. Naturally white or light foliage; requires but little banking up to blanch; very early, and extensively grown for market . . . . $25 \quad \begin{array}{llll}75 & 250\end{array}$

457 Golden Self-Blanching. A grand variety, on the style of White Plume, except that it is golden yellow where the Plume is white ....... per pkt., ro cts. . 30

$45^{8}$ Rose-Ribbed Golden Self-Blanching. A sport from the Golden Self-Blanching, differing from that variety only in the handsome rose-tinted ribs . . per pkt., Io cts. . 30

460 Perfection Heartwell. One of the finest and largest of winter varieties, either for family or market-garden. The heart is golden yellow, and of superior quality . 20

46I Thorburn's Schumacher. Immense size; solid and crisp; firm, golden yellow heart; a fine keeper; highly recommended .............. 30

462 Perle le Grand. A highly recommended new variety. Full golden heart, and rich flavor, and an excellent keeper ................. 20

463 Giant Pascal. An easily blanched and fine keeping large late sort, of good flavor . 20

465 Large-Ribbed Kalamazoo. A good, half dwarf, white, solid Celery . . . . . 20

467 Evans' Triumph. Fine, large, solid green variety . . . . . . . . . . . 20

469 Crawford Half Dwarf, or Golden Heart. Of vigorous growth and excellent flavor . 20

470 Dobbie's Invincible White. Medium size, fine solid white . . . . . . . . . 25

472 Sutton's A1. Deep red, fine flavor, solid and long-keeping . . . . . . . . $3^{\circ}$

474 Sandringham Dwarf White. Small, white, solid; for soup greens . . . . . . 20

475 Cooper Cutting. For soup greens . . . . . . . . . . . . . . I5

476 Pink Plume. The same as White Plume, except that the stalks are tinged with pink. It is of very attractive appearance, rich flavor and long-keeping . . . . . 30

480 London Red Prize. A popular English red sort ............... 25

48 I CELERIAC, or Turnip-Rooted Celery. Has edible roots, used for soups and stews. If boiled and served with white sauce, it makes an excellent dish . . . . . . I

482 Celeriac, Thorburn Giant. The best of the class; very large roots, used for soups and stews. The roots, when cooked and sliced like beets, make fine winter salad .

483 Celeriac, Apple. Has small foliage, and small, smooth roots; for soups . . . . .

\section{CHERVIL}

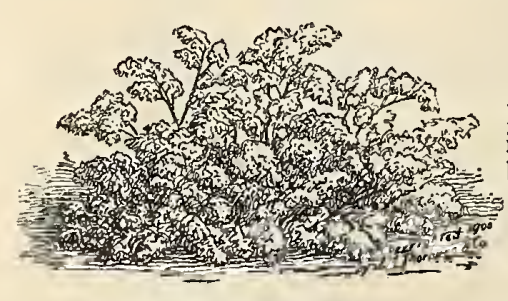

CURLED CHERVIL.

\section{Cerfeuil Perifollo Benienlaud}

Culture.-Cultivate and use the curled variety of Chervil like Parsley. Sow at any time in the spring, in shallow drills, I foot apart, in well-prepared ground. The seed of the Tuberous Chervil should be sown in August or September, and treated like the Carrot.

490 Curled. The leaves of this are used for Peroz. 1/4lb. Lb. flavoring soups and stews, and for garnishing, same as Parsley 49 I Plain. Like above but not curled .... Io 30 I 00 492 Tuberous. A variety which has edible roots. . $20 \quad 60 \quad 200$

We pay postage or express charges on all seeds bought by the ounce or packet. 


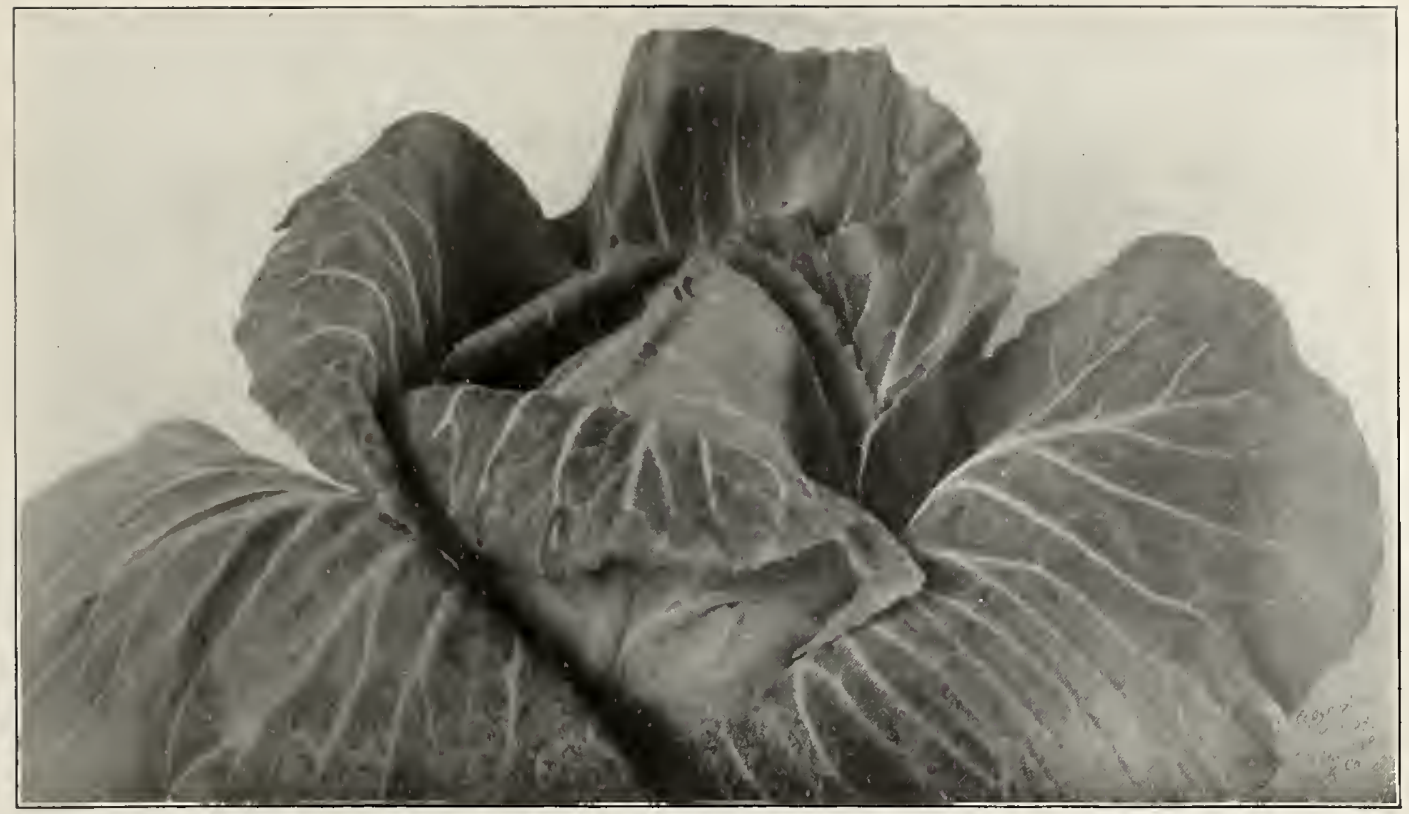

Early Jersey Wakefield Cabbage

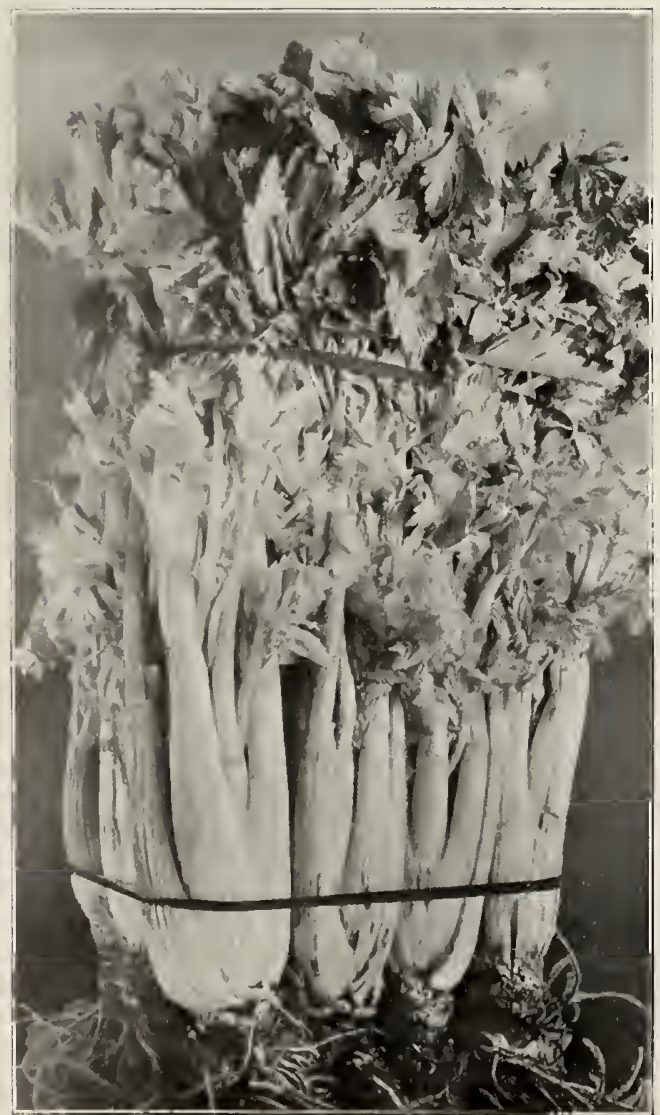

Golden Self-Blanching Celery

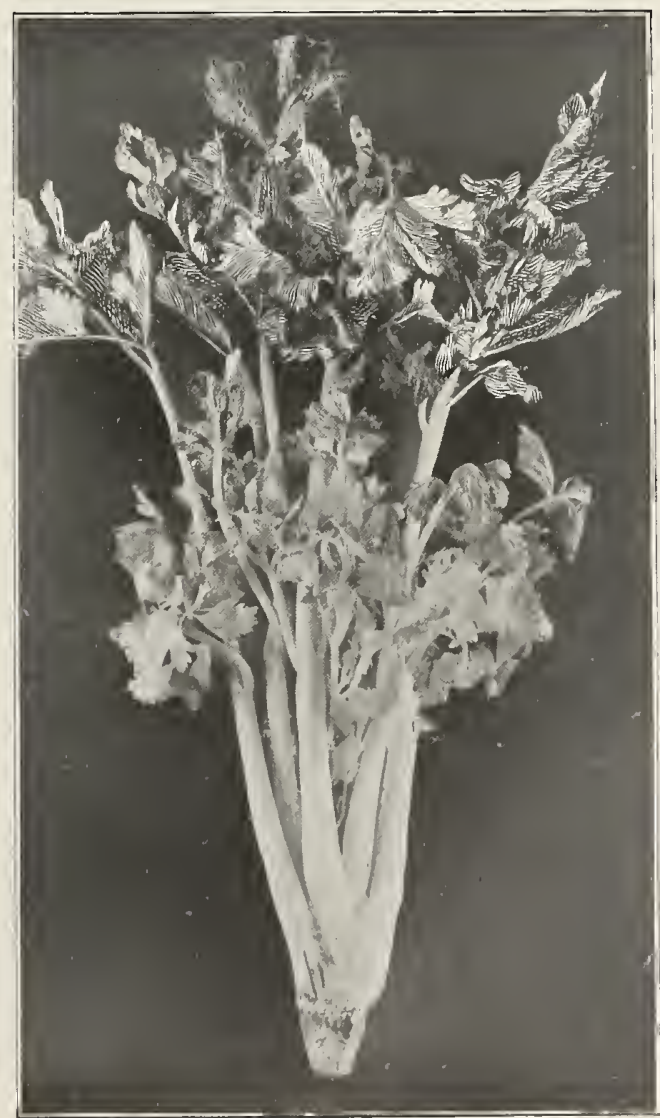

White Plume Celery 


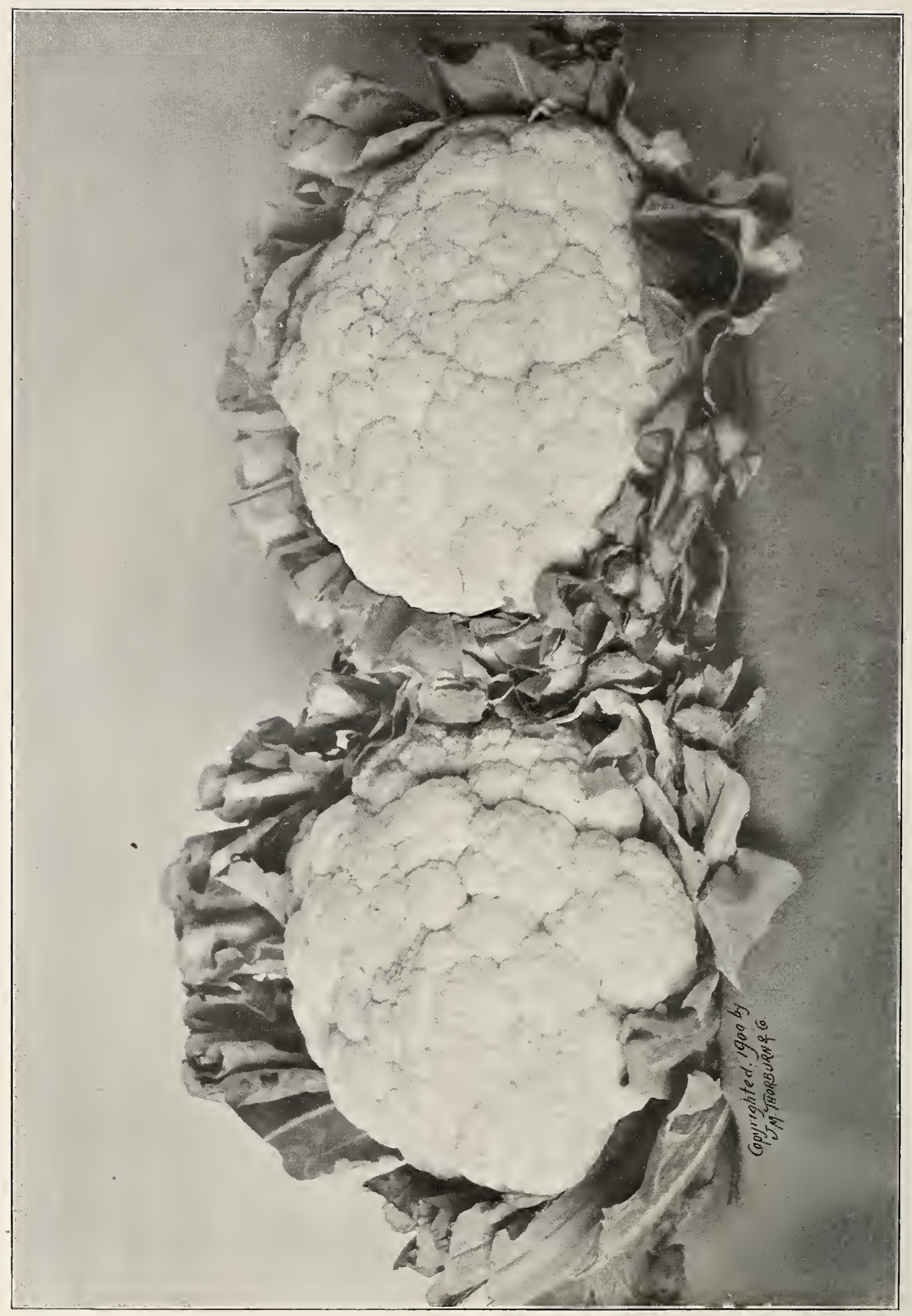

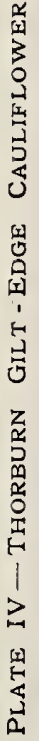




\section{CAULIFLOWER}

\section{Chou-Fleur Colifior Blumenfohl}

Culture. - The same as for Cabbage, except that extra manure and plenty of water will pay upon Cauliflower. If the soil be dry, water frequently, and if the plants could have a heavy mulch of hay or straw, it would keep the soil moist, and the plants would not suffer from drought. The early kinds should be strong enough to plant out not later than the middle of April; the late kinds may be planted out same time as for Cabbage. To destroy the Cauliflower-maggot, it is recommended to take I ounce of sulphuret of potassium and dissolve it in I gallon of water. Heat the liquid to about roo degrees, take a large spoon, or something that will hold the Iooth part of a gallon, and pour the liquid against the stalk of the plant just above the ground.

500 Extra-Early Dwarf Erfurt. The very best and earliest for forcing under glass;

Per oz. $\quad$ z/alb. Lb. very dwarf and compact, with short stem and small leaves. It should not be confounded with entirely different sorts advertised under the same name . . . . . . . . . . . . . per pkt., 50 cts. $\$ 600$

502 Thorburn Extra-Early Snowball. Our strain of this popular variety is unequaled. It is one of the best for forcing under glass or for the open ground. This is the same formerly called "Thorburn Early Snowball." We now call it Extra-Early to distinguish it from our Large Early Snowball, a sort that is not so early, but considerably larger . . . . . . . per pkt., $25 \mathrm{cts.} 225 \$ 750 \$ 3000$

504 Thorburn Large Early Snowball. A large strain of the above, but not so early. It is a very sure header ............ per pkt., $25 \mathrm{cts} .22257503000$

506 Thorburn Gilt-Edge. Large, heavy sort, maturing immediately after our Snowball. It is, without any exception, the very best and surest of all sorts now

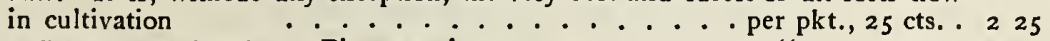

507 Large Early Dwarf Erfurt. Finest strain.......... " 25 cts. . 225

508 Denmark. On the style of Large Erfurt; very fine . . . . . . . 10 cts. . I 75

509 Extra-Early Paris. Heads of medium size; first-class . . . . " 10 cts. . 60

510 Lenormand Short Stem. Has very large heads; white and firm . per pkt., roc. .

5 I I Large Algiers. Market-gardener's popular late sort; enormous. " IOc. .

512 Early London. Large and hardy ....................

5 I3 Walcheren. Very late, hardy variety ................. 5

514 Autumn Giant. Vigorous in growth, and very large; late ... . . . . . 5

$75 \quad 200$

75200

40 I $00 \quad 400$

50 I $50 \quad 500$

50 I $50 \quad 500$

\section{CARROTS}

\section{CARotTe Zanahoria Diöbren}

CUlTURE.-Sow No. 520 as early as the ground can be worked; or, for late crop, until the latter part of July. For main crop, sow from the middle of May to the first of July. Thin out early crop to 5 inches in the row, main crop 6 to 7 inches; the rows ro inches apart for early crop, 14 for main crop. Hoe often and deeply between the rows. Soil, light, sandy loam, richly manured and deeply dug. Sow at the rate of 2 pounds to the acre.

520 Early Round Parisian. Small and very tender; for frames or

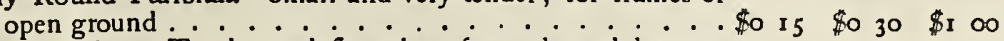

522 Early Forcing. Tender and fine; best for early and late crops and frames . . . . . . . . . . I $_{5}$

Bellot. Very early and tender French sort; valuable for forcing or outcloors . . . . . . . . . . . . . 15

Paris Exposition. A very fine new stump sort, very bright red color and of finest quality . . . . . . . . . I5 Half Short Oxheart (Guerande). Very thick and short .... IO Early Scarlet Horn. Very thick roots . . . . . . . . . . I 5

528 Half Long Pointed. A very well-known strain; productive. . Io

529 Half Long Stump-Rooted. An excellent sort, of good quality . Io

530 Half Long Stump-Rooted, Nantes Strain. Very popular .. . I5

532 Half Long Stump, Chantenay. Style of Nantes; broader shoulder . I5

533 Carentan. Half long stump-rooted; coreless, red flesh . . . . . Io

Half Long Stump-Rooted, Luc. Useful main crop sort; early and productive ....... . . . . . . . . • . I5

Half Long Danvers. Thick; of good quality and exceedingly productive; one of the most popular sorts . . . . . . Io

Long Scarlet Intermediate . . . . . . . . . . . I5

St. Valery. A thick, intermediate long red .......... Io

Long Orange. Best for stock-feeding ............. Io

$54 \mathrm{I}$ White Vosges. Large, thick, short . . . . . . . . . . . . . Io

542 Long White. Very large; for stock. . . . . . . . . . . . Io

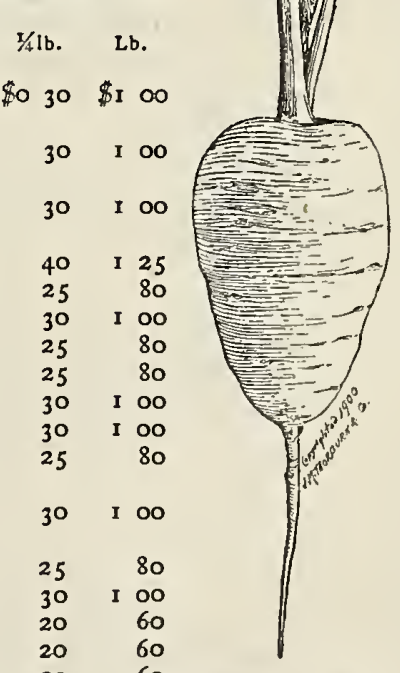

ROUND PARISIAN FORCING CARROT. 


\section{CORN, SWEET or SUGAR}

\section{MaIz Maiz Maiz}

Culture.-Plant in hills 3 feet apart each way, and five or six kernels in a hill. Hoe often and draw soil up to the stem; break off side shoots. Make the ground rich with well-rotted manure. Sown in drills, a greater yield from a given surface will be obtained. The best fertilizer is Thorburn's Complete Manure. By sowing successive lots and properly selecting varieties, the supply of Sweet Corn can be kept up until hard frosts kill the plants.

\section{EXTRA-EARLY}

550 Early Cory. A very early variety, with good-sized ears and large Per grains. Excellent for market, and has attained wide popularity. \$o o5

White Cory. Resembles the ordinary Cory, but with white cobs . . 05

554 Mammoth White Cory. The ears are double the size of old Cory . of

555 Metropolitan. Large, handsome ears of fine quality; very early . . 05

556 Marblehead. One of the earliest; dwarf, with short, thick ears; of good quality for an early sort, which especially commends it . . 05

557 Minnesota. Nearly as early as Marblehead; of dwarf growth . . . o5

$55^{8}$ Perry Hybrid. Very early and of large size; most valuable for market . o5

559 Melrose. As early as the Perry Hybrid, and much larger; valuable . o5

560 Burbank Early Maine. Large ears of fine quality; extra-early . . . 05

561 Extra-Early Adams. Not a Sugar Corn; but grown for early use of

562 Manhattan. The earliest Sweet Corn grown, but the ears in consequence very small; valuable for the far north .......

\begin{tabular}{|c|c|c|c|c|}
\hline $\begin{array}{c}\text { Per } \\
\text { qt. }\end{array}$ & $\begin{array}{l}\text { Per } \\
1 / 2 \mathrm{pk} .\end{array}$ & & $\begin{array}{l}\text { Per } \\
\text { pk. }\end{array}$ & $\begin{array}{c}\text { Per } \\
\text { bus. }\end{array}$ \\
\hline 20 & $\$ 060$ & $\$ 1$ & ০o & $\$ 350$ \\
\hline 20 & 60 & I & ০০ & \\
\hline 20 & 60 & I & ০o & 3 \\
\hline 25 & 75 & I & 25 & \\
\hline 20 & 60 & I & ০০ & \\
\hline 20 & 60 & I & o० & \\
\hline 20 & 60 & 'I & ০০ & \\
\hline 25 & 75 & I & 25 & \\
\hline 20 & 60 & I & oo & 3 \\
\hline 20 & 60 & I & ০o & 3 \\
\hline
\end{tabular}

\section{SECOND-EARLY, or INTERMEDIATE}

565 Early Champion. Very large ears, considering its earliness . . . 05

567 Shaker Early. Very large, white grain, and quite early ..... o5

569 Crosby. Matures after Minnesota ; fair-sized ears of good quality .. o5

570 Potter Excelsior. Good size, and a week earlier than Large Excelsior. o5

571 Moore Concord. Of strong growth; ears large and well filled . . . o5

572 Early Evergreen. Like the Stowell Evergreen, but a week or ten days earlier . . . : . . . . . . 05

573 Early Adams. Not a Sugar Corn, but grown extensively for market. of

\section{GENERAL CROP}

574 Large Eight-Rowed. Very productive, and of superior richness . . o5

575 Asylum. Thick, 12-rowed . . . ....... o5

580 Triumph. Large ears, very white; productive ... . . . os

582 Hickox Improved. Handsome ears, very white and of rich flavor. . o5

584 Roslyn Hybrid. Large-growing variety of very fine quality . $\because$. 05

$5^{85}$ Stowell Evergreen. Remains green a long time, and is highly prized; one of the most popular varieties . . . . . . . . o5

586 Early Mammoth. Very large and not very late........ 05

\begin{tabular}{|c|c|c|c|c|}
\hline 25 & 75 & & 25 & 400 \\
\hline 20 & 60 & I & ०० & 350 \\
\hline 20 & 60 & I & ০० & 350 \\
\hline 20 & 60 & I & ০० & 350 \\
\hline 20 & 60 & I & ০० & 35 \\
\hline 20 & 60 & I & ০০ & 3 \\
\hline 20 & 60 & I & ০০ & 300 \\
\hline 20 & 60 & I & ০० & \\
\hline 20 & 60 & I & ০০ & 35 \\
\hline 20 & 60 & I & o० & 350 \\
\hline 20 & 60 & I & ০০ & 35 \\
\hline 20 & 60 & I & ०० & 35 \\
\hline 20 & 60 & I & ০० & 3 \\
\hline & 60 & I & ০০ & 3 \\
\hline
\end{tabular}

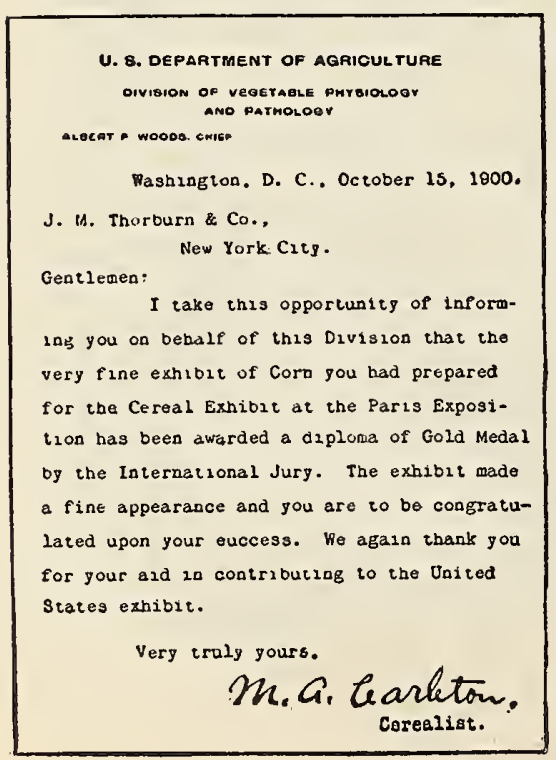

\section{LATE}

590 Black Mexican. Very sweet and of superior flavor; grains black .

592 Ne Plus Ultra, or Shoe Peg. Small, but one of the sweetest sorts grown $\dot{R}$.

594 Late Mammoth. Rank in growth; large ears, rich and sweet.

595 Egyptian. Large and of superior quality; largely used for canning . -...

596 Country Gentleman. Same as $\mathrm{Ne}$ Plus Ultra, but with large ears; of delicious quality . - . .

597 Sweet Fodder Corn. Made u p of the largest growing Sweet Corns; fine for soiling and ensilage.... . 


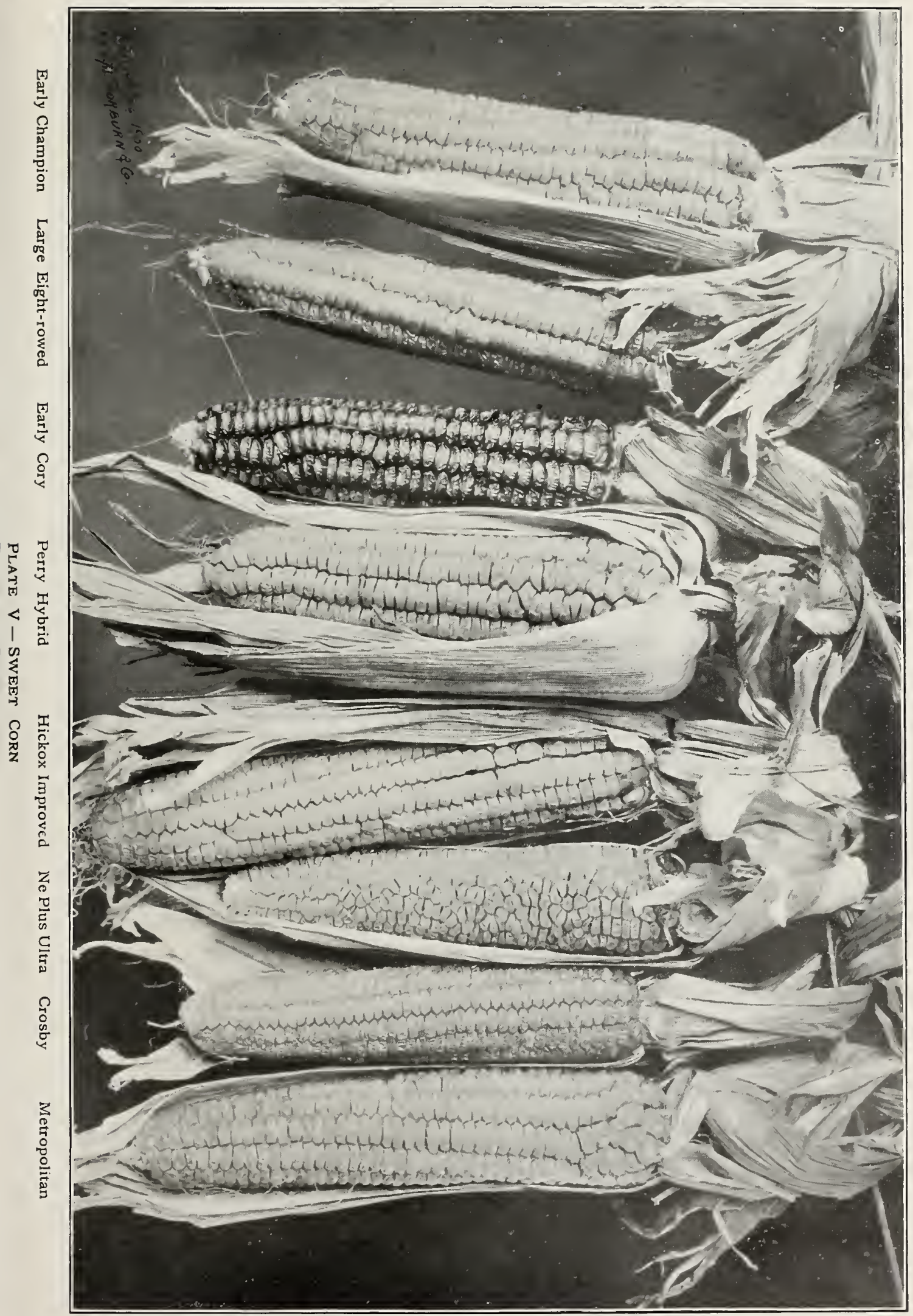




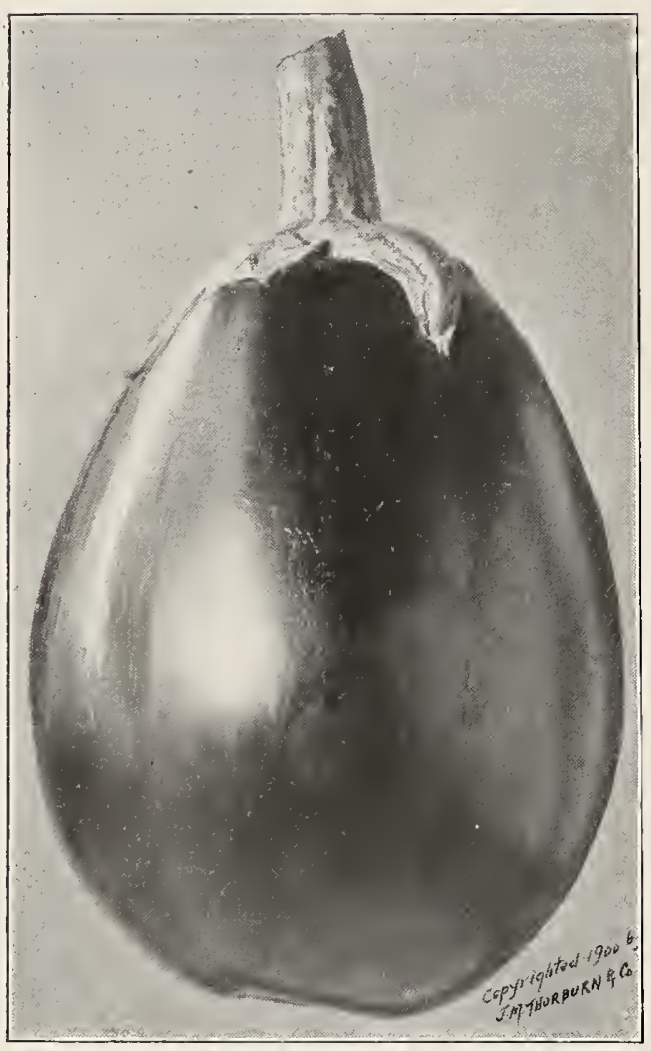

New York Improved Purple Egg-plant

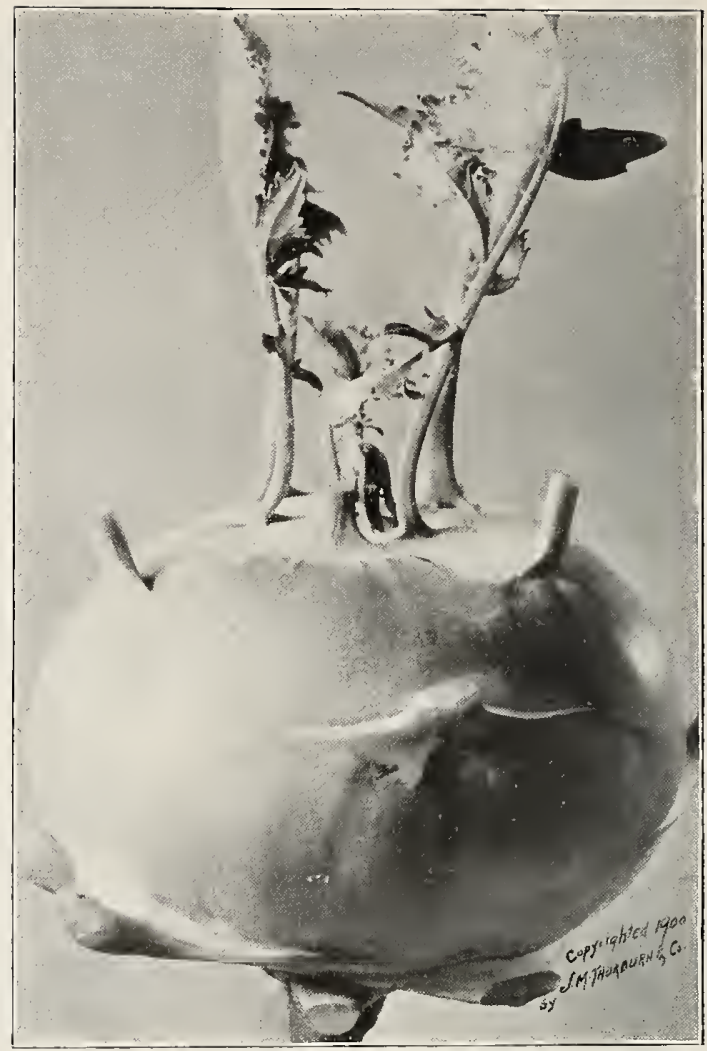

White Vienna Kohlrabi

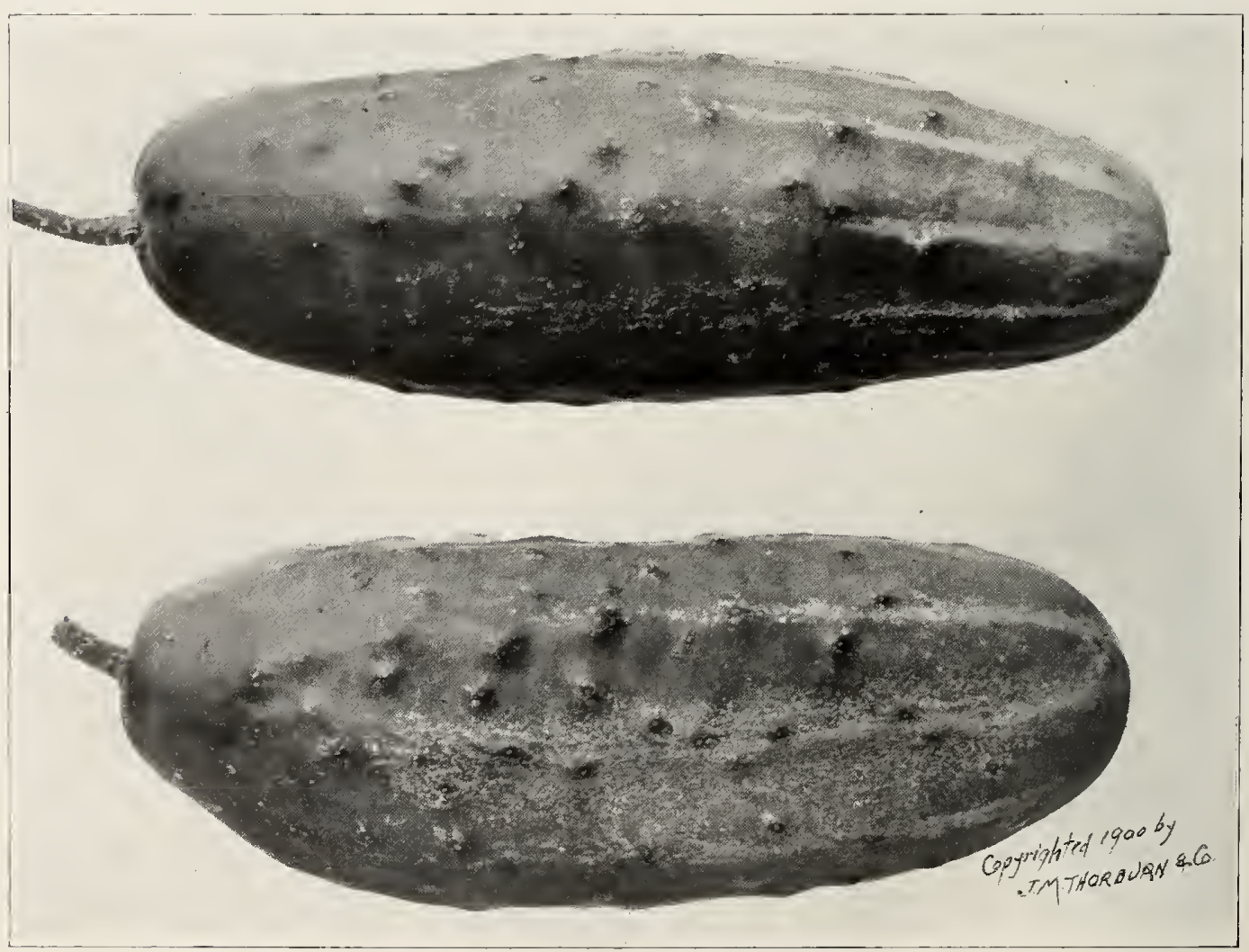

Plate VI

Cucumbers - New Orleans Market (upper), White Spine Improved (lower) 


\title{
CUCUMBER
}

\author{
Concombre Pepino Burfe
}

Culture.-For very early, sow seeds in hotbeds upon pieces of sod, or in small pots, and they can be readily transplanted with a gain of about six weeks before they can be sown in the open ground. Plant out in rich soil when danger of frost is over, or they may be protected by hand glasses, or even by paper held down at the corners with a handful of earth. For general crops, sow in the open ground as soon as the weather is settled and warm, and again every two weeks for a succession. For pickles, sow from the middle of June to the first week in July. Sod land, turned over in the fall, is the best for them. Plant in hills 4 feet apart, putting a shovelful of well-rotted manure in each hill.

610 Thorburn 1896 Pickler. In size, symmetry, slimness, color and productiveness,

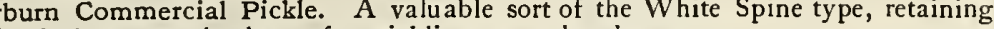

its dark green color long after pickling; very handsome . . . . • . . .

Thorburn Everbearing. Small-sized; very early and enormously productive, and valuable as a green pickler. It continues to flower and produce fruit until killed
by frost, whether the ripe Cucumbers are picked off or not . . . by frost, whether the ripe Cucumbers are picked of or not - $\cdot \dot{\cdot} \cdot \dot{*} \cdot \dot{*}$;

616 Fordhook Pickling. A first-class new pickling sort. It is wonderfully prolific, and continues to bear longer than all others. It is tender and crisp, and of the best

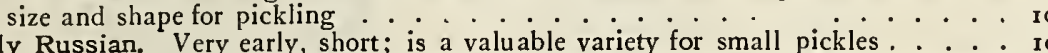

617 Early Russian. Eool and Crisp. Extra-early and very prolific; long, straight, slender, and very dark green; good either for pickling or slicing ............ . I0

Early Short Green. Good for pickling; productive . . . . . . . . . . . . . . . IO

621 Early Green Cluster. Fruit small and in clusters; very prolific . . . . . . . . . 10

624 New Orleans Market. Very productive; a good keeper and shipper; good for forc-

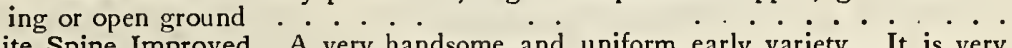

626 White Spine Improved. A very handsome and uniform early variety. It is very productive, crisp and of fine flavor. This is the sort that is so largely grown in the south for early shipping to the northern markets.

628 " "Extra Long. A beautiful, large and well-shaped Cucumber, slightly longer in maturing than the above . . . . . .

630 " Arlington. A fine strain of the Improved White Spine. It is fine either for forcing or for outdoors............. . Io

632 " " Peerless. Very early strain ................. 10

633 Evergreen. Very early and prolific; deep green color in all stages of growth . . . 10

635 Long Green. Long and crisp; a popular and reliable variety for pickles . . . . . 10

636 Long Green Turkey. Fruit very long and rather slim . . . . . . . . . 10

637 Long Green Parisian. Long, green, cylindrical, firm and crisp . . . . . . . 20

638 Giant Pera. Very long, and one of the best for table use . . . . . . . . . . 10

639 Green Prolific Pickling. One of the best for pickling; dark green, very productive and of uniform small size

640 Nichol Medium Green. Most symmetrical, and a very fine table sort. . . . . Io

642 Boston Pickling. A favorite eastern sort, of fine quality . . . . . . . . . 10

643 Tailby Hybrid. Very long, and superior for table use . . . . . . . . . . 10

644 White Pearl. The best white sort; it ripens early and is very productive . . . . . ro

645 Small Gherkin. Very small burr; used for pickles .............. . 10

646 Japan Climbing. Good for frames or open ground . . . . . . . . . . . 10

$20 \quad 60$

2060

2060

$20 \quad 50$

2060

10 $20 \quad 60$

$10 \quad 20 \quad 60$

2060

\section{ENGLISH CUCUMBERS FOR FRAMES}

\section{(Concombre espèces Anglaise pour Couches)}

CULTURE. - The following are for growing in hotbeds, or houses particularly constructed for forcing, so that a supply can be furnished during the winter months, at which time the prices are very remunerative. Sow seeds in October, November or December, according to the time they are wanted, in small pots, in fibrous loam lightened and enriched with old manure, taking care to give plenty of air and water. Robustness of habit is especially valuable in winter, and therefore the soil must not be too light. Plunge the pots in a frame near the glass, where there is a little bottom heat, and keep them covered with a sheet of brown paper until the seeds germinate. Afterwards uncover and ventilate, to insure steadiness of habit. More seeds should be planted than the number of plants required, as some may fail to grow, and others that germinate may be weaklings. None but strong plants should be employed. It will be necessary to fertilize the pistillate flowers with the staminate, in order to render the vines productive, as, owing to the absence of insects, they will not produce a crop under glass the same as in the open ground.

Packets contain from 5 to $I_{5}$ seeds each, according to sort.

We pay postage or express charges on all seeds bought by the ounce or packet.

650 Prescott Wonder. Rapid growing and Per pkt. very prolific; long dark green fruit .\$o 25

652 Duke of Edinburgh. Very large and long; dull green; quite smooth ....... 25

653 Giant of Arnstadt. Good bearer . . . . . 25

654 Sutton's Progress. Rich, dark green .. . 25
656 Noa's Forcing. Very productive... . \$o 25 657 Goliath. Very prolific....... 25 $65_{8}$ Telegraph. Free-bearing; long and extensively grown; handsome ...... 25

659 Lockie's Perfection. Fine color. . . . 25

660 Tender and True. Fine form; good color. 25 


\section{CHICORY}

670 Common, or wild. Used in Barbe de Capucin, a salad much made in France. Sown in June, the roots are transplanted in autumn into sand in a cellar. The young shoots form the Barbe de Capucin . . . . . . . . . \$o

672 Witloof. May be sown in May and June in drills. Transplanted or thinned to 6 inches, treat as Endive, except that in the latter part of summer or fall it should be gradually banked up like Celery. The stalks, when blanched, make a delicious salad. It is also used by the French as a boiled vegetable, dressed in the same manner as Cauliflower . . . . . . . . . . . . . Is

674 Large-Rooted Magdeburg. Roots are the Chicory of commerce . . . . .

Per oz. I/Alb. Lb.

\section{COLLARDS}

\section{Chou CABu Cabu Blattertogl}

Culture.-Sow seed, as for Cabbage, in June, July and August, for succession. Transplant when a month old, in rows a foot apart each way, and hoe often.

680 Peroz. 1/4tb.

\section{CORN-SALAD, or FETTICUS \\ MACHE Macha o Valerianilla Stechjalat}

Culture.-Sow during August, or early in September, in drills $1 / 4$ inch deep and 6 inches apart. If the weather is dry when the seed is sown, tread it lightly to insure germination. Keep down weeds with hoe. Just before the winter, cover thinly with straw or leaves.

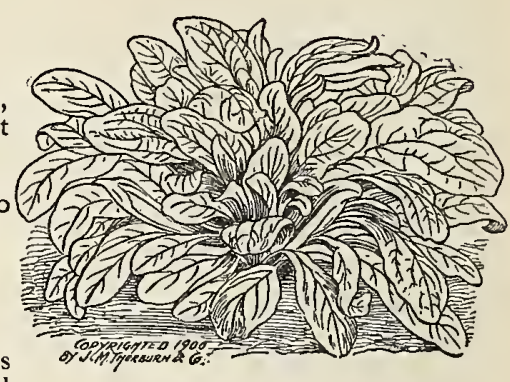

CORN-SALAD, or FETTICUS.

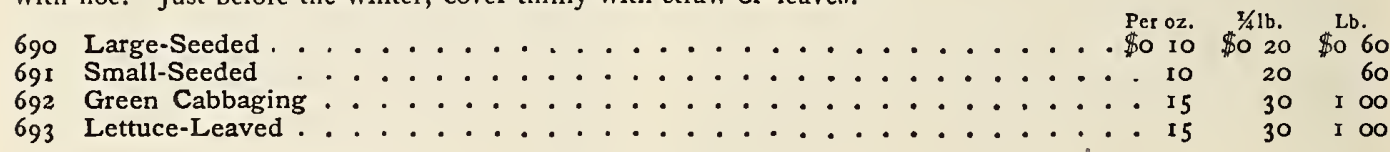

\section{CRESS}

\section{Cresson Berro o Mastuerzo sreffe}

Culture.-Sow Nos. 700 and 702 thickly, in shallow drills, every two or three weeks. No. 700 should

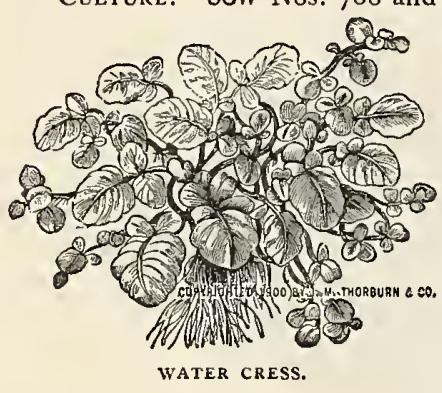

be cut often, and it will continue to grow. It is useful not only for salad, but for the breakfast table and for garnishing. Nos. 706 and 708 should be sown in damp soil; or if a stream of water can be utilized, they would be much finer. They will also thrive well in damp hotbeds. Rightly managed, their culture is very profitable. To obtain early salad, it is a good plan to sow with water-cress seed a strip 4 inches wide on the outer margin of a hotbed, inside the frame, where it is always cool.

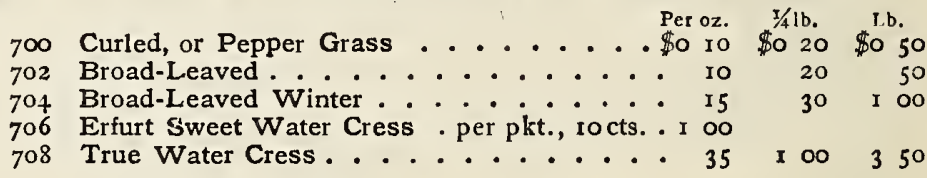

\section{DANDELION}

\section{Pissenlit Amargon \$arbeblum}

Culture.--The Dandelion is a hardy perennial plant, and one of the most desirable early spring salads. Sow in early spring, in drills $1 / 2$ inch deep and 18 inches apart; thin out the plants to I2 inches. Keep clear of weeds during the summer, and the ensuing spring the leaves will be fit to cut. They are best, however, when blanched, which makes them tender, and destroys to some extent their bitter taste, without in any way impairing the qualities which make them desirable as greens. The blanching may be done by placing a couple of boards over the rows thus: $\wedge$ This excludes the light and improves the greens, rendering them far superior to those found growing wild in the grass without cultivation, which are almost sure to be bitter, and are often unsightly and tough as well.

7 ro French Garden ......... \$0 $25 \quad \$ 075 \quad \$ 250$ 712 Improved Thick-Leaved ..... 50 I $50 \quad 500$

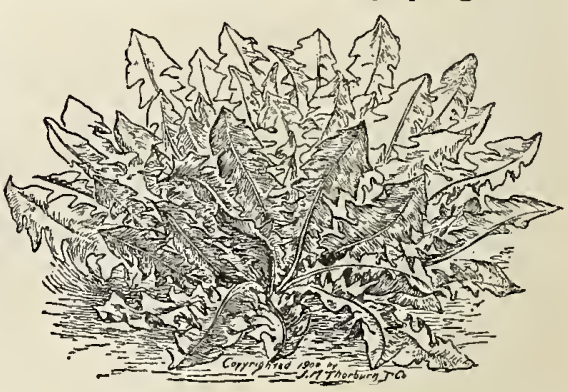

IMPROVED THICK-LEAVED DANDELION. 


\section{EGGPLANT}

\section{AUBERGINB Berengena Eierpflanze}

CutTURE.-Sow in hotoeds very early in spring and transplant when 2 inches high into a second bed or into small pots. If this is not done, thin to 4 inches apart. Do not plant out until weather has become perfectly settled and warm. Cool nights or wet weather will check them. Keep some back in frames for a second planting, in case of weather changing unexpectedly. Set out plants 3 feet by 2 .

Improved New York Spineless. The Per oz. 1/4lb. Lb. deep purple ; early and productive. (See Plate VI.)

721 Early Dwarf Purple. Dwarf, very early; small-sized, ovoid fruit of good quality 25

722 Long Purple. Of distinct shape and fine quality . . . . . . . . . . 20

723 Round French. Medium size, pear-shaped, pale purple; good quality . . . . . 25

724 Black Pekin. Round, blackish purple fruit; has dark foliage . . . . . 25

725 Mammoth Pearl. Large, handsome; like New York Improved, but white . . . 35

726 Scarlet Chinese. Small and ornamental . . . . . . . . . . . 30

727 Round White. Small and ornamental . . . . . . . . . . . . . . 30

728 Long White. Small and ornamental . . . . . . . . . . . . 30

729 Striped. Fruit is striped purple and white . . . . . . . . . . 35

$\$ 1$ oo $\$ 350$

75250

60200

75250

75250

100350

85300

85300

85300

I 00350

\section{ENDIVE}

\section{Chicoree Escarola o Endivia Endivie}

Culture. - Sow in June, July and August; cover lightly; when up, thin out to 8 inches apart, and water well afterward, if dry. When the leaves are 6 or 8 inches long, blanch by gathering in the hand and tying

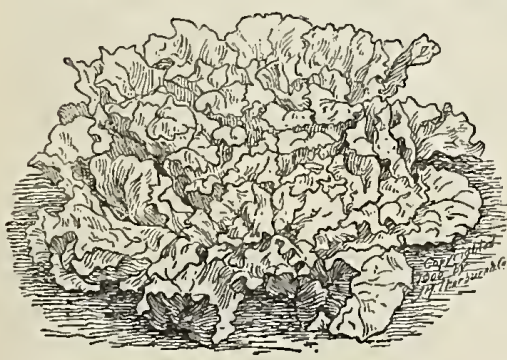

BROAD-LEAVED ENDIVE. together near the top with yarn or bast. This must be done when quite dry, or they will rot. At the approach of winter, take up carefully, with a ball of earth to each plant, and place close together in frame or cellarfor use. They must be kept dry, and have plenty of air, or they will rot.

740 Green Curled Winter. Standard sort Per oz. 3/4b. Lb.

for fall and winter crop .... \$O I5 \$0 50 \$I 50

White Curled. For early use ...... 15 50 150

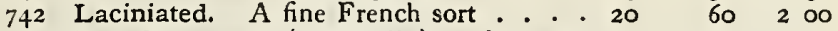

743 Broad-Leaved (Escarolle). A sweet variety; fall and winter . . . I 15 50 I 50

744 Large Green Curled (de Ruffec). Broad ribs; fine for fall and winter . . . 20 $60 \quad 200$

745 Savoy-Leaved (Pancalier) .....20 6020

\section{FENNEL, FLORENCE or NAPLES}

\section{FenOUlL De Florence. Finocchio di Napoli}

CULTURE. - Sow in spring, in rows 16 to 20 inches apart. Thin out so as to have the seedlings 5 or 6 inches apart, and water as plentifully as possible. The plant is usually eaten boiled. In flavor it resembles Celery, but with a sweet taste and a more delicate odor. 750 Per oz., is cts.; $1 / 4 \mathrm{lb}$., $50 \mathrm{cts}$.; lb., $\$ \mathrm{I} .50$.

\section{KALE, or BORECOLE \\ Chou vert Frise Col Sraushohl}

CULture. - Nos. 760 to 765 are cultivated and grown exactly like Cabbage. No. 766 sow in September for early greens. Sow 770 early in the spring in a hotbed, and when from 1 to 2 inches high transplant into a bed or border that has been highly manured and deeply dug. Sea Kale is not fit to eat until it has been blanched, either under large pots, or by banking up with sand.

760 Curled Dwarf Green Scotch. Very dwarf Peroz. 1/4b. Lb.

762 a and spreading; best strain... \$o ro \$o 25 \$0 75

“ Tall Green Scotch. A taller growth

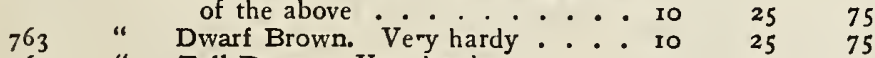

764 "Tall Brown. Very hardy.... 15 30 I oo

765 " Striped and Variegated. For garnishing ........... 25

766 " Siberian, Thorburn Improved. Uniformly dwarf, green curled; hardy . 10 $25 \quad 75$

770 Sea Kale. Very fine; resembles Celery ‥ $30 \quad 85 \quad 3$ oo

772 Pe-tsai. (The Chinese Cabbage.) Grows

like Cos Lettuce $\ldots \ldots 25 \quad 75 \quad 250$

774 Jersey Winter Kale, or Cow Cabbage . . . 10 30 I 00

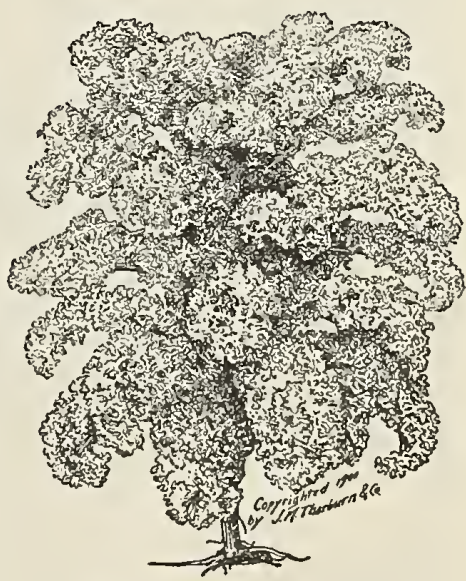

TALI GREEN SCOTCH KALE.

We pay postage or express charges on all seeds bought by the ounce or packet. 


\title{
LETTUCE
}

\author{
LaItue Lechuga Salat
}

Culture.-Sow Nos. 785, 793, 796 and 797 in hotbeds in March, and in the open ground as soon as it can be worked, and transplant to rows 8 inches apart. Sow in two weeks' time same varieties again, as also Cos, for a succession. In August sow any of the varieties. In October some of these may be planted in frames, to head in winter and early spring. Always sow thin, and thin out well, or the plants will not be strong. The last spring sowing had better be grown where sown, being thinned out to 6 or 8 inches apart. To have Cos in good order they must be sown in a hotbed early in the year, and transplanted to a coldframe, so as to have good plants to set out at the opening of the ground. They require tying for a few days, when grown, to blanch. Lettuce requires good ground, enriched with thoroughly rotted manure and well pulverized. The afterculture should be close and careful, to secure the best results.

780 Thorburn Maximum. The largest, solidest, crispest and best . . . . . . \$o 20 \$o 60 L 60 Lb.

7 . . \$o 20 \$0 60 \$2 00

785 Thorburn Market-Gardener's Private Stock. A selected strain; solid, large heads,

resisting the sun for a long time before shooting up . . . . . . . 20

790 Coldframe White Cabbage. For starting in coldframes and setting out early . . . 20

791 Thorburn Yellow Winter. The finest of all coldframe sorts . . . . . . 20

792 Hubbard Market. A large, white Cabbage variety; for forcing or open ground . . I5

793 Big Boston. Fine for forcing in coldframes or for open ground . . . . . . . . 20

794 Large Boston Market. Very large, solid heads; fine for forcing . . . . . . . . . 20

795 Deacon. Large, solid summer cabbage variety . . . . . . . . . . . . . I5

796 Early Curled Simpson. A leading early sort; very tender; white seed . . . . . . I5

797 Black-Seeded Simpson. A superior variety; large, and of light color . . . . . . I5

799 American Gathering. Twisted and curled leaves; fine for early or late sowing . . . I5

8 oo Reichner. Large, white, solid heads; good for forcing or outside . . . . . . . . I5

80 I Sensation. A fine, solid head variety; for forcing or open ground . . . . . . I5

802 Thorburn Glass-House. For forcing under glass . . . . . . . . . . 20

805 Tennisball White Seed. A well-known forcing variety . . . . . . . . . . I5

807 Stone Tennisball Black Seed. Forms close, hard heads; for forcing . . . . . . . I5

810 White Summer Cabbage. Close heads, of good size; fine for summer . . . . . . I 5

812 New York Cabbage. Large, solid heads; dark green color . . . . . . . . . 20

$81+$ Golden Stone Head. A handsome Head Lettuce; small and solid; for forcing . . 20

815 Golden Queen. Medium size, golden yellow, solid heads; very early . . . . . . 20

816 Denver Market. Large, solid heads; good for forcing or outdoors . . . . . . I 5

817 Inproved Salamander. Fine, compact heads, which resist the summer heat admirably. 20

8I 8 Thorburn Mammoth Butter, Black Seed. A selected strain, with large, solid yellow heads. The favorite variety of New York market*gardeners . . . . . . . 20

8 I9 Large Gray-Seeded Butter. One of the best; large head....... I5

820 Grand Rapids Forcing. Large, tender; one of the best for early forcing . . . . . 20

82 I Brown Dutch. Leaves tinged brown; large, solid heads; very hardy . . . . . . I 5

822 Shotwell Brown Head. Large, handsome, tender heads; very hardy . . . . . . . 30

823 Trocadero. Hardy and early; for spring or summer; green leaves, tinged russet . . 20

824 Improved Hanson. Very large and solid; withstands the hot sun well. . . . . . I5

826 Iceberg. Large, solid heads, very handsome; tender and crisp . . . . . . . . I5

827 Mignonette. Distinct russet-colored; very solid and compact . . . . 20

828 White Cos Romaine. Fine, if sown very early; requires tying up to blanch . . . I5

829 Trianon Self-Closing Cos. The finest of all the Cos sorts, resisting warm weather . 20

60200

$60 \quad 200$

60200

$30 \quad$ I 00

50 I 75

60200

35 I 25

30 I 00

3० I

30 I 00

30 I 00

30 I 00

60200

35 I 25

35 I 25

30 I 00

50 I 50

50 I 50

50 I 50

35 I 25

50 I 50

50 I $5^{\circ}$

$30 \quad 1$ oo

50 150

40 I 25

85300

50 I 75

30 I 00

$4^{\circ}$ I 25

50 I 50

$40 \quad$ I 25

$50 \quad 150$

\section{KOHLRABI}

\section{Chou-Rave Colinabo Sohlrabi}

CUlturE. - This is an excellent vegetable, and should be grown in every garden. Sow in spring, in rows I 8 inches apart, afterwards thinning the plants to 8 or to inches. If the weather is suitable the thinnings may be planted, but it is considered difficult to transplant. Keep the weeds down, and when the thickened stems above ground are 2 or 3 inches through they are fit to eat, and should be used at once, being tough when old. They are cooked same as turnips, and when well grown and used at the proper stage, are tender and very palatable, with a fine and delicate flavor.

8 to Early White Vienna. Handsome and delicate; white ball. (See Plate VI). . Po 25 . \$o 75 \% $\$ 2$ Lb.

842 Early White Vienna. For frames . . . . . . . . . . . . . . . 35 I 00 350

$8+3$ Early Purple Vienna. Purple ball; a very good sort . . . . . . . . . . . . . . $30 \quad 8530$

$8+5$ Early Purple Vienna. For frames . . . . . . . . . . . . . . 35 I $00 \quad 350$

$8+6$ Large White, or Green. Forms a larger ball; not so fine, but more productive. . . I5 50 I 50

847 Large Purple. Productive ..................... I5 50 I 50

\section{ICE-PLANT}

Culture.-Sow in good garden soil as soon as the ground becomes warm in spring, in shallow drills I foot apart. Thrives well in hot, dry climates. Desirable for boiling like Spinach, or for garnishing. 850 Pkt. 5 cts., oz. 40 cts.

We pay postage or express charges on all seeds bought by the ounce or packet. 


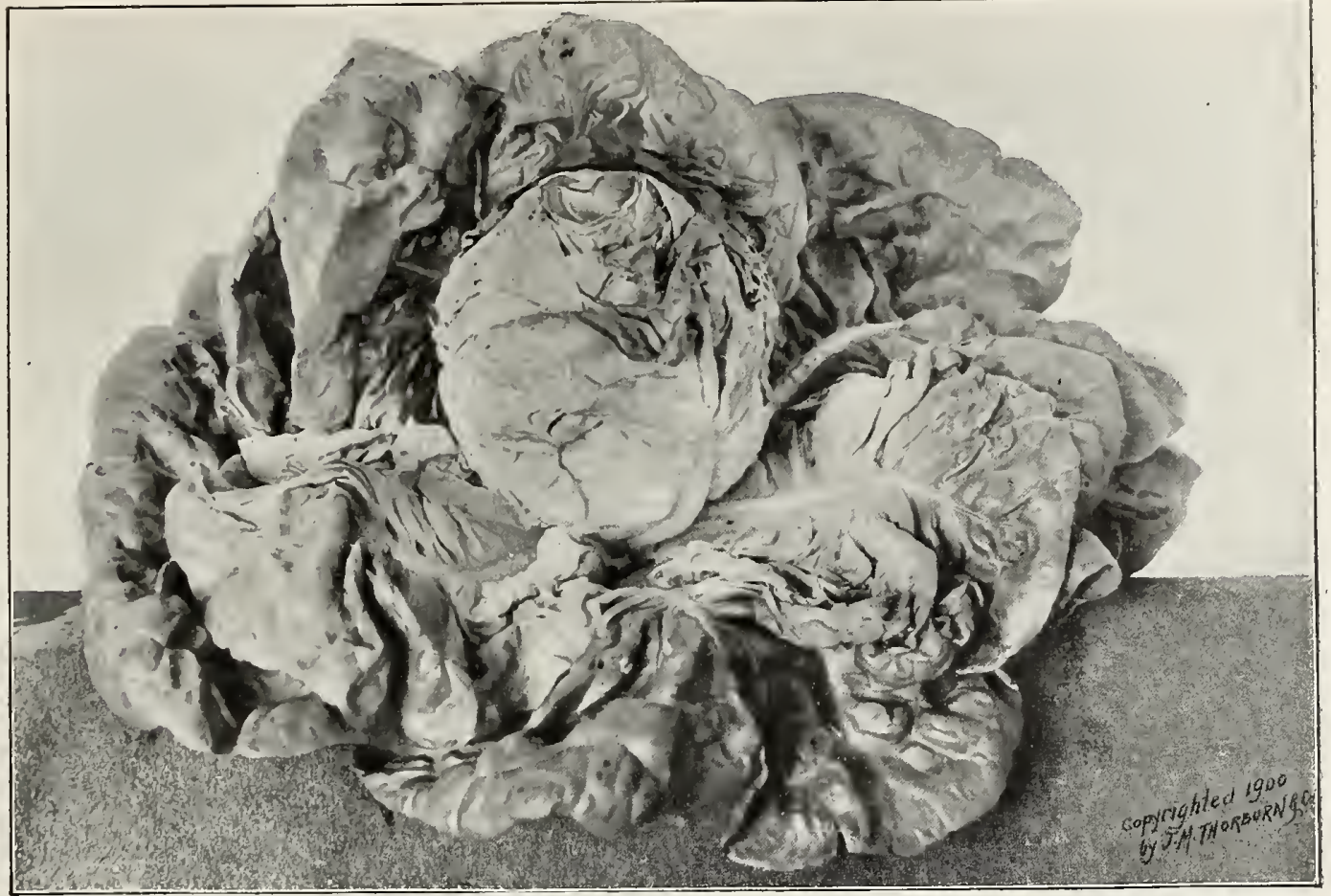

Thorburn's Maximum Lettuce

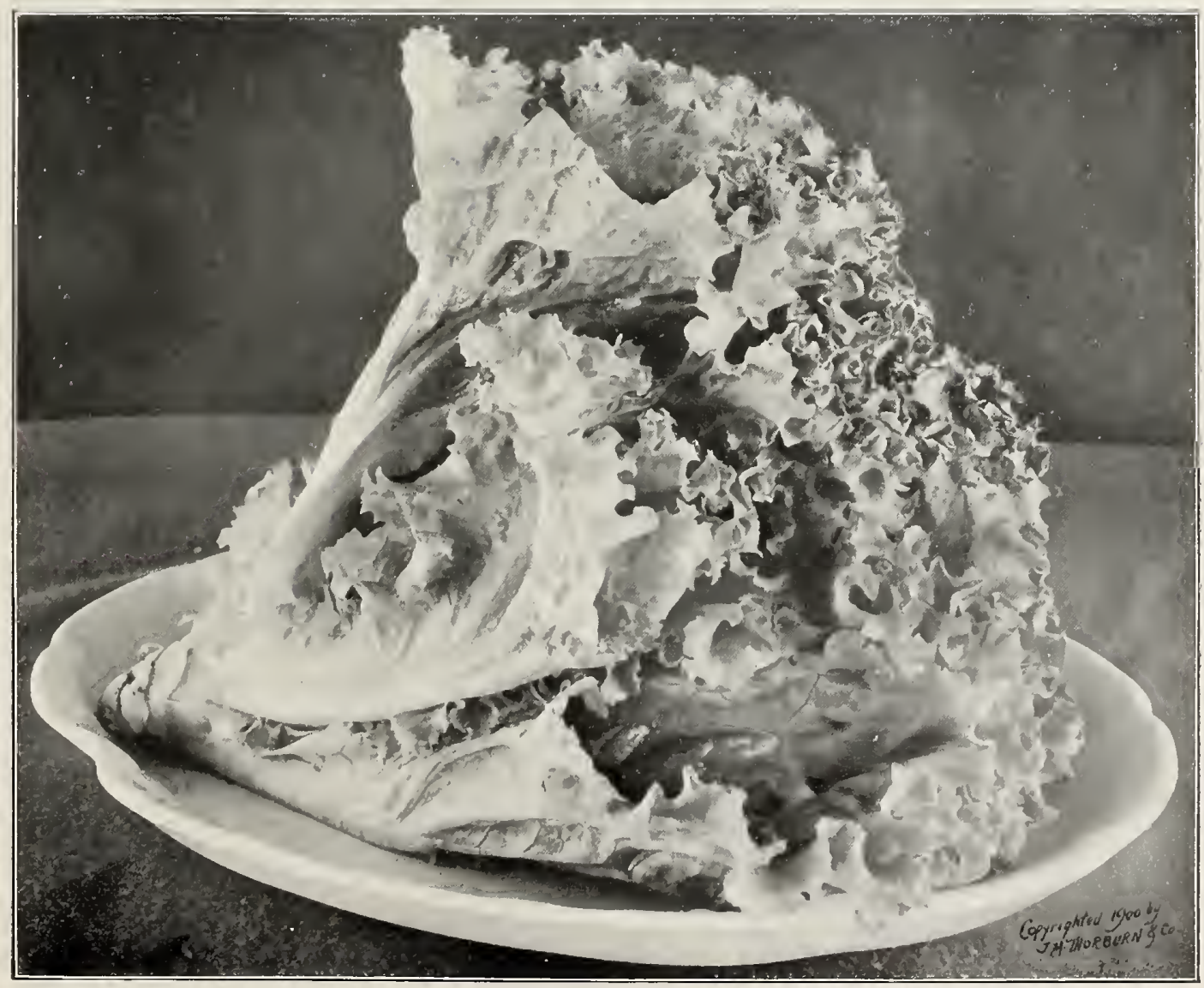




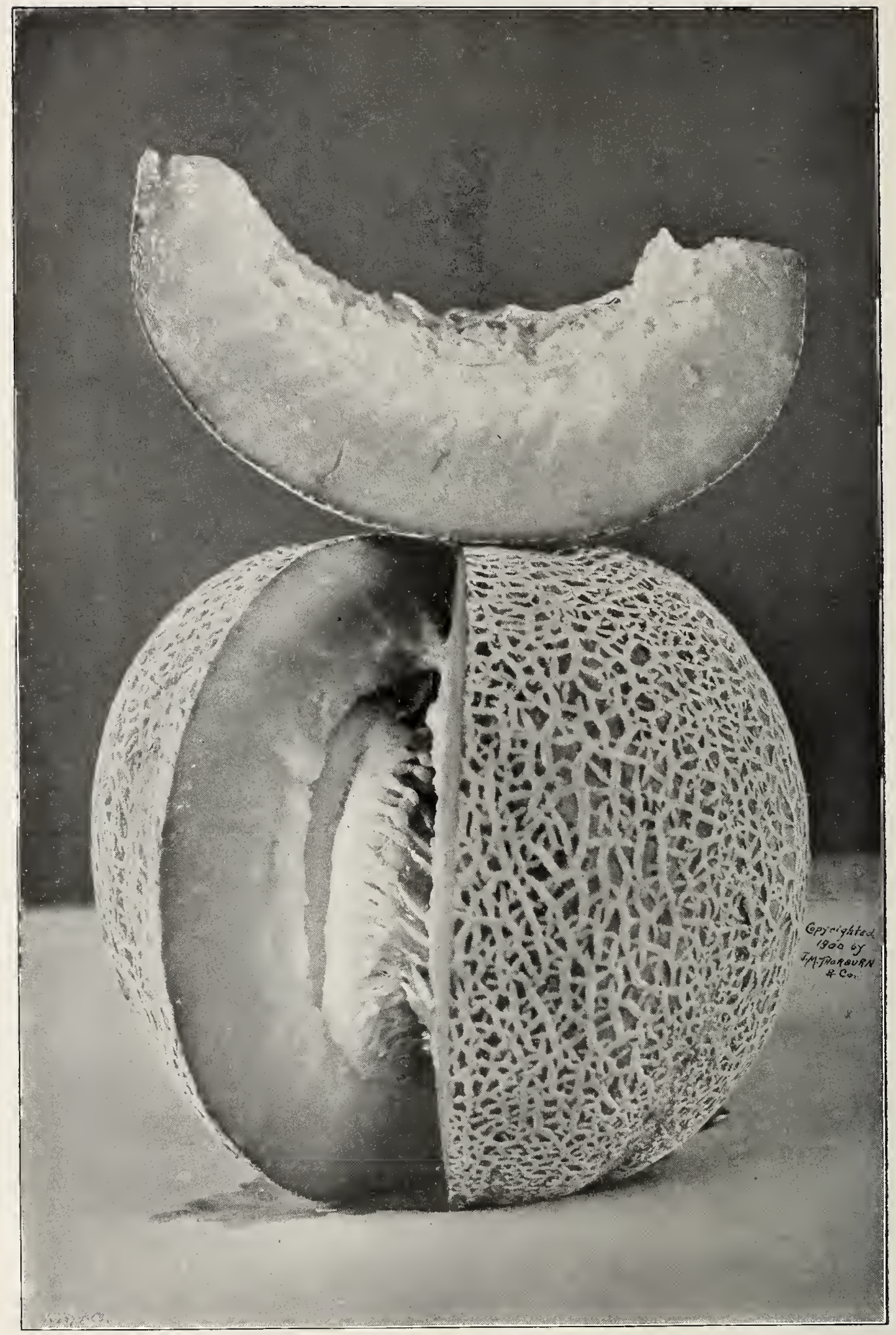

Plate VIII - ThORBuRN'S LONG IsLAND BEAUTy MUSKMELON 


\section{MELON, MUSK}

\section{Melon Muscade Melon Muscatel cantalupe}

Culture.-Select a light, sandy, rich soil, and after all danger of frosts is over, and the ground has become warm and dry, plant in hills 4 to 6 feet apart each way, 6 to 12 seeds to a hill. When up, and all danger of insects has passed, pull out all but 3 plants. Cultivate until the vines cover the ground, and pinch the ends of the growing shoots to induce early fruiting. Ashes, lime, or even dry road dust, is excellent to sift over young plants when the dew is on, to prevent the attacks of insects. A few hills for early use may be had by sowing in hotbeds, on pieces of sod or in pots. The seed may also be started out of doors under hand frames or glasses.

It is quite important that proper soil be selected for growing Musk Melons, as on heavy soil the quality will be poor.

860 Long Island Beauty. On style of Hackensack. The earliest and finest in quality, and the most beautiful Musk Melon

$$
\text { Peroz. 1/4lb. Lb. }
$$

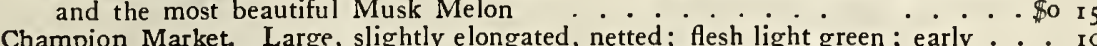

Champion Market. Large, slightly elongated, netted; flesh light green; early . . . ro

Netted Gem, Round. Very early; small and of fine flavor; green flesh.... . . . ro

Netted Gem, Oblong. Same as above, save in shape . . . . . . . . . . 10

873 The Surprise. Early; oblong, with rich orange flesh of good quality . . . . . Io

874 Melrose. Oval, dark green, densely netted; flesh green, shading to salmon . . . . Io

Rocky Ford. Improved Netted Gem; very sweet and fine flavored; oblong

Nutmeg. Named for its shape; green flesh, sweet; good for main crop; early . . . ro

Jenny Lind. Small, green-fleshed; very early; good quality . . . . . . . 10

Hackensack. Large, round and of good quality; a popular variety; early . . . 10

Extra-Early Hackensack. Ripens ro days earlier than the Hackensack; very early . ro

Osage. Cocoanut-shaped; yellow flesh; light green, netted skin; good quality . . Io

Hybrid Bay View. Very prolific, and of great size, oblong; green flesh; late . . . ro

French Perfection. Salmon flesh, very sweet; round, netted . . . . . . . Is

Orange Christina. One of the finest orange sorts; round, very sweet and very early . I 5

The Banquet. Beautifully netted, medium-sized; flesh rich salmon; fine quality. . ro

Ward Nectar. Small, finely netted; green flesh; fine flavor; early . . . . . . . ro

Cosmopolitan. Round, densely netted; green flesh; very sweet . . . . . . . Io

Baltimore Market. Oblong; orange flesh, of fine quality; intermediate. . . . . . 10

Newport. Extra-early, small, round; green flesh of fine flavor . . . . . . .

Emerald Gem. Small, extra-early; dark green skin, orange flesh; very sweet . . . Io

Perfected Delmonico. Heavily netted, orange-pink flesh, fine flavor; small, round . ro

Tip Top Nutmeg. An improved strain; very sweet

Green Montreal. Large, round, netted; flesh thick and light green; late . . . . . Io

Long Yellow Cantelope. Yellow flesh, late; well adapted to the north . . . . . Io

Paul Rose. Handsome, oval, new variety; rich orange flesh, very sweet . . . . . 10

Jersey Belle. Deeply ribbed, heavily netted; green flesh; fine quality . . . . . 10

Banana Citron. Cucumber-shaped, highly perfumed; of indifferent quality; late . . ro

Pomegranate. Ornamental; for perfume; late - . - . . . I5

Mango Melon, or "Vine Orange." (Also called "Vegetable Peach.") Size, shape and color of an orange; thick, meaty flesh. Fine for preserving or pickling :

Winter Pineapple. An extraordinary melon, which can be kept in splendid condition
for months after being pulled. Suitable for the south only; very late

New Giant. Round-shaped; light green color; skin smooth, with little netting; flesh deep salmon color, thick, fine-grained, and not stringy; very late . . . . . I

$15 \quad 35 \quad 125$

\section{IMPORTED VARIETIES}

\section{ENGLISH FRAME SORTS}

9ro Royal Favorite. Very fine, white, thick Pkt. flesh; a most valuable new sort . . . \$o 25

Invincible Scarlet

Monroe's Little Heath ........ 25

Blenheim Orange ...... 25

Gilbert's Green Flesh . . . . . . . . 25

Lord Beaconsfield ....... 25

Bishop's Favorite ........ 25

\section{MARTYNIA}

\section{(For Pickles.) (Gem[enfyorn}

Culture.-Sow in May in the open ground, 3 feet apart in each direction, where the plants are to remain; or the seed may be sown in a hotbed, and the seedlings afterwards transplanted. 'These varieties are productive, and fine for pickles. Pick when small and tender, and preserve the same as Cucumbers. 930 Craniolaria, 931 Proboscidea, 932 Lutea (three varieties) . . . . . . . each \$o 30 \$o $85 \$ 30 \mathrm{ccc}$ 


\section{MELON, WATER}

\section{Melon D'EAu Zandia \$affermelone}

Culture. - Treat the same as Musk Melon, except that they should be planted 8 or ro feet apart, according to variety. Light soil is best.

940 Hungarian Honey. A very early sort. Fine for northern latitudes; perfectly Per oz. 3/1b. Lb.

945 Jordan Gray Monarch. Largest grown; crimson flesh; late ........

953 Kolb Gem. Large, and a good shipper; bright red flesh of fine quality, intermediate . Io

954 Pride of Georgia. Round, large; crisp, bright red flesh; intermediate . . . . . . Io

955 The Boss. Oblong, dark green; flesh deep scarlet, and rind thin; intermediate . . Io

959 Dark Icing. Solid, with thin, dark green skin; of superior quality; white seed; early. Io

960 Light Icing. Round; pink flesh of fine quality ... . . . . . . . . . . Io

962 Mammoth Ironclad. Long, very large, late; red flesh; good shipper . . . . . . ro

963 White-Seeded Ice Cream. Very early; red flesh . . . . . . . . . . . . I0

965 Phinney. Early, and of fine quality; red flesh . . . . . . . . . . . I0

967 Dixie. Excellent quality; very large and solid; flesh red; intermediate . . . . . 10

968 Duke Jones. Large, handsome, dark green; red flesh of fine flavor . . . . . . Io

970 Seminole. Very large; quality first-rate; intermediate . . . . . . . . . Io

97 I Cuban Queen. Solid and heavy; skin marked regularly; excellent quality; early . Io

974 Black Spanish. Large, roundish, nearly black; dark red flesh; early . . . . . . to

975 Black Boulder. Very large and productive; oblong, symmetrical; dark green skin;

fine quality . . . . . . . . . . . . ro

$\$ 020 \$ 060$

$20 \$ 60$

$20 \quad 50$

2050

2060

2060

$20 \quad 60$

2060

2050

2060

$20 \quad 50$

$20 \quad 50$

$20 \quad 50$

$20 \quad 50$

2050

976 Black Diamond. Dark green tough skin, large size, round . . . . . . . . . . 10

978 Kleckley Sweets. Exceedingly sweet and fine flavored; dark green skin, thin rind, flesh solid, scarlet and firm .................... ro

980 Mountain Sweet. An old and reliable sort; flesh red; late. . . . . . . . . . ro

984 Florida Favorite. A superior strain; improvement on Rattlesnake; intermediate . 10

987 Goodwin Imperial. Crimson flesh, fine quality; small, nearly round; extra-early . Io

990 Southern Rattlesnake. Oblong, dark and striped; bright red flesh; late . . . . ro

991 Cole Early. Medium size; red flesh; green skin . . . . . . . . . . . . . 10

992 Sweetheart. Very large; bright skin; fine quality . . . . . . . . . . . . ro

993 Wonderful Sugar. Very sweet; handsome, oblong shape . . . . . . . . . 10

994 Apple Pie, or Colorado Citron. Used for preserves; green seed . . . . . . . . ro

995 Citron. Round and handsome; for preserving; red seed . . . . . . . . . . ro

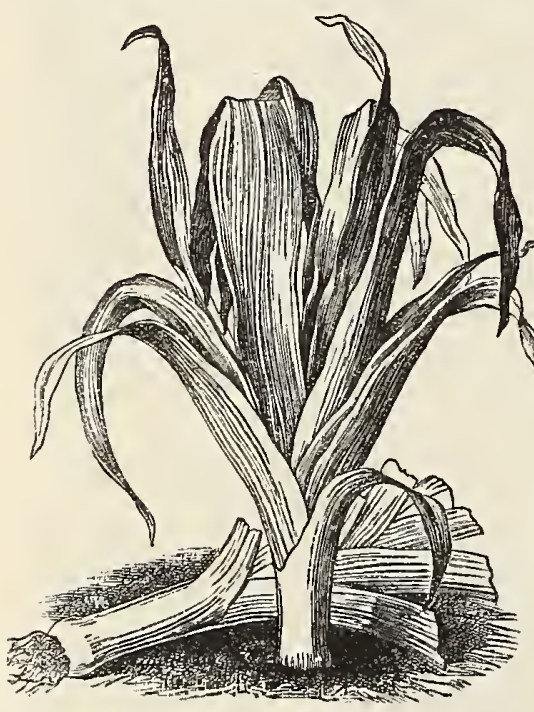

LEEK.

\section{LEEK}

\section{Porreau Puerro Porro}

Culture.-Sow very early in the spring in drills 6 inches apart and $I$ inch deep. Thin out to $x$ inch. When about 7 inches high, transplant them in rows 12 inches apart, and as deep as possible, but do not cover the young center leaves. Water thoroughly, if dry when planted out. Draw earth up to them as they grow; rich soil is required. Take up and store in earth in a cool cellar before winter weather. The seeds may also be sown in September, and the young plants transplanted in spring to where they are to remain. roro Best Large Flag Winter. Hardy and Peroz. K/lb. Lb. productive ......... \$O 20 \$O 50 \$1 75 Io1 2 Large Rouen Winter. A standard sort; remains long in good condition -20 jo 175

ror4 Large Carentan, or Musselburgh. A variety with distinct and dark-colored leaves; stout in habit, and hardy . $20 \quad 60 \quad 200$ Ior 5 London Summer ....... I5 40 I 25

\section{MUSTARD}

\section{MOUTARDE Mostaza Senf}

Culture.-Sow thickly during early spring, in shallow drills, and press the earth well down. For fall salad, sow in September, or in frames or boxes during winter.

Per oz. $1 / 4 \mathrm{lb}$.

rozo Black. These seeds form the mustard of commerce ...........\$0 o5 \$0 10 \$0 25

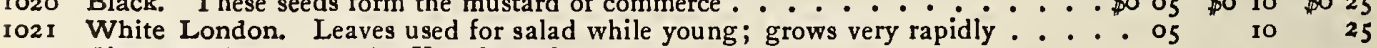

1023 Giant Southern Curled. Very large leaves . . . . . . . . . . . . . . 10 2590

1024 Chinese Broad-Leaved. Leaves of agreeable flavor when cooked like Spinach . 15 I 150 


\section{MUSHROOM SPAWN}

\section{BlanC DB Champicnon Seta Ehampignonbrut}

Culture.-Mushrooms may be grown in cellars, under benches of greenhouses, or in sheds, wherever the temperature of 50 degrees can be kept up through the winter. The beds should be made from November to February, according to the time the Mushrooms are wanted, and it requires about two months for them to begin bearing. Secure fresh horse-dung, free from straw and litter, and mix an equal bulk of loam from an old pasture with it. Keep this under cover, taking care to turn it every day to prevent heating, until the pile is large enough to make a bed of the required size. Three or four feet wide, 8 inches deep, and any length desired, are the proper proportions for a bed; but these may be varied. Prepare the mixture of loam and manure, mak-

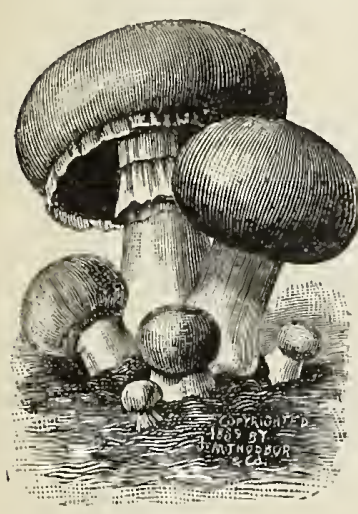

MUSHROOM. ing the bed in layers, and pounding down each with the back of the spade. Leave this to heat through for a few days, and as soon as the heat subsides to go degrees, make holes in the bed about a foot apart each way, into which put pieces of the spawn 2 or 3 inches in diameter; fill up the holes with the compost, and at the expiration of a week or Io days the spawn will have thoroughly diffused itself through the bed. Spread a layer of fresh soil over the heap to the depth of 2 inches, and cover with 3 or 4 inches of hay, straw or litter. Examine the bed often to see that it does not get dry. Take special care, however, when water is given, that it be at a temperature of about 100 degrees.

From experience with French and English Spawn we find there is an important difference between them. If the manure in the bed is in proper condition, the French Spawn will take hold and grow fully as well as the English; but if the bed is not in the right state, it will often rot. The English Spawn, on the contrary, after starting a little, will remain in a comparatively dormant state for a long time without losing its vitality. It is well to keep these points in mind in ordering spawn.

I030 English Spawn. I 5 cts. per lb., ro lbs. for $\$ 1$, roo lbs. $\$ 9$.

103 I French Spawn. Per 3-lb. box, $\$$ r.20; in bulk, per lb., 45 cts.

\section{NASTURTIUM}

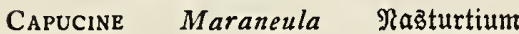

Culture.- - Sow as soon as all danger of frost is past, in drills about an incli deep. The tall kinds require fences or poles on which to climb. The seeds are used in flavoring pickles, or as a substitute for Capers.

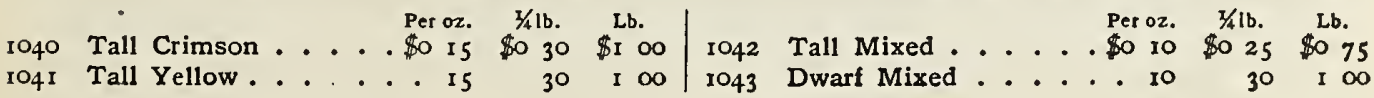

\section{OKRA, or GUMBO \\ Gombaud Quimbombo Safran}

CulruRE.-Sow late in the spring, after the ground has become warm, in drills 3 feet apart, where the plants are to remain. Thin out to from 9 to 12 inches. They should be well manured. They may also be raised in pots or a hotbed, and transplanted.

\section{Long Green. Dwarf, very productive, Per 02. $3 / 4$ lb. Lb. long, green pods ... \$o ro \$0 20 \$0 50 \\ ro46 White Velvet. Tender white pods; smooth and velvety in appearance ....... Io \\ 1047 Dwarf Green Prolific .......... I0 \\ 1048 Round White. Smooth pod ....... I0 \\ ORACH, or FRENCH SPINACH \\ ARROCHe Armuella}

CUlture.-Sow early in spring; cultivate and use like Spinaci.

ro50 Red. Distinct; dark red leaves..... Per oz. 1/41b. Lb.

ro5 I White. Pale green leaves, almost yellow ................ I5 30 I 100

MESSRS. J. M. ThORBURN \& $\mathrm{CO}$

El Paso, July 27, 1898 .

Dear Sirs: 1 consider it my duty to inform you about the results 1 had with the seeds 1 bought of your firm. The Jute seed gave an enormous amount of plants. The same is the case with your Cotton, and the Honduras Tobacco, which is a broad-leaved kind, ls doing extremely well in this climate, far superlor to the Havana Tobacco. The Sunfowers came up exceedingly well. Alfalfa. which 1 sow in poor, sandy soil, can be cut already, after three months, being 2 feet high. As for Muskmelons, Long lsland Beauty ls kind that cannot be pralsed enough, on account of earliness, productiveness, and slze. In all, 1 must thank you for the honest way you treated me, and cannot omlt to recommend the southern farmer to buy your northern-grown seeds, as they never fall to give satisfactlon and to yield immense crops. 


\title{
ONION
}

\author{
Oignon Cebolla 3wiebel
}

Culture. - Sow in rich, sandy soil, in drills $I$ foot apart, as soon as the ground can be worked in spring. Thin to 3 or 4 inches, using the rake and hoe frequently to keep down the weeds. The finest Onions are produced by the new method of sowing the seed in hotbed in February and March, and transplanting the seedlings to the open ground.

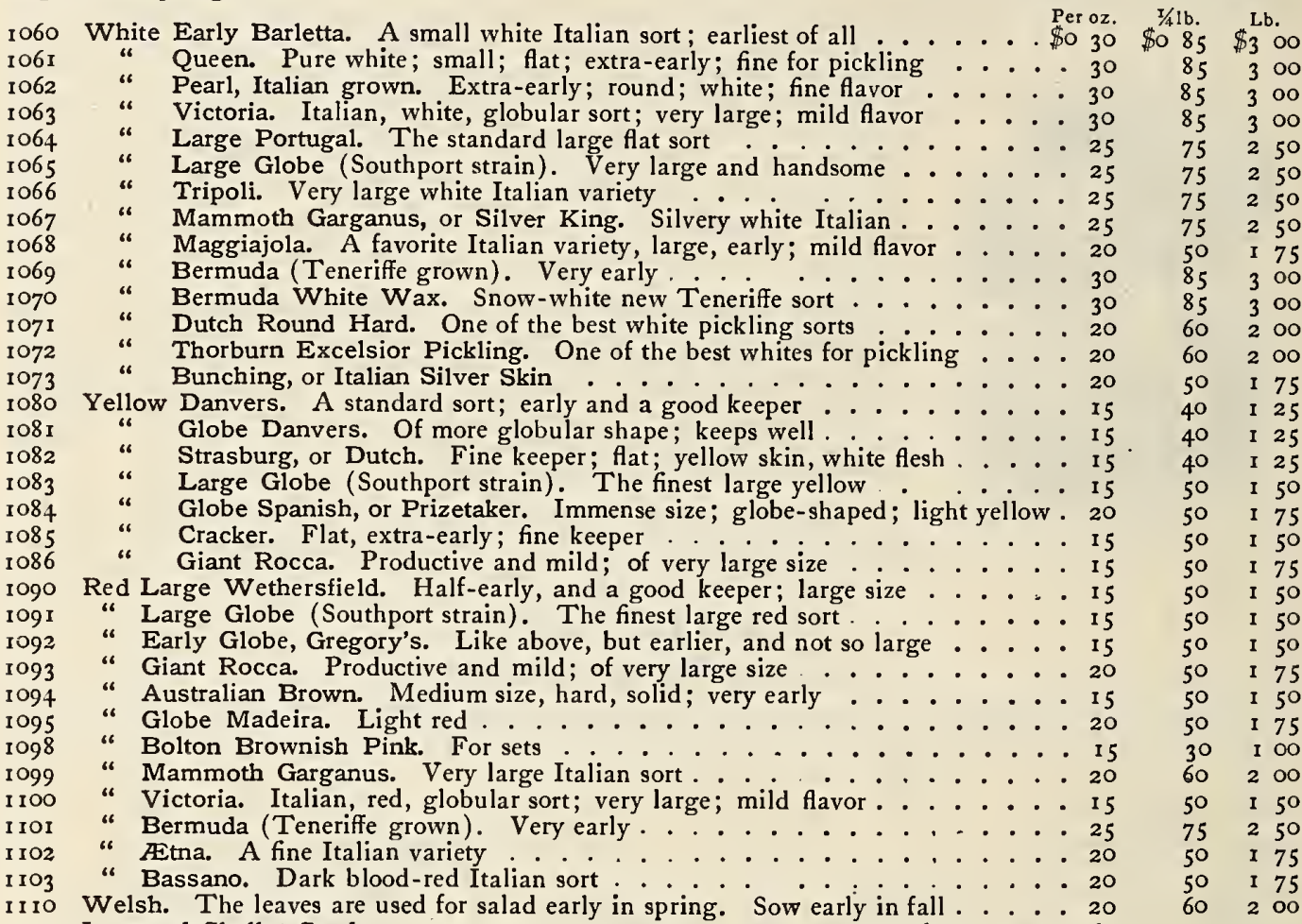

I I 3 Imported Shallot Seed ............... per pkt., io cts. . 60

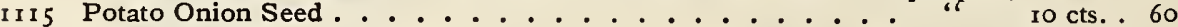

I1 17 Chives Seed................... " $25 \mathrm{cts.}$

\section{ONION SETS, ETC.}

Onion Sets and Tops should be planted near the surface, in drills about 12 inches apart and 4 inches in the rows. They must have high culture for the best results. They are valuable for early use, and where Onions from seed cannot be raised the first year, they are essential.

These are the prices ruling in January; later on they may be higher, ouving to shrinkage and rotting.

\begin{tabular}{|c|c|c|c|c|c|c|c|c|c|}
\hline Yellow Oni & $\begin{array}{r}\text { Per qt. } \\
\text {. } 020 \text { o }\end{array}$ & $\begin{array}{l}1 / 2 \mathrm{pk} . \\
\$ 060\end{array}$ & $\begin{array}{c}\text { Pk. } \\
\$ 100\end{array}$ & $\begin{array}{c}\text { Bus. } \\
\$ 350\end{array}$ & Red Top Onions. & $\begin{array}{l}\text { Per qt. } \\
\$ 020\end{array}$ & $\begin{array}{l}\$ 1 / 2 \mathrm{pk} . \\
\$ 060\end{array}$ & $\begin{array}{l}\text { Pk. } \\
\$ \mathrm{I}\end{array}$ & $\begin{array}{c}\text { Bus. } \\
\$ 255^{\circ}\end{array}$ \\
\hline Oni & $\therefore 25$ & 75 & 125 & 400 & White Potato Onions . & $\because 25$ & 75 & I 25 & 400 \\
\hline Onio & . 20 & 60 & 100 & 375 & Yellow Potato Onions & 25 & 75 & I 25 & 400 \\
\hline
\end{tabular}

\section{MESSRS. J. M. THORBURN \& CO.}

Dear Sirs: I have sold out my garden business. I regard my successor as perfectly responsible for any seeds he may order from you. I hope he may get as good seeds as I have for the last 20 years, for it is just 20 years ago you received my first order. In all that time I have not had an ounce of bad seed.

Yours respectfully,

(Signed)

EDWIN P. GOODE.

MESSRS. J. M. THOR BURN \& Co

Gentlemen: I can beat E. P. Goode, of Chicago, Illinois, in his record of your seeds by 14 years. I bought my first seed of you 34 years ago this spring. The length of time that I have used your seeds shows whether I think they are good or not.

$$
\begin{aligned}
& \text { Yours truly. } \\
& \text { (Signed) }
\end{aligned}
$$

R. W. PARR.

MESSRS. J. M. THORBURN \& Co.

Auburn, N. Y., March 15.1890.

Gentlemen: I have used your seeds for the last 35 years, and fail to call to mind a single instance of failure to germinate perfectly or fail. ure to come true to name. This I consider as unusual, and I congratulate you upon the fact. My father used seeds purchased of the originator of your House-Grant Thorburn. With best wishes, I remain yours, etc. 


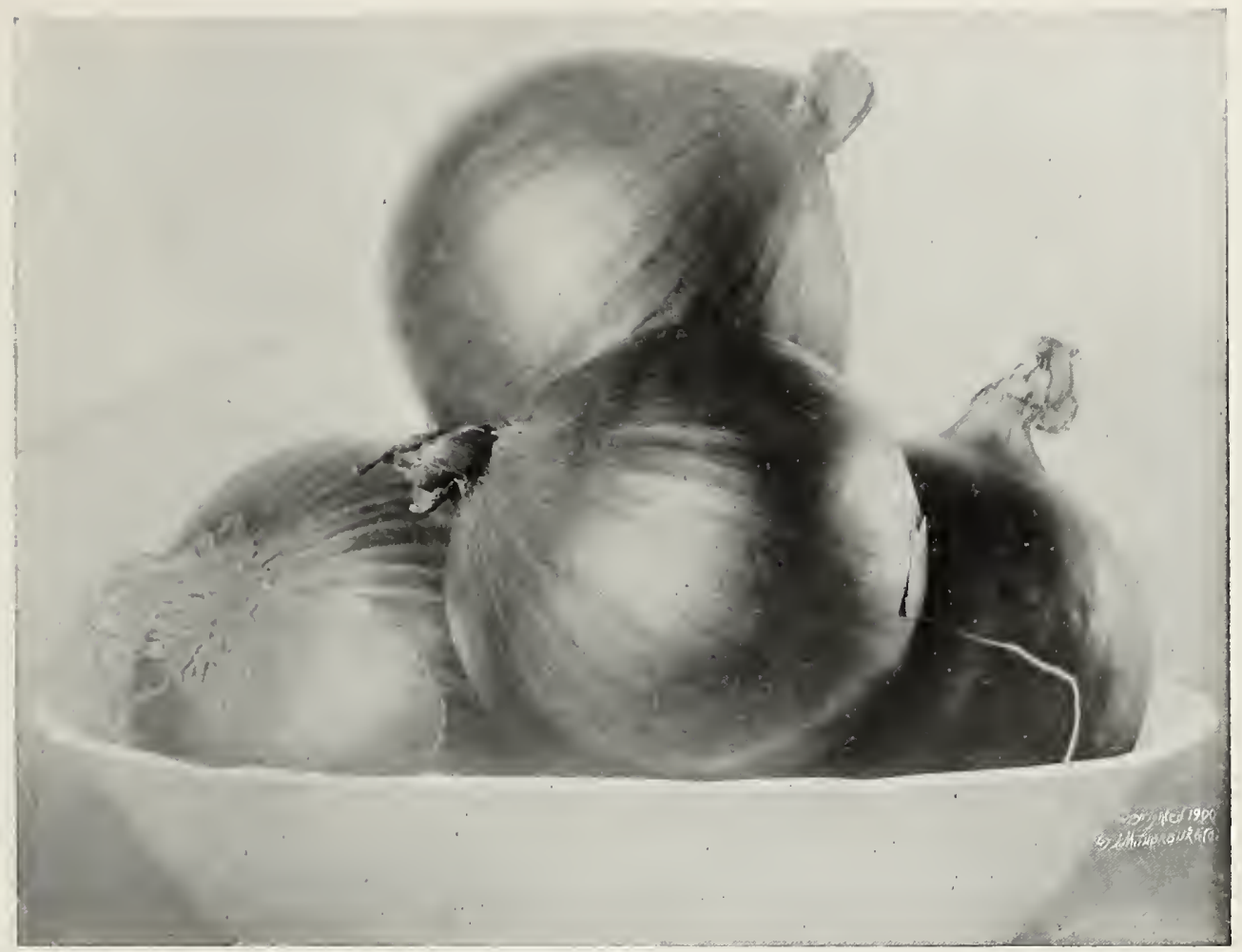

Red Globe Onions

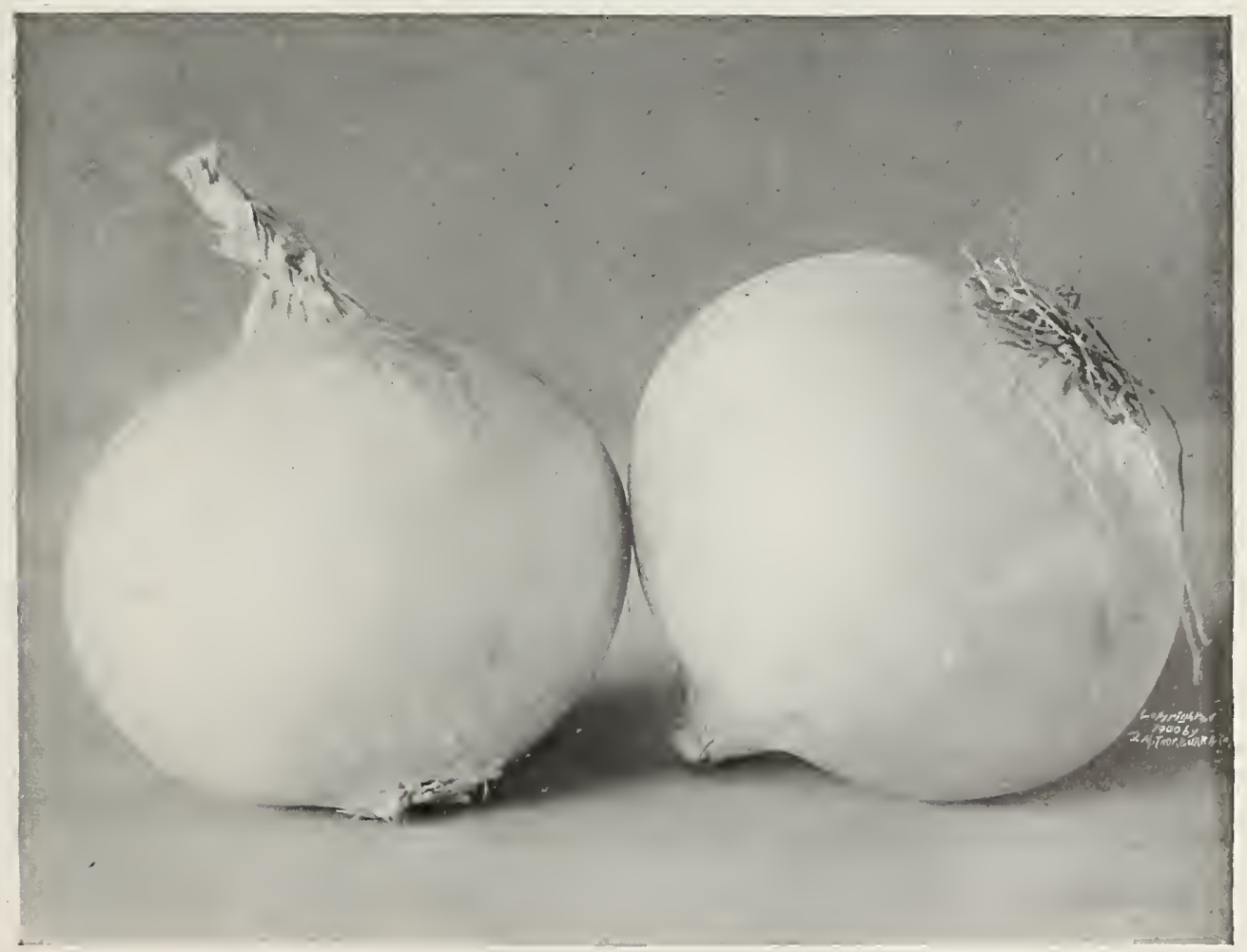

White Globe Onions

Plate IX 


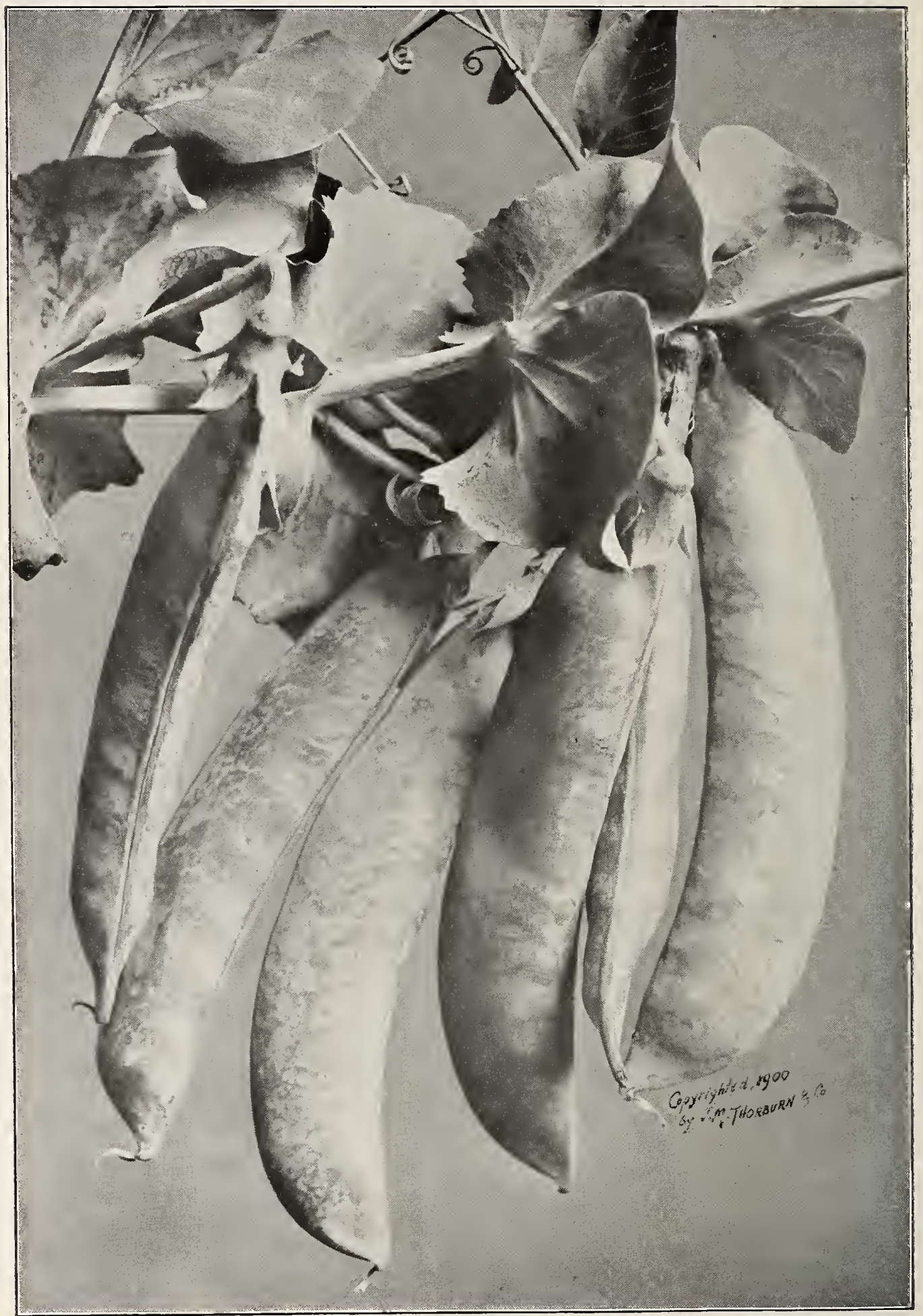

Plate $\mathrm{X}$ - Telephone Pea 


\section{PEAS}

\section{Pois Chicharos o Guisantes Erbjen}

Culture. - A week may be gained in earliness by sowing a quantity in moist sand placed in a box in the cellar, and planting outside when well sprouted. Light, dry soil, not overrich, suits the Pea. Sow as early as the ground can be worked, and again every ten days for succession. Peas may be sown in this vicinity as late as 2oth of August. Medium and late Peas must be planted early; Extra Earlies may be planted again in August. Sow in single or double rows, from 4 to 6 feet apart, according to the different heights, about an inch apart in the row (except such sorts as we note to sow thinly), and 4 inches deep. In this climate the O'Rourke Pea, if planted from the roth to the last of August, will produce a fair crop for fall picking, when Peas will be most acceptable. Hoe often, and keep the ground clean and fine. The tall sorts can be made to bear more freely by pinching-in. The dwarf varieties may be grown in beds like bush beans, with rows about the same distance apart. The holes which are sometimes found in Peas are caused by the pea weevil (Bruchus pisi). The beetles lay their eggs on the young pods, and the larvæ, as soon as hatched, make their way through the pods into the nearest Peas. If the new aphide attacks the peas spray the vines every day with clear water of the same temperature as the atmosphere.

\section{EXTRA-EARLY PEAS}

1130 Thorburn Extra-Early Market. Our standard market-garden extraearly Pea; productive and profitable to grow . . . . . . . 21/2\$0 $25 \$ 075 \$$ I $25 \$+50$

I 32 First-of-All. First-class selected strain of extra-earlies . . . . . $21 / 2$

I 34 Philadelphia. Resembling First-of-All .......... . . 3

I 36 Daniel O'Rourke Improved. Extra-early; favorite market-garden sort . . $21 / 2$

I 38 Alaska. One of the very earliest blue Peas; quite productive . . . $21 / 2$

II 40 *Gradus. Without doubt the finest extra-early Pea yet introduced; it is in condition to pick about four days after our Extra-Early Market. The pods are very large, and well filled with large zurinkled deep green peas of the very finest quality

I 4 I ${ }^{*}$ Exonian. One of the finest extra-early wrinkled sorts. (See Plate XII). ${ }_{2}^{3} / 2$

I 42 *American Wonder. Early and productive; fine quality (S) Plate XII) I

I 44 *Alpha. An extra-early wrinkled Pea; sow thickly ........ 3

I 145 *Premium Gem. Early; straight pods, well filled.......... I

I146 * McLean Little Gem. Early; straight pods . . . . . . . . . . . . . I 1/2

I $47{ }^{*}$ Blue Beauty. Pods medium size; peas of fine flavor. . . . . . . . 2

I 48 * Gregory's Surprise. A fine wrinkled variety, and only four days later than our Extra-Early Market . . . . .

I $149{ }^{*}$ Station. Extra-early wrinkled, very productive; large pods, well filled, and ripening but a few days later than the very earliest . . . . 2

I $50{ }^{*}$ Chelsea. Extra long pods, well filled with peas of finest quality . . I I 12

I 5 I *Duke of York. Very large, long, full pods, and peas of the finest flavor; very early and productive; one of the finest Peas grown .....3

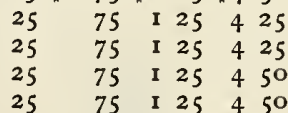

$25 \quad 75 \quad I 25 \quad 450$

$\begin{array}{lllllll}50 & 1 & 50 & 2 & 50 & 9 & 00 \\ 30 & 1 & 00 & 1 & 75 & 5 & 50 \\ 30 & 1 & 00 & 1 & 75 & 6 & 50 \\ 30 & 1 & 00 & 1 & 75 & 6 & 50 \\ 30 & & 85 & 1 & 50 & 5 & 00 \\ 30 & 85 & 1 & 50 & 5 & 50 \\ 30 & 85 & 1 & 50 & 5 & 50 \\ 30 & 85 & 1 & 50 & 5 & 00 \\ 30 & 85 & 1 & 50 & 5 & 50 \\ 30 & & 85 & 1 & 50 & 5 & 50 \\ 30 & 85 & 1 & 50 & 5 & 00 \\ 30 & & & & & & \\ 30 & & & & & \\ 30 & 5 & 50\end{array}$

\section{EARLY AND MEDIUM PEAS}

1160 *Daisy. A dwarf, wrinkled, second-early variety, bearing large, well-filled pods, each containing 8 to ro deep-colored peas of the finest flavor . I $1 / 2$

$1162{ }^{*}$ McLean Advancer. A fine standard sort, of excellent quality . . . . $21 / 2$

I 64 *Abundance Long, round, well-filled pods; sow thinly . . . . I $1 / 2$

II65 *Horsford Market-Garden. On the style of Advancer; very prolific . . $2 \frac{1}{2}$

I $66{ }^{*}$ Everbearing. Long pods, large peas; sow thinly . . . . . . . $21 / 2$

I 67 Pride of the Market. Very large pods, green peas; sow thinly . . . 2

1168 *Prince of Wales. Heavy cropper; peas of fine flavor....... 3

$1169{ }^{*}$ Champion of England. A well-known, standard variety; sow thickly. 5

$I_{1} 7^{\circ}$ *Duke of Albany (American Champion). Immense pods on style of Telephone; very superior ............. . . . 5

I 7 I *Heroine. Large, full pods; enormously productive . . . . . . . . $21 / 2$

I 72 Fillbasket. Of excellent flavor; one of the best. . . . . . . . $21 / 2$

I 73 *Shropshire Hero. Very productive; fine flavor; long, handsome pods . $21 / 2$

I 74 *Yorkshire Hero. A spreading variety; very productive; sow thinly . . $21 / 2$

\begin{tabular}{|c|c|c|c|c|}
\hline 35 & 12 & 2 & oo & 75 \\
\hline & & I & 25 & 4 \\
\hline 5 & & I & 25 & 4 \\
\hline 5 & & I & 25 & 4 \\
\hline 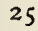 & & I & 25 & 4 \\
\hline 30 & & I & 50 & \\
\hline 25 & & I & 25 & 4 \\
\hline & & I & 25 & \\
\hline 0 & & I & 50 & \\
\hline 0 & & I & 50 & \\
\hline 5 & & I & 25 & \\
\hline & & I & 25 & 4 \\
\hline & & I & & \\
\hline
\end{tabular}

\section{MAIN AND LATE CROP PEAS}

I $180{ }^{*}$ St. Duthus. A fine new wrinkled main-crop variety; round, dark green pods, well filled with very sweet and finely flavored peas. . . . 4

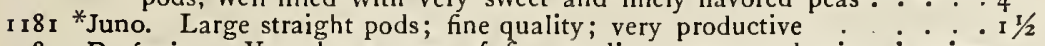

II82 Profusion. Very large peas of fine quality; very productive, bearing continuously for several weeks; a splendid main-crop variety . . 3

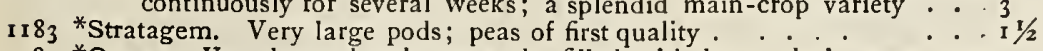

II84 *Queen. Very large, handsome pods, filled with large, dark green peas of finest flavor; first-class main-crop variety........ $2 \frac{1}{2}$ 


\section{MAIN AND LATE CROP PEAS-Continued}

$\begin{array}{ccccc}\text { Height } & \text { Pet } & \text { Per } & \text { Per } & \text { Pes } \\ \text { in feet } & \text { Qt. } & \text { 1/2pk. } & \text { pk. } & \text { bus. }\end{array}$

I185 Telegraph (L. I. Mammoth). Very large pods and peas of excellent

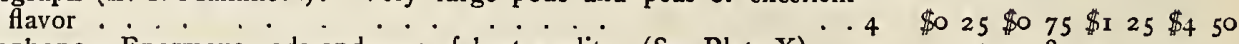

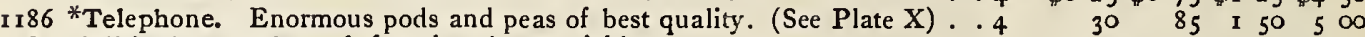

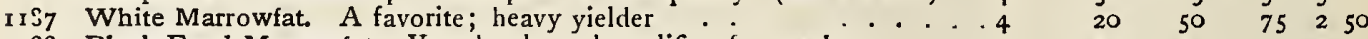

I 188 Black-Eyed Marrowfat. Very hardy and prolific; for market. . . . . $3 \begin{array}{llll}20 & 50 & 75 & 2\end{array}$

\section{SUGAR PEAS (EDIBLE PODS)}

Sugar Peas have edible pods, which are eaten when young.

1189 Giant White. Very large; fine quality . . . . . . . . . . . 5

I I90 Mammoth Melting Sugar. One of the best edible pod sorts . . . . 4

II 91 Tall Erfurt Sugar. Very large; white seed; finest quality - pint, 4oc. . 4

I 92 Mammoth Gray-Seeded Sugar. Immense pods . . . . . " 40c. . 5

$\begin{array}{lllllll}35 & 1 & 25 & 2 & 25 & 8 & 00\end{array}$

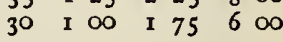

75

75

Those marked with a star $\left(^{*}\right)$ are wrinkled marrows, and, unless otherwise stated, should be sown thicker than the round Peas, and not till the ground has become warm, as they are more liable to rot. They are the finest flavored of all Peas.

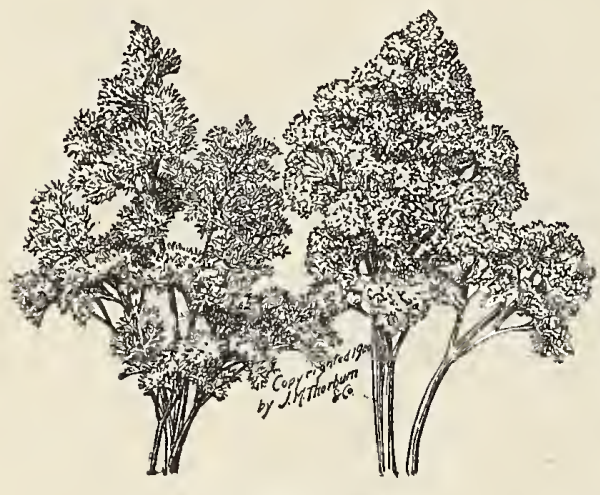

EXTRA-CURLED PAR8LEY.

\section{PARSLEY}

\section{Persil Perijil Peterjilite}

Culture. - Soak the seeds a few hours in lukewarm water, and sow early in spring, and until the middle of July, in drills I foot apart. Thin out the plants to 4 inches. To preserve in winter, transplant to a light cellar or coldframe. No. 1217 should be thinned out while young, and managed in after cultivation the same as Carrots and Parsnips.

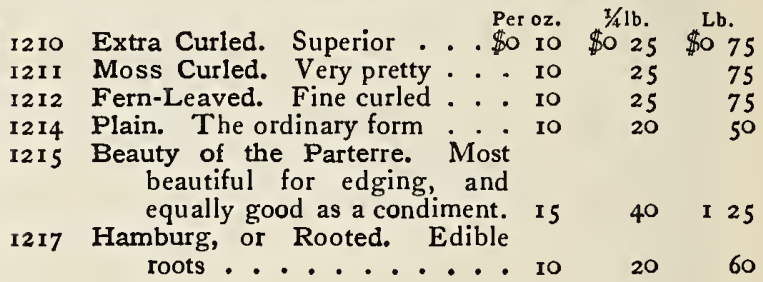

\section{PARSNIP}

\section{Panals Chirijia Paştinate}

Culture.-Sow as early in the spring as the ground can be worked, in rich soil, in drills is inches apart. The ground should be well and deeply dug. Thin to 6 or 8 inches in the rows. Hoe and cultivate often to keep down weeds.

I220 Thorburn Hollow Peroz.
Crown. A market-
gardener's strain. \$o ro \$o 20 \$o 50
I222 Long White. A standard

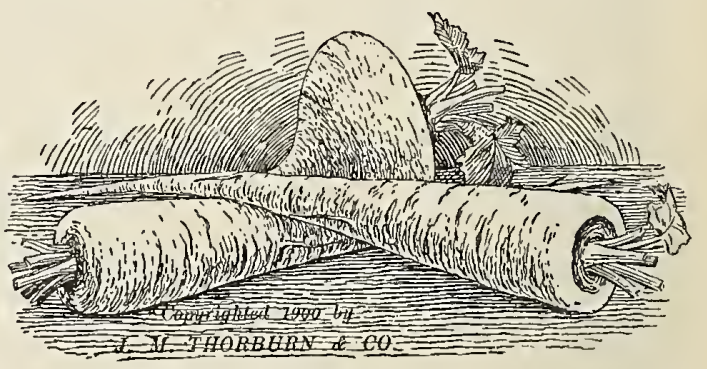
variety. A standard 10 . 20 . 50

1223 Abbott Improved. Smooth and quite large ; fine sort $\quad$ Per oz. ${ }^{1 / 4 \mathrm{lb} .} \mathrm{Lb}$.

1224 Maltese. One of the best sorts; not quite as long as the Long White... . . . 10 \$0 20 \$0 50

1225 Early Round . . . . . . . . . . . . . . . . . 10 20 50

THE AMATEUR'S PRACTICAL GARDEN BOoK.-In addition to the very carefully prepared directions for culture which are found in this Catalogue, our customers frequently desire further information, and ask many questions. To all such, and indeed to all our friends, we especially commend THE AMATEUR's Practical Garden-Book, which has been prepared, largely at our suggestion, by Mr. C. E. Hunn and Prof. L. H. Bailev, of Cornell University. This handy little book is alphabetically arranged and answers with accurate information hundreds of queries on garden work. It deals succinctly with vegetables and flowers, with fruits and trees, with bulbs and plants. Troubles with insects and plant diseases are discussed and remedies presented. Indeed, it might well be called a pocket -ncyclopedia, couched in plann language, stripped of all unnecessary scientific verbiage. We wish that every one of our customers might have a copy, which we will gladly send on receipt of the price. 250 pages, many illustrations, cloth, $458 \times 63 / 4$; sent postpaid for $\$ 1$. 


\section{PEPPER}

\section{Piment Pimiento झifeffer}

CUlture. - Sow in hotbeds in March, and when the soil has become warm, set in rows 2 feet apart and 18 inches in the rows; hoe frequently. The plants may also be forwarded in small pots.

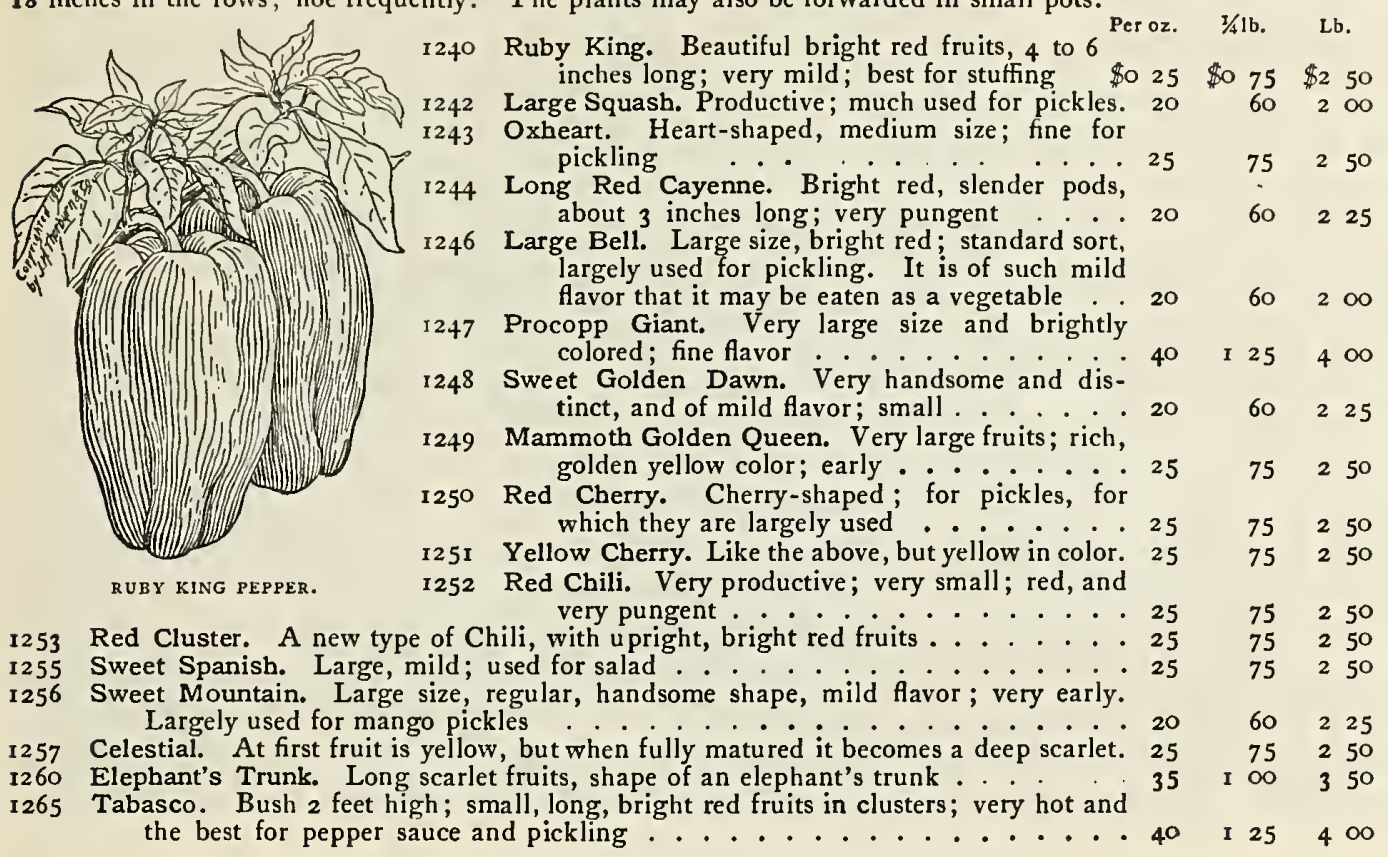

\section{PUMPKIN}

\section{Potron Calabaza Brofie fürbifis}

Culture. - May be planted middle of spring, among the Indian corn or in the field or garden, in hills 8 or to feet apart each way, four seeds in a hill. In other respects, are cultivated in the same manner as melons and cucumbers. Avoid planting them near other vines.

1270 Large Cheese. Flat; one of the best varieties for family use Per oz. $1 / 4 \mathrm{lb}$. Lb.

small yellow............ 10 $20 \quad 50$

Fine for pies, very prolific and a good keeper .......... ro 2579

1275 Winter Luxury. A fine keeper, and one of the best for pies . . . . . . . . 10 20 50

1276 Black Negro. New Hampshire Pumpkin. . . . . . . . . . . . . . . . . . . 10 2060

1277 Golden Oblong. Orange skin, light yellow flesh; fine quality, good keeper . . . Io 2050

1278 White Cushaw. A pure white, crookneck variety of excellent quality . . . Io 25

1279 Striped Cushaw. Medium size, Per oz. 1/4lb. Lb. crookneck; very productive. \$o Io \$o 25 \$o 70

1280 Red Etampes. Medium size, flat: fine for cooking .... I5 $35 \quad$ I 25

128 I Japan Crookneck. Fine keeper, of first quality; entirely distinct.

1282 Golden Marrow. Oblong-shaped, slightly ribbed; skin golden orange color; flesh of fine flavor; one of the best for pies...

1283 Mammoth King. Grows to an enormous size.......

1284 Calhoun. Very superior quality; yellow flesh; fine for pies . .

1285 Mammoth Tours. A very large French variety . . - . B .

1286 Tennessee Sweet Potato. Bellfor pies. . . . . . . .

1287 Connecticut Field. Grown for stock; productive ......

\begin{tabular}{|c|c|c|}
\hline IO & 20 & \\
\hline Io & 20 & \\
\hline I5 & 50 & I \\
\hline IO & 20 & \\
\hline IO & 25 & \\
\hline IO & 25 & \\
\hline
\end{tabular}

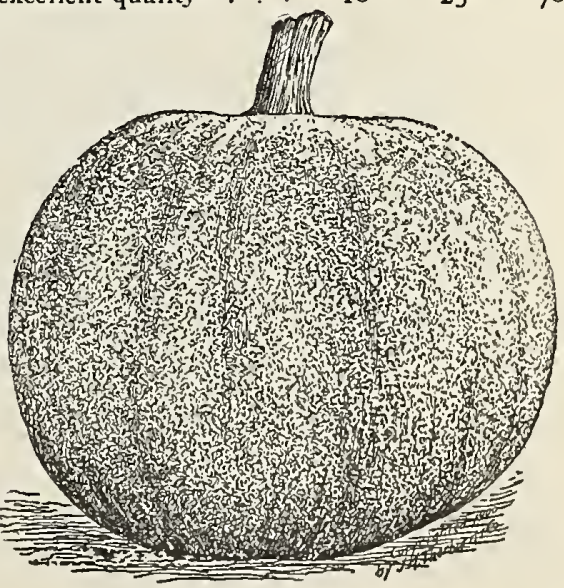

WINTER LUXURY PUMPKIN. 


\title{
SEED POTATOES
}

\author{
Grown Expressly for Seed
}

\section{POMME DE TERRE Patalas Rartoffeln}

Culture.- In order to have the best success in growing Potatoes, it is necessary to plant as early as the ground can be made ready. Select a rich soil, and plant in rows 3 feet apart, and the sets $I$ foot in the rows. If wood ashes and plaster can be procured, sow a good dressing over the field after the Potatoes are up. If a very early crop is desired, it will be necessary to sprout the Potatoes before planting. Cut the Potatoes into pieces of any size desirable, and place in a warm, light room for four to six weeks before required for planting in the open ground. During this time shoots will start out strong and vigorous, so that, as soon as planted, they will send out roots and grow much more rapidly than those treated in the ordinary way. Another method is to place the sets in a hotbed two weeks before they are wanted, and then lift carefully and set out on fresh horse-dung, so that the heat will cause them to start at once. If the Colorado potato-beetle makes its appearance, the vines must be dusted with Paris green mixed with about 80 parts of plaster; or, what is better, mix the Paris green in water, one small tablespoonful to a pail, and apply with a small brush or broom. Take care to stir the mixture often, or else the Paris green will settle to the bottom. Two or three applications during the season will usually suffice to clean off all the beetles. Three to 4 barrels to the acre.

These are the prices ruling in January; later on they may be higher.

\section{EARLY VARIETIES}

1300 The Thorburn. We recommend it as positively the best for first crop. It is the earliest of all, and the best in quality; is also very productive and of good size and form . . . . . . . . . . . . . . \$0 50 \$0 $85 \$ 20 \$ 40$

I 302 Thorburn's Beauty of Hebron. Slightly flesh-colored skin, with pure white flesh. Very productive and of the finest quality; a first-class early variety * $40 \quad \begin{array}{llllll}70 & 2 & 00 & 3 & 75\end{array}$

1304 Early Norther. Extra-early, very prolific; shape of the Early Rose; fine table quality . . . . . . . . . . 40

I 305 Early Puritan. Very early; white skin and flesh, finest quality . . . . . . . 40

1306 Bovee. Extra-early, very productive, of fine quality; flesh white and very dry . 50

I307 Early Rose. The popular market sort; very early, fine quality; very productive. 40

$\begin{array}{llllll}70 & 2 & 00 & 3 & 75\end{array}$

$\begin{array}{lllllll}70 & 2 & 25 & 4 & 00\end{array}$

$\begin{array}{llllll}85 & 2 & 50 & 4 & 50\end{array}$

$\begin{array}{lllll}70 & 2 & 00 & 3 & 75\end{array}$

\section{INTERMEDIATE AND LATE VARIETIES}

13 Io Thorburn New White Peach-Blow. The flesh and skin are pure white and

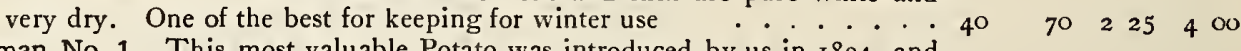

1312 Carman No. 1. This most valuable Potato was introduced by us in 1894 , and it is now a recognized high-class standard sort the world over. It is in every respect the finest second-early Potato ever offered; enormous yielder; handsome and uniformly large; peculiarly white skin and flesh; perfect in

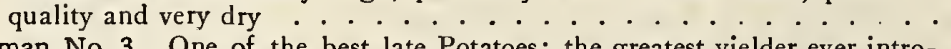

I3 I4 Carman No. 3. One of the best late Potatoes; the greatest yielder ever introduced; very large tubers; of handsome form and few and shallow eyes * . $40 \quad \begin{array}{llllll}70 & 2 & 00 & 3 & 75\end{array}$

I315 Sir Walter Raleigh. A fine new variety for main crop; very productive and uniform, all the tubers being of marketable size. Flesh white and of best quality. . . . . . . . . . . . . . . . . . 50

1316 Uncle Sam. Handsome shape, good size, fine quality and very productive . . 50

I3 17 State of Maine. Very productive; white skin and flesh; free from rot and of superior quality; a fine late variety ... . . . . . . . . 40

I3 8 Delaware. Large, and of fine quality; in color white; an immense yielder . . 50

$\begin{array}{llllll}85 & 2 & 50 & 4 & 50\end{array}$

$85 \quad 2 \quad 50 \quad 450$

$\begin{array}{lllll}70 & 2 & 00 & 4 & 00\end{array}$

$85 \quad 250 \quad 450$

\section{LARGE POTATO YIELD}

Edward Bonynge, of Stroud township, near Stroudsburg, planted about three pounds of "The Thorburn, earliest and best," this spring, and in go days he dug from this planting three bushels and some quarts of very fine, large Potatoes. This varicty is great in size and very nicely proportioned; is considerably earlier than the Early Rose and much better for cooking.-Monroe Democrat.

J. M. THORBURN \& CO.

Belleville, Ill.

Gentlemen: From the 2 barrels of Carman No. 3 bought of you Iast spring, I dug 512 bushels of as fine, smooth, even-sized Potatoes as ever grew. There were not small ones enough to count the bushels. Don't you think I have broken the record of regular field culture?

$$
\begin{aligned}
& \text { Yours truly, } \\
& \text { (Signed) }
\end{aligned}
$$

Dear Sirs: I am so well pleased with the Carman No. I Potatoes I purchased of you last spring, that I must write and let you know how they succeeded. I planted $\mathrm{r}$ bushel, $1 / 3$ of which rotted in the ground during the wet spell in spring. I gave them common field culture, and in fall 1 dug 95 bushels of nice Potatoes. 


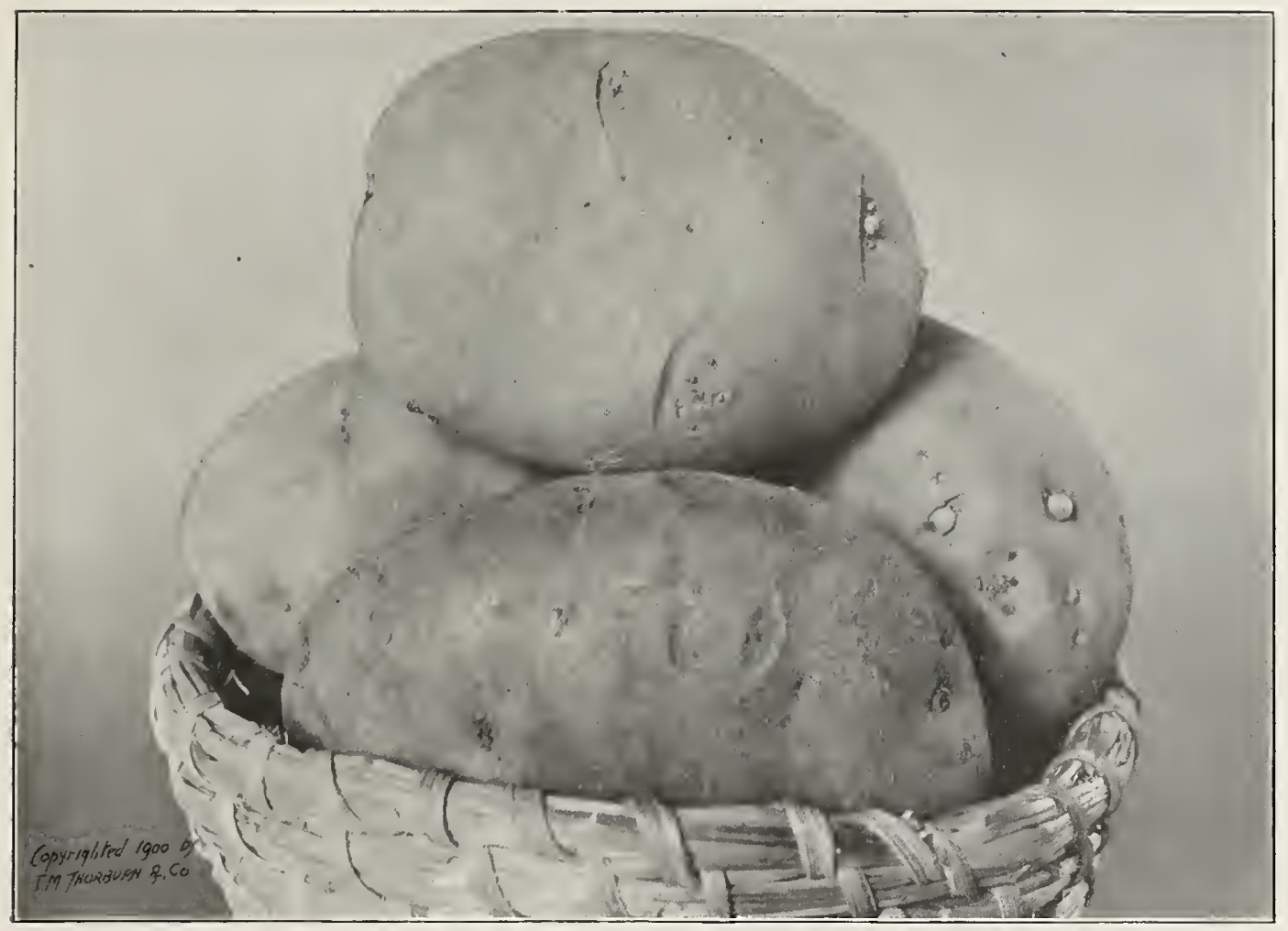

The Thorburn Potato

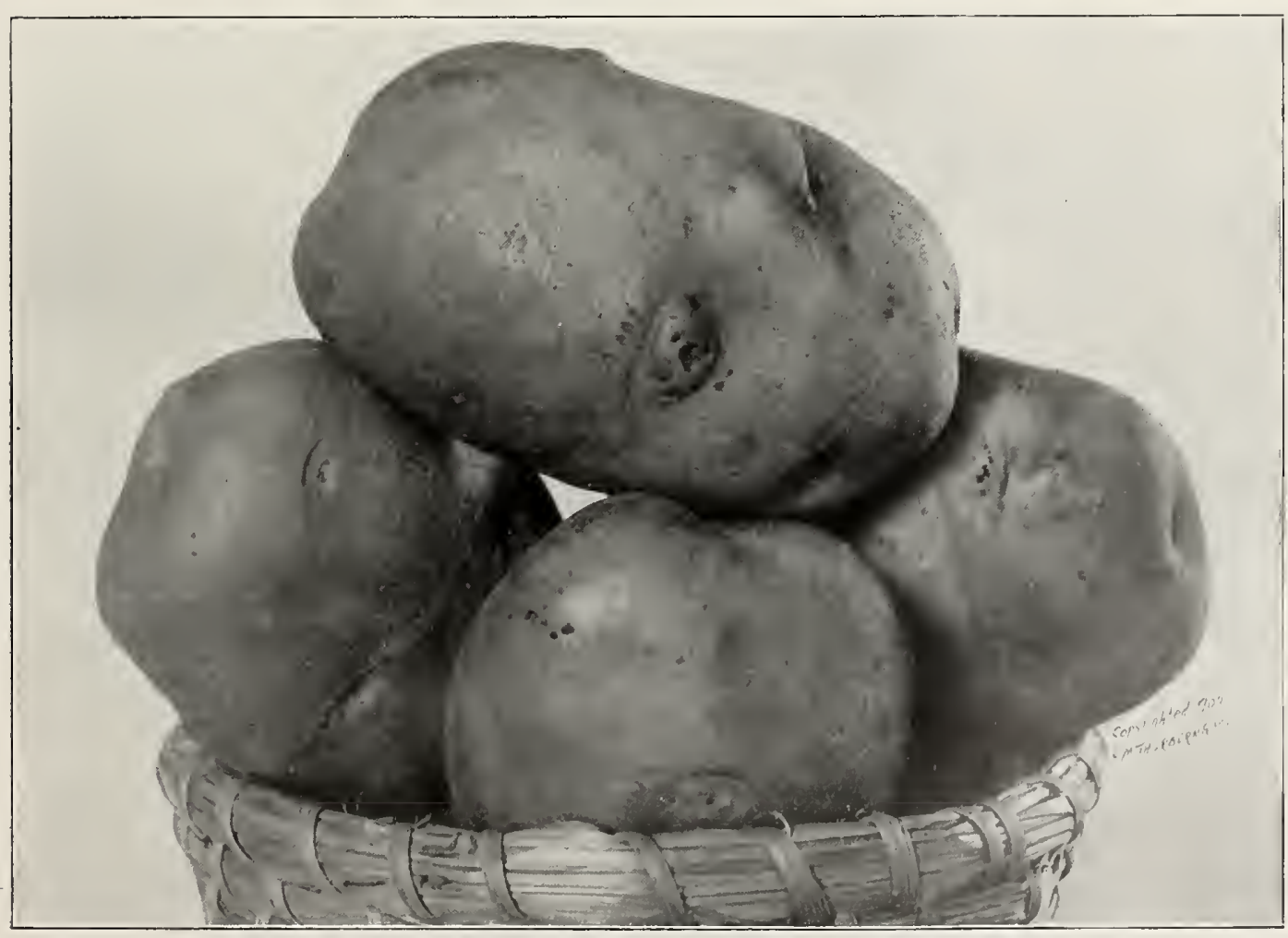

Carman No. 1 Potato

Plate XI 


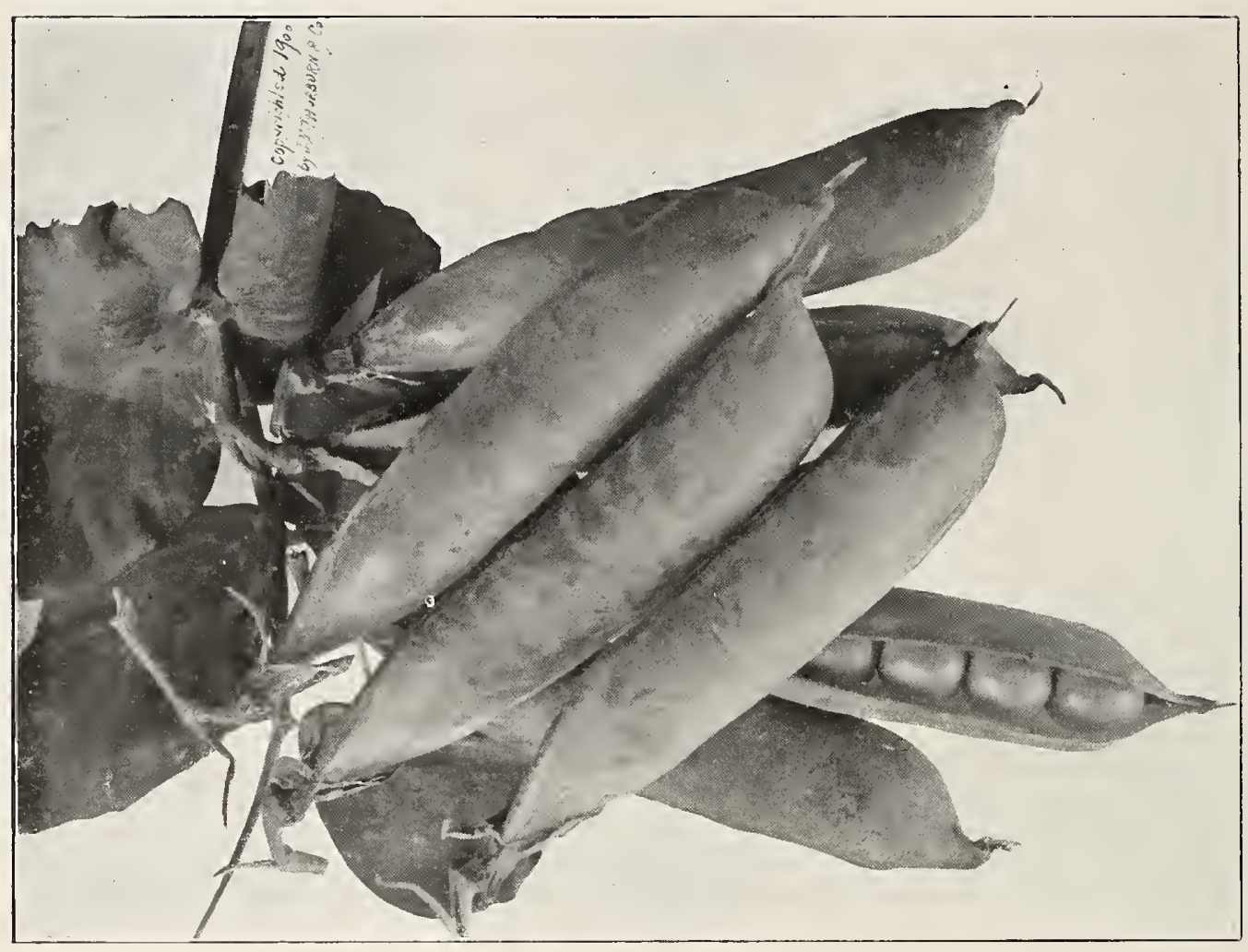

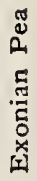

븣

$\stackrel{5}{\vdots}$

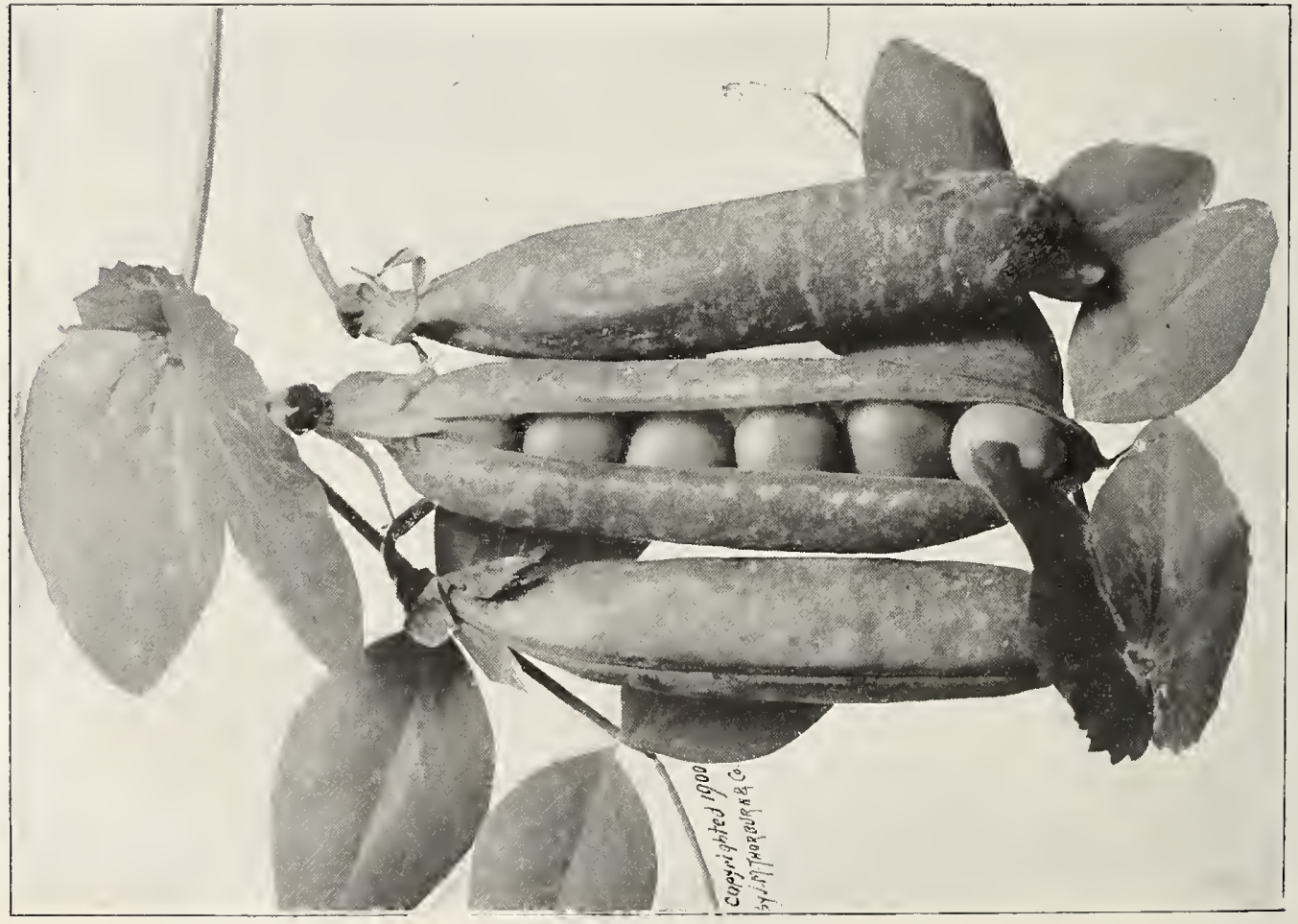

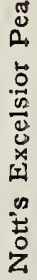




\section{RADISH}

\section{RAdIS ET RAVE Rabanos y Rabanitos Rabies uno Rettig}

Culture. - Sow as soon as the ground is dry in the spring, in rows 8 to 12 inches apart, every week or ten days for a succession, up to the middle of June, after which they are but little used, unless a cool northern spot can be had, where the ground is shaded during part of the day. They should be sown in light, rich soil, as a crisp Radish cannot be produced in heavy soils. Sow also in early fall for late crops and winter use. Sow 8 to Io pounds to the acre. Radishes should be eaten when quite small; it is a mistake to let them grow too long and too large. This applies particularly to the French Breakfast and small turnip-shaped sorts.

Those marked with the asterisk $\left(^{*}\right)$ are best suited for market-gardeners.

330 *Turnip, Early French Scarlet. Very early . . . . . . . . . . . Per oz. T1/1b. Lb. 133 I " " " " " * * * * Forcing. Crisp and beautiful; very early . . . 10 25 Scarlet. Very early

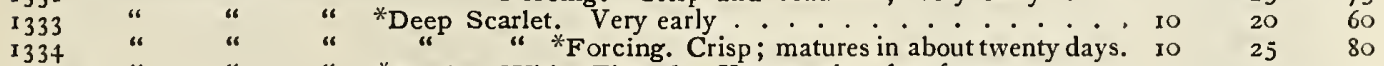

I336 " " *Scarlet, White-Tipped. Very early; for frames or out-

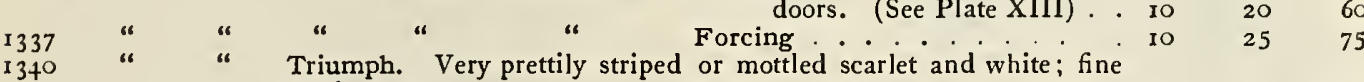

I 34 I " “ *Prussian Scarlet Giobe-Shaped. Fine for forcing or open ground. 35

1342 " “ *Non Plus Ultra. Extra-early scarlet forcing; short-leaved..... Io

I 343 " " Deep Blood-Red. Extra-early forcing sort . . . . . . . . . Io

I 344 " "White or Box. Suitable for forcing; flesh pure white and sweet . 10

I 345 " Large White Summer. Of large size; roundish. (See Plate XIII) . . Io

1346 " *Yellow Summer. Dull yellow; fine flesh; popular in New York market . 10

I 347 "Golden Summer. Smooth and bright skin . . . . . . . . . . . . 10

I350 Round Scarlet China. Fine for winter or summer; grows in six to eight weeks . . 1o

I 355 *Olive-Shaped French Breakfast. Pink and white; early. (See Plate XIII). . . Io

I356 " Golden Yellow. A new sort of very fine quality . . . . . . . IO

1357 "White. Mild and fine for summer.............. I0

1358 " Deep Scarlet. Crisp; very early . . . . . . . . . . . . I0

I359 “ Delicacy. Snow - white, smooth and tender; fine for forcing . . . IO

I360 Half-Long Deep Scarlet. Flesh bright and crisp . . . . . . . . . . Io

$1365{ }^{*}$ Long Scarlet Short Top. Very long, crisp; for frames or outdoors. (See Plate XIII). Io

1366 " Brightest Scarlet White-Tipped ................ I0

1367 "* * ${ }^{*}$ carlet Chartier White-Tipped . . . . . . . . . . . . . . . . 10

1368 " *Wood Early Frame. Long, red, crisp, and good for forcing . . . . . 10

1369 "White Naples. Slender; for summer use ". . . . . . . . . Io

I370 "White Vienna, or Lady Finger. Crisp and tender in summer. . . . . . Io

I37 " Icicle. Pure white, of fine flavor; suitable for forcing . . . . . . . . . 30

1375 *White Strasburg Summer. Very large; the German's favorite. (See Plate XIII). 10

I 377 "* *Stuttgart Summer. Very early and very large . . . . . 10

1380 *Winter Scarlet Chinese. Very handsome and distinct, and keeps well . . . . . . Io

I382 " *Long Black Spanish. The popular winter sort . . . . . . . . . IO

I 383 " *Thorburn Improved Half-Long Black Spanish. Very fine strain ..... Io

I384 " Round Black Spanish. Fine for winter ............... I0

I385 " Large White Spanish. Fine for winter

I 386 " California White Mammoth. A very large white winter variety . . . . Io

1387 "Celestial. The best of the winter sorts; very large, white; solid, crisp flesh Io

I390 Raphanus Caudatus (Edible-Pod Radish; Rat-Tailed Radish). Has edible seed pods; used raw or pickled ........... per pkt., ro cts. . 5o

$\begin{array}{ll}\text { I OO } & 350 \\ 25 & 90 \\ 25 & 75 \\ 25 & 75 \\ 20 & 60 \\ 20 & 60 \\ 20 & 60 \\ 20 & 60 \\ 30 & 100 \\ 20 & 60 \\ 25 & 75 \\ 20 & 60 \\ 25 & 75 \\ 20 & 60 \\ 25 & 75 \\ 20 & 60 \\ 20 & 60 \\ 25 & 75 \\ 20 & 60 \\ 20 & 60 \\ 20 & 60 \\ 85 & 300 \\ 20 & 60 \\ 20 & 60 \\ 20 & 50 \\ 20 & 50 \\ 20 & 60 \\ 20 & 50 \\ 20 & 50 \\ 20 & 50 \\ 25 & 75 \\ & 6\end{array}$

\section{RAMPION}

\section{RAIPONCE Reponche Rapunzel=Rübe}

CULTURE.- - Sow in the open ground early in May, either broadcast or in drills ro inches apart. As the seed is very fine, it merely requires to be pressed firmly into the soil. Thin out the seedlings if they come out too thick, and water frequently during hot weather. The roots may be gathered for use from October onward throughout the winter.

I 400 Rampion. The roots and leaves are excellent $\mathrm{J} / 4 \mathrm{Ib}$. Lb. salad..................... \$30 \$0 $85 \$ 300$

\section{ROQUETTE}

\section{RoQUETTE Jaramago}

Culture.-Sow early in spring, in rows, and thin out to 8 or to inches. If kept well scuffled and watered, the tart flavor of the leaves is greatly diminished. This flavor is not pronounced in the small leaves, which are used for salad. The flowers, appearing from May to June, have very much the odor of orange blossoms.

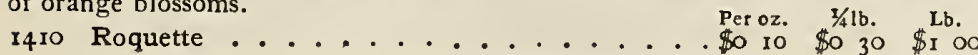

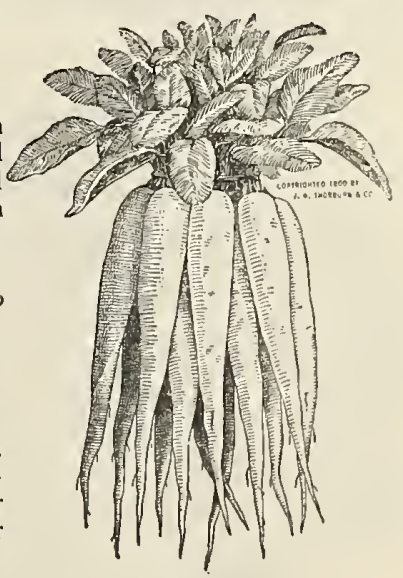

RAMPION. 


\section{RHUBARB \\ RHUBARB Ruibarbo Rhabarber}

Culture. - Sow seed in a coldframe, in a fine, rich, sandy loam, about the first of March, in drills 4 inches apart. Keep the frame covered during nights and cold days, so that the soil will not freeze, and in six to eight weeks the plants will be large enough to set in the open ground. Transplant to a rich soil, and set in rows 12 inches apart and 12 inches in the row. The following spring transplant again to 4 or 5 feet apart each way, and the next spring the stalks will be large enough to pull. When roots are set out, plant them 4 or 5 feet apart each way, and keep the weeds down. If roots are used, a crop may be had after one season, which is much better than sowing seeds where only a few plants for family use are needed. In the fall the bed should have a thick dressing of coarse manure, to be spaded under in spring.

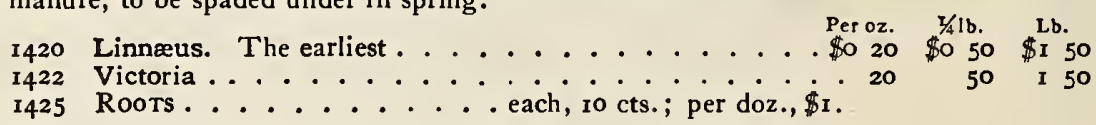

\section{SALSIFY, or VEGETABLE OYSTER}

\section{Salsifis Ostion Vegetal beafertwurzel}

Culture.-Sow as early as the ground can be worked in the spring, in drills 12 inches apart, $I$ inch deep, and thin out to 6 inches in the row. Keep them free from weeds. Cultivate the same as for Carrots and Parsnips. A part of the crop may be left in the ground till spring, when it will be found fresh and plump. The roots are cut into pieces $1 / 2$ inch long, boiled until tender, and then served with drawn butter, in which way it is a delicious vegetable. They are also mashed and baked like Parsnips, and have a sweet, agreeable favor. Mashed and fried, the flavor is much like that of the oyster. Sow 8 to ro lbs. to the acre.

1430 Long White French............... Peroz. 1/4lb. Lb.

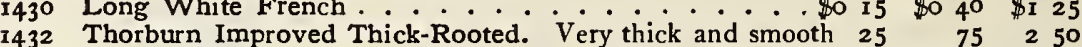

I435 Mammoth Sandwich Island. Large and superior ..... I5 50 I 50

\section{SCOLYMUS}

A vegetable from Spain. The roots resemble a small Parsnip, and will keep through the winter like a Turnip. It is cultivated exactly like the Carrot, except that it should be grown in rows 3 feet apart and 18 inches in the rows. It is eaten boiled, like Salsify.

I445 Scolymus ................................ Po 30 \$o 85 Lb.

\section{SCORZONERA}

\section{SCORzONERE Escorzonera Scorgiontwirgel}

Culture.-Cultivate the same as Salsify. It is cooked in the same manner, but on account of being somewhat more difficult to raise, is seldom seen in cultivation. Considered by many superior to Salsify. It is also called Black Salsify.

1450

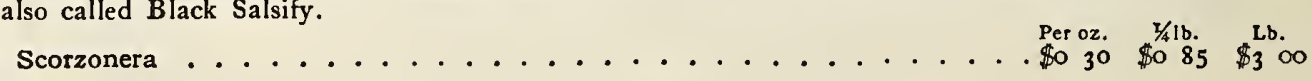

\section{SORREL}

\section{Oseille Acedera Sauerampfer}

Culture.-Sow in spring in drills 18 inches apart, in a rich soil, and keep the flower-stems cut off as they appear. It remains in the ground year after year, and only needs to be taken up and divided once in four or five years. To be cut and cooked precisely like Spinach; or it is excellent cooked with it, one-third Sorrel to two-thirds Spinach. It is also used for soups. Very nice to be eaten after it has become cool. Inasmuch as the hot sun tends to increase its acidity, a northern exposure is preferable.

I455 Garden, Large French ....... \$o I5 \$o 40 \$I 25

1456 " Mammoth Lyons. Extra-large improved strain ..... 20 50 I 50

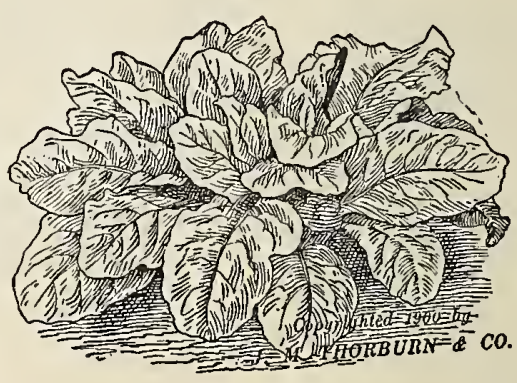

SORREL.

We pay postage or express charges on all seeds bought by the ounce or packet. 


\section{SPINACH}

\section{EPINARD Espinaca Spinat}

CULture. Sow in early spring, in drills a foot apart (ro to $12 \mathrm{lbs}$. to the acre), every two weeks, for a succession, and as it grows, thin out for use. For fall use sow in $\Lambda$ ugust, and for winter crop in September. Cover that which is left out over winter with straw or leaves, after the weather becomes quite cold. Keep clear of weeds. Sow the seed of New Zealand (which must be scalded and soaked in hot water before sowing) in hills 3 feet apart each way, three or four seeds in a hill. This is fit for cutting all summer.

I460 Round Viroflay (Thick-Leaved). Has very large, thick, dark green leaves; the favorite market-gardeners' sort for fall or spring sowing . . \$o ro \$o I5 \$o 35

1462 Round-Leaved Flanders. A standard sort ............... ro 15 r 35

1464 Lettuce-Leaved. Popular French sort . ro I5 35

I466 Curled-Leaved Savoy, or Bloomsdale. Large curled and wrinkled leaves; tender, and of the finest flavor... ro 15

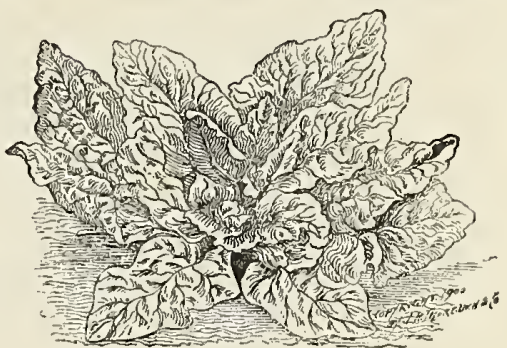

LONG-STANDING SPINACH.

I467 Long-Standing (Round Thick-Leaved). Dark green; leaves large and thick; Per oz. 3/4tb. Lb. very long-standing before running to seed. The best for spring growing. . \$o ro \$o I5 \$o 35

1468 Victoria (new). Extra dark black-green color. Two or three weeks later than the ordinary "Long-Standing." A fine variety for spring sowing . . . . . 10 I5 35

1469 Prickly, or Winter. Vigorous and hardy, and recommended for fall sowing . . . . 10 15

I470 New Zealand Summer. Distinct; grows well during hot summer weather, when the ordinary Spinach cannot be had . . . . . . . . . . . . . Io 30 I 00

\section{SKIRRET}

\section{CHERvis Buctertourzel}

CUlture. - Sow in drills $1 / 2$ inch deep, a foot apart; thin out to 8 inches in the row ; keep down the weeds. Take up the roots before winter, and store in sand or earth. It is a plump, fleshy root, containing a quantity of sugar, and is eaten like Scorzonera or Salsify.

r 480 skirret........................ . per pkt., ro cts. . \$o 40

\section{SPROUTS}

\section{Choux Verts non Pommes}

Culture.-Sow No. 1485 very early in spring, and Winter Kale in September. Full directions for

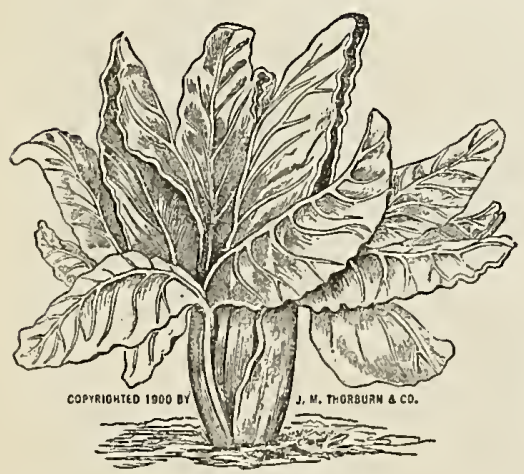

SWISS CHARD. growing the latter will be found on page $2 \mathrm{I}$, under head of Kale.

${ }^{4} 85$ Spring Sprouts, or English Rape. Per oz. $\quad x / 4 b$. Lb.

${ }_{4} 47$ Winter, or Siberian, Thorburn Improved ........ \$0 ro \$0 25

\section{SWISS CHARD, or SILVER BEET}

This is a Beet producing leaves only, of a superior quality to those of the ordinary Beet, and excellent as greens. Cultivate about the same as Spinach, by sowing the seed in early spring, in drills about a foot apart. As it grows, thin out for use, and keep clear of weeds if success is desired. Good cultivation will greatly increase the delicacy and tenderness of the leaves.

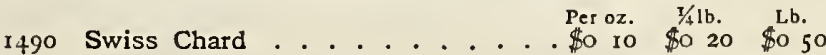

J. M. THORBURN \& CO.

Cutchogue, L. I., July $I \Upsilon, 1898$

Gentlemen: I have grown your Large Erfurt Caulifower since 1876 , and your Snowball and Gilt-Edge since tbey were introduced, and at this time $I$ grow no other varieties. The Gilt-Edge produces very large, heavy heads, requires a long season, and is desirable for early setting to grow for pickling. It makes good heads in warm weather. Tbe Large Erfurt has very fine wbite heads of large size. We consider it the best for setting from July 4 to 25 . Your Snowball is a fine medium-sized variety, heads very clean and quickly, and nearly all at one time. It is, therefore, very valuable for late setting for storing for winter. We use it almost exclusively for the growing of winter Canliflowers, taking up and storing small, half-grown heads in the latter part of November, in cool cellars or sheds, and holding for tbe good prices of Christmas and New Year. 


\title{
SQUASH
}

\author{
Courge Calabaza Speife Sürbiß
}

Culture. - Sow in hills in the same manner and at the same time as Cucumbers and Melons, the bush varieties 3 to 4 feet apart, and the running kinds from 6 to 9 feet apart.

\section{BUSH VARIETIES}

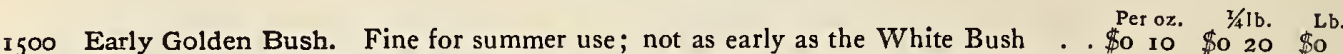
1502 Golden Custard. Mammoth strain of the Golden Bush. A valuable new bush variety; golden yellow flesh; fine quality . . . . . . . . . . . 10 2060

I504 Early White Scallop Bush. A good early shipping variety . . . . . . . . . . . Io

I506 Long Island White Bush. An improved strain of the above, very prolific and of fine quality ....................... Io

${ }_{507}$ Silver Custard. A mammoth strain of Early White Bush. It is very large, and the flesh is of fine quality ................... 10

I 508 Summer Crookneck. Yellow fruit; distinct; best for summer . . . . . . . . . I0

1509 Giant Summer Crookneck. Double the size of the above . . . . . . . . . . . Io

I5IO Giant Summer Straightneck. Same as above, except that most of them are straightnecked ...... .................. Io

I 5 I I Eggplant Bush Squash. White flesh; suitable for frying, like eggplant . . . . Io

I5I2 Cocozell Bush. A fine variety; oblong shape; skin smooth, dark green, marbled yellow or pale green ........................ I5

\section{RUNNING VARIETIES}

I530 Golden Bronze. Skin dark green; flesh golden yellow, fine-grained, and very sweet.

1532 Early Orange Marrow. Quite dịstinct; very early, and of most delicate flavor; suitable for fall or winter . . . . . . . . . . . . . . . Io

1534 Bay State. Hard, blue shell; for fall or winter . . . . . . . . . . . . . ro

1536 Boston Marrow. Oval; bright orange; flesh yellow and fine . . . . . . . . Io

I537 Hubbard. Well known and liked for late use; of superior quality; large size; color green, marked with orange; flesh dry, fine-grained, and of fine quality . to

1538 Golden Hubbard. The same as the above, but with skin of a bright red color . . 10

I539 Mammoth Warted Hubbard. Of immense size, and completely covered with warts. Of fine table quality ................. Io

I540 The Faxon. Medium size; very early and productive; orange flesh of fine quality. Io

1541 Turban. Orange-yellow flesh; good flavor ................ Io

1542 Essex Hybrid. A good fall and winter sort . . . . . . . . . . . . . . Io

I543 Marblehead. Resembling the Hubbard, but has gray skin; very productive, and a fine keeper; dry, sweet, and of the finest flavor . . . . . . . Io

1544 Perfect Gem. Round, white ; very productive and of fine quality ; for fall or winter Io

I545 Cocoanut. Of first-rate quality, and very prolific ............ Io

1546 Delicata. Orange-yellow, striped green; small size, but very prolific; it is extraearly, very solid, and a good keeper; flesh dry and of fine quality ...... Io

1547 Fordhook. One of the best winter sorts; fine quality . . . . . . . . . . IO

1548 Pineapple. Peculiar shape, white skin and fesh; fine late sort . . . . . . . . 10

I549 Canada Crookneck. Small, well-known winter sort; green skin . . . . . . . . . Io

1550 Winter Crookneck. One of the best winter sorts . . . . . . . . . . . . Io

I551 Der Wing. Light yellow flesh; very sweet; small, warty, winter sort . . . . . Io

I552 The Warren. A new type of the Essex Hybrid; of superior quality. . . . . . . Io

I553 Mammoth Chili. Grows to an enormous size; rich orange-yellow . . . . . . I5

I554 Mammoth Whale. New French variety of enormous size ; flesh solid, bright orange,

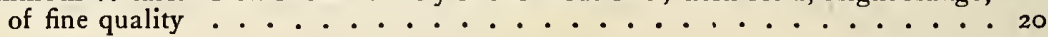

\section{VEGETABLE MARROW}

1560 English. The true English strain; cream-color, merging into deep yellow; white flesh; about 9 inches long Grows about 20 inches long, with a diameter of 3 or

I562 Italian (Cocozelle di Napoli). Grows about 20 inches long, with a diameter of 3 or 4 inches. Skin smooth, dark green, marbled yellow or paler green. In Italy it is eaten when quite young.................

Cutchogue. N. Y., July $13,1898$. used other for the three years past for the Southold Town Agricultural Society, and the demand is three to one in favor of yours. Yours respectfully. (Signed) 


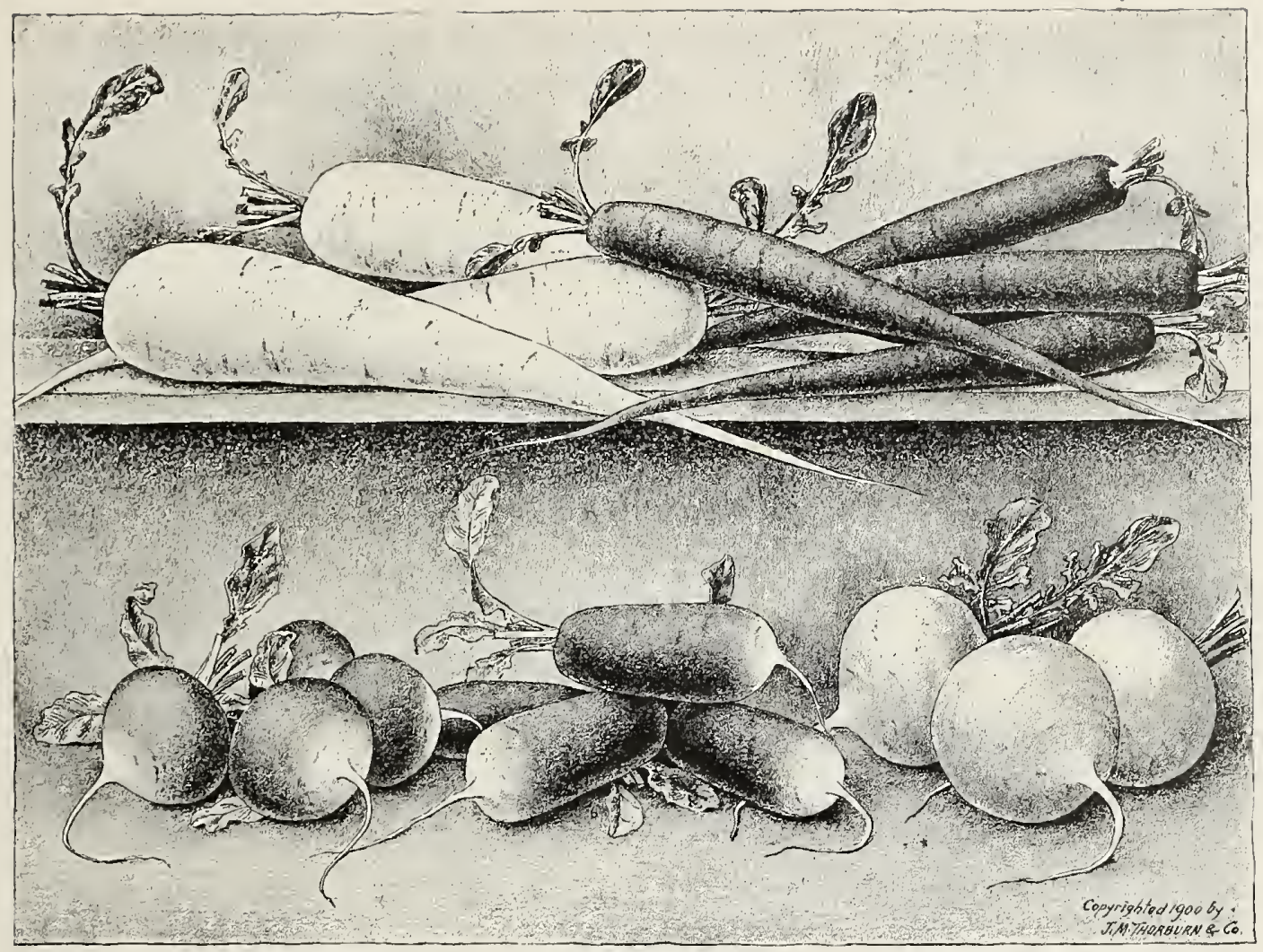

White Strasburg

Early French Scarlet White-Tipped
RADISHES

French Breakfast
Long Scarlet Short Top White Summer

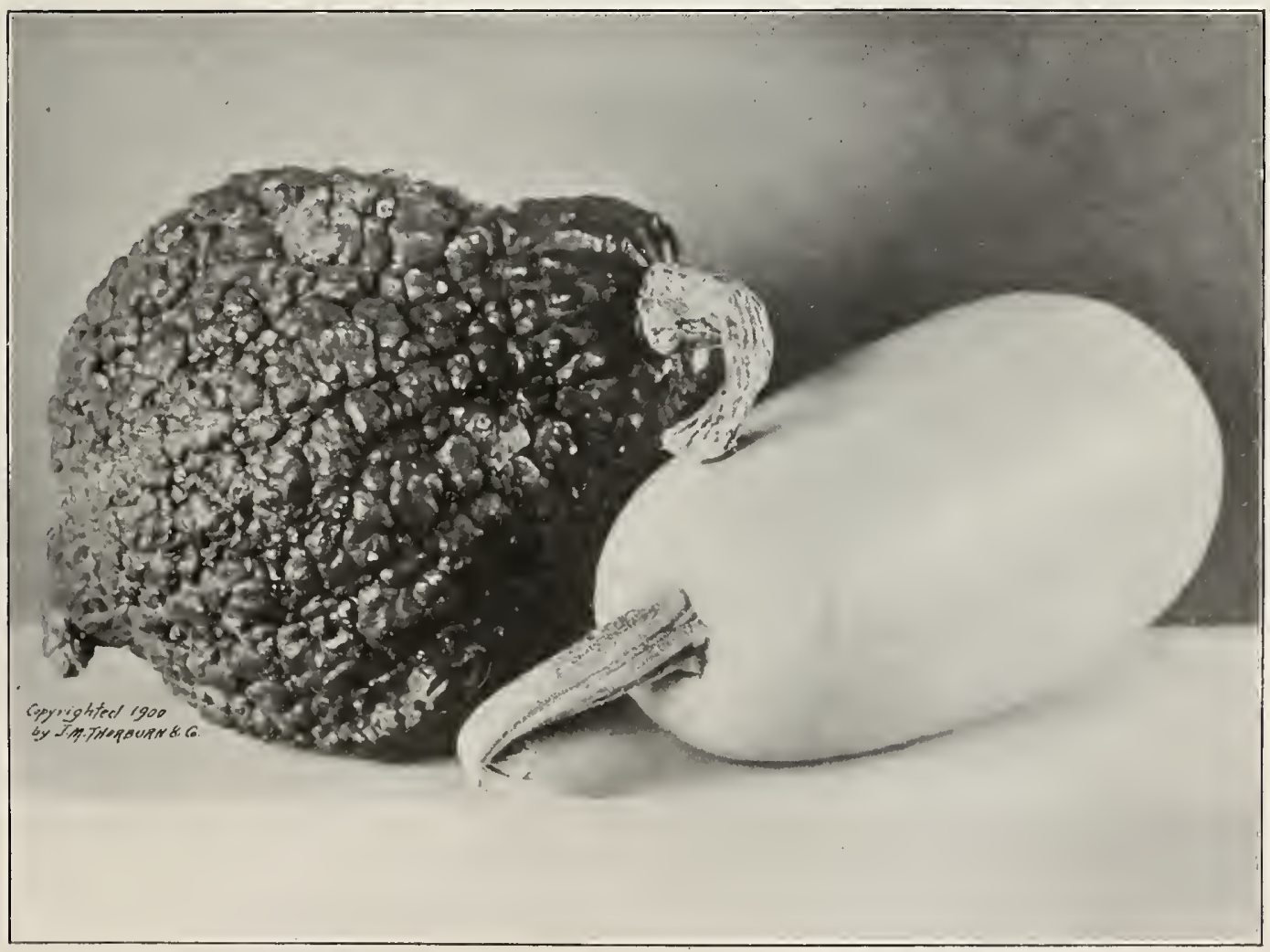




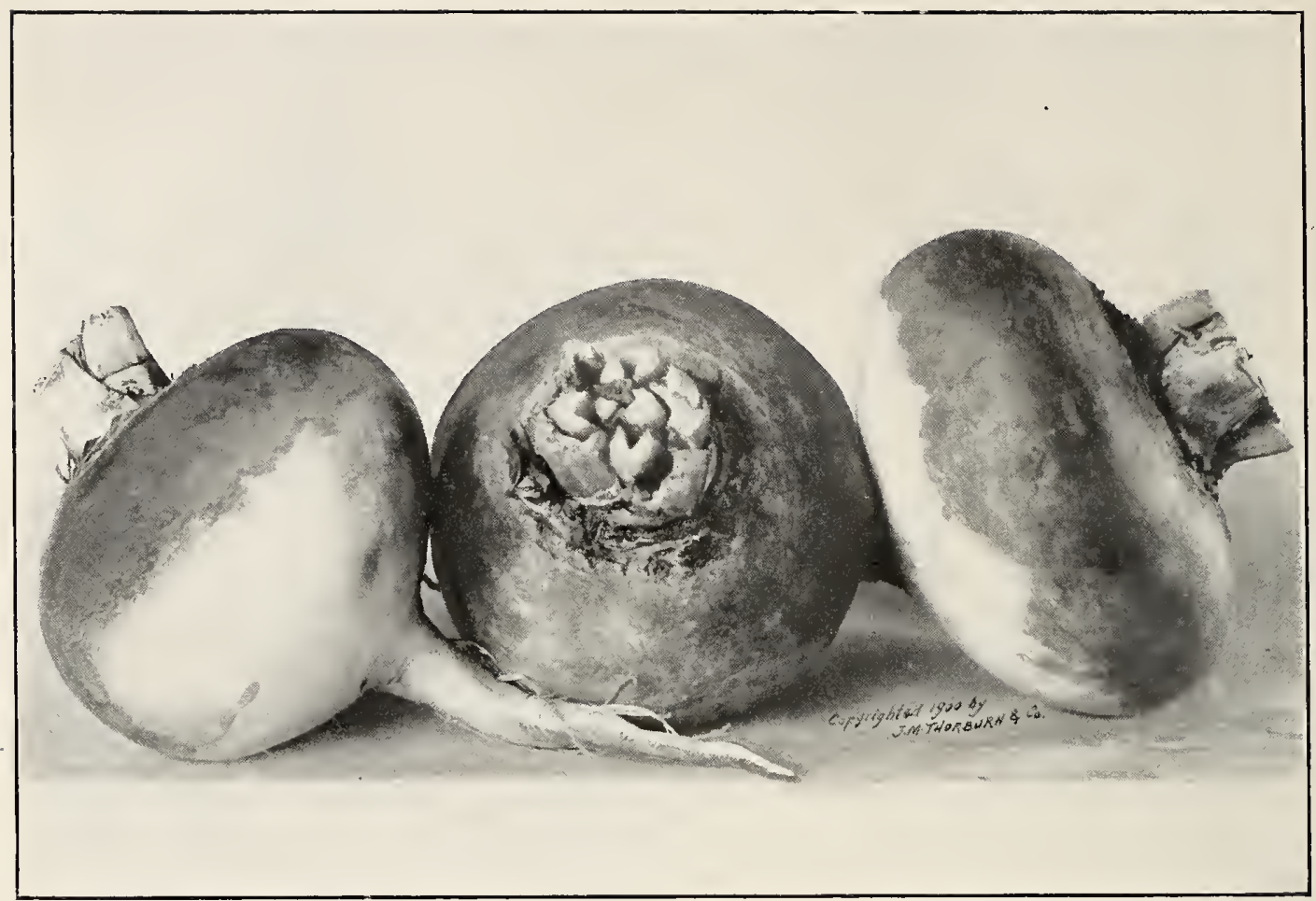

Red Top Globe Turnip

Red Top Strap Leaf Turnip

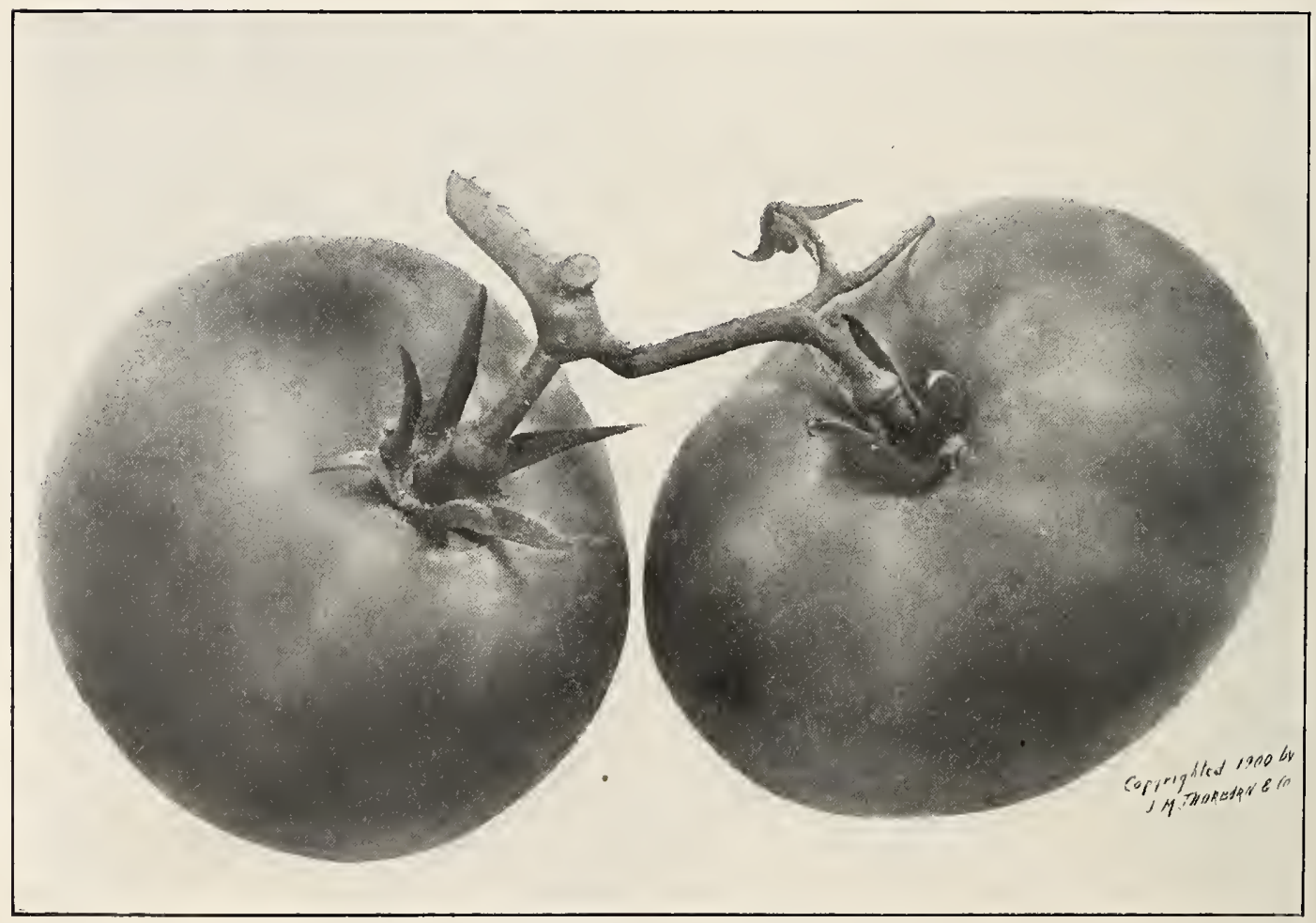

Thorburn Century Tomato

PLATE XIV 


\section{TOMATO}

\section{Tомato Tomates \&iebezapfel}

Culture.-Sow in a hotbed in early spring, or the seed may be sown in shallow boxes and placed in a window, when one does not wish to have the trouble of making a hotbed. Transplant to the open ground when all danger of frost is past, setting the plants 3 or 4 feet apart each way. Some support should always be provided for the vines, to keep the fruit from touching the ground. Fruit may be had several weeks earlier by sowing seed quite early, and transplanting to small pots; when these are filled with roots, shift to a larger size, and transplant to open ground when the weather is warm and settled, shading from the sun for a day or so.

The sorts marked with the star $\left(^{*}\right)$ are specially suitable for forcing as well as for open ground.

1600 Thorburn Century. Our splendid novelty of this year. For description, see Novelties ................ per pkt., 25 cts.

1605 Thorburn Rosalind. Beautiful rose color; large and of uniform, round shape,

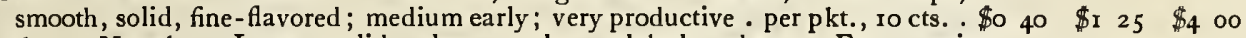

16 ro *Thorburn Novelty. Large, solid; deep scarlet; globular shape. For growing

I615 The Waldorf. (Thorburn.) Perfect shape, large, smooth, solid ; rose color ; 40

Per oz. y/4b. medium early; very productive . . . . . . . . . . . . 30

I620 The Democrat. (Thorburn.) The finest large Tomato; bright rose . pkt., ioc. . 35

I625 The Autocrat. (Thorburn.) Very large, solid and productive; color of Acme . . 25

1630 Thorburn Terra Cotta. Quite distinct in color, form, skin and flesh; pure terra cotta............................ 30

I632 Thorburn Lemon Blush. Skin and flesh bright lemon, with a faint rose blush; large .................... . . . . 30

1634 Thorburn Long Keeper. Bright red, early, very productive; fine keeper . . . . . 25

1635 Thorburn New Jersey. One of the finest sorts; large, solid, smooth, bright scarlet. 30

1637 Freedom. Early, regular and uniform; bright scarlet . . . . . . . . . 25

I638 Matchless. Extra large; smooth and handsome; bright red; very solid . . . . . 30

1639 Early Ruby. Very early; large size; bright scarlet color. . . . . . . . . . 30

I640 Ponderosa. The largest variety in cultivation. . . . . . . . per pkt., 10 cts. . 50

I64 I Crimson Cushion. Extra large; handsome; bright crimson . . "

I 642 Ignotum. Very prolific; earliest of the large, deep red, smooth varieties . . . . . 25

1643 *Sutton's Best of All. Highly recommended for growing under glass . pkt., roc. . 50

I644 *Sutton's Eclipse. Medium size, perfect shape and color; for forcing or open ground ..................... per pkt., ro cts. .

I646 Dwarf Champion. Quite distinct, early; resembles the Acme in appearance . . 25

I647 Scarlet Champion. Light scarlet color; prolific, early; good quality . . . . . . 30

I648 Imperial. Early, large, smooth, solid; fine quality; color of Beauty . . . . . 25

I649 Atlantic Prize. The earliest of all; smooth, bright red and of good size . . . . . 25

r650 Perfection. Early, regular and productive; reddish scarlet . . . . . . . . 20

1652 Favorite. Large, smooth, productive, and a good shipper . . . . . . . . 20

I653 Beauty. Large, smooth, dark, pinkish red; thick flesh; regular form . . . . 20

I654 Stone. Very large, perfectly smooth; fine bright scarlet . . . . . . . . 20

I6 $55{ }^{*}$ Combination. Large, smooth, solid, deep scarlet; for forcing or open ground . . .

I656 Fordhook First. Extra-early, fine, smooth, solid; medium size . . . . . . . . 30

I657 Acme. Medium size; smooth and good; purplish pink color . . . . . . . . 20

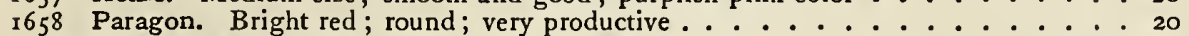

1659 Table Queen. Large, smooth, round, solid . . . . . . . per pkt., ro cts. . 40

I660 Honor Bright. Rich, bright red; long keeper and fine shipping sort . . . . . . 25

I662 Royal Red. Intense bright red color ; good main-crop variety . . . . . . . . 20

I664 Fordhook Fancy. Bushy habit; fruits medium size, smooth and regular . . . . 35

r665 Mikado. Very large, smooth, solid; purplish red ............. . 25

I666 Trophy Improved. Very solid ; standard late variety; fine for canning; dark scarlet. 25

r667 * Lorillard. Bright, glossy red, smooth; of fine flavor, and very early . pkt., roc. .

r668 Golden Queen. About size and form of Beauty; smooth, golden yellow . . . . 30

I669 Red Plum. Bright red, round, regular; for pickles . . . . . 25

I670 Yellow Plum. Round and regular; bright yellow; used for pickles . . . . . 25

I672 Yellow Pear. Handsome, yellow, pear-shaped fruits............ 25

1674 Red Pear. Fruit handsome and solid; fine for preserves . . . . . . . . . 25

I678 Red Peach. Resembling a peach; for preserves, pickles and exhibition; quality

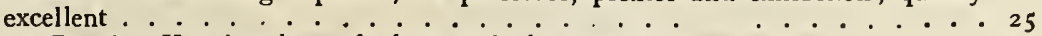

I679 Yellow Peach. Very handsome in form and of a beautiful clear yellow . . . . 25

r680 Yellow Cherry. Similar to preceding, save in color

1681 Red Cherry. Small fruits, used for pickles; very handsome . . . . . . . . 25

1682 Red Currant. Very small and handsome; for preserves . . . . . . . . . . 30

I685 Strawberry (Winter Cherry, or Husk Tomato). Small fruit; makes delicious

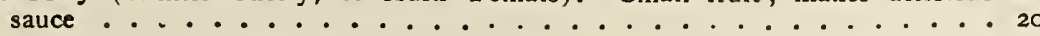

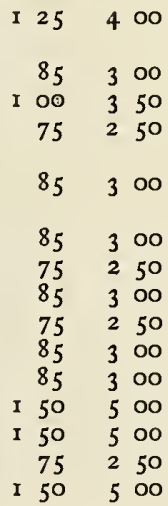




\section{TURNIP}

\section{Navet Nabo $\Re u ̈ b e$}

Culture.-For early Turnips sow as soon as ground opens in spring. Nos. 1766 to $\mathrm{r} 774$ should be sown from any time in July to first of August; but the other kinds, for winter use, may be sown from middle of July to end of August. Turnips are generally sown broadcast, but much larger crops are obtained (particularly of the Rutabagas) by cultivating in drills 18 inches apart, and thinning to 6 inches in the drill. Sow in drills, one pound to the acre; broadcast, two to three pounds to the acre.

1700 Early Milan Purple-Top. Earliest of all, with purple top . . . . . . . \$o 10 \$0 20 \$o 60

170r Early Milan Pure White. As early as the above; beautiful, pure white . . . . 10 2575

r705 Purple-Top Munich. One of the earliest . . . . . . . . . . . . 10 2060

I706 Scarlet Kashmyr. Small, flat, extra-early, pure white flesh of finest quality . . . I5 30 I

1707 White Model. Perfectly globular, snow-white .............. ro

1708 White Egg. Oval, handsome and sweet . . . . . . . . . . . . . 10

1709 Early Snowball. Small, and of rapid growth; pure white ........... 10

I7I5 Early Dutch. Rather flat; good white early sort .............. I0

I7 I8 German Teltow. Small, early, and of distinct flavor; keeps well . . . . . . I5

1722 Red-Top Strap-Leaf. The popular fall flat sort. (See Plate XIV.) . . . . . . . 10

1724 Red-Top Globe-Shaped. A standard sort in the New York market. (See Plate XIV.) ro

1726 White Norilik. Globular, late, solid ............... 10

1728 White Strap-Leaf Flat. A good early white flat sort . . . . . . . . . 10

1733 White French, or Rock. Very productive and a fine keeper . . . . . . . . . 10

1738 Pomeranian White Globe. Good either for table or stock . . . . . . . . . . . 1o

1739 Cow Horn. Long, white, in shape resembling a cow's horn . . . . . . . . . 10

$174^{\circ}$ Large White Globe. Large English variety . . . . . . . . . . . . . . . 10

$174 \mathrm{I}$ Green Globe. Very large, white-fleshed, green top . . . . . . . . . . . . . 10

1747 Yellow Globe. Good and sweet; keeps fairly well . . . . . . . . . . . . . . . 10

$174^{8}$ Thorburn Yellow Stone. Fine, hard winter sort . . . . . . . . . . . 10

1749 Golden Ball. Very handsome; keeps fairly well . . . . . . . . . . . . . . 10

1750 Yellow Malta. Early and of fine flavor . . . . . . . . . . . . . . ro

1760 Yellow Aberdeen. Hardy, productive, and a good keeper ........... Io

I76I Yellow Tankard . . . . . . . . . . . . . . . . . . 10

1762 Black Store. Dark skin; very solid .................. ro

1763 Gray Stone. Solid and sweet; keeps well ................. 10

1764 Seven Top. The tops are used for greens . . . . . . . . . . . . . ro

1766 Rutabaga, Thorburn Family. A fine strain for family use ; finest quality . . . . Io

1767 "Thorburn Purple-Top Improved . . . . . . . . . . . . . 10

1768 "Champion Purple-Top .................. 10

1769 " Laing Improved. One of the earliest............... 10

1774 "White-Fleshed. Large and productive ............. ro

\section{VEGETABLE PLANTS}

CABBAGE, Coldframe plants. (Ready in March.)

Per 100 r,000

Early Jersey Wakefield . . . . \$I oo $\$ 75^{\circ}$

Stein Early Flat Dutch ..... I oo 750

Improved Early Summer ..... I 007 50

CAULIFLOWER, Thorburn Early Snowball, Coldframe plants. (Ready in March.) $35 \mathrm{cts}$. per doz., $\$ 2$ per roo, $\$ 15$ per 1,000 .

CELERY PLANTS. (Ready in June.) Per 100 1,000

Golden Self-Blanching ..... \$0 50 $\$ 400$

Perfection Heartwell ...... 50 400

White Plume ....... 50400

EGGPLANTS, Pot-grown. (Ready about May 15.) Improved New York Purple. Large size, grown in 3 -inch pots. \$I per doz., $\$ 7.50$ per 100 .
LETTUCE, Thorburn Market-Gardener's Private Stock, Transplanted plants, grown in Flats. 20c. per doz., \$I per roo.

PEPPER, Large Bell, or Bull Nose, Transplanted plants, grown in Flats. $25 \mathrm{cts}$. per doz., $\$ 1.50$ per roo.

TOMATO PLANTS, Transplanted, grown in Flats. (Ready about May $I$.)

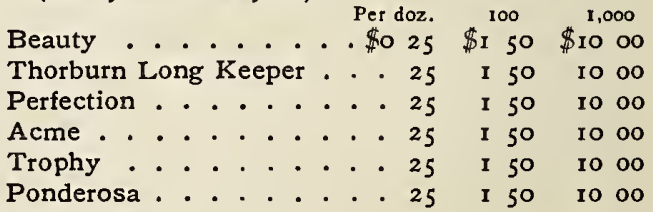

\section{ESCULENT PLANTS AND ROOTS}

Asparagus Roots, Conover Colossal. Two years old . . . . . . . per r,ooo, \$6. " " Palmetto. Two years old ............ . per 1,000, $\$ 6$

" " Barr Mammoth. Two years old .......... . per 1,000, \$6.

“Columbian Mammoth White. Two years old.....

Chive Plants .... . . . . . . . . . . . per bunch, 25 cts.

Cinnamon Vine Roots (Dioscorea Batatas, Chinese Yam), 4 to 7 inches long. . . . . \$o 60

Horse-Radish Roots. Cut in pieces. . . . . . . . . . . . . . . 20

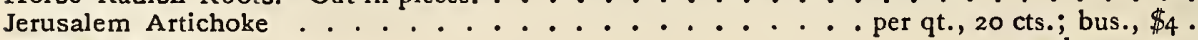

Rhubarb Roots . . . . . . . . . . . . . . . . . . each, ro cts. . I $\infty$

Tarragon Plants (Estragon) .................................. 35 cts. 350 


\section{Seeds of Pot, Sweet and Medicinal Herbs}

Agrimony. For medicinal purposes . . . . . Agrimonia officinalis \$o 10 \$o 75 Angelica, Garden. For flavoring wine and cakes . . . . Archangelica officinalis . 05

Anise. Seeds aromatic and carminative ....... Pimpinella anisum . . . 05

Arnica. Tincture of arnica is made from it . . . . . . Arnica montana . . . . 10

Balm. For culinary purposes . . . . . . . . Melissa officinalis . . o5

Basil. Dwarf or Bush. Culinary herb . . . . . . . . Ocymum minimum . . o5

Sweet. Culinary herb used for flavoring soups, etc. . . Ocymum basilicum . . . o5

Belladonna. Used in medicine . . . . . . . . . . Atropa Belladonna . . 1o

Bene. The seeds yield a good oil. The leaves are used for chil-

dren for dysentery and diarrhœa ......... Sesamum orientale . . . o5

Boneset . . . . . . . . . Eupatorium perfoliatum . o5

Borage. Leaves used as a salad . . . . . . . . . . Borago officinalis . . o5

Caraway. Used in flavoring liquors and bread . . . . . . Carum Carui . . . . o5

Catnip. Has medicinal qualities ......... Nepeta cataria ... ro

Chamomile ............... Matricaria Chamomilla . ro

Coriander. Seeds aromatic . . . . . . Coriandrum sativum . . 05

Dill. Seeds used for flavoring vinegar . . . . . . . Anethum graveolens . . o5

New Mammoth. Much larger than the above..... Anethum graveolens . . 05

Elecampane. Has tonic and expectorant qualities . . . . . Inula Helenium . . . 10

Fennel, Sweet. Seeds aromatic; for flavoring . . . . . Anethum Fœniculum . . 05

Florence. In flavor resembling celery ....... Anethum Fœniculum . . o5

Foxglove, Purple. Has medicinal qualities . . . . . Digitalis purpurea . . o5

Fumitory. A medicinal herb . . . . . . . . . . Fumaria officinalis . . ro

Gromwell. A medicinal herb; poisonous . . . . . . . Lithospermum officinale . 05

Hemlock. Has medicinal qualities; poisonous . . . . . . . Conium maculatum . . ro

Henbane. Has medicinal qualities .......... Hyoscyamus niger . . 05

Horehound. Has medicinal qualities . . . . . . . Marrubium vulgare . . o5

Hyssop. Has medicinal qualities . . . . . . . . Hyssopus officinalis . . 05

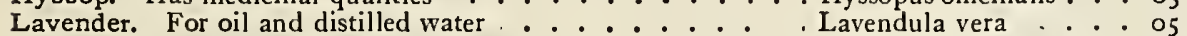

Lovage. Has medicinal qualities ......... Levisticum officinale . . o5

Marshmallow. Has medicinal qualities ......... Althæa officinalis . . o5

Marigold, Pot. Used in soups. . . . . . . . . Calendula officinalis . . o5

Marjoram, Pot. Used in seasoning . . . . . . . . Origanum Onites . . . 10

Sweet. Used in seasoning ........ Origanum Majorana . . o5

Pæony officinalis. Has medicinal qualities . . . . . . Pæonia officinalis . . . 05

Pennyroyal. Has medicinal qualities ......... Hedeoma pulegeoides . . ro

Peppermint . . . . . . . . . Mentha piperita . . . 25

Rosemary, Yields an aromatic oil and water . . Rosmarinus officinalis . . os

Rue. Said to have medicinal qualities ........ Ruta graveolens : . . 05

Saffron. Used in medicine, and also in dyeing . . . Carthamus tinctorius . . o5

Sage, Common. A culinary herb; also used in medicine . . . Salvia officinalis . . . o5

" Red. Used as a culinary herb, and also in medicine. . Salvia Horminum . . . o5

" Purple. Used as a culinary herb, and also in medicine. Salvia Horminum . . 05

Savory, Summer. Used as a culinary herb ........ Satureja Hortensis . . o5

Winter. Used as a culinary herb ....... Satureja montana .... . . . 5

Tansy. Generally used in bitters . . . . . . . . . Tanacetum vulgare . .

Tarragon. True. Does not produce seed. Roots in fall and

spring . * . . 35 cts. each, \$3:50 per doz. . Artemisia Dracunculus .

Thyme, Broad-Leaved English. Used as a seasoning. . . Thymus vulgaris . . . o5

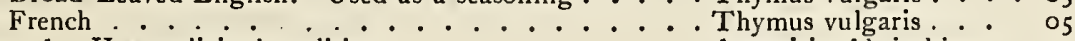

Wormwood. Has medicinal qualities . . . . . . Artemisia Absinthium . . . . . . . A5

10 \$I OO

10 80

125

30

$20 \quad$ I 50

$20 \quad 125$

60

15

15

40

75

10

10

20

75

10

15
20

\section{BIRD SEEDS, ETC.}

\section{Prices Variable}

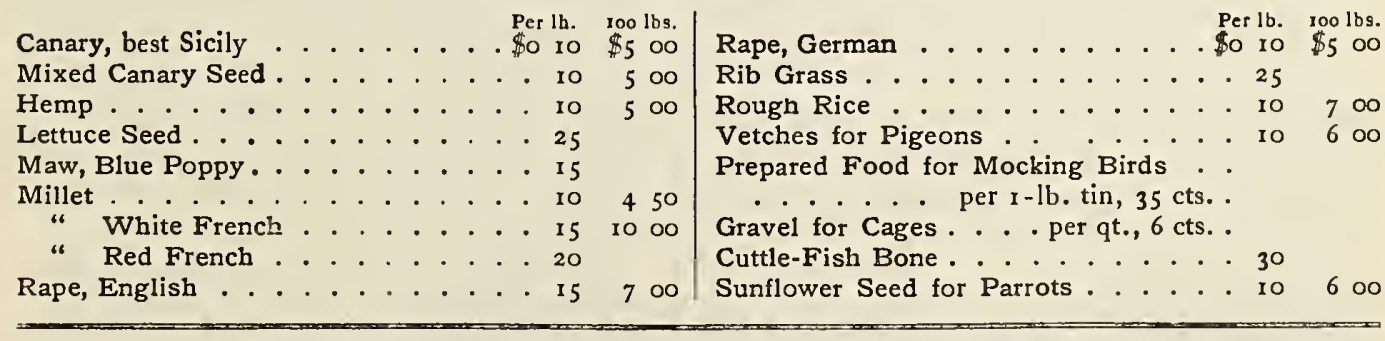

Dr. F. M. Hexamer, of the American Agriculturist, New York: "The Thorhurn' potato has donc splendidly with me. It is a large, handsome potato, vcry prolific, remarkahly uniform in size, and of excellent table quality. Its tlesh is pure whitc, fine-graincd, and while it cooks through complctely and quickly, it does not fall to pieces." 


\section{STRAWBERRY PLANTS}

Layer plants can be had in Spring and again in Fall. Pot-grown plants ready after July 15.

Beder Wood. Very early and productive; large, conical, bright red color, and of excellent Layer, Pot-grown, 100 per 100 quality ................................... \$1 00 per $\$ 300$

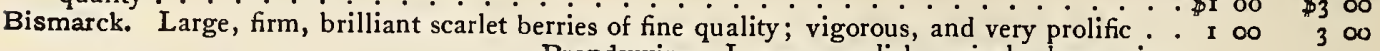

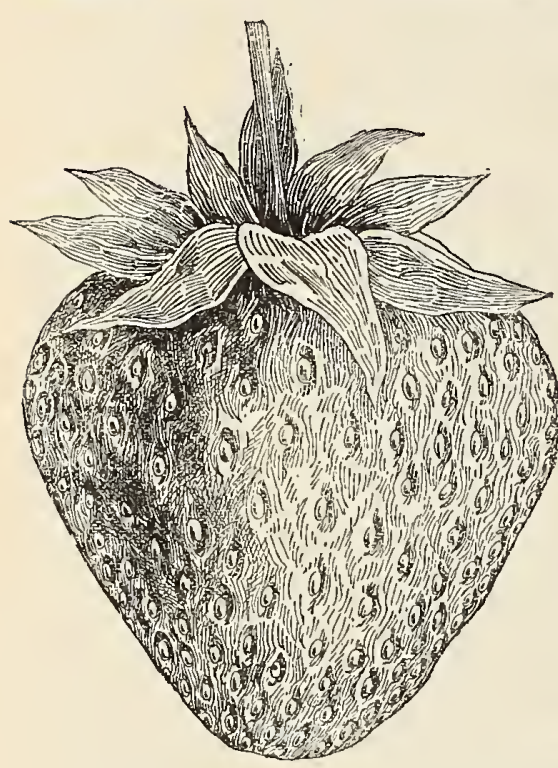

Brandywine. Large, roundish conical, glossy crimson, firm and solid; of fine, aromatic flavor. Plant vigorous and productive; succeeds on any soil. Mid-season to late. . I oo

Bubach No. 5. A very large berry of dark color. Productive; of fair flavor; largely grown for

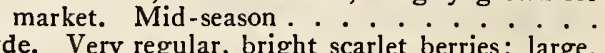
and of excellent flavor; firm, and a good shipper. Plant remarkably healthy, vigorous and productive. Season early... . . . . . I $\infty$

Excelsior. Very early, large, good color, firm and of fine quality. A vigorous grower and very

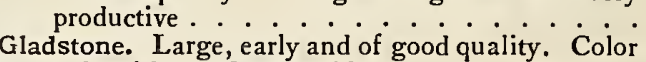
red, with red flesh, solid Mary. Of large size. Bright, glossy crim- $^{-}$ son, of fine flavor; plant is strong and healthy, very prolific and on good soil the berries are large to the end of the season. Early . . .

Johnson's Early. A fine new extra-early, of large size and deep red color; glossy, firm, sweet and

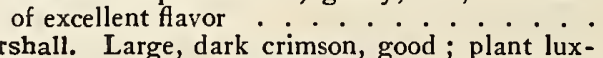
uriant, but needs rich soil and careful culture.

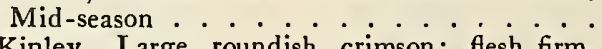

McKinley. Large, roundish, crimson; fiesh firm, and quality good. The plant is vigorous, and a great yielder; flowers bi-sexual or perfect. Season medium to late . . . . . . . I oo

Nick Ohmer. Very large, dark glossy red, firm and excellent. Vigorous and productive . . I oo

Sharpless. Demands rich, strong soil; plant large and vigorous; berries very large, irregular in shape, crimson, moderately firm and of good quality. Mid-season . . . . . . . I oo

Success. Early, large, bright crimson color, high flavor and continues bearing a long time. I oo

Wm. Belt. The berries are as large as Bubach, more perfect in shape, just as productive and the color is perfect

\section{TOBACCO SEEDS}

Brazilian American. The finest Brazilian strain grown here; makes excellent cigars and delightful, aromatic pipe-smoking tobacco. Per oz,, $25 \mathrm{c}$.; per lb., $\$ 2$.

Climax. A cross between Burley and Sterling. Extra fine, bright variety. Per oz., 25 cts.; per lb., $\$ 2$. Connecticut Seed-Leaf. The popular sort, used for cigar wrappers. Per oz., 25 cts.; per lb., \$I.50.

Conqueror. A superb, bright yellow, and a healthy, vigorous grower of the best form and finest texture. It ripens early, and is easily cured to the brightest color. Per oz., 25 cts.; per lb., $\$ 2$.

Havana. Seed gathered for us from the celebrated plantations of the "Vuelto de Abajo." Per oz., 40 cts.; per lb., $\$ 4$.

Honduras. A new mahogany variety, producing the very highest quality of tobacco of this type. A healthy and vigorous grower. Per oz., 25 cts.; per lb., \$2.50.

Kentucky White Burley. Per oz., 3oc.; per lb., \$3. Kentucky Yellow. Per oz., 25 cts.; per lb., \$2.

Oronoka Yellow. A reliable old yellow variety, grown for more than fifty years and improved with reference to the production of yellow stock. Per oz., 25 cts.; per lb., \$2.

Oronoka, White Stem. From the Yellow Oronoka, which it resembles. Per oz., 25 cts.; per lb., $\$ 2$.

Persian Rose. Finer than the Muscatel, and may be relied upon to make the best cigars. Per oz., 25c.; per lb., \$2.50.
Pryor, Yellow. Preferred by many for brights, and succeeds where the other yellow sorts fail. The west is giving it preference as a main crop sort. Per oz., 25 cts.; per lb., \$2.

Pryor, Blue. The genuine James River favorite. Per oz., 25 cts.; per lb., $\$ 2$.

Safrano. Of a rich-saffron-yellow color, and possessing a soft, silky texture and a delightful flavor. Per oz., 25 cts.; per lb., $\$ 2$.

Sterling. The newest and brightest of the yellow type and the earliest to ripen. Per oz., $25 \mathrm{cts}$.; per lb., \$2.

Sumatra. European grown from imported stock. Per oz., 30 cts.; per lb., $\$ 3$.

Tuckahoe. Preferable to most of the older varieties for possessing more body. Leaf long and extra fine; the perfection of a wrapper. Per oz., 25 cts.; per lb., \$2.

Virginia Oak Hill Yellow. Resembles White Burley in color and Oronoka in shape and habit. Unsurpassed in delicacy of fiber. Per oz, , 25c.; per lb., $\$ 2$. Virginia "One Sucker." Large leaf; wide, lanceshaped; rather coarse than fine. Per oz., 25 cts.; per lb., $\$ 2$.

Yellow Mammoth. A new western variety of the export type. Per oz., 25 cts.; per lb., $\$ 2$.

Zimmer's Spanish. One of the most popular and extensively grown cigar varieties. Very early; finest quality. Per oz., 30 cts.; per lb., $\$ 3$. 


\section{CEREALS}

Grain in quantities of one-half bushel and upward should be shipped in canvas bags, which we can supply at following rates: One-half bushel, 8 cents; one bushel, II cents; two bushels, 20 cents. Customers will please add cost of bags to remittance when ordering.

The prices of some varieties may change as the season advances.

\section{FIELD CORN}

All northern-raised sorts ( ${ }_{5} 6$ lbs. to bushel) -

Early Yellow Canada. Very early yellow Flint . . . . . . . . . \$o Is

Farmer's Favorite. Very handsome yellow Dent; very prolific.... Is

Compton Early Flint. Extra early and very prolific . . . . . . I I

Golden Beauty. Large grain, small cob; very productive . . . . . . I 5

King Philip. Early, deep yellow, Flint . . . . . . . . . . I5

Hickory King. Large grain and small cob; white Dent; late .. . . I5

King of the Earlies. Small cob; yellow Dent. Said to mature farther

north than any other Dent variety . . . . . . . . . . I5

Long White Flint, or Sanford. Large, eight-rowed ....... I 5

Longfellow (Yellow Flint). Small cob and large grain . . . . . . . I5

Pride of the North. Very large ears. (Dent.) ......... I 5

Champion White Pearl ................. I5

Mastodon Dent. Very early, strong-growing Corn, with exceedingly

large ears and grains . . . . . . . . . . . . Is

Leaming Early. Large, deep grains; bright yellow . . . . . . . . I5

Blunt's Prolific. Valuable for fodder ... . . . . . . . . . . I5

Mammoth White Surprise. Very large, dented, deep grain . . . . . Is

Legal Tender. Large, comparatively early. . . . . . . . . I5

Angel of Midnight. Flint, eight-rowed, good size . . . . . . . . Is

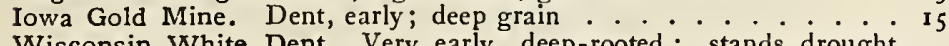

Wisconsin White Dent. Very early, deep-rooted; stands drought well . • • • • • • • • • . . . . . I5

Virginia Horse Tooth. For fodder and ensilage . . . . . . . .

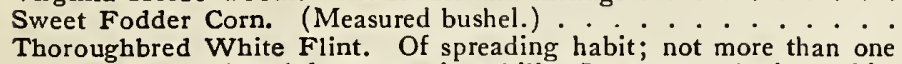
kernel should be left to grow in a hill. Its great suckering habit, breadth of blade and smallness of stalk recommend it as the most valuable, both for fodder and ensilage ...... per ear, 5 cts.; roo ears, $\$ 3.50 . \$ 0$ I5 $\$ 1$ I 75

Tuscarora, or Flour Corn ............. per ear, 5 cts.; roo ears, $\$ 3$.

Pop Corn . . . . . . . . . . . . . . . . . In ears, per lb., ro cts. .

\section{MISCELLANEOUS CEREALS \\ All subject to change in price}

BARLEY ( $48 \mathrm{lbs}$. to bushel). 2 bushels to the acre-

Champion Vermont. An early and prolific variety. . . . . . Price variable; about $\$ 0$ Io $\$ 25$

BUCKWHEAT ( $48 \mathrm{lbs}$. to bushel). I bushel to the acre-

American Silver Hull. Earlier and more productive than the common .......... I5 I 40

Japan. Enormously productive; the grains are much larger than those of any other variety . I 5 I 40

MILLETS ( 5 o lbs. to bushel) -

Japan Barn-Yard (Panicum Crus-galli). Excellent for fodder; very productive. Less harsh and woody than any other tall-growing Millet. In recent experiments it yielded 7,800 lbs. of well-cured hay to the acre. I bushel to acre . . . . . . . per lb., I 5 cts.; Ioo lbs., $\$ 8$.

Hungarian. Most valuable soiling plant. Good also for hay or green fodder. Grows in any ordinary soil, and withstands drought well. May be sown in this latitude as late as the first of July. I to I $1 / 2$ bushels to the acre. Price variable.

White French. Very handsome white grain. Sow same as above .. . . . . . . . . . . . I5 Io oo

Golden. Useful in the same way as the Hungarian. The seed is also largely grown for feed-

ing birds. I to $1 \frac{1}{2}$ bushels to the acre ......... per lb., Io cts.; Ioo lbs., $\$ 4.50$.

Pearl Millet. Very valuable fodder plant for the south . . . . . . . . . . . . . . I5 9 oo

OATS. All the approved sorts furnished. 2 to 3 bushels to the acre. Price on application.

RYE ( 56 lbs. to bushel). I to $1 / 2$ bushels to acre-

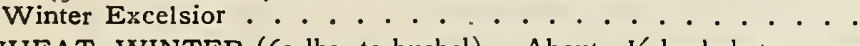

WHEAT, WINTER (6o lbs. to bushel). About $\mathrm{I} / 2 \mathrm{z}$ bushels to acre-

Red Clawson. Bald, hardy, great yielder ................... I 75

White No. 6. Bald, good yielder . . . . . . . . . . . . . . . . . . . . . . I 75

Red Poole. Deep red berry, hardy; bald . . . . . . . . . . . . . . . . . . . I 75

Red Rochester. Bald, hardy, great yielder .. . . . . . . . . . . . . . . . . . . I 75

White Rover. A new, bald, hardy, very prolific variety . . . . . . . . . . . . . . . . 2 oo

Carman No. 1. By parentage half wheat, half rye. Heads compact, symmetrical, pointed, bearded. Three grains to a spikelet, eight spikelets to a side. Kernels hard, dark amber. As

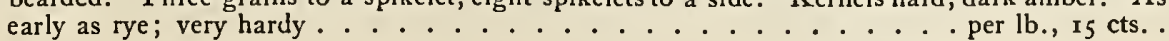




\title{
Clovers
}

\author{
Subject to change of price. Our quotations are those ruling at this time.
}

ALFALFA, or LUCERNE (Medicago sativa). One of the most valuable and largely grown forage plants. It requires a deep, rich, well-drained soil. It roots very deeply, the tap-root descending often to a depth

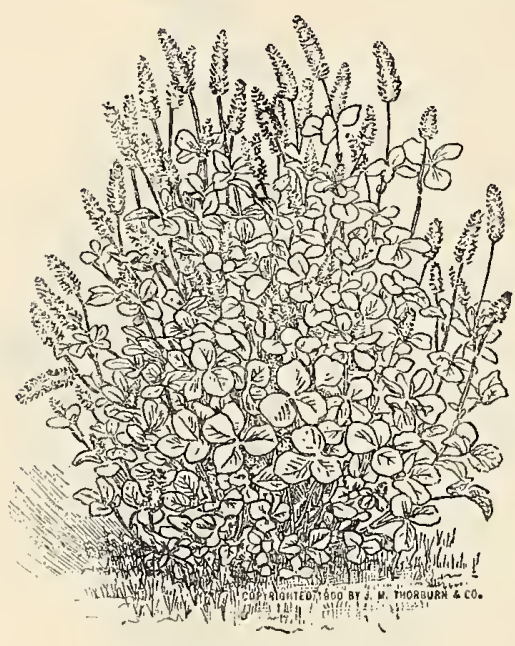

CRIMSON OT SCARLET CLOVER.

(T'rifolium incarnatum.) of 1o or 15 feet in loose soil. It is consequently capable of resisting great droughts. In the west it is the best crop for hay or for soiling. It should be sown alone, in thoroughly prepared deeply plowed soil, at the rate of 15 to $25 \mathrm{lbs}$. to the acre. The crop should be cut when the plant is coming into bloom. In suitable soil the plant is perennial, and several crops may be cut every year. Height, i to 3 feet. Per lb., $20 \mathrm{cts}$.; IOo lbs., $\$ 15$.

ALSIKE, or HYBRID CLOVER (Trifolium hybridum). A perennial I to 3 feet high, succeeding best in cold and stiff soils, and in marshy lands which are too wet for other species. It grows well in the far north and in high altitudes, and can withstand severe cold. It is recommended as a honey plant for bees. I 5 lbs. to the acre. Per lb., 22 cts.; I0o lbs., \$I8.

BOKHARA CLOVER (Melilotus alba). A most valuable sort for soiling. It grows from 3 to 5 feet high, and if sown in rich soil may be cut three times; lasts two years or more if cut before flowering; good for ensilage and bees. $15 \mathrm{lbs}$. to the acre. Per lb., 25 cts.; Ioo lbs., \$20.

EGYPTIAN CLOVER ( $T$ rifolium Alexandrinum). Yields heavily in Egypt, and would likely do well on irrigable land in warm countries. It is as productive as Lucerne, and grows a little taller. Io lbs, to the acre. Per lb., $50 \mathrm{cts}$.

CRIMSON, or SCARLET CLOVER (T'rifolium incarnatum). Erect annual, $x$ to 2 feet high, with bright scarlet flowers. It is a native of southern Europe, and is now largely grown in our southern states for improving the soil by turning under. In Virginia and southwards it is sown in the autumn for winter and early spring forage. It will not stand severe frost and cannot be depended upon to stand the winter north of New Jersey. It makes a very valuable crop for soiling, pasturage or green manure. For hay it should be cut when in full bloom. Sow $20 \mathrm{lbs}$, to the acre. Price variable.

JAPAN CLOVER (Lespedeza striata). A perennial, growing about 12 inches high; valuable only in southern localities, where it thrives in any soil and in the driest season; it makes a fair hay, and stock eat it readily when green. It is also valuable for turning under as green manure. Sow in spring broadcast at the rate of 30 lbs. to the acre. Per lb., 30 cts.; roo lbs., $\$ 25$.

KIDNEY VETCH, or SAND CLOVER (Anthyllis vulneraria). A deep-rooted, herbaceous hardy perennial plant, valuable for dry sands and inferior soils, upon which Red Clover will not thrive. Eaten with avidity by sheep, cattle and horses; useful in mixture for dry soil. Produces abundantly of hay and seed. Sow 20 lbs. to the acre. Per lb., 25 cts.; 100 lbs., $\$ 22$.

RED CLOVER, MEDIUM (Trifolium pratense). One of the most valuable farm crops of the eastern states for pasture, soiling, hay, or for turning under for green manure. It requires a deep, rich soil, and yields two hay crops in the season. In this section it should be sown in the spring at the rate of 15 lbs. to the acre. Price variable.

MAMMOTH RED, or PEA VINE CLOVER (English Cow Grass). Grows much larger and lasts longer than the common Red Clover; most valuable for plowing under. Io lbs. to the acre. Price variable.

WHITE CLOVER (Trifolium repens). Some White Clover is usually included in lawn grass mixtures. It makes an excellent turf that stands constant trampling. It is of dwarf habit, the stems creeping and rooting at the joints. It spreads rapidly, and is very hardy, resisting extremes of heat and cold, dryness and humidity, and accommodating itself to all kinds of soils. It is valuable in mixtures for permanent pastures, its forage being very sweet and nutritious and much relished by cattle. The seed should be sown in the spring. In mixtures, $I$ or $2 \mathrm{lbs} . ;$ if alone, 8 or ro lbs. to the acre. Per lb., 25 cts.; roo lbs., \$20.

YELLOW SUCKLING CLOVER (Trifolium filiforme). Native of northern Europe. Prefers sandy clay soils; valuable for sheep pastures; recommended in grass mixtures for wet, sandy meadows. Per lb., 35 cts; 100 lbs., \$30.

YELLOW TREFOIL (Medicago lupulina). An annual or biennial suitable for pasture in wet meadows or for stiff, clayey soils which are too poor for Red Clover. Also called Black or Hop $\mathrm{Me}$ dick and Nonesuch. Is very useful in some sections of the country. Deep-rooting; is sometimes used for hay. I 5 lbs. to the acre. Per lb., 20 cts.; 100 lbs., \$12.

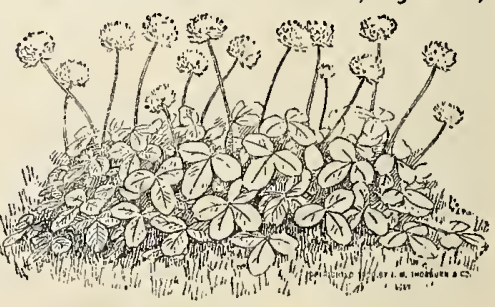

WHITE CLOVER (Trifollum repens). 


\section{GRASS SEED MiXTURES}

\section{For Meadows and Pastures}

For nearly a hundred years our house has made a specialty of grasses. We were probably the first to introduce to this country, for commercial distribution, the many valuable natural and cultivated foreign species that now take such an important part in our agricultural economy. The formation of permanent pastures and meadows has for many years been a subject of careful study with us, and the following formulæ for seeding grass-lands have received universal recognition.

It is a well-ascertained fact that a thicker and more prolonged growth is produced by a mixture of many sorts of grasses than by only one or two. For every different kind and condition of soil there are grasses that are especially suitable. Some sorts do best on high ground and in dry weather; others prefer plenty of moisture. Some mature so early, and others so late, that from the beginning of spring until winter sets in, there is no time when one species or another is not at its best. The quantities given are the minimum, and may ofien be increased to advantage.

\section{MEADOW MIXTURES FOR ONE ACRE}

\author{
No. I. On Good Land, neither \\ Too Dry nor Too Wet. \\ 3 lbs. Red Top. \\ “ Meadow Foxtail. \\ $1 / 2$ “Perennial Sweet Vernal. \\ 2 " Tall Meadow Oat Grass. \\ 3 " Orchard Grass. \\ 2 "Hard Fescue. \\ 2 “" Sheep's Fescue. \\ 4 " Perennial Rye Grass. \\ 16 " Timothy. \\ I “ Red Clover. \\ $1 / 2$ " Alsike Clover.
}

35 lbs. Price per acre, $\$ 4.25$.
No. 2. For High and Dry Land.

3 lbs. Red Top.

4 “ Tall Meadow Oat Grass.

2 "Meadow Brome Grass.

r/2 “ Crested Dog's-tail.

5 " Orchard Grass.

2 "Hard Fescue.

3 " Sheep's Fescue.

I " Meadow Soft Grass.

12 " Timothy.

I “ Rough-stalk Meadow Grass

I " Red Clover.

$1 / 2$ " White Clover.

35 lbs. Price per acre, $\$ 5$.
No. 3. On Wet, Late Land.

5 lbs. Red Top.

$21 / 2$ " Creeping Bent Grass.

5 " Orchard Grass.

2 "Tall Meadow Oat Grass.

2 "Meadow Fescue.

I "Tall Fescue.

I " Meadow Soft Grass.

" Perennial Rye Grass.

ro " Timothy.

I “ Red Clover.

1/2 “ Alsike Clover.

35 lbs. Price per acre, $\$ 4.75$.

\section{PASTURE MIXTURES FOR ONE ACRE}

No. 4. On Good Land, neither Too Dry nor Too Wet.

2 lbs. Tall Meadow Oat Grass.

2 " Red Top.

$1 / 2$ “ Perennial Sweet Vernal.

4 " Orchard Grass.

3 " Sheep's Fescue.

I "Hard Fescue.

I " Meadow Soft Grass.

5 " Perennial Rye Grass.

I " Meadow Foxtail.

7 “ Kentucky Blue Grass.

6 " Timothy.

$1 / 2$ " Yellow Trefoil.

I " Red Clover.

I " White Clover.

35 lbs. Price per acre, $\$ 5.25$.
No. 5. On Dry Land.

3 lbs. Creeping Bent Grass.

31/2" Tall Meadow Oat Grass.

I " Meadow Brome Grass.

3 " Orchard Grass.

I "Hard Fescue.

4 “" Sheep's Fescue.

$1 / 2$ “ Perennial Sweet Vernal.

6 "Timothy.

5 " Perennial Rye Grass.

2 " Field Burnet.

4 " Sainfoin.

I “ Red Clover.

I " White Clover.

35 lbs. Price per acre, $\$ 5.75$.
No. 6. On Wet Land.

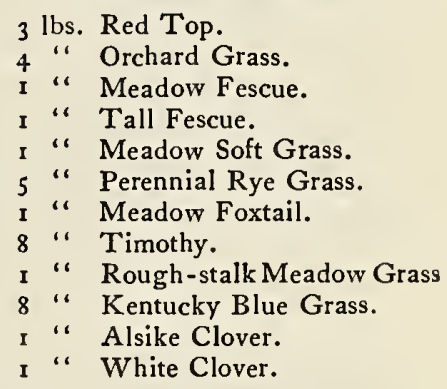

35 lbs. Price per acre, $\$ 4.75$.

\section{GRASS SEEDS}

We desire to call particular attention to the fact that Grass Seeds are sold in the trade by sample, and each sort is divided into three or four grades of quality, according to purity, germination and weight. The price of the best grade is often double that of the ordinary. The Grass Seeds here offered by us are in every case the VERY HIGHEST GRADES.

The prices of some varieties may change as the season advances.

AGROSTIS CANINA (Rhode Island Bent Grass). Resembles Red Top (A. vulgaris, described below), but is of dwarfer habit, with shorter and narrower leaves. It makes a beautiful, close, fine turf, and is one of the very best grasses for lawns. It adapts itself to almost any soil, rich and moist, or dry, sandy and sterile. It is a native of Europe, but has been cultivated in our eastern states for many years. Of late years we have been unable to obtain true and pure seed of it here, and we now import it from Europe, where it has been more carefully cultivated. 50 pounds of seed to the acre is recommended for lawns. Height, I to 2 feet. (I 5 lbs. to the bushel.) Per lb. 35 cts.; 100 lbs., $\$ 30$. 


\section{GRASS SEEDS, continued}

AGROSTIS STOLONIFERA (Creeping Bent, or Fiorin). The distinctive feature of this species is, as the name implies, its compact, creeping, rooting stems. It prefers low bottom-lands, especially if they are

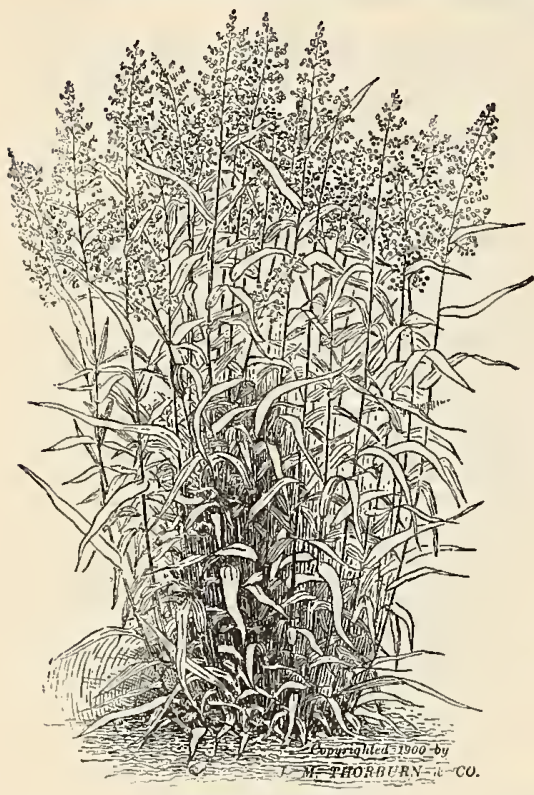

AGROSTIS VUIGARIS. somewhat sandy. It is of rapid growth and spreading habit, and the stoloniferous roots form a strong, enduring turf, that is positively improved by constant trampling. Being of fine texture, it is one of the most valuable of our lawn grasses. If sown alone, 50 lbs. to the acre should be used. Height, I to 2 feet. (I 5 lbs. to the bushel.) Per lb., 35 cts.; roo lbs., $\$ 30$.

AGROSTIS VULGARIS (Red Top; Herd's Grass). A very hardy native perennial grass, succeeding best on moist land. It accommodates itself to a variety of soils, however, even to quite dry situaations, and stands our hot climate admirably. It is, perhaps, the most permanent grass we have, and it enters largely into the composition of our best natural pastures. It remains green for the greater part of the year, and its long trailing stems form a very close, matting turf, that is not affected by trampling. It grows well as far south as Tennessee. Height, I to 2 feet. The seed, as usually sold, weighs I 4 pounds to a bushel. The bulk of this is, of course, chaff, and 4 bushels of it would be required to sow an acre. The absolutely clean or "fancy" seed offered below weighs over $30 \mathrm{lbs}$. to the measured bushel, and $30 \mathrm{lbs}$. of it is sufficient to sow an acre. Per lb., I 5 cts.; roo lbs., $\$$ II.

Fancy Heavy Red-Top Grass. Absolutely clean and free from chaff. 30 lbs. to the acre. Per lb., 25 cts.; 10o lbs., \$20.

AIRA CAESPTOSA (Hassock Grass). A coarse grass, preferring stiff and marshy bottoms, and thriving in moist and shady woodlands. In England door-mats are formed of it by the cottagers. 30 lbs. to the acre. Per lb., 25 cts.; roo lbs., $\$ 20$.

AIRA FLEXUOSA (Wood Hair Grass). Delights in high and rocky hills; is of little agricultural value, except for sheep pasture. $30 \mathrm{lbs}$. to the acre. Per lb., $20 \mathrm{cts}$; $100 \mathrm{lbs}$., $\$ 18$.

ALOPECURUS PRATENSIS (Meadow Foxtail). One of the best permanent pasture grasses for rich moist lands. Its chief characteristics are its extreme earliness and its faculty of standing high summer heats without burning. Although it prefers moist, low grounds, yet it accepts drier situations, and makes an earlier spring verdure than any other variety. It should be sown only in connection with other grasses, 3 or 4 pounds to the acre. Height, 2 to 3 feet. ( 7 lbs. to the bushel.) Per lb., 35 cts.; roo lbs., \$30.

AMMOPHILA ARUNDINACEA (Beach Grass). Valuable on the sandy seashore, canal and railway banks, etc. Its strong creeping, matting roots bind the drifting sand into natural embankments against the action of wind and waves. This grass is usually propagated by transplanting in the fall. Where it is necessary to use seed, it should be sown in spring, and ground covered with brush to hold the seed in place until it has taken firm hold. Height, 2 to $3 \mathrm{ft}$. Per lb., 45 cts.; roo lbs., $\$ 40$.

ANTHOXANTHUM ODORATUM (True Perennial Sweet Vernal Grass). For a mixture with pasture grasses, it is valuable on account of its vernal growth, and also for continuing to throw up root foliage until late in the autumn. For meadows, its chief merit is the fragrant odor which the leaves emit when partially dried, thus sweetening hay. It is a vegetable condiment, rather than a grass of much nutritive value. From 2 to $3 \mathrm{lbs}$. to the acre when mixed. Per lb., 85 cts.; Ioo lbs., $\$ 75$.

ANTHOXANTHUM ODORATUM PUELLI (Annual Sweet Vernal Grass). Much smaller than the perennial, and of much less value, lasting one year only. 20 to $25 \mathrm{lbs}$. to the acre. Per lb., 20 cts.; roo lbs., \$15.

ARRHENATHERUM AVENACEUM (Tall Meadow Oat Grass). See Avena elatior.

AVENA ELATIOR (Tall Meadow Oat Grass). Most valuable for pastures on account of its early and luxuriant growth; it produces an abundant supply of foliage, which is relished by cattle, early and late. For hay it may be cut twice a year, and for green soiling it may be cut four or five times in favorable seasons. It is very hardy, and withstands extreme drought and heat and cold. It is very valuable for our southern states, where it is extensively cultivated for winter grazing and for hay. Height, 2 to 4 feet. 50 lbs. to the acre. ( $x_{3}$ lbs. to bushel.) Per lb., 25 cts.; roo lbs., $\$ 18$.

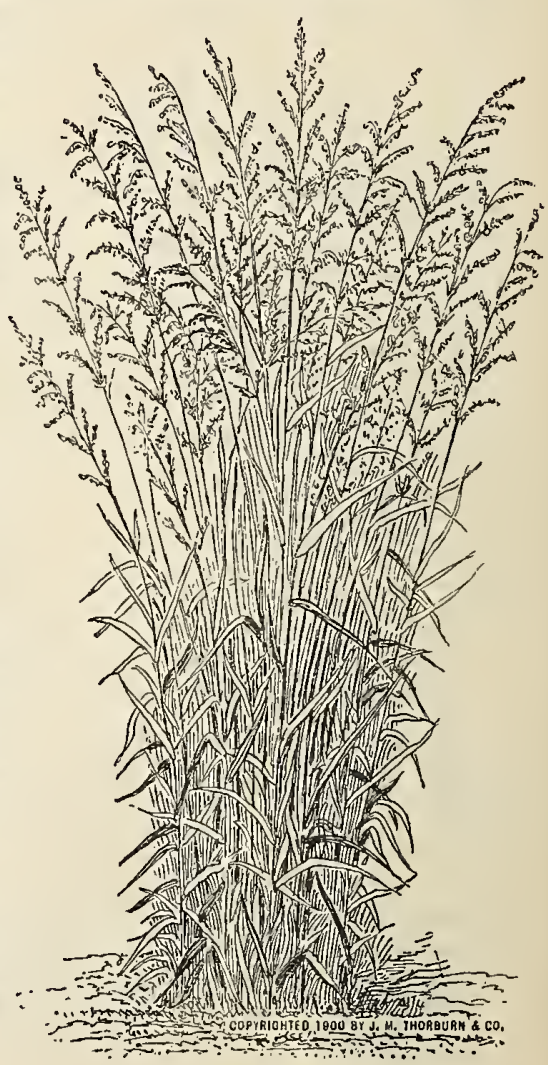

AYENA ELATIOR. 


\section{GRASS SEEDS, continued}

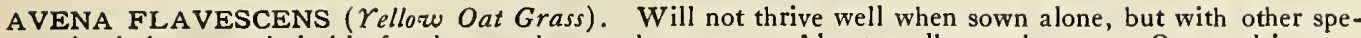
cies it becomes desirable for dry meadows and pastures. About $25 \mathrm{lbs}$. to the acre. Our seed is true. What is usually sold under this name is Aira flexuosa. Per lb., $\$ \mathrm{r}$; roo lbs., \$9o.

BEACH GRASS. See Ammophila arundinacea.

BERMUDA GRASS (Cynodon dactylon). A most valuable grass for our southern states, both for pasture and lawns. It is of dwarf habit, with long creeping stems, rooting at the joints and covering the ground with a matting of fine turf, which no amount of trampling will impair. It is also useful for binding drifting sand and for steep embankments subject to wash. When once established it is difficult to eradicate, and is therefore unsuitable for temporary pastures. As it cannot endure frost, it is of no value north of Virginia. It thrives in the poorest and sandiest soil, and resists extreme drought and the most intense tropical heat. It should be sown at the rate of I 5 lbs, to the acre. Per lb., 80 cts.; 100 lbs., $\$ 70$.

BLUE GRASS, CANADA. See Poa compressa.
" " ENGLISH. See Festuca pratensis.

" " KENTUCKY. See Poa pratensis.

BROMUS INERMIS (Awnless, or Smooth Brome Grass). An erect perennial, 3 to 5 feet high, native of Hungary, where it is considered one of the best hay grasses, yielding a good return in the arid and silicious soil. The nutritive quality of its hay, however, is much inferior to that of our standard native sorts, so that we should recommend it only for dry, arid soils, where the better and more delicate grasses would not grow. It has been found to do well in the semi-arid regions of the west and northwest on account of its remarkable drought-resisting powers, while its extreme hardiness recommends it for the colder sections of Canada. It is strongly stoloniferous, its creeping rootstocks spreading rapidly under ground and giving out new plants. It is on this account undesirable for temporary meadows, being difficult to eradicate when once established. Sow 35 or 40 lbs. to the acre. Per lb., 25 cts.; 100 lbs., $\$ 18$.

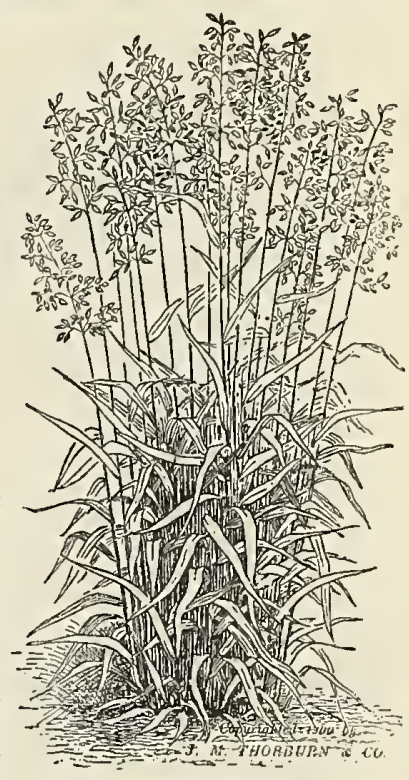

BROMUS INERMIS.

BROMUS MOLLIS (Soft Chess). This annual grass is so called because its stems and leaves are downy and soft to the touch. In good soil it rapidly produces an abundant forage, but of poor quality, and little relished by cattle. It can be recommended only for poor, sandy soil, where grasses of better quality would not grow. $30 \mathrm{lbs}$. to the acre. Per lb., 25 cts.; 100 lbs., \$20.

BROMUS PRATENSIS (Meadow Brome Grass). A hardy perennial, 2 to $3 \frac{1}{2}$ feet high, much used in mixtures for meadows, both for mowing and pasture. It is not recommended to be sown alone except in poor soil, on dry and stony hillsides, where better grasses will not grow. It withstands extreme cold and drought, and if cut before flowering it makes a good hay. If left to grow older, it becomes very tough and indigestible. 30 lbs. to the acre. Per lb., $25 \mathrm{cts}$.; roo lbs., \$2O.

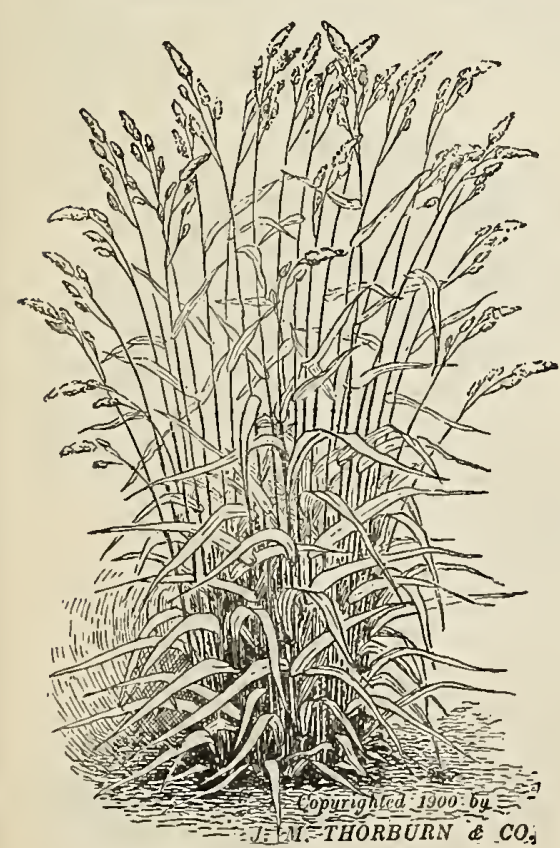

DACTYLIS GLOMERATA (Orchard Grass).

BROMUS SCHRADERI (Rescue Grass). In good, rich soil several crops have been cut in a season. It cures into hay of fair nutritive quality, but heavy and difficult to eat. For pasture, or for cutting and feeding green, it is more suitable. When first introduced it was claimed to be enormously productive, yielding five heavy crops in a year, but this and other claims of superiority have not been borne out, and the grass is not now so largely grown. Height, I to 2 feet. $30 \mathrm{lbs}$. to the acre. Per lb., 30c.; 100 lbs., $\$ 25$.

CALAMAGROSTIS ARENARIA. SeéAmmophila arundinacea.

CYNOSURUS CRISTATUS (Crested Dog's-tail). A stoloniferous perennial, forming a smooth, compact and lasting turf. It thrives best on rich, moist land, but it can accommodate itself to almost any soil. Its roots penetrate deeply into the ground, which enables it to stand severe droughts. It is, on this account, valuable for hilly situations. It makes a good bottom grass and is very nutritious, and is therefore valuable in mixtures for permanent pastures. It thrives well in the shade, and is valuable for shaded parts of lawns. If sown alone 30 pounds to the acre is none too much, but it is recommended only in mixture with other sorts. Height, I to 2 feet. Per lb., 50 cts.; roo lbs., $\$ 45$.

DACTYLIS GLOMERATA (Orchard Grass; Cocksfoot). One of the grasses most employed in permanent meadows, either for pasture or for mowing. It is very hardy and succeeds well anywhere in the United States. It is very productive and makes excellent hay. If cut before it flowers it is less hard and the pith of the stem is soft and sweet. It blossoms about the same time as Red Clover, and is therefore desirable in mixture with that plant. Stock of all kinds are very fond of it, either dry or green, and it endures constant cropping better than any other grass. After being mown it grows up quicker and yields a heavier aftermath 
DACTYLIS GLOMERATA, continued

\section{GRASS SEEDS, continued}

than any other variety. It can stand considerable shade, and is recommended as a pasture grass for woodlands. Its tendency to grow in tussocks is diminished if it is sown with other grasses, and also by heavy

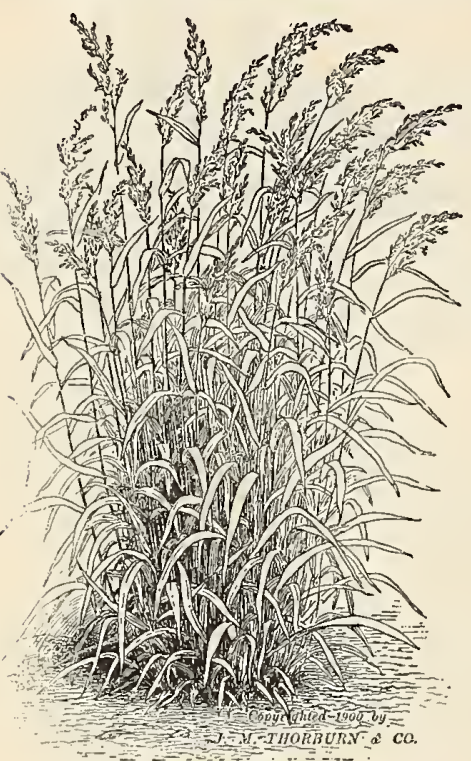

FESTUCA PRATENSIS (Meadow Fescue) rolling in the spring. But it is quite unsuitable for lawns. Height, 3 feet. (14 lbs. to the bushel.) Sow 3 or 4 bushels to the acre. Per lb., 20 cts.; roo lbs., \$17.

DOG'S-TAIL. See Cynosurus cristatus.

ELYMUS ARENARIA (Lime Grass). Valuable on the sandy seashore, canal and railroad banks, etc. It tends, with its tough, wide-spreading and thickly matting roots, to form natural and permanent embankments, thus serving to prevent the drifting of the sand and to protect an exposed shore from wind and waves. It is of no agricultural value. Per lb., 45 cts.; roo lbs., $\$ 40$.

FESTUCA DURIUSCULA (Hard Fescue). This is a variety of $F$. ovina, dwarfer and less vigorous in growth, but possessing all the other valuable characteristics of that variety. It is emphatically a grass for dry lands, doing well on sandy and shallow silicious soils. It is exceedingly hardy and withstands extremes of heat and cold, and also long periods of drought. For permanent pastures on poor lands it is especially valuable, but it may also be used in meadow mixtures for well-manured clayey lands. In the latter case it has been known to yield a good crop of excellent hay and a very large aftermath. On account of its stooling habit it is not recommended for lawns. Height, 1 to 2 feet. 30 lbs. to the acre. Per lb., 25 cts.; roo lbs., $\$ 20$.

FESTUCA ELATIOR (Tall Meadow Fescue). This grass is a native of Europe, but was long ago introduced to this country and is now naturalized and widely grown here. It succeeds best in moist, alluvial and strong clayey soils. It is very productive and of long duration, and is especially valuable for permanent pasture. Stock of all kinds eat it readily, and its nutritive value is said to be very great. On rich, moist lands it yields a large amount of hay of excellent quality. It is not suitable for lawns. Height, 3 to 4 feet. 40 lbs. to the acre. Per lb., 35 cts.; roo lbs., $\$ 28$.

FESTUCA FLUITANS (Floating Fescue). A perennial with long, creeping roots, and preferring a rich, muddy or alluvial soil. It is found in ditches, shallow ponds, sides of rivers and lakes, and in boggy and marshy ground. As trout and wild ducks are very fond of the seeds and tender shoots, it is often introduced on the margins of ponds and rivers with the view of affording them nourishment. Per lb., 40 cts.; roo lbs., $\$ 35$.

FESTUCA HETEROPHYLLA (Various-Leaved Fescue). A very early hardy perennial, 2 to 3 feet high, thriving best in cold, moist soils that are rich in humus and potash. In such soils it yields heavily and is valuable in grass mixtures for permanent meadows, either for mowing or grazing. Its great production of root leaves makes it an excellent bottom grass. Its nutritive value is said to be very high. It grows very well in the shade, and it is highly recommended for shaded lawns and woodland parks. 40 lbs. to the acre. Per lb., 30 cts.; ioo lbs., \$25.

FESTUCA OVINA (Sheep's Fescue). This grass is a native both of America and of Europe. In our northwestern states there are many varieties of it, some of which grow 2 or 3 feet high. It prefers dry uplands, and thrives in poor, shallow, gravelly soils where other grasses would fail. It is very hardy, resisting extreme heat and cold. 'Though of dwarf growth, it grows thickly, yielding a large amount of very nutritious herbage, which is much relished by sheep. In grass mixtures for pastures on high and dry lands it is especially valuable. Though a "bunch grass," it may be included in lawn mixtures on account of its fine foliage and dwarf, dense growth. Height, $1 / 2$ to $1 \frac{1}{2}$ feet. 35 lbs. to the acre. Per lb., 25 cts.; roo lbs., $\$ 20$.

FESTUCA PRATENSIS (Meadow Fescue, or English Blue Grass). One of the grasses most used in permanent or temporary meadows for mowing or for pasture. It succeeds best in cold, moist, light soils, in well-drained meadows and in low valleys rich in organic matter. It should not be grown at all in warm, dry land. It does not reach its full development till the second or third year, when it far exceeds most other sorts in the quantity of its produce and nutritive matter. After being mown it grows again very quickly. The forage, either green or dried, is very nourishing and much relished by cattle, especially when it has been cut young. Height, 2 feet. 40 lbs. to the acre. Per lb., 25 cts.; roo lbs., $\$ 18$.

FESTUCA RUBRA (Red, or Creeping Fescue). A creeping-rooted species, forming a close and lasting turf, and specially adapted for dry, sandy soils. It resists extreme drought, and thrives on very inferior soils, gravelly banks and exposed hillsides. It is also valuable for binding shifting sands on the seashore. As a lawn grass, its chief merit is for positions too shaded for better sorts. 30 lbs. to the acre. Per lb., 25 cts.; 100 lbs., $\$ 22$.

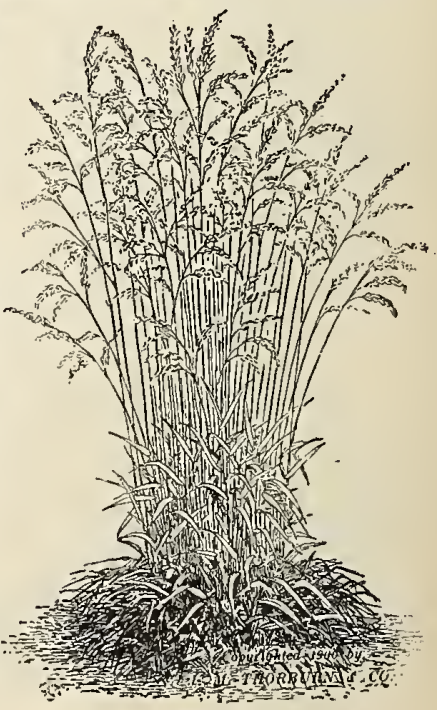




\section{GRASS SEEDS, continued}

FESTUCA TENUIFOLIA (Slender Fescue). This is really a variety of Festuca ovina, with much finer leaves. It will grow on very dry and inferior soil, and its dwarf habit of growth and fineness of leaf render it not unsuitable for dry slopes on lawns. It stands grazing well, is very hardy and lasts long, and may therefore be recommended for permanent pasture on high and dry situations. 30 lbs. to the acre. Per lb., 40 cts.; roo lbs., \$35.

FOX-TAIL. See Alopecurus pratensis.

HOLCUS LANATUS (Meadow Soft Grass; Velvet Grass). This grass is not of much agricultural value, except on peaty or sandy soil, where better sorts will not grow. It is perennial, very hardy and grows rapidly. As a forage plant it is not of the first order, its nutritive value being small; yet it makes a hay that is eaten readily by cattle, especially when it is sprinkled with salt. Height, I to 2 feet. 35 lbs. to the acre. Per lb., 25 cts.; roo lbs., \$20.

HUNGARIAN GRASS. See Panicum Germanicum.

JOHNSON GRASS. See Sorghum Halepense, page 49.

LOLIUM PERENNE (Perennial Rye Grass). Although called a perennial, it seldom lasts more than three or four years. It is the most valuable grass of Great Britain, both for pastures and for meadows, occupying there the same relative position of importance that Timothy holds here. The cool, moist climate of England seems to suit it best, yet it succeeds very well in our middle and eastern states, and adapts itself to a great diversity of soils. The seed is large and heavy, and produces a strong, verdant growth in four or five weeks after

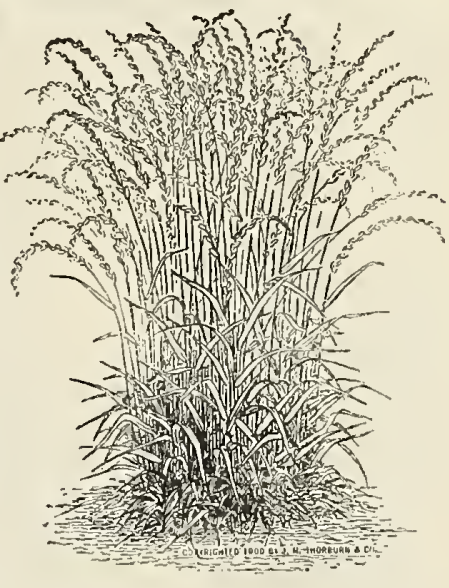

Lolium PERENNe (Petennial Rye Grass). sowing. It cures into a hay that is rather hard, but having a sweet flavor, and much relished by cattle and horses. Its nutritive value, especially in mixture with Red Clover, is very great. It is excellent in mixtures for quick effects in lawns. Height, $1 \frac{1}{2}$ to 2 feet. $60 \mathrm{lbs}$. to the acre. Per lb., 12 cts.; $100 \mathrm{lbs}$., $\$ 8$.

LOLIUM PERENNE, THORBURN'S SELECTED DWARF. A carefully selected, short-seeded, dwarfgrowing strain, suitable for lawns. Makes a fine green turf in three weeks. Per lb., I5 cts.; I00 lbs., $\$ 1$.

LOLIUM ITALICUM (Italian Rye Grass). Though lasting two or three years under very favorable circumstances, it is practically an annual. Like the Perennial Rye Grass, it is a remarkably rapid grower, and has, in addition, the advantage of standing extremes of temperature, remaining green throughout the winter, and retaining its freshness in the hottest summer months and during prolonged droughts. When sown very thickly, or in mixture with other sorts, it makes a good, dense turf, and it has been used with much satisfaction on lawns as far south as Jacksonville. On rich, moist soils it is exceedingly productive, yielding an abundant cutting in four or five weeks after sowing, and every six weeks after that until late in the fall. For temporary meadows, on soils that are neither too stiff nor too dry, it is one of our most valuable grasses. Height, $1 \frac{1}{2}$ to $2 \frac{1}{2}$ feet. 50 lbs. to the acre. Per lb., I2 cts.; I00 lbs., $\$ 9$.

OAT GRASS. See Avena elatior.

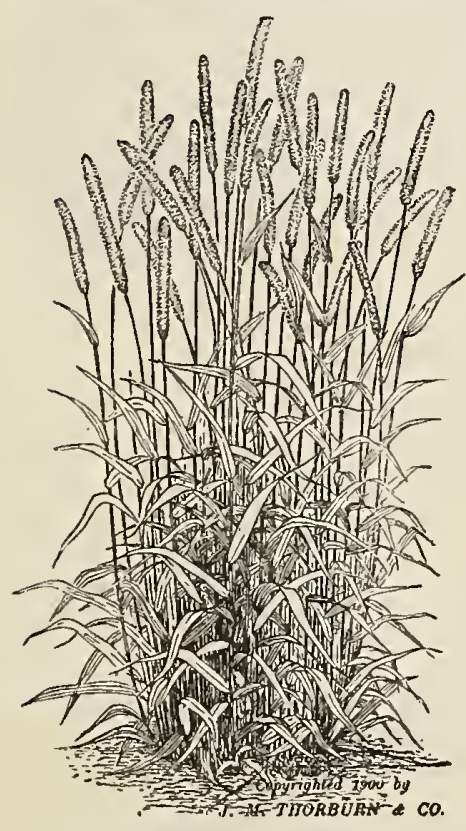

PHLEUM PRATENBE (Timothy).

\section{ORCHARD GRASS. See Dactylis glomerata.}

PHALARIS ARUNDINACEA (Reed Canary Grass). A very hardy perennial, preferring stiff, wet land, but also doing fairly well in dry, sandy soils. It grows well in ditches and by riversides, where its strong, creeping rootstocks render it valuable for binding the banks. Its seed also affords food for trout and wild fowl. When young it may be cut for green forage for cattle, but in its more matured state it is too coarse for this purpose. Per lb., 75 cts.; Ioo lbs., $\$ 65$.

PANICUM GERMANICUM (Hungarian Grass). One of the most valuable annual soiling plants. It grows on any ordinary soil; withstands drought well. As it is of very rapid growth, being ready for cutting within sixty days, it may be sown in this latitude as late as the middle of July for hay, or the middle of August for green fodder. It should be cut just before blooming. Sow I to I $1 / 2$ bushels to the acre. (50 lbs. to the bushel.) Price variable.

PHLEUM PRATENSE (Tinothy). A native of Europe, but long ago naturalized in America, where it ranks as by far the most important of hay grasses. Its popular name, by which it is now known the world over, refers to Timothy Hanson, who did most to make it known and apprecıated. On moist, loamy or clayey soil it produces a larger hay crop than any other grass. It is not so well suited for light, sandy soils. Though preferring a moist, temperate climate, it withstands drought and extreme heat and cold. Its hay is very nourishing and can be preserved for a long time. It should be cut when flowering, as if left later the hay becomes hard and coarse. It is often sown along with Red Clover, and the nutritive value of the hay is greatly increased by this mixture. Height, 2 to 3 feet. If sown alone, at least 
PHLEUM PRATENSE, continued

\section{GRASS SEEDS, continued}

one-half bushel to the acre should be used. The seed weighs $45 \mathrm{lbs}$. to the bushel. Several grades are always on the market, differing in purity and vitality. It is always most economical to buy the highest grade, known as "Fancy." Market price.

POA AQUATICA (Water Meadow Grass). This is an excellent pasture grass for very wet situations. It also does well in bogs and marshes, and is useful in the same way as Festuca fluitans. 20 lbs. to the acre. Per lb., 5o cts.; roo lbs., $\$ 45$.

POA COMPRESSA (Canada Blue Grass). A very hardy perennial grass, with creeping rootstalks, forming a close and durable turf of fine texture. It grows on the poorest and driest soils, sandy, gravelly

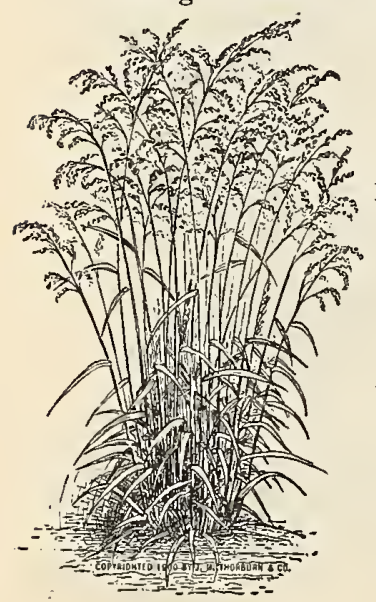

POA NEMORALIS. or clayey, standing extremes of wetness or drought, and keeping green till the severe frosts of winter. It is said to be especially valuable for dairy pastures, cows feeding on it yielding the richest milk and finest butter. It is distinguished from the Kentucky Blue Grass by its flattened, wiry stems and by its decidedly bluer color. Height, 6 to 18 inches. ( 44 lbs. to the bushel.) 3 bushels to the acre. Per lb., is cts.; roo lbs., $\$ 12$.

POA NEMORALIS (Wood Meadow Grass). The chief characteristic of this grass is its special fitness for shaded positions in lawns and woodland parks, where other grasses will not grow. It is very permanent and hardy, resisting extremes of heat and cold, and is one of the first grasses to show a rich green growth in the spring. The creeping roots are formed underground, and make a good turf. It is excellent for pasture, and in good soil grows tall enough for hay. $30 \mathrm{lbs}$. to the acre. Per lb., $50 \mathrm{cts}$; roo lbs., $\$ 43$.

POA PRATENSIS (Kentucky Blue Grass; June Grass). One of our most widely distributed and valuable native grasses. It combines more points of excellence than any other sort. It is a true perennial, lasting indefinitely and improving every year. Its densely creeping rootstalks, spreading habit, and smooth, even growth, fine texture and rich green color render it one of the very best grasses for lawns. It forms a close turf, starts very early in the spring, and lasts till frost. It succeeds in almost any soil, dry, rocky, sandy or gravelly, and stands long-continued dry weather and hot suns. It takes, however, two or three years to become well established, and should, therefore, be sown only in connection with other grasses. If the soil is specially suitable it will eventually crowd these out, and make the finest possible sward. It is one of our most valuable pasture grasses, very productive and nutritious. Height, 9 to 18 inches. ( 14 lbs. to the bushel.) 3 bushels to the acre. Per lb., 18 cts.; roo lbs., $\$ 13$.

POA TRIVIALIS (Rough-Stalked Meadow Grass). A spreading, thickly matting, stoloniferous-rooted species, forming a fine turf, and well adapted for the more shaded portions of lawns. It thrives on rich, moist soil, and in sheltered situations, but does not do well on dry land. It is very valuable for fo ning bottom grass in mixtures for permanent pastures. Height, I to : feet. 20 lbs. to the acre. Per lb., $50 \mathrm{cts}$.; 100 lbs., $\$ 43$.

RED TOP. See Agrostis vulyzris.

RESCUE GRASS. See Bromus Schraderi.

RYE GRASS. See Lolium Italicum and Lolium perenne.

RHODE ISLAND BENT GRASS. See Agrostis canina.

SWEET VERNAL GRASS. See Anthoxanthum odoratum.

TIMOTHY. See Phleum pratense.

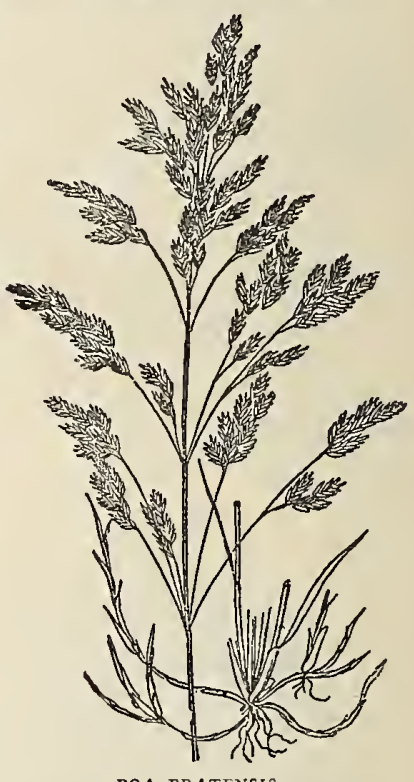

POA PEATENSIS.

\section{VARIOUS VEGETABLES USED FOR PICKLES}

Directions for culture of each will be found under the proper heads. For prices, see body of Catalogue.

Beans, Refugee.

" Lyonnaise.

Beet, Blood Turnip.

Brussels Sprouts, Best French.

Cabbage, Red.

Cucumber, Green Prolific.

Cauliflower.
Gherkin.

Melon, Vine, Orange or Mango.

Martynia.

Nasturtium, Tall.

Onion, White Portugal.

Pepper, Chili.
Pepper, Celestial.

Sweet Mountain.

Tomato, Yellow Plum.
“ Red Cherry.
“ Strawberry.
" Yellow Cherry.
“ Peach.

\section{VARIOUS VEGETABLES USED FOR SALADS}

For prices and cultural directions for these vegetables, see body of Catalogue.

\begin{abstract}
Amarantus caudatus.
Borage.

Burnet.

\author{
Corn Salad. \\ Curled Cress. \\ Dandelion. \\ Endive.
}

Celery.
Escarolle.

Lettuce.

Nasturtium, Tall.

Pepper, Sweet Spanish.
Roquette.

Sorrel.

Water Cress.

Witloof. 


\section{The Thorburn Lawn Grass}

Practically all the very finest lawns in America were produced from this mixture. IVe could give thousands of testimonials to justify this high claim, but we have space only for the few on the next page. These, it will be noticed, all refer to lawns widely celebrated for their beauty.

The Thorburn Lawn Grass Mixture is composed exclusively of permanent grasse that make a finer and thicker turf the older they becone, and yet give a rich green sward in three or four weeks from the time of sowing. For many years we sold this mixture under the name of "Central Park Mixture," but we find that this name is now applied by many dealers to mixtures of their own, differing entirely from ours. We have therefore dropped the name "Central Park," and put up the same seed under the name of Thorburn Lawn Grass. It should be sown at the rate of + to 5 bushels to the acre ( 15 lbs. to the bushel). Per quart, $25 \mathrm{cts}$.; $1 / 2$ peck, $65 \mathrm{cts}$; peck, $\$ \mathrm{r}$; bushel, $\$ 3.50$.

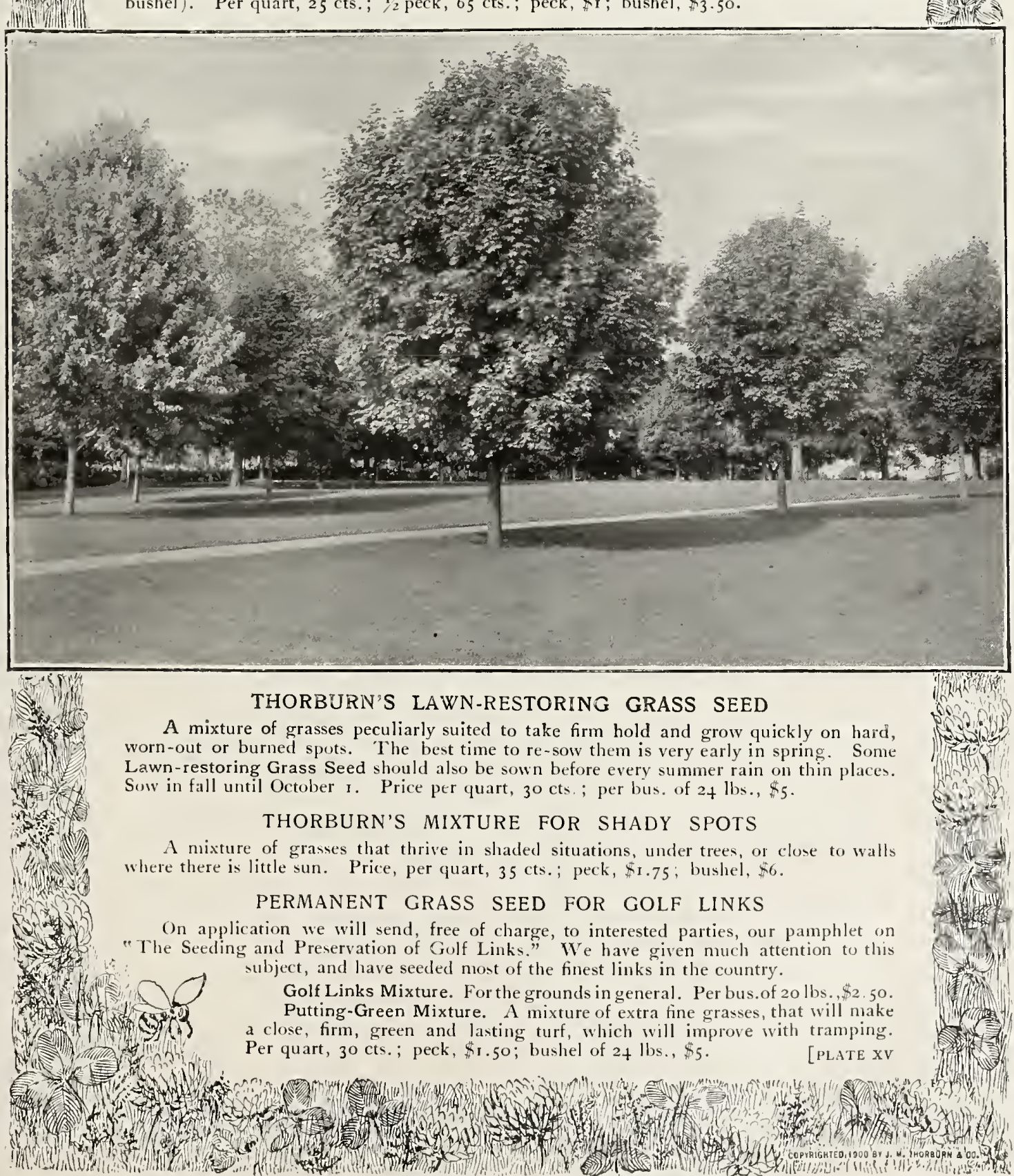




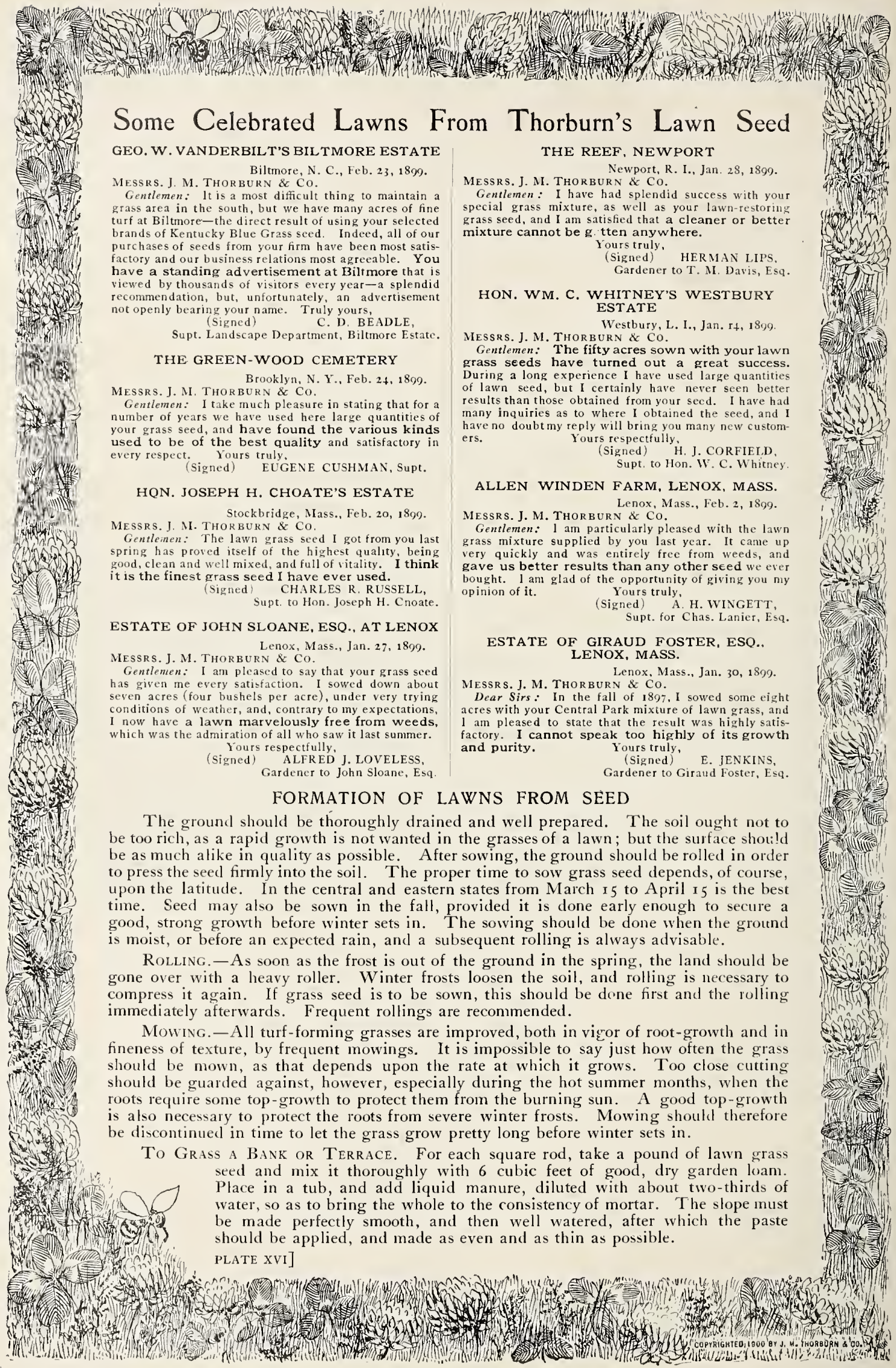




\title{
Forage, Economical and Miscellaneous Seeds
}

\author{
All subject to change in price
}

ASPERULA odorata (Waldmeister). Perennial, about 6 inches high ; very fragrant flower. In Germany it is thought much of as imparting a certain bouquet to Rhine wine, making the wellknown Maitrank. Per pkt., 5 cts.; per oz., 6oc. AUSTRALIAN SALT-BUSH (Atriplex semibaccatum). A valuable forage plant recently introduced by the University of California. Experiments show that it thrives in soils on which nothing else will grow, and it is recommended highly for alkali soils and all regions subject to periodical drought. It is very nutritious, and good for all kinds of live stock. One pound of seed is sufficient for an acre. The soil should be well plowed and harrowed. The seed may be sown in garden bed and the seedlings planted out when 2 inches high, 7 or 8 feet apart. Per oz., I5 cents; per lb., \$I.50. Special quotations for large quantities.

BEANS-Common English Horse Bean. Per qt., 20 cts. ; per bus., $\$ 4$.

Soja Bean (Soja hispida; Glycine hispida). The haulm is stiff, and the pods are produced in clusters of from two to five, and contain each four smooth, oval, nankeen-colored seeds. Thrives well in hot and dry weather; very valuable for the south, for either man or beast. Is planted at rate of $1 / 2$ bushel to the acre, in drills $21 / 2$ to 3 feet apart, and cultivated same as Indian corn. It does not make very good hay, but is good as ensilage or green fodder. The feeding value of the bean is very great. Per qt., 20c.; per bus., $\$ 3$.

Velvet Bean (Dolichos multiflorus). Used by the farmers in Florida and Louisiana as a forage plant, and also as a fertilizer plant for turning under just in the same way as the Cow Pea. Stock readily eat the vines and leaves, and the Beans when ground with or without the pod, are used in place of oats or corn, or mixed with them. As a fertilizer for orange groves the Velvet Bean is said to be unequaled. It is planted in rows 4 feet apart and $I$ foot in the row, 2 or 3 beans in a place, as soon as danger of frost is past. Yield, 20 to 35 bushels to the acre. Per qt., 20c.; per bus., $\$ 3$.

BEGGAR-WEED (Florida or Giant Beggar-Weed; Desmodium tortuosum). An erect leguminous annual, growing from 3 to 8 feet high, with abundant foliage, valuable as forage or for soil renovation in subtropical regions. It is highly recommended for improving light, sterile, sandy soils by plowing under, and it also makes hay of a fine quality. It should be sown at the rate of ro pounds of clean seed to the acre, after the ground is warm and moist. The seed should be but very lightly covered. If for hay, it should be cut just as it begins to bloom. Perlb., 50 cts.; per roolbs., $\$ 40$.

BROOM CORN (I2 quarts to the acre). Broom Corn succeeds in a good, deep soil, fresh but not damp; it is very sensitive to cold.

Long-Brush Evergreen. Per lb., I5 cts.; per 100 lbs., $\$ 7$.

Improved Dwarf. Per lb., I 5 c.; per I00 lbs., $\$ 8$. Early Japan. Per lb., I 5 cts.; per Ioo lbs., $\$ 8$.

California Golden Long-Brush. Grows from 12 to I 4 feet high. Per lb., I 5 cts.; per Ioo lbs., $\$ 7$.

BROOM-Scotch (Genista scoparia). The young growth of this shrub is chiefly valuable as food for sheep and other animals in winter. It is also employed for the making of coarse brooms. Peroz., Ioc. ; per lb., 5o cts.
BURNET-Common Field (Poterium Sanguisorba). Perennial; makes excellent pasture for sheep; grows on the poorest ground - on dry, sandy or calcareous soils; resists the extremes of heat and cold. Sow in April, and again in September, with Sainfoin, Clover, Rye, Grass, etc., 30 lbs. to the acre. Per lb., 20 cts. ; per roo lbs., $\$ 12$.

C A N A I G R E (Rumex hymenosepalus). Used in the tanning of leather. Per pkt., roc.; peroz., 50 cts.; per lb., $\$ 5$.

CAPER TREE (Capparis spinosa). Per paper, I 5 cts.; per oz., 75 cts.

CATERPILLARS. A curious plant. Of interest only on account of the curious fruits, from which its name is derived. Amusement is caused by mixing them in salads. Per paper, 5 cts.; per oz., $40 \mathrm{cts}$.

CHICORY-Large-Rooted. A perennial, remaining five or six years in the same soil, if cut before flowering. It may be cut four or five times during the same season for green fodder. Sow broadcast in autumn or spring, either alone or with any kind of Clover. Sown in drills, the roots become well developed. When they are dried, roasted and ground they become the Chicory of commerce, and are used in adulterating coffee. Per oz., ro cts.; per lb., 75 cts.

COTTON-Sea Island. Per lb, , I 5 c.; per roo lbs. , $\$ 7$. Upland. 25 lbs. to the acre. Per lb., 15 cts.; per roo lbs., $\$ 7$.

African Limbless. Extremely productive, cluster sort. Per lb., 20 cts.; per Ioo lbs., $\$ 12$.

Russell Ozier Big Boll. Very prolific. Per lb., 20 cts.; per I0o lbs., $\$ 12$.

COW PEAS (Vigna Catjang). Specially adapted to warm countries; extensively grown in our southern states; also valuable in this latitude as a fodder plant; their chief value, however, is as a green crop to plow under. They require a deep, rich, sandy soil for best results. The seed should not be sown till the ground has become well warmed. I bushel to the acre. Per qt., I 5 cts.; per bus., $\$ 2.50$.

CYTISUS PROLIFERUS ALBUS ( $\mathcal{T}$ agasaste). An African fodder plant of merit that has done well in Australia and in California. It is a leguminous shrub, growing well in dry soil and furnishing excellent "browse" for stock. Sow in boxes and transplant when the plants are a few inches high. The seed should be passed through boiling water and then steeped in cold water for 24 hours before sowing. Per oz., 20 cts.; per lb., \$2.

DHOURA-Guinea Corn. See Sorghum. 


\section{MISCELLANEOUS SEEDS, continued}

ESPARTO GRASS (Stipa tenacissima). This is the true Esparto Grass, extensively grown in Spain and other parts of the Mediterranean countries for making ropes, etc. Per oz., \$1.50.

ESPARSETTE. See Onobrychis sativa.

FENUGREEK. Annual. The seed is often sought by hostlers to give a temporary fire and vigor to their horses. It is frequently given to oxen and pigs when fattening, causing them to drink and digest their food. Considered to be good for soiling when green. Per oz., ro cts.; per lb., 30 cts.

FLAT PEA. See Lathyrus sylvestris.

FLAX SEED. I I $/ 2$ bushels to acre. Price variable. FURZE (Ulex Europea). Also known as Whin and Gorse. A perennial leguminous shrub, native of northern Europe. The crushed sprigs of one year's growth of this shrub furnish an excellent green fodder in winter. It grows well on dry, barren hillsides and in poor sandy soil, where it makes an excellent forage plant. Sheep are very fond of it. 25 lbs. to the acre. Per oz., roc.; per lb., 85c.

GUINEA GRASS. This name is sometimes applied to Johnson Grass, but the real Guinea Grass does not mature seed in the United States.

GUIZOTIA oleifera. An annual from Abyssinia, from the seed of which oil is extracted. Per oz. $10 \mathrm{cts}$; per lb., 75 cts.

HEMP. One bushel to the acre. Price variable.

HOP SEED. Per pkt., Io cts.; per oz., \$1.

INDIGO SEED (Indigofera tinctoria). Per oz., 20 cts.; per lb., $\$ 1.50$.

IRIS pabularia. A forage plant, flourishing in the driest and most arid soil. The seeds should be sown in beds, and the young plants set out 10 inches apart each way, where they are to remain, very early the following spring. Per oz., $75 \mathrm{cts}$.

JAPAN CLOVER. See Lespedeza striata.

JERUSALEM CORN. See Sorghum.

JUTE. Annual. Thrives in any good corn ground. Sow in drills, about 8 inches apart, 4 pounds to the acre. Requires no cultivation, as it will out strip in growth all weeds. May be also sown broadcast. 6 to 7 pounds per acre. Per oz., Io cts.; per lb., 75 cts.

KAFFIR CORN. See Sorghum.

KALE-Jersey Winter, or Cow Cabbage. Said to be hardy from New Jersey southward, where it will stand out all winter, the leaves making valuable winter cattle feed. Sow at same time as winter cabbage. Per oz., 10 cts.; per lb., $\$ 1$.

KIDNEY VETCH, or Sand Clover See Clovers, page 40.

LATHYRUS sylvestris (Flat Pea). A perennial forage plant. The vines when cut dry out readily and make a nutritious hay, which is relished by cattle and horses. It grows well on very poor, unimproved, sandy soil, can withstand pretty severe frosts, and roots so deeply that it is not injured by severe drought. Valuable for plowing under in a green state as a soil renovator to supply nitrogen to poor soils. It is recommended to sow seeds in a small garden bed and transplant to the field when the plants are of suitable size. Per oz., $10 \mathrm{cts}$; per lb., 75 cts.

LENTILS-Best Imported (Ervum lens). Succeed best in dry, sandy soil. A leguminous annual, the seeds of which are valuable for pigeons, and are largely used for soups. The leafy stalks make good forage. Per lb., 30 cts.
LESPEDEZA striata (Japan Clover). A perennial, growing about 12 inches high, valuable only in southern localities, where it thrives in any soil and in the driest season; it makes a fair hay, and stock eat it readily when green. It is also very valuable for plowing under as green manure. It is usually sown in the spring, broadcast, at rate of $30 \mathrm{lbs}$. to the acre. Per lb., 30 cts.; per 100 lbs., $\$ 25$.

LIQUORICE (Glycyrrhiza glabra). Seed in pods, per $02 ., 25$ cts.

LOTUS corniculatus (Bird's-Foot Trefoil). Perennial, used in pastures. Cattle and sheep eat it readily, and it is said to be quite nutritious. It grows on the lightest and most sterile soils, and can withstand severe droughts. It is excellent for sowing in mixtures for dry pastures. Per lb., 6oc.

LUPINS-Yellow. Succeeds well in the poorest soil, and is exceedingly valuable for plowing in to improve sandy soils. It makes good forage either green or as hay. The seeds are very fattening when used with hay. Sow in the spring when the ground has become warm, at rate of 90 pounds to the acre. Per lb., 20 cts.; I 00 lbs., $\$ 8$.

White. One of the best plants known for green manure, as it gathers large quantities of nitrogen from the air. It may be sown from April to July, and plowed under when in flower. The seed, when burned, is excellent manure for orange and olive trees. Per lb., 20 cts.; per 100 lbs., $\$ 9$.

Blue. Used for the same purpose as the white variety. Per lb., 20 cts.; per 100 lbs., $\$ 8$.

MADDER (Rubia tinctoria). A perennial, the roots of which, when dried and reduced to powder, furnish a red coloring matter. If cut the second year when in flower, it furnishes a good green fodder. Per oz., 10 cts.; per lb., $\$ 1$.

MADIA sativa. An annual plant, producing good sheep pasturage; valuable in dry and warm soil. An excellent lubricating oil is extracted from the seeds. Per oz., ro cts.; per lb., 60 cts.

MILLETS. See Cereals, page 39.

MILLO MAIZE. See Sorghum, Branching.

ONOBRYCHIS sativa (Sainfoin, French; Esparsette, German). A perennial leguminous plant, belonging to the same family as Clover and Lucerne. It is a valuable plant for growing on barren hillsides. When once well established it lasts for many years, yielding heavy hay crops of the highest nutritive value. Sow in the spring, covering the seeds quite deeply, at rate of 80 lbs. or 100 lbs. to the acre. Per lb., 15 cts.; per 100 lbs., $\$ 9$.

OSAGE ORANGE (Maclura aurantiaca). Useful for hedges. See Tree seeds, page 53 .

PEARL MILLET (Penicillaria spicata). A valuable fodder plant for the south; is enormously productive. Sow the seed in drills 18 inches apart and 8 to 10 pounds to the acre. Per lb., 15 cts.; per 100 lbs., \$9.

PEAS-Canadian Field. Valuable for northern climates, for cattle feeding, especially for milch cows. It also makes fine ensilage. It is sown broadcast in the spring and harrowed in. Price variable; about I 5 cts. per qt., $\$ 1.50$ per bus.

PYRETHRUM roseum. The plant from which insect powder is made in Europe. Per oz., 50 cts.

POPPY-Opium. The seed furnishes an agreeable sweet oil, used for the table, for painting and for illuminating. May be sown in spring either broadcast or in trills, covering thinly. Also cultivated for opium. Per oz., $20 \mathrm{cts}$.; per lb., \$1. 


\section{MISCELLANEOUS SEEDS, continued}

POLYGONUM Sachalinense (Sacaline). Hardy perennial, native of the Island of Saghalin, between Japan and Siberia. Although known for many years, its merits as a forage plant have only lately been pointed out. It grows well on the poorest soils, and endures the extremes of heat and cold. Reaches a height of ro or 12 feet, and can be cut two or three times in the season. The stems and leaves, which are very nutritious, are said to be eaten either green or dry by cattle and sheep. Seed, per oz., 60 cts.; per lb., $\$ 6$.

RAMIE-Silver China Grass (Urtica nivea). Extensively cultivatcd for its fiber. The seed should be germinated on cotton floating in lukewarm water, and transferred to a bed, screened from the hot sun. When the plants are 4 inches high, transplant to a field in rows + feet a part each way; when 3 feet high, turn them over and peg down, covering with earth, and they will start in every direction. Per oz., $\$ \mathrm{I}$; per lb., $\$$ rz.

RAPE-Dwarf Essex, English. Largely grown in the northern United States and in Canada. It is excellent for sheep pasture, and also for soiling. It may be sown in May, and will be ready for pasturing in July and August. Or it may be sown in June or July, and yet furnish a large amount of pasture or fodder. It may even be sown after taking off a crop of early potatoes. In drills, sow 5 pounds to acre; broadcast, io lbs. to acre. Per lb., I5 cts.; per roo lbs., $\$ 8$.

REANA luxurians (Teosinte). A valuable fodder plant from Central America, in growth resembling Indian corn. Well adapted to our southern states. Per oz., I 5 cts.; per lb., 75 cts.

RICE SEED, for sowing. Per lb., roc.; roo lbs., $\$ 8$. See Wild Rice.

SAINFOIN. See Onobrychis.

SALT BUSH. See Australian Salt Bush.

SACALINE. See Polygonum Sachalinense.

SCURVY GRASS (Cochlearia officinalis). Used as a pepper grass. Per oz., 25 cts.

SERADELLA. A valuable forage plant, admitting of one, and sometimes two cuttings, in one season. It succeeds well in a dry, sandy soil, and furnishes a good pasture for sheep. It may also be cured for hay. Can be sown with winter rye. About 50 pounds to acre. Per lb., 20 cts.; Ioo lbs., \$IO.

SNAILS. Used in the same way as Caterpillars. Per paper, 5 cts.; per oz., 40 cts.

SORGHUM (I $8 \mathrm{lbs}$. to acre if sown in drills. For dry fodder 2 bushels should be sown to the acre).

Early Amber Sugar Cane. Ripens wherever Indian corn matures. Per lb., I 5 cts.; roo lbs., $\$ 6$.

Early Orange Sugar Cane. Ripens about ten days after Early Amber. Per lb., i 5c.; per ioo lbs., $\$ 6$.

Brown Dhoura Corn. Per lb., I 5 cts.; per roo lbs., $\$ 6$.

Yellow Branching ( $Y$ ellow Millo Maize). Nonsaccharine; useful for the large amount of foliage, green fced or cured fodder that it furnishes and for its grain. Per lb., 20 cts. ; per roo lbs., $\$ 7$.

White Branching (White Millo Maize). This nonsaccharine Sorghum when cut for feeding starts again from the stumps with renewed strength and vigor; thrives in the hottest and driest localities. Per lb., 20 cts.; per 100 lbs., \$7.

Red Kaffir Corn, or Sorghum. Non-saccharine. The plant is low, stalky, perfectly erect. The whole stalk, as well as the blades, cures into excellent fodder, and in all stages it is available for green feed. Per lb., is cts.; per roo lbs., $\$ 6$.
SORGHUM-White Kaffir Corn. Per lb., I 5 cts.; per roo lbs., $\$ 6$.

White African Sorghum, or White Dhoura. Perlb., r 5 c.; per roo lbs., $\$ 6$.

Halepense (Johnson Grass). One of the most valuable southern fodder plants. On rich soils it may be cut three or four times in a season. Sow in August and September, 25 to 35 pounds to the acre Per lb., 20 cts. per roo lbs., \$ro.

SPURRY (Spergula arvensis). Annual. Grows well on poor, dry, sandy soils, may be sown every month from March to August. Excellent pasture for cattle and sheep; also, as a fertilizer for light soil. Is lbs. to the acre. Perlb., 20c.; roo lbs., $\$ 9$.

Giant Spurry. Per lb., 20 cts.; per Ioo lbs., $\$ 9$.

SUNFLOWER-Large Russian. Per lb., xo cts.; per xoo lbs., $\$ 6$ (price fluctuates).

TEASELS-Fullers'. Heads used for combing cloth. Require a good, deep soil; sow in A pril or May. The young leaves are often used for feeding silkworms. Per lb., $30 \mathrm{cts}$.

TEOSINTE. See Reana luxurians.

VELVET BEAN. See under Beans, page 47.

VETCHES-Spring Tares (Vicia sativa). Sown broadcast at rate of $I$ to $I 1 / 2$ bushels to the acre, like wheat or barley, and sometimes mixed with oats for soiling. Used in France or Canada as a substitute for peas. Also ground up into flour, after which it is mixed with wheat flour for making bread. Per qt., $20 \mathrm{cts}$.; per bus., $\$ 3.50$.

Sand, Winter, or Hairy Vetch (Iicia villosa). Thrives on poor, arid, sandy soils. It is sown either in fall or in spring, mixed with rye, for a support. Grows 3 to 4 feet high, and can be cut as soon as the bloom appears, and again for the seed. Perfectly hardy, and the produce is recommended as most nutritious. Sow I $1 / 2$ bushels to the acre. Per qt., 25 cts.; per bus., \$5.50.

WILD RICE (Zizania aquatica). A native of our northern and western states. Valuable as a forage plant for swamps and inundated lands, but chiefly as an attraction for water fowl. Before sowing, soak in water for 24 hours. Sow in water which is from 6 inches to 5 feet deep, with soft mud bottom. In running water, sow out of strong current. Per lb., 25c.; per Ioo lbs., \$I5.

WORMS. Used the same as Snails and Caterpillars. Per pkt., 5 cts.; per oz., 40 cts.

YARROW (Achillea Millefolium). Thought worthy of cultivation on light soils on account of its nutrient properties. Per lb., $\$$ I.50. 


\title{
TREE AND SHRUB SEEDS
}

\author{
HOW TO GROW THEM
}

In order to preserve seeds of Conifers and other Evergreen Trees, it is best to keep them in perfectly dry sand until the time of sowing. For this latitude, the seeds should be sown thinly, as early in the spring as the ground can be worked, in beds of fine, sandy loam. Cover to the depth of about the thickness of the seed, and press the beds gently with the back of the spade to firm the earth around the seeds. Great care must be taken not to give too much water, as the young plants damp off very easily. Water with a very fine rose, but never so that the ground becomes soggy. Some shade must be used to protect the young plants from the hot, drying sun and winds, and also to keep the birds from destroying them. Seeds of the rarer sorts may be sown in coldframes or boxes; if in coldframes, the sashes should be shaded and the frames raised at the corners 3 or 4 inches, to allow the air to circulate freely. Keep the young plants well weeded, and allow them to remain from one to two years before transplanting.

The propagation of Deciduous Trees from seeds is less difficult than that of Evergreen species, a little attention only being required to sow at the proper season to insure success. Acorns, Hickory Nuts, Chestnuts and Walnuts should be planted in autumn, or kept during the winter in earth or moss. They shrivel up by too long exposure to the air, and many of them lose their power of vegetating. Those seeds with hard shells, like the Locust, Gymnocladus, etc., should be planted in autumn or placed in boxes with sand, and exposed to frost before planting. They may not vegetate till the second year after planting, but if these seeds are received too late in the spring to expose them to the action of the frost, they may be put into a vessel of hot water for an hour or so before planting. American Elm, Silver Maple, and a few other sorts ripen their seeds early in summer, and if gathered and planted soon after they fall from the tree, will make fine plants the same season. The seeds of other Deciduous Trees and Shrubs should be planted from the middle of April to the middle of May, in drills about 2 feet apart, and covered about half an inch in depth, according to size.

The varieties here offered are on hand now, or are due from foreign countries, having been collected for us of the 1900 crop. As the season advances many sorts become worthless from various causes, or are sold out, and cannot be replaced until the new crop is ready next season.

\section{EVERGREEN TREE SEEDS}

We do not sell Tree or Shrub Seeds in quantities of less than an ounce of any one variety, except those quoted at over 25 cents per ounce; of these, 25 -cent packets may be ordered.

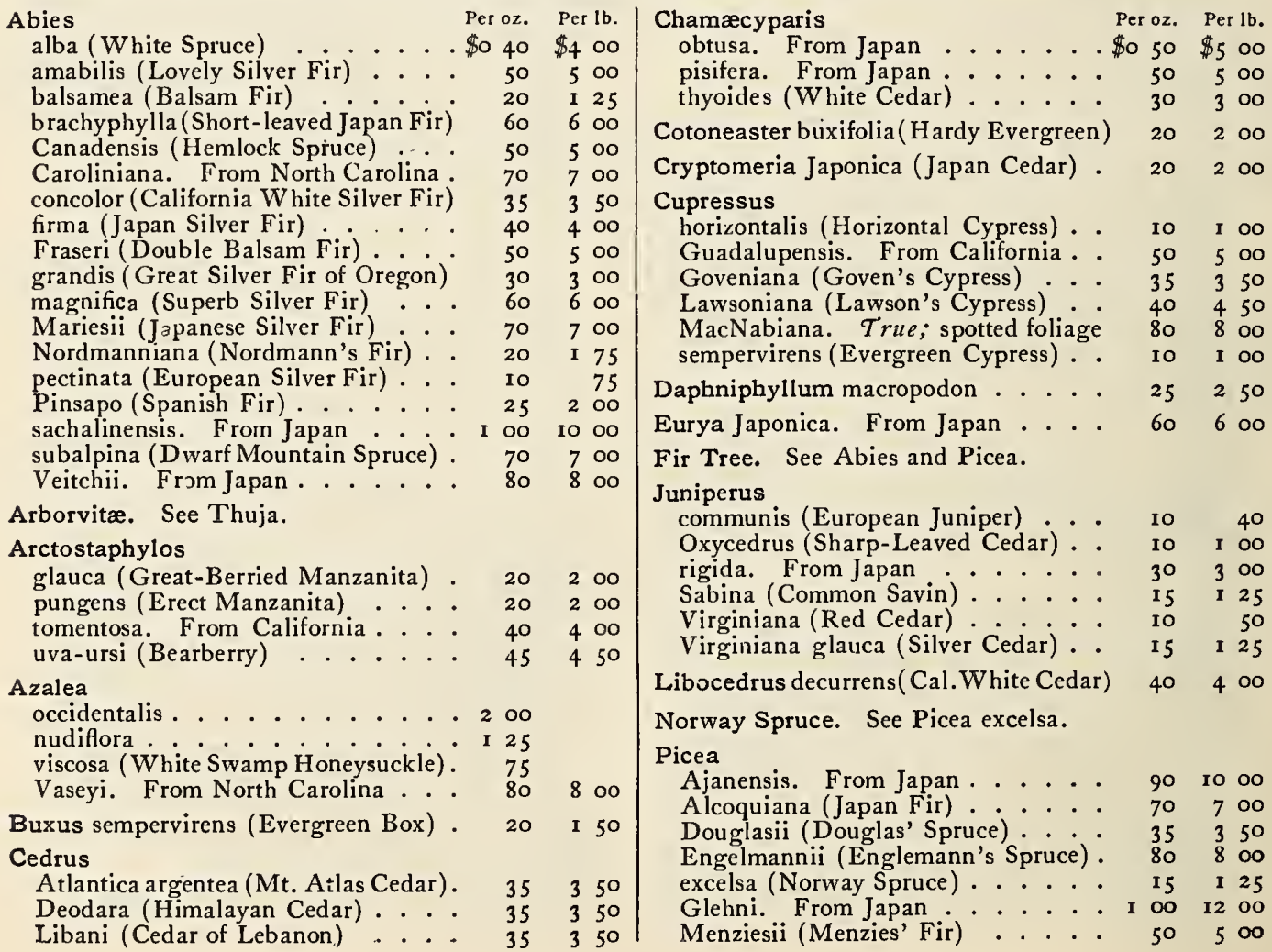


EVERGREEN TREE SEEDS, continued

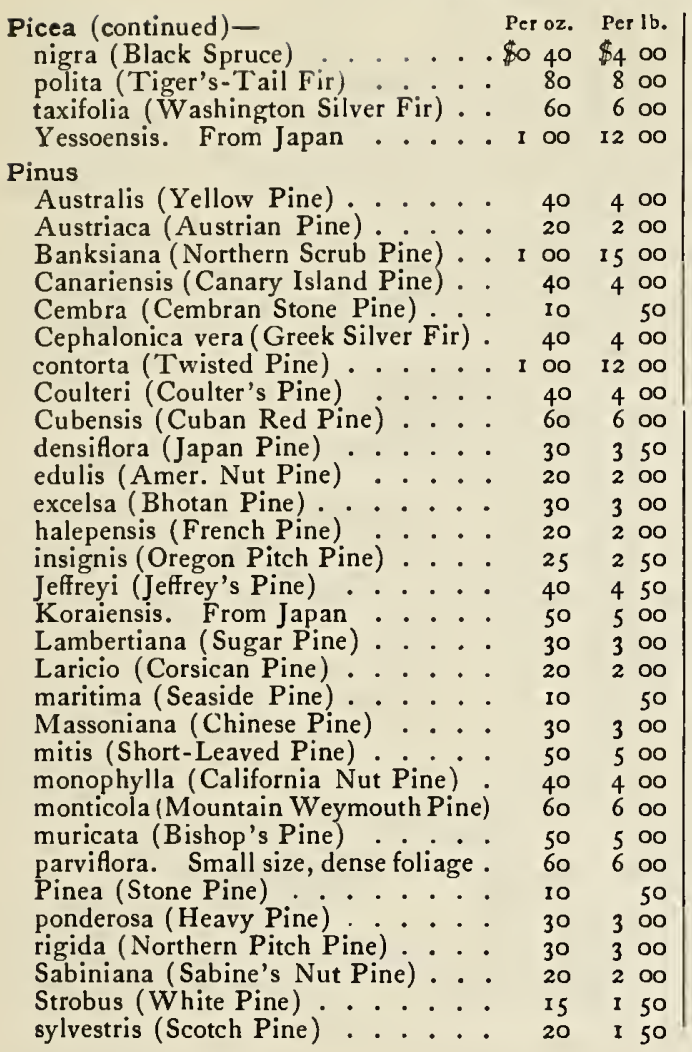

Pinus (continued)-

Per oz. Per lb. Taeda (Loblolly) . . . . . . . \$o 50 \$5 oo Torreyana ('Torrey's Pine) .... 35350 tuberculata (Tubercled Pine) . . . . 6060

Retinospora. See Chamæcyparis.

Sciadopitys verticillata (Umbrella Pine of Japan). $60 \quad 600$

Scotch Fir. See Pinus sylvestris.

Sequoia gigantea (Big Tree of California) . $\quad 70 \quad 7$ oo sempervirens (California Redwood) . 40450

Spruce Tree. See Abies and Picea.

Taxus

baccata (European Yew) .... I 15 I 50 brevifolia (California Yew) . . . . I 001200 cuspidata (Japanese Yew) ..... 80900

Thea viridis (Tea Plant of Japan) . . 15 I 50

Thuja

aurea (Golden Arborvitæ) . . . . 15 I 50 occidentalis (American Arborvitæ) . $20 \quad 200$ orientalis (Chinese Arborvitæ). . . I5 I 00 compacta (Compact Arborvitæ) . . . 20 I 75 gigantea (Giant Oregon Arborvitæ) . $\quad 40 \quad 400$

Thujopsis

dolobrata (Japanese Thuja) . . . 60600

Standishii. From Japan..... 80 ro 00

Torreya

Californica (California Nutmeg) . . $20 \quad 200$

nucifera (Japanese Nutmeg . . . . $30 \quad 300$

Tsuga Sieboldii(Siebold's Japan Spruce) $80 \quad 8$ oo

Yucca

baccata (Berry-Bearing Yucca) . . . I 00

filamentosa (Adam's Needle). . . 6o 600

gloriosa (Mound Lily)...... 80900

\section{DECIDUOUS TREE AND SHRUB SEEDS}

(For Fruit Tree Seeds, see page 54)

We do not sell Tree or Shrub seeds in quantities of less than one ounce of any one variety, except those quoted at over 25 cents per ounce; of these, 25-cent packets may be ordered.

\begin{tabular}{|c|c|c|c|c|c|c|c|c|c|}
\hline Acer & & & Per 1 & & Andromeda & & & & \\
\hline tre (European Field Maple) & $\$ 0$ & ro & & & arborea (Sour Wood) . . . . & & & & \\
\hline Round-Leaved Maple) & & 25 & & & calyculata (Leather-Leaf) . . . & & 50 & & \\
\hline macrophyllum (Large-Leaved Maple) & & ro & & 75 & ligustrina. Five feet high . . . . & & 15 & & \\
\hline rlet Maple) . . . & & 25 & 25 & 50 & Mariana (Stagger Bush). . & . & 15 & & 50 \\
\hline icum (Striped Maple). & & 30 & 3 & oo & racemosa (Pepper Bush). & - & 30 & & oo \\
\hline $\begin{array}{l}\text { platanoides (Norway Maple) } \\
\text { pseudo-platanus (Sycamore Maple) }\end{array}$ & & $\begin{array}{l}\text { 10 } \\
\text { 10 }\end{array}$ & & $\begin{array}{l}50 \\
50\end{array}$ & & & & & \\
\hline palmatum. From Japan & & 50 & 5 & ০० & $\begin{array}{l}\text { Sieboldii. From Japan } \\
\text { Sieboldii variegata (Variegated leaves) }\end{array}$ & j) 1 & $\begin{array}{l}40 \\
\text { oo }\end{array}$ & $\begin{array}{r}4 \\
12\end{array}$ & $\begin{array}{l}\text { oo } \\
\text { oo }\end{array}$ \\
\hline Actinidia arguta. A Japanese climber & & oo & & & Arbutus & & 30 & & \\
\hline Ailantus glandulosus (Tree of Heaven & & 10 & & 75 & Unedo (Strawberry Bush) . . & & 20 & & \\
\hline $\begin{array}{l}\text { Alnus } \\
\text { communis (Common }\end{array}$ & & Io & & 50 & Ash. See Fraxinus. & & & & \\
\hline $\begin{array}{l}\text { incana (Smooth White Alder) } \\
\text { Oregona (Oregon Alder) }\end{array}$ & & 15 & & 75 & Asimina triloba (Papaw) & & 10 & & \\
\hline $\begin{array}{l}\text { Amelanchier } \\
\text { alnifolia (Oregon Shad Bush) }\end{array}$ & & & 3 & & $\begin{array}{l}\text { Baccharis halimifolia (Groundsel Tree) } \\
\text { Berberis }\end{array}$ & & 60 & & \\
\hline Amorpha fruticosa (Bastard Indigo) & & Io & & 75 & $\begin{array}{l}\text { ifolium (Holly-Leaved Barberry) } \\
\text { osa (Nerve-Leaved Barberry). }\end{array}$ & & $\begin{array}{l}15 \\
60\end{array}$ & & \\
\hline Ampelopsis & & 15 & I & oo & $\begin{array}{l}\text { vulgaris (Common Barberry) } \\
\text { vulgaris purpurea (Purple-Leaved) }\end{array}$ & & $\begin{array}{l}10 \\
15\end{array}$ & & $\begin{array}{l}75 \\
50\end{array}$ \\
\hline $\begin{array}{l}\text { Veitchii (Japan or Boston Ivy). } \\
\text { Amygdalus } \\
\text { vulgaris dulcis (Sweet Almond) }\end{array}$ & & 15 & $I$ & 25 & $\begin{array}{l}\text { a alba (White Am. Birch) } \\
\text { ite European Birch) }\end{array}$ & & $\begin{array}{l}15 \\
10\end{array}$ & & $\begin{array}{l}50 \\
40\end{array}$ \\
\hline
\end{tabular}


DECIDUOUS TREE AND SHRUB SEEDS, continued

Betula (continued) lenta (Mountain Mahogany) . . . \$o 30 \$3 oo lutea (Yellow Birch) ...... 30 30 nigra (Black Birch) ; . . . . papyracea (Paper Birch) . . . . . populifolia (Poplar-Leaved Birch) .

Birch. See Betula.

Boston Ivy. See Ampelopsis Veitchii.

\section{Brahea}

filifera (Washingtonia) . . . .

robusta ...........

Broussonetia

papyrifera (Paper Mulberry) . . .

Callicarpa Americana(French Mulberry)

\section{Calycanthus}

foridus (Sweet-Scented Shrub) . . occidentalis (Western Allspice) . .

Camellia Japonica. From Japan ...

Camphora officinalis (Camphor Tree).

Carpinus

Americana (Blue or Water Beech).

Cassia Marilandica (Southern Cassia).

Castanea Japonica (Japan Chestnut) .

Catalpa

Kæmpferi (Japanese Catalpa) . . speciosa (Hardy Catalpa)

Teas' Hybrid (Hybrid Catalpa) .

Ceanothus

Americanus (New Jersey Tea) . : divaricatus (Branching Red-Root) . velutinus (Soft-Leaved Red-Root) .

Cedrela Chinensis . . . . . . .

Celastrus

scandens (Climbing Bittersweet).

Celtis

australis (European Nettle Tree). occidentalis (Hackberry) . . . .

Cephalotaxus drupacea. From Japan .

Ceratonia Siliqua (St. John's Bread) :

Cercidiphyllum Japonicum . . . . . . I 50

Cercis

Canadensis (American Judas Tree) . occidentalis (California Judas Tree) . Siliquastrum (European Judas Tree).

Cherry. See Prunus.

Chionanthus Virginica (Va. Fringe Tree)

Cinnamomum camphora (Camphor) .

Citrus trifoliata (Hardy Japan Orange).

Cladrastis tinctoria (Yellow Wood). .

\section{Clematis}

flammula (White Virgin's Bower) . ligusticifolia

paniculata (Panicled Virgin's Bower). Virginiana (Virgin's Bower) . . . vitalba (Traveler's Joy) . . . . . . viticella (Purple Virgin's Bower) .

Clethra alnifolia (Sweet Pepper Bush) .

Colutea

arborescens (Shrubby Bladder Senna)

Cornus

alternifolia (Alternate-Leaved Dogwood)

brachypoda (Japanese Dogwood) . circinata (Round-Leaved Cornel) . . florida (Flowering Dogwood) . . . mascula (Cornelian Cherry) ...

30300

25250

I 5 I 50

IO

I 00

$40 \quad 400$

I 5 I 50

25250

$15 \quad 150$

$20 \quad 200$

Io 60

20

IO 100

20200

20

200

$80 \quad 800$

$20 \quad 200$

I 5

5 oo

75

250

200

400

I 50

8 oo

400

I 50

I 50

200

I 50
Cornus (continued)-

paniculata (Panicled Cornel) sanguinea (Scarlet Dogwood) . . . ro 75 sericea (Silky Cornel) . . . . . . $20 \quad 200$ stolonifera (Osier Dogwood) ... . 10 I 00

Coronilla Emerus (Scorpion Senna). $50 \quad 500$

Cratægus

coccinea (Scarlet-Fruited Thorn) . . ro 80

Oxyacantha (Hawthorn) .... 10 ro 50

pyracantha (Evergreen 'Thorn) ... 10 75

pyrifolia ......... 20200

Cytisus

alpinus (Scotch Laburnum) .... 20 I 50

I 50

Laburnum (Laburnum) . . . . . ro

Daphne Mezereum (Mezereon) . . . 40

Diospyros

Lotus (European Persimmon) . . . Io I 00

Mexicana . . . . . . . . 25250

Virginiana (Wild Persimmon) . . Io 75

Dirca palustris (Leatherwood) . . . $25 \quad 250$

Dogwood. See Cornus.

Edgeworthia

papyrifera (Indian Paper Tree) . . $30 \quad 300$

Elæagnus

angustifolia (Oleaster) . . . . . $25 \quad 250$

pungens (Stinging Oleaster)... . $20 \quad 200$

Elm. See Ulmus.

Eriobotrya Japonica (Japan Medlar) . I 5 I 50

Eucalyptus

globulus (Tasmanian Blue Gum) . . $\quad \begin{array}{lll}35 & 350\end{array}$

All other sorts imported from Australia to order.

Euonymus

alata. From Japan ....... 25250

Americana ....... . . 20200

atropurpurea (Burning Bush) . . . $20 \quad 200$

Europæa (European Burning Bush) . Io I oo

Japonica. From Japan ..... 15 I 50

Eurya Japonica ........ 60600

Exochorda grandiflora ...... 40400

Fagus

sylvatica (European Beech) . . . . ro 50

Fraxinus purpurea (Purple Beech) . $25 \quad 250$

alba Americana (White American Ash) 10 40

excelsior (European Ash) . . . . ro 40

pendula (Weeping Ash) . . 10 50

Ornus (Flowering Ash).....

platycarpa (Carolina Water Ash) . . 30

Fremontia Californica (Califor. Shrub). I oo

Furze. See Ulex.

Gardenia florida (Cape Jessamine) . . 40

Garrya elliptica ....... 200

Gaultheria

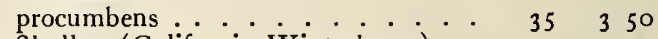

Shallon (California Winterberry). . $50 \quad 500$

Gaylussacia

dumosa (Dwarf Huckleberry) . . . $30 \quad 300$

frondosa (Blue Dangleberry) .... $30 \quad 300$

resinosa (Black Huckleberry). . . . 30 300

Genista

juncea (Rush-Leaved Broom) . . . 10 75

2 oo scoparia (Scotch Broom)..... Io 50

50 tinctoria (Green Broom) . . . . . 15 I 50

Ginkgo biloba. See Salisburia. 


\section{DECIDUOUS TREE AND SHRUB SEEDS, continued}

Gleditschia

horrida (Horrid Thorn)

Japonica. From Japan $\ldots$. . triacanthos (Honey Locust) . . . .

Gymnocladus

Canadensis (Kentucky Coffee Tree) . ro

Halesia

diptera . . . . . . . 25

tetraptera (Silver Bell) ..... 25

Hamamelis

Virginica (Witch-Hazel) . . . . 30

Japonica (Japan Witch-Hazel) . . 2

Hedera Helix (English, or Hardy Ivy).

Hibiscus Syriacus A. pl. (Double Rose of Sharon) ........

Idesia polycarpa. A new tree from Japan.

Ilex

Aquifolium (European Holly) . . . decidua (Deciduous Holly) . . . glabra (Inkberry) . . . . . opaca (American Holly) . . . . . .

Illicium religiosum .......

Indigofera tinctoria (Indigo Tree) . .

Itea Virginica (Virginian Willow) . . 3

Juglans

cordiformis. From Japan .... Io

cinerea (Butternut) . . . . . . per qt., I 5 c.; per bus., $\$ 3$. nigra (Black Walnut). . . . per qt., I 5 c.; per bus., $\$ 3$.

Sieboldii. From Japan ..... Io

Kalmia

angustifolia (American Laurel) . . 20

latifolia (Calico Bush) . . . . 40

Kœlreuteria

paniculata (Chinese Bladder Nut).

Kosteletzkia Virginica . . . . . . . 80

Laburnum. See Cytisus.

Larch. See Larix.

Larix

Europæa (European Larch) . . . . 20

leptolepis (Money Pine of Japan) . . 70

Laurus

Benzoin (Spicewood) ...... Io

nobilis (Sweet Bay)....... ro

Leiophyllum buxifolium (Sand Myrtle).

Ligustrum

Japonicum (Japan, or California Privet)

vulgare (Common Privet) .....

Linden. See Tilia.

Liquidambar styraciflua (Sweet Gum) .

Liriodendron tulipifera (Tulip Tree) .

Locust. See Gleditschia and Robinia.

Maclura aurantiaca (Osage Orange) .

Magnolia

acuminata (Cucumber Tree) . . . glauca (Sweet Bay) . . . . grandiflora (Large-Flowering Magnolia) ......... hypoleuca. From Japan . . . . . Kobus. From Japan ...... macrophylla (Great-Leaved Magnolia) tripetala (Umbrella Tree) . . . .

Maple. See Acer.

Menispermum Canadense (Moonseed).

Morus

alba (White Mulberry) ..... $20 \quad 200$

nigra (Black Mulberry) . . 2020

I 50

75

4 oo

I 50

3 oo

60

60

75
Morus (continued) - Per oz. Per lb. rubra ............ \$o $20 \$ 200$ tatarica (Russian Mulberry).... $40 \quad 400$

Mulberry. See Morus.

Myrica

Californica (California Wax Myrtle) . $\quad 35 \quad 350$ cerifera (Candleberry Myrtle) ... I $_{5}$ I 25 pumila.......... 60600

Myrtus communis (Common Myrtle). $20 \quad 200$

Negundo aceroides (Box Elder) . . . r 10

Neillia opulifolia ........ I 25

Nelumbium

speciosum (Chinese Water Lily) . . $\quad \begin{array}{lll}25 & 2 & 50\end{array}$

Nuttallia cerasiformis (Nuttall's S'rub). $50 \quad 500$

Nyssa multiflora (Sour Gum Tree) . . Io 50

Oaks. See Quercus.

Oreodaphne Californica (Cal. Laurel). $\quad 20 \quad$ I 75

I oo Osage Orange. See Maclura.

Ostrya Virginica ......... 15 I 25

Paliurus aculeata (Christ's Thorn) . . I0 40

Paper Mulberry. See Broussonetia.

Pardanthus Chinensis . . . . . 40400

Parkinsonia aculeata ...... 25250

Paulownia imperialis (Paulownia) . . $\begin{array}{llll} & \text { I } 5 & 25\end{array}$

Phytolacca decandra ...... 20 200

Platanus occidentalis (Buttonball, or Plane Tree) ....... r.

Plum. See Prunus.

Podocarpus macrophyllus. From Japan. $80 \quad 8$ oo

Populus

alba (Abele Tree) . . . . . $20 \quad 200$

nigra ............... 15 I 50

tremula ........... I 5 I 50

Prunus

Americana (Wild Plum) .... . I 5 I ००

Lusitanica (Portugal Laurel) . . . . Io I oo

maritima (Beech Plum) ...... I 5 I 50

mollis (Oregon Wild Cherry) . . . $50 \quad 5$ oo

Pennsylvanica (Wild Red Cherry) . $\quad 20 \quad 225$

serotina (Wild Black Cherry) .. . Io 75

Virginica (Choke Cherry) .... I 5 I 25

Ptelea trifoliata (Hop Tree).... 20 I 50

Pyrus

arbutifolia (Chokeberry) . . . . . $25 \quad 250$

Aucuparia (European Mountain Ash). Io 50 rivularis (Oregon Crab Tree) .. $50 \quad 500$

Quercus-Oaks. All the leading sorts in season, from $\$ 4$ per bus. to . . 25

Rhamnus

Alaternus (Barren Privet) ..... Io I 00

Californicus ........ $30 \quad 300$

Carolinus (Alder Buckthorn) . . . . I5 I 00

catharticus (Buckthorn) : .... r ro I oo

Purshianus. From Washington . . 30300

Rhododendron

Californicum (California Rose Bay). I 25

maximum (Great Laurel) .... . 40

occidentale . . . . . . . 300

Rhus

copallina (Dwarf Sumach) . . . . Io 75

cotinus (Smoke Tree) . . . . . . $25 \quad 250$

glabra (Smooth Sumach) ..... Io I oo

succedanea (Tallow Sumach) .... $25 \quad 250$

toxicodendron .... 20200

typhina (Staghorn Sumach) ... I 15 I 25

venenata (Poison Sumach).... I 5 I 50 


\section{DECIDUOUS TREE AND SHRUB SEEDS, continued}

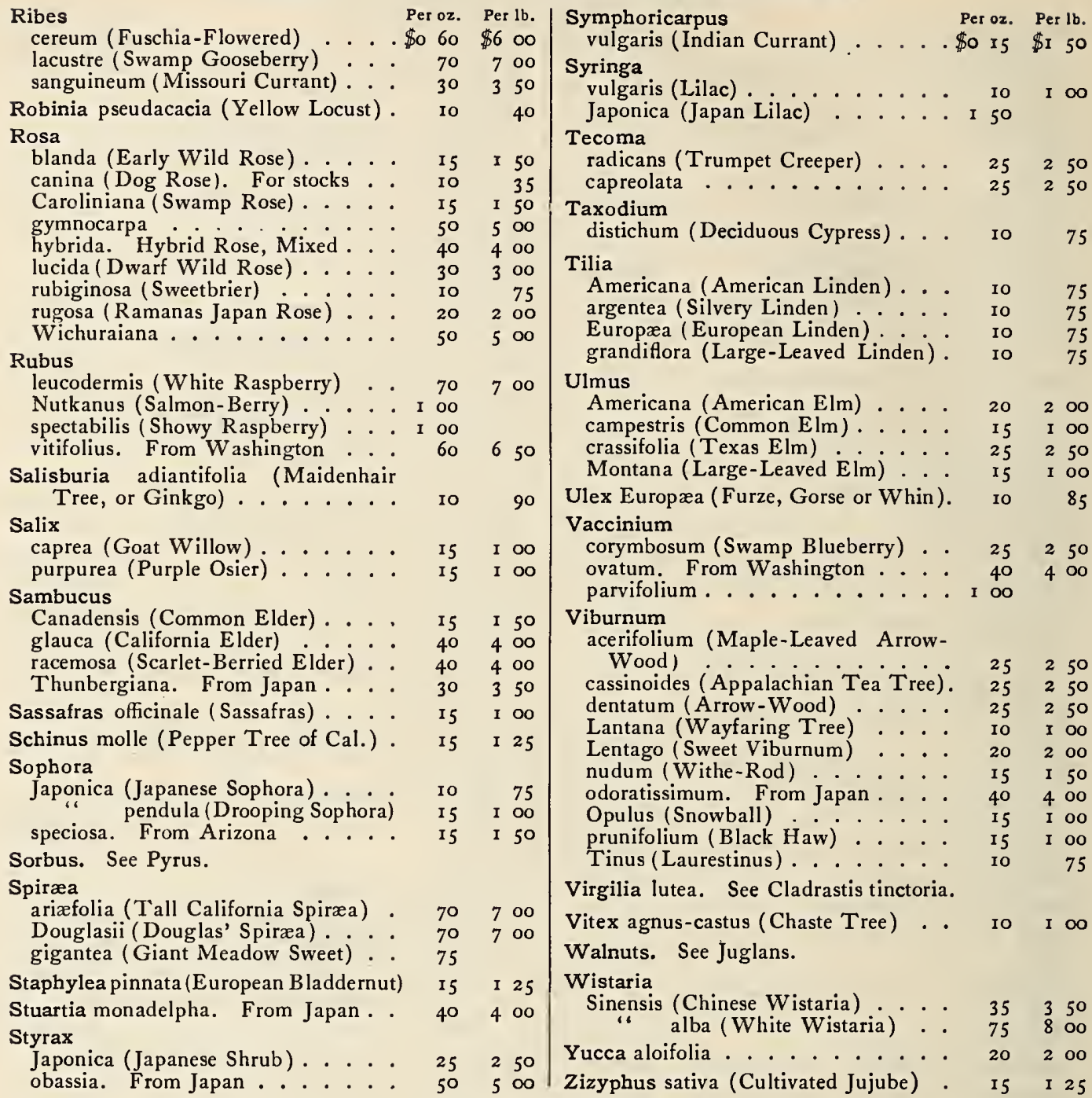

\section{FRUIT SEEDS}

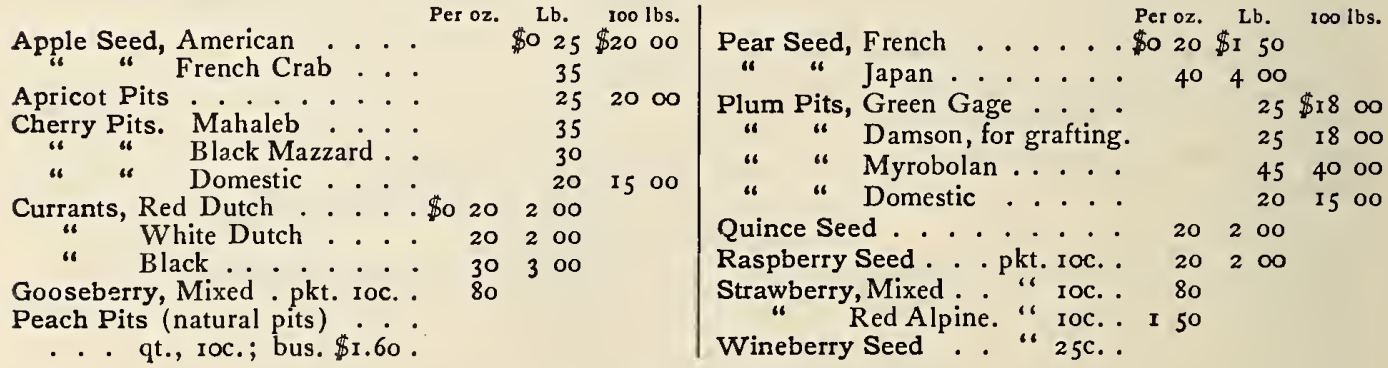

\section{NATIVE GRAPE SEEDS}

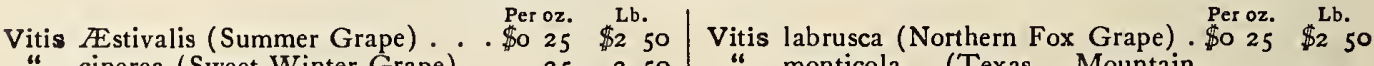
" cinerea (Sweet Winter Grape) . 25 2 250 " monticola (Texas Mountain

“ Cognetix (from Japan) . . . . 50 o 6 oo Grape). . . . . . . . $252^{2} 50$

"cordifolia (Frost Grape) .... 25250 " 25 rotundifolia ......... 25250 


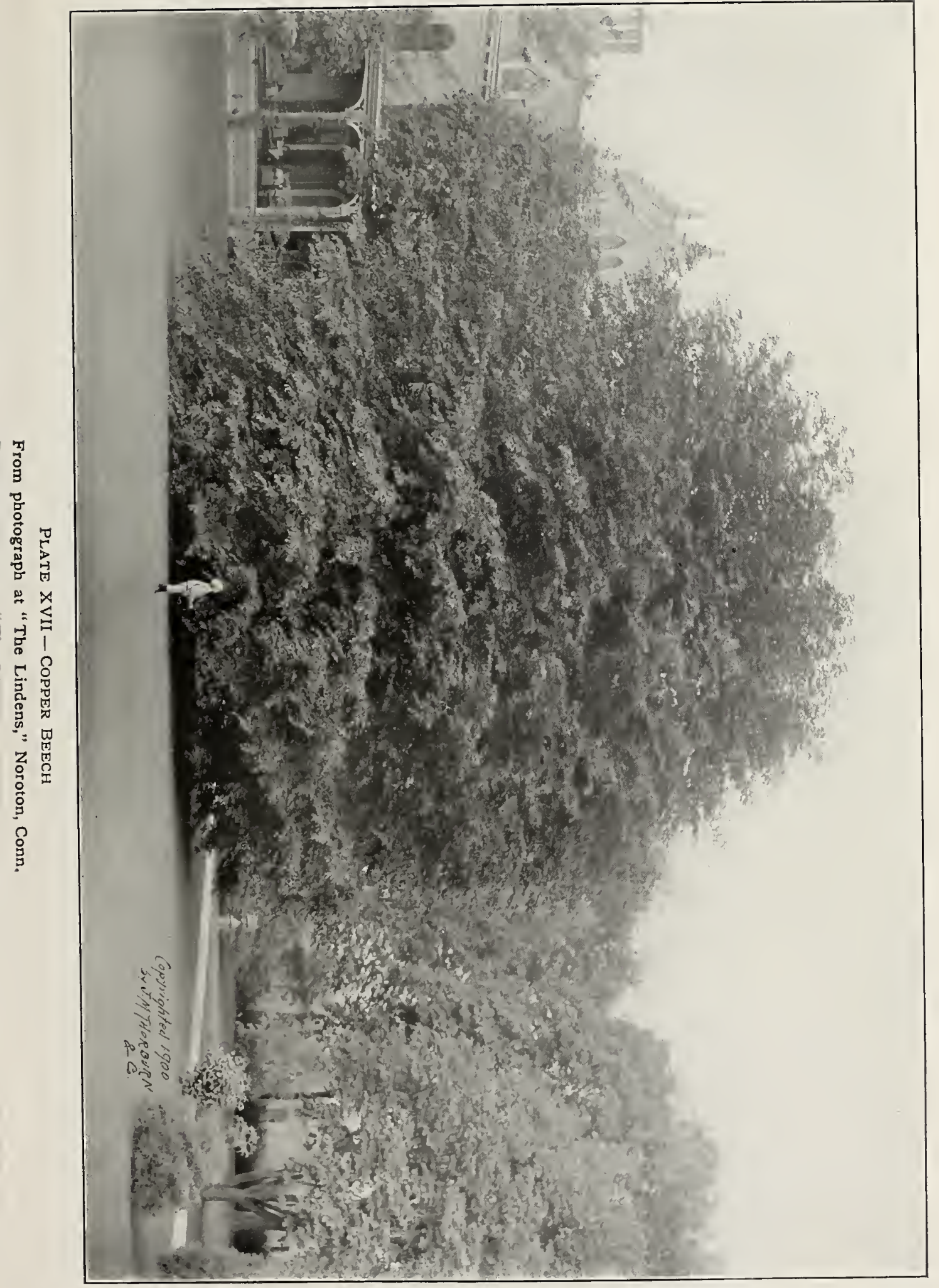




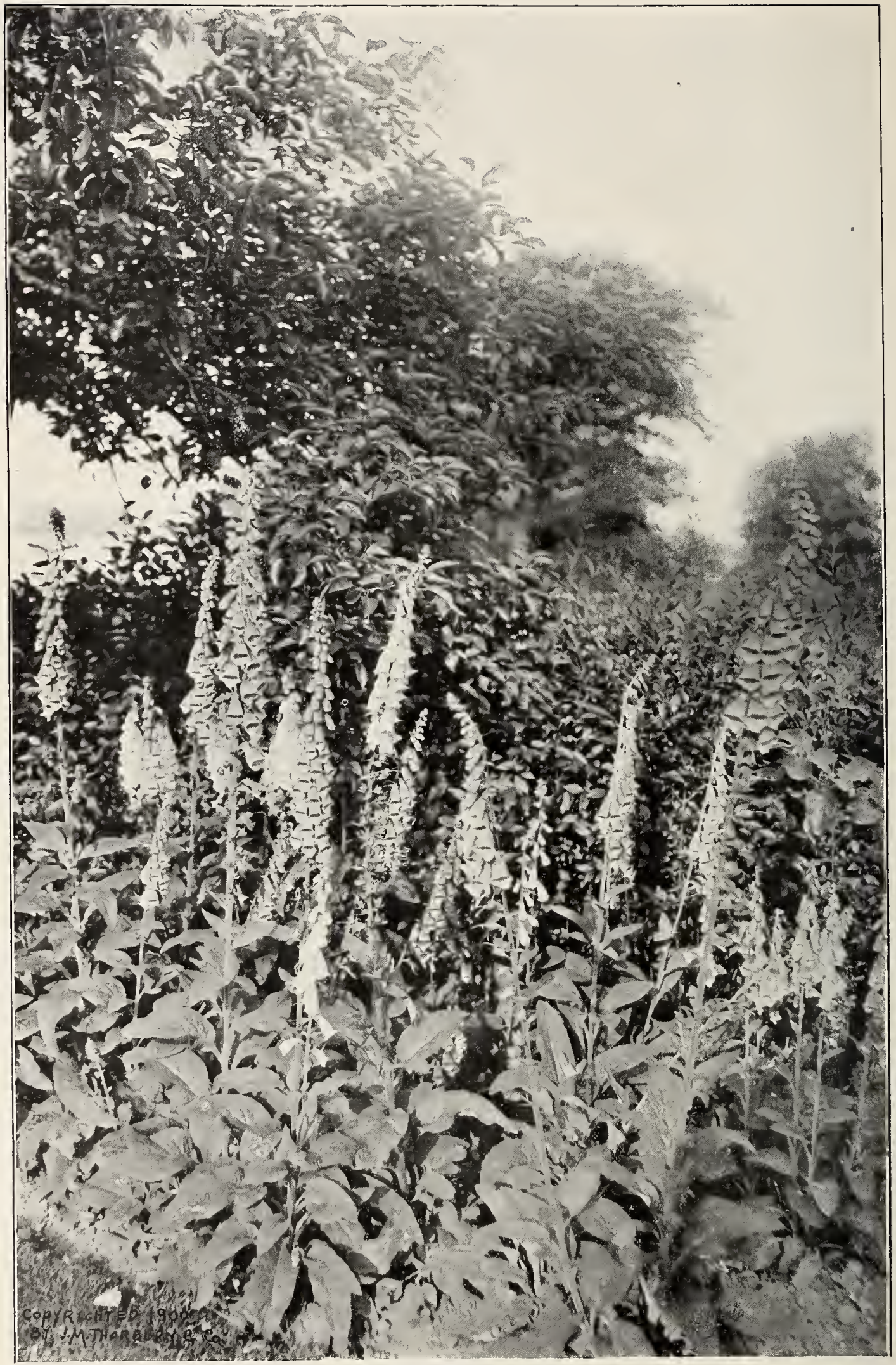

Plate XVIII - Foxgloves

(From a photograph made at our Trial Grounds) 


\section{FLOWER SEEDS}

Practical Directions for Culture, Treatment, Etc.

HARDY ANNUALS (hA).--Sow in April or May, according to the latitude, in shallow boxes or pots placed in a warm window, a hotbed or, if possible, in a greenhouse. A second sowing ought to be made from two to four weeks after for a succession, as well as to provide against failure the first time. For sowing seeds in there is nothing better than shallow boxes from 2 to 3 inches deep and of any convenient size. The most suitable soil in which to sow seeds of all the smaller kinds is a very fine, rich, sandy loam. The soil from old hotbeds is excellent, or sods from an old pasture piled up and allowed to rot for two or three years and then mixed with a little old stable-manure and sand. After the seeds are up care must be taken to give them plenty of air and moisture, and yet not too much water or they will "damp off." When the young plants are well out of the seed-leaf they must be transplanted to new boxes. If pots 2 inches or more in diameter can be had, set out from three to a dozen or more of the young seedlings along the edges of the pot, so that as soon as the ground is warm enough they may be easily turned out and planted singly, as by that time they will have made good roots. When the pots cannot be had, boxes, tin cans, etc., may be substituted.

A common mistake in sowing flower, as well as other seeds, is covering too deep. As a general rule, cover only to the depth of the thickness of the seeds, or with medium-sized seeds, like Balsams, Zinnias, etc., half an inch or so is none too much. Such fine seeds as Portulacas need only to be pressed into the soil with a piece of board or the palm of the hand. Always press the earth down firmly after sowing all flower seeds, else there is danger of their drying up before the roots can get firm hold of the soil. Seeds of the hardier Annuals may be sown where they are to grow; but as a rule it is preferable to transplant, as the plants are generally stronger and stand the drought better. During very dry weather, and when the seedlings are first set out, they should be watered frequently. Provide some support for all such Annuals as require it.

The weeds should be kept down and the ground loosened often, so that the plants will receive the full benefit of the rains and dews, which they will not if the ground is allowed to become hard and baked.

Seeds of Biennials and some Hardy Annuals may be sown in September in boxes and placed in coldframes. They will make strong plants by spring and flower early. Do not put on the sashes until heavy rains and frosts begin, and then always remove during the day whenever the temperature is above freezing in winter.

HARDY BIENNIALS ( $\mathrm{hB}$ ) and PERENNIALS (hP).-These require the same treatment as the Hardy Annuals. In addition to the above, both Hardy Biennials and Perennials may be sown in the open border in September; for if not sown until spring, the seeds of many Perennials require two years before they germinate. In this case it is a good plan, at the commencement of frost, to cover them lightly with straw, leaves or any dry litter, in order to afford some protection from the extreme severity of the winter. As soon as the frost is out in the spring remove the covering and loosen the surface around the plants which, when large enough, may be transplanted to the flower garden where they are to remain.

HALF-HARDY ANNUALS (hhA). - These may be sown in shallow boxes, pots or a hotbed, as directed for Hardy Annuals. They may be sown thus at any time after the middle of April, as the hotbed will be sufficient protection; but it is best to cover the glass with a mat or straw at night until danger of frost is past. In the day give all the air possible. After the end of May sow in the border, like Hardy Annuals.

HALF-HARDY BIENNIALS (hhB) and HALF-HARDY PERENNIALS (hhP) require the same treatment. Though plants and their bloom are greatly forwarded by sowing the seeds early in boxes under cover, it may be stated that nearly all kinds of hardy and half-hardy flower seeds may be sown in the open border in a warm and sunny spot, as soon as the soil has become dry and warm; so that those who have no glass frames or greenhouses need not be without flowers. They can have them, but it will be later.

TENDER ANNUALS, BIENNIALS and PERENNIALS. - The best method to obtain an early bloom of the Tender Annuals ( $t A)$, and to insure strength to the plants, is to sow the seeds in boxes or pots in March, placing them in a warm greenhouse, or plunging in a moderate hotbed, carefully protecting them from the cold, shading from the midday sun, and watering with a fine rose. The seed should be sown in very light, sandy compost, and the pots well drained by placing broken pots or bits of sod in the bottom. The finer seeds must not be covered more than an eighth of an inch deep, and the soil pressed down closely over them. Water frequently, particularly if the house or hotbed is very warm. As soon as the plants are out of the seed-leaf, transplant into shallow boxes or small pots, and when they have acquired sufficient strength transplant into the flower beds; not, however, before the middle of May.

GREENHOUSE SEEDS ( $\mathrm{g}$ ) should be sown as directed for Tender Annuals, in pans, pots or shallow boxes, and be kept in the house, carefully watched, slightly watered occasionally, and sheltered from the hot sun till strong enough to transplant. Most varieties may be sown at any season of the year.

The smaller seeds of Greenhouse Plants are sometimes difficult to germinate unless great care be taken in the mode of sowing. Hence the supposition is produced that the seed itself is not good, whereas the fault is not in the seed, but in the treatment. Fine seeds of this description should be sown in leaf-mould or peat, with some fine sand added to it; press firmly down in the seed-pan or pot, and make perfectly level at the top, so that the mould may not afterward sink materially with watering. Sow the seed very thin, and cover very lightly with a little compost, or with silver sand. Success is more certain if a pane of glass is placed over the pan or box till the plants have appeared, when it should be removed. By this method the difficulty of starting fine seeds will be removed. As soon as the young plants have two leaves, they should be transplanted into similar compost in another pan or box. To do this do not pull them out of the seed-pan, but break up the 
soil by running a stick or trowel under it, when the plants can be taken out with good roots. After transplanting they should be kept in a shady part of the greenhouse for a few days, and watered very sparingly, until they are somewhat established in the new soil, when they may be removed to the light.

There are many minute plants from the finer seeds killed by drenching with water while very young. One way to avoid this is to give it to them by dipping a clothes-brush in water, shaking off the greater part from the brush, and then (holding the brush over the seed-pan) drawing the hand over the bristles several times; this will cause the water to be thrown on the young plants almost like dew. Some of the vaporizers and atomizers (as used for perfumes) now in use are admirably adapted for watering tender young plants. In the first stage of their existence plants require moisture in a minute quantity, often repeated, and not in such large quantities as to saturate the soil in which they are growing.

Primula Sinensis.- Sow the seed in drills in a light, rich soil, in shallow boxes, at any time from the middle of March to the middle of May; the earliest-sown seed will naturally produce the earliest bloom. Cover the seeds about an eighth of an inch, and press the soil on them with a board or the bottom of a pot. Water moderately, avoid forcing the seed, and keep the young plants away from drip. The boxes may be placed in the greenhouse or out of doors in a frame. As soon as the plants are well out of the seed-leaf, transplant them singly into 2 - or $21 / 2$-inch pots, using a light, rich soil. The object now is to make good, stocky plants, and they must therefore be repotted as often as the pots become tolerably filled with roots, until they are in 5- or 6 -inch pots, when they may be allowed to flower. Previous to this any flower stalks that appear must be pinched out. In a suitable place the plants will do better out of doors during summer. The plants will bloom continuously during the winter in either the greenhouse or a well-lighted room not too warm; they should not be moved about often.

Cineraria.-This is a rather difficult plant to grow if its requirements are not understood. The mistake generally made is in growing it in a warmhouse instead of a cool one. The seed should be started in the greenhouse. For winter blooming, sow the seed in April and May, in shallow boxes, in fine soil; drop the seed in shallow drills, cover, and press the earth rather firmly with a piece of board or the bottom of a pot. Set the box where it will get the morning sun, but be free from drip; water moderately and carefully. The treatment of the seedlings should be similar to that given to the Primula Sinensis. As soon as the plants are out of the seedleaf transplant singly into small pots, in a rich soil with some vegetable mould in it. Repot as often as the pots become moderately filled with roots, or sufficiently often to prevent the roots from becoming pot-bound, and so avoid checking the growth. . If specimen plants are wanted the repotting should be continued until the plants are in pots from 8 to ro inches in diameter. The last two pottings should be liberal ones, and drainage well provided for as the plants will need copious watering. When the fower-stalks appear manure water may be used once or twice a week. Aphis and red spider are the chief enemies to be guarded against; this is best done by frequent syringings or sprinklings overhead. The plants will do best during the summer out of doors, in some place where they will not get too much sun, and be free from the drip of trees. In the fail the plants should be placed in a cool greenhouse, where the temperature can be kept low and the air moist. The plants should be placed on a table by themselves, and the pots always kept far enough apart to prevent the leaves in one pot from touching those in the next.

Calceolaria.-The seeds are very small and should be sown on the surface of shallow boxes filled with a light, sandy soil which has been sifted. Sow moderately thick in rows on the surface, and cover very lightly with sifted sphagnum moss, cocoanut waste or very light soil. Press the soil firmly on the seed. The watering should be done carefully; an atomizer or brush is best. To retain the moisture the box may be covered with panes of glass which must be removed, however, as soon as the plants appear. The box should have plenty of light but not much sun. As soon as the piants can be handled, transplant singly into pots 2 to $2 \frac{1}{2}$ inches in diameter. The soil should be light and rich, and vegetable mould is an excellent addition. Repot as often as the pots are fairly filled with roots, and continue the repotting, if fine flowers are wanted, till the plants are in 8 -inch pots. If the plants become root-bound they are apt to run prematurely into fower. Water regularly and abundantly to prevent drooping. As the pots increase in size, drainage must be supplied to carry off the surplus water. Place in a cool greenhouse in the winter, as directed for Cinerarias, and keep the pots apart to prevent the leaves from touching. An occasional smoking with tobacco will keep down the green fly.

Pansy.-For spring blooming the seed should be sown in August, September and October, in a coldframe with a southern aspect. Plenty of air and light is essential. During mild weather the sashes should be removed; when it is frosty, coverings are preferable to artificial heat. If wanted for winter bloom, sow in July and transplant in beds or benches near the glass in the greenhouse, in a low and even temperature.

Geraniums.-The Scarlet or Horseshoe Geranium (or, more properly, Pelargonium), now so extensively used for bedding, may be easily grown from seed at any season of the year. If during the summer, better out of doors than anywhere else; but in a greenhouse or sitting-room during the winter. Sow the seeds in pots or shallow boxes in any common soil; cover about an eighth of an inch, and press the soil on the seed. Transplant as soon as out of the seed-leaf, into small pots in a soil only moderately rich; or, if the seeds were started out of doors, the plants may be put in the border. Seed sown indoors in the fall or early winter, and the plants grown in the greenhouse, will show flowers in June or July, while plants from those sown in March or later will not come into flower till August and September, and some even later.

Petunias.-Fill shallow boxes with fine, light soil, say an even mixture of leaf-mould and sand, and wet thoroughly by pouring on boiling water, which kills insects and heats the soil. When the soil has cooled sufficiently, but is still warm, sow the seeds very thinly in the boxes, so that the plants may be I inch apart; cover the seeds very slightly with sifted sand, and place slate or glass on top of the boxes. If the white root-points of germination appear before the leaves, sift on more sand, replace slate, and watch closely. When the small leaves appear remove slate and give plenty of light, to produce stocky plants. The soil may now need water, which should be applied very gently. Later the larger plants may be transplanted into other boxes or pots. As the weakest plants frequently give the finest blossoms, every plant should be preserved until the blossoms appear. 


\title{
SELECTED LIST OF FLOWER SEEDS
}

\author{
Our complete list of Flower Seeds begins on page 79
}

\section{ASTER \\ (Half-hardy Annual)}

This great group is so prominent among our finest autumn annuals tnat special effort has been given to its improvement, with most gratifying results. Its splendid double flowers are now displayed in a perfect luxury of colors and their variety of form is surorising. They need cool weather, with a touch of frost in the air, to bring out their colors, and by hurrying them into bloom too soon we lose much of their beauty.

The Aster's vigor and ease of culture are other factors of its popularity. Plants from seed sown in the open ground in May bloom finely in September and October, when the flowers are seen at their best. For July and August flowers, sow in March or April, in coldframe, spent hotbed, or pots or boxes in the house. Cover the seeds about an inch deep with rich, light soil, and when the plants have three or four leaves transplant about 18 inches apart each way into well-prepared beds. Manures too fresh or used in too large quantities sometimes induce disease in Asters. When used they should be thoroughly well decayed and mixed with the soil. Small quantities of unslaked lime, or of fresh wood ashes, stirred into the surface of the Aster beds, form good tonics for the plants and keep disease and insects from the roots. When given plenty of water and rich, fine soil, Asters can also be grown into beautiful pot plants.

DWARF CHRYSANTHEMUM - FLOWERED.

The plants grow only about ro or 12 inches high, but the flowers are large and double like chrysanthemums.

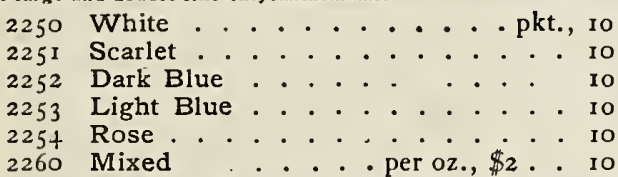

TRUFFAUT'S PAONY PERFECTION. A hand-

somc Aster that grows stifly erect and about $r 8$ inches tall. The class is remarkable for the brilliant colors of its great incurved flowers.

2266 Snow-White ........ pkt., Io

2267 Pale Yellow . . . . . . . . . . Io

2268 Apple Blossom . . . . . . . . 10

2269 Crimson ............ . 10

2270 Rose .............. . 10

227 I Scarlet . . . . . . . . . . IO

2272 Rose and White Striped . . . . . Io

2273 Light Blue . . . . . . . . . . I0

2279 Mixed . . . . per oz., $\$ 2$. I

VICTORIA. Plants of this magnificent race bear from 10 to 20 fine, beautifully reflexed flowers in an elegant pyramid about 18 inches high. The best sort for pot-culture.

2287 White . . . . . . . . pkt., ro

2289 Rose ............... I0

2290 Apple Blossom . . . . . . . . . 10

229x Light Blue ............. . xo

2292 Dark Scarlet . . . . . . . . Io

2294 Mixed . . . . . per oz., $\$ 2$. . Io

COMET. This, the most artistic-flowered of all the Asters, has become a fixed type in which spccialists arc continually developing some new strain. The outer petals are wavily reflexed, centering in a whorl of shorter curled and twisted oncs, forming flowers of extraordinary size and beauty.

2298 Rose... . . . . . . . . pkt, , ro

2299 Carmine ........... IO

2300 Light Blue . . . . . . . . . 10

23ox Dark Blue ............ 10

2302 Snow-White .......... I0

2303 Peach Blossom .......... Io

2304 Rose and Wbite ......... 10

2306 Mixed ...... per oz., \$2 . . 10

2308 Giant White ............ 10

23 10 " Rose............ . 10

23 II " Azure-Blue ......... Io
COMET, continued

2312 Giant Crimson... . . . . . pkt., ro 23 I6 " Mixed . . . per oz. $\$ 2$. . 10

IMBRICATED POMPON. A well-known, fine old type. Height, 18 inches.

23 I9 White . . . . . . . . pkt., Io

2320 Violet .............. 10

2322 Rose ............... Io

2324 Mixed . . . . per oz., $\$ 1.50$. Io

QUEEN OF THE MARKET. The best early

Aster, usually in full bloom two weeks before most other sorts begin to blossom. Of graceful, spreading habit. Height $1^{1 / 2} \mathrm{feet}$ 2328 White . . . . . . . . pkt., ro 2330 Crimson ............. 10

2332 Rose .. . . . . . . . . . . 10

2333 Dark Blue . . . . . . . . . . Io

2334 Mixed ..... per oz.,\$1.50.. Io

JAPANESE TASSEL. An unusually distinct and picturesque variety. The flowers are grand in size, and their long petals are so curiously waved and curled as to resemble a Japanesc chrysanthemum.

2338 Mixed . . . . . . . . pkt., ro

BALL, or JEWEL. Flowers of this strain are longstemmed, quite round, and therefore especially desirable for cutting or bunching. Dwarf and free-flowering.

2348 White ........... . pkt., Io

2349 Apple Blossom . . . . . . . . Io

2350 Crimson ........... 10

235 I Dark Blue . . . . . . . . . . Io

2352 Mixed .............. I0

LADY ASTER. An exquisite Aster, distinguished for its profuse bloom, graceful habit and peculiar, straight-cdged leaves. Each plant produces 40 or more buds.

2356 Pure White (Lady in White) ; pkt., Io $235^{8}$ Rose (White, passing to Rose) . . . Io

TRIUMPH. The rich, heavy flowers are elegantly incurved, and have a wonderful depth and brilliancy of color. Height, to to 12 inches.

2362 Scarlet . . . . . . . . . pkt., Io

BRANCHING. This vigorous type forms broad, handsome bushes, covercd with large, long-stemmed and longpetaled flowers that are graceful and feathery in effect.

${ }_{2365}$ Pink ............ pkt., ro

2366 White ............. 10

2367 Crimson . . . . . . . . . Io

2368 Mixed . . . per oz.,\$r. 
ASTER, continued

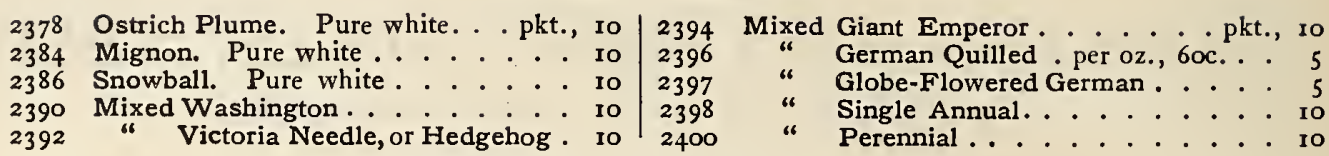

\section{COLLECTIONS OF CHOICE ASTERS}

These collections are put up by the famous German Aster-growers, and they contain only seed saved from the very finest plants. In each collection the colors are separate, the collection of 24 Victoria Prize, for instance, containing 24 separate and distinct colors of that class.

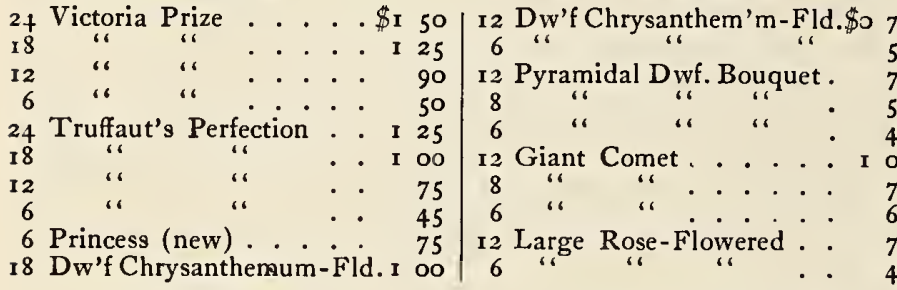

\section{AGERATUM}

For strengthening the garden's color forces in blue, no annual is so good as the Ageratum, which shows some exquisite and unusual shades of this color. Though ordinarily used in bedding and borders in contrast with such plants as geraniums, perillas, amarantus, etc., the rose, white and blue sorts are all exceedingly attractive when mingled with alyssum, candytuft and similar plants. They grow so well almost anywhere that many combinations are possible for them. The plants are neat, bushy and erect, with a continual profuse clustering of pretty brush-like flowers throughout the season. Sow under glass early in the season or, later; outdoors in a mellow seed-bed. Seeds sown in August will produce good plants for winter flowering.:

2420 conspicuum. This and the next are tender perennials; sow early; flowers white; I ft. . pkt., 5

2422 Lasseauxi. Rose-colored clusters; $\mathbf{f t .} \ldots \ldots \ldots \ldots$

2424 Mexicanum. Parent stock of the half-hardy annuals below; flowers blue; $11 / 2 \mathrm{ft}$. . per oz., 4oc. . 5

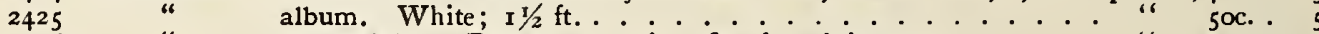

2426 Dwarf Blue. Extra neat; 9 in.; fine for edgings ....... " " 6oc. . 5

2427 " Dwarf White. Pretty for contrast; 9 in.; fine for edging .. . “ 600. . 5

$2428 \quad$ Little Dorrit. Six inches high, I foot across; flowers azure-blue . " $75 \mathrm{c}$. . 10

2430 " Swanley Blue. A fine new large-flowered sort; I ft. ..... “ $75 \mathrm{c}$. . 10

2434 " Mixed. All varieties .................. " 40c. . 5

\section{ALYSSUM}

For borders, edgings, baskets, pots, rockwork and for cutting, we recommend a liberal use of this dainty little flower. In borders sow thickly so as to form masses, and quite early in spring or even the previous autumn. For winter bloom sow late in August, and thin the seedlings to about a dozen for a good-sized basket. Cut back after the first flowers fade, and others will come.

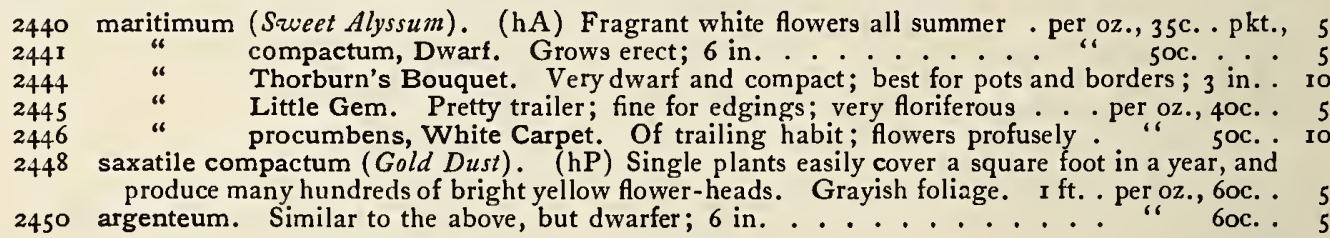

\section{AQUILEGIA (Columbine)}

\section{(Hardy Perennials)}

A most desirable border plant in all its many varieties. It forms large clumps, blooms early, long and abundantly, is quite hardy, useful for cutting and elegant in habit. Sow seed in the open ground in spring, preferably where the plants are to grow, and thin to about a foot apart. They may also be sown in the fall for flowering the following season. They thrive well with ordinary garden culture, but such rare sorts as $A$. ccerulea and $A$. chrysantha do best in partially shaded, well-drained nooks. Few hardy perennials are so easily grown from seed.

2456 caryophylloides. Oddly striped with red and white; $1 / 2 \mathrm{ft} \ldots \ldots \ldots$. . . . pkt., 25

$245^{8}$ chrysantha. Flowers large, long-spurred, canary-colored; $3 \mathrm{ft} . \ldots \ldots \ldots \ldots$

2460 ccerulea (Rocky Mountain Blue Columbine). Finest of all.' Sepals deep blue, petals white. $3 \mathrm{ft}$. . 25 


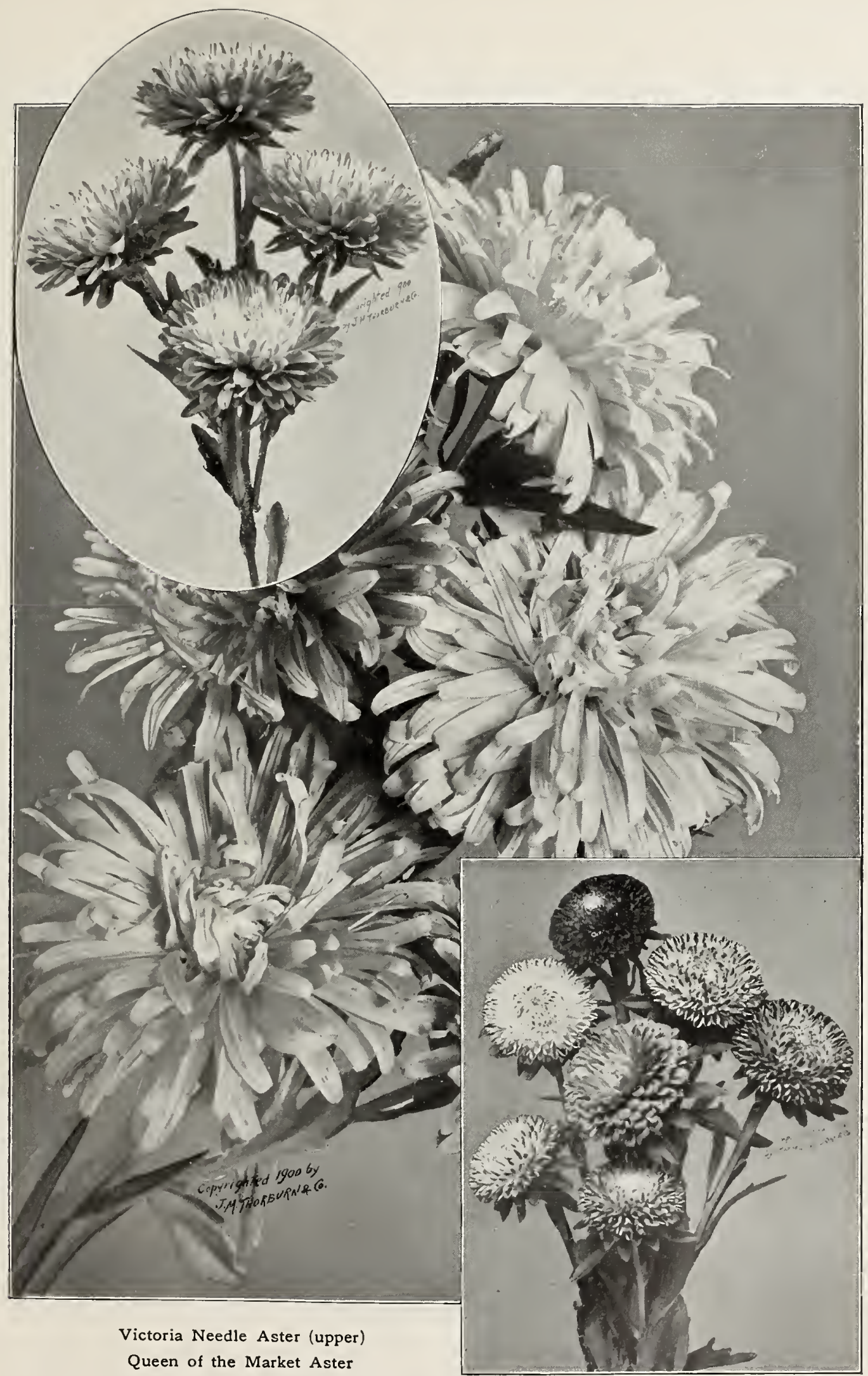

Queen of the Market Aster

Imbricated Pompon Aster 


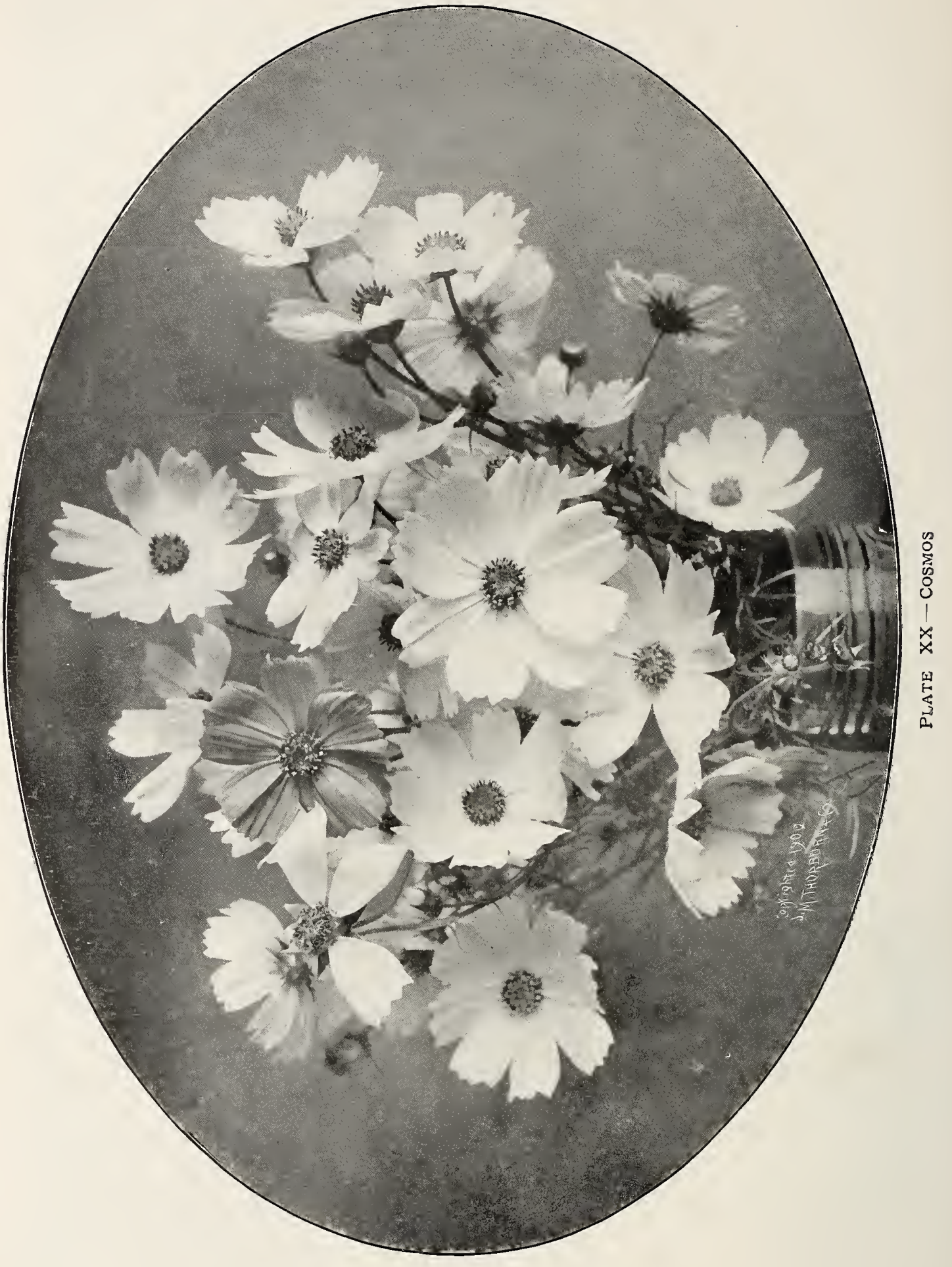


AQUILEGIA, continued

2464 flabellata nana alba. White flowers; very early; I ft. . . . . . . . . . . . . . . pkt., ro

2466 Hybrids and Species. A superb mixture, including all the finest sorts-Skinneri, chrys-

antha, Canadensis, etc. . . . . . . . . . . . . . . . . . . . 10

2468 truncata. Dwarf, scarlet and yellow; i ft. . . . . . . . . . . . . . . . . . Io

2470 Skinneri (Mexican Columbine). Very handsome and quite distinct; spurs and sepals long,

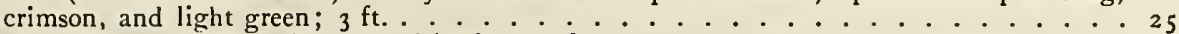

2472 vulgaris, Double White. Showy and lasting; $2 \mathrm{ft} . \ldots . . . . . . . . . . . . . . .55$

2473 " " Mixed. Best colors . . . . . . . . . . per oz., 3oc. . . 5

2474 " Single Mixed. Many good sorts . . . . . . . . . . . . . . . ." " 30c. . . 5

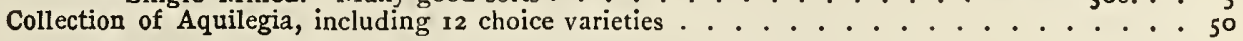

\section{BALSAM}

(Impatiens Balsamina. hhA)

A native of India, the garden Balsam loves hot sun, rich soil and plenty of water. The young plants are quick, sure growers and from seed sown in the open ground in May soon form handsome bushes thickly massed with large, rose-like flowers. Transplanting two or three times has a tendency to dwarf the plants into better shape and to make the flowers more double. Balsams are not often given room for perfect development; they will easily cover 12 to 18 inches of space each way. For the finest flowers choice seed is more than usually essential, for cultivation and selection have wrought wonders with this plant. We offer only the finest double sorts.

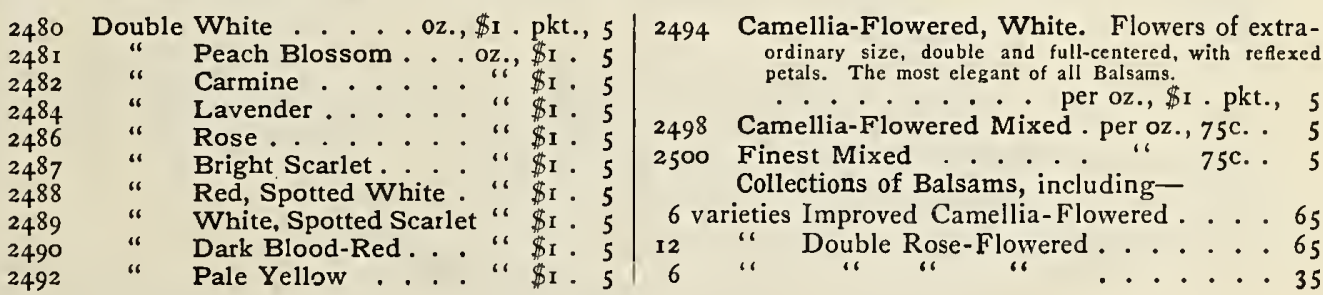

\section{CALENDULA}

Hardy annuals about a foot high. The seed may be sown in the open ground quite early in spring, and the plants will be in bloom early in summer, and continue until late in the autumn. The flowers exhibit every shade of yellow from ivory to deep orange, are produced in great profusion, and are strongly effective in beds, borders or backgrounds. The dried flowers are sometimes used for flavoring soups and stews. The first eight varieties are all very double.

\begin{tabular}{|c|c|c|c|c|}
\hline $252 I$ & & Very large-flowered; new strain . . . . & oz., & 3ос. \\
\hline & “ & " sulphurea. Light yellow, large-flowered, extra ch & & 3oc. . \\
\hline 23 & “ & 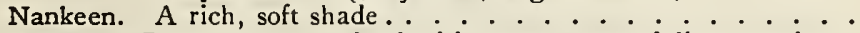 & “" & $25 \mathrm{c}$. \\
\hline 24 & “ & Meteor. Creamy center, edged with orange; especially attractive . & “ & 25 c. . \\
\hline 26 & “ & Prince of Orange. Glittering orange and yellow; very vivid-flowered & “ & $25 \mathrm{c}$. \\
\hline & " & La Reine. A choice pure yellow variety of great beauty .... & “ & 40c. . \\
\hline & “ & ranunculoides (Garden Marigold). Handsome double flowers & " & 3oc. . \\
\hline 534 & suffruticos & sa. Rich yellow white $\cdot \dot{*} \cdot \cdot \cdot$ & “ & 40c. . \\
\hline 538 & Pongei fl. & 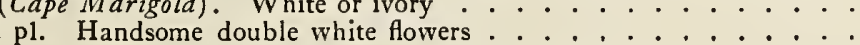 & “ & $\begin{array}{l}25 \mathrm{c} . \\
4 \mathrm{OC} .\end{array}$ \\
\hline
\end{tabular}

\section{CALLIOPSIS (Coreopsis)}

This is another of the garden's great forces in yellow, strengthened with rich red-maroons and browns. Sow in the open ground in spring, and in thinning or transplanting give the plants plenty of room to spread. Their tall, slender habit makes neat staking and tying necessary. All are fine for cutting, especially $C$. grandiflora and $C$. lanceolata.

2550 marmorata (hA). Maroon and gold; $1 \mathrm{t} / 2 \mathrm{ft} . \ldots . . . . . .$. per oz., 30c. . . pkt., 5

2552 cardaminifolia $(\mathrm{hA})$. Red and yellow; $1 \mathrm{l} / 2 \mathrm{ft} \ldots \ldots \ldots$

2553 Drummondii (Golden Wave) (hA). Gold and brown; ift. . . . . . per oz., $300_{.} .{ }_{5}$

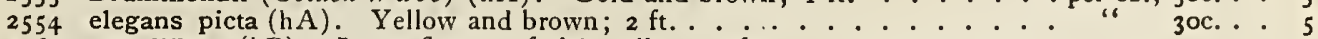

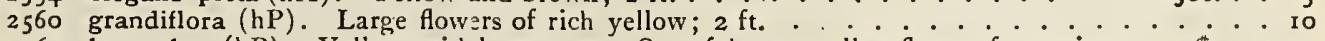

2562 lanceolata $(\mathrm{hP})$. Yellow, with brown eye. One of the best yellow flowers for cutting. oz., \$I . . Io

$25^{6} 3$ California Sunbeams (hP). Flowers very large, in a great variety of beautiful forms and various shades of yellow and brown; $\mathrm{Ift} . . \ldots$. . . . . . . . . . . ro

2564 trichosperma (hB). Hardy biennial; flowers yellow; $2 \mathrm{ft} . \ldots$. . . per oz., 50c. . 5

2566 Mixed ............................... 5 


\title{
CAMPANULA
}

\author{
(Canterbury Bell)
}

These fine old plants are rich in color, profuse in bloom, and of easy culture. For outdoor effects, when planted in quantity, they are glorious, and finest full-blown specimens of such varieties as $C$. calycanthema can be transplanted to pots for house decoration by soaking the soil about them with water and lifting with a ball of earth. Sow seed of biennials outdoors early in July and thin or transplant to temporary quarters until October. Transplant, then, 6 or 8 inches apart, in a coldframe, where they will make large plants by spring and are as easily cared for as pansies. The old practice of covering Canterbury Bells with leaves through winter is not satisfactory. Transplant in spring, 18 to 20 inches apart in beds where they are to bloom. In June and July they flower most profusely, and are in fine form a long time. They also make beautiful pot plants for Easter. If sown early in good soil the hardy perennials will bloom early the next year. All varieties like a rich, sandy soil, with good drainage.

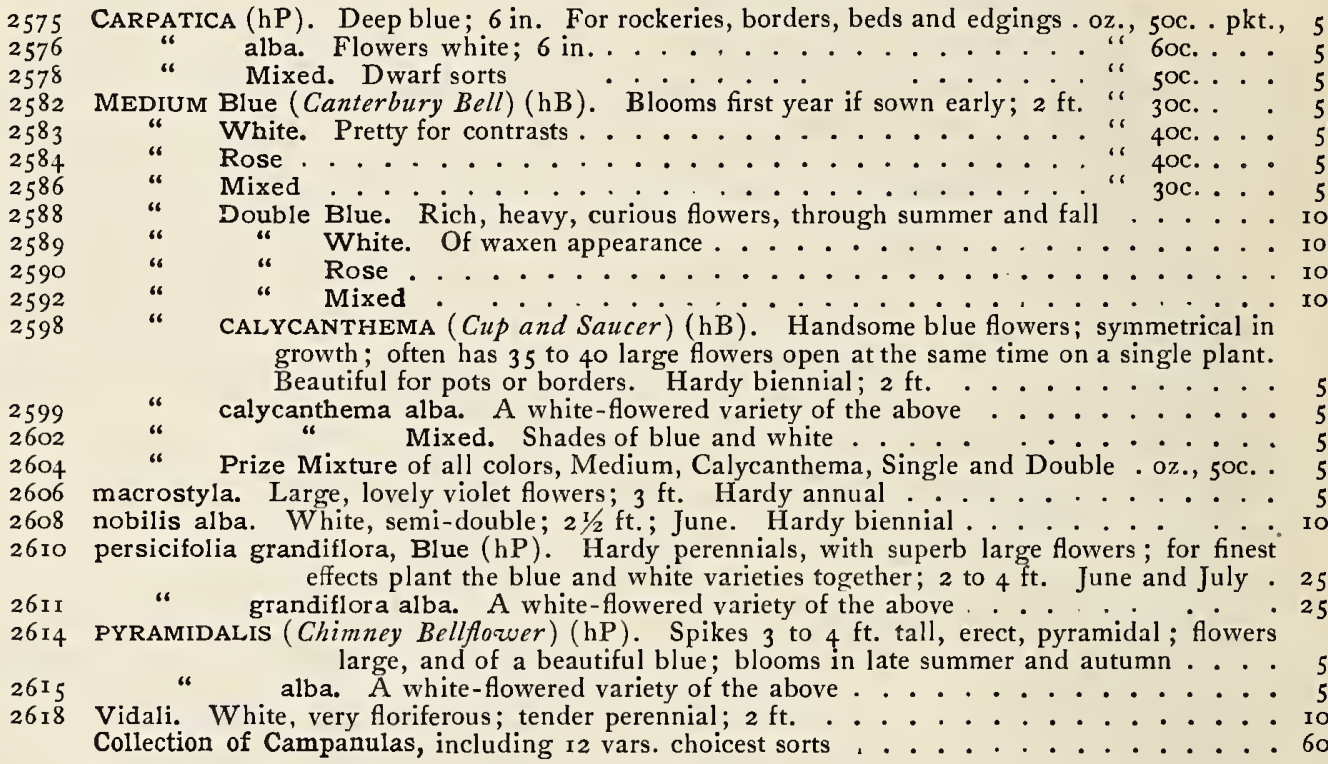

\section{CANDYTUFT}

(rberis)

The Candytufts are among our best white flowers for edgings, for bedding or massing, for rockeries and for cutting. Several of the varieties are fragrant, and all are profuse in bloom. Sow outdoors in April, where they are to bloom, and thin well when the plants grow about an inch. Sow again in a month, and late in July for fall flowers. September sowings will give winter-blooming plants. The soil should be rich and the plants well watered. They make many branches, and if some are pruned away the flowers will be larger.

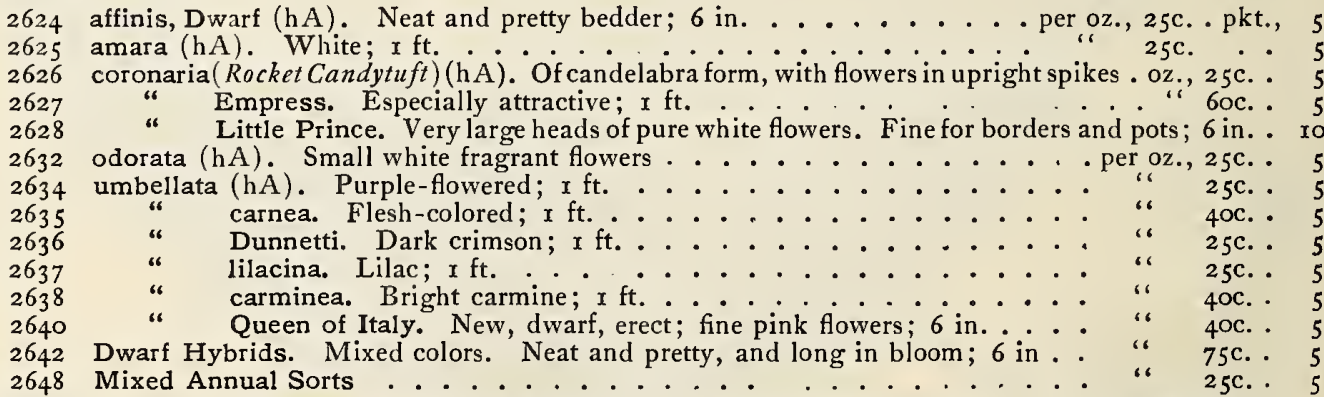

PERENNIAL CANDYTUFTS. These are shrubby, hardy, evergreen plants, and make a magnificent showing the second year from seed. They bloom very early, cushioning rock ledges, borders, or unsightly, rough spaces with banks of bloom. Sow outdoors either in spring or fall in any sunny place.

2656 sempervirens. The white flowers remain fresh nearly a month; I ft . . . . . . . . . . 5

2658 Gibraltarica. Beautiful blush-white; $\mathbf{x} \mathrm{ft}$. . . . . . . . . . . . . . . .

Collection of Candytuft, including 6 vars. choicest annual sorts . . . . . . . . . . 30 


\section{CARNATION}

(Dianthus caryophyllus)

The splendid Carnation of the florist is a very interesting plant to grow from seed, and it is not overexacting. Sown under glass in early spring, or later in the open ground, the plants will flower finely the second summer. For largest, richest flowers we recommend their culture in pots of rich soil, but with many they are also garden favorites, and grown in this way flowers of good quality may be enjoyed all summer if given plenty of water, good soil and a mulch about their roots. With tall varieties neat staking and tying is also necessary. Young plants are perfectly hardy outdoors, but when two or three years old they are injured by winter cold, so that sowings should be made every year.

MARGARET CARNATIONS are an extra vigorous race especially adapted for outdoor culture. They are very neat in habit, and remarkable for their rich profusion of flowers, produced in five months from sowing. For masses of bloom few plants are finer; and for pots, also, their neat habit makes them very suitable. Grown as annuals, from seed sown every spring, they are most satisfactory. Our seed of these varieties is grown exclusively by Mr. Chabaud, in the famous arden of Carnations, Provence, France.

2670 Margaret, Double White. Large, perfect flowers; $11 / 2 \mathrm{ft} . . . . . . . . . . . .2$ pkt., ro

2672 " " Yellow. A clear, soft shade; $11 / 2 \mathrm{ft} \ldots . . . . . . . . . . . . .25$

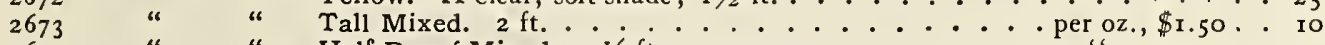

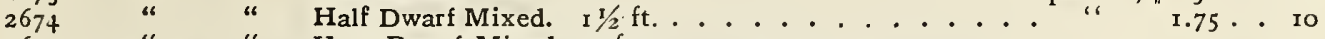

2675 " " Very Dwarf Mixed. I ft. . . . . . . . . . . . . . . . 10

2678 Giant MARgaret. Extra-large and perfect flowering, in a rich variety of colors, including yellow; 80 per cent of the flowers come double; I ft. . . . . . . . . . . 25

PERPETUAL CARNATIONS. This race has large, elegantly formed flowers, continually abloom upon closely branched, symmetrical plants, often called from their neat habit, "Tree Carnations."

2686 Chabaud Perpetual; Double. Mixed, yellow, red, white, etc.; $11 / 2 \mathrm{ft}$. Blooms in 7 months . 25

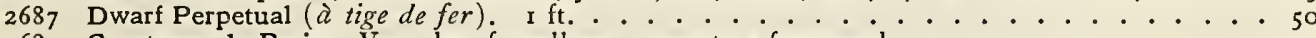

2689 Comtesse de Paris. Very dwarf; yellow; comes true from seed . . . . . . . . . . . . . . 50

2691 Mme. B. Chabaud. A superb introduction of last year. Flowers yellow, shading to salmon and bright cherry-red. Blooms the first year from seed, as do also the next three . . . . 50

2693 Giant Perpetual, White. Very large, perfectly double; flowers in seven months after sowing . 50

2694 " " " and striped

2696 “ " Fine Mixed. Enormous flowers, perfectly double; splendid colors ..... . 50

2698 Rose-Leaved, Mixed. Round petals; $2 \mathrm{ft} . . . . . . . . . . . . . . . . .50$

BORDER CARNATIONS, ETC. We invite attention to the splendid collections below.

2704 Red Grenadine, Double. Brilliant scarlet; $2 \mathrm{ft}$. . . . . . . . . . . . . . . . . 25

2706 Early Dwarf Vienna. Fine for garden culture and for cutting; i ft. . . . . . . . . . . ro

2708 Fine Double Mixed. Many colors; $2 \mathrm{ft}$. . . . . . . . . . . . . . . . . . 10

27 Io Double Mixed ....................... per oz., \$1 . . . 5

2712 Ordinary Mixed ....................... . . . . . . . . . 500

Choice Collections, including-

50 varieties Carnation and Picotee ..... \$3 oo 12 varieties Carnation and Picotee . . . . \$1

25 "،

18 " " " " 6 . . . . . 1 25

\section{CENTAUREA}

(Cornflower)

C. cyanus is also known as "Bachelor's Button," "Ragged Sailor," and "Kaiser Blumen." These are bright-flowered plants of hardiest nature and simplest culture, yet esteemed among the most attractive and graceful of all the old-fashioned flowers. When placed in water the flowers increase in size.

PERENNIAL FLOWERING. A dry, sandy soil of moderate fertility seems to suit them best. The last

two are elegant new sorts, with large, fragrant flowers of much value for cutting. If started early, inside, they will flower first season.

2724 macrocephala. Flower-heads large, showy, bright yellow; $3 \mathrm{ft}$. . . . . . . . . . . . pkt., 10

2726 odorata Chameleon. Yellow and rose; fragrant; superb. . . . . . . . . . . . . . 10

2728 Margaritæ. Pure white, $21 / 2$ inches across, exquisitely laciniated and delightfully scented ; forms stocky, well budded little bushes. A garden treasure; $11 / 2 \mathrm{ft}$. . . . . . . . . Io

PERENNIAL SILVER-LEAVED. These are used for borders or edgings, and thrive anywhere. Flow-

ers white, leaves grayish; height, $\mathrm{I}$ ft.; half-hardy.

2732 candidissima .................... . . per I, ooo seeds, $\$ 1$. . Io

2733 Clementei ... . . . . . . . . . . . . . . . " " " 50c. . 10

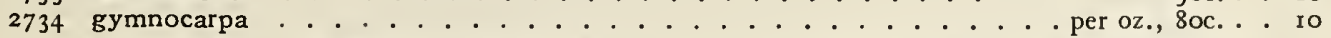

HARDY ANNUALS. These flower finest in full sun and thin soil. Sow in the open ground in spring.

$273^{8}$ Americana. Flowers lilac-purple; $3 \mathrm{ft}$. . . . . . . . . . . . . per oz., 40c. . . 5

2739 imperialis, Mixed. New; very large-flowered hardy class . . . . . . . . . . . . ro moschata. See Sweet Sultan in General List of Flower Seeds.

274 Cyanus (Blue Cornflower). Sow plentifully in large, irregular beds; I I/2 ft. . “ “ 300. • 5

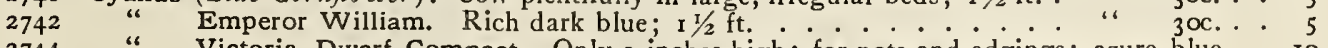

2744 “ Victoria, Dwarf Compact. Only 9 inches high; for pots and edgings; azure-blue . . 10

2746 " nana compacta hybrida. Another charming dwarf. All colors mixed; 9 in. . . . . Io

2748 " Mixed ............................ 25c... 5

2750 " Double Mixed. Odd and pretty . . . . . . . . . . . . 5

Collection of Centaurea, including 6 varieties $C$. Cyanus $($ Cornflower) $\ldots \ldots$ 


\section{CHRYSANTHEMUM, ANNUAL}

The Annual Chrysanthemums bloom profusely from early summer until frost, and when grown in large beds or masses their bright colors make a splendid show. The plants can be brought into bloom early by sowing the seed in frames or window boxes, and afterwards transplanting to the garden; or seed may be sown where the plants are to flower, if the seedlings are thinned to 8 or 10 inches apart. A little pinching back in early growth makes the plants bushy and shapely. Average height, I to I $1 / 2 \mathrm{ft}$.

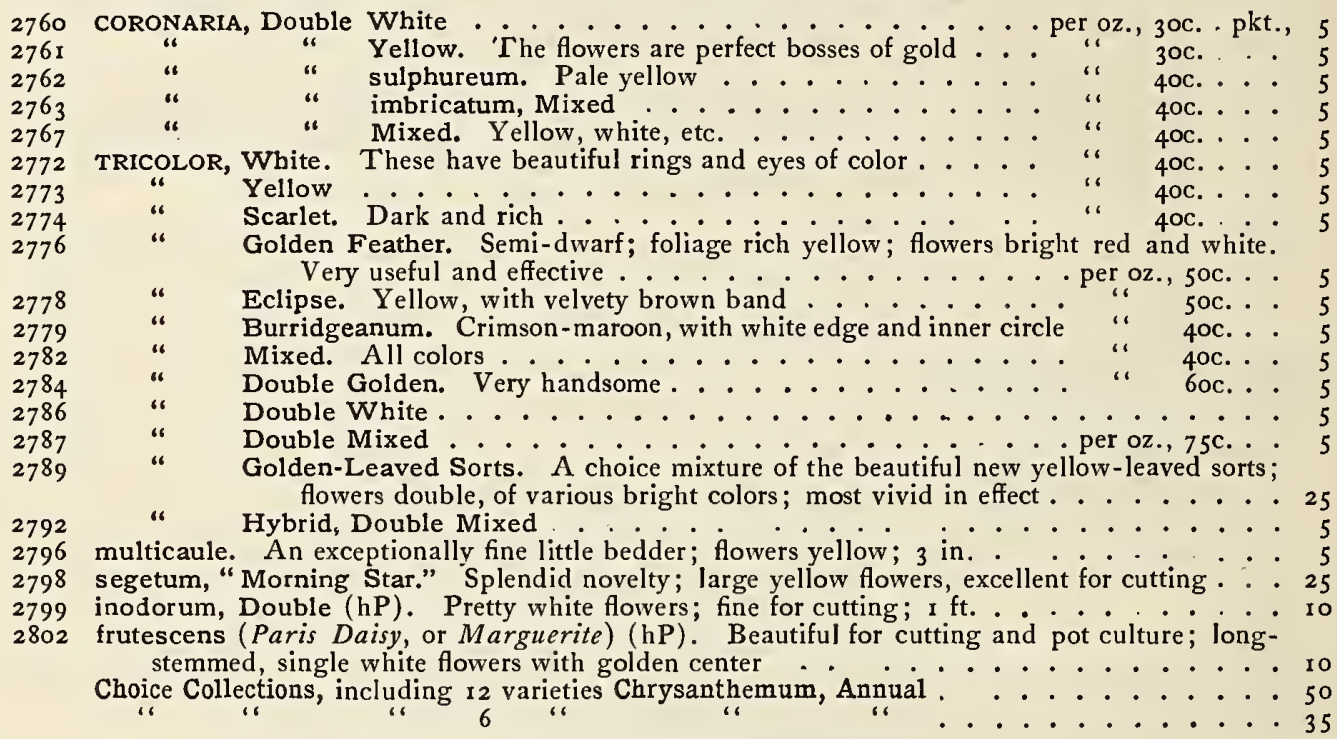

\section{PERENNIAL CHRYSANTHEMUM}

This section includes the splendid, large-flowered sorts of the autumn shows, and also the pretty, hardy pompons that make bright masses of color in our gardens long after heavy frosts have cut down other flowers. We wish to make quite clear the distinction between this class and the Annual Chrysanthemums, described above, that, as has sometimes happened heretofore, customers may not order seed of the summerblooming garden varieties, expecting them to yield the grand show flowers of late fall. The great blooms of the exhibitions are obtained from cuttings carefully cultivated. For ordinary culture and room decoration plants pinched back to form a number of branches and holding from 15 to 20 flowers, will be found satisfactory. Average height of show kinds, 3 feet.

28 ro Indicum grandiflorum. Will produce superb flowers of different types and colors . . . . pkt., ro

28 I I Japonicum. Japanese varieties; globe-shaped, incurved, grandly double . . . . . . . . ro

2812 "

2813 " " Pompon. The pretty, hardy dwarfs, with bright, clustered flowers; $1 \mathrm{r} / 2 \mathrm{ft}$. . . . 10

2815 " "California Fantasies." A superb mixture, containing a wonderful variety of the most beautiful æsthetic and fantastic forms ........... 25

\section{CLARKIA.}

These are among the prettiest native hardy annuals that come to us from beyond the Rocky Mountains. They bloom so freely and have flowers of such various bright colors that a bed of them in full bloom is a very beautiful sight. They are useful, too, for hanging baskets, for vases and as edging plants. Sow outdoors in early spring and grow in partial shade. They bloom through midsummer to late autumn. Average height, $1 / 2 \mathrm{ft}$.

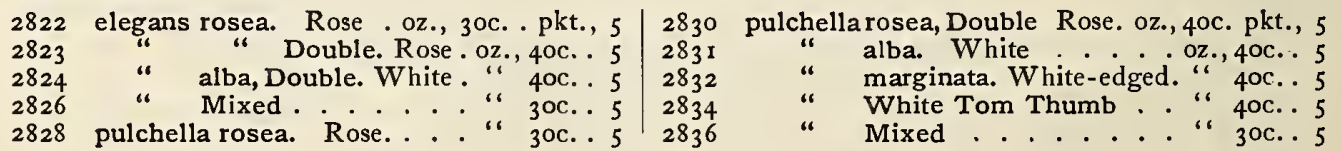

\section{BEGONIA HYBRIDA, NEW FRINGED}

We invite special attention to this splendid new strain of single fringed Tuberous-Rooted Begonias.

2840 New Fringed, Mixed . . . . . . . . . . . . . . . . . . . pkt., 50 


\section{COCKSCOMB}

(Celosia cristata. hhA)

We prize and plant the Cockscombs as an odd and picturesque decorative feature of the garden. The bright red and crimson varieties are most effective, both in gardens and in winter bouquets, for which they are cut before fully ripe and dried in the house. The dwarf varieties make novel and attractive borders; the tall ones form striking groups. Transplanting into rich soil about the time the combs begin to form makes these flower-heads much larger. They are bright from midsummmer until frost.

2846 Empress, Dwarf Crimson. Combs immense and vivid; foliage dark; 9 in. . . . . . . pkt., ro

2847 President Thiers. Very dwarf; combs bright red .................. . 10

2848 All-Aglow. Large, fiery scarlet combs; quite dwarf . . . . . . . . . . . . . . . 25

2850 Queen of Dwarfs. Six or 8 inches tall, with ruby heads almost as broad . . . . . . . . . 10

2852 Glasgow Prize. Dark leaves and crimson combs; I ft. . . . . . . . . . . . . . . . . . I0

2854 Dwarf Large Crimson. A superb new sort, with enormous combs of richest, deepest crimson. A good plant for exhibitions; 6 in. . . . . . . . . . . . . . . . . 10

2856 Dwarf Fiery Scarlet. A miniature plant, with enormous combs of intense fiery red. New,

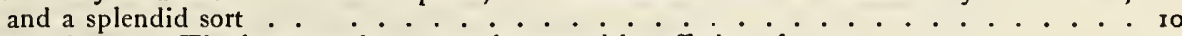

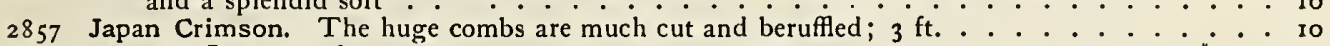

2860 Mixed. Large comb sorts . . . . . . . . . . . . . . . per oz., \$I . 5

\section{COSMOS}

This is now one of the notable fall flowers, the specialist's skill having recently added much to its beauty. A strong, tall-growing annual, its bold flowers have yet an exquisite daintiness and airiness, heightened in effect by their foliage-setting of feathery green. It is most effective when planted in broad masses, or long background borders against evergreens or fences at some little distance from the house and the garden walks. From seed started early in the house the plants will be 3 or 4 feet high by September, and tossing into the air a perfect storm of bright-colored, daisy-like flowers. Sowing the seed late and in poor soil will dwarf the plants. We offer only the choice large-flowering strains, with an average height of 4 feet.

GIANT FANCY. The great flowers are often 5 inches wide, and show many shades of crimson, mauve, pink, white and white delicately clouded. Often the petals a re beautifully fringed.

2870 Giant Fancy White . • . . . . . . . . . . . . . . . . pkt., ro

2871 " " Red. Deep and dark . . . . . . . . . . . . . . . . . . . I0

2872 " " Pink. Bright clear shades . . . . . . . . . . . . . . . . . 10

2875 " " Mixed. All shades from pure white to deep crimson . . . . . . . . . . . . ro

2878 Tints of Dawn. Of compact, bushy growth, early flowering. The handsome white circular flowers are delicately flushed with rose around the center. . . . . . . . . . . . . Io

2880 Marguerite. Petals deeply and irregularly fringed; in various bright colors; exquisitely pretty. I 5

2882 Single Dahlia-Flowered. Great flowers of deep, velvety crimson that, but for their lightness, would look like single dahlias ........................ Is

2883 Mammoth Perfection Rosita. Pink . . . . . . . . . . . . . . . . . . . . . . 10

2884 " " Erlinda. White . . . . . . . . . . . . . . . . . . 10

2886 " " Conchita. Crimson ....................... . . 10

2887 Yellow. A distinct shade; blooms early and all season; $2 \mathrm{ft}$. . . . . . . . . . . . . . . I5

2888 Klondyke. A new variety from Mexico, with large, bright yellow flowers; $2 \mathrm{ft} . . . .$. . . . Io

2890 White Pearl. Dainty and transparent.............. per oz., 75c. . 5

289 I Pink Pearl . . . . . . . . . . . . . . . . . . . " $75 \mathrm{c} . .95$

2894 Mixed ................................. 50c... 5

\section{DELPHINIUM (Larkspur)}

In variety and beauty of its blue tints, which are as numerous as they are charming, no other plant can equal the Delphinium. The brilliant flowers can be seen from a long distance and are strongly effective in beds or masses, in borders, shrubberies, or in combination with white lilies. Ordinarily the tall sorts are planted among shrubbery, or as a background for dwarfs, which are favorites for bedding. Improvements are continually being made in the size of the flowers, as well as in the length and fullness of the spikes. Some of the species flower both early and late; the season for all can be prolonged by cutting away withered flower-stems. They are sometimes increased by division, but are much more robust when grown from seed. All varieties are easily cultivated and adaptable to many conditions, but in a soil deeply dug and well enriched with fine old manure their blooms are the finest. They must have plenty of room to grow ; $x^{1 / 2}$ to 2 feet each way is not too much for the taller sorts.

ANNUAL VARIETIES. These include the Rocket and Hyacinth-flowered, so called from their long, narrow flower-spikes. They bloom best in a rather cool, moist soil. Sow seed in the open border, either in spring or fall, preferably the latter, so that germination may take place very early in spring. As the seedlings grow, thin them to stand 6 to 18 inches apart, according to variety. The shades of color include light, dark and azure-blue, white, buf, rose, apple-blossom, pink, brick-red, red lilac, dark lilac, violet and 


\section{DELPHINIUM, continued}

fawn. The varieties are seldom kept separate, as they are quite as pretty and convenient for cutting when sown in mixture, Some of these are really hardy biennials. but because they bloom the first season we treat them as hardy annuals.

2904 Ajacis Dwarf Rocket. Finest colors; beautiful for bedding; I ft. . . . . per oz., 30c. . pkt., 5

2905 "Tall Rocket. Long, showy spikes; $2 \mathrm{ft} \ldots . . . . . . . . . . " 30 c . . . .5$

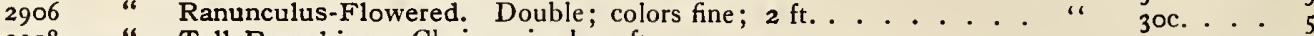

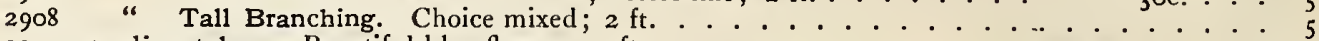

29 ro cardiopetalum. Beautiful blue flowers; I ft. . . • • . . • . . . . per oz., 4oc. . . . 5

2912 Emperor, Branching Rose. This and the next are splendidly bright and showy, often showing

$29{ }_{3}$ " " 40 or 50 erect spikes of flowers; $2 \mathrm{ft} . . . . . . .$. per oz., 60c. . . . 5

PERENNIAL VARIETIES. These are usually taller than the annuals, requiring more space between the plants. If sown in fall or very early in spring nearly all will bloom the first season. The foliage is clean and pretty; habit strong and neat; flower-spikes long and dazzling.

2920 Brunonianum. Lovely blue, musk-scented flowers; very distinct; $3 \mathrm{ft}$. . . . . . . . . 25

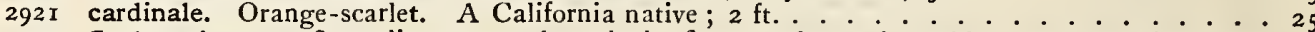

2922 Cashmerianum. Spreading, many-branched; flowers often 2 in. wide; deep purplish blue; superb; $3 \mathrm{ft}$.

2924 Chinese, Mixed ( $\dot{C}$ grandiflorum). The stems have many lateral branches, gracefully set with large flowers ranging from pure white to deep indigo-blue, the paler colors being especially admired. Young seedlings will bloom from midsummer until frost; $2 \mathrm{ft}$. . per oz., 50c. . .

2926 elatum, Blue (Bee Larkspur). Soft, clear blue flowers in fine tall spikes; $3 \mathrm{ft}$. " “". 50c. . 5

2927 " Mixed ... . . . . . . . . . . . . . . . . . “ 50 . . 5

2929 formosum. Brilliant blue, with white center; especially fine and attractive; $3 \mathrm{ft}$. " " $75 \mathrm{c}$. . . I0

2930 hybridum, fl. pl. Finest double sorts in choice colors; a superb mixture; $3 \mathrm{ft} . . . . .25$

2933 nudicaule. The most brilliant species of all, and the only pure bright scarlet. Dwarf and compact in growth, with flower stems of fine length. I ft. A native of California . . . . Io

2934 Zalil (sulphureum). Very beautiful hardy perennial, with long spikes of yellow flowers . . . ro

Choice Collections of Delphinium, including-

12 varieties Dwarf Rocket ........ \$o 50 varieties Emperor . . . . . . . . . . \$o 35

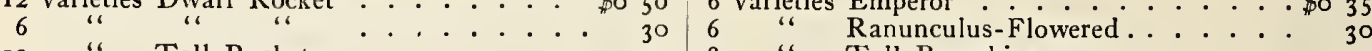

12 “ Tall Rocket ............ .

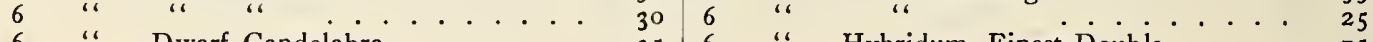

“ Dwarf Candelabra . . . . . . . $35 \mid 6$ “ 35 Hybridum, Finest Double ......

\section{ESCHSCHOLTZIA}

\section{(Califarnia Poppy)}

The state flower of California. An annual incomparably bright and rich in its pure tints of yellow and orange. The plants average about a foot in height, have beautiful silvery foliage, and produce their large, poppy-like flowers quite lavishly from early spring until frost. They are most effective when grown in beds of considerable size, over which the seed may be sown broadcast thinly and lightly raked in. These sowings may be made early in spring or late in autumn, for earlier germination and bloom the next spring. Also very useful as a pot plant, and for cut-flowers.

2943 Californica. True California Poppy. Rich yellow . . . . . . . . . . per oz., 40c. . pkt., 5

$29+4$ " alba. Creamy white ................" “ 40c. . . 5

2945 " Rose Cardinal. Intense carmine ..................... 5

$29+6$ crocea. Pure deep orange . . . . . . . . . . . . . . . per oz., 4oc. . . 5

2947 “ Double Orange . . . . . . . . . . . . . . . . . . . . “ “ 75c. . . 5

$29+8$ "Double White . . . . . . . . . . . . . . . . . . . . . . 5

2950 Golden West. A superb new variety, with very large flowers of deep yellow; $2 \mathrm{ft}$. . . . . . I0

2952 tenuifolia. Bright yellow; leaves dense and finely cut; $\mathbf{~ f t . ~ . ~ . ~ . ~ . ~ . ~ . ~ . ~ . ~ . ~ . ~ . ~ . ~ 5 ~}$

2954 maritima. Canary-yellow, with orange center; leaves grayish and beautifully cut ... . . . to

2955 Mandarin. Red-gold flowers, orange within and scarlet without . . . per oz., 50c. . . 5

2957 Hunnemannia. Flowers large, jonquil-yellow; $21 / 2 \mathrm{ft}$. Blooms well in winter also. New .. Io

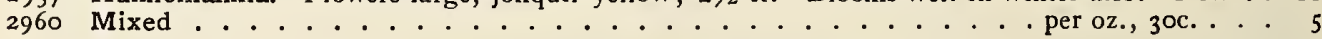

\section{FORGET-ME-NOT}

(Myosotis)

These aantıly elegant little flowers ase hardy perennials that love cool, moist soils and, like pansies, bloom most freely in fall and early spring. 'They make beautiful close borders, or edgings, thickly sprinkled with pretty flower-sprays, and will bloom nicely in winter in a cool room or coldframe. Once at home in a garden they establish themselves by self-seeding. All the varieties are general favorites. Sow in spring in a warm, sunny border. Most varieties bloom freely. the first season and profusely the second. Average height, 6 inches.

2970 MYOSOTIS ALPESTRIS.

A pretty trailer, with blue flowers . . . . . per oz, $75 \mathrm{c}$. : pkt., 10 rosea. Rosy flowers; a pretty contrast for blue and white varieties . Io alba. White; especially pretty ...... per oz., 90c.... Io 


\section{FORGET-ME-NOT, continued}

MYOSOTIS ALPESTRIS elegantissima. Blue; leaves white-edged; very attractive . . . . pkt., IO " $"$ robusta grandiflora, Grown extensively for cutting. Florets large, sky-blue with yellow eye, in large clusters ......... ro Victoria. Symmetrical and strong-growing; dwarf habit; flowers large, globular, sky-blue, abundant; fine for pots and cutting . . 25
Mixed......... per oz., 75 c. . ro

Mrosotis Azorica, Dark blue, with white eye; ift. . . . . . . . . . 25

" dissitiflora. Blooms very early; flowers blue. From Switzerland . . . . . . . . . . ${ }^{2} 5$ " palustris (True Forget-me-not). Blooms the second year abundantly all season;

" sylvatica. Blue, with yellow eye; likes dry soil; i to $2 \mathrm{ft} . \cdots$ per oz., $75 \mathrm{c}$. .

\section{FOXGLOVE}

\section{(Digitalis)}

The tall flower stems of the Foxgloves are particularly handsome when seen growing among shrubbery, or in bold masses along walks or drives. Used as a background for lower plants they are also very fine. Often the spikes are two or three feet long and thickly strung with scores of showy, thimble-shaped flowers. Some new sorts rival gloxinias in shadings and markings. Seed may be sown outdoors in spring and the seedlings transplanted where they are to grow, or, preferably, to a coldframe, where they make extra-strong plants that will flower in magnificent spikes the next season. They are most satisfactory when treated as biennials, sowing the seed every year in rich, deep soil and partial shade. Average height, 2 to 3 feet. Easily cultivated. When the center spike begins to fade it should be cut out and the side shoots will, in consequence, grow more vigorously.

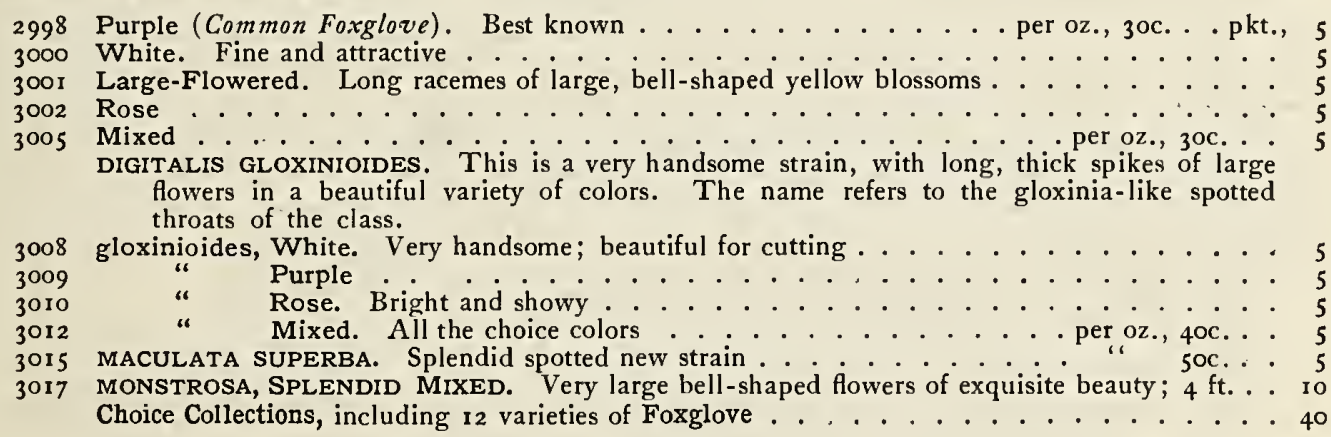

\section{GODETIA}

Choice, free-blooming annuals, with widely opened flowers of satiny texture and of the most delicate and lovely colors. They are beautiful for solid beds, border lines, for pots, and to grow in shaded places where so few really fine flowers will flourish. Sow seed in the open border in spring, or in a coldframe, and transplant seedlings to stand about a foot apart in rather thin soil. They bloom from early spring until frost. Average height, $1 / 2$ feet.

3027 rubicunda splendens. Bright red; r ft. . . . . . . . . . . . . . . . . . . . . . pkt., 5

3028 Princess of Wales. Dark crimson . . . . . . . . . . . . . . . . . . . . 5

3029 Lady Satin Rose. Bright carmine; very effective . . . . . . . . . . . . . . . . . . . 5

3030 Fairy Queen. Large white flowers, with carmine spots . . . . . . . . . . . . . . . . . . I0

3032 gloriosa. Darkest red, dwarf and compact . . . . . . . . . . . . . . . . . . . . . 5

3033 grandiflora maculata. Great white flowers, blotched with carmine . . . . . . . . . . . 5

3035 White Pearl. Beautiful glossy white flowers ..................... 5

3036 The Bride. White, with blush spots . . . . . . . . . . . . . . . . . . . . . . 5

3038 Duchess of Albany. Satiny white . . . . . . . . . . . . . . . . . . . . . . 5

3039 Lady Albemarle. Dark crimson . . . . . . . . . . . . . . . . . . . . . . . . . . 5

3040 Lindleyana. White and red; I ft. . . . . . . . . . . . . . . . . . . . . . . . . . 5

3042 Bijou. Of dwarf, bushy habit; lovely blush color . . . . . . . . . . . . . . . . . . 5

3044 Whitneyi. Compact, with superb rosy flowers blotched with crimson; elegant pot plant . . . 5

3046 " Brilliant. Carmine; very showy ................... 5

3047 " $\quad$ Duke of Fife. Intense red, with white spots; large-flowered and showy . . . . 5

3048 " Duchess of Fife. White flowers, with satiny flesh-colored spots; bright red at

Mixed petal-bases . . . . . . . . . . . . . . . . . . 5

3052

Collection of Godetias, including 6 choicest varieties . . . . . . . . . . 30 


\section{HOLLYHOCK \\ (Althea rosea)}

These stately, old-fashioned perennials are most striking when seen in groups or long rows against evergreen hedges, shrubbery, etc., and, in their turn, form a very fine background for plants of lower growth. Their color-variety is wonderful, ranging from pure white through almost every conceivable shade of yellow, red and rose to ashen-gray and almost black. Although Hollyhocks are very permanent and hardy it is advisable to sow seed every year, as the flowers on young, vigorous plants are much finer than on old ones. Sowings can be made even so late as August to flower the next year. In final transplanting give each seedling a foot or more of space each way for development. Average height, 4 feet. Our seed is of magnificent double varieties grown from Chater's celebrated collection, which has revolutionized the popular estimation of the Hollyhock.

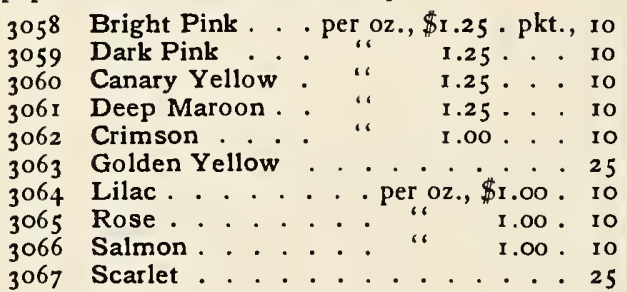

\begin{tabular}{|c|c|c|c|}
\hline 3069 & Snow White & 1.25 - pkt., & \\
\hline 3070 & White Dwarf . & 1.00 . . & \\
\hline 71 & Yellow. . . & I.00. & \\
\hline 3074 & Mixed Allegheny & 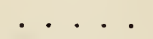 & \\
\hline 075 & Mixed . . . • · . . p per & oz., 7 & \\
\hline $\begin{array}{r}12 \\
8\end{array}$ & $\begin{array}{l}\text { Choice Collections, including- } \\
\text { rieties Hollyhocks, Double Prize }\end{array}$ & . & \\
\hline 6 & “ & . & \\
\hline
\end{tabular}

\section{IPOMOEA}

(Moonfower. Morning-Glory. Cypress Vine)

Of all our climbers for garden and greenhouse, these are the quickest and most luxuriant in growth, carrying to great height a splendid curtain of leafage, studded, as summer heat comes on, with large, satiny blooms of lovely colors. Ipomœas grow so easily from annual sowings that it is no longer thought necessary to winter over roots or young cutting plants under glass. The large, horny seeds of some varieties should be soaked in hot water before planting. For early flowers sow in hotbeds or pots and boxes under glass, and transplant to rich, deep soil in summer quarters as soon as danger of frost is over, when sowings may also be made in the open ground. We have nothing finer for porches, screens, trellises, etc. ANNUAL VARIETIES. From early sowings these begin to bloom in June and July and are full of beautiful flowers all the season, often blooming fully until cut down by frost.

3085 Baby Blue. Exceedingly beautiful sky-blue flowers . . . . . . . . . . . pkt., 10

3086 coccinea. Scarlet flowers; ro ft. . . . . . . . . . . . . per oz., 1 5 c... 5

3087 "lutea. A yellow-flowered variety . . . . . . . . . . " " 20c. . 5

3089 Imperial Japanese. See Japanese Morning-Glories, page $68 \ldots \ldots$. . . . . . . . . ro

3090 "Northern Light." A beautiful hybrid, with extra large and handsome flowers of a beautiful lavender-pink; blooms very early; $15 \mathrm{ft} . . . . . . . . . . . . . .10$

3092 hederacea grandiflora. Rich sky-blue flowers with white margin; $15 \mathrm{ft} . . . . . . . . .55$

3093 " marmorata. Beautifully marbled with light and dark blue; throat pink; $15 \mathrm{ft} . .25$

3094 Nil. Flowers purple; $15 \mathrm{ft} . . . . . . . . . . . . . . . . . . . . . .55$

3095 limbata. Violet and white; 5 ft. . . . . . . . . . . . 20c. . . 5

3097 Mexicana grandiflora alba. The great white Moonflower; is ft. . . . . “ $75 \mathrm{c}$. . . Io

3098 " hybrida. Flowers very large and numerous; blooms earlier; $15 \mathrm{ft} . . .10$

3 roo bona nox (Good-Night, or Evening-Glory). Opens large white flowers in the evening. I $5 \mathrm{ft}$. . 5

3ror hybrida Heavenly Blue. The very large clustered flowers of beautiful sky-blue open early in the morning. Unusually distinct and handsome; ro ft. Sow early ........ 25

3104 Quamoclit (Cypress Vine, Star Flower). A tender annual, with fine cut leaves and small, star-shaped flowers. This, the type, is scarlet-flowered; ro ft. . oz., 30c. . 5

3105 "White ................ ...." " 30c... 5

3106 " Kerberi. A fine new scarlet-flowered variety that blooms late......... . I0

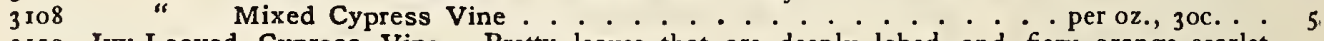

3rio Ivy-Leaved Cypress Vine. Pretty leaves that are deeply lobed and fiery orange-scarlet flowers. A hardy annual ................ . . per oz., $30 \mathrm{c.}$. .

GREENHOUSE CLIMBERS. These handsome vines grow nicely in the open ground, but bloom almost too late to be very useful there, in all except warm climates. Grown in pots, tubs, or greenhouse beds, they flower grandly between October and spring.

3112 Horsfalliæ. A superb West Indian species of vigorous growth. The rich, thick leafage is

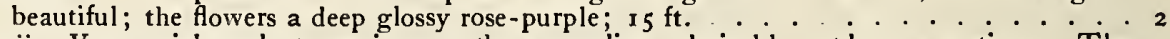

$3 \times 13$ Learii. Very quick and strong in growth, succeeding admirably outdoors sometimes. The flowers are a beautiful violet-blue; is ft. . . . . . . . . . . . . . . 25

3 II4 rubro-ccerulea. Bright red; $8 \mathrm{ft}$. . . . . . . . . . . . . . . . . . . . . . 10

3115 " " alba. White flowers; $8 \mathrm{ft}$. . . . . . . . . . . . . . . Io

3116 setosa (Brazilian Morning-Glory). This vine makes an immense, thick growth of great lobed leaves, lighted by a profusion of large rosy flowers with a satiny pink star in the center. The red pubescent stems and seed pods add to its attractiveness; to to $20 \mathrm{ft}$. . . ro

3 II chrysantha. Yellow flowers; ro ft. . . . ................... 10 Collection, including 12 varieties, Annual sorts.................. 50 


\section{LOBELIA}

The Erinus varieties are charming little plants that bloom very quickly from the seed and continue gay with flowers all through the season. For beds, edgings, baskets and pots, we have nothing prettier; their exceedingly clear, cheery colors and generous bloom make them welcome anywhere. Sow outdoors in early spring, where the plants are to grow and thin moderately; or transplant several inches apart in rich, open soil. Some stimulant given when they are in bloom greatly improves the flowers. Almost all are also good winter conservatory plants of trailing habit. The perennial or tall varieties are handsome, showy plants, found quite effective for backgrounds and grouping.

\section{ERINUS VARIETIES-}

gracilis. Blue; trailing; beautiful for baskets....... pkt., speciosa. A favorite blue-flowered edging plant; 6 in. . . . . . 10

alba. White flowers...... . 10

kermesina. Crimson . . . . . . 5

Lindleyana. Rose; white eye... . 5

Paxtoniana. Blue and white ... . ro

grandiflora superba. Large blue flowers ro erecta, Crystal Palace. Dark blue; finest for bedding; 6 in. 25 “ Emperor William. Light blue. ro “ Golden Queen. Dwarf; blue flowers, yellow leaves ...
ERINUS VARIETIES, continued

${ }_{31} 8$ erecta, White Lady. Splendid new large-flowered white....pkt., 25

3 I 40 Royal Purple. Deep blue, with a distinct white eye ...... ro

3I I Mixed....... per oz., 6oc. . 5

PERENNIAL, or TALL VARIETIES-

3143 cardinalis (Cardinal Flower). Long spikes of richest cardinal-red . . 10

3I44 splendens. Slender scarlet spikes; $3 \mathrm{ft}$. Io

3145 ramosa. Blue flowers in fall; I ft. . Io Choice Collections, including-

12
6

\section{MARIGOLD}

(Tagetes)

These, like the Calendulas, are valuable because they light the garden with such a grand glitter of yellow far into the frosts of autumn. The dwarf varieties make a fine border for taller sorts, and both are effective when planted in groups or in garden borders. Hardy annuals. Average height, I $1 / 2$ to 2 feet.

3154 AFRICAN. Stronger in growth and larger in flower than the French varieties. The dwarf sorts grow only about 18 inches high and bloom earlier than tall ones. Easily grown, but do not plant or sow outdoors while there is danger of frost. Flowers lemonyellow, double................... oz., 5oc. . pkt., 3156 " Eldorado. Large, quilled, perfectly double; brilliant shades of yellow . oz., 6oc. . 3157 " Nugget of Gold. Golden yellow, double . . . . . . . . . . "75c. . 3158 " Pride of the Garden. Extra large, double flowers of richest yellow; dwarf, and neat . ro 3159 " Delight of the Garden. Also dwarf and large-flowered; lemon-yellow, double.. Io 3 I62 “ Mixed Double.................... per oz., 50c. . 5

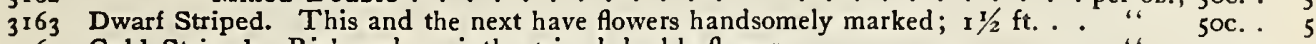

3164 Gold Striped. Rich and quaintly striped double flowers . . . . . . . . . . . . . 50c. . 5 3 I66 FRENCH. These dwarf, stocky little plants yield an amazing number of charmingly conventional, orange-colored little blossoms; $1 \mathrm{ft} . . . . . . . .$. per oz., 5oc. .5

3 I 68 " Legion of Honor. Single golden yellow blooms, marked with velvety red; very dwarf . Io

3169 " Tall Mixed Double ................... per oz., 50c. . 5

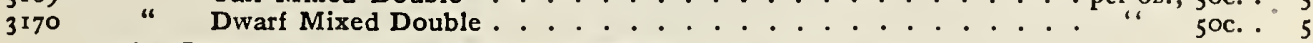

Choice Collections, including 8 varieties Marigold, Double French . . . . . . . . . . . 35

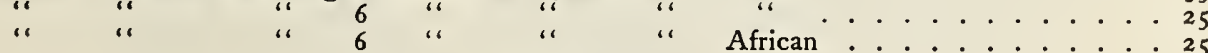

\section{MIGNONETTE}

\section{(Reseda. ha)}

Every in or out-door garden must have Mignonette in plentiful supply. The seed can be sown at any time, and if successive sowings are made, its fragrant, modest colored flowers may be gathered outdoors until November. Sow in pots or boxes under glass in February or March and thin or pot off the seedlings to make good plants for bedding out about April 15. Sow outdoors in rows about April r, and again regularly at intervals of about three weeks till August, a row or two at a time for succession. The July sowing will make good winter flowering plants. Average height, $\mathrm{I} f \mathrm{ft}$.

3 176 Reseda odorata. Sweet . oz., r 5c..pkt., 5

3177 grandiflora. Large flowers . oz., 15c. . 5

${ }_{3178}$ Golden Queen. Golden yellow. oz., 30c. 5

3179 Crimson Queen. Crimson . oz., 30c. . 5

3I80 Machet, Dwarf. Deep red; 9 in. oz., 6oc. ro

3182 Bismarck. New improved dwarf; fine. ro

3183 Gabrielle. Large red; 9 in. . oz., 6oc. . ro

3184 Victoria. Compact; rich brilliant red; 6 in...... per oz., 6oc. . 10
3 I86 Miles' Spiral. I ft. . . per oz., 30c. . pkt.,

3187 Giant Pyramidal. I $1 / 2 \mathrm{ft}$. - per oz., 20c. .

3 Igo Allen's Defiance. Full, round spikes of great length; very fragrant and fine for cutting; $1 / 2 \mathrm{ft} . . . . . . .10$

3192 Elois Francois. Spikes long, of a rich, attractive red; best for forcing; $r \mathrm{ft}$. . ro

3193 Parson's White. White and buff; 9 in. . S

Choice Collection, including5 5 ro (1) ro varieties of Mignonette . . . . . . . 50 


\section{IMPERIAL JAPANESE MORNING-GLORY}

This race is now celebrated everywhere for extraordinary beauty. One great charm lies in the infinite variety of its flowers and leaves. The latter differ greatly in shape as well as in size, and while some are plain green, others are oddly marbled and blotched with white or yellow. The colors and markings of the flowers are almost indescribable, varying from pure white to rose, crimson and carmine, through blues and purples of every shade to almost black. There are velvety single self-colors, a few doubles and semi-doubles, others with quilled or feathered petals, many fancifully bordered, blotched, striped, penciled and marbled, hardly any two plants from a seed packet seeming alike. The vines are wonderfully vigorous, growing rapidly to a height of 30 or $40 \mathrm{feet}$, and their foliage is spangled with hundreds of these large and lovely flowers. In sowing or planting give them about twice as much space as the ordinary Morning-Glory and do not sow quite so early. (For Morning-Glories see page 66 and General List of Flower Seeds.)

3200 Mixed Colors. Single, Fringed and Double . . . . . . . . . . . per oz., 40c. . . pkt., ro

3202 New Yellow. Pure light yellow flowers and very curious, crinkled, sleepy foliage; quite distinct. Io

\section{NASTURTIUMS}

A marvelous range of new colors has been developed in this favorite flower, which for three or four months of the season makes a better display than almost any other plant. No other annual will produce such a lavish profusion of flowers for so long a time with the same small outlay of time and labor. The maximum of bloom is produced in thin soils, and never flags through the hottest weather. In soils too rich leaves predominate, and the plants are apt to rot off in wet weather, especially if standing too close. Plant the seeds an inch deep, and thin seedlings to ro or 12 inches apart. The rows for bedding varieties should not be less than a foot apart, for tall varieties 4 feet.

\section{DWARF, or TOM $\underset{(\text { Tropeolum nanum) }}{\text { THUMB NASTURIUMS }}$}

These have a neat, compact habit and attractive foliage, are not disturbed by insects, bloom in two months from sowing and most profusely the whole season. A bed of them in full bloom is a perfect glory of color, and a good $6 \times 20$ foot bed will yield about $\mathrm{I}, 000$ flowers per day. Average height, 9 inches.

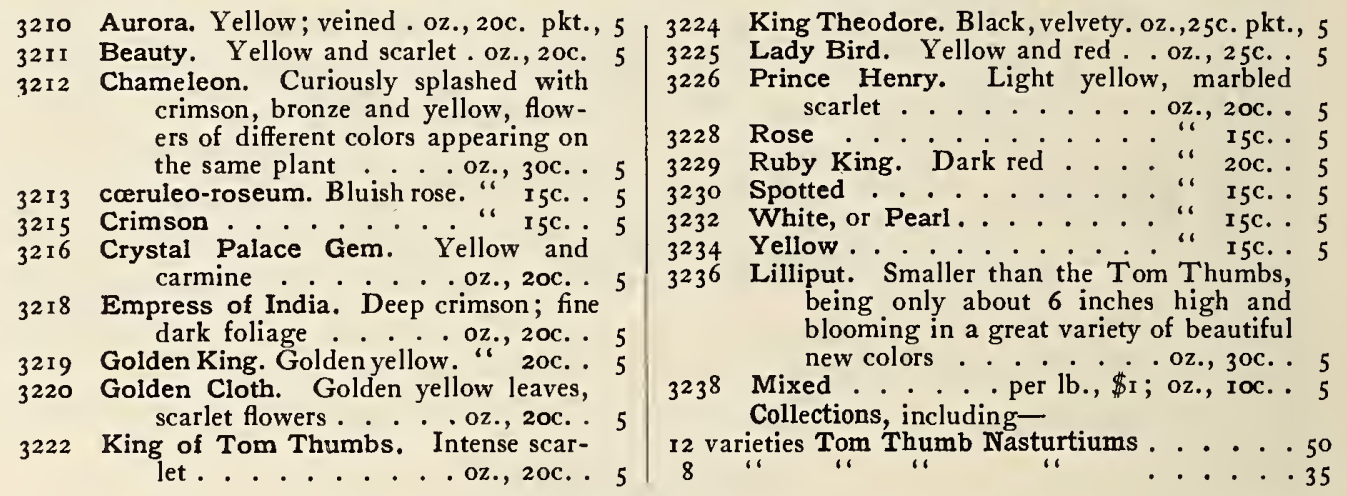

\section{TALL, or CLIMBING NASTURTIUMS}

(T'ropacolum majus)

Besides their ordinary garden use for trailing over fences, trellises, stone walls, etc., these can also be grown as pot-plants for winter flowering, as screens, or as trailers for hanging baskets and vases. Sow plenty of seed in drills, and thin to 6 inches. They bloom most quickly and profusely in poor soil. Their flowers are usually a little larger than those of the dwarf sorts. Average height, 5 feet.

3244 Chameleon. Various . oz., r 5c. . pkt., 5

3245 Dark Crimson .. . . " 15 c. . . . 5

3246 Edward Otto. Brownish lilac . oz., I $5 \mathrm{c}$. 5

3247 Golden-Leaved. Scarlet flowers. "I I 5

3248 bemisphæricum. Orange .." I5c. 5

3249 Orange . . . . . . " I 5 c. 5

3250 Pearl. Whitish. . . . . . " I 5 c. 5

3252 Rose........... “I5c. 5

3254 Scarlet . . . . . . . . I Ic. 5

3255 Scheuerianum. Straw color, spotted.
3257 Scheuerianum. Scarleț-striped ...... ........ oz., i 5 c. . pkt., 5

3258 Schillingi. Yellow, spotted . . oz., 15c. . 5

3259 Schulzi. Darkest-leaved.... " I 5 c. . 5

3260 Striped ........... “ I $_{5}$ c. . 5

3262 Yellow ............ “ " I5c. . 5

3266 Fine Mixed . . per lb., 75c. . " roc. . 5 Choice Collections, including-

I 2 varieties Tall Nasturtiums . . . . . . . 50 ........ oz., r 5 c. . 5

8 " ". . . . . . . 35 


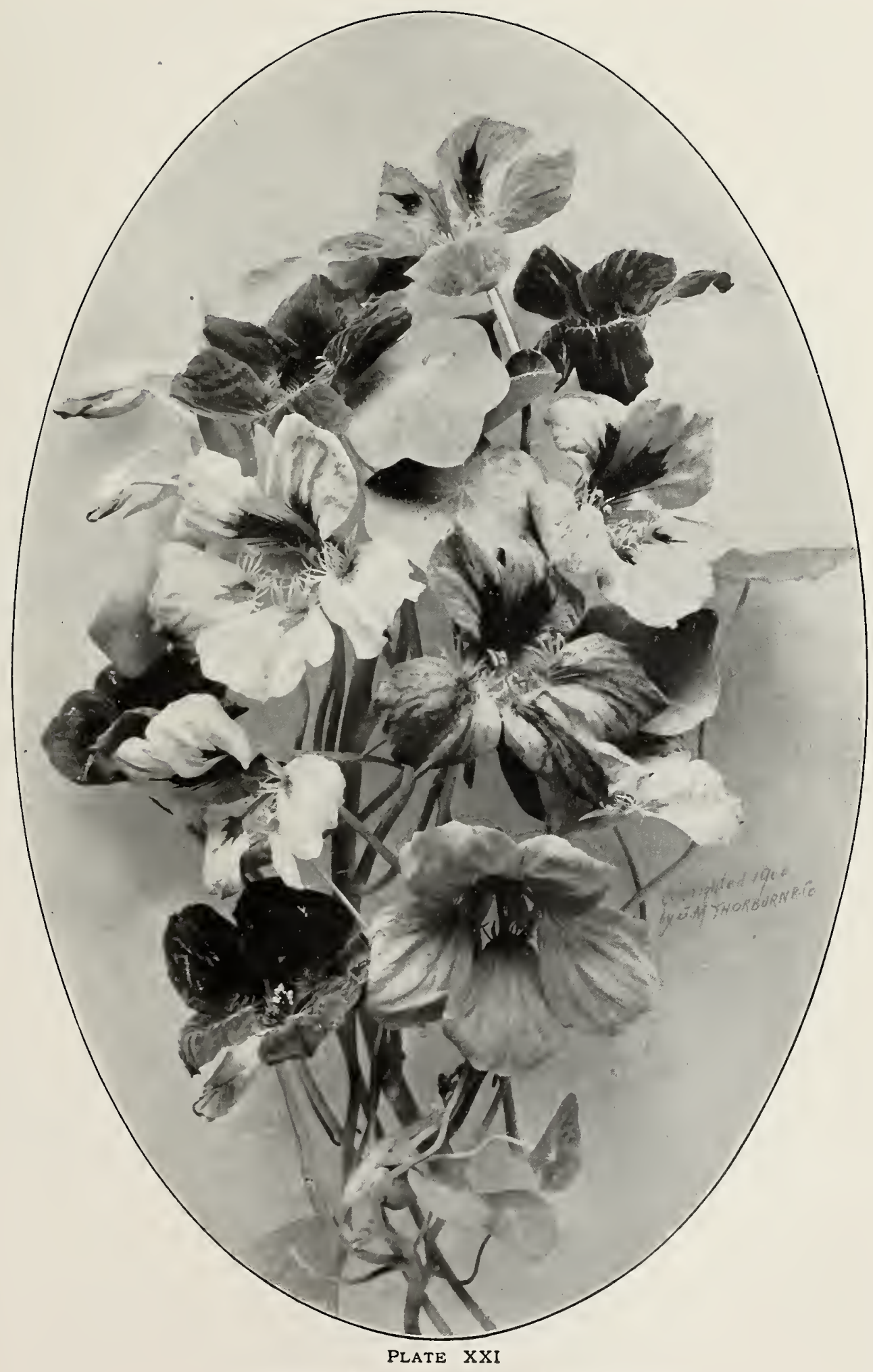

THORBURN'S MIXED TORI THUMB IJASTURTIUM 


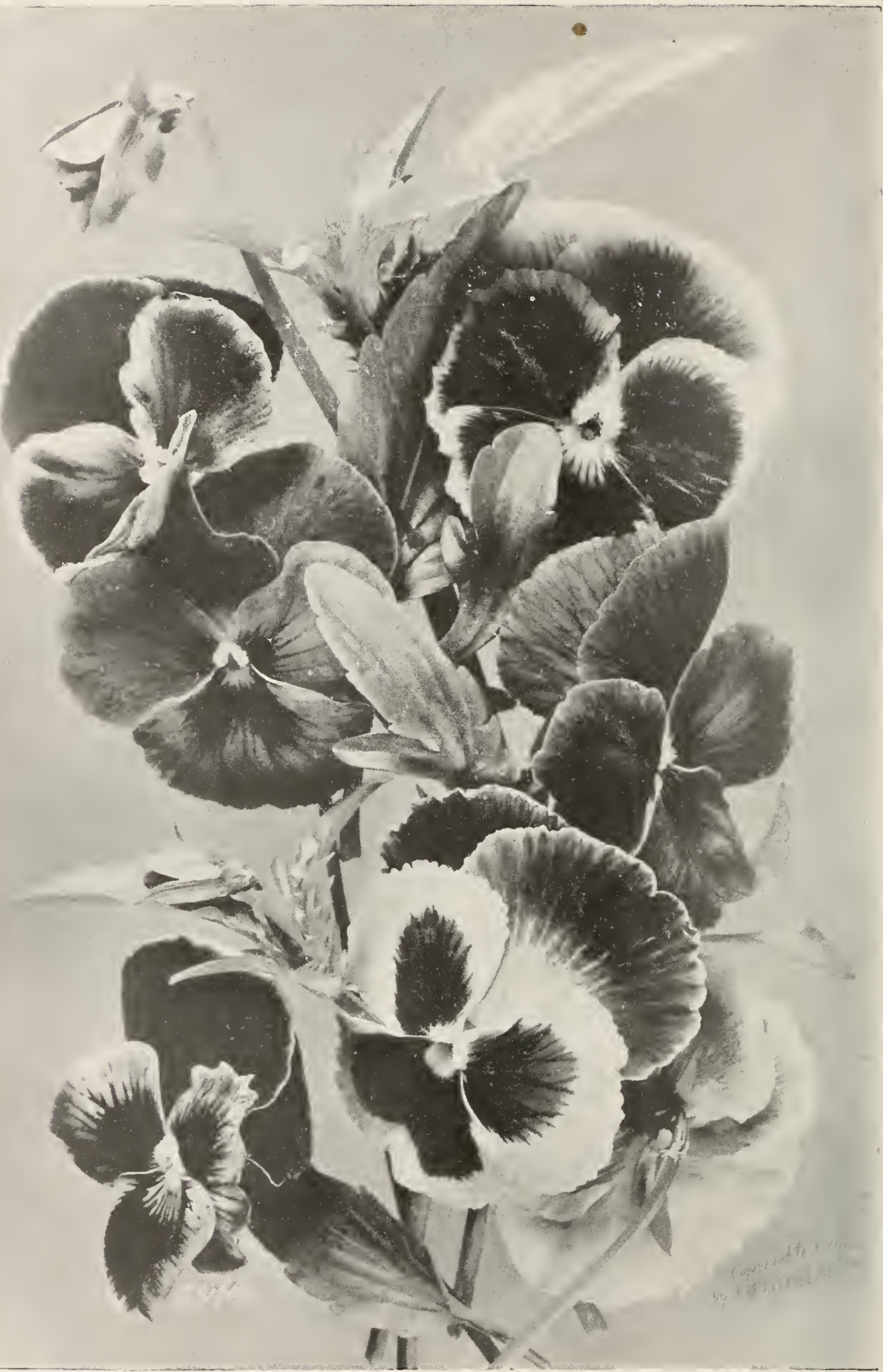

Plate XXII - Thorburn's Superb MiXed Pansies 


\title{
LOBB'S AND OTHER NASTURTIUMS
}

\author{
(Tropcolum Lobbianum, Etc.)
}

TROPAOLUM LOBBIANUM. This class is remarkable for the intensely brilliant colors of its flowers, which are a trifle smaller than those of other sorts. In moderately rich soil they climb high and bloom brilliantly. Average height, 6 feet.

3272 Asa Gray. Yellowish white. . . . . . . . . . . . . . . . . per oz., $25 c$. pkt., 5

3273 fulgens. Dark scarlet . . . . . . . . . . . . . . . . . 6 $25 \mathrm{c} . . .5$

3275 Lucifer. Very dark scarlet . . . . . . . . . . . . . . . . . . . . 25c. . . 5

3276 Crown Prince of Prussia. Blood-red.................. . . . . . . 5

3277 Geant des Batailles. Sulphur and red . . . . . . . . . . . . . “ . 25c. . . 5

3279 Crystal Palace. Scarlet . . . . . . . . . . . . . . . . “ . 25c. . . 5

3280 Spitfire. Brilliant scarlet . . . . . . . . . . . . . . . . . “ “ 25c. . . 5

3282 Lily Schmidt. Scarlet . . . . . . . . . . . . . . . . . . “ . 25c. . . 5

3286 Finest Mixture . . . . . . . . . . . . . . . . . . . . . . . “ 20c. . . 5

3288 MADAME GUNTER HyBRIDS. A French strain noted for wide range of fine colors . oz., $25 \mathrm{c}$. . 5

GREENHOUSE PERENNIALS. Beautiful climbers for house decoration. Should be grown in pots.

3290 pentaphyllum. Orange and yellow

329I tricolor grandiflorum. Orange, purple and red-brown . . . . . . . . . . . . . . . . . 25

Collections, including 12 varieties Tropæolum Lobbianum . . . . . . . . . . . . . 50

6 ".................. 30

PANSY

(Viola tricolor, Heart's-ease. hA)

The Pansy is a plant that we all delight to grow in plentiful supply for flowers all the year. For very early outdoor bedding the seed is sown in fall, in a coldframe, or in rich, moist garden beds from which the plants can be transferred to a coldframe, setting them 2 or 3 inches apart each way, before severe winter weather begins. In spring three-fourths of them can be lifted out for bedding and the rest left to bloom in the frame. For winter bloom in the frame, set the plants about twice as far apart, and thin out half of them in spring. Cover the blooming plants with sashes, adding a covering of matting or straw in very cold weather. In mild weather remove the mats and tilt the sashes to admit light, heat and fresh air. In outdoor beds raised a few inches above the ground, with a mulch of dry leaves and some brush to hold them in place, Pansies will often winter nicely, and bloom until midsummer, when a relay of young, vigorous plants should be ready to replace them. Spring sowings should be made early, so as to secure good flowers during the early rains. Seeds sown in a cool, moist place in June and July, and well tended, will give good flowering plants for fall. If they come into bloom in the heat of summer the flowers may be small at first, but as the weather becomes cooler they will increase in size and beauty. Through summer heat the flowers are finer in a somewhat shaded place, but in almost any situation good Pansy seed will give fine flowers in spring and fall. Early fall sowings give the finest flowers. Average height, 6 inches. Our strains of Pansy seed cannot be surpassed in color and blooming qualities. The collections offered will give superb flowers in a great variety of beautiful colors.

3308 Azure-Blue. Very fine color . . . . . . . . . . . . . . . per oz., \$1.oo . pkt., ro

3309 Black-Blue. Dark velvety •. . . . . . . . . . . . “ 1.00... 10

33 Io Black (Faust, or King of the Blacks). Almost coal black . . . . . . . “ $\quad$ 1.25 . . . 10

33 II Bronze. Golden bronze . . . . . . . . . . . . . . . . " 1 1.25 . . . 10

3312 Bugnot Superb Blotched. An exceedingly large three-blotched strain, with upper petals finely lined; great diversity of finest colors . . . . . . . . per oz., \$7.00 . . 50

3315 Cassier, Finest Mixed. Flowers of grand size, beautifully spotted . . . . ‘ 5.00 . . 25

3316 Coquette de Poissy. Distinct mauve, shading almost to white on the upper petals . oz., \$1.50 . Io

3318 Dark Purple. Deep, rich color .................. “ 1.00 . 10

3319 " "Silver-Edged. Margins pure white . . . . . . . . . . . . " 1.25. 10

3320 Emperor William. Splendid; ultramarine-blue; very showy . . . . . . . . . . “ 1.25 . I0

3322 Fawn Color (Prince Bismarck). Quaint and pretty . . . . . . . . . . . . . . “ 1.00. 10

3323 Fire King. Golden yellow; upper petals purple . . . . . . . . . . . . . . . “ 1.50 . 10

3324 Gold-Margined. Splendid bright color . . . . . . . . . . . . . . . . . . “ 1.00. 10

3325 Light Blue. Lovely sky-blue . . . . . . . . . . . . . . . . . . . . . . . “ 1.00. 10

3326 Lord Beaconsfield. Deep purple-violet, shading to light blue . . . . . . . . . “ 1.25 . 10

3328 Meteor. Bright yellow and brown; attractively blotched and margined . . . . . “ 1.50 . I0

3329 Odier. Extra large; blotched; rich colors; Show Pansies . . . . . . . . . . “ " 5.00 . 25

3330 Peacock. Large, peacock-blue flowers, edged with white . . . . . . . . . . . “" 4.00 . 25

3332 President Carnot. Pure white petals, each with a deep blotch . . . . . . . . . “ 3.00 . 10

3334 Rainbow, or Pheasant's Eye (Quadricolor). Very fine strain. . . . . . . . . . “ 1.25 . 10

3335 Red, Fine Large English. All reds Mixed . . . . . . . . . . . . . . . . . . “ 1.25 . 10

3336 Red Riding Hood. Brilliant shades of red . . . . . . . . . . . . . . . . . . . 1.25. 10

3338 Snow Queen (candidissima). Pure satiny white . . . . . . . . . . . . “ 1.25 . 10

3339 Spotted on Yellow Ground. New extra-fine English strain . . . . . . . . . . “ 1.25 . 10

$334^{\circ}$ Tiger. Curiously striped and mottled .................... " 1.50. 10

TRIMARDEAU GIANT. This strain has remarkably large flowers, carried well above their leaves, and generally marked with large blotches; the plants are extra vigorous and compact.

3342 Trimardeau Giant White . . . . . . . . . . . . . per oz., \$3.00. 25

Yellow (Golden Crest) ............. " 3.00 . 
PANSY, continued

3344 Trimardeau Giant Striped $\ldots$.
3346

\section{PETUNIA HYBRIDA}

$(h h A)$

Once fairly started the Petunias grow almost as easily as weeds and furnish a glorious succession of bloom from early summer until frost. The Large-Flowered strains are very beautiful and of almost endless variety. Seed of the Double and Giant-Flowered Petunias is made expensive by the great amount of labor involved in hand-fertilization, and it is well to handle seed and tiny seedlings with some care. Sow in hotbed, coldframe, or in boxes of fine soil in the sunny windows of a warm room in April or May, and transplant about a foot apart in garden beds. Seed of the double varieties has not so much vitality as that of single sorts and needs a little more care in watering to be sure of germination. We have no better plants than the Petunias for beds and masses, borders, window-boxes, baskets and vases. They will grow in almost any soil and bloom profusely through long droughts. The newer varieties are of brilliant colors.

SINGLE LARGE-FLOWERED. These have flowers 4 or more inches across. Our strains are superb, and the collections offered contain only the finest varieties. Average height, $1 \frac{1}{2}$ feet.

3376 White. Clear paper-white flowers of unusual size . . . . . . . . . . . . . . pkt., ro

3377 intus aurea. Large, yellow-throated, crimson flowers . . . . . . . . . . . . . . . . 25

3378 Crimson Giant "Midnight." Great flowers of deepest crimson . . . . . . . . . . . . . . 25

3380 Purple. Royal in color and size . . . . . . . . . . . . . . . . . . . . 25

3382 Rose. A charming shade . . . . . . . . . . . . . . . . . . . . . 25

3383 The Rainbow. Of richest colors, with yellow, penciled throats . . . . . . . . . . . 50

3385 Ring of Emerald. Pink and crimson, bordered with green . . . . . . . . . . . . . . 50

3386 alba magnifica. A new variety, with large flowers of the clematis shape . . . . . . . . . 50

3388 superbissima. Grand flowers of various colors, with richly tigered throats . . . . . . . . . 50

3390 Thorburn Superb Giant. A strain of surpassing beauty, with flowers extremely large and deepthroated; some of them are exquisitely penciled and elegantly fringed . . . . . . 25

3392 Superb Single Mixed. Offers a grand variety of colors ... . . . . . . . . . . . 25

FRINGED LARGE-FLOWERING. These have deeply cut and fluted margins.

3394 White, "Snow Storm." Finest white in this section . . . . . . . . . . . . . . . 25

3395 Crimson .. . . . . . . . . . . . . . . . . . . . . . . . 25

3397 Titania. Beautiful velvety purple flowers with broad white margins . . . . . . . . . . . 50

3398 Ruffled Giants. Extra large flowers, beautifully ruffled, fluted and fringed . . . . . . . . . 50

3399 THORBuRN's CENTURy PRIzE. An unrivaled strain of fringed, ruffled, giant-flowered sorts in most beautiful colors, now first offered . . . . . . . . . . . . . . . . 50

3400 Mixed . . . . . . . . . . . . . . . . . . . . . . . . . 25

3402 Perfection. Choicest fringed sorts. . . . . . . . . . . . . . . . . . . . 50

DOUBLE LARGE-FLOWERING. Our seed will produce flowers large, fragrant, elegantly formed and

beautiful either for house, garden or conservatory. The Double Petunias are great favorites for pot culture in ordinary windows.

3404 Double Mixed . . . . . . . . . . . . . . . . . . . . . . . 50

3405 " Fringed Mixed. Flowers large and much beruffled; very choice . . . . . . . . 75

3407 " " " $"$ Lady of the Lake. Exquisite flowers of finest size and purest white. . . . 75

3409 " " Snowball. Pure white; extremely double................ 75

SINGLE BEDDING VARIETIES. Smaller-flowered sorts, found most valuable for beds and masses.

3415 Countess of Ellesmere. Dark rose, with fine white throat . . . . . . . . . . . . . ro

34 I6 Inimitable Dwarf. Bushy little plants, covered with masses of star-shaped flowers; 5 to 8 ins. . ro

3417 venosa. Variously colored; beautifully veined . . . . . . . . . . . . . . . 10

3422 Mixed Single. Very fine colors, striped and blotched . . . . . . . per oz., \$1.25. 5

Collections of Petunias. These contain only the finest varieties.

12 varieties Single Large-Flowering . . . . . \$ I oo 6 varieties Double Fringed . ... . . . . 80

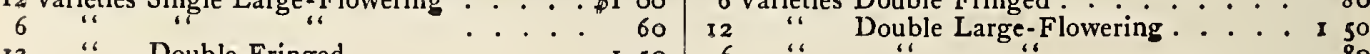

12 " Double Fringed . . . . . . . . I $50 \mid 60$ " 6 " " . . . 80 


\title{
PHLOX DRUMMONDII, ETC.
}

\author{
(Flame Flower)
}

The annual Phloxes are dazzling in effect, particularly so when sown in masses or ribbon beds of contrasting colors. Few flowers are so easy to grow from seed, so pretty and compact in habit, so quick to bloom, or give such a brilliant display of color for so little cost and care. There are few desirable colors beyond their range, and if given good soil and plenty of water they furnish a long supply of delicate flowers for cutting. For pot culture, as trailers, and as an undergrowth for tall, bare-stemmed plants they are also valuable. The first sowings should be made as soon as the frost is out of the ground in spring; later ones in May, either where the plants are to bloom, or on a seed-bed, as the Phlox transplants readily. In transplanting set the taller kinds about a foot apart; if planted too thickly they suffer from mildew. Cutting away the flowers and seed-pods makes the plants more bushy and compact, and lengthens their blooming time. Average height, I foot.

3428 atropurpurea striata. Dark purple, with white stripe.... * * pkt., 5

3429 Black Warrior. Deep dark red . . 5 3430 variabilis atropurpurea. Purple of various shades ....... 5

3431 Leopoldi. White and crimson... 5

3432 Radowitzii. Pure white ...... 5

3433 rosea. Delicate rose ...... 5

3434 oculata alba. White and lilac... 5

3436 coccinea. Blazing scarlet; very effective. 5

3437 cuspidata (Star of Quedlinburg). Starshaped flowers in many colors; forms a lace-like cluster . . per oz., \$1 . ro

$344^{\circ}$ Mixed. All colors ... " 50c. . 5 DWARF VARIETIES. Plants of this charming section grow only 6 or 8 inches high, and form dense masses of bloom all summer. They are especially useful for beds, edgings, pots, etc.

3442 Surprise. Last year's novelty. Brilliant vermilion flowers with pure white star center; splendid for groups and edgings........ pkt., 25

3443 Snowball. Pure white...... 10 3444 Fireball. Bright flame-red .... . 10 3446 Fancy Mixed .... per oz., \$2 . I0
GRANDIFLORA. This section has beautiful, roundpetaled fowers, larger than in the older sorts. Showy and constant. 3450 Chamois Rose. A soft shade . pkt., 10 3451 Eclipse. Rosy violet, blue-veined . . to 3452 Half-Dwarf Blood-Red. Dark, velvety "red; only 9 inches high . Io 3453 " “ Crimson Bouquet. Rich . Io 3454 " " Black-Brown. Dark . . 10 3456 coccinea. Large brilliant scarlet . . 10 3457 alba. Pure white ....... 10 3459 kermesina. Vivid crimson; one of the best sorts for masses..... 10

3460 splendens. Scarlet and white . . . 10 3462 stellata splendens. Large, star-like crimson flowers ....... 10

3464 Mixed. Various large - flowering sorts . . . . per oz., 75c. . 10

PERENNIAL PHLOXES. These hardy Phloxes make large bushes about 3 feet high and bear large heads of finely colored flowers.

3470 Phlox decussata, Mixed . . . pkt., 10 347 Large-Flowered White Perennial. Splendid strain ...... 25

3472 Large-Flowering Hybrids Mixed . . 25 Collection, including-

10 varieties Phlox Drummondii ..... 50

\section{PIN K}

(Dianthus)

In this large and greatly varied genus are some of our most beautiful and best-loved flowers, unsurpassable for color and fragrance. They are hardy biennials that bloom finely the first season, remaining green all winter and blooming the next year also, if lightly protected. Old plants flower the earliest, but as young ones give the largest, finest flowers, sowings are made every year. Seed can be sown under glass in spring, or in an open sheltered bed. The seedlings are easily transplanted and should stand 8 to 12 inches apart; dwarf ones about 6 inches. If especially large, brilliant flowers are desired, a bed of wellmixed turfy loam, leaf-mould and well-decayed manure should be prepared for them. Average height, I foot.

3478 Dianthus dentosus hybridus. Pretty lilac flowers . . . . . . . . . . . . . pkt., 5

3479 superbus, Dwarf Double White. Very double, snowy flowers, of fine form and size; 9 in. . . 5 CHINENSIS (China, or Indian Pinks). The flowers of all are double and showy.

3482 Double White China Pink . . . . . . . . . . . . . . . . . . . . 5

3483 " Dark Red China Pink. A rich, constant color .................. . . . . . .

$34^{84}$ “ Mixed China Pink. All best colors . . . . . . . . . . . per oz., 40c. . . 5

HEDDEWIGII (Japan Pinks). Unusually large and brilliant; often oddly edged, striped and ringed.

3486 Single Mixed . . . . . . . . . . . . . . . . . per oz., $75 \mathrm{c} .$. . 5

3487 "Queen of Holland. Splendid pure white Japan Pink introduced two years ago . . 10

3488 " Eastern Queen. Rose-colored flowers, 2 to 4 inches across; splendidly striped and stained. 10

3489 "Crimson Belle. Flowers large and handsome; dark red . . . . . . . . . . . . . 10

3491 Double Mixed . . . . . . . . . . . . . . . . . . per oz., 75c. . . 10

3492 " "Mourning Pink." Very large, double flowers of blackish crimson, fringed white . . . 10

3494 " diadematus (Diadem Pink). Magnificent in color and variety . . . per oz., \$1.25 . . 10

3495 laciniatus, Salmon Queen. Beautiful rosy salmon; single .............. . 10

3496 " Oriental Beauty. Petals wide, crinkled, richly marked with pink, white, etc. . . 10

3498 " " Single Mixed. Fringed flowers of all colors . . . . . . . per oz., 75c. . 5

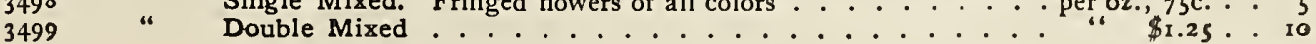




\section{PINK, continued}

IMPERIALIS, FL. PL. (Double Imperial Pink). Robust, bushy growers, with large, double flowers. 3502 Double Mixed ". A . . · . . . . . . . . . per oz., 5oc. . pkt., 5

3503 " Dark Red. A deep, rich color . . . . . . . . . . . . . . . . . . . 5

3504 “ Dwarf White. Great snowy flowers; 9 in. . . . . . . . . . . . . . . . 5

3505 " " Mixed . . . . . . . . . . . . . . per oz., 50c. . . 5

PLUMARIUS (Sweet May Pinks). These are the fine, fragrant perennials of old-time gardens, still reckoned among the most beautiful of all Pinks for massing and cutting.

3507 Pheasant's Eye. Pretty fringed flowers . . . . . . . . . . . . . . . . . . . . . . . . 5

3508 Scoticus (Double Scotch Pink). A new series of exquisite colors; ours is the very finest strain . 25

3509 semperflorens (Perpetual Pink). Double, semi-double and single; of various colors; fragrant io

35 ro Single Pink, Mixed . . . . . . . . . . . . . . . . . per oz., 40c. . . . 10

35 II Double and Semi-Double Grass Pinks. Pretty flowers of delicate colors . . . . . . . . . Io Collections of Pinks, including 12 varieties Fine China . . . . . . . . . . . . . 50 “.

\section{POPPY}

\section{(Papaver)}

Before tulips are fairly gone our gardens begin to be gay with Poppies, which, in some one or other of their many forms, continue to enliven it with a profusion of bright blooms until frost. No other flower so bold and brilliant has the same grace of stem, airiness of poise, and delicacy of tissue. For beds and borders with a background of green, there is nothing finer; some sorts are admirable for naturalizing in open wooded grounds; others, like the Shirley, are beautiful for cutting. A sandy loam suits Poppies best, and as their strong tap-roots are difficult to transplant, it is well to sow seed where the plants are to bloom. Sowings made in fall and at intervals in spring will provide a long succession of flowers. Sow thinly, covering very lightly, as the seed is quite small, and thin the plants to stand about a foot apart. The best plants are those grown from early sowings while the earth is cool and moist.

PERENNIAL VARIETIES. Tall, large-flowered and showy; effective among shrubbery. Average height, 2 to 4 feet.

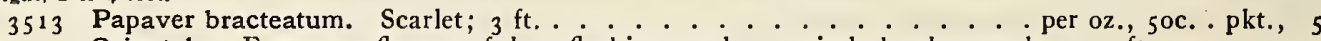

$35^{1} 4$ Orientale. Enormous flowers of deep flashing scarlet; entirely hardy anywhere; $3 \mathrm{ft}$. . . . IO

3515 Thorburn Giant White. White flowers of grand form and size; 3 to $4 \mathrm{ft} . . . . . . . .10$

3516 Maid of the Mist. Pure white, single, very large, deeply fringed; 3 to $4 \mathrm{ft}$. . . . . . . .

35 I 7 nudicaule (Iceland Poppy). These dwarf, bright yellow Poppies form one of the chief attractions of the garden through several months. They are most beautiful when grown in masses from seed sown early every year; $\mathbf{x t . ~ . ~ . ~ . ~ . ~ . ~ . ~ . ~ . ~ . ~ . ~ . ~ r o ~}$

3518 " aurantiacum. Orange. All this class has crimped petals and peculiar grace . . . 10

3519 " album. Pure white . . . . . . . . . . . . . . . . . . . 10

3520 " Mixed Iceland Poppies . . . . . . . . . . . . per oz., 75c. . xo

ANNUAL VARIETIES. This section includes double and single flowers of greatly varying sizes, self-

colored and daintily edged. All are easily cultivated and greatly admired. Average height, $\mathrm{I}^{1 / 2}$ feet.

3524 Mephisto. Beautifully fringed; varies from red and black to rose and white . . . . . . . 5

3525 Flag of Truce. Pure white, large and showy flowers . . . . . . . . per oz., 75c. . . Io

3526 Shirley. Indescribably bright, dainty and gauzy; a favorite for cutting . . " $75 \mathrm{c}$. . xo

3528 glaucum ( $T$ ulip Poppy). Striking, tulip-shaped flowers of intensely brilliant scarlet; dwarf . xo

3529 pavonium (Peacock Poppy). Intense scarlet, with broad bands of purplish black . . . . . 5

3530 umbrosum. Rich crimson, spotted with black . . . . . . . . . . . . . . . . . . 5

353 I lævigatum. Scarlet, with white marks at petal bases; very showy . . . . . . . . . . . . . xo

3533 Danebrog. Large, single, scarlet, with white cross at base of petals . . . . . . . . . 5

3535 Double White . . . . . . . . . . . . . . . . per oz, 25c. . 5

3536 " Scarlet . . . . . . . . . . . . . . . . . ." " 25c... 5

3537 " Mikado. Large white flowers, attractively fringed with rose . . . “ 25c. . 5

$353^{8}$ "Cardinal. The immense scarlet flowers last unusually well . . . . . . . . xo

3539 " American Flag. White, bordered with scarlet .................. . IO

$354^{\circ}$ " Carnation-Flowered. Very double, fringed, colors dazzling . . . . per oz., 20c. . . 5

3541 " Pæony-Flowered. Large, handsome flowers of many colors . . . " " 20c. . . 5

3542 " Ranunculus-Flowered. Flowers small, finely formed, double . . . " 3 oc. . . 5

Collections of Poppies, including-

12 varieties Double Carnation-Flowered ... . 50|6 varieties Double Dwarf Pæony-Flowered . . 30

12 "Double Pæony-Flowered ..... 50 6 ". Ranunculus-Flowered ..... 30

\section{PORTULACA}

This charming little annual is unrivaled for brilliancy among plants of low growth, and has the happy faculty of flourishing under almost all conditions, though hot sun and a light sandy soil suit it best. Nothing is prettier for beds, edgings, rockwork, and for filling up irregular spaces or unexpected gaps in flower beds. As an undergrowth for taller plants it is also valuable. Through the driest, hottest seasons it flourishes amazingly, carpeting the ground with a mat of succulent foliage that in the forenoon is hidden 


\section{PORTULACA, continued}

by gayest flowers. The seed does not germinate until hot weather, and should be sown late. Beyond the sowing, this plant requires little care; it can be transplanted in full flower. Average height, 6 inches.

SINGLE VARIETIES. Each strong plant will cover a space about 2 feet in diameter.

3546 splendens. Crimson ..... . pkt., 5

3547 Rose Carnation-Striped . . . . . . 5

3548 Thellusonii. Scarlet . . . . . . 5

3549 albiflora. Pure white . . . . . . . 5

3550 aurea. Deep golden yellow ..... 5

355 I Thorburni. Beautiful bright yellow . 5

3552 rosea. Rich rose . . . . . . . 5

3554 Mixed . . . . per oz., 50c.. . 5

DOUBLE VARIETIES. The flowers are so full and perfect as to resemble tiny roses; toward the close of the season they will increase in size and beauty. A few plants will usually revert to the single type, but these bloom earlier than the double sorts and can be weeded out before the latter begin to open.

3556 Double Scarlet . . . . . . pkt., I 5
DOUBLE VARIETIES, continued

3557 Double Salmon ..... . . . pkt., is

$355^{8}$ " Yellow . . . . . . . . . I5

3559 " Orange . . . . . . . . I5

3560 " Bright Rose... . . . . I

356 I " Bright Red . . . . . . . I 5

3562 " Carnation-Striped . . . . I I5

3563 " Rose . . . . . . . . . I 5

3564 "Golden ".......... I5

3565 "White . . . . . . . I5

3566 "New French White..... 25

3567 "

3570 " Mixed . . . per oz., $\$ 5$. . 10

Collections, including-

12 varieties Portulaca, single ........60 60

6 " 6 double........ . . 60

\section{R I C I N US}

\section{(Castor-Oil Plant)}

Picturesquely showy and imposing, the Ricinus gives to the garden magnificent semi-tropical effects, and may be used in a variety of ways. Grown as a specimen, it makes a perfect pyramid of gigantic leaves; a dozen plants in a large bed show a glorious mound of glistening colors and may be admired from a long distance; planted thickly it soon forms a handsome screen or hedge; the lower-growing, darkleaved sorts are beautiful for dotting here and there among Cannas, scarlet Pelargoniums, etc. Tall varieties grow from 8 to 10 feet high, with leaves several feet across and beautifully lobed. Half-hardy annuals.

3574

3575

3576

3577

3578

3579

3580

3581
Borboniensis. Violet; ro ft. . . . . .

Africanus. Bright colors; $8 \mathrm{ft}$. . . 5

Gibsoni. Violet-bronze; $5 \mathrm{ft}$. . . 5

macrophyllus. Dark purple; $6 \mathrm{ft}$. . 5

Cambodgensis. Leaves glistening redmaroon; stems nearly black; $5 \mathrm{ft}$. ... . . . per oz., 4oc. . .

macrocarpus. Deep purple; $5 \mathrm{ft}$. . . 5 Philippinensis. Immense leaves; $6 \mathrm{ft}$. 5 purpureus. Rich purple
$35^{82}$ sanguineus. Red stems and seeds; $6 \mathrm{ft}$..pkt., 5

3583 Zanzibariensis. Surpasses all in size and beauty of colors, which include glaucous-green, coppery brown, metallic red, brownish purple, red-maroon and bronze; 8 to so ft. . . . per oz., 50c. . ro

3584 cœruleus. Blue stems and seeds; $6 \mathrm{ft}$. . 5

$35^{88}$ Mixed ........ . per oz., 15c. . 5

Collections, including-

12 varieties Ricinus, choicest sorts . . . . . . 50

\section{SA L V I A}

\section{(Flowering Sage)}

The Salvia is a standard bedding plant that keeps the garden bright with color until late in autumn. For pot culture, for cutting, for borders, and for forming bushy, hedge-like lines in the garden it is very valuable. Sow seed in window-boxes or frames, in March or April, and set the plants outdoors after danger of frost is past; or sow outdoors in May. The plants grow and bloom profusely in any light, rich soil. Both the tender and hardy perennial sorts bloom the first year and all are treated as annuals.

3592 argentea. Silvery leaved; flowers white; blooms in spring; $3 \mathrm{ft}$. . . . . . . . . . pkt., 5

3593 farinacea $(\mathrm{hA})$. Light blue flowers in great abundance; forms a neat bush; $3 \mathrm{ft} . . . . . .5$

3594 patens. A handsome tender perennial, with erect spikes of superb rich blue flowers in summer; beautiful for pots or borders; $3 \mathrm{ft}$. . . . . . . . . . . . . . 25

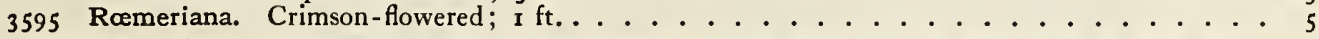

SPLENDENS. These are the well-known bedders, single plants of which carry hundreds of long, flaming fower-spikes open at one time, keeping up the display until frost.

3597 splendens, Scarlet. Best known; a rich-flowered bedder; $2 \mathrm{ft}$. . . . . . per oz., \$1.50 . . 10

3598

3599

3600

“

3601

3602

3603

3604
Tall Dark Scarlet. A splendid new strain, with rich dark leaves and large flowers of intense scarlet, standing in a mass, bouquet-like, above them; $2 \mathrm{ft} . . . .25$ grandiflora pendula. Very large, velvety scarlet flowers; $1 / 2 \mathrm{ft} . \ldots . . . . .$. Io Dwarf Dark Rose. A distinct and lovely new sort, with erect flower-spikes of dark rose-color; dwarf and compact; comes true . . . . . . . . . . . . . . . compacta erecta "Bonfire." Our well-known dwarf Salvia-the neatest, freestblooming of all, seemingly on fire all the time with dense, flaming scarlet spikes 2

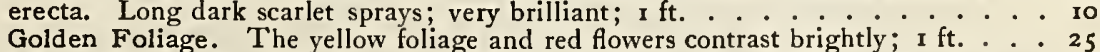
"Silverspot." A striking new variety originated by us, with rich green leaves elegantly spotted with yellow. The intense bright scarlet flowers are large and lavishly borne; the habit of the plant is neat and compact. . . . . . 25 


\section{SNAPDRAGON}

(Ansirrhtnum)

The Snapdragon is one of our finest border perennials. Its bright-colored, curiously formed flowers always excite interest, and among the newer sorts are flowers of a great variety of colors and markings, some of wonderful brilliancy, others soft and pleasingly shaded, and still others with a velvety appearance. Their rich spikes are beautiful for cutting, and keep fresh a long time. From seed sown in the open ground plants will bloom in July and August. For early flowers sow under glass in February or March and transplant into beds of warm, dry soil moderately enriched. If protected by a coldframe, or even a mulch of leaves, the plants will winter over and bloom early the following year. Now, however, most perennials and biennials which bloom the first year, and of which any particular display is desired, are treated like annuals and sown every year. The Snapdragon blooms freely and continually until frost. Average height, $11 / 2$ feet.

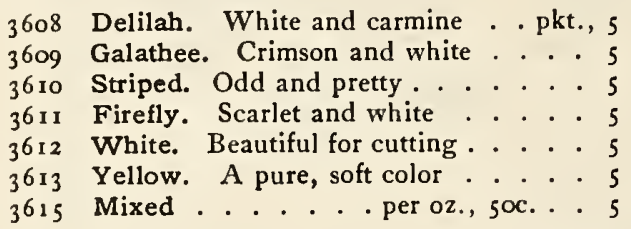

DWARF VARIETIES. Plants of this section make elegant bedders, as they bloom extra profusely and are only about 6 inches bigh.

3617 Fine Dwarf Mixed . peroz., 5oc. pkt., 5

3618 Tom Thumb Mixed. . per oz., $\$ 1$. . S Collections, including-

12 varieties Snapdragon, Finest Tall . . . . . 50

\section{STOCKS}

(Mathiola)

From the general make-up of the great Stock family no desirable quality seems to have been omitted. The plants have good habit, fine leaves, beautiful and fragrant flowers in all refined colors, a long seaşon of lavish bloom, vigor, and adaptability to many conditions of culture. Such plants naturally have many uses: we find them unsurpassed for bedding, edgings, pot culture, house or conservatory decoration, and for cutting. For bouquets and floral work the double white sorts are especially useful. To secure fine early flowers, sow under glass in March or April, transplanting the seedlings when an inch high into other pots or boxes, or into fine soil spread over some discarded hotbed. In showery May weather transfer to garden beds of deep, rich soil, setting the plants about a foot apart. Transplanting several times in the early stages of growth tends to give them a more dwarf and compact habit. For later flowers sowings may be made in the open ground in May. If plants that began to bloom late are carefully lifted and potted in fall they will flower finely all winter in a house that is tolerably cool and moist. The blossoms are very lasting, and the side-shoots, with their succession of flowers, greatly lengthen the blooming season. Average height, $x$ to $1 / 2$ feet.

GERMAN TEN WEEKS. These are the favorite half-hardy annuals, all the more prominent qualities of which have been given above. Our seeds are saved from the choicest double varieties.

3622 Dwarf Snowflake Forcing. Flowers pure white, unusually large and double; extremely early . . pkt., 25

3623 White Dresden Perpetual. Robust, branching; flowers large, pure white, in fine rosette shape . . 25

3624 "Cut-and-Come-Again." The wellknown profuse and perpetualblooming double white variety . . Io

DWARF LARGE-FLOWERING. LONg, splendid spikes of very large double flowers.

3626 - White . . per oz., $\$ 4$. pkt., 10

3627 - Canary Yellow ...... 10

3628 - Crimson . . . per oz., \$4 . 10

3629 - Chestnut. Red-brown .... 10

3630 - -Blood-Red. Very rich ..... I

3631 - -Carmine . . . . . . . . . 10

3632 - -Rose. Very dainty ...... . 10

3633 - - Light Blue. Exquisite . oz., $\$ 4$. Io

3634 - - Shining Purple-Carmine ... . 10

3635 - -Mixed ..... per oz., \$3. . 10

GIANT PERFEction. Tall, handsome; spikes large; flowers rose-like.
GERMAN TEN WEEKS, continued

WALLFLOWER-LEAVED. The popular cut-flower variety, with flowers of clearest possible colors, and dark glossy leaves.

3642 - -Wbite....... pkt., 10

3643 - Crimson ......... 10

3644 - - Mixed ..... per oz., $\$ 4$. . 10

3646 DWARF GERMAN BOUQUET MIXED. Flower-spikes thickly massed above the leaves; $x \mathrm{ft}$. . . per oz., $\$ 3$. Io

EMPEROR LARGE-FLOWERING. SOW in spring for autumn and winter flowers; sow in midsummer for abundant spring bloom. Very handsome.

3648 - -White ......... 25

3649 -Crimson ....... 25

3650 - Mixed ......... 25

AUTUMNAL and LATE-FLOWERING SORTS.

From seed sown in spring and summer these half-hardy biennials begin to bloom in fall and will keep up the display all winter and late into spring if transferred to cool, airy quarters in house or greenhouse. Usually the plants are wintered over in a frame for a greenhouse. insually the pow many colorg as the Ten Weekg, but are larger and carried on longer, bolder spikes.

3652 Dwarf Crimson Bouquet Winter. Bright flowers thickly massed above pretty dwarf plants; makes fine edgings; 9 in. . . . pkt, 25 


\section{STOCKS, continued}

AUTUMNAL AND LATE-FLOWERING SORTS, continucd 3654 INTERMEDIATE White . . . pkt., 25 3655

3656 warm color... 25 Warm color.
ch flowered; beautiful for house-culture if not kept too warm and dry.

3658

3659
3660 BROMPTON, Empress Elizabeth. Splendid carmine-rose ; dwarf; for pots and groups. Introduced last year . . pkt., 25 3661 " Mixed Winter..... . 25 3663 QueEN Purple. Royal purple . . . . 5 3664 " White........... 5 3665 " Scarlet . . . . . . . . . 5 3666 " Mixed . . . . . . . . 5

\section{CHOICE COLLECTIONS OF STOCKS}

We invite special attention to the collections here offered; they contain only the very choicest varieties.

\section{GERMAN TEN WEEKS}

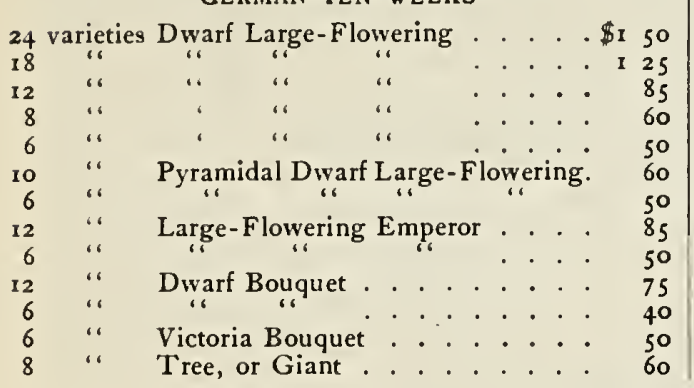

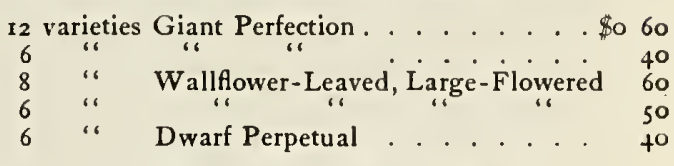

AUTUMNAL AND WINTER, ETC.

8 varieties Intermediate German . . . . . .\$0 60

6 " " " . . . . 50

East Lothian Autumn . . . . . . 40

Fine Winter . . . . . . . . 80

"Dwarf Bouquet Winter . . . . .

Cocardeau Winter....... . . so

\section{SUNFLOWER}

(Helianthus)

Very stately decorative plants with great masses of yellow flowers. A few plants of the tall sorts can be placed here and there throughout the grounds with telling effect; it is the gardener's art to know how to locate them. Their golden yellow disks are like sunbursts among the shrubbery, and for backgrounds and screens nothing could be finer. Their long stems and wonderful lasting qualities also make them valuable as cut-flowers. Like the Eucalyptus, they are said to be good for absorbing the miasma of low grounds. Plant the seed in the open garden in spring, and thin the plants to stand 3 or 4 feet apart. The height of the different varieties varies greatly; all those below are hardy annuals except $H$. strumosus.

3670 Single Russian. Giant-flowered; 5 to $8 \mathrm{ft}$. . . . . . . . . . . . . . . per oz., roc. pkt. 5

3671 "" "Henry Wilde." Tall, small-flowered, graceful . . . . . . " per., 15c. . . . 5

3672 " Primrose-Colored. Graceful flowers of a lovely color; beautiful for cutting . oz., 2oc. . 5

3674 macrophyllus giganteus. Huge leaves and yellow flowers; $5 \mathrm{ft}$. . . . . . . . "15c. . 10

3675 cucumerifolius (Miniature Sunfower). Of pyramidal growth; covered with hundreds of bright

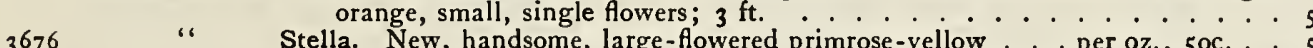

3677 " $\quad$ Orion. A very handsome new variety, with petals twisted like those of the best cactus-shaped Dahlias; excellent for cutting ..... . per oz., $75 \mathrm{c}$. . 10

3679 argyrophyllus ( $\mathcal{T}$ exas Silver Queen). Has handsome silvery foliage and a profusion of small, elegant single flowers; $4 \mathrm{ft}$. ................ per oz., 20c. . . 5

3680 Double California. Dark yellow; 2 to $5 \mathrm{ft}$. . . . . . . . . . . . . . . . " I $5 \mathrm{c}$. . . 5

3681 "Globe-Flowered. Ball-shaped; blooms late; 3 ft. . . . . . . . . . " $15 \mathrm{c} . .25$

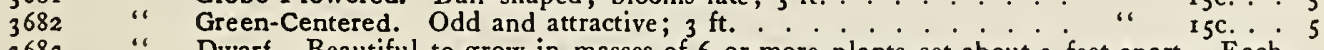

3683 " Dwarf. Beautiful to grow in masses of 6 or more plants set about 3 feet apart. Each stem is tipped with a fine dahlia-like flower, 3 inches across, and of brightest golden yellow; $2 \mathrm{t} / 2 \mathrm{ft}$.................. per oz., $15 \mathrm{c}$. . . 5 “ Dwarf Variegated. Leaves beautifully spotted with yellow . . . . . . . . . . . . . 5

3686 strumosus. A hardy perennial, with rich yellow flowers and downy leaves; $6 \mathrm{ft} . \quad . . . . .10$

\section{CHENOPODIUM}

3690 atropurpureum. A new and rare very ornamental bedding plant on the style of tall Amaranthus, with dark red leaves and imposing habit. . . . . . . . . . . . . . . pkt., 10

\section{HIBISCUS}

Two rare sorts omitted from our general list on page 88.

3692 Californicus. A hardy herbaceous perennial worthy of special notice. It has large yellow flowers with deep red center, and is very handsome and striking . . . . . . . . pkt., ro

3693 grandiflorus. (T rue, not moscheutos.) Large, rosy, dark-centered fiowers 7 to 8 inches wide . Io 


\title{
SWEET PEAS
}

\author{
(Lathyrus odoratus)
}

Through the skill of specialists the Sweet Pea has become a much larger and lovelier flower than before it took such a strong hold on popular fancy. The plants are more robust, dwarf, branching, and bloom earlier and more freely, some varieties showing 3 to 4 blooms on a stem. Many new colors, deep, dark, brilliant and delicately lovely, have appeared in the blossoms, often in combinations exquisite and indescribable. There are flowers, too, of quite distinct shapes, some of which are a great improvement upon the Sweet Pea of the old type.

A deep, rich moist soil is best suited to Sweet Peas. They are usually grown in double rows, with a wire trellis, or a row of brush between. For each double row make the drills about 5 inches deep and 9 or ro inches apart. Sow plentifully, covering about 2 inches deep, and by degrees, as the vines grow up, fill the trenches with soil. Spring sowings should be made just as early as the ground can be prepared; frost does not hurt the little seedlings. The earliest flowers are from seed sown in fall, preferably in a dry situation, and 4 or 5 inches deep, giving them level culture.

\section{THORBURN'S SELECTED SWEET PEAS}

\section{ASSORTMENTS CONTAINING-}

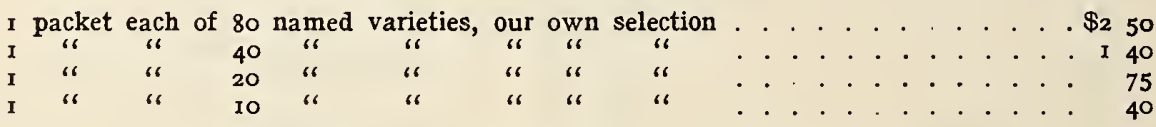

\section{EIGHTY NAMED VARIETIES}

all five cents per packet

Pright Peroz. Per $1 / 4 \mathrm{lb}$. Per lb.

..... \$O IO \$O $20 \$ 060$

3702 Apple Blossom. Bright pink and blush, beautifully shaded . . . . . . . . Io 20 I0

3703 Aurora. Flowers extra large; standard and wings flaked and striped bright orange-salmon on white ground ................ Black Knight. Deep maroon self-color . . . . . . . . . . . . . . . . .

Blanche Ferry, Extra-Early. Pink and white; ten days earlier than the ordinary sort . . . . . . . . . . . . . . . . . . . . Blushing Beauty. Soft pink, suffused with lilac; extra large . . . . . . .

Boreatton. Crimson-purple; very dark, large flowers

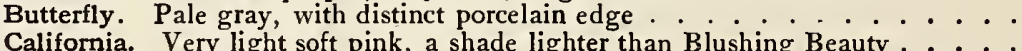

Captain of the Blues. Bright purple and pale blue . . . . . . . . . .

Captivation. Light magenta, self-colored . . . . . . . . . . . . .

Chancellor. Bright orange-pink . . . . . . . . . . . . . .

Coquette. Deep primrose, shaded fawn . . . . . . . . . . . . . . .

Countess of Cadogan. Reddish mauve standard; wings violet-blue; new . .

Countess of Radnor. Standard delicate lavender, wings dark mauve; lovely

Countess of Powis. Orange, suffused with light purple

Countess of Shrewsbury. White wings, rose standard; very beautiful . . . .

Crown Jewel. Creamy white, veined with violet-rose............

Cupid, White. Dwarf white; fine for pots inside. . . . . . . . . . . . .

" Pink. Like the above, but pink color . . . . . . . . . . . .

" Alice Eckford. Cream-tinted cerise standard; white wings . . . . . .

" Beauty. White, shaded and edged light pink . . . . . . . . .

" Primrose. Light primrose-yellow blossoms; same as tall Primrose...

Dorothy Tennant. Standard rosy mauve ; wings bluish mauve . . . . . . .

Duke of York. Bright rosy pink standard; primrose wings, tinted white . . .

Duke of Clarence. Rosy claret; self-colored flowers; extra large . . . . . .

Duke of Sutherland. Purplish maroon standard, indigo-blue wings... . . .

Duke of Westminster. Standard rosy maroon; wings violet-purple; new . . .

Earliest of All. Blossoms like Extra-Early Blanche Ferry, but earlier . . . .

Eliza Eckford. White, shaded and edged with light pink on standard ....

Emily Eckford. Porcelain-blue, suffused with reddish mauve . . . . . . . .

Emily Henderson. Splendid pure white; good for forcing . . . . . . . . . .

Emily Lynch. Rose-pink standard; wings light pink and primrose, hooded . .

Fashion. Light purplish carmine; a distinct color and very pretty; new. . .

Gray Friar. Beautiful grayish lavender, on white ground. . . . . . . .

Golden Gate. Lavender and pinkish lavender, blended and shaded . . . . . 


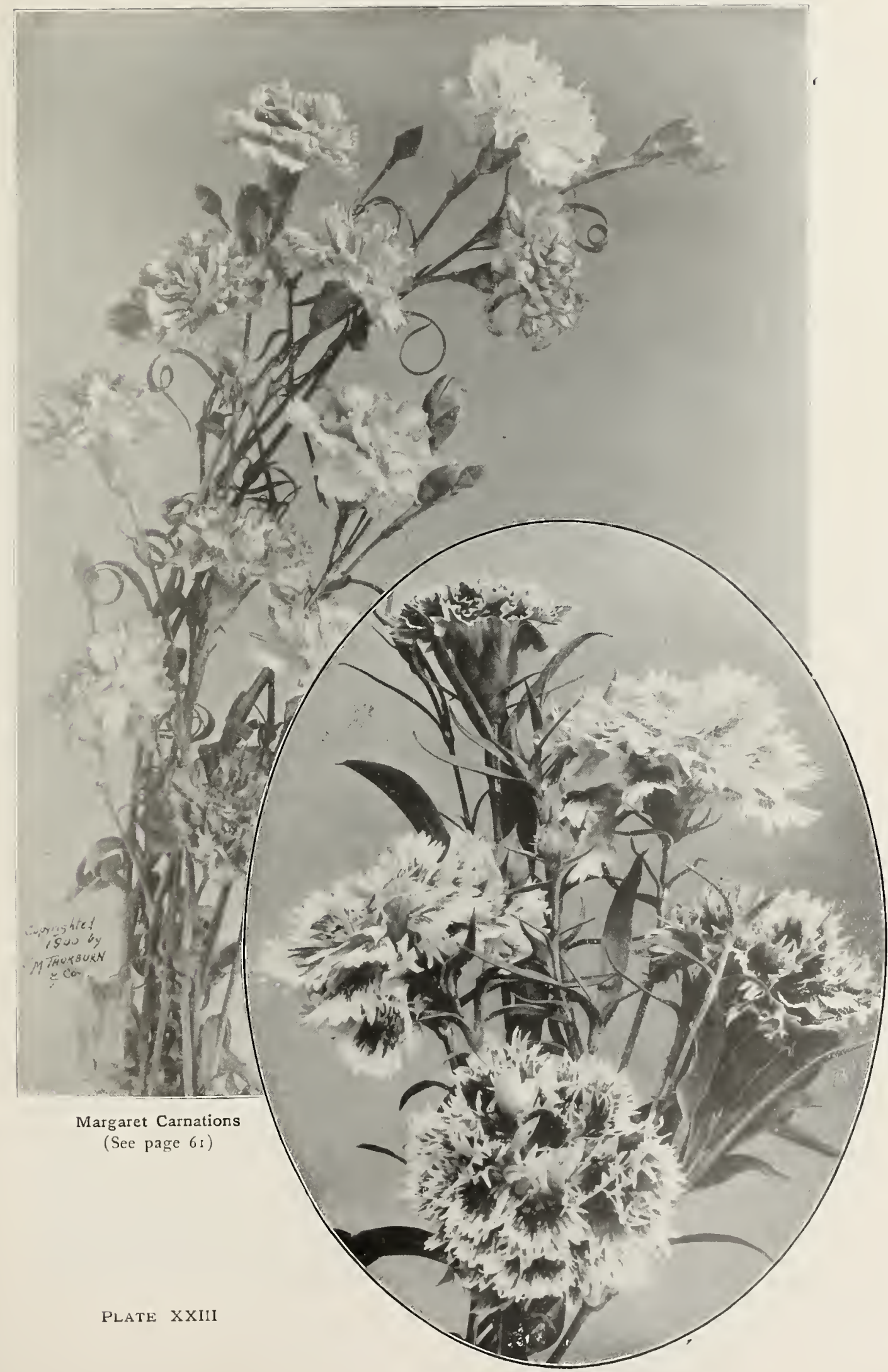

JAPAN PINKS (Dianthus Hedderutgii) (See page 71 ) 


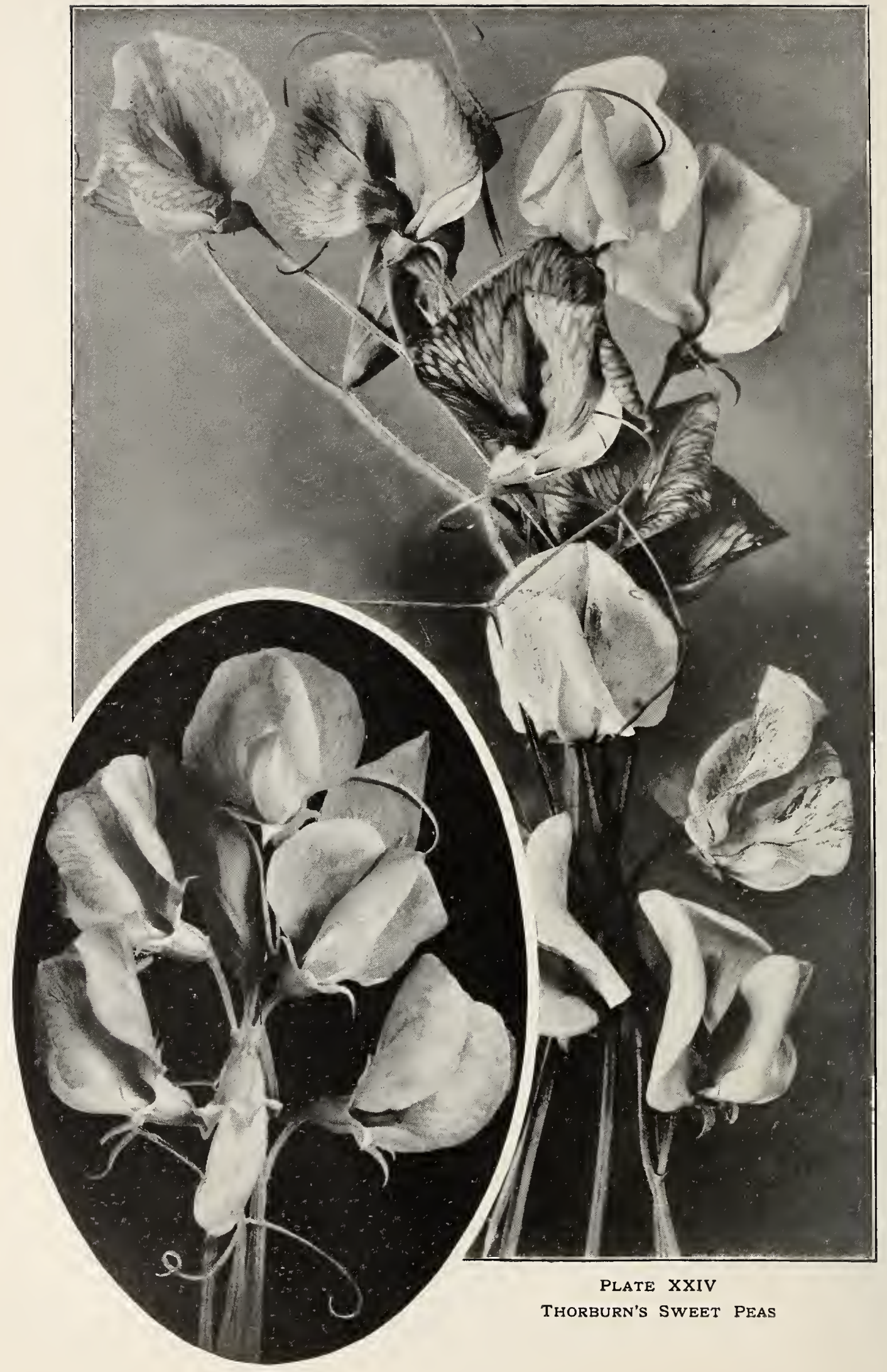


SWEET PEAS, NAMED VARIETIES, continued

3752 Her Majesty. Beautiful soft rosy pink; very large flowers.......... \$o Io \$o 20 \$o 50

3753 Hon. F. Bouverie. Standard flesh-pink; wings rosy buff; new . . . . . . . 15 I5 125

3754 Indigo King. Maroon-purple standard; indigo-blue wings. . . . . . . . IO

3755 Katherine Tracy. Soft, brilliant pink................. 10 20 60

$375^{8}$ Lady Grisel Hamilton. Pale lavender-blue; very fine; new . . . . . . . . . I5 15 I 25

3759 Lady Mary Currie. Orange-pink, shaded rosy lilac . . . . . . . . . . .

3760 Lady Nina Balfour. Very beautiful mauve . . . . . . . . . . . . .

3761 Lady Penzance. Beautiful bright rose; splendid form . . . . . . . . . . .

3762 Lady Skelmersdale. Pale rose-pink standard; wings white suffused lavender; new

3763 Little Dorrit. Pink standard; white wings; beautiful . . . . . . . . . . .

3764 Lottie Eckford. Rose and white, edged with blue . . . . . . . . . . . .

3765 Lottie Hutchins. Pale primrose, striped with light pink . . . . . . . . .

3766 Lovely. Deep rose at base of standard and wings, shading to pale pink and

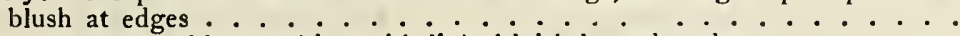

3768 Maid of Honor. Almost white, with light bluish lavender edge . . . . . . .

3769 Mars. Bright crimson-scarlet wings, fiery scarlet standard . . . . . . . .

3770 Mrs. Dugdale. Beautiful deep rose; unexcelled for cut-flowers; new . . . . .

377 I Mrs. Eckford. White, delicately shaded with primrose . . . . . . . . . .

3772 Mrs. Jos. Chamberlain. White, striped and flaked with bright rose . . . . .

3773 Modesty. Very delicate pink; a beautiful flower . . . . . . . . . . . . . .

3775 Navy Blue. Bluish purple standard; navy blue wings. New and distinct; very

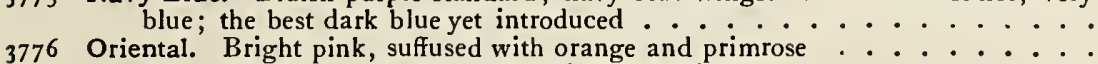

3777 Othello. Deep glossy maroon; splendid new variety . . . . . . . . . . .

3778 Ovid. Standard and wings rosy pink, margined rose . . . . . . . . . . . .

3779 Peach Blossom. Salmon pink standards; soft pink wings . . . . . . . . . .

3780 Prima Donna. Light blush pink; very beautiful; large flower . . . . . . . .

3781 Prince Edward of York. Cerise standard and crimson wings. Large open form and vigorous vine . . . . . . . . . . . . . . . . . . . . .

3782 Prince of Wales. Fine bright rose ; self-colored

3783 Princess Beatrice. Delicate blush pink, marked with deeper shades . . . . . .

3784 Queen Victoria. Light primrose-yellow . . . . . . . . . . . . .

3785 Ramona. Very large flowers; creamy white, shaded pale pink . . . . . . .

3786 Royal Robe. Delicate pink standard; wings soft blush pink . . . . . . . .

3788 Royal Rose. Fine deep rose-colored . . . . . . . . . . . . . . . . . .

3789 Sadie Burpee, White Seed. The largest pure white Sweet Pea. An improve ment on Blanche Burpee; new . . . . . . . . . . . . . . . .

3790 Sadie Burpee, Black Seed. Large, pure white flower; hardier than the whiteseeded variety; new. . . . . . . . . . . . . . . .

3791 Salopian. Splendid brilliant scarlet; best of all . . . . . . . . . . .

3792 Senator. Chocolate and creamy white, mottled and blotched . . . . . . .

3793 Sensation. White, suffused with faint rose ...............

3794 Shahzada. Dark maroon, shaded purple . . . . . . . . . . . . . . .

3798 Stella Morse. Primrose, flushed pink; very beautiful . . . . . . . . . . .

3799 Venus. Salmon-buff; standard delicately shaded with rosy pink . . . . . .

All five cents per packet

\section{SWEET PEAS IN MIXTURE}

${ }_{3} 806$ THORBURN'S SPECIAL MIXED. Comprising the finest Eckford and other new and choice large-flowering varieties.....\$o no

3807 Eckford's Mixed. Composed of Eckford's varieties only . . . . . . .

3808 Choice Mixed ....................

Per $1 / 4 \mathrm{lb}$. Per $1 / 2 \mathrm{lb}$.

Per lb.

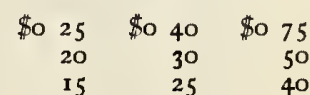

\section{PERENNIAL PEAS AND OTHER SPECIES}

(Lathyrus latifolius, Etc.)

These have not the fragrance of Sweet Peas, but bloom through a long season, are perfectly hardy and will live for years. They make a beautiful screen for rocks, stumps, fences, stony banks, etc. Height, 2 to 8 feet.

$3^{812}$ latifolius, White (hP). Valuable for cut-flowers in midsummer; 4 to $8 \mathrm{ft}$. . per oz., 50c. . pkt., 5

3813 " " Scarlet. Brilliant-flowered; perhaps the handsomest form of the type - per oz., 3 oc. . 5

3814 " $\quad$ Pink Beauty. Blossoms white, veined, edged and shaded rose-pink . "6 " 5oc. . 5

3815 " Mixed Everlasting Peas ... . . . . . . . . . . . " 40c. . 5

3818 Lord Anson's Blue $(\mathrm{hA})$. Strong-growing; almost evergreen; flowers dark purple-blue ;

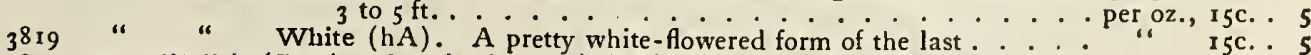

rotundifolius (Persian

3822 tingitanus (Tanger Scarlet Pea) Low-growing; flowers copper-red; likes shade 5

3822 tingitanus (Tangıer Scarlet Pea) (hA). Dark red-purple; blooms early; 3 ft. . per oz., I5c. . 5 


\section{VERBENA HYBRIDA}

In rich soil single plants of this pretty perennial creeper will carpet a space. 3 to 4 feet in diameter with neat foliage and scores of fine flower-umbels. For beds, borders, mounds, vases and window-boxes it is particularly fine, and is frequently used for an undergrowth to tall plants like lilies. Plants raised from seed are not only cheaper, but more vigorous, producing more and larger flowers for a longer season than those grown from cuttings. Moreover, seedling Verbenas are often fragrant, particularly among the white and blue sorts, For early spring bloom, sow the seeds under glass in February; for later flowers, sow in March or April. Soak the seed a few hours in tepid water and sow in seed-boxes filled with light, rich soil, cover one-fourth of an inch deep, press down firmly, and water sparingly. When the seedlings are about an inch high, transplant into other boxes. Use a liberal amount of manure in the beds that are to receive them, and plant out ro to $\mathrm{I}_{5}$ inches apart each way in May. Give a sunny position. The plants bloom from early summer until frost. Our seed is saved from very fine named varieties, and will produce healthy plants, with flowers of fine colors.

3840 scarlet. Fine bedder. . . . . . . . . . . . . . . . . . . . .

3841 " Defiance. Intensely brilliant scarlet, fine for bedding . . . . . . . . . . . . . 10

3842 Blue-Black, White Eye . . . . . . . . . . . . . . . . . . . . . . . . 10

3844 Yellow. Primrose color . . . . . . . . . . . . . . . . . . . . . . . . . 10

3845 Golden-Leaved (Cloth of Gold). Bright yellow foliage and flowers of various colors . . . . . 10

3847 candidissima. Large trusses of purest white flowers . . . . . . . . . . . . . . . . 10

3848 auriculæflora. Brilliant flowers of fine size, each with a large white eye . . . . . . . . . . 10

3850 Italica striata. Brightly striped . . . . . . . . . . . . . . . . . . . . . Io

385 c cerulea. Bright blue in various shades. . . . . . . . . . . . . . . . . . . . 10

3853 Mixed . . . . . . . . . . . . . . . . . . . . . per oz., 75c. . 5 5

3854 Finest Mixed. Extra choice . . . . . . . . . . . . . . "\$1.50. . 10

3856 Mammoth Mized. Plants and flowers are unusually large; the strain is extremely floriferous and the colors splendid. (See our illustration of a bed grown from this seed.) . oz., $\$ 2.50$. yo

Collection, including 6 varieties Verbena . . . . . . . . . . . . . . 50

\section{LEMON VERBENA}

(Verbena citriodara, Aloysia)

An attractive greenhouse shrub, grown for the delightful citron scent of its light green leaves. It is easily grown from seed and becomes quite tall with age, but is usually pruned back to a pretty bush form.

3860 Sweet-Scented Verbena . . . . . . . . . . . . . . . . . pkt., ro

\section{ZINNIA}

(Youth and old Age)

Few flowers are so easily grown from seed sown in the open ground, or bloom so abundantly and continuously through the entire season. Marvelous improvements have been wrought in the newer strains. During the month of August Zinnias are almost incomparably bright. We recommend a free use of them for groups, beds, borders, garden lines and summer hedges. Sow seed in the open ground early in spring. Average height, $I \frac{X}{2}$ to 2 feet. The collections offered below are very choice.

TALL DOUBLE. Showy, large-flowered; beautiful for borders and groups; 2 feet.

3870 Carmine . . . . . . oz., 40c. . pkt., 5

387 I Crimson . . . . . . "40c... . 5

3872 Flesh-Colored . . . " 40c.... 5

3874 Lilac . . . . . . " 40c... . 5

3875 Purple... . . . . " 400... . 5

3876 Rose

3877 Scarlet........ “ 400... . 5

3878 Violet... . . . . " 40c. . . 5

3880 White....... " 40c... . 5

3882 Yellow, Sulphur. . . " 40c... . 5

3884 " Golden . . . " “ 40c. . . . 5

$\begin{array}{ll}3885 & \text { Mixed . . Odd and beautiful little } \\ 3886 & \text { Pompon. }\end{array}$ flowers, with petals forming a smooth cone. . . oz. 50c. . . 5

DWARF DOUBLE. These are of compacter and neater habit than the tall varieties, with flowers quite as handsome. 3888 Purple . . . . . . oz., 50c. . pkt., 5 3889 Salmon . . . . . " 50c... . 5 3890 Large Robust. Magnificent, extra large flowers of rich scarlet ...

${ }^{8} 892$ Scarlet "Fireball." Dazzling fiery scarlet . .., , oz., 75c.., 10
DWARF DOUBLE VARIETIES, continued.

3894 Bright Scarlet ... " 75c.. pkt., 5

3895 White "Snowball". . "75c... . 10

3896 Yellow, Sulphur . . " 50c. . . . 5

3898 " Golden ... " 50c.... 5

3902 Mixed ......." 40c... . 5

LILLIPUT. This strain has none of the coarseness of some larger sorts. The little plants grow about 15 inches high, nearly the same in breadth, and are covered with a hundred or more flowers all open at one time. The flowers are very double and of bright, pure colors. Plant in light, warm, thin soil.

3904 Scarlet Gem . . . . . . . pkt., ro

3905 White ............... 10

3906 Mixed . . . . . . . . . . . 10

3908 Tom Thumb Mixed. Dwarfs about 6 inches high. Beautiful for beds, edgings and cutting . oz., $\$ \mathrm{I}$. ro

3910 Haageana. Yellow; I ft. " \$I.25. 10

3912 Curled and Crested Mixed. Long petals, gracefully curled and crested .......... . . ro

Collections of Zinnia, includingIo varieties Beautiful Double . . . . . . . 50

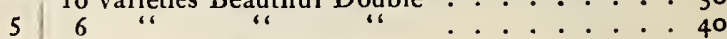

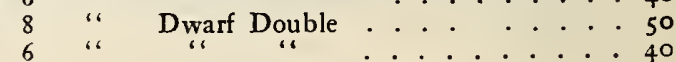




\section{GENERAL LIST OF FLOWER SEEDS}

Flower Seeds delivered free by mail on receipt of the stated price

\section{Explanation OF THE SignS EMPLOYED IN THIS LIST}

The asterisk $\left(^{*}\right)$ designates ornamental-leaved plants. This mark $(\ddagger)$ prefixed indicates the climbers. The third column presents in figures the COMPARATIVE TIME OF FLOWERING, thus:

1 designates early-blooming in sprine and early summer. 2 designates intermediate-blooming in midsummer. 3 designates late-blooming in late summer and autumn.

The fourth column gives the DURATION or CHARACTER, and HARDINESS.
A represents Annaal-lasting but one year.
B ". Biennial-lasting two years.
$\mathrm{P} \quad$.* Perennial-lasting three or more years.
Evergreen-retaining foliage the entire year. . . designates, in every case, repetition.
S represents Shrubs-plants of bushy habit.
g. ". greenhouse plants.
Bu . balbous plants.

As a large number of Biennials and Perennials, if sown early, flower the first season, this distinguishing mark $(t)$ is affixed to such.

The hardiness is denoted by the following abbreviations, but it should be understood that this is intended to apply to the climate of the Middle Atlantic states, and further north or south these designations apply only in a comparative way:

h represents hardy-plants for open border. hh represents half-hardy-plants that require to be forwarded in pots or frames. $t$ represents tender-requiring protection.

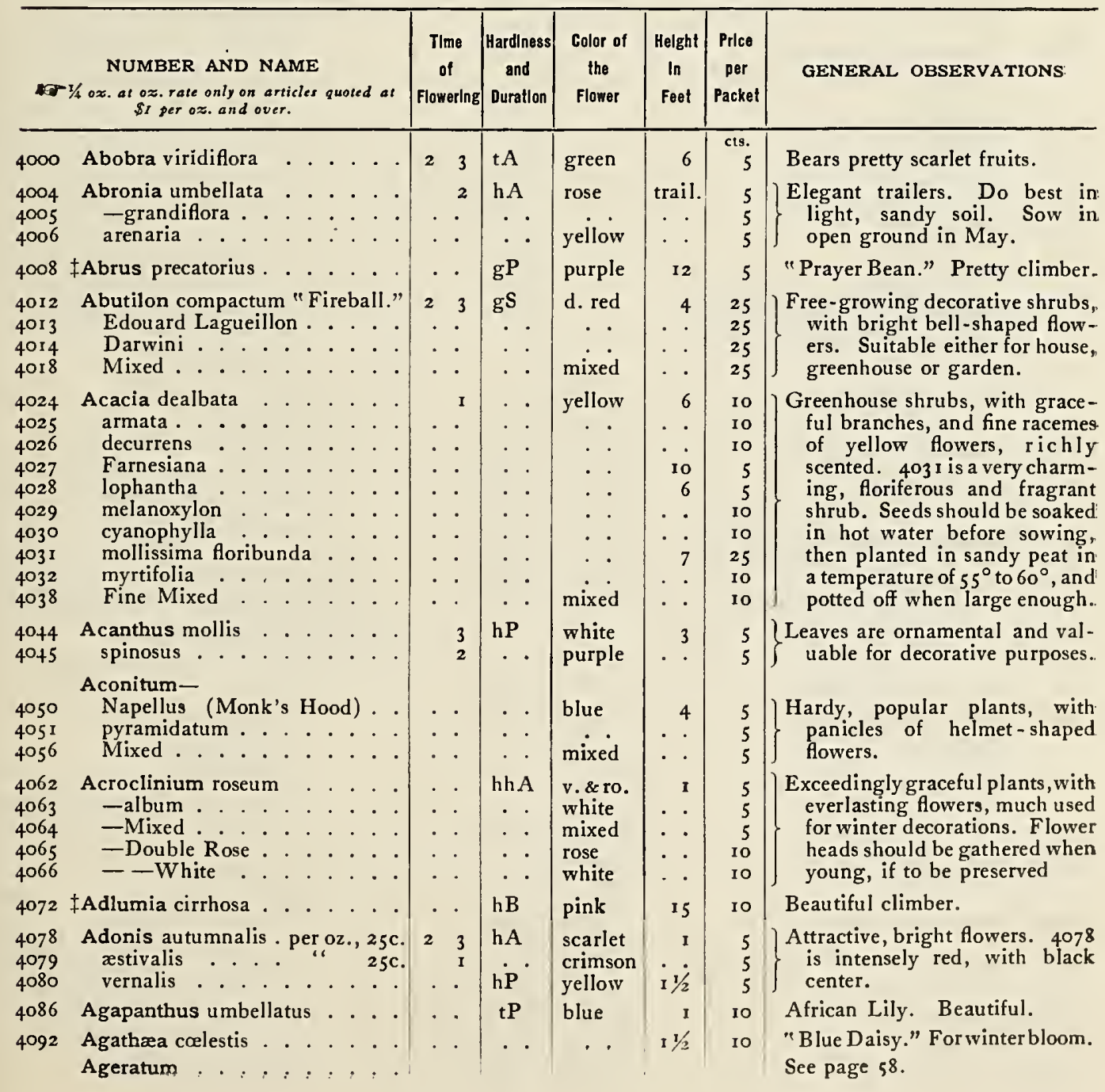




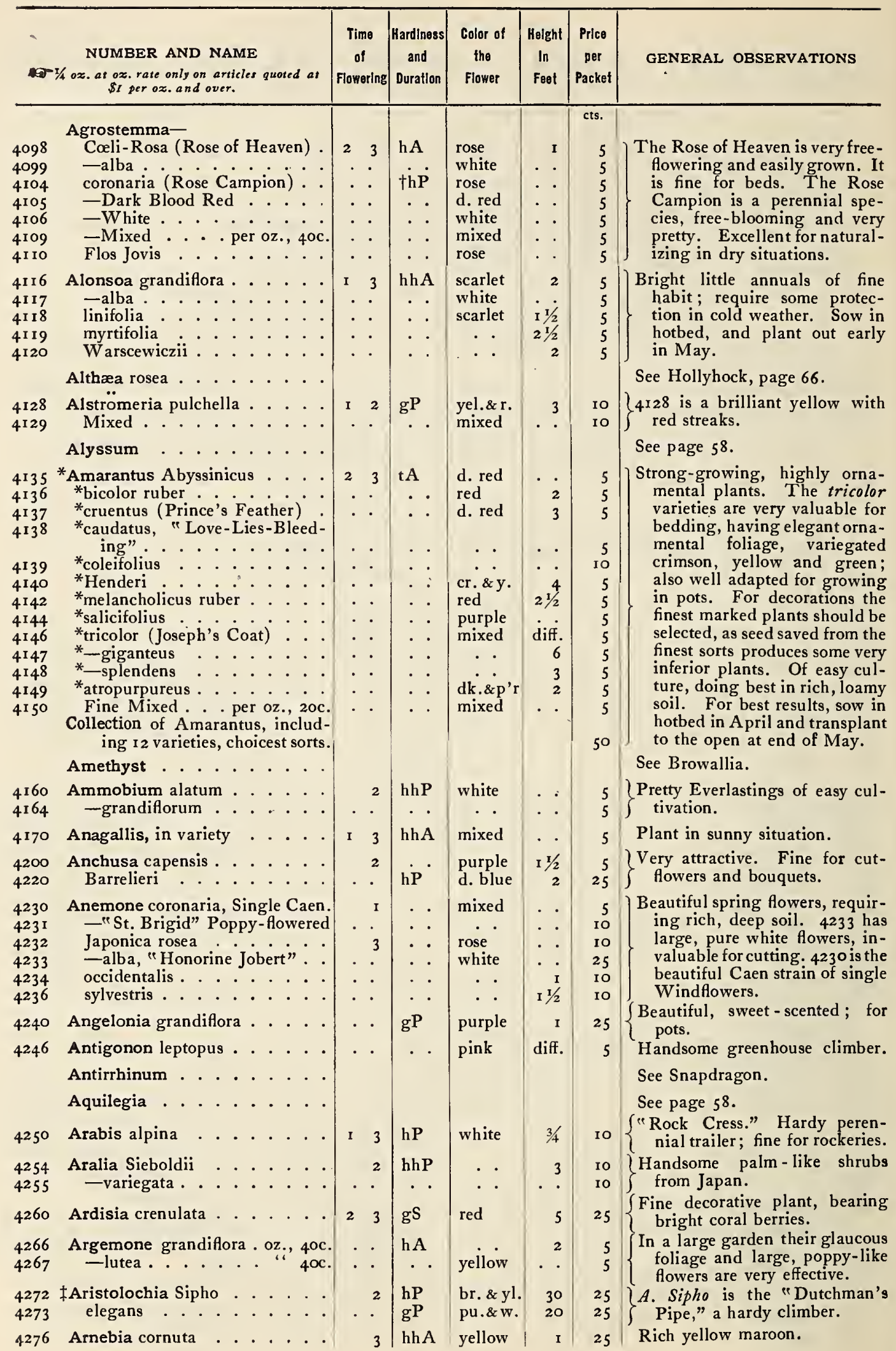




\begin{tabular}{|c|c|c|c|c|c|c|c|}
\hline$\infty$ & $\begin{array}{l}\text { NUMBER AND NAME } \\
-1 / 4 \text { oz. as oz. rate only on articles quoted at } \\
\text { \$i per oz. and over. }\end{array}$ & $\begin{array}{c}\text { TIme } \\
\text { of } \\
\text { Flowering }\end{array}$ & $\begin{array}{c}\text { Hardiness } \\
\text { and } \\
\text { Duratlon }\end{array}$ & $\begin{array}{l}\text { Color of } \\
\text { the } \\
\text { Flower }\end{array}$ & $\begin{array}{c}\text { Holght } \\
\text { In } \\
\text { Foot }\end{array}$ & $\begin{array}{c}\text { Price } \\
\text { per } \\
\text { Packet }\end{array}$ & GENERAL OBSERVATIONS \\
\hline $\begin{array}{l}4280 \\
4281 \\
4282\end{array}$ & 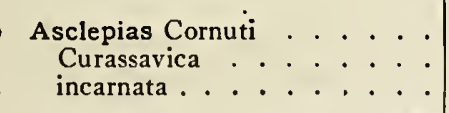 & $\begin{array}{l}2 \\
3 \\
2\end{array}$ & $\begin{array}{l}\text { hP } \\
\text { gP } \\
\text { hP }\end{array}$ & $\begin{array}{l}\text { purple } \\
\text { orange } \\
\text { rose-p. }\end{array}$ & $\begin{array}{r}4 \\
3 \\
. \quad\end{array}$ & $\begin{array}{r}\text { cts. } \\
5 \\
5 \\
5\end{array}$ & $\begin{array}{l}\text { Silkweed; sweet-scente } \\
\text { Swallowwort; free bloc } \\
\text { Swamp Milkweed. }\end{array}$ \\
\hline $\begin{array}{l}4286 \\
4287 \\
4288 \\
4290\end{array}$ & 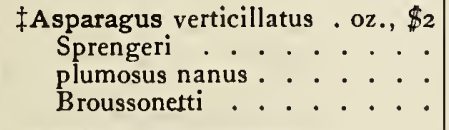 & 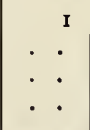 & $\begin{array}{l}\mathrm{gP} \\
\mathrm{hP}\end{array}$ & $\begin{array}{c}\text { white } \\
\text { : } \\
\text {. }\end{array}$ & $\begin{array}{r}12 \\
\text { I } \\
\text { 10 }\end{array}$ & $\begin{array}{l}\text { 10 } \\
25 \\
50 \\
\text { 10 }\end{array}$ & $\begin{array}{l}\text { Very beautiful fern-like foliage ; } \\
\text { fine for bouquets. } A \text {. Brous- } \\
\text { sonetti has very graceful foli- } \\
\text { age and bright scarlet berries. }\end{array}$ \\
\hline $\begin{array}{l}4296 \\
4297\end{array}$ & $\begin{array}{l}\text { Asperula setosa azurea } \\
\text { odorata (Woodruff) } \\
\text { Asters . . . . . . . . . . . . . . . . }\end{array}$ & $\begin{array}{ll}2 & 3 \\
\cdot & \cdot\end{array}$ & $\begin{array}{l}\operatorname{hhA} \\
\mathrm{hP}\end{array}$ & $\begin{array}{l}\text { 1. blue } \\
\text { white }\end{array}$ & $1 / 2$ & $\begin{array}{l}5 \\
5\end{array}$ & $\begin{array}{l}\text { Sweet-scented, long-bloomers } \\
\text { for borders or rockwork. } \\
\text { See page } 57 .\end{array}$ \\
\hline $\begin{array}{l}4302 \\
4303 \\
4304 \\
4305\end{array}$ & 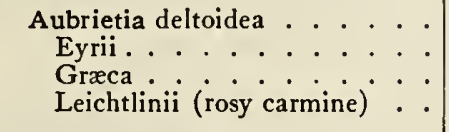 & I & $\begin{array}{l}\therefore \\
\dot{:} \\
\dot{ }\end{array}$ & $\begin{array}{l}\text { purple } \\
\text { blue } \\
\text { carmine }\end{array}$ & \begin{tabular}{c|} 
trail. \\
$\cdot$ \\
$\cdot$ \\
$\cdot$ \\
$\cdot$
\end{tabular} & $\begin{array}{l}\text { 10 } \\
\text { 10 } \\
\text { 10 } \\
25\end{array}$ & $\begin{array}{l}\text { Resembling Alyssum in char- } \\
\text { acter; fine for rockwork or } \\
\text { bedding. } A \text {. Eyrii has lovely } \\
\text { large, dark blue flowers. }\end{array}$ \\
\hline 43 II & Auricula, finest . . . . . . . . & I & $\cdot \cdot$ & mixed & $1 / 2$ & 25 & shades of color. \\
\hline $43 I 7$ & $\begin{array}{l}\text { Azalea hybrida . . . . . . . . } \\
\text { Balsam Apple and Pear . . . . } \\
\text { Balsams . . . . . . . . . }\end{array}$ & 2 & hS & $\cdot$ & 2 & 25 & $\begin{array}{l}\text { Seeds from finest varieties. } \\
\text { See Momordica. } \\
\text { See page } 59 .\end{array}$ \\
\hline 4320 & $\begin{array}{l}\ddagger \text { Balloon Vine . . per oz., zoc. } \\
\text { Banana . . . . . . . } \\
\text { Baptisia australis...... }\end{array}$ & 2 & hhA & w. \& gr. & Io & 5 & $\begin{array}{l}\text { (Cardiospermum). Very pretty. } \\
\text { See Musa Ensete. } \\
\left\{\begin{array}{l}\text { (False Indigo.) It has beauti- } \\
\text { ful light blue flowers. }\end{array}\right.\end{array}$ \\
\hline $\begin{array}{r}4328 \\
4329\end{array}$ & $\begin{array}{l}\text { Bartonia aurea . . per oz., } 40 \mathrm{co} . \\
\text {-nana ..... } \\
\text { *Beet- }\end{array}$ & $\begin{array}{ll}\text { I } & 3 \\
. & \cdot\end{array}$ & $\begin{array}{c}\text { hA } \\
\cdot .\end{array}$ & $\begin{array}{c}\text { yellow } \\
.\end{array}$ & $1 x^{3} / 2$ & $\begin{array}{l}5 \\
5\end{array}$ & $\begin{array}{l}\text { Golden yellow flowers; very fra- } \\
\text { grant in the evening. }\end{array}$ \\
\hline $\begin{array}{l}4335 \\
4336 \\
4337 \\
4338 \\
4339 \\
4340 \\
4341\end{array}$ & 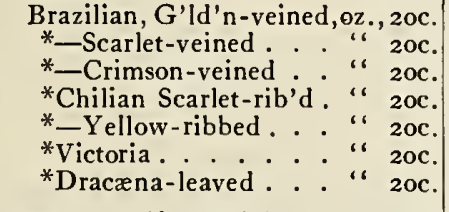 & & 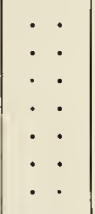 & & $\begin{array}{l}\cdot \\
: \\
\cdot \\
: \\
: \\
: \\
.\end{array}$ & $\begin{array}{l}5 \\
5 \\
5 \\
5 \\
5 \\
5 \\
5\end{array}$ & $\begin{array}{l}\text { Beets having no tubers, but } \\
\text { with handsome ornamental } \\
\text { foliage of very beautiful, rich } \\
\text { colors. Very effective in cen- } \\
\text { ter of beds, or anywhere in } \\
\text { contrast with other plants. }\end{array}$ \\
\hline $\begin{array}{l}4346 \\
4347 \\
4348 \\
4349 \\
4352 \\
4353 \\
4354 \\
4355 \\
4356\end{array}$ & 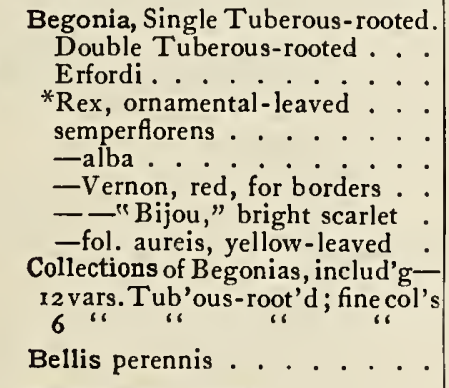 & $\begin{array}{l}. \\
. \\
. \\
. \\
. \\
\therefore \\
\therefore \\
\therefore \\
\therefore\end{array}$ & 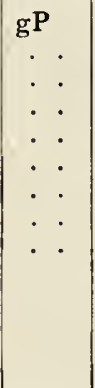 & $\begin{array}{l}\text { mixed } \\
\quad \cdot \quad \text { carmine } \\
\text { mixed } \\
\text { rose } \\
\text { white } \\
\text { red } \\
\text { scarlet } \\
\quad . \quad .\end{array}$ & 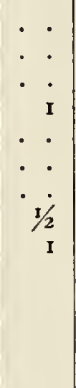 & $\begin{array}{r}25 \\
75 \\
25 \\
25 \\
25 \\
25 \\
25 \\
25 \\
25 \\
\$ 1 \\
\$ 15 \\
100\end{array}$ & $\begin{array}{l}\text { Fine for growing in pots, being } \\
\text { perfect in habit, with very } \\
\text { handsome foliage. } 435^{2} \text { and } \\
4353 \text { are very free-flowering, } \\
\text { and fine for bedding. No. } \\
4356 \text { has scarlet flowers and } \\
\text { beautiful golden y ellow } \\
\text { leaves; excellent for edging. } \\
B \text {. Erfordi is a free-bloom- } \\
\text { ing, rosy carmine variety; fine } \\
\text { for groups. } \\
\text { See Daisy. }\end{array}$ \\
\hline $436_{3}$ & Benincasa cerifera..... & 2 & $\mathrm{tA}$ & yellow & 6 & Io & Black, wax-like gourd. \\
\hline $\begin{array}{l}4369 \\
4374\end{array}$ & $\begin{array}{l}\text { Bidens atrosanguinea . . . } \\
\text { Blue Bottle . . . . . . }\end{array}$ & . & h A & d. red & 2 & Io & $\begin{array}{l}\text { Showy, like the Calliopsis. } \\
\text { See Centaurea Cyanus. }\end{array}$ \\
\hline $\begin{array}{l}437^{8} \\
4382\end{array}$ & $\begin{array}{l}{ }^{*} \text { Bocconia Japonica . . . } \\
\text { Bouvardia Jacquini . . . }\end{array}$ & $\cdot \cdot$ & $\begin{array}{l}\text { tP } \\
\text { gP }\end{array}$ & $\begin{array}{l}\text { white } \\
\text { scarlet }\end{array}$ & 4 & 25 & $\begin{array}{l}\text { Ornamental habit and foliage. } \\
\left\{\begin{array}{c}\text { Handsome greenhouse ever- } \\
\text { green. }\end{array}\right.\end{array}$ \\
\hline $\begin{array}{l}4386 \\
4387 \\
4388\end{array}$ & 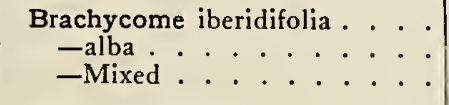 & $\begin{array}{l}3 \\
\cdot . \\
\cdot\end{array}$ & $\begin{array}{c}\text { hhA } \\
\cdot \text {. }\end{array}$ & $\begin{array}{l}\text { purple } \\
\text { white } \\
\text { mixed }\end{array}$ & I. & $\begin{array}{l}5 \\
5 \\
5\end{array}$ & $\left\{\begin{array}{l}\text { (Swan River Daisy.) For edg- } \\
\text { ing. Should be started in } \\
\text { hotbed. }\end{array}\right.$ \\
\hline $\begin{array}{l}4394 \\
4395 \\
4396 \\
4397 \\
4398\end{array}$ & 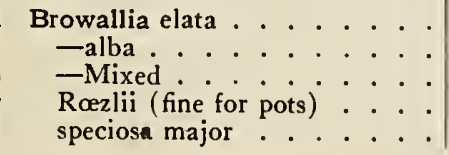 & . & $\begin{array}{l}\text { gA } \\
\dot{.} \cdot \\
\text { gP }\end{array}$ & $\begin{array}{l}\text { blue } \\
\text { white } \\
\text { mixed } \\
\text { white } \\
\text { blue }\end{array}$ & $\begin{array}{l}2 \\
. \\
. \\
. \\
. \\
.\end{array}$ & $\begin{array}{l}\text { 10 } \\
\text { 10 } \\
\text { 10 } \\
25 \\
25\end{array}$ & $\begin{array}{l}\text { (Amethyst.) Elegant green- } \\
\text { house annuals ; fine for cut- } \\
\text { ting. } 4397 \text { has large, lovely } \\
\text { flowers, some white, some pale } \\
\text { blue. }\end{array}$ \\
\hline
\end{tabular}




\begin{tabular}{|c|c|c|c|c|c|c|c|}
\hline 45 & $\begin{array}{l}\text { NUMBER AND NAME } \\
1 / 4 \text { oz. at oz, rate only on articles quoted at } \\
\$ 1 \text { per oz. and over. }\end{array}$ & $\begin{array}{c}\text { Time } \\
\text { of } \\
\text { Fiowering }\end{array}$ & $\begin{array}{c}\text { Hardiness } \\
\text { and } \\
\text { Duration }\end{array}$ & $\begin{array}{l}\text { Color of } \\
\text { the } \\
\text { Flower }\end{array}$ & $\begin{array}{c}\text { Height } \\
\text { In } \\
\text { Feet }\end{array}$ & $\begin{array}{c}\text { Price } \\
\text { Der } \\
\text { Packet }\end{array}$ & GENERAL OBSERVATIONS \\
\hline $\begin{array}{l}404 \\
408\end{array}$ & $\begin{array}{l}\text { Bryonopsis laciniosa erythrocarpa } \\
\text { Buphthalmum cordifolium . . }\end{array}$ & . . & tA & $\begin{array}{l}\text { red } \\
\text { yellow }\end{array}$ & 5 & $\begin{aligned} \text { cts. } & \\
\text { co } & \end{aligned}$ & $\begin{array}{l}\text { Very pretty ornamental gourd. } \\
\text { Ornamental hardy perennial. }\end{array}$ \\
\hline & 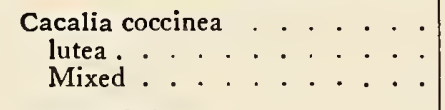 & $\begin{array}{l}\cdot \dot{ } \\
\cdot \\
\cdot\end{array}$ & $\begin{array}{l}\text { hA } \\
. \\
\cdot\end{array}$ & & $\begin{array}{l}2 \\
.\end{array}$ & $\begin{array}{l}5 \\
5 \\
5\end{array}$ & $\begin{array}{l}\text { (Tassel Flower). Very pretty } \\
\text { annuals; easily grown. }\end{array}$ \\
\hline 4422 & $\begin{array}{l}\text { Cactus, Mixed . . . . . . } \\
\text { †Calampelis scabra . . . . . . }\end{array}$ & . & hhP & orange & diff. & $\begin{array}{l}25 \\
10\end{array}$ & $\begin{array}{l}\text { Start in greenkouse in moist sand. } \\
\text { Fine climber for trellises. }\end{array}$ \\
\hline $\begin{array}{l}426 \\
427 \\
428 \\
429\end{array}$ & 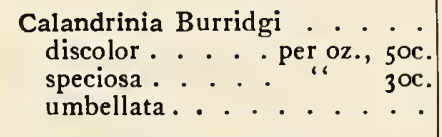 & 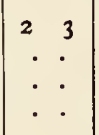 & $\begin{array}{l}\text { hA } \\
\cdot \dot{\cdot} \\
\text { hh }\end{array}$ & $\begin{array}{l}\text { red } \\
\text { rose } \\
\text { purple } \\
\text { violet }\end{array}$ & $\begin{array}{l}1 / 2 \\
1 / 4 \\
1 / 2\end{array}$ & $\begin{array}{r}5 \\
5 \\
5 \\
10\end{array}$ & $\begin{array}{l}\text { Brightly colored little plants, } \\
\text { fine for edgings; plant in } \\
\text { sunny situations. }\end{array}$ \\
\hline $\begin{array}{l}435 \\
436 \\
437 \\
438 \\
440\end{array}$ & $\begin{array}{l}\text { Calceolaria hybrida- } \\
\text { Large-flowered, self-colored } \\
\text {-Tigered, or Spotted .... } \\
\text {-Dwarf Tigered . . } . . . \\
\text {-Tigered and Self-colored . } \\
\text { rugosa (shrubby) . . . . . }\end{array}$ & $\dot{.}$ & $\begin{array}{l}\text { gP } \\
: . \\
: \\
: \\
.\end{array}$ & $\begin{array}{c}\operatorname{mixed} \\
: \cdot \\
: \\
: \\
.\end{array}$ & $\begin{array}{l}2 \\
\text { i } \\
2 \\
1\end{array}$ & $\begin{array}{l}25 \\
25 \\
25 \\
25 \\
50\end{array}$ & $\begin{array}{l}\text { id greenhouse plants, with } \\
\text { rs beautifully striped, } \\
\text { hed and variegated. Our } \\
\text { are saved from the finest } \\
\text { ties. Special cultural } \\
\text { tions are given on p. } 56 \text {. }\end{array}$ \\
\hline 46 & 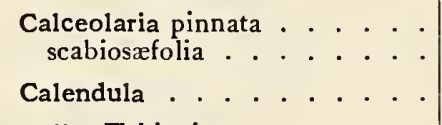 & . & $\mathrm{hA}$ & $\begin{array}{c}\text { yellow } \\
\cdot \text {. }\end{array}$ & $\therefore$ & $\begin{array}{r}10 \\
5\end{array}$ & $\begin{array}{l}\text { edding varieties. S } \\
\text { eolaria hybrida. }\end{array}$ \\
\hline 4452 & $\begin{array}{l}\text { Calla } \text { Ethiopica . . . . . . } \\
\text { Calliopsis . . . . . . . . }\end{array}$ & 3 & gP & white & $1 \mathrm{I} / 2$ & IO & $\begin{array}{l}\text { The popular Calla Lily. } \\
\text { See page } 59 \text {. }\end{array}$ \\
\hline $\begin{array}{l}458 \\
459\end{array}$ & 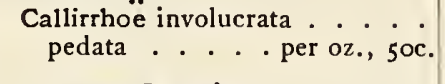 & $\begin{array}{l}1 \\
.\end{array}$ & $\begin{array}{l}\text { hP } \\
\text { hA }\end{array}$ & $\begin{array}{l}\text { c. \& w. } \\
\text { v. \& w. }\end{array}$ & $\begin{array}{c}\text { trail. } \\
2\end{array}$ & $\begin{array}{l}5 \\
5\end{array}$ & \\
\hline 4463 & $\begin{array}{l}\text { Camellia Japonica . per oz., } 25 \text { c. } \\
\text { Campanula . . . . . . }\end{array}$ & . & gP & mixed & 3 & IO & $\begin{array}{l}\text { Grand greenhouse plant. } \\
\text { See page } 60 .\end{array}$ \\
\hline 469 & $\begin{array}{l}\text { †Canary-Bird Flower. oz., 5oc. } \\
\text { Candytuft . . . . . . . }\end{array}$ & 3 & hhA & yellow & 10 & 5 & $\begin{array}{l}\text { (Tropaolum Canariense.) } \\
\text { See page } 60 .\end{array}$ \\
\hline $\begin{array}{l}475 \\
476 \\
477 \\
478\end{array}$ & 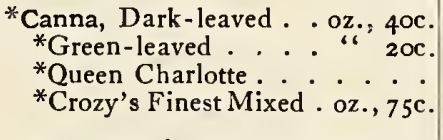 & $\begin{array}{ll}\text { I } & 3 \\
. & : \\
. & .\end{array}$ & $\begin{array}{l}\text { gP } \\
: . \\
. \\
.\end{array}$ & $\begin{array}{l}\text { mixed } \\
\text { sc.\&yel. } \\
\text { mixed }\end{array}$ & $\dot{4} \cdot \dot{4}$ & $\begin{array}{r}5 \\
5 \\
10 \\
10\end{array}$ & $\begin{array}{r}\text { Cann } \\
\text { orn } \\
\text { plo } \\
\text { ing }\end{array}$ \\
\hline 1484 & $\begin{array}{l}\text { Cannabis gigantea . per oz., zoc. } \\
\text { Canterbury Bells........ }\end{array}$ & . & hh $A$ & . & 10 & 5 & emp.) For backs of \\
\hline $\begin{array}{l}1490 \\
+492\end{array}$ & 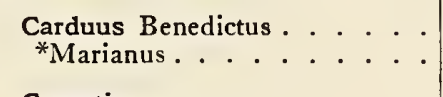 & 2 & $\begin{array}{l}\mathrm{hA} \\
\cdot .\end{array}$ & $\begin{array}{l}\text { yellow } \\
\cdot .\end{array}$ & 2 & & $\left\{\begin{array}{l}\text { (Blessed Thistle.) C. Marianus } \\
\text { has large, variegated leaves; } \\
\text { fine for edging. }\end{array}\right.$ \\
\hline 4498 & 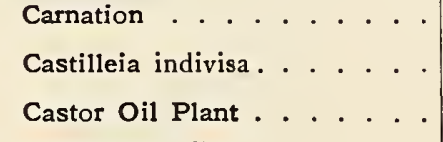 & 2 & thhP & b. red & I $1 / 2$ & 25 & 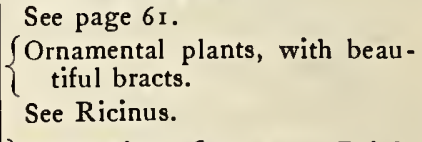 \\
\hline 504 & 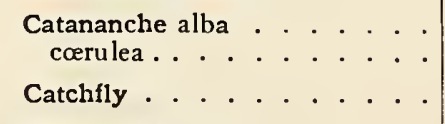 & $\dot{\cdot}$ & $\begin{array}{l}\mathrm{hA} \\
\text { thP }\end{array}$ & & 2 & & $\begin{array}{l}\text { sting flowers. Bright } \\
\text { rs and free-flowering. } \\
\text { lene. }\end{array}$ \\
\hline 4510 & Cedronella cana . . . . . . & . & & & 3 & 5 & lish rimon $A$ o \\
\hline $\begin{array}{l}4516 \\
4518 \\
4519 \\
4522\end{array}$ & 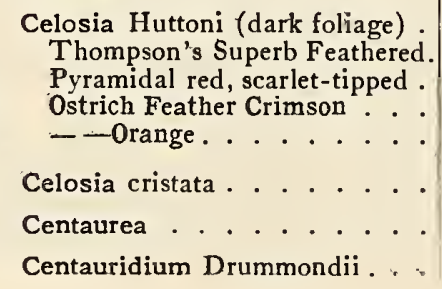 & $\begin{array}{l} \\
\\
. \\
. \\
. \\
.\end{array}$ & $\begin{array}{l}\text { :A } \\
: . \\
. \\
. \\
.\end{array}$ & $\begin{array}{l}\text { crimson } \\
\text { r. \& sc. } \\
\text { crimson } \\
\text { orange }\end{array}$ & $11 / 2$ & $\begin{array}{l}5 \\
\text { 10 } \\
\text { 10 } \\
10 \\
\text { 10 }\end{array}$ & $\begin{array}{l}\text { plants. Nos. } 4522-23 \text { produce } \\
\text { very large plumes, which re- } \\
\text { semble an ostrich feather. } \\
\text { Sometimes do not attain to } \\
\text { perfection till autumn. } \\
\text { See Cockscomb, page } 63 \text {. } \\
\text { See page } 61 \text {. } \\
\text { Pretty little Composite. }\end{array}$ \\
\hline
\end{tabular}




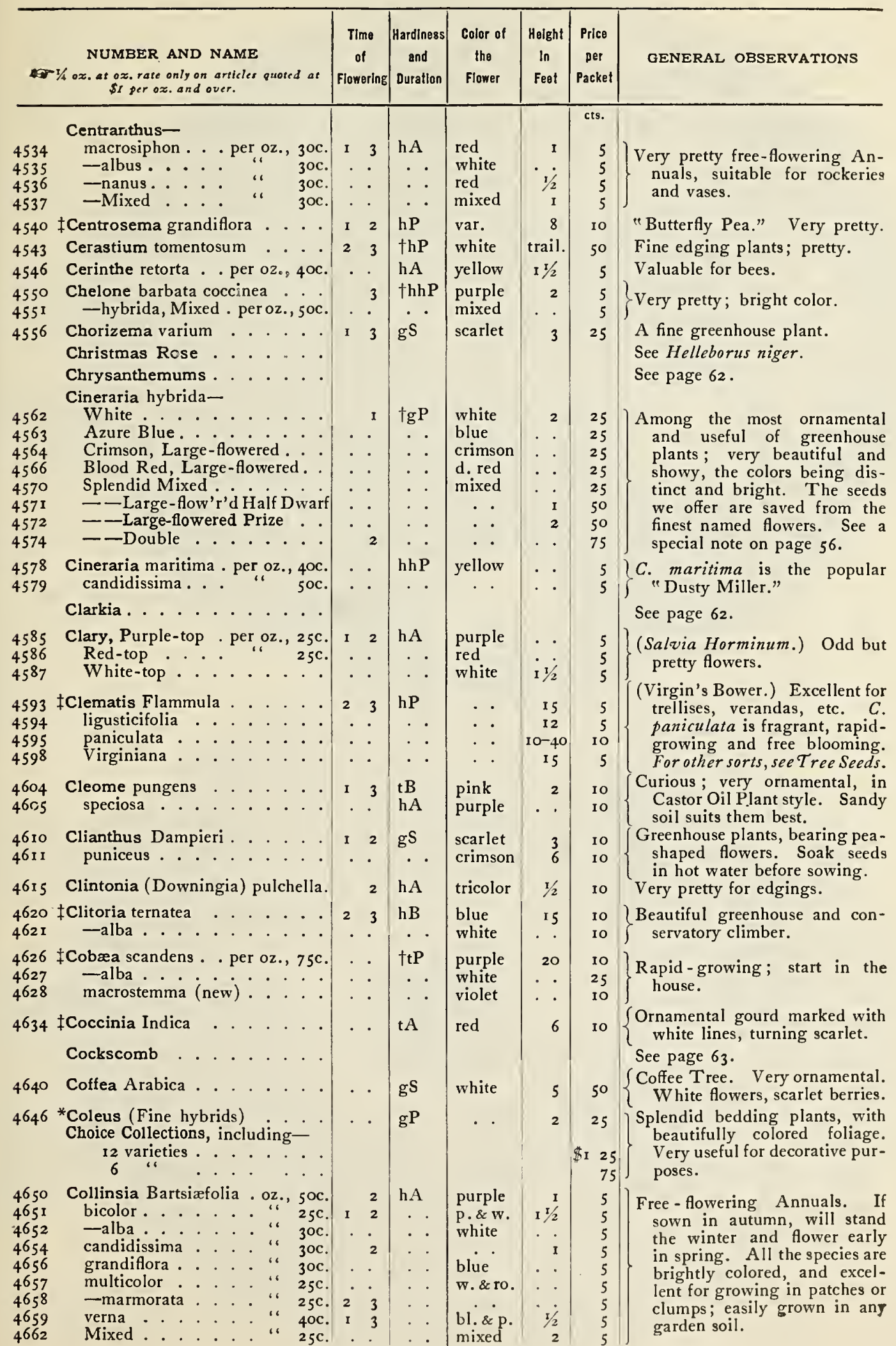




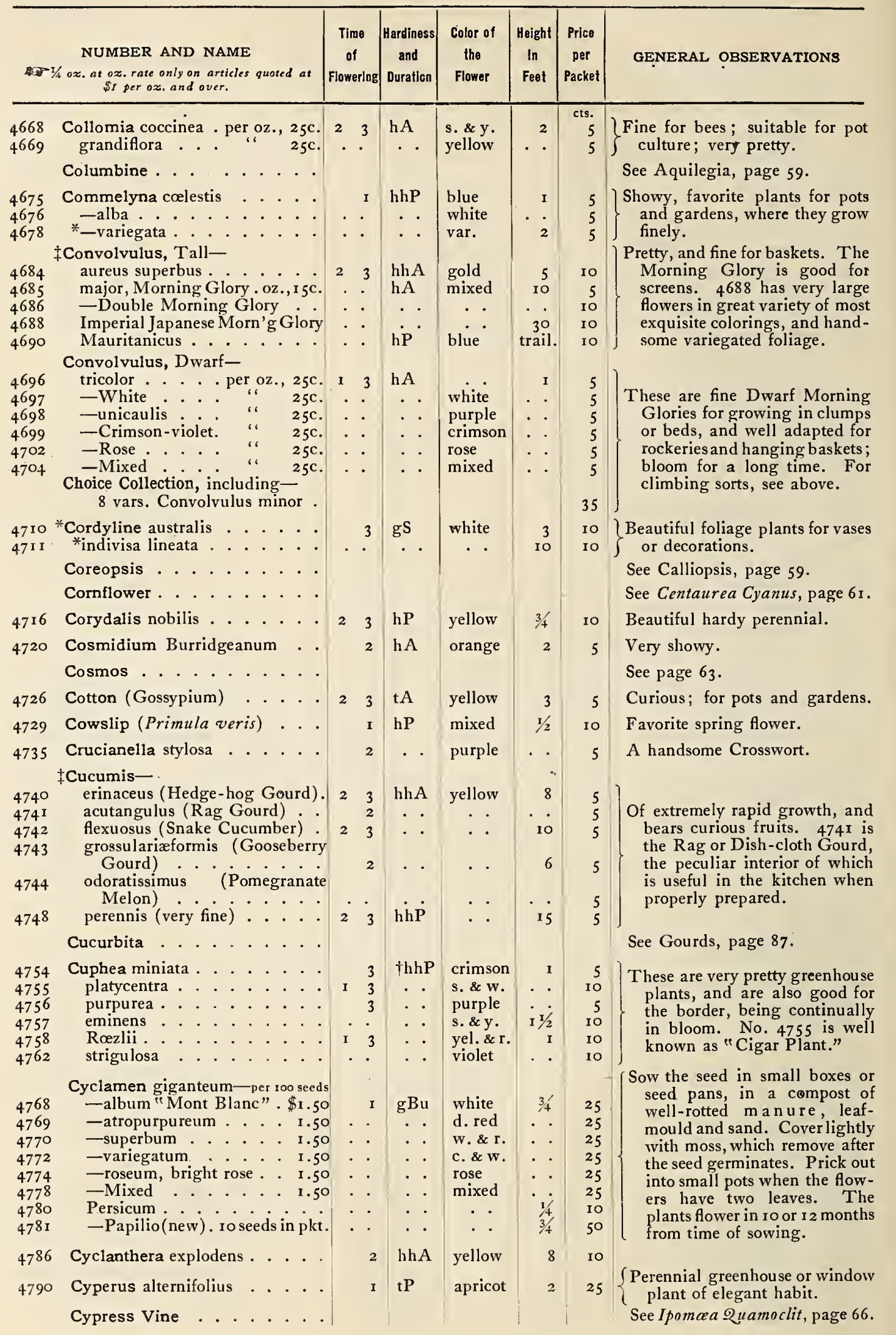




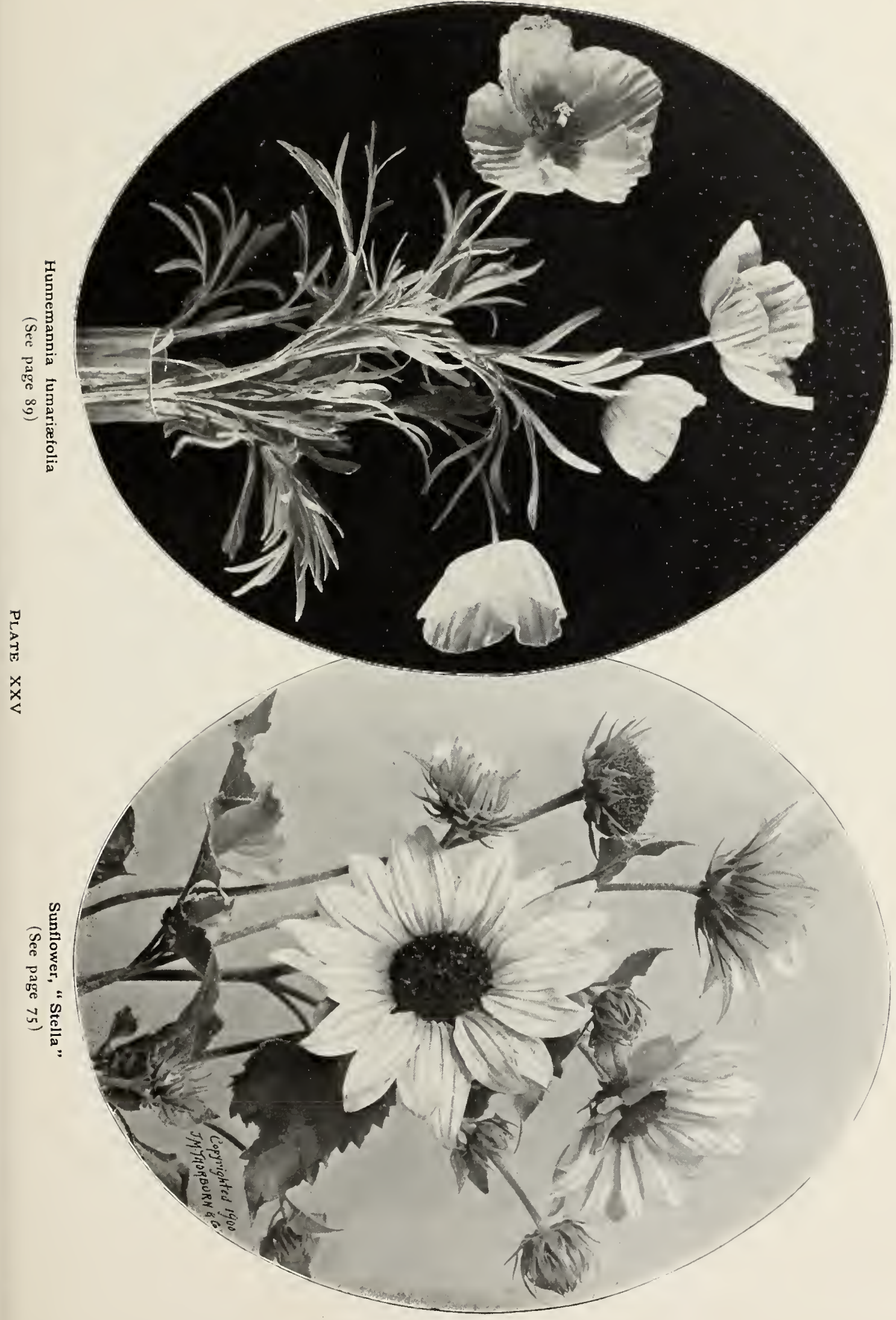




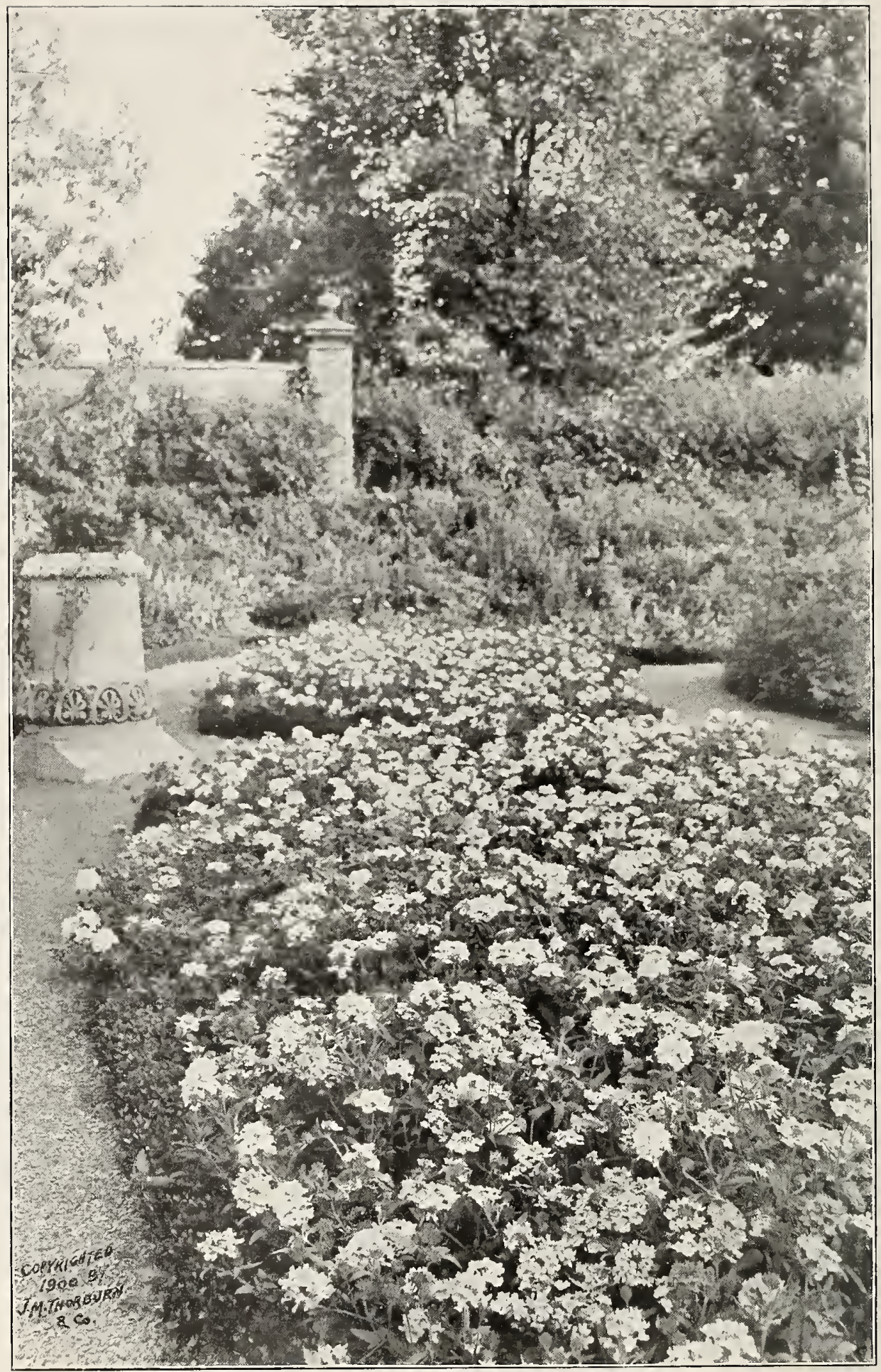

Plate XXVI - ThorbuRn's Mammoth VERBENA

(From photograph of a bed grown from our seed)

(See page 78 ) 


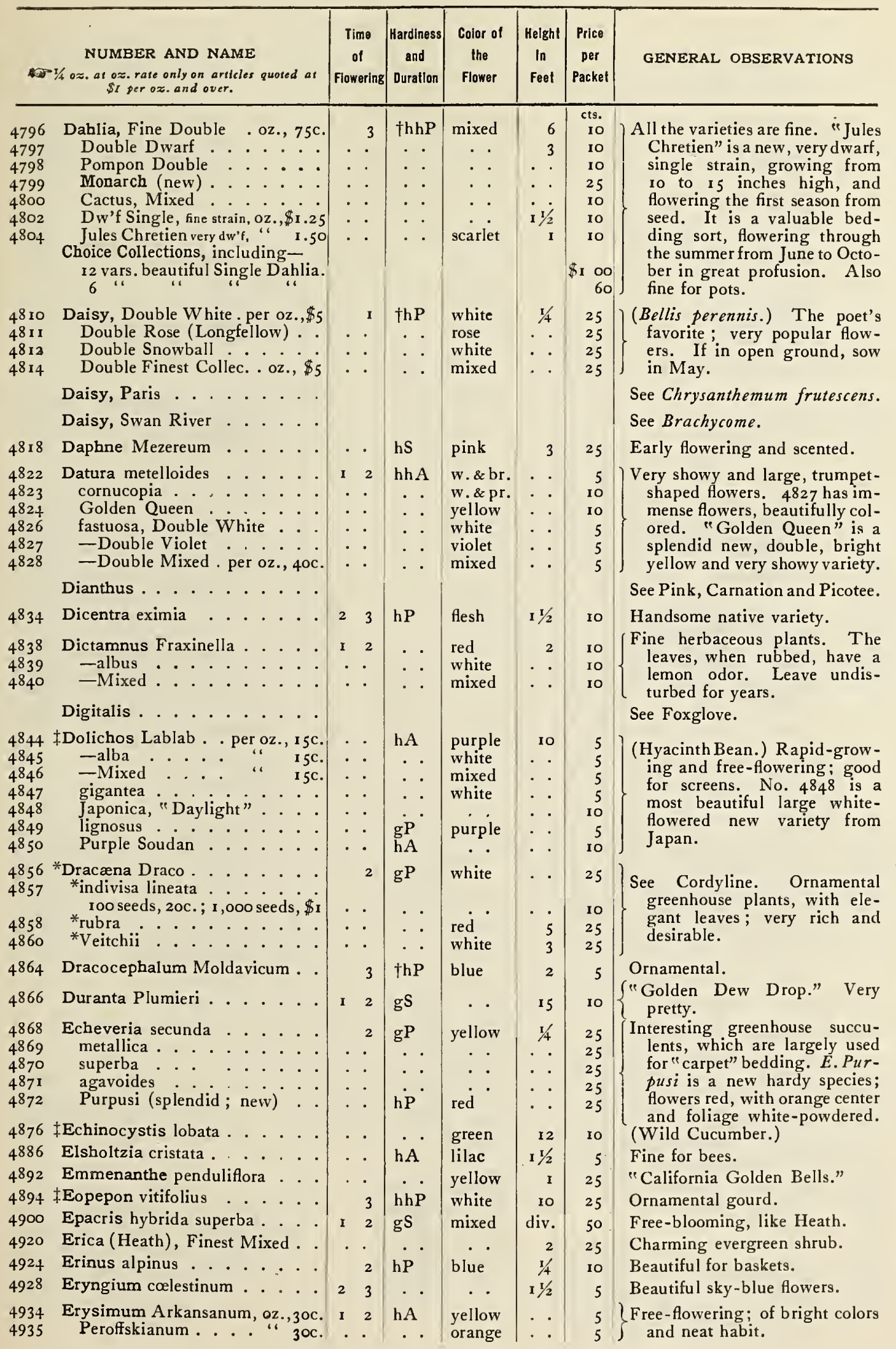




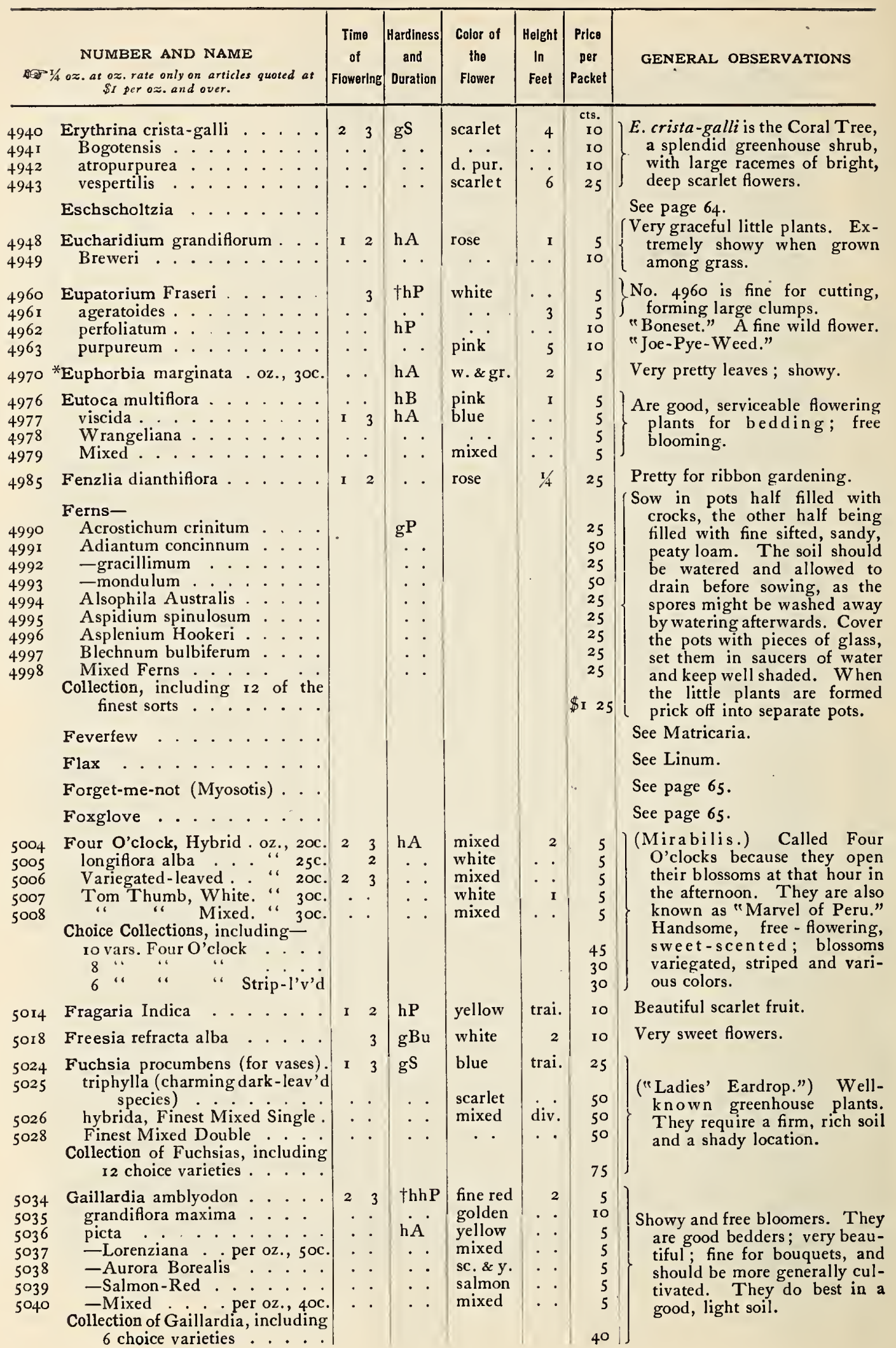




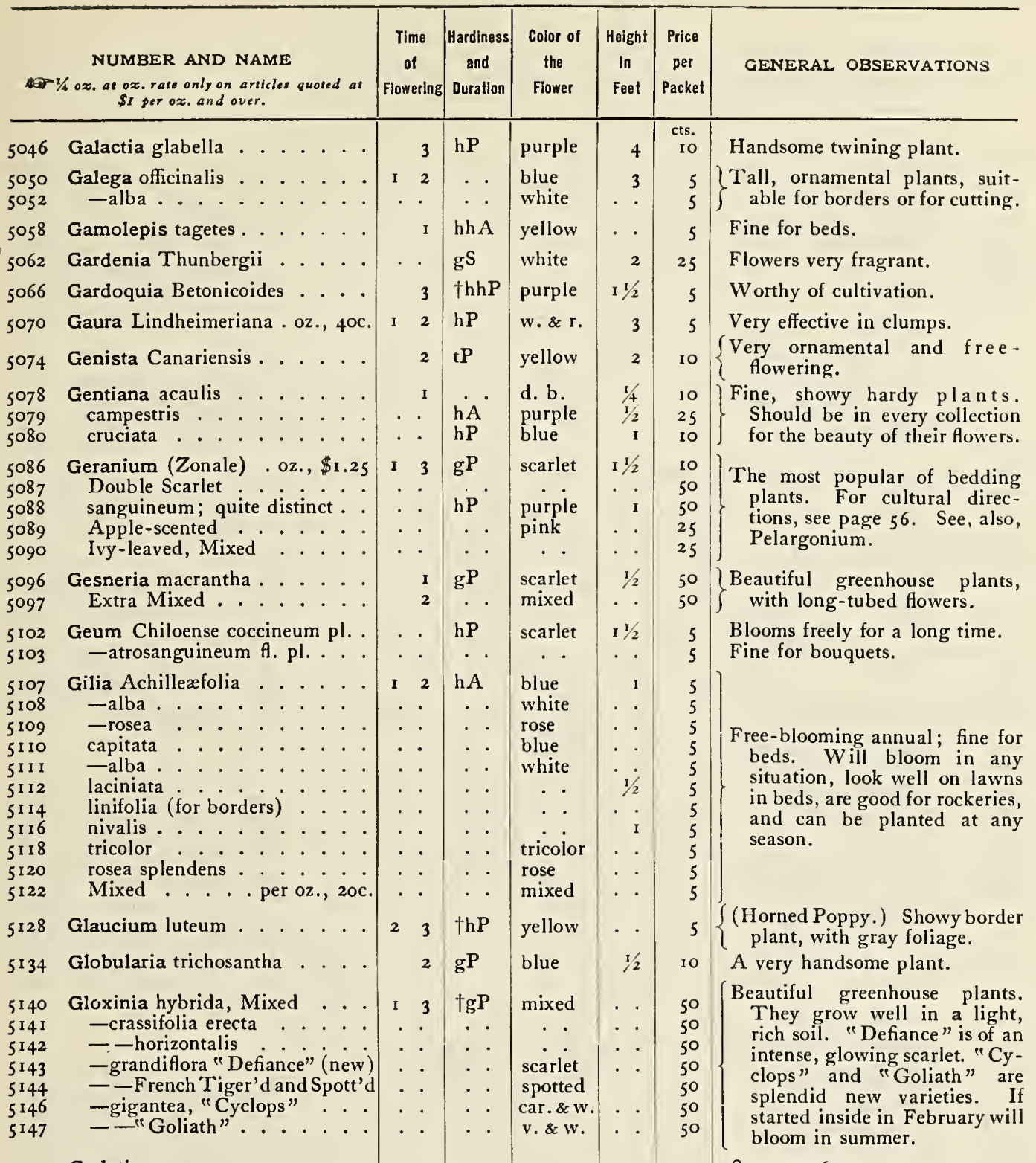

See page 65 .

See Pyrethrum, page 94.

Golden Feather

Gomphrena globosa . . . . .

-alba........

-violacea . . . . .

-carnea . . . . . . . . . .

-nana compacta rubra . .

- - - alba

-Mixed .

aurea superba

Collection, including-

6 vars. Globe Amaranth . .

Gourd, Mock Orange . . . . .

red

white

violet

pink

striped

v. red

white

mixed

orange

Egg-shaped

Apple-shaped

5172

5173

5174
Pear-shaped

\begin{tabular}{c|c|c} 
yellow & 15 & 5 \\
.. & 10 & 5 \\
.. &. & 5 \\
.. &. & 5 \\
. &. & 5 \\
\hline
\end{tabular}

The Globe Amaranths are among the most popular of the Everlastings. Their round heads of flowers are also called "Bachelors' Buttons." An old favorite for winter bouquets. The best soil is a mixture of sandy loam, stable manure and some silver sand.

Excellent for covering verandas or trellis-work, and for training over arbors, fences, etc. 


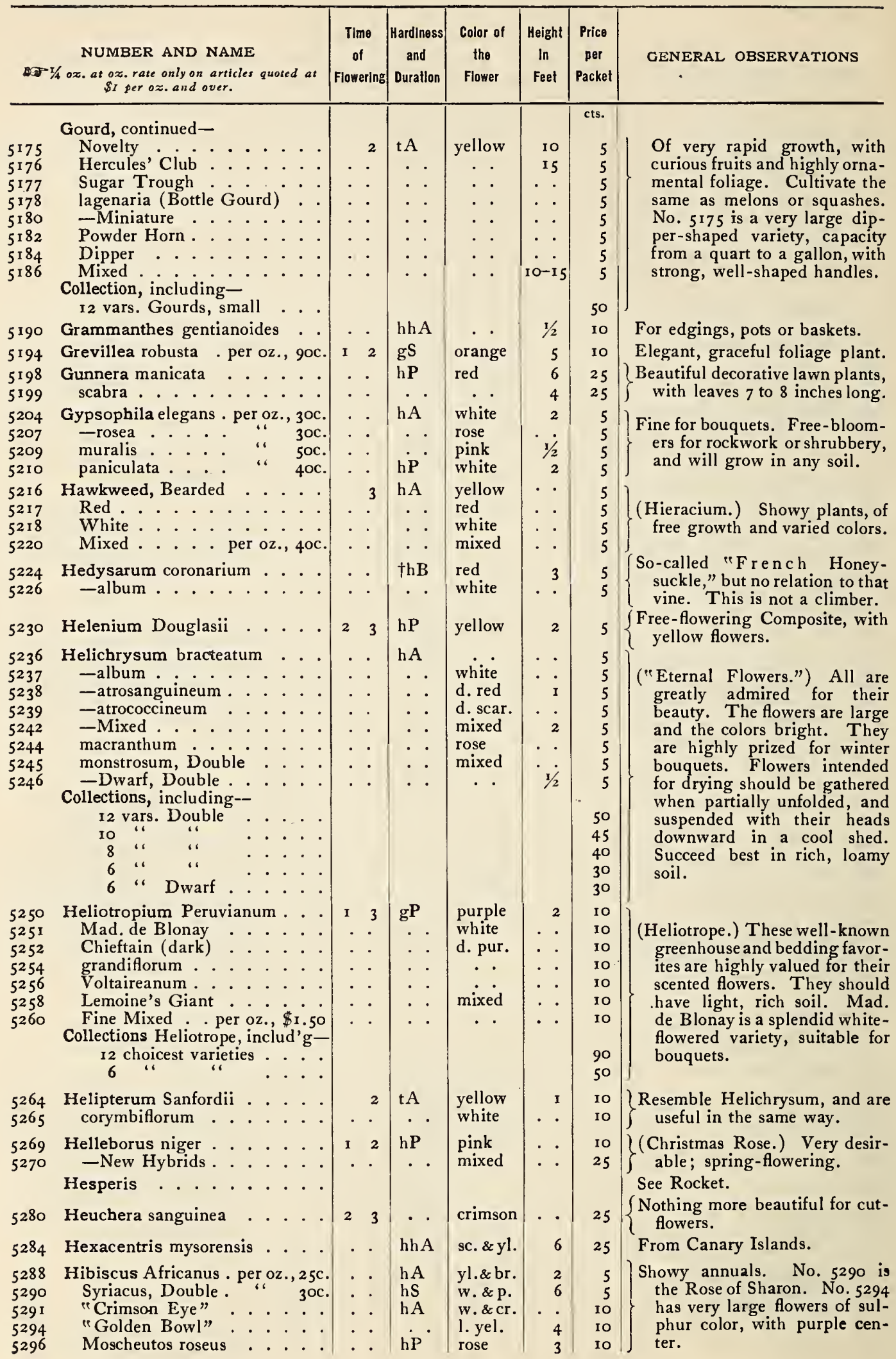




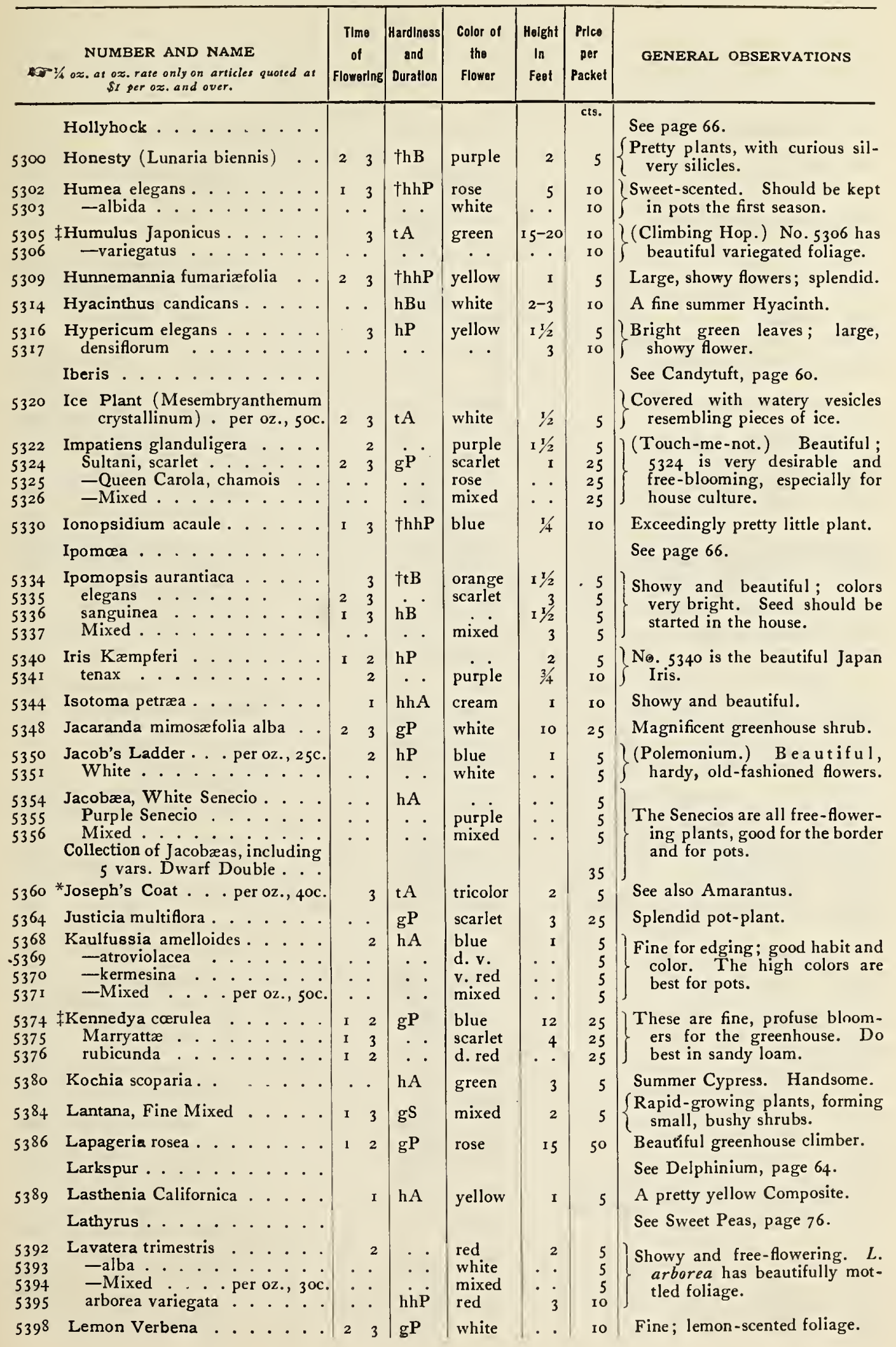




\begin{tabular}{|c|c|c|c|c|c|c|c|}
\hline & $\begin{array}{l}\text { NUMBER AND NAME } \\
\text { oz. at ox. rate only on articles quoted } \\
\$ 1 \text { per oz. and over. }\end{array}$ & $\begin{array}{c}\text { Time } \\
\text { of } \\
\text { Flowering }\end{array}$ & $\left|\begin{array}{c}\text { Hardiness } \\
\text { and } \\
\text { Duration }\end{array}\right|$ & $\begin{array}{l}\text { Color of } \\
\text { the } \\
\text { Flower }\end{array}$ & $\begin{array}{c}\text { Height } \\
\text { In } \\
\text { Feet }\end{array}$ & $\begin{array}{c}\text { Prico } \\
\text { per } \\
\text { Packet }\end{array}$ & GENERAL OBSERVATIONS \\
\hline 02 & Leontopodium alpinum $\cdot \cdot$ & 3 & hP & yellow & $1 / 2$ & cts. & Curious; the "Edelweis \\
\hline & 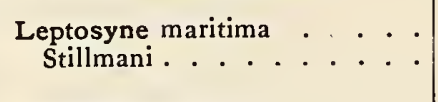 & $\therefore$ & $\begin{array}{l}\text { hhA } \\
\cdot \cdot\end{array}$ & golden & $\stackrel{2}{\cdot}$ & $\begin{array}{l}\text { IO } \\
25\end{array}$ & $\begin{array}{l}\text { eleg: } \\
\text { gold }\end{array}$ \\
\hline & 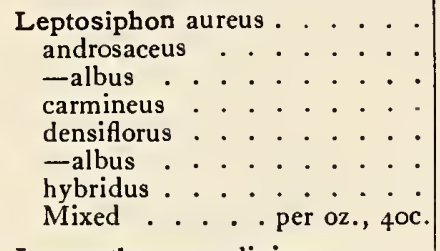 & 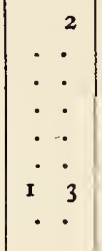 & $\begin{array}{l}\text { hA } \\
. \\
. \\
. \\
. \\
. \\
. \\
.\end{array}$ & $\begin{array}{l}\text { orange } \\
\text { blue } \\
\text { white } \\
\text { carmine } \\
\text { blue } \\
\text { white } \\
\text { mixed } \\
\quad\end{array}$ & $\begin{array}{r}1 / 2 \\
1 \\
. \\
. \\
. \\
. \\
. \\
. \\
.\end{array}$ & $\begin{array}{r}5 \\
5 \\
5 \\
10 \\
5 \\
5 \\
5 \\
5\end{array}$ & $\begin{array}{l}\text { Fine for edging o } \\
\text { blooms in mass } \\
\text { mineus has very b } \\
\text { mine flowers. }\end{array}$ \\
\hline 26 & Leucanthemum uliginosum . . & . & hP & white & $1 / 2$ & Io & ers; fin \\
\hline 5430 & Liatris scariosa . . . . . . . & 2 & hhP & purple & 2 & Io & ner \\
\hline+34 & Limnanthes Douglasii . . . & . $\cdot$ & hA & w. \& y. & I & 5 & Fre \\
\hline $\begin{array}{r}38 \\
-39 \\
40 \\
44\end{array}$ & $\begin{array}{l}\text { bipartita alba } \\
\text { ndida }\end{array}$ & $\begin{array}{ll}2 & 2 \\
\cdot & 3 \\
\cdot & \cdot\end{array}$ & $\dot{\mathrm{hP}}$ & $\begin{array}{l}\text { white } \\
\text { purple } \\
\text { rose } \\
\text { violet }\end{array}$ & $\begin{array}{r}1 / 2 \\
3 / 4 \\
\text { trail. }\end{array}$ & $\begin{array}{l}5 \\
5 \\
5 \\
5\end{array}$ & $\begin{array}{r}\text { Sna } \\
\text { si } \\
\text { gc }\end{array}$ \\
\hline & $\begin{array}{l}\text { Linum flavum . . . . . . } \\
\text { grandiflorum rubrum . oz., } 20 \mathrm{c} \text {. } \\
\text { Lewisii variegatum. }\end{array}$ & $\dot{1} \dot{2}$ & $\begin{array}{l}\text { thhP } \\
\text { hhA } \\
\text { thP }\end{array}$ & & $\begin{array}{r}3 / 4 \\
3\end{array}$ & $\begin{array}{r}10 \\
5 \\
5\end{array}$ & $\begin{array}{l}\mathrm{Fla} \\
\text { in } \\
\mathrm{m}\end{array}$ \\
\hline 54 & Lisianthus Russellianus . . . & 2 & gA & blue & $1 \% / 2$ & 25 & \\
\hline & 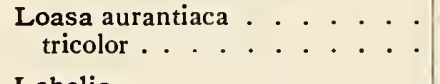 & $\dot{\cdot}$ & $\begin{array}{l}\text { hhA } \\
\text { hA }\end{array}$ & & $\begin{array}{l}6 \\
2\end{array}$ & $\begin{array}{l}5 \\
5\end{array}$ & $\begin{array}{l}\text { and flowers of } \\
\text { e. }\end{array}$ \\
\hline & Lobelia . . . . . . & & & & & & See page \\
\hline & $\begin{array}{l}\text { Lophospermum scandens . } \\
\text { coccineum . . . . . }\end{array}$ & $\dot{*}$ & tP & & 8 & $\begin{array}{l}10 \\
25\end{array}$ & rers. \\
\hline & 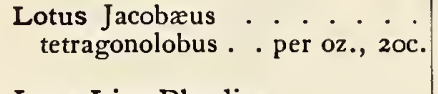 & $\begin{array}{l}\text { I } \\
2\end{array}$ & $\begin{array}{l}\text { gA } \\
\text { hA }\end{array}$ & & $\stackrel{2}{3 / 4}$ & $\begin{array}{l}5 \\
5\end{array}$ & ig. \\
\hline 474 & Love-Lies-Bleeding . oz., $20 \mathrm{c}$ & - & $\cdot \cdot$ & crimson & 3 & 5 & \\
\hline & 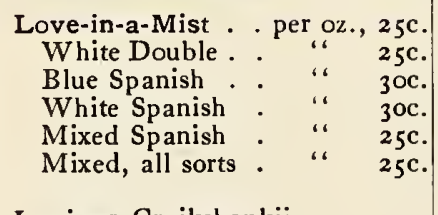 & 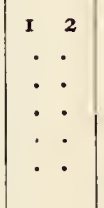 & $\begin{array}{l}. \\
: \\
: \\
: \\
.\end{array}$ & $\begin{array}{l}\text { blue } \\
\text { white } \\
\text { blue } \\
\text { white } \\
\text { mixed } \\
\quad \text {. }\end{array}$ & $\begin{array}{l}\mathbf{I} \\
\dot{.}\end{array}$ & $\begin{array}{l}5 \\
5 \\
5 \\
5 \\
5 \\
5\end{array}$ & $\begin{array}{l}\text { ella.) Curious and orna- } \\
\text { ntal; fennel-leaved; easily } \\
\text { wn and hardy. }\end{array}$ \\
\hline & 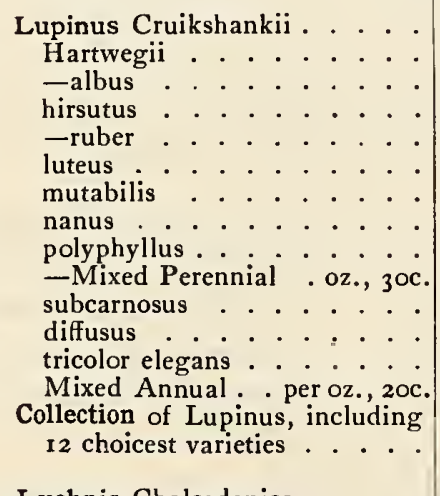 & 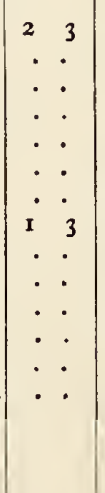 & $\begin{array}{c}\text { hP } \\
\cdot \\
\text { hA } \\
\dot{0} \\
\text { hP } \\
\text { hA } \\
\text { hP } \\
\text { hA } \\
\text { hP } \\
\text { hA }\end{array}$ & $\begin{array}{l}\text { var. } \\
\text { b.\&pk. } \\
\text { white } \\
\text { blue } \\
\text { rose } \\
\text { yellow } \\
\text { var. } \\
\text { b. \& v. } \\
\text { blue } \\
\text { mixed } \\
\text { white } \\
\text { blue } \\
\text { o.\& ro. } \\
\text { mixed }\end{array}$ & 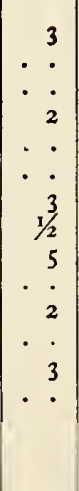 & $\begin{array}{r}5 \\
5 \\
5 \\
5 \\
5 \\
5 \\
5 \\
5 \\
5 \\
5 \\
5 \\
10 \\
5 \\
5 \\
40\end{array}$ & $\begin{array}{l}\text { No. } 5500 \text { grows } 5 \text { o } \\
\text { high, and has imme } \\
\text { cemes of lovely dark bl } \\
\text { ers. No. } 5504 \text { is a fin } \\
\text { perennial, with lovel } \\
\text { blue flowers. Some } \\
\text { are especiallycharming } \\
\text { spikes of highly color } \\
\text { ers, silver foliage an } \\
\text { habit. A rich loam } \\
\text { duce the finest plants a } \\
\text { ers. Dwarf species } m \\
\text { best bedding plants. } \\
\text { rieties are free-flower } \\
\text { tractive, bright, easily }\end{array}$ \\
\hline$\frac{9}{6}$ & 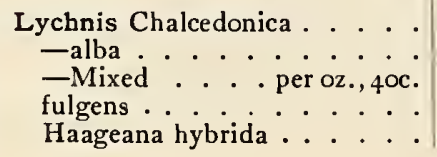 & $\begin{array}{ll}\text { I } & 2 \\
\cdot & \cdot \\
\cdot & \\
\cdot & \text { I }\end{array}$ & $\begin{array}{l}\mathrm{hP} \\
\dot{\mathrm{tP}} \\
\mathrm{hP}\end{array}$ & & $\begin{array}{l}2 \\
\dot{2} \\
\dot{1} \\
.\end{array}$ & $\begin{array}{r}5 \\
5 \\
5 \\
10\end{array}$ & $\begin{array}{l}\text { Brilliantly colored border plants; } \\
55^{19} \text { is a superb variety, and } \\
\text { the original of the beautiful } \\
\text { Haageana hybrids, which in- } \\
\text { clude the choicest flowers. }\end{array}$ \\
\hline
\end{tabular}




\begin{tabular}{|c|c|c|c|c|c|c|c|}
\hline$\infty$ & $\begin{array}{l}\text { NUMBER AND NAME } \\
-1 / 4 \text { oz. at oz. rate only on articles quoted as } \\
\$ 1 \text { per oz. and over. }\end{array}$ & $\begin{array}{c}\text { Time } \\
\text { of } \\
\text { Flowering }\end{array}$ & $\begin{array}{c}\text { Hardiness } \\
\text { and } \\
\text { Duration }\end{array}$ & $\begin{array}{l}\text { Color of } \\
\text { the } \\
\text { Flower }\end{array}$ & $\begin{array}{c}\text { Height } \\
\text { In } \\
\text { Foot }\end{array}$ & $\begin{array}{c}\text { Price } \\
\text { por } \\
\text { Packet }\end{array}$ & GENERAL OBSERVATIONS \\
\hline 5526 & Madia elegans . . per oz., $4 \circ$ c. & 2 & hA & yellow & 2 & cts. & $\left\{\begin{array}{l}\text { Handsome flowers; should be } \\
\text { in a shady position. }\end{array}\right.$ \\
\hline $\begin{array}{l}5530 \\
5531 \\
5532\end{array}$ & 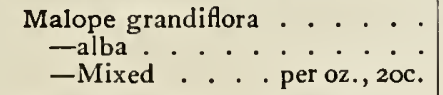 & $\begin{array}{ll}2 & 3 \\
: & \cdot\end{array}$ & $\begin{array}{l}: \dot{r} \\
\dot{\cdot}\end{array}$ & $\begin{array}{l}\text { red } \\
\text { white } \\
\text { mixed }\end{array}$ & $\therefore$ & $\begin{array}{l}5 \\
5 \\
5\end{array}$ & $\begin{array}{l}\text { Mallow-like flowers; very } \\
\text { pretty. Sow early. }\end{array}$ \\
\hline 5537 & Malva miniata. . . . . . . & - $\cdot$ & $t A$ & scarlet & 4 & 5 & $\left\{\begin{array}{c}\text { Beautiful flowers; has been ad- } \\
\text { vertised as "Sunset Plant." }\end{array}\right.$ \\
\hline $554^{\circ}$ & $\begin{array}{l}\ddagger \text { Mandevillea suaveolens . . . } \\
\text { Marigold .......... }\end{array}$ & . & gP & white & Io & 10 & $\begin{array}{l}\text { Beautiful greenhouse climbers; } \\
\text { very fragrant. } \\
\text { See page } 67 .\end{array}$ \\
\hline $\begin{array}{l}5546 \\
5547 \\
5548 \\
5549\end{array}$ & 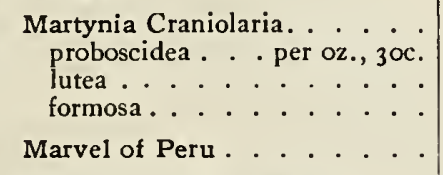 & $\begin{array}{l}: \dot{ } \\
: \\
\dot{.}\end{array}$ & $\begin{array}{l}\text { hhA } \\
.: \\
. \\
.\end{array}$ & $\begin{array}{l}\text { w. \& sp. } \\
\text { vio.sp. } \\
\text { yellow } \\
\text {. }\end{array}$ & $\dot{.}$ & $\begin{array}{l}5 \\
5 \\
5 \\
5\end{array}$ & $\begin{array}{l}\text { Curious and very handsome } \\
\text { plants for the border. } \\
\text { See Four O'clock, page } 86 \text {. }\end{array}$ \\
\hline $\begin{array}{l}5554 \\
5555 \\
5556\end{array}$ & $\begin{array}{l}\text { Matricaria eximia plena } . . . \\
\text { capensis plena . . } . . \cdot \cdot \cdot \cdot \\
\text { "Golden Ball" (very beautiful). }\end{array}$ & $\begin{array}{l}\cdot \dot{ } \\
\dot{.}\end{array}$ & $\begin{array}{l}\text { hA } \\
. \\
.\end{array}$ & $\begin{array}{l}\text { white } \\
\text { yellow }\end{array}$ & $\dot{2}$ & $\begin{array}{r}5 \\
5 \\
25\end{array}$ & $\begin{array}{l}\text { (Feverfew.) Pretty and neat; } \\
\text { small double flowers. }\end{array}$ \\
\hline 5560 & Mathiola bicornis . . . & . & hhA & white & $1 / 2$ & 5 & $\left\{\begin{array}{l}\text { Very fragrant at night, but clos- } \\
\text { ing during the day. }\end{array}\right.$ \\
\hline $\begin{array}{l}5566 \\
5567 \\
5568 \\
5570 \\
5572 \\
5574\end{array}$ & 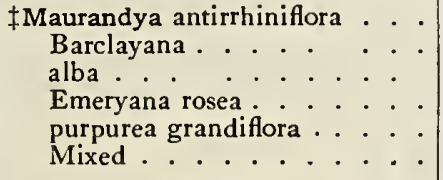 & $\begin{array}{ll}\text { I } & 3 \\
\cdot & \cdot \\
\cdot & : \\
\cdot & \cdot \\
\cdot & :\end{array}$ & $\begin{array}{l}\operatorname{tgP} \\
: \dot{ } \\
: \\
: \\
:\end{array}$ & $\begin{array}{l}\text { purple } \\
\text { bl. \& w. } \\
\text { white } \\
\text { rose } \\
\text { purple } \\
\text { mixed }\end{array}$ & $\begin{array}{l}\text { 10 } \\
. \\
. \\
. \\
. \\
.\end{array}$ & $\begin{array}{l}10 \\
10 \\
10 \\
10 \\
10 \\
10\end{array}$ & $\begin{array}{l}\text { Abundant bloomers, and very } \\
\text { desirable for the greenhouse } \\
\text { and garden. Should be in } \\
\text { every collection. }\end{array}$ \\
\hline 5578 & ${ }^{*}$ Melianthus major . . . . . & . & $\mathrm{gP}$ & brown & & 10 & Has very ornamental foliage. \\
\hline $\begin{array}{l}55^{82} \\
55^{86}\end{array}$ & $\begin{array}{l}\text { Melilotus cœrulea . per oz., зoc. } \\
\ddagger \text { Melothria scabra . . . . . . }\end{array}$ & . & $\begin{array}{l}\text { hP } \\
\text { hhA }\end{array}$ & $\begin{array}{l}\text { blue } \\
\text { 1. b. }\end{array}$ & $\begin{array}{l}1 / 2 \\
10\end{array}$ & $\begin{array}{r}5 \\
10\end{array}$ & $\begin{array}{l}\text { Ornamental; like the Lotus. } \\
\text { Tropical vine. }\end{array}$ \\
\hline $\begin{array}{l}5590 \\
5591 \\
5592 \\
5594\end{array}$ & 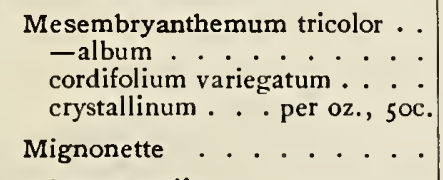 & 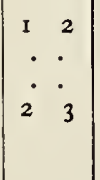 & $\begin{array}{l}\mathrm{tA} \\
\mathrm{tP}\end{array}$ & $\begin{array}{l}\text { tricolor } \\
\text { white } \\
\text { yellow } \\
\text { white }\end{array}$ & $\begin{array}{l}1 / 2 \\
\dot{.} \\
.\end{array}$ & $\begin{array}{r}5 \\
5 \\
25 \\
5\end{array}$ & $\begin{array}{l}\text { Beautiful dwarf edging plants, } \\
\text { flowering profusely in dry and } \\
\text { sunny situations. Fine for pots. } \\
5594 \text { is the "Ice Plant." } \\
\text { See page } 67 .\end{array}$ \\
\hline 5600 & Mimosa pudica . per oz., $75 \mathrm{c}$ & - & . . & pink & $3 / 4$ & 5 & (Sensitive Plant.) Very odd. \\
\hline $\begin{array}{l}5604 \\
5605 \\
5606 \\
5608 \\
5610\end{array}$ & 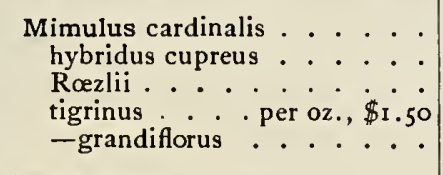 & $\begin{array}{ll}\text { I } & 2 \\
1 & 3 \\
2 & 3 \\
\text { I } & 3 \\
\text {. } & \text { - }\end{array}$ & $\begin{array}{l}\text { thP } \\
\text { hA } \\
. \\
. \\
.\end{array}$ & $\begin{array}{l}\text { scarlet } \\
\text { mixed } \\
\text { yellow } \\
\text { spotted } \\
\quad .\end{array}$ & $\begin{array}{l}1 / 2 \\
1 / 2 \\
1 \\
.\end{array}$ & $\begin{array}{l}10 \\
10 \\
25 \\
10 \\
25\end{array}$ & $\left\{\begin{array}{l}\text { (Monkey Flower.) Very showy, } \\
\text { musk-scented, and free-flower- } \\
\text { ing. The hardy kinds are } \\
\text { well suited for borders. Any } \\
\text { common soil suits. See Musk } \\
\text { Plant. }\end{array}\right.$ \\
\hline $\begin{array}{l}5614 \\
5618\end{array}$ & $\begin{array}{l}\ddagger \text { Mina lobata } . . . \\
\text { Molucella spinosa } \ldots . .\end{array}$ & 2 & hP & $\begin{array}{l}\text { wh. \& } \mathrm{r} . \\
\text { rose }\end{array}$ & $\begin{array}{r}15 \\
7\end{array}$ & $\begin{array}{l}10 \\
25\end{array}$ & $\begin{array}{l}\text { Curious; free bloomers. } \\
\left\{\begin{array}{l}\text { A splendid new Shell-flower, } \\
\text { with very fine foliage. }\end{array}\right.\end{array}$ \\
\hline $\begin{array}{l}5622 \\
5623 \\
5624 \\
5625\end{array}$ & 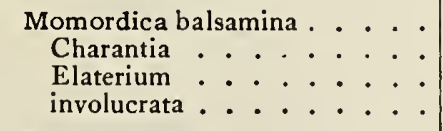 & $\begin{array}{l}\dot{.} \\
\dot{\cdot} \\
\dot{\cdot}\end{array}$ & $\begin{array}{l}\text { hhA } \\
\dot{\cdot} \cdot \\
\dot{\cdot}\end{array}$ & $\begin{array}{c}\text { yellow } \\
: \cdot \\
. \\
.\end{array}$ & $\begin{array}{l}\text { 10 } \\
. \\
.\end{array}$ & $\begin{array}{r}5 \\
5 \\
5 \\
25\end{array}$ & $\left\{\begin{array}{l}\text { Handsome ornamental gourds. } \\
5622 \text { is the Balsam Pear and } \\
5623 \text { the Balsam Apple. } 5624 \\
\text { is the Squirting Cucumber. }\end{array}\right.$ \\
\hline 5629 & $\begin{array}{l}\text { Monk's-Hood } \\
\text { Moon-Flower . . . . . . . . . . } \\
\text { Morning Glory . . . . . . . . } \\
\text { Mourning Bride . . . . . . . }\end{array}$ & & & & & & $\begin{array}{l}\text { See Aconitum. } \\
\text { See Ipomaea Mexicana. } \\
\text { See pages } 66 \text { and } 8 \mathbf{4} \\
\text { See Scabiosa. }\end{array}$ \\
\hline $\begin{array}{l}5632 \\
5636\end{array}$ & $\begin{array}{l}\text { Mukia scabrella } . . . . . \\
\text { Musa ensete . . roo seeds, } \$ \text { I.50 }\end{array}$ & I & & y. \& br & & 10 & $\begin{array}{l}\text { Handsome ornamental gourd. } \\
\left\{\begin{array}{l}\text { (Abyssinian Banana.) Splendid } \\
\text { tropical plant. }\end{array}\right.\end{array}$ \\
\hline $\begin{array}{l}5639 \\
5640\end{array}$ & 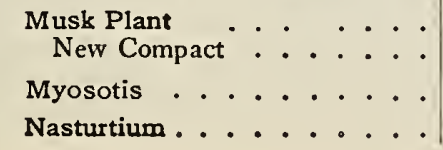 & $\begin{array}{ll}\text { I } 3 \\
.\end{array}$ & tA & $\begin{array}{c}\text { yellow } \\
.\end{array}$ & $\begin{array}{l}1 / 2 \\
1 / 3\end{array}$ & $\begin{array}{l}\text { 10 } \\
\text { 10 }\end{array}$ & $\begin{array}{l}\text { Musk-scented Mimulus. } \\
\text { See Forget-me-not, page } 65 \\
\text { See page } 68 .\end{array}$ \\
\hline
\end{tabular}




\begin{tabular}{|c|c|c|c|c|c|c|c|}
\hline 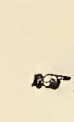 & $\begin{array}{l}\text { NUMBER AND NAME } \\
\text {-1/4 oz. at oz. rate only on articles quoted at } \\
\text { \$1 per oz. and over. }\end{array}$ & $\begin{array}{c}\text { Time } \\
\text { of } \\
\text { Fiowering }\end{array}$ & $\begin{array}{c}\text { Hardiness } \\
\text { and } \\
\text { Duratlon }\end{array}$ & $\begin{array}{l}\text { Coior of } \\
\text { the } \\
\text { Flower }\end{array}$ & $\begin{array}{c}\text { Height } \\
\text { in } \\
\text { Feet }\end{array}$ & $\begin{array}{c}\text { Price } \\
\text { per } \\
\text { Packet }\end{array}$ & GENERAL OBSERVATIONS \\
\hline 644 & Nægelia hybrida $\cdot \cdot \cdot \cdot \cdot \cdot$ & 3 & gP & var. & $1 / 2$ & 25 & Beautifu \\
\hline & 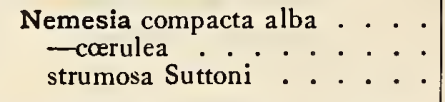 & $\begin{array}{l}2.3 \\
:\end{array}$ & $\begin{array}{l}\text { tA } \\
\text { hA }\end{array}$ & $\begin{array}{l}\text { white } \\
\text { ro. \&b. } \\
\text { var. }\end{array}$ & $\begin{array}{l}1 / 2 \\
. \\
.\end{array}$ & $\begin{array}{r}5 \\
5 \\
25\end{array}$ & $\begin{array}{l}\text { Very pretty an } \\
\text { plant for ed } \\
\text { new and very }\end{array}$ \\
\hline $\begin{array}{l}58 \\
59 \\
60 \\
62 \\
63 \\
64 \\
66 \\
68\end{array}$ & 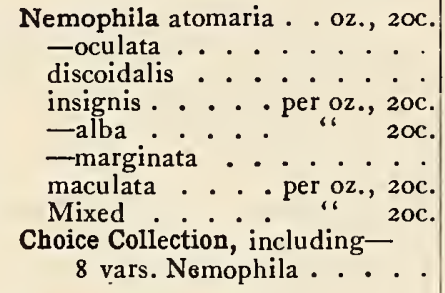 & $\begin{array}{l}\text { I } \\
: \vdots \\
: \\
: \\
: \\
:\end{array}$ & $\begin{array}{l}: \dot{ } \\
\dot{0} \\
\dot{.} \\
\dot{.} \\
\dot{.} \\
\dot{.}\end{array}$ & $\begin{array}{l}\text { w.\&pu. } \\
\text { b.\&w. } \\
\text { purple } \\
\text { blue } \\
\text { white } \\
\text { bord. } \\
\text { spotted } \\
\text { mixed }\end{array}$ & 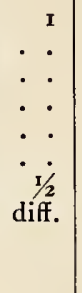 & $\begin{array}{l}5 \\
5 \\
5 \\
5 \\
5 \\
5 \\
5 \\
5\end{array}$ & $\begin{array}{l}\text { This genus consi } \\
\text { pretty annuals of } \\
\text { they deserve ext } \\
\text { vation; are good } \\
\text { for edging, in roc } \\
\text { the garden. }\end{array}$ \\
\hline 5674 & Nerium Oleander . . . . . & 2 & gS & red & Io & Io & Oleander. Orn \\
\hline 5678 & Nertera depressa...... & - & $\mathrm{gP}$ & white & cr. & 25 & Pla \\
\hline & 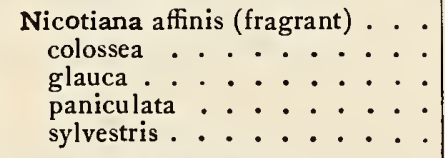 & $\begin{array}{l}: \dot{ } \\
: \\
:\end{array}$ & $\begin{array}{l}\text { hhA } \\
: \dot{ } \\
\therefore \\
\therefore\end{array}$ & $\begin{array}{c}\cdot \dot{\cdot} \\
\text { yel. \&gr. } \\
. \cdot\end{array}$ & $\begin{array}{r}3 \\
10 \\
3 \\
. \quad \\
. \quad\end{array}$ & $\begin{array}{r}5 \\
25 \\
5 \\
10 \\
10\end{array}$ & $\begin{array}{r}\text { Speci } \\
\text { dec } \\
\text { fra }\end{array}$ \\
\hline $\begin{array}{l}690 \\
6991\end{array}$ & 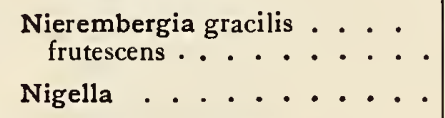 & & $\underset{h P}{g P}$ & w. \& li. & $\begin{array}{l}\text { I } \\
2\end{array}$ & $\begin{array}{l}\text { 10 } \\
\text { 10 }\end{array}$ & $\begin{array}{l}\text { fine for hang- } \\
\text { r edgings. } \\
\text { t. }\end{array}$ \\
\hline $\begin{array}{l}5696 \\
5697 \\
5698 \\
5699 \\
5700 \\
5704\end{array}$ & 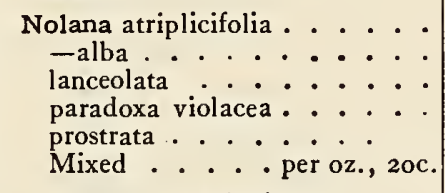 & $\begin{array}{l}{ }^{2} \\
. \\
. \\
. \\
.\end{array}$ & 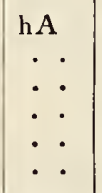 & $\begin{array}{l}\text { b.w. \&y. } \\
\text { white } \\
\text { b. \& w. } \\
\text { b. \& v. } \\
\text { blue } \\
\text { mixed }\end{array}$ & $\begin{array}{c}1 / 2 \\
\cdot \\
1 \\
\text { trail. } \\
I\end{array}$ & $\begin{array}{l}5 \\
5 \\
5 \\
5 \\
5\end{array}$ & $\begin{array}{l}\text { Are very showy } \\
\text { and should b } \\
\text { border; fine } t\end{array}$ \\
\hline $\begin{array}{l}57 \text { IO } \\
57 \text { I I }\end{array}$ & $\begin{array}{l}\text { ia selaginoides } . \quad \cdot \therefore \\
\text { sis } \cdot \cdot \cdot \cdot \cdot \cdot \cdot \cdot\end{array}$ & 23 & hhP & & $3 / 4$ & $\begin{array}{l}5 \\
5\end{array}$ & \\
\hline 5716 & 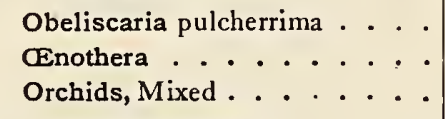 & 2 & †hP & r. \& y. & diff. & 25 & $\begin{array}{l}\text {, page } 94 \text {. } \\
\text { cies. }\end{array}$ \\
\hline $\begin{array}{l}5718 \\
5719\end{array}$ & 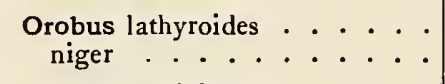 & $\begin{array}{ll}2 & 3 \\
\cdot & -\end{array}$ & . & & $\begin{array}{r}1 / 2 \\
3\end{array}$ & $\begin{array}{l}5 \\
5\end{array}$ & \\
\hline 5722 & $\begin{array}{l}\text { Oxalis Valdiviana } \ldots . . \\
\text { Oxyura chrysanthemoides. . . }\end{array}$ & 2 & $\begin{array}{l}\text { tP } \\
h A\end{array}$ & $\begin{array}{l}\text { yellow } \\
\text { white }\end{array}$ & $\begin{array}{r}1 / 2 \\
\text { trail. }\end{array}$ & 10 & $\begin{array}{l}\text { Charming little plants. } \\
\text { Showy Composite. }\end{array}$ \\
\hline $\begin{array}{l}5728 \\
5729 \\
5730\end{array}$ & $\begin{array}{l}\text { Pæonia officinalis } \ldots . . \\
\text { Sinensis } \\
\text { arborea (Tree Pæony) }\end{array}$ & $\begin{array}{l}2 \\
. \\
\cdot\end{array}$ & hP & $\begin{array}{l}\text { red } \\
\text { mixed } \\
\cdot \cdot\end{array}$ & $\begin{array}{l}2 \\
3\end{array}$ & $\begin{array}{r}5 \\
10 \\
10\end{array}$ & $\begin{array}{l}\text { Beautiful hardy plants, with } \\
\text { large, handsome flowers. }\end{array}$ \\
\hline 5736 & Palafoxia Hookeriana . . . . & . & hA & blush & $1 / 2$ & 5 & lasting. \\
\hline 5740 & 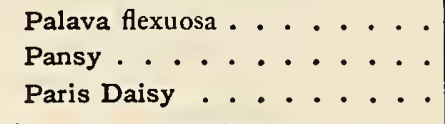 & 2 & hhA & rose & . . & 5 & $\begin{array}{l}\text { flowers. } \\
9 . \\
\text { anthemum frutescens. }\end{array}$ \\
\hline $\begin{array}{l}5746 \\
5747 \\
5748 \\
5749\end{array}$ & 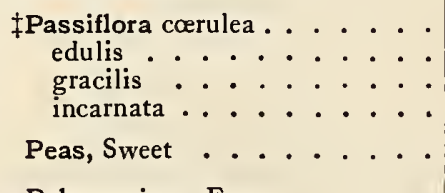 & 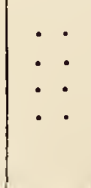 & $\begin{array}{l}\dot{:} \\
\dot{\cdot}\end{array}$ & $\begin{array}{l}\text { blue } \\
\text { white } \\
\text { pink }\end{array}$ & $\begin{array}{l}10 \\
25 \\
10 \\
25\end{array}$ & $\begin{array}{l}\text { 10 } \\
\text { 10 } \\
10 \\
10\end{array}$ & $\begin{array}{l}\text { Called "Passion Flower" on ac- } \\
\text { count of a fancied resemblance } \\
\text { in the flower to the appear- } \\
\text { ance presented at Calvary. } \\
\text { See page } 76 \text {. }\end{array}$ \\
\hline $\begin{array}{l}5760 \\
5761 \\
5764\end{array}$ & 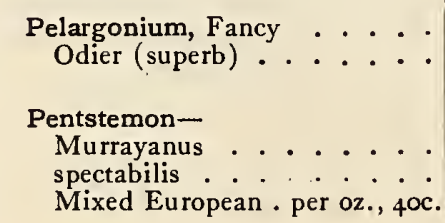 & $\begin{array}{l}: \\
: \\
:\end{array}$ & gP & $\begin{array}{l}\text { scarlet } \\
\text { blue } \\
\text { mixed }\end{array}$ & $\begin{array}{l}3 \\
2 \\
.\end{array}$ & $\begin{array}{r}10 \\
10 \\
5\end{array}$ & $\begin{array}{l}\text { Beautiful greenhouse } \\
5756 \text { has magnificen } \\
\left\{\begin{array}{c}\text { Beautiful herbaceous p } \\
\text { should be grown ex } \\
\text { very hardy and free- } \\
\text { fine for bedding; as } \\
\text { color as Gladioli. }\end{array}\right.\end{array}$ \\
\hline
\end{tabular}




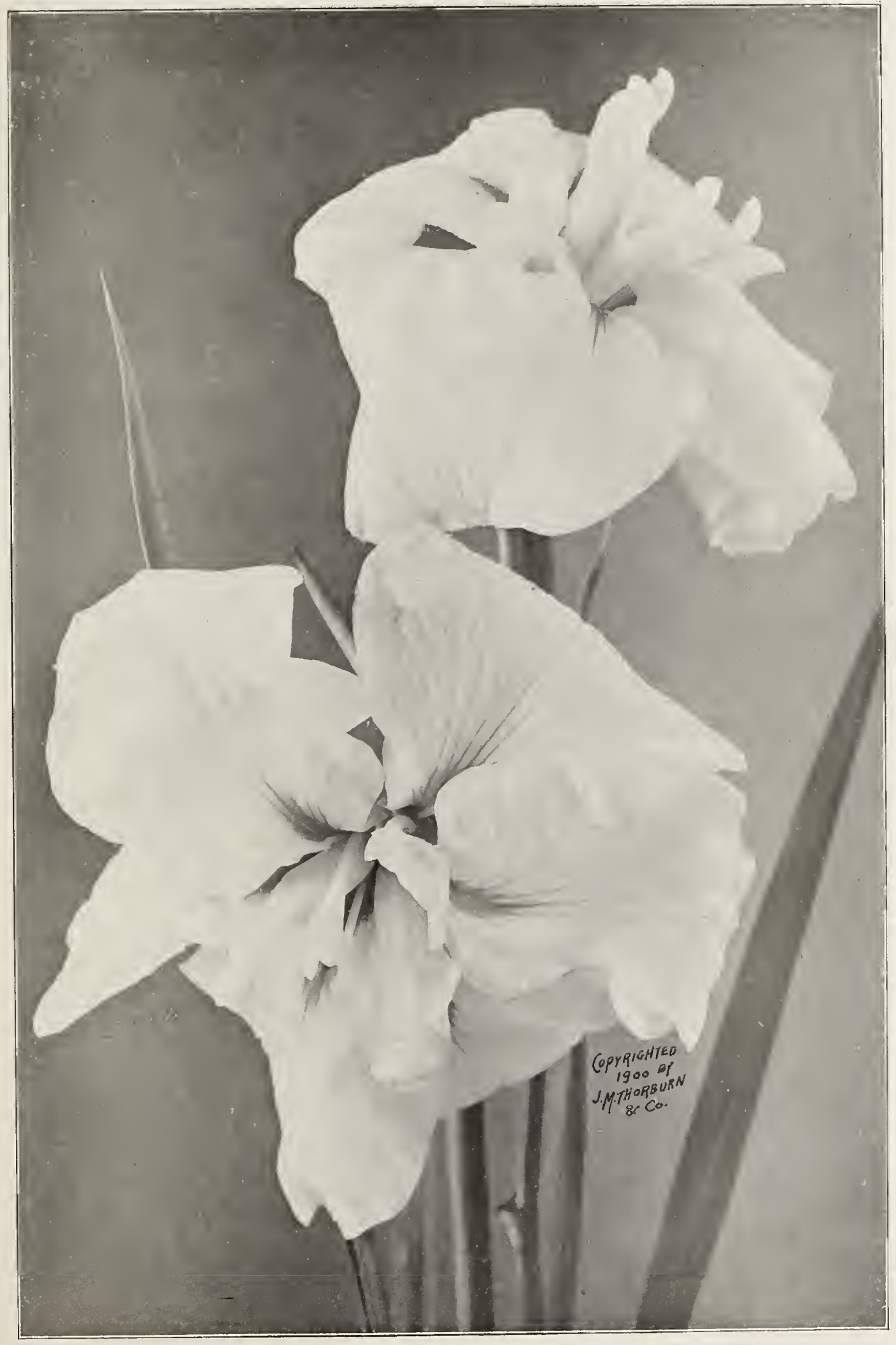

PLATE XXVII - NEW LARGE-FLOWERING JAPAN IRIS (See page I06) 


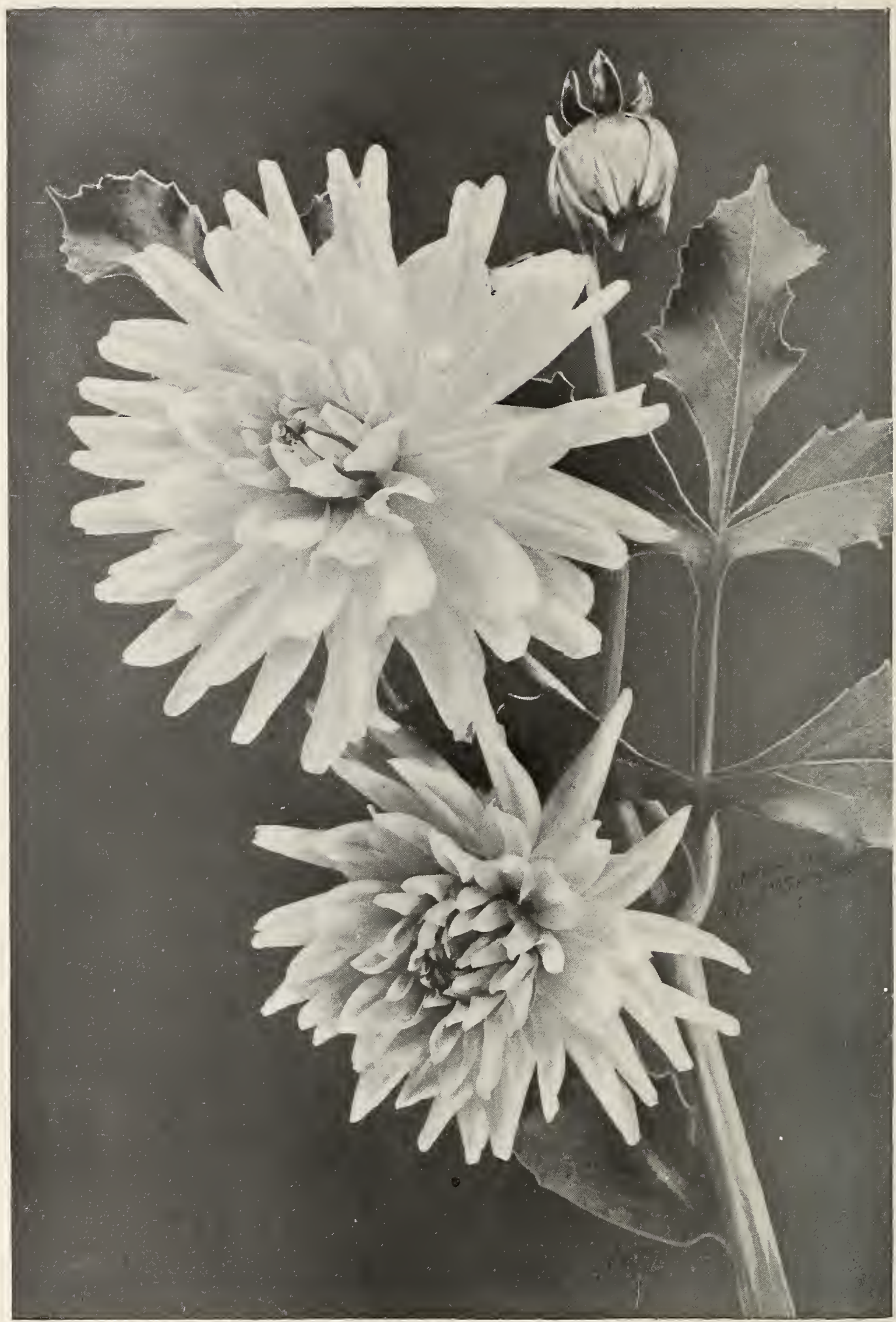

Plate XXVIII-Cactus Dahlia

(See page ro4) 


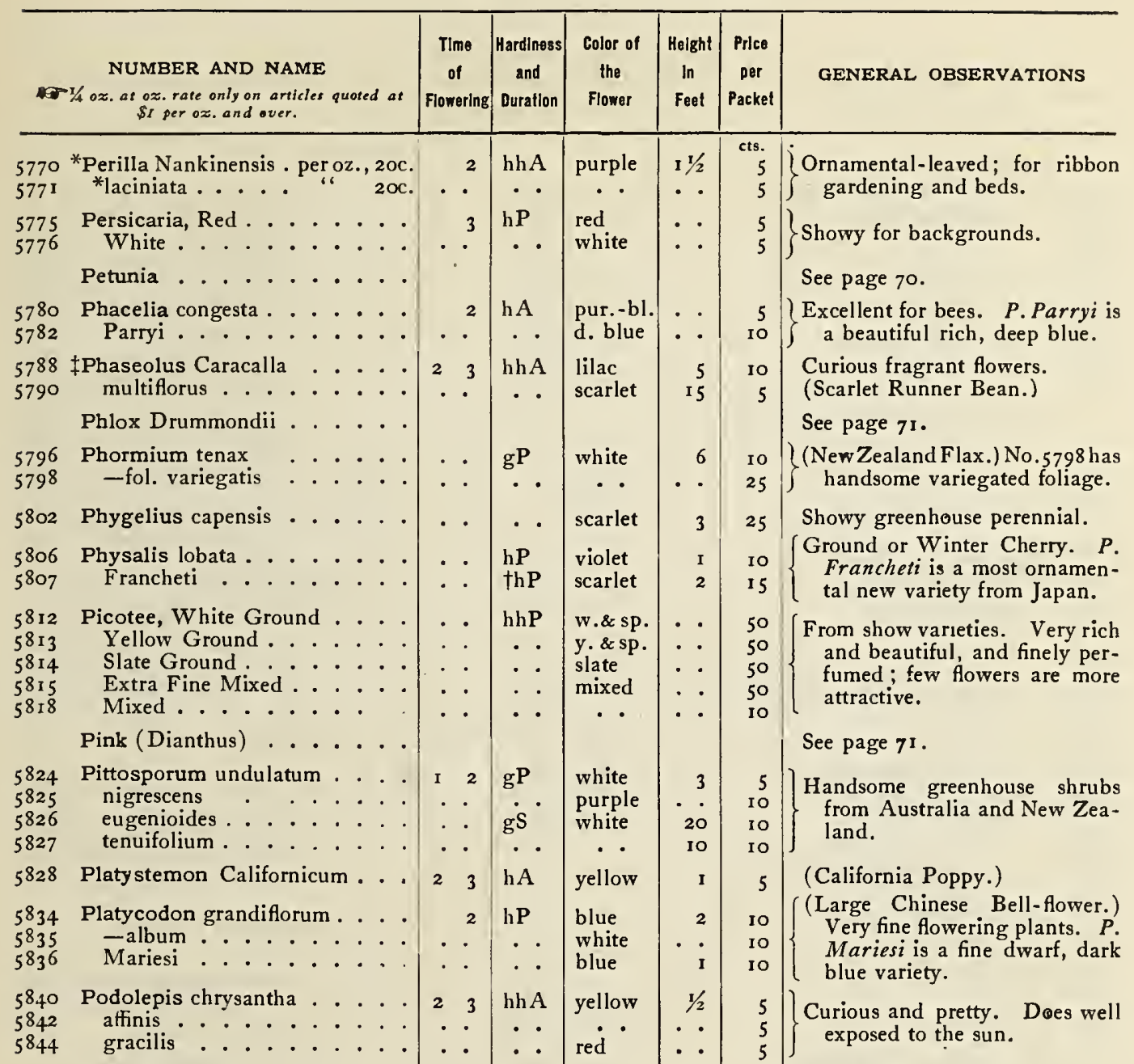

See Jacob's Ladder.

(Primula.) Fine varieties.

From named varieties.

5848
5849

Plemonium

25

5850

Poppy . . . . . . . . .

5856

Potentilla atrosanguinea

Collection, including6 vars. Potentilla, choicest

Primula cortusoides

Cashmertusoides.....

Japonica . . $\cdot \cdot \cdot \cdot \cdot$

Forbesi

English Yellow Prime thP

obconica grandiflora alba .

- -rosea .......

verticillata

Mixed Hardy Garden sorts .

See page 72 .

See page 73 .

Showy and hardy border plants.

5882 Primula Sinensis fimbriata rubra.

These are the hardy Primroses. $P$. Japonica is called the "Queen of Primroses." $P$. Forbesi has pretty rosy lilac flowers, and is fine for pots. $P$. verticillata has large white powdered leaves and golden flowers, and is one of the finest species.

From primus, first, referring to their early flowering. The Chinese Primroses (Primula Sinensis) are fine for winter and spring blooming; they are free flowering, and especially valu- 


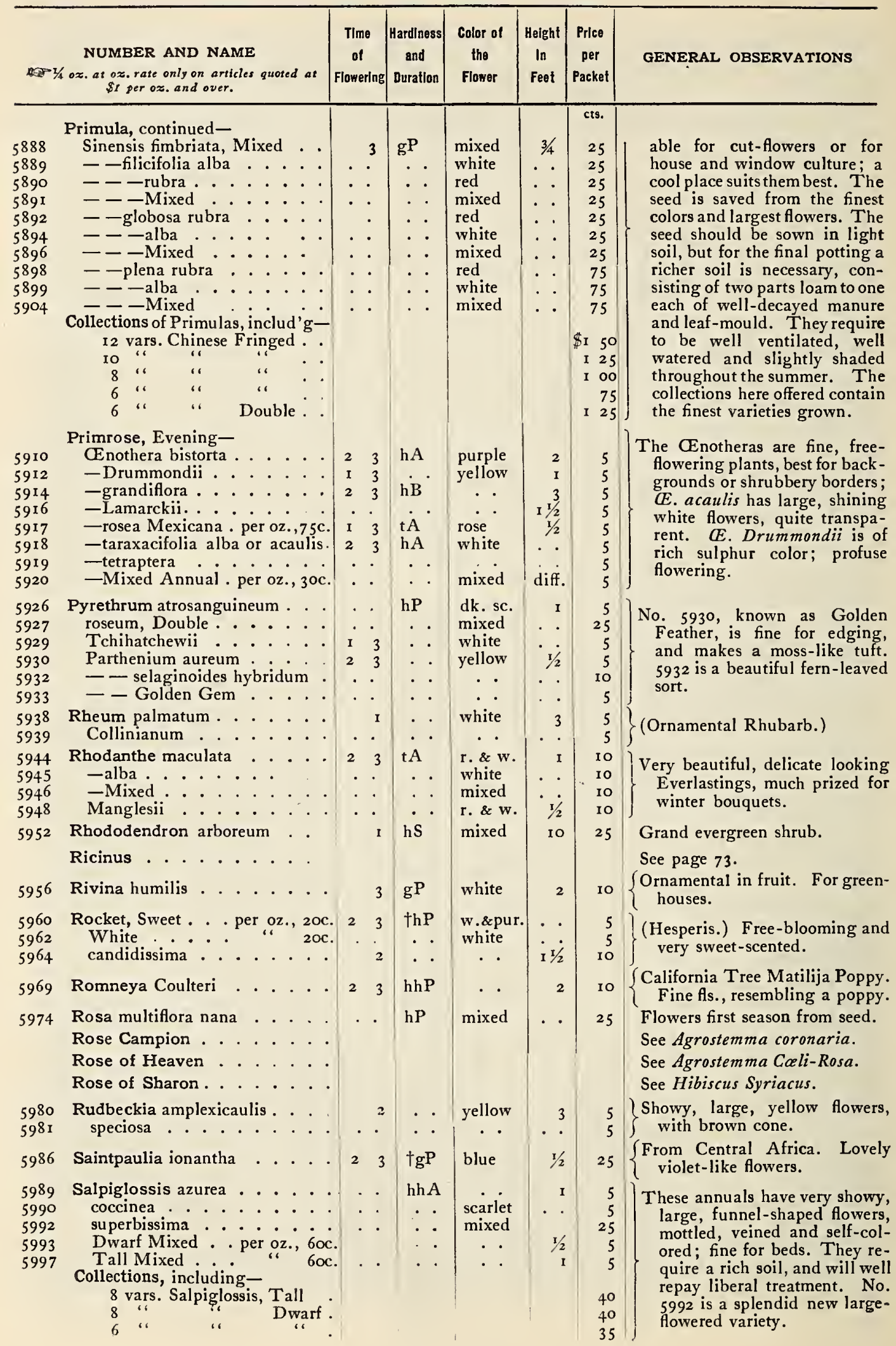




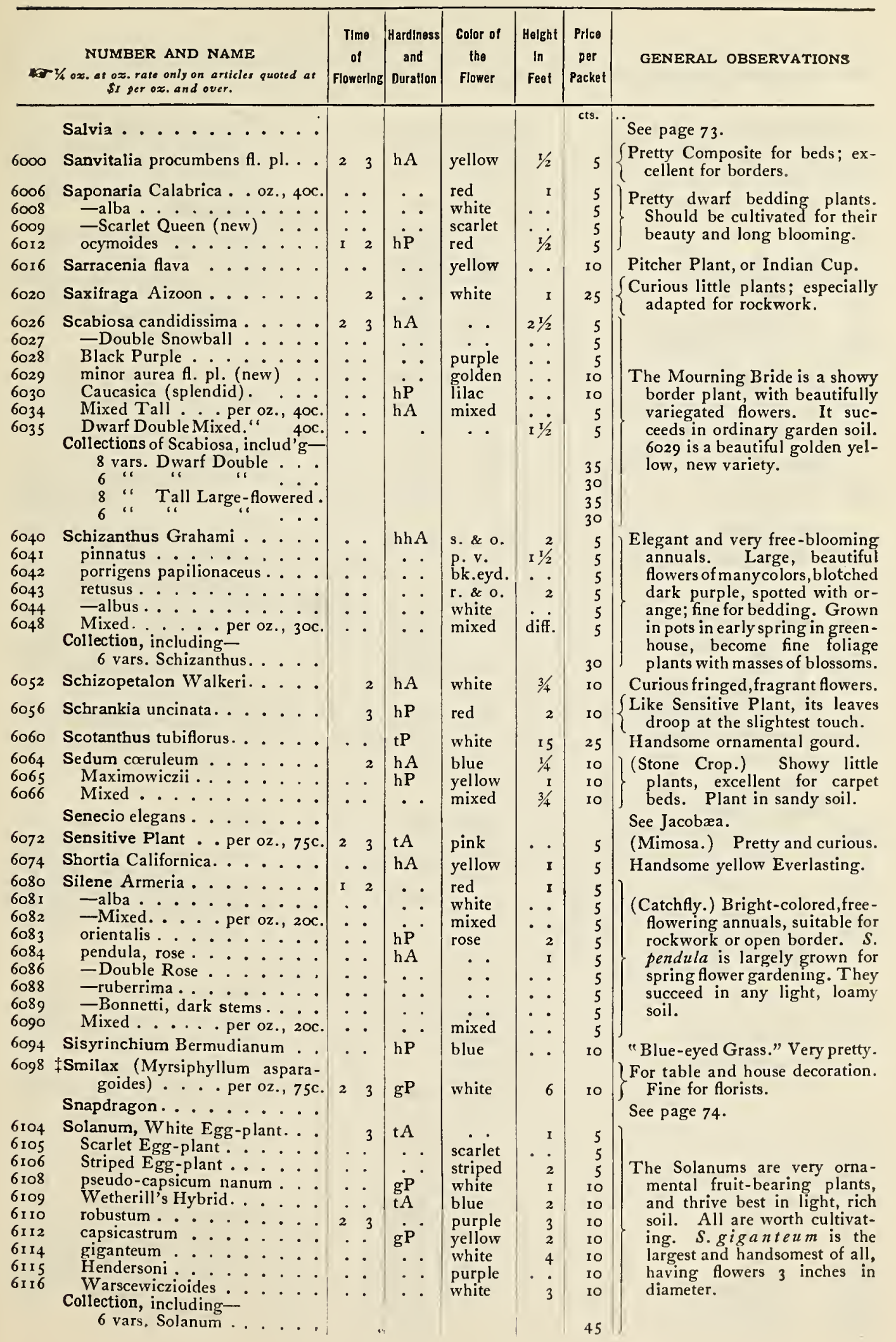




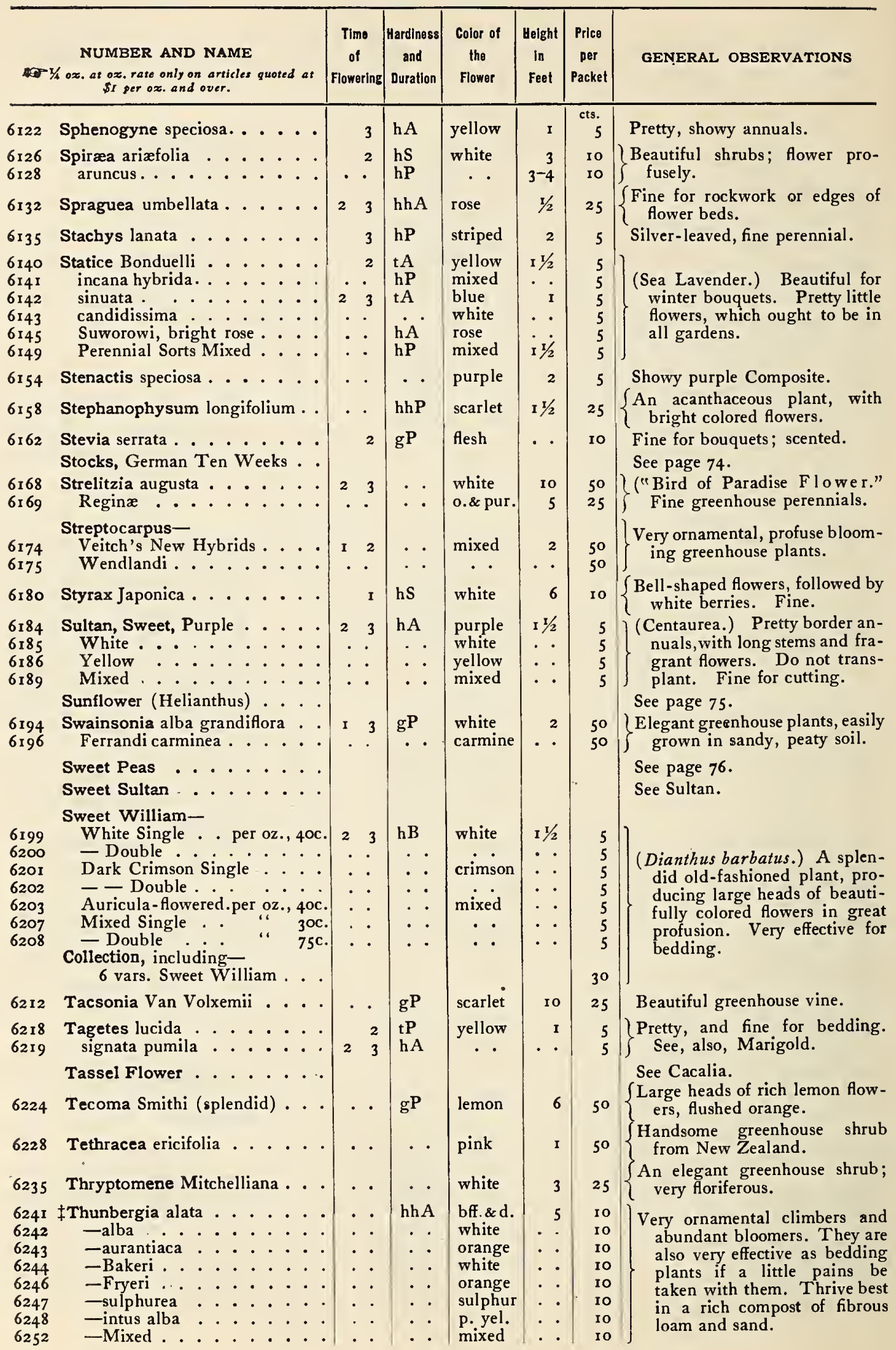




\begin{tabular}{|c|c|c|c|c|c|c|c|}
\hline 80 & $\begin{array}{l}\text { NUMBER AND NAME } \\
=1 / 4 \text { ox. at oz. rate only on articles quoted at } \\
\$ \& \text { per oz. and over. }\end{array}$ & $\begin{array}{c}\text { Time } \\
\text { of } \\
\text { Flowering }\end{array}$ & $\begin{array}{c}\text { Hardiness } \\
\text { and } \\
\text { Duration }\end{array}$ & $\begin{array}{l}\text { Color of } \\
\text { the } \\
\text { Flower }\end{array}$ & $\begin{array}{c}\text { Height } \\
\text { In } \\
\text { Feet }\end{array}$ & $\begin{array}{c}\text { Price } \\
\text { per } \\
\text { Packet }\end{array}$ & GENERAL OBSERVATIONS \\
\hline $625^{8}$ & Tommasinia verticillaris . . . & 2 & $\mathrm{hP}$ & yellow & $\mathbf{I}$ & $\begin{array}{l}\text { cts. } \\
25\end{array}$ & Splendid single lawn plant. \\
\hline $\begin{array}{l}6262 \\
6263 \\
6265\end{array}$ & 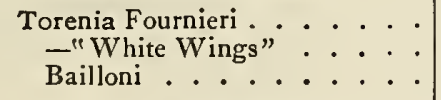 & $\begin{array}{l}\cdot \dot{ } \\
\cdot \\
\cdot\end{array}$ & $\begin{array}{l}\mathrm{tA} \\
\therefore \\
.\end{array}$ & $\begin{array}{l}\text { purple } \\
\text { white } \\
\text { yellow }\end{array}$ & $\begin{array}{l}: \\
\bullet \\
\dot{*}\end{array}$ & $\begin{array}{l}25 \\
25 \\
25\end{array}$ & $\begin{array}{l}\text { For borders and baskets. } 6265 \text { is } \\
\text { golden yellow, with deep red } \\
\text { throat; } 6262 \text { is fine for pots. }\end{array}$ \\
\hline 6269 & Trachelium cœruleum . . . . & 2 & thP & blue & $I 1 / 2$ & 5 & Valuable; border or greenhouse. \\
\hline 6274 & Trachymene cœrulea (Didiscus). & . . & $\mathrm{gA}$ & . & . & 5 & Fine long-blooming annuals. \\
\hline $\begin{array}{l}6278 \\
6279 \\
6280\end{array}$ & 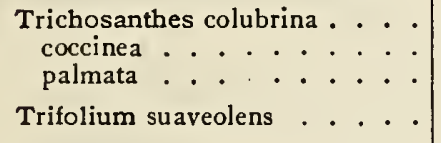 & $\begin{array}{l}3 \\
2 \\
3 \\
2\end{array}$ & $\begin{array}{l}\mathrm{gP} \\
\dot{\cdot} \cdot \\
\mathrm{hP}\end{array}$ & $\begin{array}{l}\text { white } \\
\text { yellow } \\
\text { white } \\
\text { purple }\end{array}$ & $\begin{array}{c}4 \\
\dot{:} \\
\text { trail. }\end{array}$ & $\begin{array}{l}\text { 10 } \\
\text { 10 } \\
\text { 10 } \\
5\end{array}$ & $\begin{array}{l}\text { (Snake Gourd.) So called from } \\
\text { the shape of its fruit. } \\
\text { An ornamental clover. }\end{array}$ \\
\hline $\begin{array}{l}6286 \\
6287\end{array}$ & $\begin{array}{l}\text { Tritoma uvaria } . . . \\
\text { MacOwani . . . . . } \\
\text { Tropæolum . . . . . }\end{array}$ & $\begin{array}{ll}2.3 \\
.\end{array}$ & hhP & $\begin{array}{l}\text { or. - red } \\
\text { r.\& yel. }\end{array}$ & $x \frac{3}{1 / 2}$ & $\begin{array}{l}10 \\
25\end{array}$ & $\begin{array}{l}\text { (Red-Hot-Poker Plant.) Strong } \\
\text { flowering plants; have very } \\
\text { showy spikes of bloom. } \\
\text { See page } 68 \text {. }\end{array}$ \\
\hline 6293 & Tunica saxifraga..$\cdot \cdot \cdot$ & 2 & $\cdot \cdot$ & white & $\mathbf{I}$ & 5 & Pretty for rockwork. \\
\hline 6296 & Tydæa hybrida grandiflora . . . & - & $\mathrm{gP}$ & mixed & . $\cdot$ & 50 & Popular greenhouse plant. \\
\hline $\begin{array}{l}6300 \\
6304 \\
6306\end{array}$ & 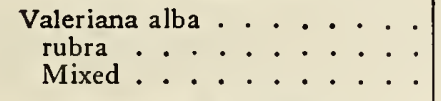 & $\begin{array}{ll}\text { I } & 2 \\
\cdot & \cdot\end{array}$ & $\begin{array}{l}\text { thB } \\
\cdot . \\
\cdot\end{array}$ & $\begin{array}{l}\text { white } \\
\text { red } \\
\text { mixed }\end{array}$ & $\begin{array}{l}3 \\
. \\
:\end{array}$ & $\begin{array}{l}5 \\
5 \\
5\end{array}$ & $\begin{array}{l}\text { Fine border plants; sweet- } \\
\text { scented flowers. }\end{array}$ \\
\hline 6310 & Venidium calendulaceum ... & 3 & hh A & orange & $\mathbf{r}$ & 5 & Beautiful for borders or pots. \\
\hline $\begin{array}{l}63 x_{4} \\
63 x_{5}\end{array}$ & $\begin{array}{l}\text { Venus' Looking-Glass . oz., } 25 \mathrm{c} \text {. } \\
\text { White . . . . . }\end{array}$ & $\begin{array}{ll}\text { I } & 2 \\
. & \end{array}$ & hA & $\begin{array}{l}\text { blue } \\
\text { white }\end{array}$ & $3 / 4$ & $\begin{array}{l}5 \\
5\end{array}$ & \} $\begin{array}{l}\text { (Specularia.) Pretty; good edg- } \\
\text { ing plant. }\end{array}$ \\
\hline 6316 & $\begin{array}{c}\text { Venus' Navelwort (Omphalodes } \\
\text { linifolia) } . . .\end{array}$ & 2 & $\cdot \cdot$ & $\cdot \cdot$ & $\mathbf{I}$ & 5 & $\begin{array}{l}\text { A handsome border flower, } \\
\text { easily grown. }\end{array}$ \\
\hline $\begin{array}{l}6320 \\
6321\end{array}$ & $\begin{array}{l}\text { Verbascum pannosum . . . . } \\
\text { Blattaria . . . . . . . } \\
\text { Verbena hybrida . . . . . . }\end{array}$ & $\therefore$ & hP & $\begin{array}{l}\text { yellow } \\
\text { pink }\end{array}$ & $\begin{array}{l}5 \\
4\end{array}$ & $\begin{array}{l}\text { 10 } \\
\text { 10 }\end{array}$ & $\begin{array}{l}\text { Fine decorative plant. Beauti- } \\
\text { ful white, woolly leaves. } \\
\text { See page } 78 \text {. }\end{array}$ \\
\hline 6326 & Verbena (Aloysia) citriodora . . & 3 & $\mathrm{gP}$ & white & 3 & ro & (Lemon Verbena.) Scented lvs. \\
\hline 6329 & Veronica, Mixed . . . . & 2 & hP & mixed & $1 / 2$ & Io & Pretty for border; fine colors. \\
\hline $\begin{array}{l}6332 \\
6334\end{array}$ & 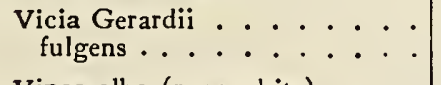 & $\begin{array}{ll}2 & 3 \\
\cdot & \cdot\end{array}$ & hA & $\begin{array}{l}\text { violet } \\
\text { d. red }\end{array}$ & . & $\begin{array}{l}10 \\
10\end{array}$ & Pretty pea-shaped flowers. \\
\hline $\begin{array}{l}6340 \\
6341 \\
6342 \\
6343\end{array}$ & 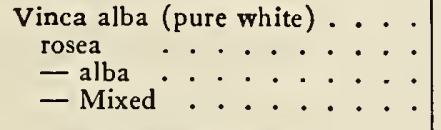 & $\begin{array}{l}\dot{\cdot} \cdot \dot{ } \\
\dot{\cdot} \\
\cdot\end{array}$ & $\dot{\cdot} \cdot$ & $\begin{array}{l}\text { white } \\
\text { rose } \\
\text { ro. \& w. } \\
\text { mixed }\end{array}$ & $\begin{array}{ll}\cdot & \cdot \\
: & : \\
. & . \\
.\end{array}$ & $\begin{array}{l}\text { 10 } \\
\text { 10 } \\
\text { 10 } \\
\text { 10 }\end{array}$ & $\begin{array}{l}\text { Fine for conservatory, parlor } \\
\text { windows and borders or beds; } \\
\text { very pretty. }\end{array}$ \\
\hline $\begin{array}{l}6349 \\
6350 \\
6351 \\
6353\end{array}$ & 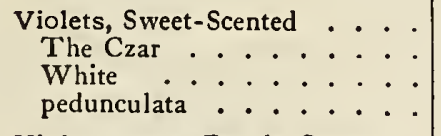 & $\begin{array}{ll}\text { I } & 2 \\
. & \cdot \\
\cdot & \cdot \\
\cdot & \cdot\end{array}$ & $\begin{array}{l}\dot{.} \\
\mathrm{hP}\end{array}$ & $\begin{array}{l}\text { blue } \\
\text { white } \\
\text { yellow }\end{array}$ & $\begin{array}{l}1 / 2 \\
\dot{0} \\
1 / 4\end{array}$ & $\begin{array}{l}\text { 10 } \\
\text { 10 } \\
\text { 10 } \\
\text { 10 }\end{array}$ & $\begin{array}{l}\text { (Viola.) All have great beauty } \\
\text { and fragrance. The seed takes } \\
\text { a long time to germinate. }\end{array}$ \\
\hline $\begin{array}{l}359 \\
360 \\
361\end{array}$ & 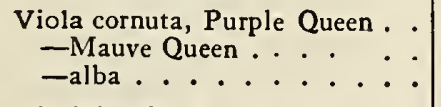 & $\begin{array}{l}. \dot{ } \\
. \\
.\end{array}$ & tP. & $\begin{array}{l}\text { purple } \\
\text { white }\end{array}$ & $\begin{array}{l}1 / 2 \\
\dot{0} \\
\dot{ }\end{array}$ & $\begin{array}{l}\text { 10 } \\
\text { 10 } \\
\text { 10 }\end{array}$ & $\begin{array}{l}\text { Fine and early-flowering. See } \\
\text { Violets. }\end{array}$ \\
\hline $\begin{array}{l}6_{3} 65 \\
6366 \\
6368 \\
6369\end{array}$ & 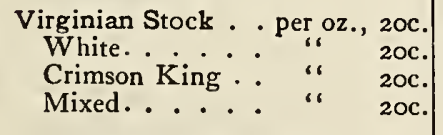 & $\begin{array}{l}\cdot \dot{ } \\
: \\
. \\
.\end{array}$ & $\begin{array}{l}\cdot \dot{\cdot} \\
\dot{\cdot} \cdot \dot{ }\end{array}$ & $\begin{array}{l}\text { red } \\
\text { white } \\
\text { crimson } \\
\text { mixed }\end{array}$ & $\begin{array}{l}\text { I } \\
. \\
. \\
.\end{array}$ & $\begin{array}{l}5 \\
5 \\
5 \\
5\end{array}$ & $\begin{array}{l}\text { (Malcolmia maritima.) Early } \\
\text { flowering and fine. }\end{array}$ \\
\hline $\begin{array}{l}6375 \\
6376 \\
6377 \\
6378 \\
6379 \\
6384\end{array}$ & 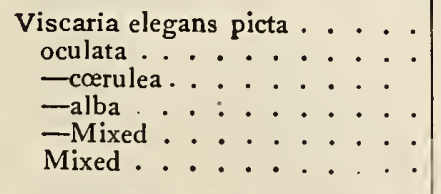 & 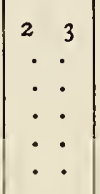 & $\dot{:}$ & $\begin{array}{l}\text { sc. \&w. } \\
\text { rose } \\
\text { blue } \\
\text { white } \\
\text { mixed } \\
\quad .\end{array}$ & $\begin{array}{r}1 / 2 \\
3 / 4 \\
: \\
: \\
\dot{I}\end{array}$ & $\begin{array}{l}5 \\
5 \\
5 \\
5 \\
5 \\
5\end{array}$ & $\begin{array}{l}\text { Abundant blooming, hardy an- } \\
\text { nuals, very effective in mass- } \\
\text { ing. They are easily grown, } \\
\text { and succeed best in light, rich } \\
\text { loam. }\end{array}$ \\
\hline $\begin{array}{l}6388 \\
6389 \\
6390 \\
6392 \\
6394\end{array}$ & 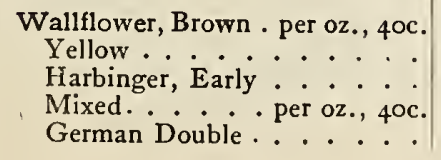 & \begin{tabular}{ll|}
1 & 3 \\
$\cdot$ & $:$ \\
$\cdot$ & $:$ \\
$\cdot$ & $:$
\end{tabular} & $\begin{array}{l}\mathrm{hP} \\
\dot{\cdot} \\
\dot{\cdot} \\
\dot{\cdot}\end{array}$ & $\begin{array}{l}\text { brown } \\
\text { yellow } \\
\text { golden } \\
\text { mixed } \\
\quad .\end{array}$ & $\begin{array}{l}1 / 2 \\
: \\
\vdots \\
:\end{array}$ & $\begin{array}{r}5 \\
5 \\
5 \\
5 \\
10\end{array}$ & $\begin{array}{l}\text { (Cheiranthus Cheiri.) Favorite } \\
\text { sweet-scented flowers, of fine } \\
\text { colors; useful as spring bed- }\end{array}$ \\
\hline
\end{tabular}




\begin{tabular}{|c|c|c|c|c|c|c|c|}
\hline 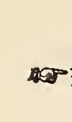 & $\begin{array}{l}\text { NUMBER AND NAME } \\
1 / 4 \text { oz. at oz. rate only on articles quoted at } \\
\$ 1 \text { per oz. and over. }\end{array}$ & $\begin{array}{c}\text { Time } \\
\text { of } \\
\text { Flowering }\end{array}$ & $\begin{array}{c}\text { Hardlness } \\
\text { and } \\
\text { Duration }\end{array}$ & $\begin{array}{l}\text { Color of } \\
\text { the } \\
\text { Flower }\end{array}$ & $\begin{array}{l}\text { Height } \\
\text { In } \\
\text { Feet }\end{array}$ & $\begin{array}{c}\text { Price } \\
\text { per } \\
\text { Packet }\end{array}$ & GENERAL OBSERVATIONS \\
\hline 6396 & 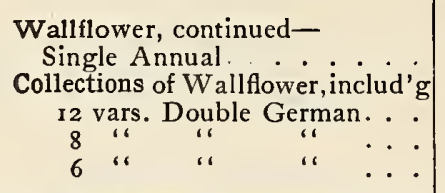 & $\begin{array}{ll}\text { I } 3 \\
.\end{array}$ & hA & mixed & $11 / 2$ & $\mid$\begin{tabular}{r|} 
cts. \\
I0 \\
\$1 \\
oo \\
80 \\
65
\end{tabular} & $\begin{array}{l}\text { ders. No. } 6396 \text { is one of the } \\
\text { most valuable of recent intro- } \\
\text { duction, flowering the first } \\
\text { season from seed. }\end{array}$ \\
\hline $\begin{array}{l}6400 \\
6401 \\
6404\end{array}$ & $\begin{array}{l}\text { Whitlavia grandiflora, per oz., } 4 \text { oc. } \\
\text {-alba } \text { gloxinioides............ }\end{array}$ & $\begin{array}{l}\cdot \dot{ } \\
\dot{\cdot} \\
\dot{\cdot}\end{array}$ & $\dot{:}: \dot{ }$ & $\begin{array}{l}\text { purple } \\
\text { white } \\
\text { b. \& w. }\end{array}$ & $\therefore$ & $\begin{array}{l}5 \\
5 \\
5\end{array}$ & $\begin{array}{l}\text { Pretty bell-shaped flowers; free- } \\
\text { flowering. }\end{array}$ \\
\hline 6408 & Worms (Scorpiurus) . . . & 2 & . & scarlet & I & 5 & Seeds are very curious. \\
\hline 6412 & Wigandia Vigieri . . . . . & $\cdot$ & $f \mathrm{tP}$ & red & 4 & 10 & Fine tropical leaves. \\
\hline $\begin{array}{l}6418 \\
6419 \\
6420 \\
6421 \\
6422\end{array}$ & 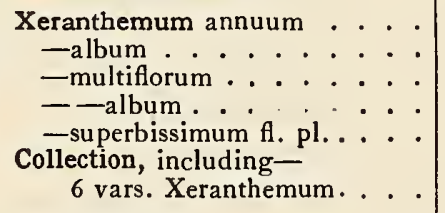 & 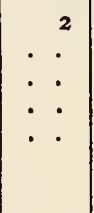 & $\begin{array}{l}\mathrm{hA} \\
: \dot{ } \\
\therefore\end{array}$ & $\begin{array}{l}\text { purple } \\
\text { white } \\
\text { purple } \\
\text { white } \\
\text { purple }\end{array}$ & $\begin{array}{l}2 \\
. \\
. \\
. \\
.\end{array}$ & $\begin{array}{l}5 \\
5 \\
5 \\
5 \\
5\end{array}$ & $\begin{array}{l}\text { One of the oldest Everlastings; } \\
\text { the flowers retain their color } \\
\text { and form longest of all. }\end{array}$ \\
\hline $\begin{array}{l}6426 \\
6430 \\
6432\end{array}$ & $\begin{array}{l}\text { Yucca baccata. . . . . . . } \\
\text { filamentosa . . . . . . . } \\
\text { gloriosa. . . . . . . . . . } \\
\text { Zinnia . . . . . . . . }\end{array}$ & $\begin{array}{ll}2 & 3 \\
. & : \\
\cdot\end{array}$ & $\begin{array}{l}\text { hhP } \\
. \\
.\end{array}$ & $\begin{array}{c}\text { gr. wh. } \\
\text {. } \\
\text {. }\end{array}$ & $\stackrel{3}{4}$ & $\begin{array}{l}\text { 10 } \\
\text { 10 } \\
\text { 10 }\end{array}$ & $\begin{array}{l}\text { Very showy, attractive plants for } \\
\text { the subtropical garden, with } \\
\text { numerous large white flowers. } \\
\text { See page } 78 \text {. }\end{array}$ \\
\hline
\end{tabular}

\section{MIXED ANNUALS FOR WILD GARDEN}

Bright colored, summer-flowering, easily grown hardy annuals in the greatest variety for sowing broadcast. Per oz., Io cts.; $1 / 4 \mathrm{lb}$., $30 \mathrm{cts}$; $1 / 2 \mathrm{lb}$., 55 cts.; lb., $\$$ r, postpaid.

\section{ORNAMENTAL GRASSES}

Many of these Grasses, if cut before they are entirely ripe, will be found useful in the formation of winter bouquets, in connection with the Everlastings.

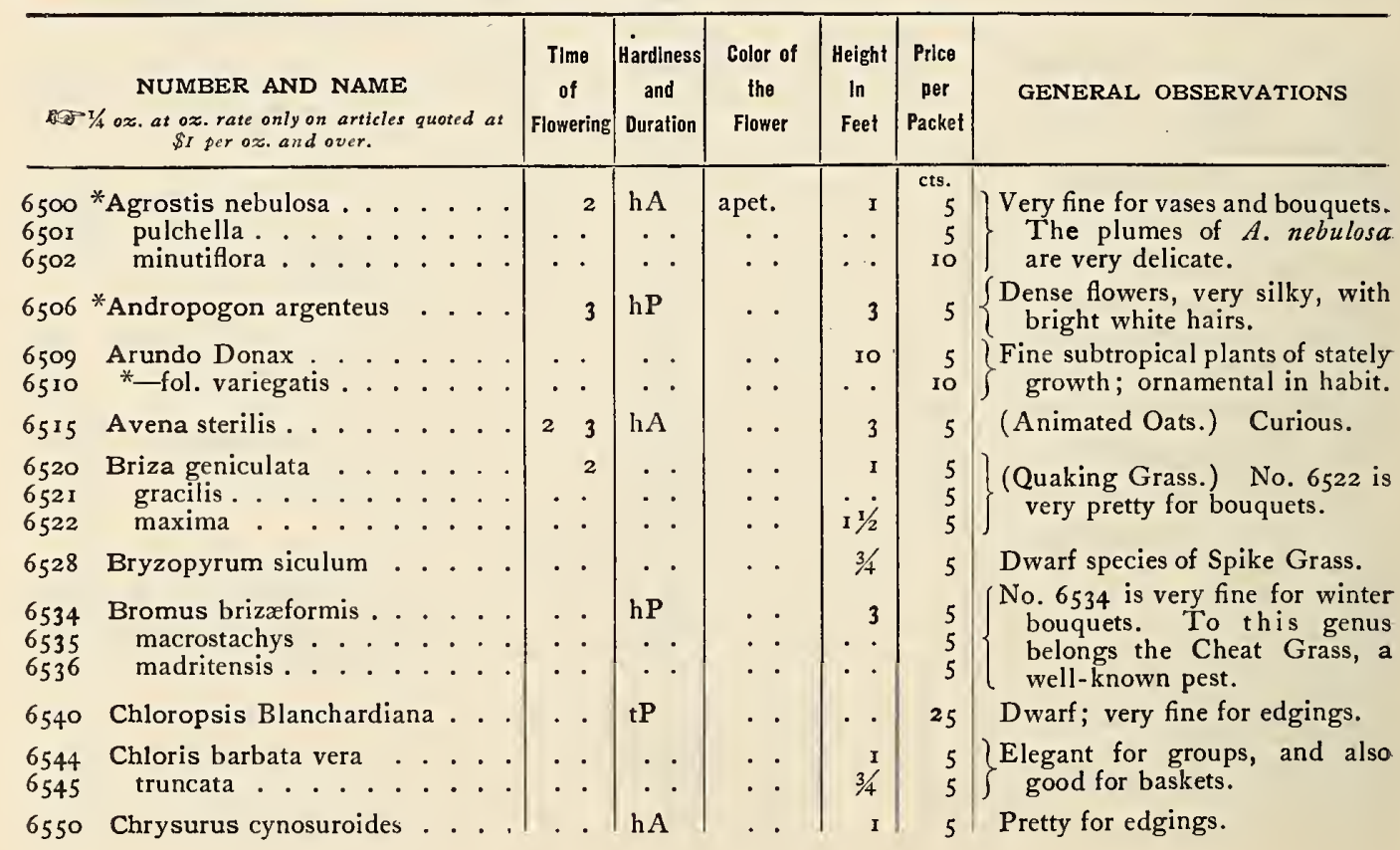




\begin{tabular}{|c|c|c|c|c|c|c|c|c|c|}
\hline 6 & $\begin{array}{l}\text { NUMBER AND NAME } \\
r 1 / 4 \text { oz. at ox. rate only on articles } \\
\$ 1 \text { per oz. and over. }\end{array}$ & quored & & $\begin{array}{c}\text { Time } \\
\text { of } \\
\text { Flowering }\end{array}$ & $\begin{array}{c}\text { Hardiness } \\
\text { and } \\
\text { Duration }\end{array}$ & $\begin{array}{l}\text { Color of } \\
\text { the } \\
\text { Flower }\end{array}$ & $\begin{array}{c}\text { Helght } \\
\text { In } \\
\text { Feet }\end{array}$ & $\begin{array}{c}\text { Price } \\
\text { Der } \\
\text { Packet }\end{array}$ & GENERAL OBSERVATIONS \\
\hline $\begin{array}{l}6554 \\
6555\end{array}$ & $\begin{array}{c}\text { Coix lachryma } \\
\text { aurea zebrina } . \\
.\end{array}$ & $\therefore$ &. . & 2.3 & hA & apet. & $1 / 2$ & $\begin{aligned} \text { cts. } \\
5 \\
\text { IO }\end{aligned}$ & $\left\{\begin{array}{l}\text { (Job's Tears.) So called from } \\
\text { the resemblance of the seed to } \\
\text { a tear-drop. }\end{array}\right.$ \\
\hline $655^{8}$ & Cryptopyrum Richardso & oni . & . & 2 & . . & . . & 2 & Io & Very fine grass. \\
\hline $\begin{array}{l}6560 \\
6561 \\
6562\end{array}$ & 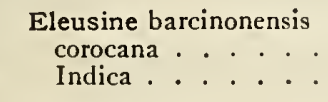 & $\begin{array}{l}\cdot \\
\cdot \\
\cdot\end{array}$ & $\begin{array}{l}. \\
\cdot \\
\cdot \\
.\end{array}$ & $\begin{array}{ll}2 & 3 \\
\cdot & \cdot \\
\cdot & \cdot\end{array}$ & $\cdot$ & $\begin{array}{l}. \dot{ } \\
. \\
.\end{array}$ & $\begin{array}{ll} & \mathbf{1} \\
. & . \\
. & .\end{array}$ & $\begin{array}{l}5 \\
5 \\
5\end{array}$ & $\begin{array}{l}\text { (Crab or Yard Grass.) E. Indica } \\
\text { is the Wire Grass. }\end{array}$ \\
\hline $65^{6} 5$ & Elymus hystrix. . . . & $\cdot \cdot$ & . . & . . & hP & . & 4 & 5 & From the Crimea. Odd. \\
\hline $\begin{array}{l}6568 \\
6569 \\
6570 \\
6571 \\
6572\end{array}$ & $\begin{array}{l}\text { Eragrostis elegans } \\
\text { amabilis . } \\
\text { Abyssinica }\end{array}$ & $\begin{array}{l}\cdot \\
\cdot \\
\cdot \\
\cdot \\
\cdot \\
\cdot\end{array}$ & $\begin{array}{ll}\cdot & . \\
\cdot & \text {. } \\
\cdot & \text {. } \\
\cdot & \text {. }\end{array}$ & $\begin{array}{ll} & 2 \\
\cdot & : \\
: & : \\
\cdot & \cdot\end{array}$ & $\begin{array}{l}\text { hA } \\
: . \\
. \\
. \\
.\end{array}$ & 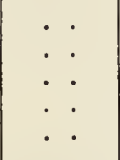 & $\begin{array}{ll} & \mathbf{I} \\
\cdot & \cdot \\
\cdot & \cdot \\
\cdot & \dot{\cdot} \\
\cdot & \cdot\end{array}$ & $\begin{array}{l}5 \\
5 \\
5 \\
5 \\
5\end{array}$ & $\begin{array}{l}\text { (Love Grass.) Pretty Grasses, } \\
\text { growing about a foot high, and } \\
\text { characterized by their beauti- } \\
\text { ful dancing spikelets; fine for } \\
\text { bouquets. }\end{array}$ \\
\hline $\begin{array}{l}6580 \\
6581\end{array}$ & $\begin{array}{l}\text { Erianthus Ravennæ. . } \\
\text { *-foliis variegatis . . }\end{array}$ & . & & $\begin{array}{l}23 \\
.\end{array}$ & $\begin{array}{l}\mathrm{hP} \\
\cdot .\end{array}$ & & Iо & $\begin{array}{r}5 \\
10\end{array}$ & $\left\{\begin{array}{l}\text { (Plume Grass.) A very fine } \\
\text { and stately-looking grass. }\end{array}\right.$ \\
\hline $65^{8} 4$ & Eulalia Japonica . . & . . & - & . . & . . & . & 5 & 10 & $\left\{\begin{array}{c}\text { Among the most beautiful of } \\
\text { the tall-growing grasses. }\end{array}\right.$ \\
\hline 6586 & Festuca glauca... & .. & . . & . . & . $\cdot$ & . . & 2 & Io & (Fescue Grass.) Ornamental. \\
\hline $\begin{array}{l}6590 \\
6591\end{array}$ & $\begin{array}{l}\text { Gymnothrix(Pennisetum } \\
\text { latifolia ...... }\end{array}$ & n)caud & data & .. & tP &. & $\dot{8}$ & $\begin{array}{l}\text { 10 } \\
\text { 10 }\end{array}$ & $\left\{\begin{array}{l}\text { Grown chiefly as curious and } \\
\text { ornamental grasses. }\end{array}\right.$ \\
\hline $\begin{array}{l}6596 \\
6597 \\
6598 \\
6599\end{array}$ & $\begin{array}{l}\text { *Gynerium argenteum . } \\
\text { *_fol. variegatis . . } \\
\text { *-roseum . . . . . . } \\
\text { jubatum . . . . . . }\end{array}$ & $\begin{array}{ll}\cdot & \cdot \\
\cdot & \cdot \\
\cdot & \cdot \\
\cdot & \cdot\end{array}$ & $\dot{\dot{v}} \dot{.}$ & 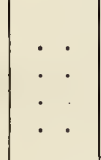 & $\begin{array}{ll}. & \cdot \\
: & : \\
. & .\end{array}$ & $\begin{array}{l}\dot{\cdot} \cdot \dot{ } \\
\dot{\cdot} \\
\dot{\cdot}\end{array}$ & $\begin{array}{l}\cdot \dot{ } \\
\dot{.} \\
\dot{.}\end{array}$ & $\begin{array}{l}5 \\
\text { 10 } \\
\text { 10 } \\
\text { Io }\end{array}$ & $\begin{array}{l}\text { (Pampas Grass.) This is the } \\
\text { noblest of the tall-growing } \\
\text { grasses, and bears magnificent } \\
\text { plumes, much used in floral } \\
\text { decoration. }\end{array}$ \\
\hline 6604 & Hordeum jubatum & . . & . . & . . & hA & . . & 2 & 5 & (Squirrel-tail Grass.) \\
\hline 6606 & Isolepis gracilis . . . . & . . & . & . & . . & . . & $1 / 2$ & Io & Very pretty rush-like grass. \\
\hline 6608 & Lagurus ovatus . . . . & . . & . & . . & . . & . . & 2 & 5 & (Hare's-tail Grass.) \\
\hline 6610 & Lasiagrostis argentea . & . . & . & . & $\mathrm{hP}$ & . & 3 & 5 & Fine for winter bouquets. \\
\hline 6614 & Miscanthus Nepalense . & . . & . & . . & . & . . & 5 & 25 & $\left\{\begin{array}{l}\text { (Himalaya Fairy Grass.) Most } \\
\text { graceful, soft, feathery plumes. }\end{array}\right.$ \\
\hline $\begin{array}{l}6618 \\
6619\end{array}$ & $\begin{array}{l}\text { Panicum virgatum . . } \\
\text { sulcatum . . . . }\end{array}$ & $\cdot \cdot$ & . & $\therefore$ & hA &. & $\begin{array}{l}4 \\
3\end{array}$ & $\begin{array}{r}5 \\
10\end{array}$ & $\left\{\begin{array}{l}\text { Very showy and hardy perennial } \\
\text { grasses. }\end{array}\right.$ \\
\hline $\begin{array}{l}6622 \\
6623\end{array}$ & $\begin{array}{l}\text { Pennisetum villosum } \\
\text { Ruppellianum . . }\end{array}$ & . & $\dot{\cdot}$ & $\therefore$ & $\therefore$ & crimson & $\begin{array}{r}\mathrm{I} / 2 \\
3\end{array}$ & $\begin{aligned} 5 \\
\text { I0 }\end{aligned}$ & $\left\{\begin{array}{c}\text { Ornamental grass. No. } 6623 \text { has } \\
\text { beautiful crimson plumes. }\end{array}\right.$ \\
\hline 6626 & Poa amabilis . . . . . & . & - & . & . . & apet. & 2 & 5 & Pretty for bouquets. \\
\hline $\begin{array}{l}6628 \\
6629\end{array}$ & $\begin{array}{l}\text { Setaria macrochæta . } \\
\text { alopecuroides nigra . }\end{array}$ & $\cdot \dot{\cdot}$ & $\begin{array}{l}. \\
.\end{array}$ & . & $\begin{array}{l}. \\
.\end{array}$ & .. & $\mathrm{I} / 2$ & $\begin{array}{l}5 \\
5\end{array}$ & $\begin{array}{l}\text { Ornamental grass. } \\
6629 \text { has graceful black spikes. }\end{array}$ \\
\hline $\begin{array}{l}6632 \\
6633\end{array}$ & $\begin{array}{l}{ }^{*} \text { Stipa pennata . . . . . . } \\
\text { elegantissima . . . }\end{array}$ & $\cdot \cdot \cdot$ & $\begin{array}{l}\cdot . \\
\cdot\end{array}$ & $\stackrel{2}{\cdot}$ & hP & $\therefore$ & $\therefore$ & $\begin{array}{r}5 \\
\text { IO }\end{array}$ & $\left\{\begin{array}{c}\text { (Feather Grass.) Grown for } \\
\text { their very graceful plumes. }\end{array}\right.$ \\
\hline 6640 & Tricholæna violacea . & $\cdot \cdot$ & . . & 23 & hA & . . & . . & Io & A very pretty grass. \\
\hline 6644 & Tripsacum dactyloides. & . . & . & . $\cdot$ & . $\cdot$ & . $\cdot$ & 4 & 5 & (Sesame Grass.) Singular. \\
\hline $\begin{array}{l}6650 \\
6651 \\
6652 \\
6654 \\
6656 \\
6657\end{array}$ & $\begin{array}{l}\text { Zea Japonica } \\
\text { Miniature Maize } \\
\text { Cuzko } \\
\text { quadricolor. New; } \\
\text { Mixed Tall Ornamenta } \\
\text { Mixed Dwarf Orna } \\
\text { grasses . . . . }\end{array}$ & $\begin{array}{l}\text { fine. } \\
\text { al gras } \\
\text { oz., } \\
\text { ment } \\
\text { oz., }\end{array}$ & $\begin{array}{l}. \\
. \\
\dot{0} \\
\text { sses } \\
25 \mathrm{c} . \\
\text { tal } \\
30 \mathrm{c} .\end{array}$ & $\begin{array}{l}{ }^{2} \\
\dot{\cdot} \\
\dot{\cdot}\end{array}$ & $\begin{array}{l}. \\
: \\
: \\
:\end{array}$ & $\begin{array}{l}. \\
\dot{.} \\
\dot{5} \\
.\end{array}$ & $\begin{array}{l}3 \\
. \\
. \\
.\end{array}$ & $\begin{array}{l}5 \\
5 \\
5 \\
5 \\
\\
5 \\
5\end{array}$ & $\begin{array}{l}\text { Ornamental varieties of Corn. } \\
Z \text {. Japanica has beautifully } \\
\text { striped leaves. }\end{array}$ \\
\hline
\end{tabular}




\section{COLLECTIONS OF FLOWER SEEDS}

\section{Free by mail at prices affixed}

Long experience in selecting enables us to make collections which are invariably satisfactory to purchasers, and our usual full assortment the present season, embracing every desirable novelty and standard sort, insures assortments of the rarest varieties and finest qualities, all of the growth of the past season, and in every case strictly TRUE TO NAME.

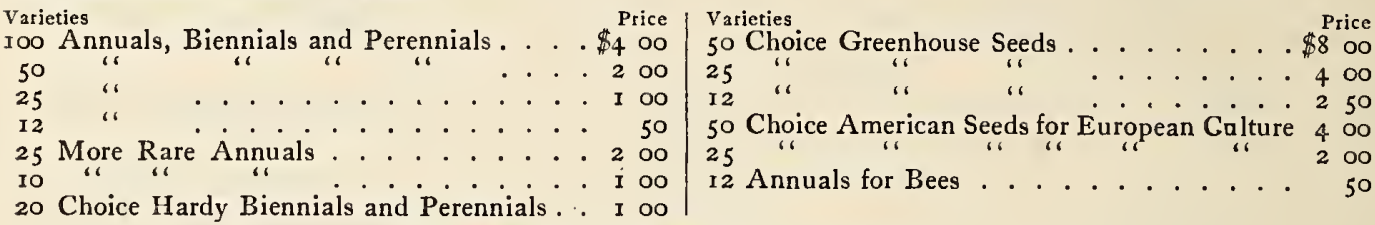

All strictly our own selections

To facilitate selecting seeds for special purposes, we have prepared the following lists. Particulars and prices will be found in body of the catalogue.

\section{LIST OF FLOWERS SUITABLE FOR BOUQUETS}

Abronia umbellata, Ageratum Mexicanum, Alyssum maritimum, Amarantus tricolor, Ammobium alatum, Aquilegia chrysantha, Aster,

Balsams,

Cacalia coccinea,

Calliopsis lanceolata, Callirhoë pedata,

Centranthus macrosiphon, Chrysanthemum inodorum, Collinsia bicolor and verna, Cosmos,
Cuphea,

Dianthus Chinensis,

Digitalis, assorted,

Gaillardia,

Gilia tricolor,

Globe Amaranths,

Godetia, assorted,

Gypsophila,

Heliotropium grandiflorum

Iberis odorata and amara,

Kaulfussia amelloides,

Leptosiphon,

Lobelia Erinus,

Malope grandiflora,

Mignonette,
Mimulus moschatus, Pansy,

Phlox Drummondii,

Reseda odorata,

Silene, Mixed,

Smilax,

Spraguea umbellata,

Statice, assorted,

Stevia serrata,

Stocks, Ten Weeks,

Verbena,

Viola tricolor (finest),

Viscaria oculata,

Zinnia all the double varieties.

\section{LIST OF FLOWERS SUITABLE FOR HANGING BASKETS}

Ageratum Mexicanum, Alyssum maritimum, Asparagus Sprengeri, Aubrietia deltoidea, Calandrinia umbellata, Cerastium tomentosum, Clintonia pulchella,

Convolvulus Mauritanicus, " aureus superbus,

Cosmidium Burridgeanum, Dwarf Nasturtiums,

Abrus precatorius, Adlumia cirrhosa

Aristolochia,

Asparagus,

Balloon Vine,

Calampelis scabra,

Canary-Bird-Flower

Centrosema grandiflora,

Clematis,

Clitoria,
Eschscholtzia tenuifolia, Eucharidium grandiflorum, Fenzlia dianthiflora, Gilia rosea splendens, Iberis amara,

Limnanthes Douglasii, Lobb's Nasturtium, Lobelia gracilis, Love-Lies-Bleeding, Lupinus nanus,

Mignonette, Mimulus moschatus,

\section{VINES AND CLIMBERS}

Cobæa scandens, Convolvulus, Cypress Vine, Dolichos,

Humulus, Ipomœa, Kennedya, Lapageria rosea, Lathyrus, Lophospermum, Mandevillea suaveolens,
Nemophila insignis and maculata, Pansy,

Petunia,

Portulaca, Double,

Sanvitalia procumbens,

Saponaria Calabrica,

Sedum cœruleum,

Silene pendula,

Spraguea umbellata,

Verbena,

Virginian Stock.

\section{SEEDS OF EVERLASTINGS}

\section{For the Formation of Wreaths and Winter Bouquets}

Acroclinium, Ammobium, Gomphrena,
Helichrysum,

Helipterum,

Rhodanthe,
Maurandya,

Mina lobata,

Moon-Flower

Nasturtium, Tall,

Passiflora,

Phaseolus Caracalla,

Smilax,

Sweet Peas,

Thunbergia,

Tropæolum 


\section{ORNAMENTAL GOURDS AND FRUIT-BEARING VINES AND PLANTS}

For prices and descriptions, see body of Catalogue.

Abobra viridiflora,

Ardisia crenulata,

Balsam Pear and Apple,

Benincasa cerifera,

Bryonopsis,

Coccinia Indica,

\author{
Cucumis, \\ Cucurbita, \\ Cyclanthera explodens, \\ Echinocystis lobata, \\ Eopepon vitifolius, \\ Gourds, \\ Melothria scabra,
}

\author{
Momordica, \\ Mukia scabrella, \\ Phaseolus, \\ Scotanthus, \\ Solanum \\ Trichosanthes.
}

\section{SEEDS OF HEDGE PLANTS}

For prices, see Tree Seeds.

Arborvitæ, American (Thuja occidentalis).

Balsam Fir (Abies balsamea).

Barberry, Common (Berberis vulgaris). Purple-leaved (Berberis folio-purpurea).

Broom, Scotch (Genista scoparia).

Buckthorn (Rhamnus catharticus).

Cornelian Cherry (Cornus mascula).

Furze, Gorse, or Whin (Ulex Europæa).

Hawthorn (Cratægus Oxyacantha).
Hemlock Spruce (Abies Canadensis).

Locust, Honey, or Three-thorned Acacia (Gleditschia triacanthos).

Locust, Yellow (Robinia pseudacacia).

Norway Spruce (Picea excelsa).

Osage Orange (Maclura aurantiaca).

Privet, Japan or California (Ligustrum Japonicum).

" Common Evergreen (Ligustrum vulgare).

Sheepberry, Black Haw (Viburnum prunifolium).

\section{PALM SEEDS}

The Palm seeds we offer are imported direct from approved sources in Australia, New Zealand, South America, Central America and the West Indies, and are unexcelled in quality and purity. Fresh seeds arrive throughout the year, as the various species mature, but the greater number come during the spring and summer. Customers are invited to let us book their orders to be sent from time to time as fresh shipments arrive.

Pkt. roo seeds

Araucaria excelsa....... \$o 25

Areca Baueri....... 12 seeds, 25

" lutescens...... I2 " 2 "

" sapida...... . . 8 "

" Míadagascariensis . . . I0 " 25

Brahea filifera (W ashingtonia) 25 "

" robusta

Chamædorea elegans .. . . 8 "

Chamærops Canariensis . . 8 "

" elegans argentea . 12 "

" excelsa ... . 25 "

" humilis...20 20

Cocos australis . . . . . 8 "

" Bonnettii . . . . . 8 "

" campestris .... . . Io "

plumosa ..... 10 "

flexuosa ..... xо "

Weddeliana ... 8 "

Yatai ...... 6 "

Corypha australis (Cabbage

Palm)..... Io "

Dracæena australis .... 20

" indivisa ... . 25 "

" " lineata. . 25

" Draco . . . . . 15

" Draco... . . 15

"Veitchii.... 20
$\$ 125$

125

I 00

200

30

50

250

I 00

I 25

30

4.0

250

250

225

225

225

250

350

10

IO

10

25

25

25
Pkt. I0o seeds

Elæis guineensis. . . . . Io seeds, \$0 $25 \$ 2 \quad 50$

Euterpe edulis . . . . . 8 " $25 \quad 2 \mathrm{co}$

Geonoma Schottiana ... . 8 " $25 \quad 250$

" gracilis..... . 8 " 25250

Kentia Belmoreana... . . I2 “ 25 I 50

"Forsteriana ..... I2 " 25 I 50

" Canterburyana (Um-

brella Palm) .. . 12 " $50 \quad 300$

"Morei ....... ro " 50 " 400

Latania Borbonica . . . . 12 " 2 10 50

Licula grandis (Fan Palm) . 12 " $25 \quad$ I 50

Musa Ensete (Abyssinian Ba-

nana)...... 10 " " 25200

"Martini ...... 8 " 8 " $25 \quad 250$

Oreodoxa regia (Royal Palm) 8 " 4 I5 I 00

Pandanus utilis (Screw Pine) I 5 " $\quad 25 \quad$ I 25

Phœnix Canariensis .... I2 " 2 10 60

" dactylifera (D a te Palm) ..... I2 " 2 10 50

" reclinata..... I 5 " 25 I 25

" rupicola ..... 10 " 25200

" tenuis..... . 8 ". 8 10 100

"Zanzibariensis... I0 " 25200

Pritchardia filamentosa . . . 20 " $25 \quad$ I 00

Ptychosperma Alexandræ .. I2 " $25 \quad$ I 50

Sabal Blackburniana ... . I2 “ 25 I 25

Seaforthia elegans ... . 8 “ 10 I $\infty$

In April we shall have Cycas revoluta stems (Sago Palm) in various sizes direct from Japan. 


\section{Bulbs for Spring Planting}

\section{GLADIOLUS}

\begin{tabular}{|c|c|c|c|c|}
\hline \multicolumn{5}{|c|}{ VARIOUS MIXED GLADIOLI } \\
\hline ixed & f Red and & & & \\
\hline “ & $\begin{array}{c}\text { Scarlet } \\
\text { White and Light. Stan- }\end{array}$ & 35 & $\$ 150$ & $\$ 10$ \\
\hline “ & $\begin{array}{l}\text { dard selection } \\
\text { White and Light. Extra } \\
\text { fine for florists' use. }\end{array}$ & 45 & 225 & $18 \mathrm{c}$ \\
\hline “ & Striped and Variegated. & 50 & 275 & 2200 \\
\hline “ & Pink . . . . . . & 40 & 200 & 15 oc \\
\hline " & Yellow and Orange & 60 & 325 & 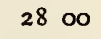 \\
\hline “ & Hybrids. All colors . & 35 & I 50 & II 00 \\
\hline " & $\begin{array}{l}\text { Finest Selected Seed- } \\
\text { lings. All colors, in } \\
\text { greatest variety . . . . }\end{array}$ & . & I 75 & 1200 \\
\hline & $\begin{array}{l}\text { Lemoine's. Fine bright } \\
\text { colorings and odd } \\
\text { markings . }\end{array}$ & & 200 & I 500 \\
\hline “ & $\begin{array}{l}\text { Childsii. Superb large- } \\
\text { flowered }\end{array}$ & 60 & 350 & 3000 \\
\hline
\end{tabular}

FINE NAMED HYBRID GLADIOLI

Addison. Dark amaranth, with white stripes ............ \$0 10 \$1 00

Admiral Courbet. Very early; tall spike of large carmine-violet flowers; white blotch, streaked cherry-rose . .

Africain. Entirely distinct variety, slaty brown on scarlet ground, streaked with scarlet and pure white, with conspicuous white blotch. A dark colored variety of remarkable effect ; dense spike...........

Amalthee, Pure white ; large violetred blotch, ground of the corolla velvety violet, the lower petals slightly tinted with lilac.........

Angele. White; showy and effective .

Apollon. Rosy lilac, with a large, light rose blotch, finely striped white in the center ...........

Ariane. White ground, slightly tinged with rosy lilac, bordered and flamed carmine-rose ; the lower petals pure white ...........

Astarte. Compact, finely shaped spike of large, well-expanded flowers, pale rosy lilac streaked with rose; faint amaranth blotch . . . . . . . .

Baucis. Handsome, compact spike, with large flowers of rose, slightly tinged with salmon; well opened; blotch dark amaranth-red .......

Benvenuto. Brilliant light orange-red, white blotch ........

10 100
$20 \quad 200$

I5

Io

I 25

75

IO

I $\infty$

I5

Bicolore, Very distinct and striking Each Doz. variety, with large flowers of bright rosy salmon, with the exception of the lower petals, which are ivory white, suffused with rose at the edges ... \$0 $20 \quad \$ 200$

Brenchleyensis, Bright vermilion scarlet...... per roo, \$1.50.

Cameleon. Fine, compact truss of large, slaty lilac flowers, flamed orange, white bands down the middle of each petal; large, creamy white blotch, streaked violet . . . . . .

Carnation. Large, well-expanded flowers of a fleshy white color, profusely tinged at the edges with the richest carmine, the lower petals blotched purplish carmine; fine, long, wellfurnished spike . . . . . . .

Celimene. Light orange-red, flamed brilliant red .........

Ceres. Pure white, spotted with purplish rose..... . per 100, $\$ 2$.

Cervantes. Flowers very large, of bright rose color, slightly tinged lilac and profusely streaked and suffused with carmine and pure white band on each petal ...........

Conquete. Large and fine flower; bright cherry-red, with a conspicuous pure white blotch, upper petals striped

Corinne. Tall and fine spike of large, rosy carmine flowers, streaked pure white and penciled carmine at the edges; blotch creamy white striped violet ............

Crepuscule. Splendid spike, with large, well-expanded flowers of lilac-rose, slightly flushed with carmine and with violet on the edges of the petals...

Escarboucle. Handsome flowers of dark carmine-red, pure white band and blood-red blotch on lower petals .

Fatma. Very large flowers of ivory white, profusely striped and suffused with bright rosy salmon; violet blotch on creamy ground . . . . . .

Flamboyant. Beautiful spike of large flowers, fiery scarlet; very effective variety . . . . . . . . . .

Fra Diavolo. Long, compact spike of large, bright orange-rose flowers, flushed violet-red at the edges of the sepals; large, pale yellow blotch; fine variety. . . . . . . . . .

Grand Rouge. Splendid spike of large flowers of bright scarlet, with small violet blotch. Splendid variety of grand effect. . . . . . . . . . $05 \quad 40$ I0 100 


\section{FINE NAMED HYBRID GLADIOLI, continued}

John Bull. White, slightly tinged with Each Doz. sulphur ....... \$0 10 \$0 75

Lamarck (de). Very long spike of large flowers, cherry colored, slightly tinted with orange, blazed with red, center well lighted; large, pure white stain; very fine plant .

Leander. Extra large; lilac shading off to carmine, white band in the middle of each petal and white blotch on lower petals .........

Le Phare. Brilliant fiery red; very showy Madame Monneret. Delicate rose . . . . . . . . per roo, $\$ 2.50$

Marechal Vaillant. Very bright scarlet, with large pure white blotch . .

Maria Dumortier. White, slightly streaked with rose; violet-purple blotch . . . . . . . .

Napoleon III. Bright scarlet; white line in each petal ... per roo, $\$ 2$.

Octoroon. A beautiful salmon-pink; very distinct . . . . . . . . .

Ophir. Dark yellow, purple blotch .

Primatice. Fine rose, tinged with lilac, flamed bright carmine, carmine blotch on white ground .......
Pyramide. Handsome spike, large, well-expanded flowers of the brightest and most delicate orange-rose . . . \$o ro \$I 00

Reine Blanche. Pure white, dark carmine blotch; very fine . . . . . .

Romeo. Very large, well-opened and regularly arranged lilac flowers, with large petals blotched and striped with darker lilac. Early flowering and very distinct ..........

I 5 I 25 Shakespeare. White, very slightly suf-

Io I oo fused with carmine-rose; large rosy blotch . . . . . . . . .

o5 45 Snow-White. Superb pure white.

Sultana. Bright satin-rose, flamed with carmine, purple-carmine blotch on white ground ..........

Surprise. Rose-amaranth ; very lateblooming variety ........

Van Dyck. Crimson-amaranth, striped with white; very fine ......

Venus. Pure white, flamed with light

carmine-rose . $\cdot \dot{*} \cdot \cdot \cdot \cdot \cdot \cdot \cdot$
Virginalis. Pure white, bordered and flamed with carmine, unusually
$10 \quad 100$

IO I 00

$10 \quad 75$

I0 I 00

10100

I 5 I 25

\section{NEW GIANT CHILDSI GLADIOLI}

These are much more vigorous than others. They are very tall and erect, often standing 4 or 5 feet high, with spikes of bloom over 2 feet long. The flowers are of great substance and of gigantic size, frequently 7 to 9 inches across. Every color known among Gladioli is represented, and many never before seen, particularly blues, smoky grays and purple-blacks, all having beautifully mottled and spotted throats, made up of white, crimson, pink, yellow, etc.

Bowdoin. Very large flower, light Each Doz. orange-scarlet, with pure white throat.

Very beautiful ........ \$o 10 \$1

Boston. Flaming orange-scarlet, with large, pure white, violet mottled throat $\cdot{ }_{0} \cdot \cdot \cdot \cdot \cdot \cdot \cdot \cdot \cdot \cdot \cdot$ Columbia. Light orange-scarlet, freely
blotched and penciled with bluish purple ............

Dr. Sellew. Large spike and very large flowers of great substance. Deep, rich, rosy crimson, slightly penciled darker. Throat pure white, mottled and spotted ..........

Henry Gillman. Deep salmon-scarlet, with pure white bands through each petal, and throat peculiarly mottled.
Very striking . . . . . . .
Hohokus, Large, flaming crimson,

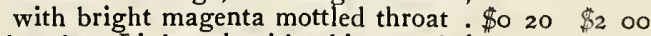
Livonia. Light red, with white mottled

throat ........... ro I oo

Mrs. Beecher. Deep rosy crimson; pure white throat, marked bright

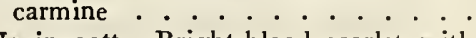

Nezinscott. Bright blood-scarlet, with deep, velvety crimson-black blotches, white mottling in throat ......

Sacramento. Deep, bright coral-scarlet, with clear and distinct white mottlings in throat ........

Splendor. Rose-magenta stain, with purple and white mottling .....

Torch Light. Light flaming scarlet flowers. Throat mottled white and

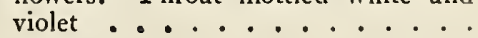

Each Doz.

I0 I 00

ro I 00

$10 \quad 100$

$15 \quad 150$

IO 100

\section{MONTBRETIAS}

Hardy, summer-flowering bulbous plants that are becoming more popular every year. They should be planted in groups and left undisturbed. Ordinary garden soil and a sunny position suit them.

Bouquet Parfait. Large, bright Each Per doz. 100 vermilion flowers, with deep

yellow center ....... \$0 06 \$0 60 \$3 $\quad$ \$ 00

Crocosmizflora. Large; bright orange, tinged scarlet.... 05

Drap d'Or. Rich yellow ; very large, handsome flowers ... o6

Eldorado. Large, golden yellow flowers; very floriferous; dwarf habit
Elegans. Bright yellow, outside Each Per do streaked with vermilion; extra

fine........... \$o o5 \$o 40 \$2 50

Etoile de Feu. Bright vermilion, with deep yellow center; large flowers........... 08 $75 \quad 400$ Golden Sheaf. Bright yellow... $06 \quad 60 \quad 300$ Pottsii. Orange and scarlet; very free-flowering and vigorous in growth ......... 05 30 I 50 


\section{DAHLIAS}

\section{SHOW AND FANCY DAHLIAS}

Storm King. An early, profuse and constant bloomer, of dwarf, branching habit. The flowers are snow-white, of perfect form, and full to the center............ \$o 30 \$3 oo

A. D. Livoni. Best clear, soft pink . I 5 I 50

Arabella. Rich sulphur, tinged pink . I 5 I 50

A. Pefferhorn. Large bright crimson. . I5 I 50 Apollo. Variegated maroon and white . . I 5 I 50 Capt. Jack. Dark rich red; striking . . I 5 I 50 Elegans. Rosy purple, striped white . . I 5 I 50 Mrs. Dexter. Very large; rich salmon . . I 5 I $5^{\circ}$ Penelope. White, flaked lavender... I 5 I 50 Psyche. Primrose, shaded rose; free. I I 5 I 50 Queen of Yellows. Pure canary yellow . . I 5 I 50 Sunbeams. Yellow, tipped bright red. . I 5 I 50

\section{DECORATIVE DAHLIAS}

Most valuable for decorative purposes. The following are 8 of the finest in cultivation :

Black Beauty. A grand dark maroon. Each Doz,

Constance. A beautiful pure white... I 5 I 50

Clifford W. Bruton. Solid, clear, pure yellow; large, full double flower . . . I 5 I 50 Maid of Kent. Rich red, tipped white . . I5 I 50 Nymphæa. An exquisite light pink, tinted lighter toward the center... I 5 I 50 Oban. Large; rosy lavender .... I 15 I 50 Red and Black. Red, margined black . I 5 I 50 Semiramis. Large; orange-scarlet . . I I5 I 50

\section{CACTUS DAHLIAS (Fine Cactus Forms)}

Beatrice Martin. Fine delicate pink Each Doz. Blanche Keith. Large pure yellow . . . I 5 I 50 Gloriosa. Bright scarlet; twisted petals . . I 5 I 50 Kynerith. Cardinal, shaded maroon.. I 5 I 50 Lady H. Grosvenor. Fine golden amber. I 5 I 50 Mrs. Peart. Cream-white; distinct . . I I5 I 50

\section{POMPON, or BOUQUET DAHLIAS}

Ariel. A fine salmon-buff . . . . \$O I5 $\$$ I $^{\text {Eaz. }}$ Catherine. Best pure yellow...... I5 I 50 Fairy Queen. Sulphur, edged peach . . I 5 I 50 Hubert. Pink, red and maroon .... I 5 I 50 Little Beatrice. White and pink .. . I I I 50 Prince Charming. Beautiful purple.. I 5 I 50 Snowclad. The best white pompon.. I 5 I 50

\section{SINGLE DAHLIAS (Butterfly Class)}

Invaluable for cutting, being of bright colors, light and artistic, on long, graceful stems.

Evelyn. White, Each Doz. . \$O I 5 \$I 50 Enchantment. Yellow and carmine . I 5 I 50 Fashion. Velvety maroon, light disk. . I5 I 50 Fragrant. Bright orange-scarlet ... I 5 I 50 Lady Whitehead. Brilliant cerise pink . I5 I 50 Marginata. White, margined crimson .. I5 I 50 Mrs. Bassett. Maroon, striped lilac . . I5 I 50 Snow Queen. Best pure white single . . I 5 I 50

\section{DWARF FRENCH CANNAS}

Price of all these Cannas, I5 cts. each, \$1.50 per doz., \$ro per 100

Austria. Pure canary-yellow ; fine large open flowers. Alphonse Bouvier. Tall crimson; very floriferous. Alsace. Sulphur-yellow, changing to cream-white; $4 \frac{1}{2} \mathrm{ft}$.

Beaute Poitevine. An excellent free-flowering crimson, that is especially valuable during a hot, dry season.

Charles Henderson. Rich crimson; compact; $3 \frac{1}{2} \mathrm{ft}$. Duke of Marlborough. A very fine deep rich crimson.

Egandale. Bronzy foliage and soft currant-red fiowers held well above the leaves; the best of its type; $4 \mathrm{ft}$.

Florence Vaughan. Golden yellow, spotted bright red ; the flowers are of grand size and form, the Eoliage massive, the plant extra floriferous; $2 \mathrm{r} / 2 \mathrm{ft}$.

Furst Bismarck. Rich scarlet-crimson flowers, produced in immense trusses; the flower-heads are large and abundant, the plant compact, vigorous and uniform in growth; distinct; $3 \mathrm{I} / 2 \mathrm{ft}$.

F. Neuvesel. Soft, pleasing carmine; bronzy leaves; $4 \pi / 2 \mathrm{ft}$.

Golden Sceptre. Bright green foliage, and large, deep golden yellow flowers; $5 \mathrm{ft}$.
Italia. Very large flowers of orange-scarlet, with golden border; handsome massive foliage of bright green, bordered with white. One of the showiest Cannas; $6 \mathrm{ft}$.

Madame Crozy. Crimson-scarlet, bordered with golden yellow; $4 \mathrm{ft}$.

Mad. Leon Leclerc. Orange-scarlet, with yellow tip and margin; $5 \mathrm{ft}$.

President McKinley. Crimson, with scarlet shading; foliage deep green, with chocolate margin; blooms early ind zontinuously; $3 \mathrm{ft}$.

Queen Charlotte. Rich scarlet - crimson, broadly banded with canary-yellow; finest of all the giltedged varieties. The flower-spikes are enormous; $3 \mathrm{ft}$.

Souvenir du President Carnot. Bronze foliage ; $5 \mathrm{ft}$.

Sam. Trelease. Pure scarlet; very rich and glowing; marked in center and on petal-edges with yellow. The petals are broad, and open out flat, forming a fine circular flower; $3 \mathrm{ft}$.

Souvenir d'Antoine Crozy. Intense scarlet-crimson, with golden border. 'The richest gilt-edged variety yet introduced; in habit the plant is compact, symmetrical, free-blooming; $3 \mathrm{ft}$.

Vice-President Luizet. Carmine, large flower; $31 / 2 \mathrm{ft}$. 


\section{LILIES}

Auratum (Golden-Banded Lily). The grandest of all hardy Lilies; flowers white, spotted with maroon, having a bright yellow band through each petal.

7 to 9 inches in circumference. Io cts. each, $\$$ I per doz., $\$ 7.50$ per Ioo.

9 to $x \mathrm{x}$ inches in circumference. I 5 cts. each, \$I.50 per doz., \$ro per roo.

II to 13 inches in circumference. $25 \mathrm{cts}$. each, $\$ 2.50$ per doz., $\$ 16$ per 100 .

Auratum macranthum, or platyphyllum. A splendid variety of the above, with much larger flowers. $40 \mathrm{cts}$. each, $\$ 4$ per doz.

Auratum pictum. Flowers like those of the common Auratum, but with larger spots; very beautiful. 5o cts. each, $\$ 5$ per doz.

Auratum Wittei. Very large, pure white flowers, with raised spots of satiny white. $75 \mathrm{cts}$. each, $\$ 7.50$ per doz.

Auratum Virginale. Very large, pure white flowers, with yellow-banded petals. $65 \mathrm{c}$. each, $\$ 6.50$ per doz.

Batemanni. Bright apricot. I 5 c. each, $\$$ I.50 per doz.

Brownii. Beautiful flowers of immense size, inside creamy white, outside shaded chocolate-purple. $40 \mathrm{cts}$. each, $\$ 4$ per doz.

Giganteum. A magnificent species, growing 6 to Io feet high, and bearing many large funnel-shaped flowers, 5 to 6 inches long; white, with purple throat. \$I.50 each.
Grayi. Rare native Lily; nodding flowers, bright crimson outside, orange-red inside, spotted maroon. 35 cts. each, $\$ 3.50$ per doz.

Humboldtii. A beautiful Lily, with orange-red flowers, spotted claret color; 4 to 5 feet. $25 \mathrm{cts}$. each, $\$ 2.50$ per doz.

Longiflorum. 6 to 8 inches in circumference. Iocts. each, \$1 per doz., \$5 per roo.

7 to 9 inches in circumference. I 5 cts. each, $\$ 1.50$ per doz., $\$ 9$ per roo.

Krameri. White, slightly tinged with red. 15 cts. each, $\$$ x. 50 per doz.

Speciosum album Krætzeri. Beautiful pure white flowers of large size. 20 cts. each, $\$ 2$ per doz.

Speciosum rubrum. White, shaded rose and spotted deep red. 15 cts. each, $\$ \mathbf{I} .50$ per doz.

Speciosum rubrum Melpomene. Very dark, crimson-spotted flowers of large size. $20 \mathrm{cts}$. each, $\$ 2$ per doz.

Tigrinum (Tiger Lily). Orange-salmon, spotted black. Io cts. each, \$I per doz.

Tigrinum splendens. Rich scarlet, with black spots. Io cts. each, \$I per doz.

Tigrinum flore pleno (Double Tiger Lily). I2 ets. each, $\$ 1.25$ per doz.

Washingtonianum. Large, trumpet-shaped flowers, pure white, tinged purple or lilac; very fragrant. 30 cts, each, $\$ 3$ per doz.

\section{AMARYLLIS}

Extremely ornamental greenhouse plants, with large, fragrant, beautifully colored flowers. The most suitable soil is good loam, with one-fourth part of leaf-mould or pulverized manure, and some sand. Good drainage is very important. The growing season is from early spring until about September, when the plants should be kept cool and allowed to rest until February. They require plenty of sunshine, but in the flowering season a light shading tends to preserve the blossoms longer. Frequent disturbance of the roots is to be avoided. Established bulbs in large pots should have a top-dressing each year when starting, and manure water during the growing season.

Aulica (Lily-of-the-Palace). Very Each Per doz. large, handsome flowers; icrimson,

shaded with green...... \$ 25

Belladonna. Violet and white; flowers in large umbels; very fragrant ...... $20 \$ 200$

" major. A large and improved form of the preceding.... 30300 Equestris (Barbados Lily). Brilliant orange-scarlet, white throat. Fine for house-culture or bedding ...... Is I 50

Formosissima (Jacobaan Lily). Pretty Each Per doz. scarlet flowers; may be planted outside in the spring ........ $\$ 0$ I5 $\$ 215$ Johnsonii (Spice Lily). Very large, exceedingly beautiful flowers; crimson, striped white ......... 70 700 Longifolia rosea. Rose; hardy ... . 30300 "s alba. White; hardy ... 35350 Vittata Mixed. Striped red and white . $50 \quad 500$ Mixed Hybrids. Beautifully colored hybrids; large bulbs...... 55550

\section{CHINESE PAEONIES}

The old-fashioned double Pæonies are too well known to require description. Their popularity is due to their great merits-their easy culture, the handsome appearance of the plant, and the brilliant and striking effect of their massive, finely formed, richly colored flowers. Among hardy herbaceous perennials, the Chinese Pæonies rank about first for lawn, or flower-border, or shrubbery decoration. They are all hardy.

Double White ......... Each $30 \begin{aligned} & \text { Per doz. } \\ & \$ 300\end{aligned}$

"Crimson........ 20200
Double Pink . . . . . . . \$o 20 Per doz.

" Mixed ........... 20 I 75 


\section{NEW LARGE-FLOWERED JAPAN IRIS (IRIS KÆMPFERI)}

Irises are of easy culture, requiring very little attention after once being planted. They do best in a light, rich, sandy soil, and in a sunny situation. Good drainage is very important. The following new varieties of Iris Kampferi are remarkable for the beauty of their colors and their stateliness of habit. Some of them send up ro or 12 flower spikes 3 feet high, each bearing 2 to 4 enormous blossoms, measuring 8 to Io inches across, and of the most delicate and beautiful colors, markings and combinations; no other flowers excel them in richness. They require a liberal supply of water when growing. (See Plate XXVII.)

\section{DOUBLE}

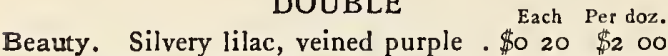
Blue Jay. Large, fine azure-blue . . $20 \quad 2$ oo Charmer. Light blue, white center . . $20 \quad 200$ Mahogany. Deep mahogany-red . . $20 \quad 2$ oo Mt. Fell. Grayish white, veined sky-blue. $20 \quad 200$ Orion. Pure white, bordered lilac . . . $20 \quad 200$ Pyramid. Violet-blue, with white veins . $20 \quad 200$ Snow-White. White, with gold center . $20 \quad 200$ Mixed New Double. Large-flowering .

\section{SINGLE}

Bluebird. Clear dark blue ..... \$0 $\$ 20 \$ 200$ Como. Reddish amaranth, white center . $20 \quad 200$ Exquisite. Fine porcelain-blue . . . $20 \quad 200$ Shadow. Dark indigo-blue . . . . . $20 \quad 200$ Snowbound. Large pure white . . . $20 \quad 200$ Souvenir. Lovely rose-pink... . . . $20 \quad 200$ Neptune. Reddish gray, freely grained . $20 \quad 200$ Quakeress. Light lavender, tinged rose . $20 \quad 200$ Mixed New Single. Large-flowering

$$
\text { ........ per 100, \$6. I5 I } 25
$$

\section{TUBEROUS-ROOTED BEGONIAS}

Splendid pot-plants for the house or greenhouse and especially valuable for bedding, flowering in the greatest profusion throughout the summer. For bedding they should be started in hotbed in March and April. The hollow end of the bulb should be up and but slightly covered. They should get very little water until the plants are growing.

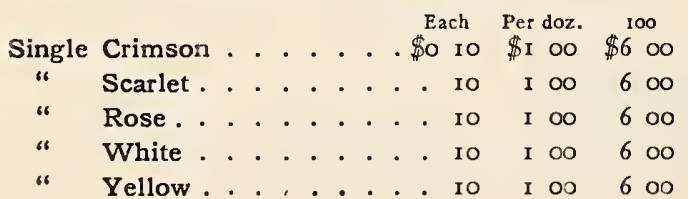

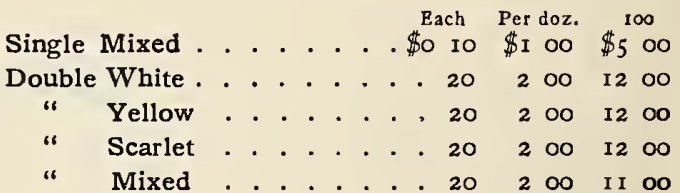

\section{MISCELLANEOUS BULBS AND ROOTS}

\begin{tabular}{|c|c|c|c|c|}
\hline ANEMONE- & Each & Per $d$ & & 100 \\
\hline Coronaria, Single Mixed . & - 05 & & 20 & \\
\hline " Double Mixed ... & 05 & & 30 & 50 \\
\hline Scarlet, Feu Superbe. Double. & 05 & & 45 & 300 \\
\hline Single Blue . . . . . . . . . & 05 & & 25 & I 50 \\
\hline Mignonne. Double, rose. & & & 45 & 300 \\
\hline Chrysanthemiflora Mixed & & I & 25 & ०० \\
\hline ANTHOLYZA Mixed. . . & IO & I & ০o & 600 \\
\hline BESSERA elegans (Coral Drops) & ) 05 & & 50 & 350 \\
\hline CALADIUM esculentum. . . & . 20 & 2 & ০० & \\
\hline CALLA, Spotted. Handsome & & & 75 & 400 \\
\hline CINNAMON Vine Roots $\cdot \cdot$ & . 05 & & 60 & 350 \\
\hline COOPERIA $\rightarrow$ & & & & \\
\hline Drummondii (Evening Star) & 05 & & 45 & \\
\hline Pedunculata. White, fragrant . & 05 & & 45 & \\
\hline Oberwetteri. Bright green . . & 05 & & 45 & 300 \\
\hline CYCLOBOTHRA flava. . . & 05 & & 40 & 250 \\
\hline DICENTRA spectabilis (Dielytra & a) 20 & 2 & ০० & 1200 \\
\hline GLOXINIAS, Finest Mixed . • & 12 & I & 25 & 700 \\
\hline $\begin{array}{l}\text { HELLEBORUS niger major } \\
\text { (Christmas Rose) }\end{array}$ & 30 & 3 & ০o & \\
\hline HYACINTHUS candicans . & . Io & & 75 & 400 \\
\hline MADEIRA Vine Roots . . . . & & & $\infty$ & \\
\hline
\end{tabular}

MILLA biflora. Pure waxy Each Per doz. 100 white....... \$0 05 \$0 $40 \$ 250$ NERINE Japonica . . . I 5 I 50 OXALIS Mixed. 2 for 5 cts. . . $20 \quad$ I 00 PHLOX decussata, Perennial Mixed ........ I 5 I 25900 RANUNCULUS-

Persian Mixed . . 2 for 5 cts. . $20 \quad$ I 00

French Mixed . . 2 for 5 cts. . 20 I oo

Turban Mixed . . 2 for 5 cts. . 20 I 00

TIGRIDIA (Tiger Flower)-

Grandiflora alba. White . . . Io $75 \quad 400$

Conchiflora. Yellow.... o8 $60 \quad 350$

Pavonia. Red ...... 08 6o 350

Canariensis. Yellow..... 08 60 350

Lilacea. Carmine and white . 08 60 350

TUBEROSES-

Dwarf Double...... . $05 \quad 35$ I 50

Albino. Early, single white . . $05 \quad 40 \quad 200$

Variegated-Leaved. Single. . 05 $40 \quad 200$ ZEPHYRANTHES-

Rosea. Rose . . . . . . 05 50 300

Candida. Pure white... 0540250 


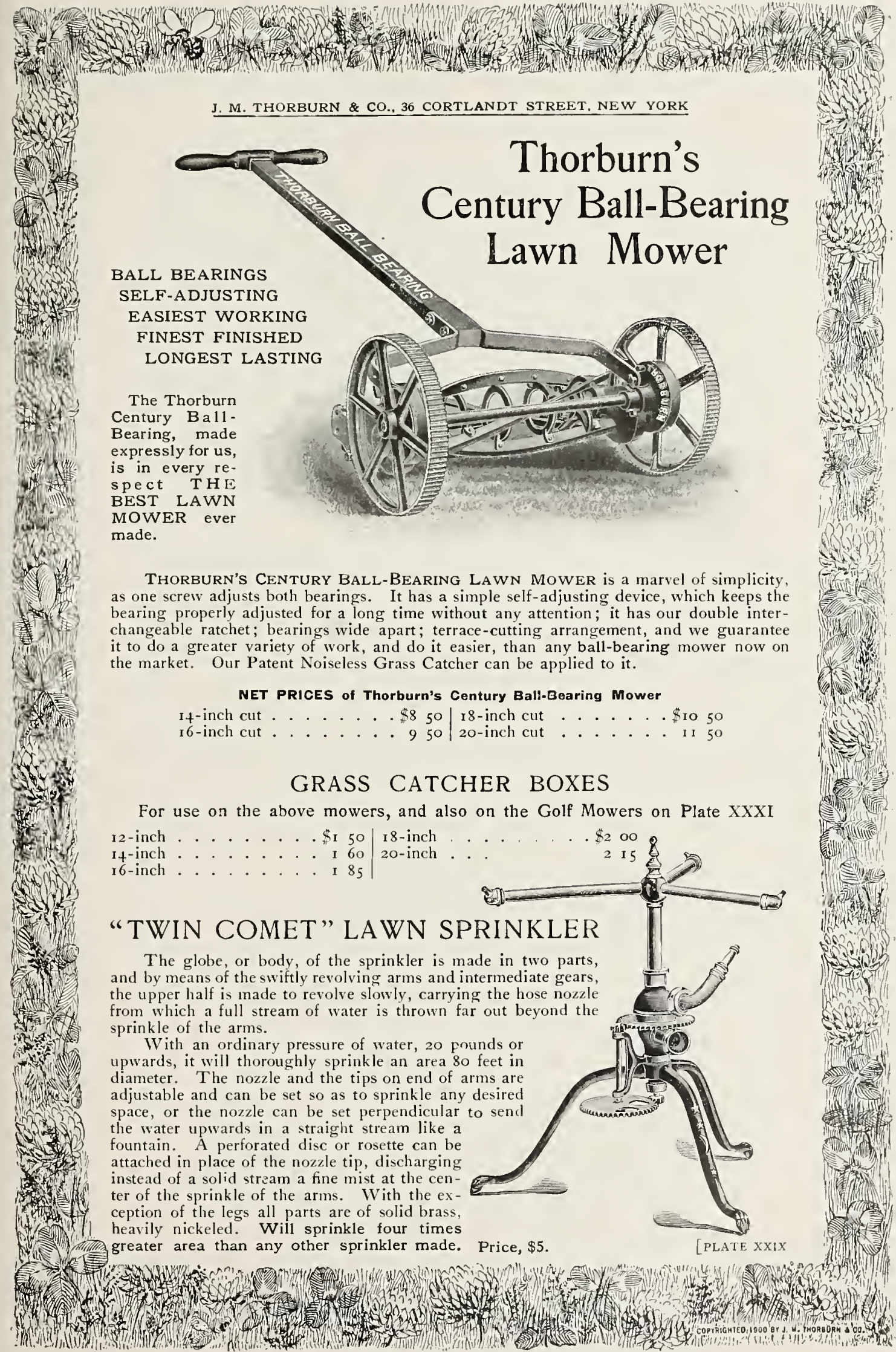




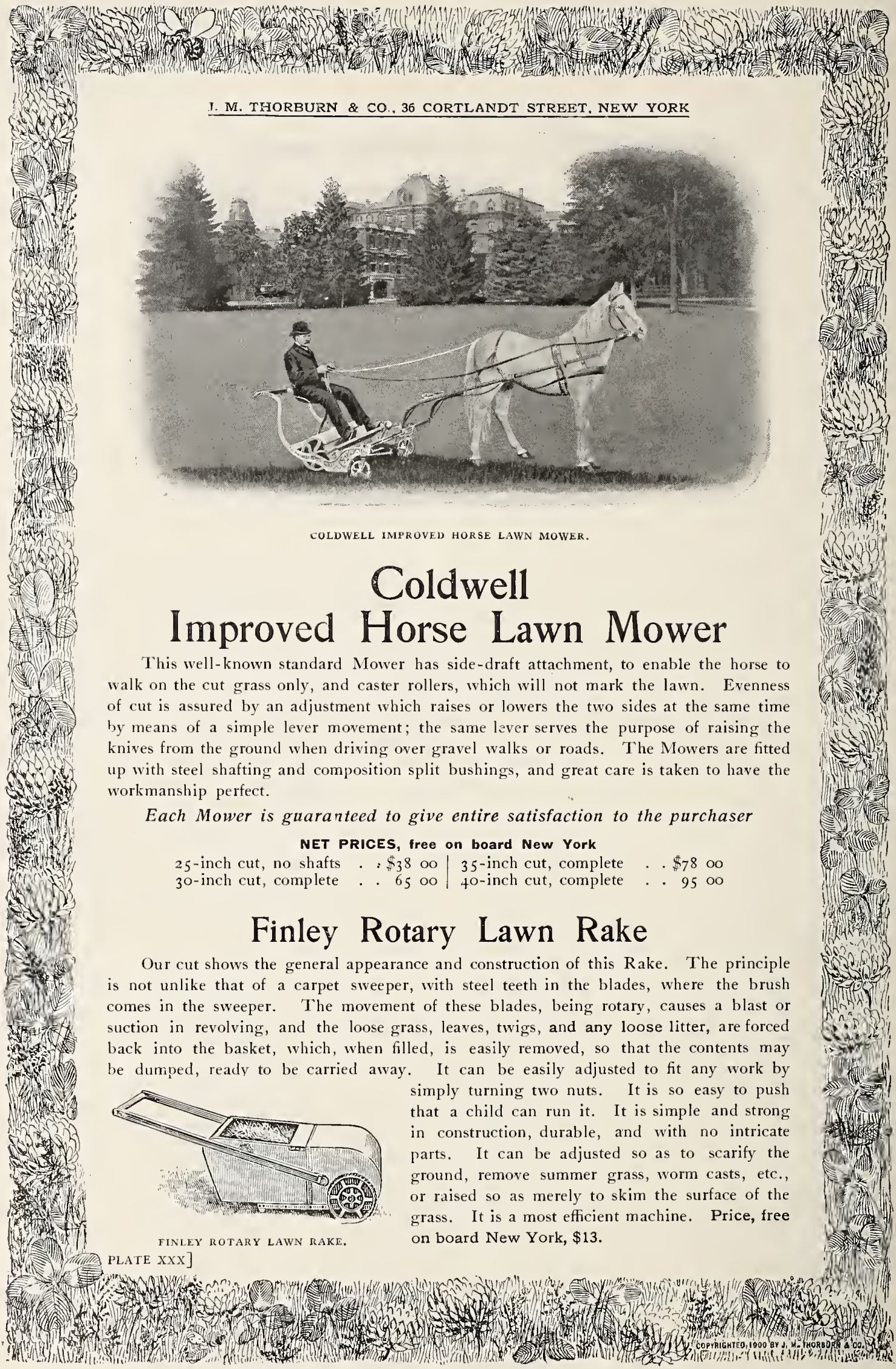









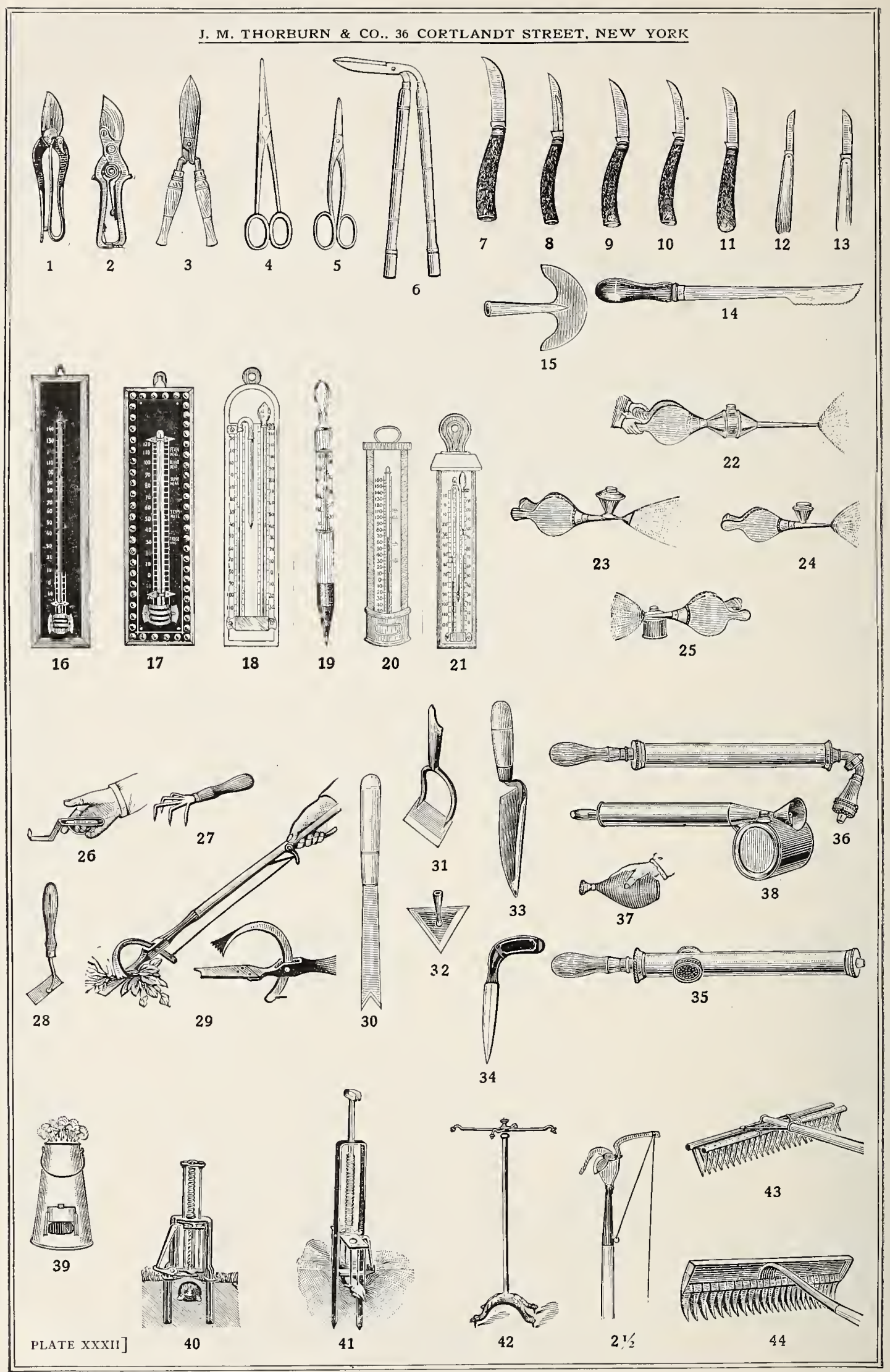




\section{Horticultural Implements and Garden Requisites}

The numbers correspond with the implement numbers on Plate $X X X I I$, opposite.

SHEARS AND SCISSORS

(1) Perfection Pruning. The best made. No. I. 7 ins. $\$ 2$ oO No. 2.8 " 250 No. 4. 10 ". 350

(2) Watch-spring English Pruning . . . . I 50 Hand-Pruning, Wiss' Solid Steel. Two sizes. 9 inches......... 225

(2 1/2) Pole-Pruning, Wiss'. 'Tivo sizes . $\$ 2.50$ and 3 oo Ladies' Small Pruning ... . . . . . 35 German Pruning . . . . . . . . . 75 Waters' Long-Handled Tree Pruners. See page 108.

(3) Hedge Shears, English. 8 - to I I-inch blade. Four sizes..... $\$ 2$ to 300

(4) Grape Scissors, Best English. For thinning the bunches. . 90 cts., $\$ 1.25$ and I 50

(5) Flower Gatherer . . . . . \$1.25 and I 50

(6) Grass Border Shears ... . . \$2.50 to 3 oo Spring Grass, English. For trimming grass. I 25 Best American . . . . . . . . . . I 00

\section{KNIVES}

(7) Saynor's Celebrated English. The best

" make. No. 938, Pruning . I 75

(8) " No. I96, Pruning, 2 blades . 225

(9) " No. 187. Pruning ...... I 50

(I0) “ No. 312, Pruning ...... I 50

(I ) “ No. 80, Pruning ...... 85

(12) “ No. 400, Budding ..... 1 00

(13) " No.40r, Budding ..... I

No. 343, Budding, 2 blades . I 25

(14) Asparagus Knives. English (saw blade). I oo American. Useful for removing dock, dandelion, plantain, etc., from lawns ......... 35

(15) Grass Edging . . . . . I 75

\section{THERMOMETERS}

(16) Oxidized Metal Scale, Polished Back.

$$
\begin{aligned}
& 8 \text {-inch size . . . . . . . . . } 75 \\
& \text { 10-" " . . . . . . . } 100 \\
& 12 \text { - “ “ . . . . . . . . . I } 25
\end{aligned}
$$

(17) Oxidized Metal Scale, Carved Back.

8-inch size . . . . . . . . . . . 75

10-" "

12 - " “ . . . . . . . . I 25

(18) Self-Registering, Polished Back.

8 -inch size . . . . . . . 250

10-" " . . . . . . . . 300

12 - " " . . . . . . . . 350

(19) Hotbed and Mushroom-bed; boxwood,

brass tip; made for plunging . . . . . I 60

(20) Japanned Tin Case . . . . . . . . . 30

2i) Self-Registering, Japanned Case.

8 -inch size . . . . . . . . . 250 ro-" “" . . . . . . . . . . . . 3 300 15 - “ “. . . . . . . 350

BELLOWS, ETC.

For full description see page Ir I.

(22) Woodason's Double-Cone Powder Bel-

(23) " lows ... · · * * 300

(23) “ Single-Cone. Large size . 2 00

(25) “ Atomizer. Large size. . 200 Small size .. 125
Lang's . . . . . . . . . . . . \$O 25

(27) Excelsior . . . . . . . . . . 15

(28) New Hand . . . . . . . . . . . . Is

(29) Cleveland Lawn Weeder. For extracting the roots of dock, etc. (Can be used easily and without stooping)

(30) Lawn. For removing docks, dandelion, etc.; can also be used as an Asparagus Knife.

\section{HOES, TROWELS AND DIBBLES}

Hoes, Draw or Corn . . . . . . . . . . 45

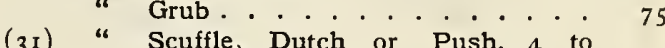
ro-inch $\cdot \cdot \cdot \cdot \cdot \cdot 45$ cts. to 80
Triangular. Used also as Tree Scrapers 90 (32) "Trowels. Solid shank, cast steel - 5oc. to 60

(34) Dibbles. All iron . . . . . . . 35

\section{SYRINGES}

For full description and other makes, see page $r$ ro.

(35) Best Plate Valve. No. 3 ..... . 600

(36) Best Conical Valve. No.6 . . . . 750

(37) Scollay's Rubber Sprinkler . . . . . . . I oo

(38) Cyclone Sprayer . . . . . . . . . 75

\section{EUREKA FUMIGATORS}

For fumigating with tobacco stems.

(39) No. I holds $1 / 2$-peck stems ... . . . . I 50 No. 2 " 1 " ". . . . . 2 200 No. 3 “ $1 / 2$-bus. " ....... 250

\section{MOLE TRAPS}

(40) Olinsted's Improved ... . . . . . . . I 50

(4I) The Reddick. Is easily set, with very powerful spring, and is in every respect a perfect trap......... 75

Hale's . . . . . . . . . 200

\section{LAWN SPRINKLERS AND RAKES}

(42) LAWN SPRINKLERS, Peck's Improved. Standard 4 feet high, surmounted with long arms, which revolve, throwing a fine shower over an area of 60 feet.

4-arm sprinkler . . . . . . 275

8-arm sprinkler ...... . 300

Twin Comet. See Plate XXIX . . . 500

Water Witch, No. 3...... 75

" " No.4.......... I 25

(43) LAwn Rakes, The "Automatic." A back ward motion of the operator will clean all the teeth at once. 26-teeth size, 80 cts. each; 38-teeth size ... . . I oo

The "Lawn King." Teeth very close. Will not tear sod as other Lawn Rakes do. 26 -teeth size, 35 c. ea. ; 38 -teeth size Steel Wire, for lawns . . . . . . 60 Wooden, for lawns ...... . 30 Finley Rotary. See Plate XXX . . . . I 300

(44) English or Daisy . . . . \$2.50 to 350 Lawn Rollers and Sweepers. See Plate XXXI. 


\section{Miscellaneous Garden Requisites}

Asparagus Knives. See page 107. ЕАсн Bill and Brush Hooks, for heavy pruning . \$I 50 Canes, Bamboo, 7 to ro feet long . . . . ... per 100, $\$ 1.25 ;$ per 1,000, $\$ 10$.

(45) Carnation Supports, Model Extension.

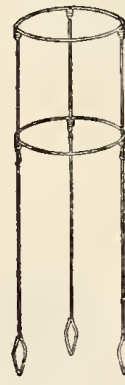

45 - per doz., 50 cts.; per 100, $\$ 3$.

Dibbles. See page 107.

Flower Vases, Pot Saucers and Rolling Stands. See page 109.

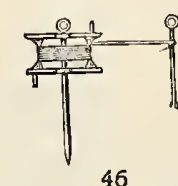

46

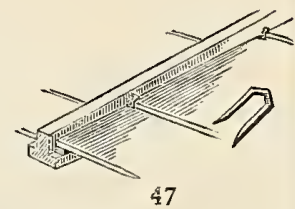

47
Forks, Digging or Spading. . . 75 cts. to I 00 "Hay or Stable . . . . 50 cts, to 75 “ Ladies' Short-Handled or Strawberry Forks . . . . . . . . . 40 “ Manure, Long and Short-Handled. . . . . . . 75 cts. to 100

Fruit Pickers . . . . . . . . . 35

Fumigator, "Eureka." For fumigating with tobacco stems.

No. I holds $1 / 2$ peck stems .... . I 50

No. 2 " I " " . . . . . 200

No. 3 " $1 / 2$ bushel stems ... . 250

Galvanized Wire Stakes. For roses, etc. 3 feet . per doz., 40 cts.; per 100, $\$ 2.50$. 4 “. " 50 cts.; “ 3.00 .

Garden Lines, Finest Braided, roo feet .

(46) " Reels, for above; of wrought iron

. . . . . . . 75 cts. and I 00 Pencils, Wolff's Indelible Black . I

(47) Glazing Points, Van Reyper's Perfect . . per I,000, $75 \mathrm{cts}$; pincers for same Gloves, Gardener's Goatskin - per pair, $\$$ I Grafting Wax. In $1 / 4,1 / 2$ and $I-l b$. pack ages ........ . lb. $30 \mathrm{cts}$.

Grass Border Shears. See page 107.

" Edging Knives (English). See p. 107.

"Hooks, or Sickles, Best English, welded back ... 35 cts. to

Hedge Shears. See page 107.

Hoes, Draw, Grub, Scuffle and Triangular. See page 107.

Hose Nozzle, "Bordeaux." The simplest and best spraying Nozzle made. For $1 / 4$-inch pipe or $1 / 2$-inch hose ... Child's "Rainmaker" Nozzle . . . . . American Ball. With or without spike . Coupling and Stock. Has 1/4-inch pipe thread which fits the Bordeaux Nozzle. Opposite end for $1 / 2$-inch or $3 / 8$-inch hose, as ordered . . . . . . . .

Gem Graduating, for $3 / 4$-inch hose . . .

Hose Menders. Useful articles for repairing rubber hose ..........
Hose, Rubber, Finest "Wallabout." Three- ЕАС ply. $3 / 4$ inch, in any length, at I 5 cts. per foot. I inch, in any length, at $2 \mathrm{I}$ cts. per foot.

Hyacinth Glasses, various styles. (See Bulb Catalogue.)

Knives, Asparagus, Budding and Pruning and Grass Edging. See page 107.

Labels, Wooden Pot and Garden$\overbrace{\text { Pet } 100 \quad 1,000}$ Per $100 \quad 1,000$

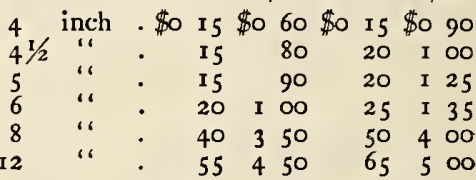

Labels, Wooden Notched TreePer 100 I,000 Per 100 I,000

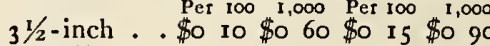
6 " . . 20 I 50 25 200 $31 / 2$ "(cop.wired) $20 \quad$ I $75 \quad 30 \quad 225$

Lawn Rakes and Sprinklers. See page I07.

Lawn Sweeper, "Model No. 1." (See cut, plate xxxi) ........\$10 00 Leaf Mould, per I barrel bag. ..... I 50 Mastica. For glazing greenhouses, sashes, etc. . . . . per qt., 40 cts.; per $1 / 2$-gal., 70 cts.; per gal. . I 25

(48) " Glazing Machine . . . . . . I oo

(49) Mats, for Covering Sashes. Made of jute, stitched through; hemmed with canvas and thickly padded; size 76 inches by 76 inches; one mat covers two sashes. An excellent article, cheap and durable . I 25 Mole Traps. See page I07.

Moss, Sphagnum, per I barrel bag . . . I 00 " " per 5 barrel bale. . . 400

Peat, Rotted, per I barrel bag ...... I 50 "Orchid, per I barrel bag .... I 50

Pincers, for glazing-points . . . . . . 50 "Planet Jr." Drills. See page II2.

Plant Stakes, Round, Painted Green.

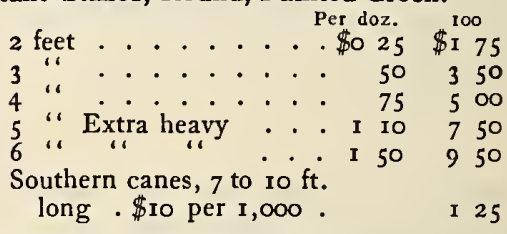

Pruners, Waters' Long-Handled Tree. 4 feet . . . . . . . . \$o 75 6 “........... 80 8 “. . . . . . . . . . I 00 10 " ......... I I0
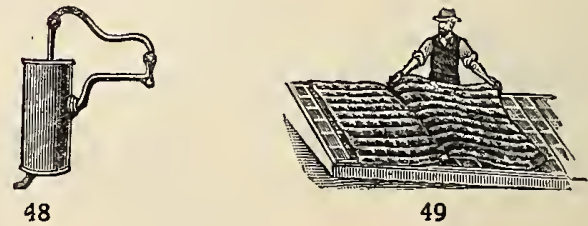

49 


\section{MISCELLANEOUS GARDEN REQUISITES, continued}

(5 $\left.{ }^{\mathrm{I}}\right)$ Raffia, for tying per lb., 20 cts.; 5 lbs., 90 cts.; ro lbs. \$I 50 Rakes, American Garden. Steel, handled . . $\cdot$. 40 cts. to Lawn Rakes, p. ro7.

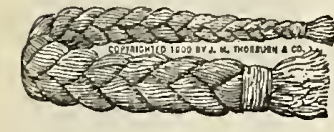

51

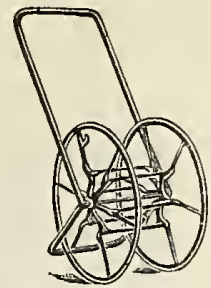

52
(52) Reels, Hose, Tubular Iron. Very light ЕACH weight, frictionless, and the wheels so high that they are very easily worked.

They never break or wear out.

No. Io, for 100 feet $3 / 4$-inch hose . . 275 No. 20, " 150 " $3 / 4$ " " . . 3 co No. 30 , " 500 " $3 / 4$ " " . . 500 Rollers. (See Plate XXXI and page 112. .)

Rubber Hose. See page Io8.

Saws, Pruning, various sizes and kinds . . . . . . . . 70 cts. to 125

Scissors, Grape, and Flower Gatherers. See page 107.

Scythes, English Lawn. Cast steel, 34 to 38 inches ....\$1.50, $\$ 1.60$ and I 75 Scythe Stones, Round Dressed Talacre. . . . . . . per doz., $\$$ I.50 . Scythe Rifles, Triple Emery-Coated . . . . . . . . . . per doz., $\$$ I .

Shears, Grass Border, best English, 8, 9 and ro inches ... $\$ 2.50, \$ 2.75$ and 3 oo Shears of all kinds. See page 107.

Shovels, Ames' Best Cast Steel. Square and diamond-pointed ; long or short handles............ I 50 Silkalene . . . . . . per lb., \$I .

Spades, Ames' Best Cast Steel . . . . . I 50 Sprayers. See pages $\mathrm{I} I 0$ and $\mathrm{I} x \mathrm{x}$.

Sprinklers, Scollay's Rubber. See No. 37,

Plate XXXII . . . I oo " " Angle-Neck Rubber. I oo " Atlas Rubber .. . . . . 75 See also Lawn Sprinklers, page 107 , and Plate XXIX.

Syringes. See page x xo.

Twine, Green Smilax . . per lb., 50 cts. .

Trowels. See page 107.

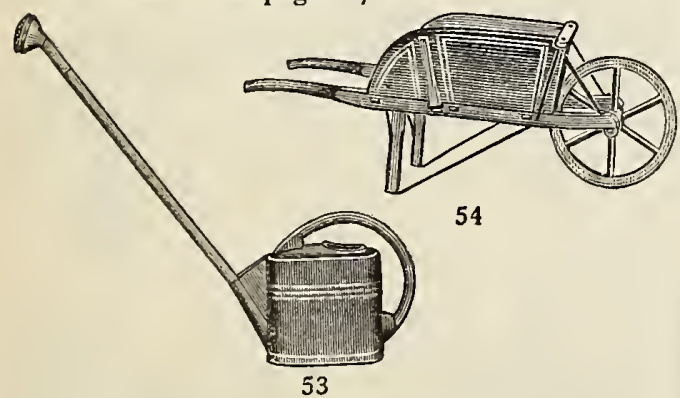

(53) Watering-Pots, French Model. Galvanized iron . . . . . . . 6 qt., \$r.75; 8 qt., 200 " The "Common Sense" .4 gt., 90 cts.; 6 qt., I ro

Watering-Pots, "Philadelphia," with brass EACH joints and two copper faced roses. $6 \mathrm{qt}$.

$\$$ I.75; 8 qt., $\$ 2$; Io qt., $\$ 2.25$; I 2 qt., $\$ 250$

Weeders. See page ro7.

(54) Wheelbarrows. For garden use. Two sizes.

Medium ........... . 375

Large .......... 425

FLOWER TUBS, VASES, SAUCERS, ETC.

(55) Flower Vases, for displaying cut-flowers

Made of indurated wood-fiber.

8 inches in diam., $x_{3}$ inches deep. \$O 60

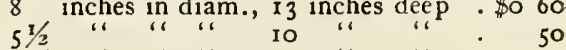

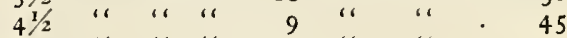

4

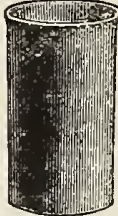

55

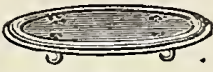

57

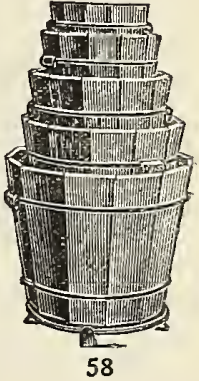

(56) Flower Pot Saucers, Indurated WoodFiber. Very light and durable. Not porous, and will protect tables on which plants stand.

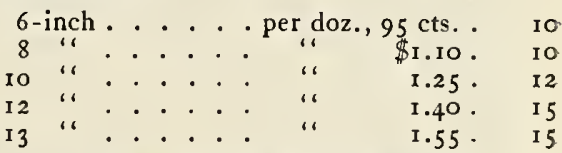

Flower Pot Saucers, Flexible Rubber, Smooth Bottom. These are absolutely damp-proof and will not scratch the smoothest surface.

4-inch . . \$o I5 $151 / 2$-inch .... . 25 $43 / 4$ “ . . $18 \mid 61 / 2$ " 8 ..... 30

(57) Flower Pot Rolling Stands, for heavy plants. Platforms are of indurated fiber ware; will not soak or rust. Casters have ball-bearings.

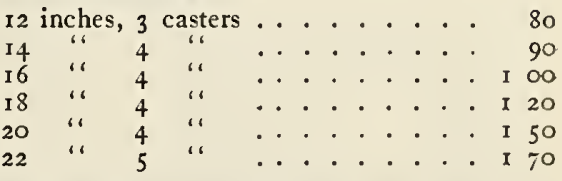

(58) Flower Tubs, Columbia. Made of cypress timber. Natural varnish finish.

12 -in. diam. by $x \mathrm{I}$ in. high..... I $\infty$ I5 " " "I4 " . . . . . I 50 I8 " " " $161 / 2$ " . . . . 200

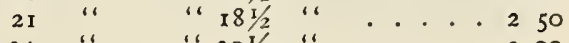
24 " " $201 / 2$ " . . . 300 


\section{MISCELLANEOUS GARDEN REQUISITES, continued}

(59) Flower or Tree Tubs, Cedar. These are made of Virginia white cedar, painted green, with hoops, handles and leg castings painted black. The bottoms are perforated and are removable.

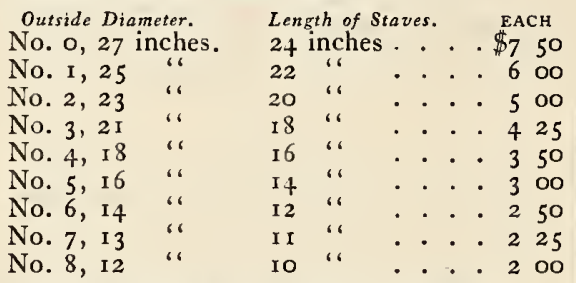

(6o) Flower Tubs, Union. Made of cypress, painted green, with iron hoops and feet and handles; perforated bottom; very strong.

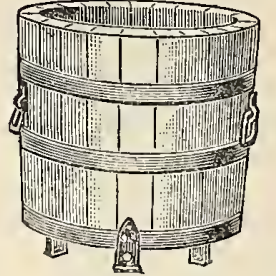

59

CEDAR FLOWER TUB.

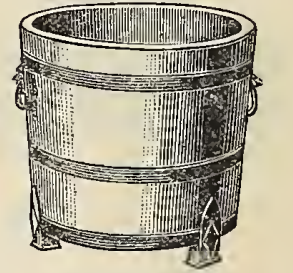

60

UNION FLOWER TUB.

\section{THE LITTLE GIANT SEED-SOWER}

It weighs but three pounds, is cheap and always in order. Will sow Clover, Timothy, Flax, Wheat,

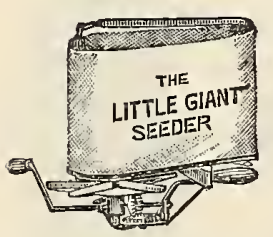

\section{SYRINGES}

Ladies' Syringe, with One Spray Rose. Length of barrel, $12 \frac{1}{2}$ inches ; diameter, $\mathrm{I} \frac{5}{13}$ inches. No. $1, \$ 2.50$.

Ladies' Syringe, with Jet and Two Spray Roses; the two roses, when not in use, are screwed on the side of the barrel. Length of barrel, $14 \frac{1}{2}$ inches; diameter, $1 \frac{5}{16}$ inches. No. $2, \$ 4$.

Best Plate Valve Syringe, large size, with One Stream and Two Spray Roses, with side pieces on barrel. Length of barrel, 18 inches; diameter $1 \frac{1 / 2}{2}$ inches. (See cut No. 35 , Plate XXXII.) No. $3, \$ 6$.

Best Conical Valve Syringe, large size, with One Stream and Two Spray Roses, which are placed, when not in use, in the handle of the syringe. The handle is strongly mounted with a solid brass cap and ring. When the finest spray is used the water should be very clean. Length of barrel, 18 inches; diameter, I $1 / 2$ inches. No. $4, \$ 6.50$.

Best Conical Valve Syringe, large size, with One Spray Rose and Gooseneck Angle Joint, turning in all directions, for washing the under surface of the leaves of plants and flowers, cleansing them from insects, etc. Length of barrel, 18 inches; diameter, 1 1 $/ 2$ inches. (See cut No. 36 , Plate XXXII.) No. 6, $\$ 7.50$.

Scollay's Rubber Sprinkler. For forists' use and window-gardening. $\$$ I

Scollay' Angle-Neck Rubber Sprinkler. For spraying under leaves. \$1.

Atlas Rubber Sprinkler. 75 cts.

Woodason's Atomizer. For the application of all liquid insecticides. $\$ 1.25$ and $\$ 2$.

Cyclone Sprayer. (See cut No. 38, Plate XXXII.) 75 cts.

\section{“FRUITALL" SPRAY PUMP}

All working parts of brass, including plunger, gland, valve, valve seats and strainer. The air chamber is of steel. The only spray pump which can be mounted on or removed from barrel or tank by the simple adjustment of two thumb screws. It is held firmly by clamp at top, and is adjustable to large or small barrel. To mount the "Fruitall" Spray Pump, saw a rectangular hole $4 \frac{1}{2}$ inches $\times 61 / 2$ inches in head of barrel next to stave. Put the pump down through this hole in the barrel, having adjustable clamp hook over the stave with thumb screws on the outside. A small spud at lower extremity of cylinder holds pump securely on bottom of barrel. Price, Outfit A Pump with one lead ro ft., $1 / 2 \mathrm{in}$. discharge hose, with "Seneca" (or Vermorel) Spray Nozzle, \$9.50. An 8-foot Iron Extension Pipe for tree-spraying fitted to attach can be supplied for $\$ 1.50$ extra.

\section{THE "SUCCESS" KNAPSACK SPRAYER}
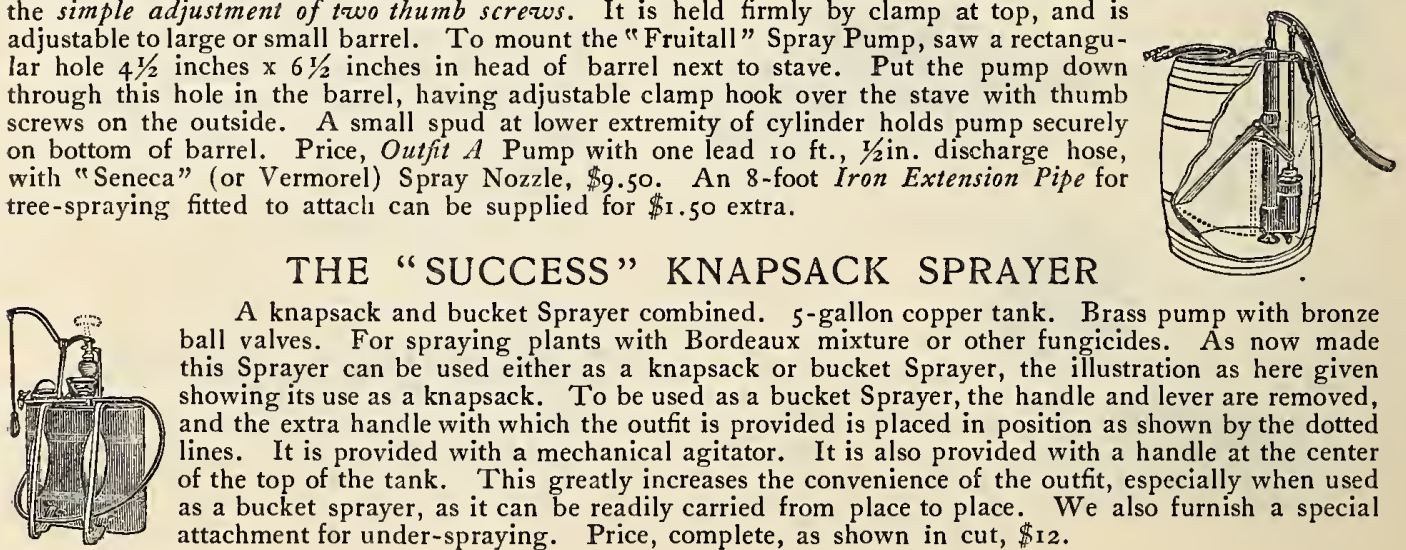

A knapsack and bucket Sprayer combined. 5-gallon copper tank. Brass pump with bronze ball valves. For spraying plants with Bordeaux mixture or other fungicides. As now made this Sprayer can be used either as a knapsack or bucket Sprayer, the illustration as here given showing its use as a knapsack. To be used as a bucket Sprayer, the handle and lever are removed, and the extra handle with which the outfit is provided is placed in position as shown by the dotted lines. It is provided with a mechanical agitator. It is also provided with a handle at the center of the top of the tank. This greatly increases the convenience of the outfit, especially when used as a bucket sprayer, as it can be readily carried from place to place. We also furnish a special attachment for under-spraying. Price, complete, as shown in cut, \$12. 


\section{MYERS' BUCKET BRASS SPRAY PUMP}

Being made of brass, it is not affected by the arsenites used for spraying. Easily operated; throws a solid stream 50 feet. It is provided with a combination nozzle, and also with a sprinkler for flowers. For spraying large trees, an 8 -foot pipe extension is supplied for 60 cents extra. This pump is also valuable for washing windows. Price, $\$ 4$.

\section{LEGGETT'S CHAMPION POWDER GUN}

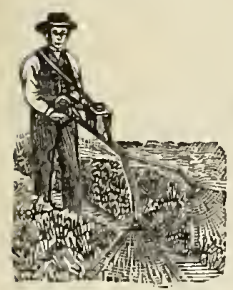

For distributing dry insecticides and fungicides, such as Paris Green, hellebore, sulphur, tobacco dust, fungiroid. It is well made, and weighs only 5 pounds. The style of it is shown by our illustration. Without the tubes it is 27 inches long, but when the four tubes are attached it is ro feet long, and it throws the powder several feet beyond that. It holds one quart of powder, and is easily operated. An invaluable machine for use in orchard, garden or field. The length of it is such that the poison is kept at a safe distance from the operator. The regular outfit consists of six nozzles, two straps, oil can and four tubes. Price, complete, $\$ 7.50$.

\section{WOODASON'S DOUBLE-CONE POWDER BELLOWS}

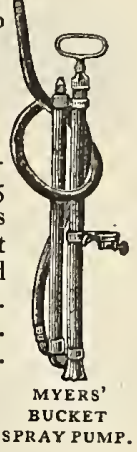

An excellent Bellows for applying powder insecticides in greenhouse, garden or field. The powder can easily be evenly distributed in any direction, under or over the foliage, without waste. (See Plate XXXII, No. 22.) Price, \$3.

\section{WOODASON'S SINGLE-CONE POWDER BELLOWS}

The style of these is shown by our cuts, Nos. 23 and 24, Plate XXXII. They come in two sizes, the smaller one being most suitable for use in the conservatory. Price, large size, $\$ 2$; small size, $\$ 1$.

\section{WOODASON'S ATOMIZER}

An excellent article for applying strong liquid insecticides, as it throws it out in a spray as fine as mist, and distributes it lightly, evenly, and without any waste. The small size is recommended for use in the house. (See Plate XXXII, No. 25.) Price, large size, $\$ 2$; small size, $\$ 1.25$.

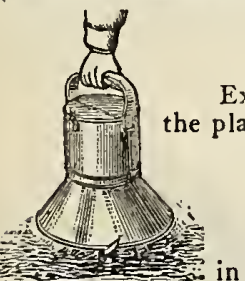

\section{NORTON'S PLANT DUSTER}

Excellent for dusting potatoes, etc., being fitted with a guard which confines the powder to the plant and prevents it from being blown away. Price, 85 cts.

\section{JUMBO POWDER GUN}

Suitable for persons having only a few plants to treat. It is 4 inches in diameter and holds 4 ounces of powder and serves its purpose NORTON'S PLANT admirably. Price, $25 \mathrm{cts}$. DUSTER.

\section{"AUTO-SPRAY" PUMP}

A self-operating sprayer of simple construction, durable, easy to carry and to work. Made of galvanized iron and solid brass and copper, with four-ply rubber hose. For spraying trees, shrubs, cleaning windows, etc. A perfect pump. Price, $\$ 4.50$.

\section{WATER BARREL TRUCK, ETC. (Combined Sprinkler, Leaf-Rack and Hand-Cart)}

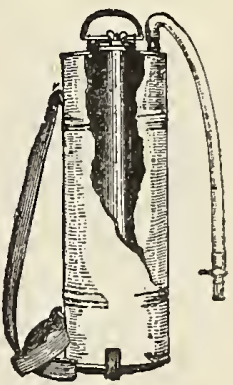

"AUTO-SPRAY" PUMP.

The barrel is easily disconnected from the truck either while full or empty. The following extra attachments can be furnished if required: ( 1 ) Box with trunnions and spring catch, forming a dumping hand-cart. (2) A sprinkler for watering walks and lawns. (3) A leaf-rack.

\section{PRICES}

Truck and barrel, $21 / 2$-inch tire ............ . \$1 1 oo

" " "

" " " 4 with sprinkler, $2 \frac{1}{2}$-inch tire . . . . . 1600

". . " " " "

" " " " " hand-cart box, $2 \frac{4}{2}$-inch tire... . . . 1500

"، " " " " " " " 4 " ". . 1600

" " " " "
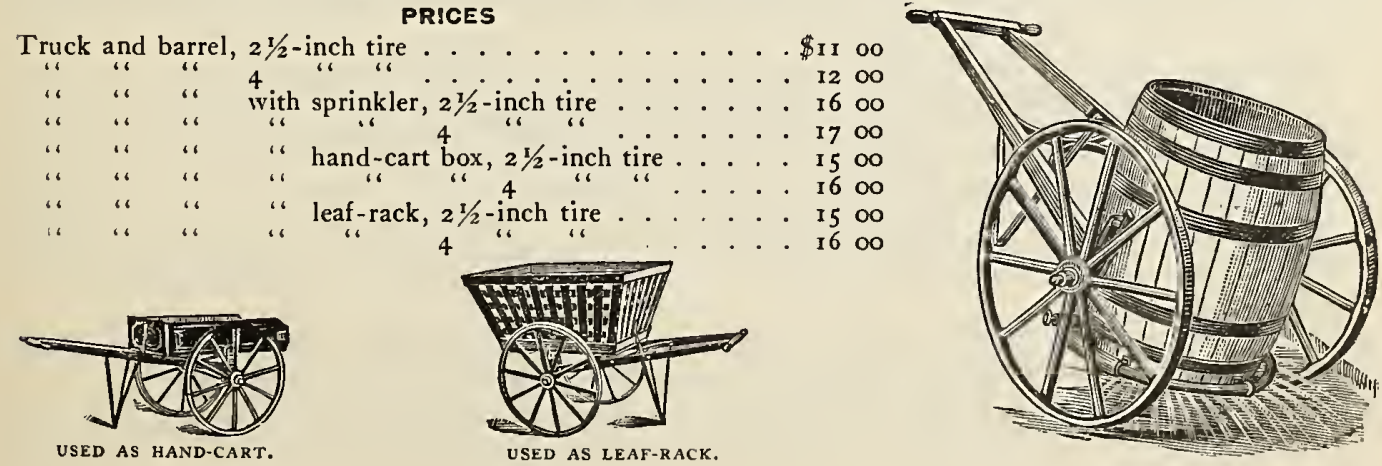


\section{THE STEVENS HAND-FERTILIZER SOWER}

Sows all kinds of lawn dressing and other commercial fertilizers, wood ashes, lime, etc., in large or very

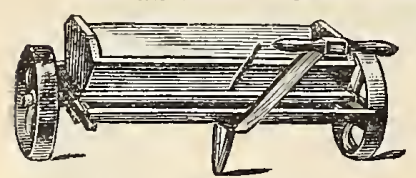
small quantities. It can also be successfully used for fertilizing strawberry beds, and other garden and field work; is excellent for sifting wood or coal ashes, sawdust or dry sand on icy walks; will also sow damp sand by removing two blades. The hopper is 34 inches long and holds one and one-half bushels. Weight of machine, 83 pounds. It is well made and nicely painted. Price, \$ra.

\section{CAST-IRON HORSE LAND ROLLERS}

(With either Pole, for two horses, or Shafts, for one horse. In ordering, state which you want)

No. r4. 20 inches in diameter, 4 feet long, in 4 sections; 850 lbs. . . . . . . . . . . . . . \$38 oo

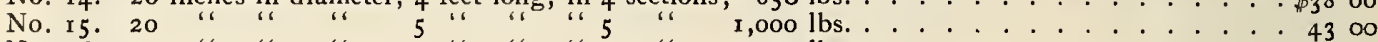

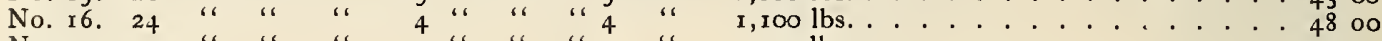

No. 17. 24 " " $"$ "

No. 18. 30 "، “ “

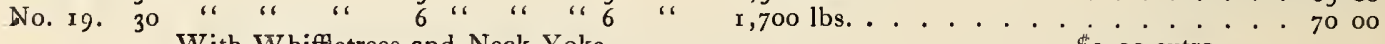
With Whiffletrees and Neck Yoke.............. \$3 oo extra

With Scraper . . . . . . . . . . . . . . . . 600 "

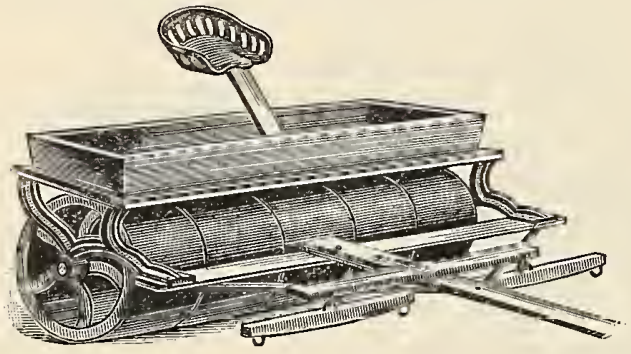

\section{GOLF GROUND ROLLERS}

\begin{tabular}{|c|c|c|c|c|c|}
\hline & & & $\begin{array}{l}\text { No. of } \\
\text { Sections }\end{array}$ & & \\
\hline & $3^{6}$ in & 4 feet; & $4 ;$ & 2,500 lbs. & - \$1 II \\
\hline & 36 & "، & $5 ;$ & 3,00o lbs. & - $\quad 135$ \\
\hline & 36 & ". & & $3,500 \mathrm{lb}$ & I 50 \\
\hline & $\begin{array}{lll}48 & 16 \\
48 & \end{array}$ & 4 . & 3 & 3,500 lbs. & $\begin{array}{l}1500 \\
1900\end{array}$ \\
\hline & 48 & $6 x / 4$ & $\begin{array}{l}4 \\
5 ;\end{array}$ & 5,500 lbs. & 225 \\
\hline
\end{tabular}

With Whiffletrees and Neck Yoke. . \$3 00 extra

\section{THE GARDEN KING CULTIVATOR \\ (Six tools in one)}

The Garden King Cultivator is the only garden tool made with attachments on each side of a frame, so that any kind of work can be done by reversing or turning the tool over. The only tool with handles attached to the axle of the wheel and adjustable to any height person. The wheel is high ( 23 inches); the power is applied against instead of down on the axle, as in tools with small wheels or those where the handles attach to a frame. These features make the Garden King run one-half easier than others. Made with reversible bulltongue blades, which can be kept sharp. All steel except handles. Will last a life-time with ordinary care. It may be used as a $H$ andHoe, Cultivator, Hand-Plow, Seed-Coverer and Double Shovel, and it is also furnished with a weeder attachment that will cultivate and keep the soil in perfect condition. Price complete, with all attachnents, $\$ 5$.

\section{"PLANET JR." SEED DRILLS, ETC.}

"PLANET JR." No. 1. Combined Drill-Seeder and Wheel-Hoe, Cultivator, Rake and Plow. Combines in a single implement a hill-dropping seeder, a perfect drill seeder, a single wheel-hoe, a cultivator, a rake and a plow. It holds three pints and as a seeder is like the No. 5 , sowing in continuous rows, or dropping in hills at any distance. With this one implement the small farmer can do practically all the work in his small crops. Price, $\$ 9.50$.

"PLANET JR." No. 4. Combined Hill and Drill-Seeder, Single Wheel-Hoe, Cultivator, Rake and Plow. This has long been the most popular combined tool made. It is an excellent seed sower, a firstclass double or single wheel-hoe, an excellent furrower, an admirable wheel cultivator, a capital garden rake, and a rapid and efficient garden plow. Price complete, $\$$ r. As a Drill only, $\$ 8$.

"PLANET JR." No. 11. Double Wheel-Hoe, Cultivator, Rake and Plow. It has II-inch wheels, which can be set at four different distances apart. The handles are adjustable at any height, and, being attached to the arch, are undisturbed in making changes of adjustment in frame, wheels or tools. Seven pairs of tools go with the complete wheel-hoe. All the blades are of tempered and polished steel. Price, $\$ 8.50$.

"PLANET JR." No. 12. Double Wheel-Hoe, Cultivater and Plow. Identical with No. rr Wheel-Hoe, except that it has fewer attachments, and is sold at a coriespondingly less price. Price, $\$ 6.50$.

"36 PLANET JR." GRASS EDGER. It will edge straight or curved work-paths, drives, borders or Hower beds-at the speed of a mile an hour. It should be the constant companion of the lawn mower. Price, $\$ 6$. 


\section{Insecticides and Remedies for Plant Diseases.}

\section{BUG DEATH}

This is a fungicide, insecticide and plant-food combined, which has been used for three years with firstclass results. It is claimed that the increase in the crop, resulting from its use, will repay the trouble and expense several times over. I-lb. package, I 5 cts. ; 3 -lb. package, 35 cts. ; 5 -lb. package, $50 \mathrm{cts}$.; 1 $21 / 2-\mathrm{lb}$. package, $\$ \mathbf{I}$.

Perfection Shaker for applying above, $65 \mathrm{cts}$. each.

\section{COPPERDINE}

A combined fungicide and insecticide, used simply by adding water in proportion of one pound of the paste to 16 gallons of water. As a fungicide it prevents black rot, downy mildew and anthracnose of the grape, pear leaf-blight, apple scab, mildew, apple rot, black spot, strawberry blight. As an insecticide, it kills codlin moths, curculio, pear insects, peach and apple borers, currant worms, cabbage worms, potato bugs and caterpillars. I-lb. box, $25 \mathrm{cts}$. makes 16 gallons spray; 5 -lb. box, $\$ \mathrm{r}$, makes 80 gallons spray.

\section{FIR-TREE OIL}

For greenhouse and house plants. It destroys all plant insects without injuring the plant. It is the best insecticide for scale, aphis, red spider, mealy bug, thrip and worms. Dilute in the proportion of $I$ pint to 20 gallons of water. Apply with vaporizer or syringe. $1 / 2$ pt., $40 \mathrm{cts}$; pt., 75 cts. ; qt., $\$ 1.25 ; 1 / 2$ gal., $\$ 2.25$; gal., $\$ 4$.

\section{FIR-TREE OIL SOAP}

This is the same as the Fir-Tree Oil, but in soap form. It is useful for the same purposes. Mix at rate of $I$ ounce to a gallon of water, and apply with bellows or syringe. $1 / 2-1 \mathrm{~b}$. tin, $25 \mathrm{cts}$. ; $2-\mathrm{lb}$. tin, $75 \mathrm{cts}$. ; $5-\mathrm{lb}$. tin, $\$ \mathbf{r} .75$.

\section{DALMATIAN INSECT POWDER}

Effective against almost all kinds of insects. Per $1 / 2$-lb. box, $30 \mathrm{cts}$.; per I-lb. box, $50 \mathrm{cts}$.

\section{GISHURST'S COMPOUND}

A certain remedy for greenfly, scale, mealy bug, etc. Excellent for greenhouse use. Full directions for use on each box. Per I-lb. box, 50 cts.

\section{HAMMOND'S GRAPE DUST}

For the prevention of mildew on roses, grapes, gooseberries, etc. Apply with bellows. 5-lb. package, 35 cts.; ro-lb. package, 6o cts.; roo-lb. keg, $\$ 5$.

\section{HELLEBORE, POWDERED}

An excellent protection from currant worms, grape slugs, caterpillars, etc. May be applied dry or mixed in water - I oz. to 3 gallons. Per $2-1 \mathrm{~b}$. box, $35 \mathrm{cts}$.; per I-lb. box, 20 cts.; $1 / 2-l b$. box, 12 cts.

\section{LITTLE'S ANTIPEST}

A sure destroyer of all insect pests. It is non-poisonous and harmless to vegetation. Mixed with water as follows it is effectual against - greenfly, I pt. to ro gals. of water; mealy bug, I pt. to I $1 / 2$ gals.; red spider, I pt. to 2 gals.; ants, wireworms and slugs, I pt. to I gal. $1 / 2$-gal. can, $\$ 1.50 ;$ gal. can, $\$ 2.50$.

\section{NIKOTEEN}

A powerful insecticide, specially prepared for use in greenhouses and conservatories. Per pint bottle, $\$$ I.50.

\section{NIKOTEEN APHIS PUNK}

It kills bugs under glass and does not injure sensitive blooms or foliage. $60 \mathrm{cts}$. per box of $\mathrm{I}$ doz. rolls; $\$ 6.50$ per case of I doz. boxes.

\section{PARIS GREEN}

Mixed at the rate of I Ib. to 200 gallons of water, it will prove effective against all chewing insects. Per I-lb. can, 35 cts.; 1/2-lb. can, 20 cts.; 1/4-lb. can, I $5 \mathrm{cts}$. This article is liable to fluctuate in price.

\section{SLUG SHOT (HAMMOND'S)}

Excellent for destroying cabbage, turnip and beet fly, potato bugs, currant worms, etc. Prepared ready for use. 5-lb. package, $30 \mathrm{cts}$; 10-lb. package, 50 cts. ; roo lbs., $\$ 4$.

\section{SULPHUR, POWDERED}

Valuable for protecting against mildew on grapes, roses, etc. Per lb., Io cts.; Io lbs., $60 \mathrm{cts}$.; roo lbs., $\$ 4$.

\section{SULPHO-TOBACCO SOAP}

Dissolve in proportion of 2 ounces to a gallon of water, and apply with a syringe or atomizer. It will destroy rose slugs, aphides, greenfly, bark-lice, etc. Per $1 / 2-\mathrm{lb}$. box, $25 \mathrm{cts}$

\section{TOBACCO DUST}

If dusted on while the foliage is moist it destroys rose lice, cabbage and turnip fleas, etc. Spread upon the ground, it keeps off all earth insects, and also acts as an excellent fertilizer. Per $\mathrm{I}-\mathrm{lb}$. box, ro cts.; $5-\mathrm{lb}$. package, $30 \mathrm{cts}$; I0-lb. package, $50 \mathrm{cts}$.; per I00 lbs., $\$ 2.50$.

\section{TOBACCO STEMS}

For fumigating plants infested with greenfly. Per bale of about roo lbs., $\$ 1.50$; per bale of about 200 lbs., $\$ 2.75$; per bale of about 400 Ibs., $\$ 4.50$.

\section{"ROSE LEAF" TOBACCO EXTRACT}

A perfectly pure, highly concentrated extract of tobacco, most effective for destroying all insects and scale on plants. Our "Rose Leaf" pamphlet gives full directions for applying. Pint can, $30 \mathrm{cts}$; ; $\mathrm{qt}$, $50 \mathrm{cts.;}$ gal., $\$ \mathbf{1 . 2 5}$.

\section{WHALE-OIL SOAP}

For washing trees and destroying all insects on the bark. Mixed at the rate of I lb. to 4 gallons of water, it will rid cabbage, rose bushes, peach trees, etc., of the aphides that so often infest them. Per $\mathrm{I}-\mathrm{lb}$. box, 18 cts.; 5 lbs., 50 cts.; Io Ibs., 90 cts.; I00-lb. keg, $\$ 7$.

\section{BORDEAUX MIXTURE, Or FUNGIROID}

For all fungous diseases, such as mildew, and the various rots of the grape. Full directions on label. Dry, I-lb. box, 20 cts.; 5 lbs. and over at I 5 cts. per lb. ; 50-lb. keg, \$6.; liquid, I gallon, $\$ \mathbf{I} .25$. 


\section{High Grade Registered Fertilizers}

These Fertilizers are specially manufactured for us, and are reliable and efficient for the purposes specified. They are registered with the authorities of the state of New York and the analysis is guaranteed. Quantity required on solls not impoverished, about one-half ton per acre.

\section{THORBURN'S COMPLETE MANURE}

Guaranteed to contain ammonia, 3 to 4 per cent; available phosphoric acid, 6 to 8 per cent; actual potash, 6 to 7 per cent; sulphate of magnesia, soda, lime, sulphuric acid, etc. Adapted for use on all crops, such as corn, tomatoes, potatoes, peas, beans and early vegetables, and is especially suited for grain crops and for seeding down grass.

Price-In I67-1b. bags, per ton, $\$ 38$; single bags of 167 lbs., $\$ 3.50$; per bag of $100 \mathrm{lbs}, \$ 2.25 ; 501 \mathrm{bs}$., $\$ 1.50$; $251 \mathrm{bs}$., $\$ 1$; 10 lbs., 50 cents.

\section{THORBURN'S POTATO MANURE}

Guaranteed to contain ammonia, $4 \frac{1}{2}$ to 5 per cent; available phosphoric acid, 8 to ro per cent; actual potash, 9 to ro per cent; sulphate of magnesia, soda, lime, sulphuric acid, etc. This manure is for special use on the potato crop, and is also adapted for sweet potatoes, vines, and fruit trees, and all leguminous plants. Price-In 167-1b. bags, per ton, $\$ 45$; single bags of I67 lbs., \$4; per bag of $100 \mathrm{lbs} ., \$ 3 ; 501 \mathrm{bs}$., $\$ 1.75 ; 251 \mathrm{bs}$., $\$ 1$; 10 lbs., 50 cents.

\section{THORBURN'S LAWN FERTILIZER}

Guaranteed to contain ammonia, 6 to 7 per cent; available phosphoric acid, all soluble, 8 to ro per cent; actual potash, 5 to 6 per cent; lime, sulphate of magnesia, soda, sulphuric acid, etc. Specially prepared for lawns and meadows as a top-dressing, imparting to grass a rich green color and vigorous growth.

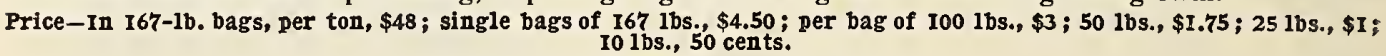

\section{CLAY'S CELEBRATED FERTILIZER}

On account of the high reputation which this Fertilizer has in England, and as we have had many inquiries for it by gardeners here, we have imported some from Messrs. Clay \& Son, which we offer at the following prices. It is undoubtedly one of the best manures for all horticultural purposes, either in greenhouse or garden, and we believe its high reputation is well deserved. It is productive and lasting, and notwithstanding its apparently high price, it is quite economical.

\section{PRICES IN BAGS}

I cwt. (I12 lbs.), \$7. $\quad 1 / 2$ cwt. ( 56 lbs.), $\$ 4$. $\quad 1 / 4$ cwt. (28 lbs.), $\$ 2.25 . \quad$ 1/8 cwt. (14 lbs.), $\$ 1.25$.

\section{PULVERIZED SHEEP MANURE}

A very rich, pure natural manure. It is excellent as a top-dressing for lawns. Its effect is immediate and very lasting. There is nothing better for mixing with the soil for greenhouse plants-one part manure and six parts soil. It is recommended for use in the vegetable garden, promoting a steady and rapid growth. It makes a rich and safe liquid manure-r pound to 5 gallons of water.

5-1b. package, 30 cents; I0 lbs., 50 cents; 50 lbs., $\$ 1.25$; 100 lbs., $\$ 2$; ton, $\$ 30$.

\section{BONE FERTILIZERS}

Pure Ground Bone Meal. This finely pulverized ground bone is excellent for rose culture. It decomposes very rapidly, and is more quickly effective than the coarser grade. It is excellent for mixing with the soil for potting. 5 lbs., 25 cts.; 50 lbs., $\$ 1.25$; roo lbs., $\$ 2$; per ton, $\$ 32$.

Ground Bone, No. 3. This is coarser than the above, and is suitable for general purposes, for top-dressing for lawns, and for garden and field crops. Per roo-lb. bag, $\$ 2.25$; per ton, $\$ 38$.

Ground Bone, No. 4. A little coarser than No. 3. Per roo lbs., \$2.50; per ton, \$40.

Crushed or Coarse Bone. Being much coarser, this takes effect more slowly, but is correspondingly more permanent. Per roo-lb. bag, $\$ 2.75$; per ton, $\$ 43$.

\section{BOWKER'S FOOD FOR FLOWERS}

A dressing made expressly for plants grown in the house, garden or conservatory; clean, odorless, and producing early and abundant blossoms, and healthy, luxuriant plants. One small package is enough for thirty plants for three months. Decidedly the best dressing for potted plants.

Small packages, I5 cts. each ; large packages, 25 cts.

\section{OTHER FERTILIZERS}

Blood and Bone Fertilizer . . . . . . . . per roo-lb. bag, \$2.25; per 200-lb. bag, \$4; per ton, $\$ 34$. Horn Shavings, Fine Grade . . . . . . . . . . . . . . per roo lbs., $\$ 5 ;$ per ton, $\$ 60$. Imported Scotch Soot. In roo-lb bags only . . . . . . . . . . . . . . . per bag, \$4. Nitrate of Soda. . . . . . . . 5-lb. pkg., 30c.; ro-lb. pkg., 50c.; 50-lb. bag, $\$ 2$; 100 lbs., $\$ 3.75$.

Unleached Wood Ashes. . per bag of $100 \mathrm{lbs}$., $\$ 1.50 ;$ per barrel of about $200 \mathrm{lbs}$. to $300 \mathrm{lbs}$., $\$ \mathrm{r} .25$ per roo lbs.; per ton, $\$ 20$.

Cotton Seed Meal . . . . . . . . . . . . . . per $200-\mathrm{lb}$ bag, $\$ 4.50 ;$ per ton, $\$ 38$. 


\section{N D EX}

\begin{tabular}{|c|c|c|}
\hline heonis $5-5$ & Catasnillare & Fertilizers \\
\hline bronia ............................. & Caterpillars............. & 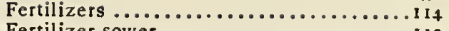 \\
\hline & & Fertilizer sower ...................112 \\
\hline$\cdots \cdots \cdots \cdots \cdots \cdots \cdots \cdots+79$ & 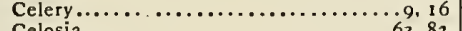 & etticus.............................20 \\
\hline 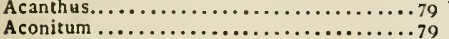 & 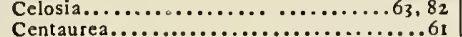 & $\begin{array}{l}\text { Flax seed } \ldots \ldots \ldots \ldots \ldots \ldots \ldots \ldots \\
\text { Flower Serds, Collections of } \cdots \cdots \cdots\end{array}$ \\
\hline 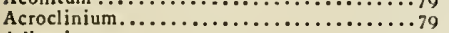 & Centranthus............................. ${ }_{3}$ & Flower Serds, Culture of ............. 55.56 \\
\hline umia ........................ & 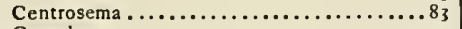 & Flower Seeds, General List of .........79-98 \\
\hline nis.......................... & Cereals............................. 39 & Flower Seeds, Novelties in. . . . . . . . . . . $5^{-9}$ \\
\hline 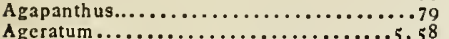 & 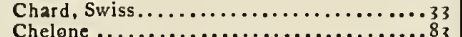 & pecialties...............5 $57-78$ \\
\hline 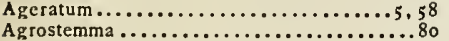 & & ers................... \\
\hline 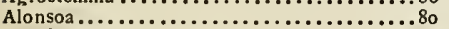 & & Flower tubs $\ldots \ldots \ldots \ldots \ldots \ldots \ldots \ldots \ldots$ \\
\hline 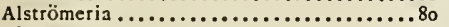 & 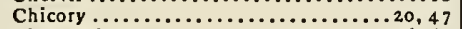 & 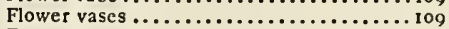 \\
\hline m............................... & hemums ..................6, 62 & ds ......................47-50 \\
\hline 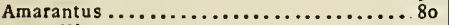 & 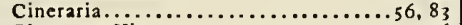 & Forget-me-not $\ldots \ldots \ldots \ldots \ldots \ldots \ldots \ldots \ldots, 6,6_{4}$ \\
\hline yllis........................... & Vine.................. & 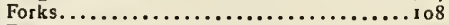 \\
\hline usa................... & 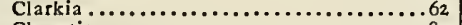 & 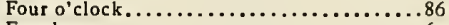 \\
\hline none.........................80, 106 & 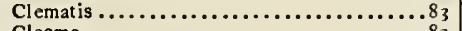 & 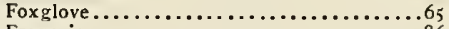 \\
\hline $\begin{array}{l}\text { Culture of } \ldots \ldots \ldots \ldots \ldots \ldots \ldots \ldots \ldots,{ }^{55} \\
\text { Mixed } \ldots \ldots \ldots \ldots \ldots \ldots \ldots \ldots \ldots 9^{8}\end{array}$ & $\cdots \cdots \cdots \cdots \cdots \cdots \cdots \cdots, 8_{83}$ & 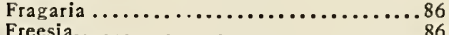 \\
\hline 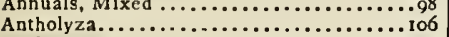 & 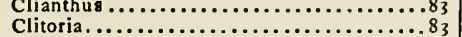 & $\begin{array}{l}\text { Freesia } \\
\text { Fruit-pickers } \ldots \ldots \ldots \ldots \ldots \ldots \ldots\end{array}$ \\
\hline$\ldots . .80$ & 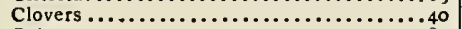 & 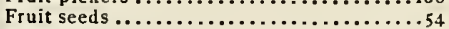 \\
\hline$\ldots 58,59$ & 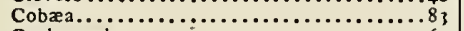 & 086 \\
\hline ....8 & nb.........................6n & $\ldots \ldots \ldots \ldots \ldots \ldots \ldots \ldots, 108$ \\
\hline ia............ & 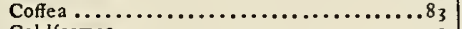 & ungicides...$\ldots \ldots \ldots \ldots \ldots \ldots \ldots \ldots \ldots \ldots \ldots \ldots \ldots$ \\
\hline 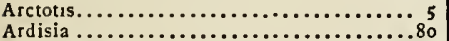 & $\begin{array}{c}n \\
\ldots \ldots \ldots \ldots \ldots \ldots \ldots \ldots \ldots \ldots \ldots \ldots \ldots \ldots \ldots \\
n_{3}^{3}\end{array}$ & Furze $\ldots \ldots \ldots \ldots \ldots \ldots \ldots \ldots \ldots \ldots$ \\
\hline 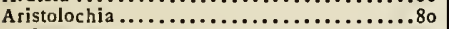 & 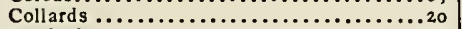 & .6 .86 \\
\hline ......10 & . $\ldots \ldots \ldots \ldots \ldots \ldots \ldots, \ldots$ & label!,$\ldots \ldots \ldots \ldots \ldots \ldots$ \\
\hline$\ldots \ldots .98$ & .............................. & Gardenia............................. \\
\hline$\ldots \ldots \ldots .68 \mathrm{t}$ & 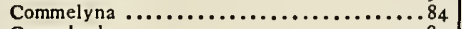 & 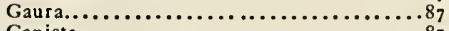 \\
\hline 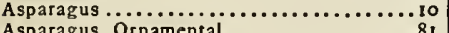 & us......................... & 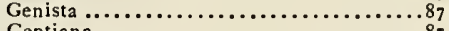 \\
\hline is, Ornamental...... & a........................... & 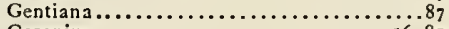 \\
\hline $\begin{array}{l}\ldots \ldots \ldots \ldots \ldots \\
\ldots \ldots \ldots \ldots \ldots \ldots\end{array}$ & 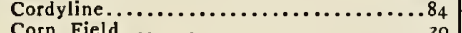 & 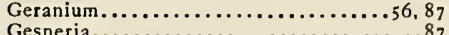 \\
\hline $\begin{array}{l}8,57,58 \\
110,111\end{array}$ & ( $\ldots \ldots \ldots \ldots \ldots \ldots \ldots \ldots \ldots \ldots \ldots \ldots \ldots$ & teria \\
\hline 0,111 & $\cdots \cdots \cdots \cdots \cdots \cdots \cdots$ & $\begin{array}{l} \\
n_{1}\end{array}$ \\
\hline$\ldots 81$ & 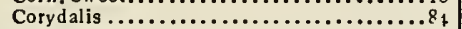 & 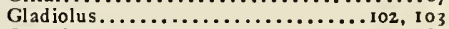 \\
\hline$\ldots . .81$ & n................... & $\cdots \cdots \cdots \cdots \cdots \cdots$ \\
\hline & & \\
\hline & $\cdots \cdots \cdots+47$ & ardeners'..$\ldots \ldots \ldots \ldots \ldots \ldots$ \\
\hline $\begin{array}{l}. .59 \\
. .39\end{array}$ & $\cdots \ldots \ldots \ldots$ & 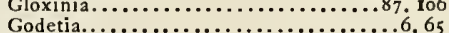 \\
\hline$\ldots$...111 & & wer $\ldots \ldots \ldots \ldots \ldots \ldots \ldots \ldots$ Plate $\mathrm{XXX}$ X. \\
\hline$\ldots \ldots 81$ & a............. & ena........................... \\
\hline $1,12,47$ & .......... & Gourds, Ornamental........ \\
\hline $\mathrm{Be}$ & & $02,0+, 0,0 \%, 00,91$ \\
\hline & Garden K & er boxes............P \\
\hline 81,106 & ............ & n................... \\
\hline 107,111 & & mental ...... \\
\hline$\ldots \ldots 106$ & 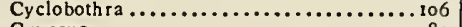 & res...................... \\
\hline$\cdots \cdots 55$ & $\ldots \ldots \cdot \ldots \ldots \ldots \ldots$ & n.m.n. \\
\hline Bird seeds ....... & 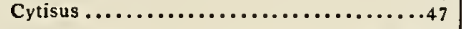 & $\ldots 54$ \\
\hline$\ldots \ldots \ldots \ldots, 4$ & & seeds................... \\
\hline .........10 & $\cdots \cdots \cdots$ & 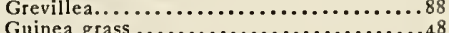 \\
\hline $\begin{array}{l}\ldots \ldots \ldots \ldots \ldots \ldots 21 \\
\ldots \ldots \ldots \ldots \ldots \ldots 100\end{array}$ & 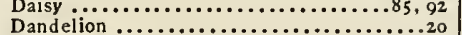 & 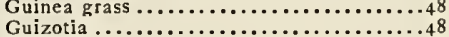 \\
\hline & (n............ & ( \\
\hline $.8 \mathrm{I}$ & $\ldots \ldots \ldots \ldots \ldots .85$ & $\ldots \ldots \ldots \ldots \ldots \ldots \ldots \ldots \ldots \ldots \ldots 99$ \\
\hline & $\ldots \ldots \ldots \ldots \ldots 63,64$ & Gypsophila......................... 88 \\
\hline .......47 & 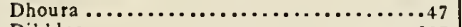 & \\
\hline$\ldots \ldots \ldots \ldots \ldots \ldots \ldots+47$ & ........ & sio....... \\
\hline$\ldots \ldots \ldots \ldots \ldots, \ldots, m_{t}$ & & 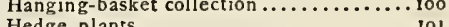 \\
\hline$\ldots \ldots \ldots 14$ & ........... & ats..................... \\
\hline & ........... & $\ldots \ldots \ldots$ \\
\hline $102-106$ & . & n.................. \\
\hline & & 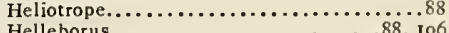 \\
\hline & & 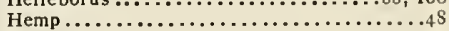 \\
\hline & & \\
\hline & .21 & ............ \\
\hline & & $\cdots \ldots \ldots \ldots \ldots \ldots y$ \\
\hline & & 107 \\
\hline & .99 & \\
\hline & & 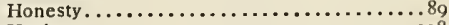 \\
\hline & & \\
\hline & .85 & d......................... \\
\hline Ion & $\ldots .86$ & \\
\hline & $.6,64$ & \\
\hline & $\ldots 36$ & ............ \\
\hline .82 & & \\
\hline & & ubber........................ \\
\hline & & 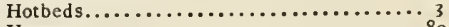 \\
\hline & & \\
\hline$\ldots 103$ & & \\
\hline & .86 & \\
\hline & & glasses................... \\
\hline & & s....................... \\
\hline & & ........ 106 \\
\hline & & \\
\hline & & \\
\hline Ca & & \\
\hline & & \\
\hline
\end{tabular}


Inpatiens

indigo seed

insecticides

Introductory

lonop sidium

I pomca...

pomopsis.

Iris.

Jacaranda

Jacobaa

Japan Clove

Justicia

Kaffir corn.

Kale .........

Kennedya.

Kochia .

Kohlrabi.

Knives.

Labels.

Lantana.

Lathyrus.

Lavatera.

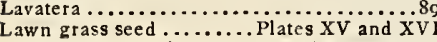

Lawn mowers..Plates XXIX, XXX and XXXI

Lawn rakes ............... 107, Plate XXX

Lawn sprinklers.............107, Plate XXIX

Lawn sweeper.

Leaf mould.

Leaf rack

Leek

Lemon Verbena

Lentil

Leontopodium

Leptosiphon

Leptosyne.

Lespedeza.

Lettuce.

Liatris.

Lilies....

Limnanthes

Linaria

Lines, Garden

Linum

Lobelia

Lophospermum

Lotus.

Love-in-a-Mist

Lupins

Lychnis .........................

Madder

Madeira vine

Madia.

Malope.

Mandevillea

Mangel-wurzels.

Marigold

Martynia

Mastica.

Mastica machine

Mathiola..

Matricaria

Mats

Maurandia.

Melons...

Me sembryanthemum

Mignonette

Millets

Millo maize.

Mimosa..

Mimulus.

Mina lobata.

$M$ iscellaneous Seed

Mole traps.

Momordica.

Montbretias.

Morning-glory

Moss, Sphagnum

Musa.

Mushroom spawn.....

Muskmelon

Musk plant.

Mustard .

Nagelia..

Nasturtiums.

Nemesia ....

8899A 52 T11

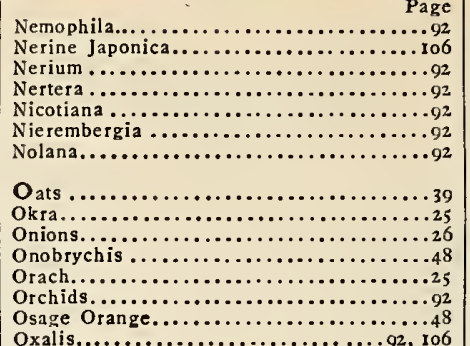

Oxalis..........................

Palm seeds...................... 10

Pansy ..........................7, 56, 69

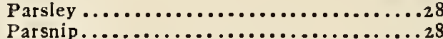

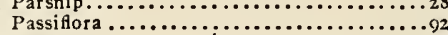

Peas $\ldots \ldots \ldots \ldots \ldots \ldots \ldots \ldots \ldots \ldots, 27,28,47,48$

Peat.............

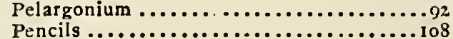

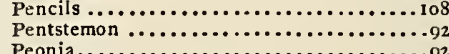

Peonia.......

Peonies

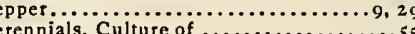

Perennials, Culture of $\ldots \ldots \ldots \ldots \ldots \ldots \ldots .55$

Persicaria..................................93

Petunia.

Phacelia ..............................

Phlox ............................. 106

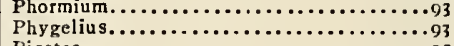

Pincers.

Pink

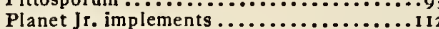

Plant duster........................ I I

Plant stakes..........................

Polyanthus.

Polygonum

Poppy......

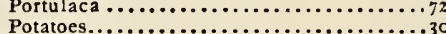

Potentill

Powder guns..............................

Primrose

Primula.

Pruners, Tree......................

Pumpkin ........................

$\mathbf{R}$ adish.

Raffia

Ramie

Rampion

Ranunculus.

Reels..............................

Rhodanthe

Rhododendron

Rhubarb

Rice.....

Rivina.

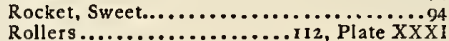

Romneya..

Roquette.

Roquette $\ldots \ldots \ldots \ldots \ldots \ldots \ldots \ldots \ldots \ldots \ldots \ldots \ldots \ldots$

Rosa multiflora.........................99

Sacaline

Sainfoin

Saintpaulia.

Salpiglossis.

Salsify ...

Salt bush

Salvia......

Saponaria...

Sarracenia.

Saws, Pruning

Saxifraga

Schizanthus.

Schizopetalon

Schizopetalon

Scolymus...
Scorzonera.

Scythe-rifes and stones.................
Scurvy grass................... Page

Sedum ............................. 95

Seed sower.........................110

Seradella...........................49

Shears and Scissors............... 107, 109

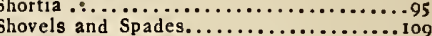

Shrub seeds............................

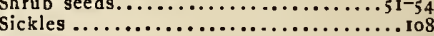

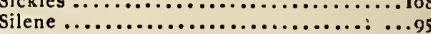

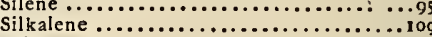

Skirret..................................

Smilax............................95

Snails .............................49

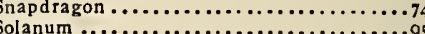

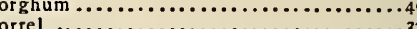

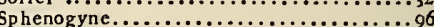

Spinach........................25. 33

Spirea .............................96

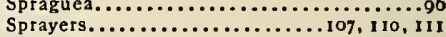

Sprayers......................... 110, I1

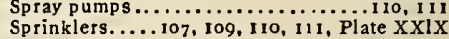

Sprouts .............................

Spurry.............................

Squash .....................................

Statice........................... 96

Stevia.............................

Stocks.........................8, 74, 96

Strawberry Plants....................

Strelitzia..........................96

Streptocarpus .......................96

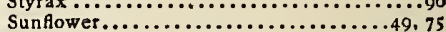

Sunfower..........................49, 75

Swainson a $\ldots \ldots \ldots \ldots \ldots \ldots \ldots \ldots \ldots \ldots \ldots \ldots \ldots \ldots \ldots \ldots \ldots \ldots \ldots, 76,7$

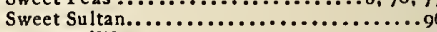

Sweet William............................

Syringes ............................., 110

Tacsonia $\ldots \ldots \ldots \ldots \ldots \ldots \ldots \ldots \ldots \ldots 6 \ldots \ldots \ldots \ldots$

Tagetes............................

Teasels............................49

Tecoma...

Thermometers.............................

Thunbergia..........................

Thunbergia ..........................96

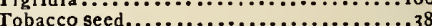

Tobacco seed............................38

Tomato $\ldots \ldots \ldots \ldots \ldots \ldots \ldots \ldots \ldots \ldots \ldots \ldots \ldots,{ }^{35}$

Torenia..........................97

Tree seeds......................50-54

Trowels.................................

Tuberose...........................106

Tunica.............................97

Turnip ..........................9., 36

Tydxa.................................

Valeriana .........................

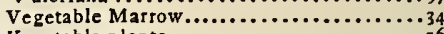

Vegetable plants......................

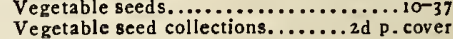

Vegetables, Culture of .....................

Vegetables for pickles and salads...........

Vegetable seeds, Novelties in.............99

Venidium ..........................99

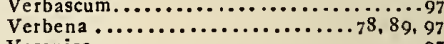

Veronica............................

Vetches...........................49

Vicia ..........................97

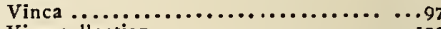

Vine collection .......................100

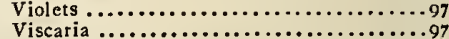

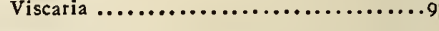

Wallfower .......................

Watering pots..................................

Watermelon........................

Weeders......................... $10_{7}$

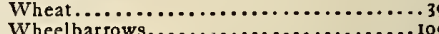

Wheelbar rows.................

Whitlavia .........................

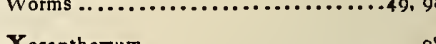

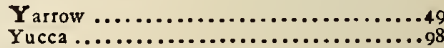

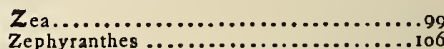

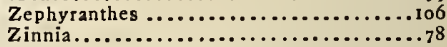




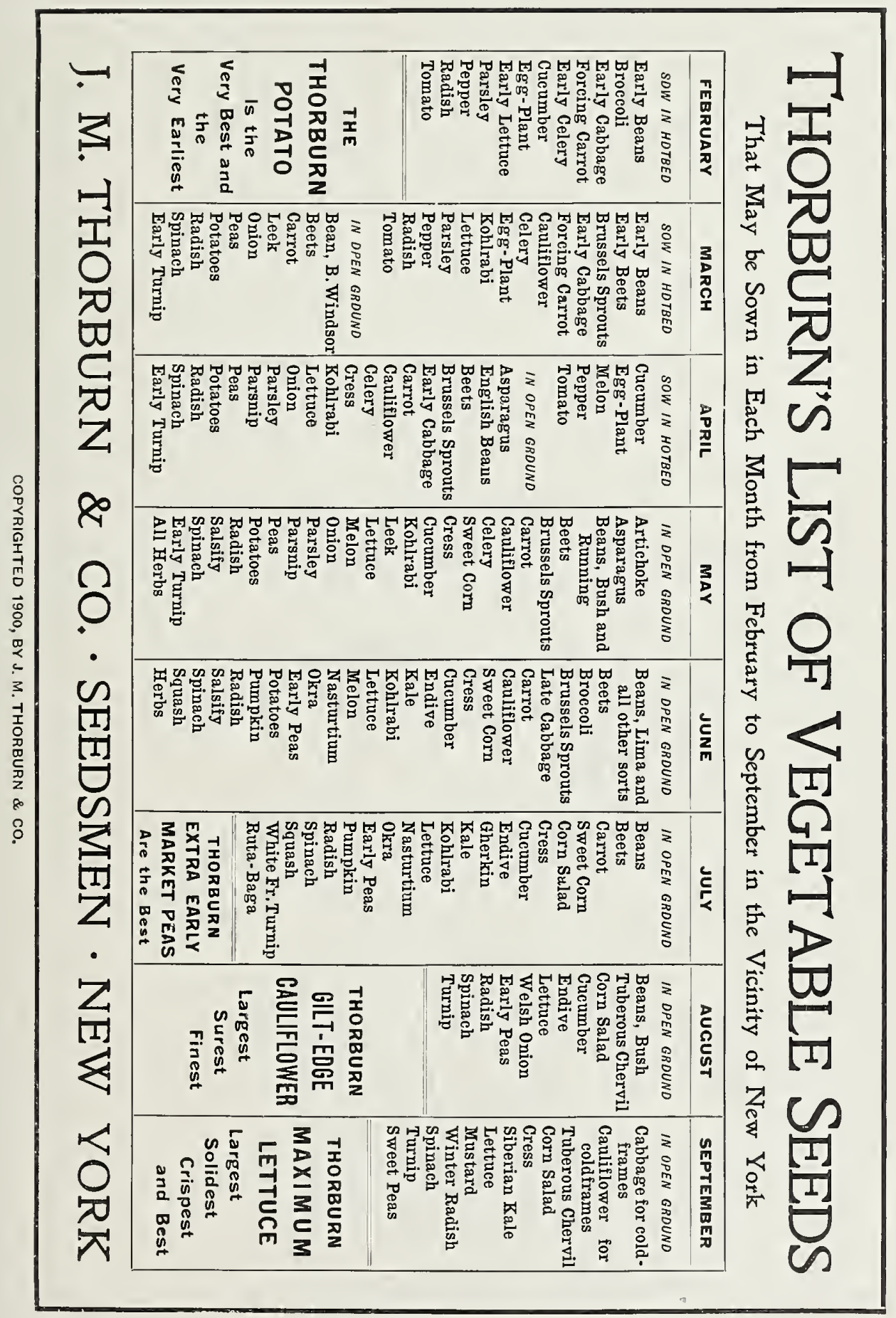



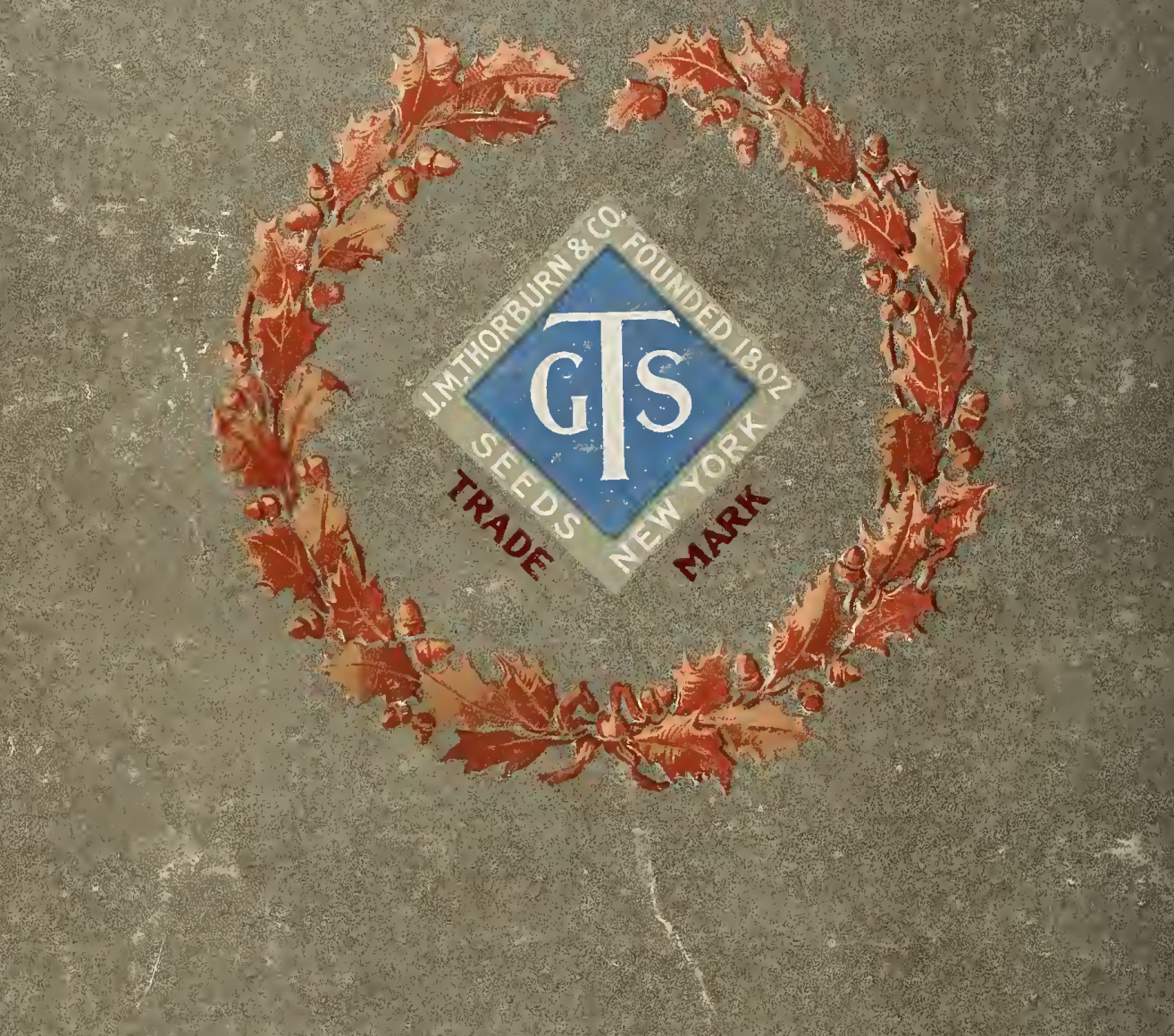

J.M.THORBURN \& CO. 36 Cortlandt St.

New Yorî 